Suffering the World:

An Augustinian Christology

Joseph Earl Lenow
Charlottesville, VA

Bachelor of Arts, University of Virginia, 2008

Master of Divinity, Duke Divinity School, 2011

A Dissertation presented to the Graduate Faculty

of the University of Virginia in Candidacy for the Degree of

Doctor of Philosophy

Department of Religious Studies 
(C) May 2017 Copyright by Joseph Lenow ALL RIGHTS RESERVED 


\title{
SUFFERING THE WORLD: AN AUGUSTINIAN CHRISTOLOGY
}

\author{
Joseph Lenow \\ Profs. Charles T. Mathewes and Paul Dafydd Jones, Dissertation Co-Directors
}

\begin{abstract}
Suffering the World: An Augustinian Christology seeks to develop a constructive christological proposal from resources found in the thought of St. Augustine of Hippo, and from the Augustinian theological tradition. The project hopes to fill a gap in present scholarship: while Augustine is noted as being one of the central figures in the history of Christian thought, only in recent years have historians and historical theologians begun to recognize the centrality of christology to his theology. Systematic and philosophical theologians have been even further behind this curve, and few if any christological proposals in the last century have sought to ground themselves specifically in Augustine's texts. This study thus attempts to draw on the resources of contemporary Augustinian studies in service of a constructive theological aim, in dialogue with thinkers in the fields of systematic theology, analytic and continental philosophy of religion, and more.

The central claim of the dissertation is that human lives are inextricably shaped by relation to the environments, events, and people in and with which they unfold and take shape. Who we are is in significant part due to the agency and causality of the people and things in the world around us. If this is true of all human persons, it must also be true of Christ; and so, I develop an account of the Incarnation in which the Word's eternal act of assuming flesh includes humans beyond Christ and draws their own agency into God's redemptive work. This is, I argue, a theological proposal in great sympathy with Augustine's theology of the totus Christus or "whole Christ," and leads us to a view of the Church as the extension of Christ's life in the world.
\end{abstract}




\section{TABLE OF CONTENTS}

Acknowledgments

$\begin{array}{ll}\text { Chapter 1. Eternity's Name } & 17\end{array}$

1.1 - Speaking of God 19

1.2 - The Unchangeable and the Changeable 30

1.3 - Speaking Trinitarianly 33

$\begin{array}{ll}\text { Conclusion } & 40\end{array}$

Chapter 2. Day from Day: Time and the Incarnation 43

2.1 - Augustine on the Nativity: Sermo 187

2.2 - The Work of Incarnation 48

2.2.1 - The Eternal Act of God 49

2.2.2 - The Act of God in Relation to the Created Order 52

2.2.2.1 - The Non-Competition of Divine and 52

Creaturely Agency

2.2.2.2 - Augustine on Eternity and Time 56

2.2.2.3 - God and the Philosophy of Time 58

2.2.3 - The Act of Assuming Flesh as an Act of the Son 68

2.2.4 - The Act of Assuming Flesh as Constitutive of 71 Christ's Person

$\begin{array}{ll}\text { Conclusion } & 78\end{array}$

Chapter 3. The Regime of Signs 82

3.1 - The Invisible God 84

3.2 - The Mission of the Word 88

3.3 - Faith in Things Unseen 98

3.4 - Reading Christ in the World 115 
Chapter 4. Completing Christ

4.1 - The Shape of Human Life 132

4.2 - The Shape of Christ's Life 137

4.2.1 - Interdependence 137

4.2.2 - Vulnerability 144

4.2.3 - Singularity 152

4.2.4 - The Body of Christ 158

4.3 - The Whole Christ 165

Chapter 5. A Broken Body 173

5.1 - Confessing Oneself 174

5.2 - The State of Sin 190

5.3 - The Work of the Spirit 202

5.4 - Binding us Together 210

5.5 - The Way of the Cross 218

Chapter 6. Rising with Christ 226

6.1 - The Glorification of the Body 227

6.2 - An Ethic of Confession 235

6.2.1 - Failures of Responsibility 238

6.2.2 - Failures of Will 243

6.2.3 - Failures of Representation 244

6.2.4 - Failures of Imagination 249

6.2.5 - The Failure of Humility 256

6.3 - Seeing Christ with Wounded Eyes 264

6.4 - Beholding God 279

$\begin{array}{ll}\text { Conclusion } & 284\end{array}$

$\begin{array}{ll}\text { Bibliography } & 294\end{array}$ 


\section{ABBREVIATIONS}

WSA - Works of Saint Augustine: A Translation for the Twenty- First Century. New City Press.

ST - Thomas Aquinas, Summa Theologiae.

NRSV - HarperCollins Study Bible, New Revised Standard Version including Apocryphal Deuterocanonical Books

Throughout, I have used the abbreviations of the Zentrums für Augustinus-Forschung for the works of St. Augustine, modified with a consonantal " $v$ " insead of a " $u$."

\begin{tabular}{ll} 
civ. & De civitate dei \\
conf. & Confessionum \\
corrept. & De correptione et gratia \\
div.qu. & De diversis quaestionibus octoginta \\
doctr.chr. & De doctrina christiana \\
en.Ps. & Enarrationes in Psalmos \\
ep. & Epistulae \\
ep.Io.tr. & In epistulam Iohannis ad Parthos \\
exp.prop.Rm. & Expositio quarundam propositionum ex epistula apostoli ad Romanos \\
Gn.litt. & De Genesi ad litteram \\
Io.eu.tr. & In Iohannis euangelium tractatus CXXIV \\
lib.arb. & De libero arbitrio \\
mag. & De magistro \\
c.Max. & Contra Maximinum Arrianum \\
mor. & De moribus ecclesiae catholicae et de moribus Manicheorum \\
nat. et gr. & De natura et gratia \\
praed. sanct. & De praedestinatione sanctorum \\
retr. & Retractationum \\
s. & Sermones \\
s.Dolbeau & Sermones a F. Dolbeau editi \\
c.s.Arrian. & Contra sermonem Arrianorum \\
trin. & De trinitate \\
virg. & De sancta virginitate \\
\hline
\end{tabular}


"For the garden is the only place there is, but you will not find it Until you have looked for it everywhere and found nowhere that is not a desert" W.H. Auden, "For the Time Being" 


\section{Acknowledgments}

What do you have that you did not receive? It seems to me that most of the most important parts of my life are things that have happened to me, rather than things I have done. I did not choose to be born when and where I was born; I did not choose to be raised by the people who have raised me; I did not choose to be brought up in the Christian faith, or to be baptized. Yet, had any of these things been different, it seems to me that I would have been an unimaginably different person.

Consider: my understanding of the cosmos and the infinitesimally small piece of it within which I live my life; my understanding of the possibilities of human nature and our ability to move freely on land, sea, and air, or our ability to manipulate the forces of nature through technology; my hopes for my own life, and estimation of the paths open to me - so much of the unquestioned background of my life would be unrecognizable in any era but the turn of the third millennium anno domini. But again, at a much more fine-grained level: the way I speak, the things I find funny, the personal tics, my faults in character, the things and people I love - it is unthinkable to me that I should have ended up the person that I am without having lived in a particular time and a particular place, without having been raised by my father and mother and alongside my brother, without having been surrounded by the friends and teachers and mentors who have in fact surrounded me throughout my life. The situation is even more dramatic when one considers the possible events that have not - but might have-occurred within my life: being born into fabulous wealth or crippling poverty, childhood disease, the early loss of those I love, disability, any of the traumas of abuse or loss that can mark the entirety of one's life, finding myself in the midst of calamity or war. To a significant extent, my life has been made what it is 
by factors beyond my (in some cases, anyone's) control; it is something I have received, something I have been shaped by, not (or not mostly) something I have fashioned. And it seems to me that the same is true also for you. ${ }^{1}$

My intent is not to suggest that our volition and choices are meaningless. On the contrary, even taking into account the constraints that circumstances beyond our control place on the courses of our lives, a fantastic range of possibilities lies open to our choice. I would not be the person that I am had I not made certain choices about the company I keep, the ways I spend my time, the things I value and believe. So also, we should not underestimate the extent to which our own attempts to make a way through the world are rooted in something utterly particular to us, the shot of originality that allows people to break the limits of their social formation. But at an inescapable level, the fact remains that even my volition is in great part responsive to forces beyond me: the activities I enjoy; my tastes in food, drink, and entertainment; the material goods I desire; the vocations I can imagine myself pursuing and my notions of the good life - all these have been profoundly influenced by the people around me, and the area of the world I inhabit, and the part of history in which I live. My desires, what I want to want, have been cultivated in me by my relations to what is outside me, and not always for the better: my view of the world and my agency within it have been shaped powerfully by racist and patriarchal social orders, and a host of other deformations of my affections are attributable (to a greater or lesser extent) to features of my upbringing or the influence of others. The importance of this receptivity to the world within my life is so evident as to be inextricable from my personhood itself - to be a human person is at least in part to stand in relations of this kind, to be determined in certain respects by who and what surrounds me. What indeed have we not received?

This is, I suggest, a constitutive feature of human existence. Our lives are given their shape through our relation to the world in which we find ourselves, both our natural environment and the other people we encounter. To have the singularity of our lives shaped through our interdependence with and vulnerability to others is simply part of what it is to be the sort of creature God has made us.

The fundamental claim of this study is that if the Word became truly human, then Jesus Christ also became who he is through the contingent and unpredictable events of life, through his relations to those around him, through his relations to the whole of the created order. Jesus is eternally predestined to be the Christ, but he becomes the Redeemer in time. If Jesus Christ is vere homo, then at the feet of others he learns obedience and grows in wisdom as he is nursed at the breast of the Blessed Virgin Mary, inherits and is included within the history of Israel in his circumcision, discourses with the doctors of the Temple, is baptized at the hand of John, is confessed to be Lord by Peter, meets the Syrophoenecian woman, finds his friends sleeping in

\footnotetext{
${ }^{1}$ We are in this together, you and I. A natural question, of course, is who is included (and, accordingly, who is not included) in this "we." In answer, I can do no better than Bernard Williams, who at Shame and Necessity, 171 n.7 writes: "The best I can say is that 'we' operates not through a previously fixed designation, but through invitation...It is not a matter of 'I' telling 'you' what I and others think, but of my asking you to consider to what extent you and I think some things and perhaps need to think others" (Bernard Williams, Shame and Necessity (Berkeley: University of California Press, 2008.)).
} 
Gethsemane, is betrayed by his companion Judas, teaches about himself on the road to Emmaus, appears to Stephen and to Paul, is praised in hymns by Ambrose and contemplated in his suffering by Julian of Norwich, is acclaimed and worshipped in our own time - all of this leaves a mark on the man Jesus Christ; all this determines him as the person he was and is. The influence of others and the effects of creaturely causes are indispensable in his coming to will as human the salvation of the world, and in his enactment of this will by giving himself over to suffering and death. Human agency and finite causes are thus included within the providential ordering of God's saving work, and granted a place within the actualization of our reconciliation with God. Redemption does not occur without this creaturely agency and causality, and so we must understand it in its inner unity with the act of Christ.

None of this is to suggest, however, that Christ was not also vere deus, or that Christ lacked divine knowledge of the whole of creation, or failed at any time in his life to possess the beatific vision of God. Christ is the person of the Word, in the forma servi as one who has assumed human flesh. To see how Christ can both receive all he is from the Father in the eternal life of God, and receive all he is in time from the flesh of his mother and from the people and events occurring around him, we must follow our christological reflection back to its heart in God's triunity and in the distinction between Creator and creature. Important here will be Kathryn Tanner's account of the non-competitive relation between God and creation. ${ }^{2}$ In light of Tanner's argument, I will suggest that the personal unity of Christ's humanity with the Word does not preclude an account of Christ's identity being shaped by his relations and responses to those around him. ${ }^{3}$

Recognition of this fact pushes us to a deeper understanding of the union between Christ's saving work and the actions of those who influenced him, and ultimately (I will argue), the agency of all humans and the whole course of creaturely causality - it pushes us to reflect not only on the person of Christ as a subsistence of human nature in union with the Word, but on the totus Christus, the "whole Christ" of Augustine's thought. By attending to the way that all human life, including that of Christ, takes shape through its relations to other persons and through being implicated in the contingent events of the world, I hope to sharpen the theological content of claims that the totus Christus exists as the mystical body of which Christ is the head, or that the Church should be considered an extension of the Incarnation. And, finally, by focusing on the way that our own action is included within the redemptive work of Christ, I hope also to explore how our unity with Christ is deepened throughout the course of the Christian life, as the Holy Spirit works in us to conform our desires and actions to those of Christ. We are, finally, caught into the movement of gift and response that defines all aspects of our created existence before God as we find ourselves ever more fully in Christ, and Christ ever more fully in us.

\footnotetext{
${ }^{2}$ In God and Creation in Christian Theology: Tyranny or Empowerment? (Minneapolis: Fortress Press, 2005), Tanner describes this relation as non-contrastive; in more recent work such as fesus, Humanity, and the Trinity: A Brief Systematic Theology (Minneapolis: Fortress Press, 2001) and Christ the Key (Cambridge: Cambridge University Press, 2009), the same conception has been marked with the more theologically suggestive description of a relation of "noncompetition."

${ }^{3}$ I am using the category of "identity" here not in a psychological sense as a stand-in for self-consciousness, but in a sense close to that Hans Frei employs in The Identity of Jesus Christ: the Hermeneutical Bases of Dogmatic Theology (Eugene, OR: Wipf and Stock Publishers, 1997).
} 
By way of introduction to this project, let me acknowledge some of my own debts, both personal and theoretical. This dissertation is a work of Augustinian theology: what, then, do I owe to Augustine? This is a question with no simple answer. As is true, I suspect, for most students of theology, Augustine was one of the first voices I encountered as I began my theological education. His voice has simply always been there, shaping the Western Christian tradition in which I was raised and thus my own piety long before I was able to recognize the voice as his. His texts have served as constant spurs to thought, provoking in me confusion, annoyance, insight, understanding, and on occasion, something like wonder. It is his articulation of the world as a gift that exists only through participation in God that serves as my constant theological reference-point, and meditations on the triune life of God and the redemptive work of Christ that I have found most captivating. It is my belief that, especially for those early in their theological educations, much can be gained by disciplining one's own thought through seeking to enter as deeply as possible into the thought of another. For better or worse, in view of both the outside significance of Augustine's thought and the charges often leveled against him, he has served in this capacity for me.

Yet Augustine is not owed, I think, unquestioning assent. As a work of constructive christology, I have sought to make it answerable above all else to the truth of God's redemptive work in Christ. Where I take Augustine to be in error, or where it seems to me that we may come to an even deeper understanding of Christ's work through developing what had gone unaddressed in Augustine's texts, I have self-consciously departed from what he has said. Here too, however, it is difficult to draw this line with any clarity. The preponderance of my argument here has been worked out through sustained meditation on Augustine's own texts; much of the form of this dissertation reflects this fact, sketching out the main lines of my christological proposal through exegesis of Augustine's texts. At times, my discussions will engage points of dispute among some number of Augustine's contemporary interpreters, giving my writing here the aspect of a historical study concerned principally with establishing what Augustine himself actually thought. I feel the pull of these questions, of course, and care deeply about the answers to them; in other writings, I even hope to contribute to the discussions surrounding these questions of history and interpretation. This work, however, is guided by constructive theological aims, and by the disciplinary conventions of philosophical theology rather than of the history of theology. I have drawn, for instance, freely and idiosyncratically on virtually the whole of Augustine's literary corpus, without concerning myself overmuch with questions of the development of Augustine's christological thought throughout his theological career.

This practice has been guided by my sense that, at various points in his writings, Augustine says things that seem to me to be true about God and Christ, and that it is desirable to have some roughly systematic account of these ostensible truths. Particularly for a thinker with a christology as unsystematic as Augustine's, any attempt to bring coherence to what I take to be his insights on these matters across the full breadth of his theological development will undoubtedly introduce distortions into a historical accounting of his thought. I offer this as a global disavowal of the historical respectability of my project: if anyone finds my christological outlook of my exegeses of particular texts useful in the project of developing a historical narrative 
of what Augustine thought about Christ at various stages of his intellectual career and of the changes that occur in his thought throughout the course of his life, this is all to the good-but that project is not my own. Augustine thus appears in these pages less as the object of my study, and more as a conversation partner. Through engagement with his texts, through learning at his feet, dissenting where he seems mistaken, and filling out the points in his writings that seem lacking, I hope to gain insight into what might be confessed of Christ today.

In this, I take myself to be stepping into a long tradition of Augustinian thought stretching through Anselm and Thomas Aquinas to the reformers and Pascal and to the present day. In each generation, parts of Augustine's thought are brought to the fore and parts suppressed; the canon of texts taken up for consideration expands or contracts; the resultant pictures of Augustine vary widely; but nevertheless, each theological perspective stands within a common Augustinian tradition in that each takes Augustine as a central authority and constant guide. It is this very diversity of the Augustinian tradition that attracts me to it, and while I have no doubt that there are points of my thought which require on the one hand, normative theological correction, and on the other, amendment if they are to serve as reliable interpretations of Augustine's thought situated within its proper historical context, I hope that my own Augustinian outlook may be one minor entry in this long and impressive series of those who have sought to understand Christ's work more deeply in conversation with the doctor gratiae. I have been tutored in this approach to Augustine's thought by three thinkers who are noteworthy both in their brilliance and in their generosity: Chuck Mathewes, Paul Griffiths, and Jim Wetzel. Each of them in conversation and in writings have pushed me to think more clearly about the central questions of faith, and each of them have opened to me the constructive theological potential of Augustine's thought. Each of them have made remarks on some point of Augustine's writings which have lodged themselves in my reflections, serving as insights to which I return over and over in the course of my own readings of Augustine, and as norms of my theological developments of him. I am immensely grateful to each of them.

At the same time, this project proceeds in the conviction that the teaching of the early centuries of the Church is often a far better guide to the truth of God's work in Christ than are the proposals of modern systematic theologians. While I have no desire (as we will see) to ignore or dismiss the many insights of contemporary theological reflection, this work presumes a deeply Catholic piety that sees the teaching of the seven ecumenical councils of the Church, and the teaching of those bishops in the succession of the apostles more broadly, as the starting point of theological reflection. It is in the early centuries of the Christian faith that the Holy Spirit led the Church to authoritative teachings on the Trinity, on the two natures of Christ in hypostatic union, on the presence in Christ of both divine and human wills, and on the representability of Christ's human flesh. While contemporary systematic theologians often draw upon the texts of one or more major figures within the early history of the Church, this is often done while assuming basic theological commitments vastly different than those held in the early centuries of Christianity. As a result, presentations of the Church Fathers and Mothers are often so skewed as 
to be almost unrecognizable; ${ }^{4}$ as is increasingly clear, the logic of Augustine's theological outlook has been particularly compromised in many modern presentations. ${ }^{5}$ While the outlook of this dissertation remains resolutely constructive, I hope to proceed in line with the theological convictions that animated Augustine's own thought. Understanding what Lewis Ayres has called the "theological 'culture" 6 of Augustine's time and the "grammar' of human speech about the divine" 7 that structured the theological discourse of his time are indispensable starting points for articulating the logic of an Augustinian theology. Consequently, we will find that even given the interpretive liberty of the constructive theological approach I have assumed, historical theologians will in many respects prove more illuminating conversation-partners than contemporary systematic theologians, surfacing theological questions that might otherwise remain obscure. I have been influenced in this theological approach above all by Robert Louis Wilken, who first introduced me to Patristic theology and to Augustine in particular; since then, I have progressed as a reader of early Christian thought with the help of Warren Smith, Judith Kovacs, and especially Karl Shuve.

In light of this outlook, the present study has benefitted greatly from the increased attention paid to Augustine's christology in recent years by historical theologians and scholars of early Christianity. Augustine has not traditionally been regarded as a particularly distinctive christological thinker. He has no single text devoted to discussion of the person and work of Christ; he has relatively few texts written as occasional responses to christological controversy. While he at times will argue against adversaries denoted through the blurry categories of "Arianism" and "Apollinarianism," he was relatively untouched by the theological battle that raged near the end of his life between Cyril and Nestorius. Though he was issued a summons to the Council of Ephesus, the emperor Theodosius who issued the decree was unaware that Augustine had died several months before. ${ }^{8}$ Indeed, Augustine's christological reflections have suffered for many years through comparison with the christological controversy in the East: though Augustine's position stands at least in significant continuity with what will come to be regarded as the orthodox doctrinal position at the Councils of Ephesus and Chalcedon, the terms in which Augustine conducts his reflections on the person and work of Christ are sufficiently different than those of Cyril of Alexandria that Augustine's own perspectives may at first glance simply appear undeveloped.

This famously led Harnack to conclude that Augustine "influenced the piety of Western Christians by a doctrine of grace which met their lower inclinations, as well as by a promulgation of the immediateness of the religious relationship which failed to do justice to Christ's significance

\footnotetext{
${ }^{4}$ As Lewis Ayres neatly displays with respect to Gregory of Nyssa in "Not Three People: The Fundamental Themes of Gregory of Nyssa's Trinitarian Theology as Seen in To Ablabius: On Not Three Gods," Modern Theology 18, no. 4 (2002): 445-74.

${ }^{5}$ Barnes, Michel René. "Augustine in Contemporary Trinitarian Theology." Theological Studies 56 (1995): 237-250.

${ }^{6}$ Lewis Ayres, Nicaea and its Legacy: An Approach to Fourth-Century Trinitarian Theology (Oxford: Oxford University Press, 2004), 1.

${ }^{7}$ Ayres, Nicaea and Its Legacy, 3.

${ }^{8}$ George A. Bevan, "Augustine and the Western dimension of the Nestorian controversy," Studia Patristica, (2010): $347-52 ; 347$.
} 
as mirror of God's fatherly heart and as the eternal mediator." 9 Later interpreters were scarcely more forgiving. Grillmeier judges that Augustine "does not always distinguish between the 'historical' and the 'mystical' person, between the individual and the total Christ. This gives his statements about the historical Christ the characteristic inconsistency which is also a feature of his picture of the Christus totus," eventually concluding, "Latin christology gained much from Augustine. But he could not provide what was needed to bring the crisis which had broken out in the East at the end of his life to a successful outcome." 10 For much of the hundred years that followed Harnack, Augustine's Christology was rarely a focus of research in historical study; William Babcock wrote in 1971 that the few existing studies were "isolated markers in a landscape that is largely blank."

In recent years, however, scholars have grown increasingly appreciative of Augustine's christological contributions. The genesis of this reappraisal lies outside the realm of Anglophone scholarship, and a new beginning on the question of Augustine's christology may be marked by the 1954 publication of Tarsicius 7. Van Bavel's Recherches sur la christologie de saint Augustin, l'humain et le divin dans le Christ d'après Saint Augustin. ${ }^{11}$ Ensuing years saw the publication of major works on Augustine's christology by Wilhelm Geerlings's Christus Exemplum: Studien zur Christologie und Christusverkündigung Augustins (1978), ${ }^{12}$ Hubertus Drobner's Person-Exegese und Christologie bei Augustinus: Zur Herkunft der Formel Una Persona (1986), ${ }^{13}$ Goulven Madec's La Patrie et la Voie: Le Christ dans la vie et la pensée de Saint Augustin (1989), ${ }^{14}$ and Basil Studer's Gratia Christi, Gratia Dei bei Augustinus von Hippo (1993). ${ }^{15}$ This research filtered into Anglo-American scholarship relatively slowly: for many years, William H. Marrevee's The Ascension of Christ in the Works of Augustine (1967) ${ }^{16}$ and William S. Babcock's unpublished dissertation "The Christ of the Exchange: A Study in the Christology of Augustine's Enarrationes in Psalmos" (1971) ${ }^{17}$ were the only monograph-length studies of Augustine's christology in English. More recently, Robert Dodaro's Christ and the Fust Society in the Thought of Augustine (2004), ${ }^{18}$ Luigi Gioia's The Theological Epistemology of Augustine's De Trinitate (2008), ${ }^{19}$ Lewis Ayres' Augustine and the Trinity (2010), ${ }^{20}$ Michael

\footnotetext{
${ }_{9}^{9}$ Cited at William Babcock, "The Christ of the Exchange: A Study in the Christology of Augustine's Enarrationes in Psalmos," (Unpublished diss., Yale University, 1972), 5.

10 Aloys Grillmeier, Christ in Christian Tradition, trans. J.S. Bowden (New York: Sheed and Ward, 1964.), 327-8.

11 Tarsicius J. van Bavel, Recherches sur la christologie de saint Augustin, l'humain et le divin dans le Christ d'après Saint Augustin, (Fribourg en Suisse: Editions universitaires, 1954).

12 Wilhelm Geerlings, Christus Exemplum: Studien zur Christologie und Christusverkündigung Augustins (Mainz: Matthias Grünewald Verlag, 1978).

${ }^{13}$ Hubertus Drobner, Person-Exegese und Christologie bei Augustinus: Zur Herkunft der Formel Una Persona (Leiden: Brill, 1986).

${ }^{14}$ Goulven Madec, La Patrie et la Voie: Le Christ dans la vie et la pensée de Saint Augustin (Paris: Desclée, 1989).

${ }_{15}$ Basil Studer, The Grace of Christ and the Grace of God in Augustine of Hippo: Christocentrism or Theocentrism, trans. M.J. O'Connell (Collegeville, MD: Order of St. Benedict, 1997).

16 William H. Marrevee, The Ascension of Christ in the Works of St. Augustine (Ottawa: University of Ottawa Press, 1967).

17 Babcock, "Christ of the Exchange."

${ }^{18}$ Robert Dodaro, Christ and the Fust Society in the Thought of Augustine (Cambridge: Cambridge University Press, 2004).

${ }^{19}$ Luigi Gioia, The Theological Epistemology of Augustine's De Trinitate (Oxford: Oxford University Press, 2008).

${ }^{20}$ Lewis Ayres, Augustine and the Trinity (Oxford: Oxford University Press, 2011).
} 
Cameron's Christ Meets Me Everywhere: Augustine's Early Figurative Exegesis (2012), ${ }^{21}$ Dominic Keech's The Anti-Pelagian Christology of Augustine of Hippo, 396-430 (2012), ${ }^{22}$ and most recently Gerald O'Collins's The Resurrection of Christ in Augustine (2017), ${ }^{23}$ have each taken as a theme the centrality of christology within Augustine's political theology, theology of the trinity, epistemology, and theology of Scriptural interpretation. Many of these projects can be traced to the influence of Rowan Williams, sometime Archbishop of Canterbury, who in teaching many of the scholars named here and in a series of essays published throughout the 1990s and 2000s (many now collected in the important volume On Augustine $)^{24}$ both synthesized the results of this French- and German-language scholarship and further extended our sense of the importance of Augustine's christology. These works, alongside a number of important essays by (inter alia) Ayres, Michel René Barnes, John Cavadini, Brian Daley, Dodaro, Matthew Drever, John McGuckin, Joanne McWilliam, and Studer, have contributed greatly in the past thirty years to our understanding of Augustine's account of the person and work of Christ.

Yet far more work remains: we still lack a real understanding of how Augustine's christology developed through the course of his life in anything but its broadest outlines. The best treatments of the subject now available are McGuckin's and Cameron's, who mostly agree with one another. McGuckin identifies three stages in Augustine's thought: the first, beginning at his conversion in 386, "concentrates on the pedagogic role of Christ." He is seen here as "a somewhat remote exemplar of virtuous living." 25 The second stage, commencing with his ordination to the priesthood in 391, involves a new understanding of the significance of Christ's humanity. Both McGuckin and Cameron mark Augustine's exegesis of the twenty-first Psalm (as numbered by the Vulgate) as a conceptual turning point. ${ }^{26}$ This period increasingly sees Augustine drawing on the classic categories of Latin christology, specifically Tertullian's "formula of the unity of person in a duality of substances" and Novatian's "principle of the distinction of operations in Christ: He does some things as God, others as man - qua Deus, qua homo." 27 McGuckin identifies the beginning of the third stage as 412, the year in which Augustine first suggests that "the Christological union was itself a grace," and even that he is "the supreme

\footnotetext{
${ }^{21}$ Michael Cameron, Christ Meets Me Everywhere: Augustine's Early Figurative Exegesis (Oxford: Oxford University Press, 2012).

22 Dominic Keech, The Anti-Pelagian Christology of Augustine of Hippo, 396-430 (Oxford: Oxford University Press, 2012).

${ }^{23}$ Gerald O'Collins, S.J., Saint Augustine on the Resurrection of Christ: Teaching, Rhetoric, and Reception (Oxford: Oxford University Press, 2017).

24 The articles, many of which have now been collected in the volume On Augustine (London: Bloomsbury Continuum, 2016), include "Sapientia and the Trinity: Reflections on the De trinitate," in Collectanea augustiniana. Mélanges T. van Bavel, ed. B. Brunig et al. (Leuven: Peeters Publishers, 1990), 316-32; "The Paradoxes of SelfKnowledge in the De trinitate," in Augustine: Presbyter Factus Sum, ed. Joseph T. Lienhard, et al. (New York: Peter Lang, 1993), 121-134; "Augustine and the Psalms," Interpretation 58, no. 1 (2004): 17-27; "Augustine's Christology," in In the Shadow of the Incarnation: Essays on Jesus Christ in the Early Church in Honor of Brian E, Daley, SJ (Notre Dame: University of Notre Dame Press, 2008), 176-89.

${ }^{25}$ John McGuckin, "Did Augustine's Christology Depend on Theodore of Mopsuestia?", The Heythrop Fournal 31 , no. 1 (1990): 39-52; 43-4.

${ }^{26}$ McGuckin, “Did Augustine’s Christology Depend on Theodore?”, 44; Cameron, Christ Meets Me Everywhere, Ch. 6.

27 McGuckin, "Did Augustine's Christology Depend on Theodore?”, 45.
} 
example of unmerited antecedent grace." 28 This final stage marks the introduction of a new set of theological concerns to Augustine's christological reflection in light of the anti-Pelagian controversy. We still await supplementation of this rather skeletal framework of progression.

Nevertheless, these studies have been sufficient to define with some clarity the features distinctive of Augustine's christological reflection. In an essay on just this subject, Brian Daley summarizes:

the distinctive elements in St. Augustine's Christology seem, above all, to be points on which he came more and more to see the intimate and unique relevance of Jesus to our salvation. In recognizing that the union of the transcendent Word to a human soul and its flesh is at least analogous to our own integrity as incarnate spirit; in seeing in Jesus the Mediator the revelation of the divine humility and selfemptying that lovingly "mediates" between God and his creation, that brings God to us and us to God; and in finding in Jesus the source and model of that life of grace in which we, his members, share through the gift of his Spirit - in all three of these developing Christological insights, Augustine the Neoplatonist grew more and more securely into Augustine the Catholic preacher, Augustine the biblical theologian. ${ }^{29}$

To these three points we may add what is perhaps the most distinctive feature of Augustine's thought, the one that grounds and underlies all these three: the theology of the totus Christus, or "whole Christ." As we will see, Augustine's christology is preoccupied with the presence of Christ in the Church, such that Christ can be said to speak with the Church's voice, act with the Church's hands, and so on. Accordingly, Williams describes Augustine's christology as "an account of how God speaks within the nexus of human relations," in which "human salvation or transfiguration... [are linked] with the idea of the Word's speech taking up and taking over the varieties of confused or rebellious human speech, anchoring the tumultuous instability of what we feel and express in a solid and unbroken self-communication, the Word's self-giving to the Father."30 In redeeming us and reconciling us to God, Williams argues, our speech is transformed, such that we are able to confess our own lives in prayer and thanksgiving to God in the same way Christ does - and in fact, with Christ's own voice. Augustine's christology centers on a particularly realist reading of the mystical union of Christ and the Church, one that is incredibly suggestive but (as Grillmeier disapprovingly noted) difficult to define with precision. One of the aims of this dissertation is to describe with as much specificity as possible just how God "speaks within the nexus of human relations" by assuming flesh in Christ.

In light of how recently Augustine's christology has become a topic of scholarly focus, few theologians have attempted to develop systematically a self-consciously Augustinian christology.

\footnotetext{
${ }^{28}$ McGuckin, "Did Augustine's Christology Depend on Theodore?”, 45.

${ }^{29}$ Brian Daley, S.J., "A Humble Mediator: The Distinctive Elements in Saint Augustine's Christology." Word and Spirit 9 (1987): 100-117; 110.

30 Williams, "Augustine's Christology," 188.
} 
Many of the works of the historical theologians already named edge toward constructive work, but for the most part, their purpose is to describe Augustine's own christological thought. Michael Hanby offers a compelling reading of Augustine's christology in the course of a larger project on Augustine's relation to modernity. ${ }^{31}$ John Milbank's essay "The Name of Jesus" clearly displays the influence of Augustine's theology of the totus Christus, but the essay does little to thematize Augustine's contributions. ${ }^{32}$ Eric Gregory quite insightfully and instructively draws upon Augustine's christology as a key resource in developing a contemporary account of the relations between love and justice in political action within liberal democratic societies. ${ }^{33}$ His is evidently one of the proposals that goes furthest toward developing a distinctively Augustinian christology, yet his concerns are primarily within the realm of Christian ethics rather than christology proper. Perhaps ironically, the likeliest book-length candidate to be identified as a constructive Augustinian christology is Maarten Wisse's Trinitarian Theology beyond Participation: Augustine's De Trinitate and Contemporary Theology, a work that seems to revel in thumbing its nose at the scholarly consensus on Augustine's purposes in the De trinitate in service of a radically Protestant interpretation. ${ }^{34}$ Wisse's book is a bracing reminder of the many Augustines that have been found in the centuries since his death, and is useful in calling attention to the shared interpretive presuppositions of many scholars presently at the forefront of Augustinian studies; yet his christological presentation will be profoundly unsatisfying as both exegesis and constructive proposal to those who find participation one of the central theoretical categories of Augustinian thought. Rowan Williams has himself turned in recent years to questions of christology, as can be seen in his 2016 Hulsean Lectures. ${ }^{35}$ To my mind, the most compelling development of Augustine's thoughts on the person and work of Christ may be found in a series of recent essays by James Wetzel, collected in the volume Parting Knowledge: Essays after Augustine. ${ }^{36}$ While these are hardly systematic (and exhibit little attraction in that direction), they will serve as a frequent reference-point throughout this dissertation.

While my debts to historical scholarship on Augustine and contemporary Augustinian theologies run deep, these are not the only currents of thought by which I find myself carried along. Both my particular interest in christology and the patterns of my thinking on the person and work of Christ are attributable in significant part to the influence of my other co-director, Paul Dafydd Jones. Study of Barth and contemporary christology with him in my undergraduate years taught me that the life of Christ may serve as the center and ordering principle of all theological reflection, an outlook I carried with me to my first readings of the De trinitate; his book called to my attention the centrality of Christ's human nature and will in any adequate account

\footnotetext{
31 Michael Hanby, Augustine and Modernity (London: Routledge, 2003), Ch. 3.

${ }^{32}$ John Milbank, "The Name of Jesus," in The Word Made Strange: Theology, Language, and Culture (Oxford: Blackwell Publishers, Ltd., 1997), 145-168.

${ }^{33}$ Eric Gregory, Politics and the Order of Love: An Augustinian Ethic of Democratic Citizenship (Chicago: University of Chicago Press, 2008); especially pp. 255ff.

34 Maarten Wisse, Trinitarian Theology beyond Participation: Augustine's De Trinitate and Contemporary Theology (London:

Bloomsbury T\&T Clark, 2011).

35 Williams, The Hulsean Lectures 2016: Christ and the Logic of Creation.

${ }^{36}$ James Wetzel, Parting Knowledge: Essays after Augustine (Eugene: Cascade Books, 2013).
} 
of the hypostatic union; ${ }^{37}$ more recent studies with him have exposed me to the significant conceptual resources of Friedrich Schleiermacher, whose thought astute readers will recognize throughout these pages, and particularly in connection with my presentation of the eternal act of God. ${ }^{38}$ In addition to learning the great systematic thinkers of German Protestantism from Jones, studying with him from so early in my theological education has also given me the gift of teaching me to read Latin American liberationist, black, womanist, and feminist theologies almost as long as I have been reading Augustine. These approaches have shaped my theological reflection from the ground up, and have contributed a great deal to my reading of thinkers from throughout the history of the Christian tradition. Indeed, I am convinced that, in at least one significant respect, liberationist thinkers are the true heirs of Augustine on the contemporary theological scene: they are the ones who most clearly call the Church to confession, for they show Christian thought where it has failed, and where it has been complicit in violence against the least of these. In many cases, they are also the thinkers who most refuse the easy consolations of pious language, and call the Church to the difficult work of justice in full knowledge of the fact that our sin is often much clearer to us than the course of action that will bring about a less oppressive society. While the form of this dissertation and especially the questions that serve as an entryway into this project in its early chapters may be very different than those characteristic of many liberationist texts, I hope the influence of these theological trajectories will become increasingly apparent as my argument unfolds.

Within the family of theological approaches that are self-reflexive about how their patterns of thought are implicated within and shaped by the social locations of their authors, I have benefitted especially from the emphasis on relationality that is characteristic of much contemporary process theology. Though my emphasis on divine transcendence and the immutability and simplicity of God's life undoubtedly forces a fairly early divergence between our theological outlooks, I believe that thinkers like Catherine Keller have rightly stressed the interconnectedness of all creaturely reality. ${ }^{39}$ Though I have not read her identify herself as a process theologian, Mayra Rivera strikes me as a fellow traveler with such approaches in her recent Poetics of the Flesh. This work is exemplary of and serves as a guide to much recent theological discourse surrounding the body, paying particular attention to the way that human flesh is marked by the categories of race, gender, sexuality, nationality, and so on. ${ }^{40}$ Rivera tells us that, "Rather than rejecting flesh on the basis of its association with sin, I seek to revalue the disavowed traits as integral to corporeality - including its links to the material elements, its vulnerability, and changeability." 41 To this I can only say yea and amen. Even so, I draw on a

\footnotetext{
${ }^{37}$ Paul Dafydd Jones, The Humanity of Christ: Christology in Karl Barth's Church Dogmatics (London: T\&T Clark, 2008).

${ }^{38}$ Indeed, I suspect that I might have written substantially the same dissertation through a reading of the Glaubenslehre, with only moderate corrections of Schleiermacher in the direction of Catholic orthodoxy.

${ }^{39}$ Keller is, of course, just one voice within the huge chorus of those theologians indebted to the philosophy of Alfred North Whitehead; nevertheless, her seemingly boundless theological creativity has made her a regular referencepoint for me. See especially The Face of the Deep: A Theology of Becoming (London: Routledge, 2003) and Cloud of the Impossible: Negative Theology and Planetary Entanglement (New York: Columbia University Press, 2014).

${ }^{40}$ Mayra Rivera, Poetics of the Flesh (Durham, NC: Duke University Press, 2015).

${ }^{41}$ Rivera, Poetics of the Flesh, 12.
} 
substantially different set of conceptual resources in my own attempt to view our interdependence as part of the good of human existence, and to see this good as a tool through which the Word works our reconciliation with God. While Merleau-Ponty and the phenomenological tradition in which he stands represents a significant point of contact with Rivera, I have tended to draw more on the Anglo-American philosophical tradition, and especially the strands emerging from the later work of Ludwig Wittgenstein into figures like J.L. Austin, Stanley Cavell, Cora Diamond, and Stephen Mulhall. Nevertheless, Rivera's work, and the work of those working along lines paralleling her own, have been especially helpful in calling attention to the connections of these fleshly realities to vectors of oppression and embodied struggles for justice. Along similar lines, I have found Queer theory and theology a particularly instructive conversation-partner, particularly as represented by Judith Butler, Linn Marie Tonstad, José Esteban Muñoz, and Judith Halberstam.

I have hardly scratched the surface: I have not even mentioned some of the thinkers whose works have proved most determinative for this text, among whom are Kathryn Tanner, Robert Sokolowski, David Burrell, and Sarah Coakley. Rather than attempting a full accounting here, I must be content to let the evidence of my debt mount throughout this dissertation. I am, at any rate, happy to avoid any suggestion that it is within my power to know and mark all the ways I have been shaped by the thought of others.

Yet I suspect I have a far firmer grasp on what I have retained from the books I have read than I do on how my thinking in this dissertation has been shaped by the people I love, the communities of faith that have shaped me, and the friends who have supported me throughout my life. This dissertation depends on the fundamental Augustinian claim that our knowing and willing cannot be neatly separated: in loving poorly, our knowing becomes distorted, and we misapprehend the world of our experience. Far more importantly, however, to know something truly is to recognize its value and place within the world God has created, and to be capable of loving it as it is rather than as we would have it be. Whatever truth I have been able to gesture towards in these pages, I have only been able to do so as my affections have been shaped by those closest to me, as they have inspired and corrected me, as they have joined with me in the attempt to discern what it is to live a good life. At points of this dissertation, the influence of these experiences seems apparent to me: my emphasis on sanctity and on the Holy Spirit's work in sanctification is, I think, attributable in significant part to my upbringing in the United Methodist Church, and particularly my time as a member of Courthouse Community, Fredericksburg, and First United Methodist Churches, and to Harry Kennon; much of the Catholic piety that shapes so much of my argument here has been learned from (in addition to some of the names I have already mentioned) my time in the Episcopal Church, from the communities of St. Luke's and St. Paul's Memorial, from the utterly unique community of the Anglican/Episcopal House of Studies at Duke Divinity School, from mentors like Anne Hodges-Copple, and Jo Bailey and Sam Wells, and from friends like Bradford Acton, Blair and Jen Anderson, Michael Boone, Joshua and Mary Caler, Julieanne Dolan, Ross Kane, Jared Maddox, Ethan Prall, Eric Prenshaw, Kara Slade, and Tom Warren. 
I am immensely grateful for the opportunity to learn from Stanley Hauerwas and the late (and dearly missed) Allen Verhey; I would not be the student of theology that I am without their influence. My time in the doctoral program at the University of Virginia has been one of the most enriching experiences of my life, and I have learned more than I can say from teachers like Larry Bouchard, Jim Childress, Nichole Flores, Jennifer Geddes, Kevin Hart, Lisa Reilly, and Heather Warren. I have learned at least as much from my friends in Charlottesville, among whom I must mention Laura Alexander, Scott Bailey, William Boyce, Gillian Breckenridge and Robert LeBlanc, Rebecca and Sarah Epstein-Levi, Matt Elia, Nauman Faizi, Matthew Farley, Jeremy Fisher, Nicholas Forti, Deborah Galaski, Charles Gillespie, Andrew and Emily Guffey, David Gundlach, Timothy Hartman, Mark and Christina Randall James, Natasha Mikles, Peter Morris, Shifa Noor, Larry Perry, Travis Pickell, Matthew Puffer, Nelson Reveley, Reuben Shank, Kevin Slaughter, Sarah Strasen and Peter Moench, George Tarasidis, Jonathan and Rachel Teubner, Petra Turner, and A.J. Walton.

I am particularly grateful for the very old friendships that have sustained me not only through my graduate education, but throughout many seasons of life. My oldest friend is Justin Pritchett, and it has been a gift for his interests to develop along the same theological and philosophical lines as mine; it has also been a gift to become friends with his wife Elsbeth Pritchett. Not too far behind are Matt and Emily Benton and Brian and Kim Johnson, who have kept me connected to the questions faced by the Church and its ministers throughout my time huddled away in a library. More recently, I must mention Ashley Faulkner, whom I would be happy to list among my teachers were he not such a good friend. I must give special thanks to the friends who first heard the ideas of this dissertation shouted across a crowded table well after midnight; who have helped me sharpen and clarify my own ideas through asking critical questions; who have read version after version of these chapters and provided comments upon it: Ashleigh Elser, Patrick Gardner, Paul Gleason and Greta Matzner-Gore, Brett and Dana McCarty, Christina McRorie, Kristopher Norris, Daniel and Leah Wise. Finally, those who have shaped me more deeply than anyone else, and who are (for better or worse) most responsible for making me the person that I am: my parents Larry and Amy Lenow, my brother John and his wife Catheryn.

I hope I may be forgiven for being so personal in an introductory chapter. Yet part of the argument of this dissertation is that in coming to know Christ, we are able to see our connections to one another more clearly; that, in fact, we come to know ourselves as one in the one body of Christ. Love of Christ is not meant to draw us away from the world, but back into it - and more specifically, back into our concrete histories, the events and people that have shaped us and that we, in turn, have shaped. As Rowan Williams writes, Augustine's

pattern of christological exposition insists that there can be no accurate discussion of the incarnation that is not itself incarnationally modeled - humble in its awareness of the inescapable context of material history, alert to the question of how justitia is realized, open to the dangerous and potentially humiliating solidarity of fallible and sinful human agents, and refusing prideful isolation. Agere personam 
sapientiae is for all believers the task of learning a new speech apt for the city of God, a méthode spirituelle that is both political, in the widest sense, and prayerful, continuous with the unbroken, transfiguring enactment of Wisdom that is Jesus Christ. $^{42}$

This passage could, in many ways, serve as a mission statement for this dissertation. My argument is structured according to an incarnational movement, beginning with the eternal life of God in which the Word wills to take on flesh, passing through the interrelation of divine and creaturely agency as encountered the act of assuming flesh, centered on the humanity of Christ which is the meeting-point of the life of God and the life of the world, and extending outward as our own particularity and concrete histories are incorporated within Christ. The aim of God's reconciling act is, finally, not just to return us to God, but to return us to our own flesh, learning to see all our lives as included within the life of Christ and acting in relation to others as he lives in us.

In Chapter 1, I seek to orient the project theoretically through a discussion of the Patristic grammar of God's eternal life. My presentation, in response to Augustine's own texts, centers on the immutability, simplicity, and triunity of God. Rather than merely describing the patterns of thought characteristic of classical Christian accounts of God's life, I try to render such an account plausible by beginning with Scripture and the confessions made about God by communities of faith, and showing how the classical doctrine of God is shaped in response to questions that might easily emerge as we seek to understand God's relation to the created order.

Chapter 2 centers on the relation between the eternal act of God's life and the temporality of the created order. Following Kathryn Tanner, the relation between divine and creaturely action is taken to be fundamentally non-competitive, existing on two different levels of agency and causality, and ordered in a relation of irreducible priority on the side of God's action. When held together with the doctrine of divine timelessness, this produces a picture of creation in which God freely creates and orders the whole course of created history in the one creative act that is included within the divine life. On the basis of this account, I argue that we must understand the Word not as somehow temporally inhabiting Christ's flesh and acting in it; the divine act of the Word is utterly eternal and timeless, even in the Incarnation. Rather, the human flesh of Christ is the life of the Word in time; all that there is of God that is temporal, is the human life of Christ.

Chapter 3 discusses how Augustine understands the life of Christ to serve as a redemptive sign for us. Though in sin we have lost the capacity to contemplate God's eternal life, Augustine argues in De trinitate 4 that God nevertheless gives us signs fit to the weakened state of our intellects in order to draw our intellects and affections back to God. In an effort to clarify just how signs accomplish this work, I offer a reading of Augustine's De magistro alongside Ludwig Wittgenstein's Philosophical Investigations, showing how signs can be both fixed conventionally yet nevertheless serve as occasions that draw us into deeper contact with the Truth as we are taught

42 Williams, On Augustine, 153. 
most truly through them by Christ the inner teacher. In light of this conversation, we are able to appreciate the significance of Augustine's claim in De trinitate 13 that Christ is both scientia and sapientia: he is the one who in the sign of his life is none other than what is signified, and the one to which all worldly signs refer. Though it is a commonplace of Platonic thought that all things are likenesses of the Word, I conclude that if this Word becomes manifest in history, all things must necessarily serve as signs too of the human life in which the Word becomes visible.

Chapter 4 serves as the central theoretical hinge of the dissertation, and turns to Augustine's interpretation of Christ's cry of dereliction from the cross. In his cry of godforsakenness, Augustine tells us that Christ speaks not in a manner proper to his own beatific life as Son of God, but with our voice, expressive of the condition of sin he has taken on in us. But what sort of relation must thus obtain between our lives and Christ's, such that he may appropriately speak our words? I argue that human lives are characterized by interdependence, vulnerability, and singularity - Christ's life no less than our own. He becomes who he is, his life is given shape, through the relations he bears to the events, environments, people, and things within the created order; in assuming flesh, the Word orders and takes on all these relations. In light of this account, we may describe the union between Christ and the Church in what Augustine calls the totus Christi as the inclusion of our lives and agency within Christ's salvific work, completing the shape of his own life and making him fully our Redeemer as we are actively redeemed.

Chapter 5 turns to the question of our inclusion within this work of Christ. It begins with a discussion of the disintegration of our lives that occurs as sin runs its course, and extends outward to the dissolution of our social orders into patterns of violence and exploitation. Looking at the structure of the human will and the root cause of sin, I argue alongside Augustine's later thought that we have no capacity to turn our hearts back to God. What is needed, then, is the reforming work of what J. Patout Burns has called "operative grace," understood as the Holy Spirit's activity within us to create charity in our hearts. As the Spirit turns our hearts back to God, She creates in us the very human desires of Christ, which move us to act in the very human ways that Christ wills us to act. To the extent that our lives are sanctified by grace, then, our lives are conformed to the life of Christ in a movement of self-dispossession, reception of ourselves as God's gift, and responsive self-offering of our lives to God.

Chapter 6 attempts to render this threefold movement of self-dispossession, reception, and response even more concrete by contextualizing it within our own lives and cultures. We live in the hope of the Resurrection, but also in wake of the Ascension. Therefore, the Christian life takes shape as an attempt to discern in the world the presence of the one who has vanished from our fleshly view. I contend that, in light of the preceding chapter's discussion of sin and grace, it is a mistake to orient our ethics through the question of how we can become more just; this is beyond our ken. Rather, our ethics should begin with confession, constantly returning to our moral failings in the hope that we will be brought to humility and a recognition of our dependence on God's grace. Then, without thought of the consequences or the possibilities for success, we must act in the way that love (as far as we can see it) demands, pursuing justice together in the knowledge that our pursuit will likely fail. We see Christ most clearly in the world, 
I suggest, in the lives of those who reveal the misshapen loves and injustices that characterize our world, moving the oppressors to a confession of their oppressiveness and the oppressed to a confession of their dignity in the eyes of God. Accordingly, the Church most clearly fulfills its nature of serving as a sign of Christ in the world inasmuch as it is united to the downtrodden. In this, it testifies to the hope of a resurrected life in which our relations to one another will be restored and perfected through the beatific vision of God.

One of the central claims of this dissertation is that sin obscures from us the truth of God, distorts our vision of the world God has created, and hides from us much of the violence we inflict on one another. There is much error in this dissertation; there is much here that contributes to the harms to which we subject one another. I offer it to you, reader, as the best confession I am able to make at present. I offer it to you seeking your correction, and if necessary, your rebuke; but always in the hope that, together, we might come to see one another more truly in Christ. 


\section{Chapter 1}

\section{Eternity's Name}

The task of christology is both enriched and immeasurably complicated by the present diversity of theological starting points. ${ }^{1}$ For much of the history of Western Christian thought, broadly Augustinian approaches provided a shared theoretical frame for theological investigations. Though such approaches varied considerably in their particulars and in the degree of their fidelity to Augustine's own thought as assessed by contemporary scholars, they were loosely unified by their common predication of - inter alia - simplicity, aseity, immutability, eternity, omnipotence, omniscience, and omnipresence of the divine nature. This is what I have in mind when I speak of the "classical" doctrine of God. Augustine is a thinker representative of those who held to this classical conception of God, and for contingent historical reasons, many later thinkers within the Christian West learned this conception of God through engagement with his texts. Coupled with developments in trinitarian theology began in the De trinitate, Augustinian assumptions shaped the form that christology would take throughout the remainder of the late Patristic and Medieval periods in the Western church. ${ }^{2}$ While theologians prior to the Reformation had many disagreements, they were generally not disagreements about these

\footnotetext{
${ }^{1}$ The title to this chapter comes from Augustine's sermo 7.7, which Lewis Ayres at Augustine and the Trinity, 204 vividly translates as: "What is 'I am who I am' if not 'I am eternal'? What is 'I am who I am' if not 'who cannot change'? This is no creature - not sky, not earth, not angel, not power, not thrones, not dominions, not authorities. Since then this is eternity's name, what is much more interesting is that he was prepared to have a name of mercy: 'I am the God of Abraham, the God of Isaac, and the God of Jacob’ [Ex. 3.15]. That name in himself, this one for us.”

2 As well as, potentially, developments in the Eastern church through St. Maximus the Confessor; Brian E. Daley, S.J., "Making a Human Will Divine: Augustine and Maximus on Christ and Human Salvation," in Orthodox Readings of Augustine, ed. George E. Demacopoulos and Aristotle Papanikolaou (Crestwood, NY: St. Vladimir's Seminary Press, 2008), 101-26.
} 
particular issues. Such shared assumptions offered a common beginning for theological reflection that could proceed along very different lines without coming to challenge this theological bedrock, but also enabled certain sorts of disagreements that otherwise might not have arisen. ${ }^{3}$

One of the complications of writing theology in the present day is that there is, depending on the scope of one's interlocutors, no such shared launching point. The theological assumptions of process theologians will be very different than those of Barthians; the Barthians will have very different assumptions than the Thomists; the process theologian, Barthian, and Thomist may (or may not) agree that the right starting-place for theological reflection is the doctrine of God while the liberationist wishes to begin with the sanctifying work of the Holy Spirit as encountered in human experience.

This all is to the good. It has produced a diffuse array of theological approaches, and even if there are many against which I would argue vociferously, each of them has brought into relief some set of theological issues that warrant detailed consideration. Yet I also wish to call to attention what I see as two negative consequences of this theological diversity.

First, the very different starting points of many contemporary theological approaches has sometimes made it difficult to identify point of disagreement between them. Two theological proposals may be superficially very similar, culminating (for instance) in the commendation of the same ethical practice, yet depend on vastly different accounts of God's life to reach this conclusion. By the same token, two superficially divergent approaches may in fact begin from surprisingly similar presuppositions. These moments of common cause or unexpected dispute can be celebrated or lamented as is one's wont; what I want to point out is that this theological diversity makes vastly more difficult attempts to compare the relative merits of theological outlooks. In particular, one can often find theological proposals that are exceedingly vague about the fundamental claims that animate and set the boundaries for the project; or one can find superficial assessments of theological proposals that pay little attention to the axioms of thought that structure a particular account. In beginning with a chapter on why Augustine comes to believe that God's life is characterized by immutability, simplicity, and a particular conception of triunity, and by trying to show the logic tying all these claims together, I am attempting to put my cards on the table and invite others to critique the presuppositions about God underlying much of this study. Part of my hope, here, is that I may avoid what I see as fairly mindless criticisms to the effect that a classical conception of God's life is "static," or that an Augustinian approach is too influenced by "Greek philosophy" and should instead begin from Scripture (which is taken to raise no questions pushing toward philosophical response) or that it privileges the oneness of essence to the exclusion of the threeness of God's life (though this last criticism may be, in large part, epiphenomenal to an improper understanding of how threeness applies to God's life). I hope to head off some of these avenues of dismissing my project at the pass.

Second, it seems to me that the proliferation of theological outlooks has, to some extent, buried the theoretical cost of adopting any of them. As we pace the shelves of the great theological bookstore in the clouds, we are confronted with any number of different

\footnotetext{
${ }^{3}$ I think of the theological disagreements between broadly Thomist thinkers and broadly Bonaventurean ones.
} 
methodological convictions, philosophical approaches, tradition-based reasonings, and authoritative figures. Each of them is presented to us by their partisans for our approval; far less commonly are we confronted with the theoretical costs of adopting any particular approach. My suspicion is that many who reject a classical conception of God's Being and act in favor to some perspective more greatly in debt to post-Enlightenment philosophy have not so much determined that a classical conception is wrong, so much as it appears to them profoundly unattractive. We draw great comfort from friends compassionately sharing in our pain as we undergo it; thus it seems the most natural thing in the world that God should suffer as well. Our experience of the world is characterized by change, and in fact much of the joy in our lives comes from delight at encountering something novel; accordingly, why shouldn't we hold that God changes alongside creation? My claim is not that non-classical accounts of God's life are in themselves incoherent, or that they can straightforwardly be shown to have disastrous theological consequences. They are, for the most part, vital perspectives that I trust will be around for a long time. I simply believe that these theological approaches have theoretical costs that are rarely acknowledged, and I aim to stick them with the bill.

This could be a massive theoretical project in its own right, and I seek only what is necessary as preface for the constructive theological argument I will pursue in ensuing chapters. I am less interested in polemicizing against particular figures on the theological landscape than I am in raising theoretical hurdles non-classical approaches face, and suggesting that Augustinian thought clears them. In so doing, I hope to make the costs of other perspectives more readily apparent, so my Augustinian approach may appear more plausible. I am under no illusion that I have given decisive arguments against all comers, but I trust that a cumulative case showing the internal logic of the Augustinian position may render it slightly more attractive to those whose fundamental theological commitments have not been settled, or at least more palatable to those inclined to dismiss it offhand. My hope is that, wherever you begin, you leave this chapter slightly more Augustinian than you entered it.

\section{Speaking of God ${ }^{4}$}

The Lord is good; His mercy is everlasting; and His truth endures to all generations. ${ }^{5}$ Such utterances are the building-blocks of Christian speech about God: they are sung in worship; read as

\footnotetext{
4 The arguments of this section have been deeply shaped by the various manners of distinguishing God from creation presented in Robert Sokolowski, The God of Faith and Reason: Foundations of Christian Theology, 2 nd Ed. (Washington, D.C.: The Catholic University of America Press, 1995); David Burrell, G.S.C., Aquinas: God and Action, (Scranton, PA: University of Scranton Press, 2008); and Katherin A. Rogers, Perfect Being Theology (Edinburgh: Edinburgh University Press, 2000). While none of these are concerned primarily with the writings of St. Augustine, they present readings of SS. Anselm and Thomas Aquinas that seem to me profoundly consonant with Augustine's work, and clarify key dynamics of Augustine's thought I take to be central to any understanding of the Augustinian tradition.

${ }^{5}$ My understanding of the damaging effects of using exclusively masculine images of and terms in reference to God comes primarily from Elizabeth Johnson's She Who Is: the Mystery of God in Feminist Theological Discourse, 10th Anniversary Edition (New York: The Crossroad Publishing Company, 2002). In light of Johnson's argument, I follow Denys Turner's practice of referring to God irregularly using masculine and feminine pronouns. Turner
} 
appointed lections; preached upon; studied devotionally; meditated upon by contemplatives; studied as a historical record of the development of Israel's religious practice; offered as praise in moments of joy and grief; recontextualized and woven into liturgical speech; printed on throw pillows or as artwork used to adorn one's walls. These words and other words like them indicate a history of election, faithfulness, sin, forgiveness, and trust. They are also probed and explored by theologians and philosophers, tested for their sense and implications, placed into synthetic unity with other Christian speech about God. But these words, both as Scriptural and liturgical, constitute the bedrock both of proclamation and of theological reflection - of the language used every day in conducting a life of Christian faith, and in the reflexive analysis of that language conducted for the sake of clarifying and extending speech about God. ${ }^{6}$

Scholarship on Augustine is increasingly aware of Scripture's role as the chief startingpoint of and a goad to his thought, including of his trinitarian and christological reflection. ${ }^{7}$ Over-against accounts that would view Augustine's trinitarian theology as merely as a development of pagan Neoplatonic themes, the scholarly emphasis has shifted to an awareness of the central place of Scripture in Augustine's thought, and on his creative appropriation of the preceding Christian exegetical tradition. ${ }^{8}$ Scripture is both a beginning and a constant companion for him.

What does it mean, then, when Scripture calls God good? Is this utterance like others that share a common form with it, the form of predicating an attribute to something, of describing something as possessing some quality? What should we make of this description of God as good in light of the diversity observed in similar utterances, both at the level of that being described (Tommy is good, Jane is good) and the level of the quality being ascribed (the car is good, the pasta is good)? Though these are philosophical questions, they are questions raised by attempting to think through Scripture's own language. There are, of course, many other sorts of valid questions that can be raised by these Scriptural utterances - how does the Psalmist understand God's goodness in light of the history of Israel? Does God's goodness include God's wrath, or are

explains his procedure at The Darkness of God: Negativity in Christian Mysticism (Cambridge: Cambridge University Press, 1998), 26, where he writes: "if we describe God both as male and as female, then we force upon our materialistic imaginations a concrete sense of the collapse of gender-language as such... It is in the collapse of ordinary language, brought to our attention by the necessity of ascribing incompatible attributes, that the transcendence of God above all language is best approached." My account of God's life will already, I suspect, seem abstract enough for some readers; I have not wanted to exacerbate the problem by ridding my argument of the personal pronoun in favor of impersonal but gender-neutral language about God. Changing irregularly between masculine and feminine pronouns has the virtue of disrupting normatively male theological speech, while making the intrinsic disruptiveness of God-talk apparent in its form. It is my hope that this practice, distracting as it may be, serves a pedagogical practice even in the distracting - for the writer as much as for the reader. To facilitate clarity in light of this decision, I have also adopted the convention of capitalizing the initial letter of all personal pronouns used to refer to God. ${ }^{6}$ In this account of first-order Christian speech and theology as reflexive analysis of it, I have been influenced by, among other broadly postliberal texts, George A. Lindbeck, The Nature of Doctrine: Religion and Theology in a Postliberal Age (Louisville, KY: Westminster John Knox Press, 1984).

7 Cameron, Christ Meets Me Everywhere serves as a recent and incredibly insightful example.

8 This case has been pressed with great force and to convincing effect by Lewis Ayres in Augustine and the Trinity; but see also Volker Drecoll's caution that the task of adjudicating Platonic and Neoplatonic influences on Augustine's trinitarian theology remains open and important; "Lewis Ayres, Augustine and the Trinity," Scottish Fournal of Theology 66, no. 1 (2013): 88-98. 
these fundamentally opposed attributions? - yet these other questions, more native to the field of Biblical studies, neither foreclose the philosophical questions raised by Scriptural attributions of qualities to God, nor answer them.

Rather than attempting to confront head-on these questions of how Scripture's predications of attributes apply to God, Augustine's practice in both homilies and in more technical theological works is to begin with a slightly different question: specifically, the question of whether, when Scripture calls God good, it is possible that this should ever be untrue, or that it should be true differently. ${ }^{9}$ Augustine's question then, is whether it is possible that God should change. The question arises regularly, and sometimes unpredictably, throughout Augustine's thought. While reflecting in his first tractate on John's Gospel on John 1.1, for example, Augustine asks his listeners to dwell on the word Deus as he speaks it:

Look; I utter a word when I say "God"; what a short word I have uttered, three letters, one syllable! ...What happened in your heart when you heard "God"? What happened in my heart when I was saying "God"? Something great and supreme occurred to our mind; it soars utterly above and beyond every changeable, carnal and merely carnal nature. And if I say to you, "Is God changeable or unchangeable?" you will answer at once, "Perish the thought that I should either think or feel that God is changeable! God is unchangeable." Your soul, even though small, even though perhaps still flesh-bound, could only answer me that God is unchangeable, even though every creature is changeable. So how could you have that spark in you, leading you toward that which is above every creature, making you sure of your reply to me that God is unchangeable? So what is that thing in your heart, when you are fixing your mind on some substance that is living, everlasting, almighty, infinite, present everywhere, everywhere whole and entire, nowhere confined? When you fix your mind on all this, there is a word about God in your heart. ${ }^{10}$

It is telling that in this first homily on John's Prologue, as Augustine begins his exposition on the Word who is both God and who assumes flesh, he pushes his listeners to reflect on the very finite, very concrete moment in which they dwell: if you wish to understand the Incarnation, pay attention to what is happening now, pay attention to the limits that mark off your life as a finite creature, pay attention to the change that you are undergoing even now. As he pronounces the word Deus, he directs his hearers to the feeble and transitory nature of our words, the sense in which the animal vocalizations slide by in both our utterance and listening - and the way in

\footnotetext{
${ }^{9}$ John Cavadini has noted the substantial continuities between Augustine's preaching and his theoretical texts at "Simplifying Augustine," in Educating People of Faith: Exploring the History of Jewish and Christian Communities (Grand Rapids: Wm. B. Eerdmans Publishing Co., 2004): 63-84.

10 Io.eu.tr. 1.8; WSA III/12, 45-6.
} 
which any ability we have to understand one another depends on some transcendence of the shifting sand of the present moment, holding the whole word together at once. ${ }^{11}$

These features define every instance of speech, of course; yet Augustine hopes that by calling attention to them in the context of our speech about God, the contrast between God's manner of existing and our own may be brought to light. In the word we hold in our heart, we catch a glimpse of a manner of existing that is not scattered across time across time as we are, and does not require a changing series of sounds to be understood. ${ }^{12}$ It is the inadequacy of our speech to this true and inner word that Augustine hopes will point us to a more vital truth about our theological speech: because our words are finite, because we understand only as changeable creatures, even our best attempts to speak about the Word will bear as little resemblance to that Word itself as our vocalizations do to the inner word that is known and understood. Our words can only hope to pull apart and analyze what exists in an integral unity within God. Even so, there is a spark in them, some connection to that Word which draws us through the transitory sounds and understandings which are native to us and into communion with the God who is beyond all the objects of our experience.

Perhaps puzzlingly, the contrast between creaturely changeability and God's unchangeability is the hinge on which all this turns. There are historical reasons why this should be the case for Augustine, ${ }^{13}$ but this does not absolve us from consideration of whether God's unchangeability should still figure as prominently in theology in our own time as it did in the fourth and fifth centuries. Augustine ventures a more densely technical discussion of this contrast between creaturely and divine existence, again centered on the unchangeability of God, in the fifth book of his De trinitate. Considering what sort of substance or ousia God may be said to be, Augustine writes

Now other things that we call beings or substances admit of modifications (accidentias), by which they are modified and changed to a great or small extent. But God cannot be modified in any way, and therefore the substance or being which is God is alone unchangeable, and therefore it pertains to it most truly and supremely to be, from which comes the name "being." Anything that changes does not keep its being, and anything that can change even though it does not, is able to not be what it was; and thus only that which not only does not but absolutely cannot change deserves without qualification to be said really and truly to be. ${ }^{14}$

\footnotetext{
${ }^{11}$ Carol Harrison has called attention to this aspect of listening to sermons in The Art of Listening in the Early Church (Oxford: Oxford University Press, 2015).

${ }_{12}$ Cf. The Incarnation of the Word: The Theology of Language of Augustine of Hippo (London: T\&T Clark, 2010), 95-9.

${ }^{13}$ See, for instance, Roland J. Teske, "Divine Immutability in Augustine," in To Know God and the Soul: Essays on the Thought of Saint Augustine (Washington, D.C.: The Catholic University of America Press, 2008), 131-52; and Michel René Barnes, "The Arians of Book V, and the Genre of De Trinitate," The Fournal of Theological Studies 44, no. 1 (1993): 185-95.

14 trin. 5.2.3; WSA I/5, 190.
} 
What would it mean for God's goodness to be changeable? Say, for the sake of argument, that it is - perhaps God is no more or less good from day to day, but that the character of Her goodness changes. But if there is something different about God's goodness tomorrow than there is today, several unattractive possibilities present themselves. Is there something which was not good yesterday, but is good now? If the answer to that question is yes, we should stand in constant fear about our knowledge of the good in general. Why should we think that anything about God's goodness tomorrow will be the same as what we know of Her goodness today? In fact, might something we today consider profoundly evil stand in accordance with God's goodness tomorrow? But say the change is not of this sort. Perhaps change in God's goodness occurs without there coming to be anything excluded from Her goodness that was included in it previously. In that case, are we to say that God previously lacked some good that She exemplifies today? Doing so would put us in profound tension with Scriptural claims about God's goodness, which suggest that God possesses and is the source of all good things. ${ }^{15}$

But perhaps we have misunderstand what it is to ascribe goodness to God altogether: on this account, Scripture's claims that God is good refer to (inter alia) God's faithfulness to Israel, God's care for the downtrodden, Her support in times of trial, and so on. To all of this, I must reply: of course! Evidently, Scripture's ascriptions of goodness to God are intimately connected to Her work of redemption, to the election of a people from all the nations of the world and to God's coming to dwell among that people in the Temple and in the person of Christ. But the question is what it means to call any of these works good - it is a question about how these acts of God are related to other acts of people, or dispositions, or qualities of things, all of which we also want to describe as good. If there is no likeness between God's actions and these more familiar creaturely examples of goodness, then we have utterly and fruitlessly lost our grip on language; saying that God's electing work is "good" might as well be saying that God's electing work is "ochre," because what we must mean by "goodness" has lost all connection to the regular pattern of language. But if what we mean when we call God and God's actions "good" bears any likeness to created goods - in spite of all their (even infinite!) unlikeness - then the question of whether God's goodness is to be thought of as changeable or unchangeable is an intelligible one, and a pressing one. And we can extend the range of concepts about which similar questions could be asked well beyond questions of goodness: already in Psalm 100, we have seen that Scripture ascribes mercy and truth to God alongside goodness; do mercy and truth change? Do power or praiseworthiness? These questions stem not from a preconceived conceptual schema into which Augustine struggles to fit the data of revelation, but rather from a concern to safeguard the claims that Scripture and Christian worship themselves make about the Lord. ${ }^{16}$

\footnotetext{
${ }^{15}$ Cf. Rowan Williams' comments on the unchangeability of God's Goodness in response to Kathleen Sands at $O n$ Augustine, 99: "Say that the Good is, indeed, properly conceived as 'various, mobile and vulnerable': this might mean that the Good is different for different created subjects, to the extent that what is good for one subject is necessarily and permanently at odds with what is good for another; that the Good genuinely differs from circumstance to circumstance, without any 'grammar' of continuity; that the Good of or for certain subjects might simply and finally fail or prove impossible of realization."

16 This is not to suggest prematurely that these abbreviated arguments have closed the door on all other validly Christian ways of conceiving the life of God in accordance with these Scriptural and liturgical claims; only to say
} 
As can be seen in the passage from De trinitate 5, however, Augustine is committed to something stronger than the claim that God does not change; he believes that there is no possibility of change in God. We can perhaps imagine an account of God's life in which change is possible for Him, but in which some other feature of our account (God's faithfulness to His promise, perhaps. Or, again, some account of God's goodness being normed by Her rationality) makes it possible for God to change, but contingently true that He does not. Two considerations support affirming Augustine's stronger claim that God is necessarily unchangeable. First, imagine that it is possible for God to change. Now imagine that there is an entity possessing all God's present goodness, as well as the goods that are only potential for our God - that is, that entity possesses already all the goods that it is possible our God will acquire by changing (or conduct the actions that we will later identify as good after our God performs them). In that case, we are left with an entity that seems to be greater than our God; and if it is possible that our God should change to be like that hypothetical entity, there is no reason to think that the existence of such an entity is incoherent. Why shouldn't we worship that entity instead, or at least alongside our God? Or, more problematically, how is it conceivable that there should be something greater than our God, when Scripture so often claims that there is not? ${ }^{17}$

Second, and as Augustine points out in the passage from De trinitate above, if something changes, it ceases to be what it was previously; and if something can possibly change, then it is possible for it not to be what it is now. Something changeable is something that can be lost, at least in principle, and if goodness is something that God can lose, then it is clearly something separate from God; but then, what is it? If God changes, then maybe goodness also changesand in fact, perhaps what is good changes in accordance with God's will. While philosophically coherent, this seems to be an undesirable position, resulting in a voluntaristic notion of the good such that God could will it to be good that a world should exist populated wholly by tortured infants. God would never do that, you may say. But if what is good is itself dependent upon God's will, how can we use our present intuitions about what is good to judge that such a world would be a worse world than the one we now inhabit? Worse, whatever God ends up willing to be good seems arbitrary, for there is no criterion of goodness by which God may determine whether one way of willing the good is better than another. It seems that God, in a sheer unfounded act without reasons available even to Her, determines what is good. And before we rest too comfortably with this dice-roll, we should remember that there is also no criterion that makes God's persisting in willing the good of which we are now conscious any better than God suddenly willing something else tomorrow - we may yet wake up in a world where God

\footnotetext{
that, from an Augustinian perspective, there is prima facie reason to view his emphasis on the immutability of God as an attempt to process the deposit of revelation rather than an illicit philosophical superimposition on it. So also, my claim that Augustine's concern with the immutability of God comes primarily from first-order Christian proclamation and from Scripture does not suggest that Augustine's arguments, and perhaps especially the language he uses to pursue this concern, are not both influenced by and indebted to his readings in Platonic philosophy. 17 This argument, if followed through, should lead us to follow Anselm's Proslogion in understanding God as thatthan-which-a-greater-cannot-be-conceived; and if we think that the existence of such a God is possible, it should lead us to think that God actually exists, as Alvin Plantinga has shown in The Nature of Necessity (Oxford: Oxford University Press, 1974), 197-221.
} 
commands torturing babies. While some may find attractive the rejection of any limitations on the divine freedom, it nevertheless seems preferable to hold that what is good is unchangeable in itself.

Perhaps, then, goodness is something that is in itself unchangeable, but possesses existence in its own right - something like a necessarily existent property, or a separable Platonic form of the good. In this case, goodness would be understood as a property that God would possess, or as an entity distinct from God that makes Him good by virtue of His being related to it. We must then ask how God possesses this property or stands in this relation, contingently or necessarily; and since we are discussing the possibility of God's goodness being changeable, the answer in this context must be that God possesses this property contingently. While God could potentially exemplify the property of goodness perfectly, possessing maximal goodness, if our theory holds that God is only contingently good, there does not seem to be anything that forecloses the possibility of God ceasing to exemplify this property - the possibility of God no longer being good. If it is possible for God to change, then, it seems possible that there is a set of circumstances in which God exemplifies goodness defectively (anything but God's being perfectly good would count here), or of God ceasing to be good entirely. Even if goodness in itself does not change, then, we must say that the degree to which God exemplifies goodness or stands in a relation of likeness to the form of the good changes; and the circumstances of this changing are either within or beyond God's control. If within, we can only pray that God's will to remain good is unchangeable. For how do we know that God is not capricious, and will not someday choose to become wicked? On the other hand, if the contingencies that produce change in God's goodness are outside God's power, or responsive to the agency of creation (as in some construals of process theology), we can only pray that circumstances leading to the corruption or failure of God's goodness will never arise. ${ }^{18}$ While these reflections do not definitively rule out the possibility of God's goodness being changeable, they do suggest that it may be preferable to think of God's goodness as unchangeable.

Here again, we reach a theoretical crossroads between various possible ways of holding that God is unchangeably good. Two options seem open to us. On the one hand, we could modify a position that we have already considered: goodness is an unchangeable property-like entity with an existence distinct from God, and God exemplifies this property maximally and necessarily - a position that seems to be the dominant one within contemporary analytic philosophy of religion. ${ }^{19}$ While Augustine could not of course anticipate the careful positions

\footnotetext{
${ }^{18}$ Perhaps we want to identify goodness as something like the proper functioning of the process of change in Godsomething like God "making space" for creaturely freedom by changing in response to creation? There is nothing obviously wrong with such a procedural notion of goodness; but what is there to ensure that the process of God's changing in response to creation is itself good? What if, in response to creaturely activity, God properly allows for creaturely freedom (thus satisfying our procedural account of the good) by changing into a morally monstrous deity? With a procedural notion of goodness alone, we have no standard of the good by which to measure whether the process of change itself is good or evil.

${ }^{19}$ For two influential and representative examples, see Alvin Plantinga, Does God Have a Nature? (Milwaukee: Marquette University Press, 1980); and Richard Swinburne, The Christian God (Oxford: Oxford University Press, 1994).
} 
adopted by contemporary philosophical theologians, he is suspicious in general of accounts that locate goodness in something external to God:

In things that are great by partaking of greatness, things where being is one thing and being great another, like a great house and a great mountain and a great heart, in such things greatness is one thing and that which is great with this greatness is another. True greatness is that by which not only is a great house great or any great mountain great, but by which anything at all is great that is called great so that greatness is one thing and things that are called great by it another. This greatness of course is primally great and much more excellently so than the things that are great by partaking of it. God however is not great with a greatness which he is not himself, as though God were to participate in it to be great; otherwise this greatness would be greater than God. But there is nothing greater than God. So he is great with a greatness by which he is himself this same greatness. ${ }^{20}$

Leave to the side for the moment the statements about non-divine realities "partaking of" or "participating in" greatness; we will have more to say about this shortly. Augustine's worry with allowing that a predicate like greatness or goodness might have any existence independent of God is that the quality of greatness or goodness would reside more properly in that independently-existing entity than it would in God. Even if God were thought to be necessarily good, God would be good only derivatively. The property "goodness," or the separable form of the good, would be that which is primarily and most basically good. Or, cast in the idiom of contemporary analytic philosophy, we might worry that the property of goodness would metaphysically ground any good thing while God would not, or that such a property would exist at a more fundamental level than and independently of God. ${ }^{21}$ Most philosophers of religion would, I suspect, simply respond to this worry by denying that properties ground the objects that exemplify them, or by positing that both God and goodness exist at the same level of fundamentality, noting that Augustine's worry seems too indebted to the logic of Platonism. By contrast, many Augustinians will be unsatisfied with this position's claim that God's necessary exemplification of maximal goodness is a brute fact - that it is true but utterly lacking in explanation. ${ }^{22}$ The notion of goodness as an entity distinct from God, even if necessarily related to Her, suggests that God's goodness is dependent on something outside Her, that there is something beyond God that is needed to explain why She is good. Unless we are content with the

\footnotetext{
20 trin. 5.10.11; WSA I/5, 196.

${ }^{21}$ On the notion of a "fundamental level" of ontology in contemporary analytic thought, see Jonathan Schaffer, "Is there a fundamental level?", Nous 37, no. 3 (2003): 498-517; Ross P. Cameron, "Turtles All the Way Down: Regress, Priority, and Fundamentality," The Philosophical Quarterly 58, no. 230 (2008): 1-14; and Kit Fine, "Guide to Ground," in Metaphysical Grounding: Understanding the Structure of Reality, ed. Fabrice Correia and Benjamin Schneider (Cambridge: Cambridge University Press, 2014), 37-80.

${ }_{22}^{2}$ Edward Feser has noted the central role of the search for explanation in classical accounts of God's life at Scholastic Metaphysics: A Contemporary Introduction (Piscataway, NJ: editiones scholasticae, 2014), 18-21.
} 
answer "She just is," the only way out of this problem is to say that God is Goodness itself - there is no goodness higher than God's, and God is not dependent on anything else for this goodness; the Good simply is God.

On the other hand, then: if this problem is raised by goodness, it will be raised by any number of other predications we make of God - truth, beauty, love, and so on. Yet we have just said that God just is Goodness, and the Good seems obviously to be different than truth or beauty, so we may wonder if the strategy we have applied to goodness is closed off for these other predications. Instead, Augustine reaches the rather more surprising conclusion that God, in fact, is Truth, and Beauty, and Love, and Being, and Wisdom, and so on for all things truly predicable of God's eternal life, again in such a way that all these come to serve not as descriptions of what God is, but as denominations of who God is. ${ }^{23}$ Just as God is not distinct from Goodness, but simply is Good, so also the Good cannot be distinct from the True, since the True is also simply God. ${ }^{24}$ While all of these predicates seem very different to us in our experience, and undoubtedly the realities of created goodness and created truth are and remain different, the truest form of these predicates is found in the one undivided life of God, where the Good and the True and the Beautiful all refer to the Lord who is the source of all good and true and beautiful things. We have come to what has been known in the Christian tradition as the doctrine of divine simplicity. As Augustine claims in the eleventh book of De civitate dei, "those things which are fundamentally and truly divine are called simple, because in them quality and substance are one and the same, and because they are divine, or wise, or blessed without participation in anything which is not themselves." 25 God is not, therefore, properly thought to possess any attributes at all - any of the predicates we ascribe truly to God are in fact identical with the divine life itself.

Even this presentation, however, stands the risk of making divine simplicity seem like a mere theoretical posit - the last cog to be snapped into place before the grand machinery of Augustine's theory can whir merrily to life. On the contrary, it is the recognition of the simplicity of God's life that answers to the intuition we saw in the first tractate on John's Gospel that God's way of existing is unthinkably different than our own. Even at its best prior to the Fall, creaturely life is fleeting, finite, extended (which is to say, stretched out) in space and time, a composite of parts with varying degrees of distance and separation between them, always gaining or losing qualities, growing and diminishing, utterly dependent on God both for setting the limits of its nature and for its very existence - and in virtue of this fact, nothing in itself, the same nothing out of which God drew it in creation. The claim that God is simple is a synecdoche for the denial of all these claims - it is, as David Burrell has noted, a "formal feature" of our speech about God, a

\footnotetext{
${ }^{23}$ In light of this fact, I have opted to follow the practice of capitalizing terms when I am predicating them substantially of God.

${ }^{24}$ Cf. trin. 6.7.8; WSA I/5, 211: "God however is indeed called in multiple ways great, good, wise, blessed, true, and anything else that seems not to be unworthy of him; but his greatness is identical with his wisdom (he is not great in mass but in might), and his goodness is identical with his wisdom and greatness, and his truth is identical with them all; and with him being blessed is not one thing, and being great or wise or true or good, or just simply being, another."

25 civ. 11.10; Augustine, The City of God against the Pagans, trans. R.W. Dyson (Cambridge: Cambridge University Press, 1998), 464. See also John P. Rosheger, "Augustine and Divine Simplicity," New Blackfriars 77, no. 901 (1996): $72-83$.
} 
rule of Christian discourse that we should deny of God all the sorts of composition and change to which creaturely life is subject. It is not simply, or even primarily, a thesis about what God's being is like. Instead, it is a way of pointing at a sort of life that is utterly unique, distinguishable from all else that exists, and on which all other life depends. Divine simplicity hopes, by way of contrast with our halting and finite attempts to reflect goodness and truth in our lives, to point to a life that is utterly integral, utterly complete, possessing all possible fullness and perfection.

It is this personal nature of God's simple life that Augustine means to call attention to in one of the most distinctive features of his thought: naming God as idipsum, the Selfsame. ${ }^{26}$ The term is found throughout Augustine's extensive career in writing, and its use as a name for God appears to be original to him. ${ }^{27}$ One sees, for example, him naming God as idipsum in the relatively early De moribus ecclesiae catholicae et de moribus Manicheorum: "Hence, we ought to love God, a certain triple oneness, Father, Son, and Holy Spirit, and I shall say that God is nothing other than being the selfsame (quod nihil aliud dicam esse, nisi idipsum esse)." 28 So also, one finds it in mid-period texts like conf. 9.4.11 and 12.7.7, into later texts like trin. 2.18.35; but perhaps his paradigmatic discussion of this name can be found in his exposition of Psalm 121:

What is idipsum? What am I to say, if not idipsum? Brothers, if you are able, understand idipsum, for whatever else I go on say, I will not have truly said idipsum. Even so, let us try through some proximate words and significations to lead our infirm minds to the thought of idipsum. What is idipsum? That which always is the same way; that which is not now one way, and then another. What, then, is idipsum, except that which is? And what is that which is? That which is eternal. ${ }^{29}$

There is a certain unsurpassability in Augustine's use of idipsum as a name for God: it is both the first word about God that should be spoken, for all the explanations that come afterward will not fully succeed in truly saying even this beginning. At the same time, it is the endpoint toward which all the "proximate words and significations" are directing us. This undoubtedly has much to do with the Scriptural provenance of this name. In the context of this passage, Augustine is commenting on the one hundred and twenty-first psalm, which reads for him Ierusalem quae aedificatur ut civitas. Cuius participatio eius in idipsum. It is, therefore, a name that God has given

\footnotetext{
${ }^{26}$ Jean-Luc Marion and Lewis Ayres each provide illuminating discussions of this feature of Augustine's thought; cf. Marion, In the Self's Place: The Approach of St. Augustine, trans. Jeffrey Kosky (Stanford: Stanford University Press, 2012), Ch. 7; and Ayres, Augustine and the Trinity, 200-208. See also Matthew Drever's discussion of idipsum in the context of the fall of the devil (155-7) and deification (170-9) in Image, Identity, and the Forming of the Augustinian Soul (Oxford: Oxford University Press, 2013).

${ }^{27}$ For a discussion of Augustine's use of idipsum in the context of his philosophical and theological predecessors, see Ayres, Augustine and the Trinity, 204-5.

28 mor. 14.24; WSA I/19, 42 (translation amended).

${ }^{29}$ en.Ps. 121.5: Quid est idipsum? Quomodo dicam, nisi idipsum? Fratres, si potestis, intellegite idipsum. Nam et ego quidquid aliud dixero, non dico idipsum. Conemur tamen quibusdam vicinitatibus verborum et significationum perducere infirmitatem mentis ad cogitandum idipsum. Quid est idipsum? Qhod semper eodem modo est; quod non modo aliud, et modo aliud est. Quid est ergo idipsum, nisi, quod est? Quid est quod est? Quod aeternum est.
} 
Herself, a name no less Scriptural than Exodus 3.14's Ego sum qui sum - and in fact, idipsum is often used as a gloss of God's self-denomination "I AM that I AM," as at en. Ps. 121.5.

To call God the Selfsame, then, is to point to the utterly unique mode of existence that we have been discussing: all that God is, God is without possibility of change, without anything prior or without any trace of composition; from all eternity, God simply is who and what God is. It is an affirmation, then, of God's self-identity, but also of God's independence from anything else that is: alone among all the things that are said to exist, God depends on no other, requires nothing for the fullness or actualization of the divine life, possesses all goods eternally in Himself. This is no sheer valorization of self-sufficiency, but rather a marker of how we are to relate to God: if God possesses the fullness of all goodness in Herself, then creation can add nothing to Her or make any contribution to the divine life. There is no internal need for creation in God; and if it is eternally God's will to create, this is attributable wholly to grace. ${ }^{30}$ It is from this mode of fullness and completion in the divine life that we must understand God's unchangeabilitybecause God possesses the fullness of Goodness and Being, because there is nothing God lacks, there is nothing into which God can change. Creaturely existence, by contrast, is from nothing, and therefore nothing in itself. It is wholly dependent upon God for its existence, and does so by virtue of its participation in Her. Here is the fundamental distinction marking of God from all that is not God, the Creator from the creation.

Yet even as naming God as idipsum helps us mark the distinction between God and creation, it sets a limit on our ability to comprehend God. If God is the Selfsame, abiding eternally complete in one simple life, all the categories we use to understand created being will fail to apply properly to God. Augustine begins his discussion of divine predication in De trinitate 5 by disavowing the adequacy of Aristotle's categories for describing God's life:

Thus we should understand God, if we can and as far as we can, to be good without quality, great without quantity, creative without need or necessity, presiding without position, holding all things together without possession, wholly everywhere without place, everlasting without time, without any change in himself making changeable things, and undergoing nothing. Whoever thinks of God like that may not yet be able to discover altogether what he is, but is at least piously on his guard against thinking about him anything that he is not. ${ }^{31}$

These tools are not fit to the task of describing God. Yet the problem is not with Aristotle's theoretical frame as such, but is with our human way of knowing itself. As creatures, we can only know in a manner fit to an existence stretched on the rack of time and space: just as our knowing is distended into separate moments of time, granting us the capacity to grow in knowledge even as it denies us the integral knowledge of God as He is, so also our acts of intellection require categories of understanding, whether these categories be understood on the Aristotelian or

${ }^{30}$ Cf. Sokolowski, God of Faith and Reason, 19.

31 trin. 5.1.2; WSA I/5, 190. On Aristotle's categories, see Aristotle, Categories and De Interpretatione, trans. J.L. Ackrill (Oxford: Oxford University Press, 1963), 5. 
Kantian models, or given through language or cultural conditioning. Though these categories may indeed assist us in coming to the partial knowledge of God proper to created intellects, any words or concepts we apply to God will fail "carve reality at the joints," for this reality admits of no ultimate metaphysical distinctions. Yet, even as this checks any misguided aspirations we may have of arriving at comprehensive knowledge of God's life, it properly locates our hope- for while philosophical conceptualizations will only get us so far, the status of idipsum as a revealed name of God tells us that this simple source of all things is one who speaks to us, who desires to draw us to Himself through the transitory signs adequate to our intellect, who wishes to be known to us as the God of Abraham, Isaac, and Jacob.

\section{The Unchangeable and the Changeable}

God does not remain alone in eternal beatitude, but calls into being the creation. Nevertheless, God can be no other than who She is in this relation. And because creation does not exist without this origin in God, every aspect of the relation between Creator and creature will be shaped by the account we give of the divine life. Several key features of how Augustine understands the created order and God's action within it thus appear as implications of - or answers to questions raised by - the account he offers of God's distinctness from creation.

Most obviously, Augustine's understanding of God's simple and unchangeable existence is explicitly contrasted with the mutable existence of creation. God is beyond any shadow of change because the divine life is not other than the predicates we ascribe to God, but the same cannot be said for creation. As we have already seen in the passage from De trinitate 5.10.11, creaturely existence is understood to be "great by partaking of greatness (participatione magnitudinis)," and for it "being is one thing and being great another."32 Creatures thus exist and possess the qualities they instantiate by virtue of participating in the true source of Being and (e.g.) Greatness; and, since God is the ultimate source of all that is not God, creatures will possess their being and its modifications not through participation in separable transcendent forms of the Good, True, and so on, but through their participation in the simple life of God. ${ }^{33}$ As a result, we should understand each creaturely nature - human, osprey, shrub, and so on - as a different "mode" of participating in the divine life, differentiated by the particular qualities the creature draws from God and the possible range of intensities it can exhibit as it participates.

Since the divine term of this participatory relation is essentially incomprehensible, it is best not to over-schematize here. ${ }^{34}$ Perhaps the most we can say about the relation of participation itself is that it is an asymmetrical relation of dependence that results in a likeness between the participant and that in which it participates. Yet Augustine's understanding of

\footnotetext{
32 trin. 5.10.11; WSA I/5, 196.

33 David Vincent Meconi has helpfully described the origins of Augustine's theory of participation and its christological applications in "St. Augustine's Early Theory of Participation," Augustinian Studies 27, no. 2 (1996): 7996; and "The Incarnation and the Role of Participation in St. Augustine's Confessions," Augustinian Studies 29, no. 2 (1998): 61-75.

34 So Paul Griffiths will speak of participation as a "figure," rather than a metaphysical theory, at Intellectual Appetite: $A$ Theological Grammar (Washington, D.C.: The Catholic University of America Press, 2009), 86-7.
} 
creaturely participation in God's life provides shape to virtually every aspect of his account of God's relation to the created order: In themselves, creatures are nothing; they are called out of nothing by the creative Word of God, and exist only inasmuch as they participate in God; because they find the origin of the particular goods they possess outside themselves, there are goods they do not instantiate that they might, or goods that they have that they might lose; this capacity for change opens the creature to modification both in ways proper to their natures (aging, movement in space, change in color, learning a new language, etc.) and in ways improper (sin); sinful change leads to the corruption of the creature, a defective participation in God that leads to the creature existing to a lesser degree than it should; reconciliation, by contrast, leads to a restored participation in God, and a greater degree of existence than it had possessed as sinner; ${ }^{35}$ evil should thus be understood as nothingness, that which does not participate in God to any degree. ${ }^{36}$ Not every particular of this highly telescoped version of Augustine's cosmology is straightforwardly entailed by the fundamental insight of creaturely participation in God; nevertheless, participation is the notion that pushes or allows Augustine's thought to develop along these lines. So also, one ought hardly to speak of creation in the Augustinian tradition without speaking in the next breath of the way that creation has been marred by sin: while it remains true that creation only exists insofar as it participates in God, its goodness has been deformed, and at times rendered hideous, by creaturely sin. I will have more to say about this in ensuing chapters, especially as we turn to more explicit discussion of Christ's redemptive work in Chapter 3.

Yet this account of creaturely participation raises in pointed form a central question for the Christian theologian: if the lack of change and composition are key features of the divine life that distinguish God from that which is not God, on which side of this distinction do the persons of the Son and Holy Spirit fall? Are they to be included somehow within the simplicity of God's life, or should they rather be included with the creation at this key juncture? The Scriptural witness unquestionably indicates a particular intimacy between God on the one hand and the Son and Holy Spirit on the other, but does not offer a theological or philosophical framework for interpreting this intimacy. Augustine was acutely aware of this question, and points to John 1.2 as offering one of the clearest Biblical indications of the Son's divinity in stating that "all things were made through him, and without him was made nothing." As Augustine writes,

\footnotetext{
35 One might resist the language of degrees of being here, and again it is important not to ossify our theological language. Nevertheless, I believe the notion to be fairly intuitive: God is Life, and one who participates in God more fully is more fully alive; God is Good, and one who participates in God more fully is more good than one who does so deficiently; God is Being, and one who participates in God more fully exists in a manner more intimate with God's own life than one who does not. A recent analytical philosophical defense of the notion of being as an intensive concept may be found in Kris McDaniel, "Degrees of Being," Philosopher's Imprint 13, no. 19 (2013): 1-18. ${ }^{36}$ Good introductions to the literature on Augustine's theology of evil as privation are: G.R. Evans, Augustine on Evil (Cambridge: Cambridge University Press, 1990); Williams, On Augustine, Ch. 5; and for the extension of this theoretical trajectory into modern political thought, Charles Mathewes, Evil and the Augustinian Tradition (Cambridge: Cambridge University Press, 2001).The question of how the good creation of God can come to be marred by evil is a separate question, and one that I shall return to in ensuing chapters.
} 
By all things he means only what has been made, that is every creature. So it is crystal clear that he through whom all things were made was not made himself. And if he is not made he is not a creature, and if he is not a creature he is of the same substance as the Father. For every substance that is not God is a creature, and that is not a creature is God. And if the Son is not of the same substance as the Father he is a made substance; if he is a made substance then not all things were made through him. But all things were made through him; therefore he is of one and the same substance as the Father. ${ }^{37}$

One rather suspects that a clever anti-Nicene thinker could find a way around this interpretation of John 1.2, but the importance of this passage lies elsewhere: Augustine is conceiving the difference between God and creation in such a way that there are no available intermediate states or degrees between God and that which is not God at which one could locate the Son. Either the Son is truly and wholly God, or the Son is to be included within the class of created beings. And our preceding discussion of divine simplicity only sharpens the problem: either somehow the Father and Son are one God in such a way that divine simplicity is preserved, or we must assert that the Father is the one simple God to the exclusion of the Son.

In fact, the technical vocabulary of the divine life that we have been exploring throughout De trinitate 5 is developed in the course of polemical engagement with Latin Homoian "Arians" who wished to ascribe a divinely exalted status to the Son without ascribing to Him the very nature of divinity, ${ }^{38}$ and we should not find this terribly surprising. The task of distinguishing God from that which is not God is straightforward when the contrast is between the Source of all that is, and the fragile, changeable creation that surrounds us; a precise grammar of divinity is only required by borderline cases, and the history of trinitarian controversy in the fourth century shows the divinity of the Son and Spirit to be cases of just this sort. Augustine's reflections on the divine life are inextricable from his discussions of the mutual relations of Father, Son, and Holy Spirit. It is, of course, never seriously a question for Augustine whether the Son and Spirit are true God along with the Father; as De trinitate 1 makes clear, he takes it to be the clear witness of both Scripture and ecclesial teaching that God is triune and that the trinitarian persons are coessential. ${ }^{39}$ But if we are to affirm that the Son is God, we must distinguish the Son from creation in the same way that we have proceeded so far - and in consequence, we must predicate omnipotence, omniscience, Goodness, Wisdom, and so on of the Son in the same way we predicate them of God, somehow allowing for trinitarian distinction without compromising our account of the simplicity of the divine life.

\footnotetext{
37 trin. 1.6.9; WSA I/5, 71.

38 See again Barnes, "The Arians of Book V."

39 trin. 1.2.4; WSA I/5, 67.
} 


\section{Speaking Trinitarianly}

To this point, the majority of my discussion in this chapter has focused on exploring the unitary and eternal character of God's divine life. This approach carries inevitable risks, foremost among them encouraging the opinion of those who still manage to believe that Augustine and the Latin Patristic tradition believe the unity of God to be more basic than the trinitarian persons (or emphasize the unity of God at the expense of God's triunity; or take the unity of God to underlie God's triunity), in contrast to the Cappadocian presumption of the basicality of the three persons. ${ }^{40}$ I offer three considerations in defense of my procedure. First, it seems to me that the fundamental logic of what we may, following Lewis Ayres, call the pro-Nicene position involves drawing a firm distinction between what is God and what is not God, and placing the three persons of the Trinity unquestionably on the divine side of the divide. ${ }^{41}$ Inasmuch as simplicity is taken to be fundamental to the grammar of Christian speech about God, then, discussion of the trinitarian persons should be conducted in light of the simplicity of God (and, no less importantly, vice-versa). ${ }^{42}$ Because the purpose of this first chapter (and this will be true of Chapter 2, as well) has primarily been to mark off the radical difference between God and creation in order properly to understand the scandal of the Incarnation, I have emphasized the unity of God to constrain our thinking, to intensify the difficulty of imagining this God becoming human, and hopefully, to understand better the gratuitousness of the Word's assumption of flesh as a result.

The second consideration is that asserting that the divine nature is simple, that each person of the Trinity possesses the fullness of the divine nature, and that each person of the Trinity is therefore properly understood to exist simply (as Catholic Christianity constrains us to do, since substantial predications made of the divine nature should also be predicated of the triune persons individually) threatens to leave the mistaken impression that there are three simple divinities, and three ultimate principles of Being, Goodness, Beauty, Truth, and so on, unless complemented by a strong emphasis on the unity and simplicity of God. This would be both theologically and philosophically disastrous; without wading into the perennial disputes about the relative weight of influences from Latin Christian and Neoplatonic sources on Augustine, it is clear that any suggestion of three divinities or three ultimate principles would be abhorrent to him. Both monotheism and the philosophical context of Late Antiquity push toward an emphasis on the oneness of God. If the incapacity of the human intellect to know and represent the divine life of God properly forces us to err, I choose to err in the direction of the name that the Lord gives to Moses on Sinai.

\footnotetext{
${ }^{40}$ Most of the guilty in our own day are systematic theologians; they should read, at the outset, Michel René Barnes, "De Régnon Reconsidered," Augustinian Studies 26, no. 2 (1995): 51-79; and Sarah Coakley, "Re-Thinking Gregory of Nyssa: Introduction - Gender, Trinitarian Analogies, and the Pedagogy of The Song," Modern Theology 18, no. 4 (2002): 431-443.

${ }^{41}$ Ayres develops simplicity, inseparable operations, and divine incomprehensibility as marks of the "pro-Nicene" theological culture's strategy of describing God's unity and triunity at Nicaea and its Legacy, 273-301.

42 The centrality of simplicity in Patristic speech about God has been well established in Andrew Radde-Gallwitz, Basil of Caesarea, Gregory of Nyssa, and the Transformation of Divine Simplicity (Oxford: Oxford University Press, 2009).
} 
Finally, I have chosen to emphasize the simplicity and unity of God's Being and action in light of a judgment about the present state of christology and trinitarian theology: it seems to me that we have grown too comfortable with the language of God's threeness, without being accompanied by a corresponding emphasis on the unity of God. ${ }^{43}$ God's unity is too often, by my lights, seen as something logically consequent to the actions of the three trinitarian personssomething that obtains in light of the threefold activity as opposed to something equally primordial in the eternal life of God. This is seen above all in the manifest heterodoxy of social trinitarianism, ${ }^{44}$ yet can also be seen in varied but unquestionably orthodox accounts of the divine life. While each individual instance is no doubt defensible, the cumulative weight of modern theologies that emphasize obedience within the trinitarian relations or the dramatic interplay within God's eternal life indicate a worrying trend. Focus on the simplicity of God fruitfully constrains christology; it makes conceiving of the Incarnation more difficult, and seeking out such difficulty can be incredibly useful in helping us avoid seductive misapprehensions. We make a mistake, I believe, by settling too naturally into the language of the threefold activity of the trinitarian persons within christological discourse.

If, then, Father, Son, and Holy Spirit must be distinguished from creation as God in identical fashion, either we must have some way of conceptually differentiating them from one another, or we must affirm that there is only one person in God. Returning to the argument of $D e$ trinitate 5-7, then, we may survey the possibilities left open to Augustine. Because each of the three persons stands on the divine side of the God-creation distinction, they cannot be distinguished according to substance; but because of the way that God must be distinguished from creationthe former as simple, the latter as granted the gift of participation in God - we cannot distinguish between the persons through some three properties or accidents that would inhere in (and thus threaten to partition) the divine substance. With these two options off the table, Augustine turns to another of Aristotle's categories, asserting that the triune persons may be distinguished according to relation. Just as "father" is a concept implicated in a necessary relation to the concept of "son" or "daughter" (because one cannot be a father without having a son or daughter), speaking of the first person of the Trinity as Father includes within it the Father's eternal relation to the Son. Speaking of God as Father or Son thus does not refer to their existence in itself, for in itself, the being of each is the one undivided substance of God. Rather, it refers to their existence in relation: one to another, and both to the Holy Spirit. ${ }^{45}$ Because these relations are not predicated accidentally, there is no possibility that they could change without changing the divine nature itself, and so must obtain eternally and unchangingly in the simple life

\footnotetext{
${ }^{43}$ John Zizioulas and Colin Gunton are paradigmatic of the tendency I have in mind; see John Zizioulas, Being as Communion: Studies in Personhood and the Church (Crestwood, NY: St. Vladimir's Seminary Press, 1997); and Colin Gunton, The Promise of Trinitarian Theology, 2nd Edition (London: T\&T Clark, 1997). Gunton's influential reading of Augustine has been ably critiqued by Bradley G. Green, Colin Gunton and the Failure of Augustine (Eugene, OR: Pickwick Publications, 2011), though Joshua McNall has attempted to revive some aspects of Gunton's proposal in A Free Corrector: Colin Gunton and the Legacy of Augustine (Minneapolis: Fortress Press, 2015).

${ }^{44}$ For a thoroughgoing critique of such approaches, see Sarah Coakley, Powers and Submissions: Spirituality, Philosophy, and Gender (Oxford: Blackwells Publishers Ltd, 2002), Ch. 7.

45 trin. 5.5.6; WSA I/5, 192.
} 
of God. As Augustine will write, comparing the case of trinitarian predication to more familiar instances of the category of relation:

Man and horse and sum of money are said with reference to self, and signify substances or beings; while master and slave and draught-animal and security are said with reference to something else, to signify certain relationships. But if it were not, for example, a man, that is some substance, there would be nothing there that could be called master by way of relationship... So if the Father is not also something with reference to himself (aliquid ad se ipsum), there is absolutely nothing there to be talked of with reference to something else. ${ }^{46}$

When predicating "father" under normal circumstances, the one said to be a father will be something in himself (a human person), as well as something in relation to some other human person who is that father's son or daughter. The case of the trinitarian predications of Father, Son, and Holy Spirit is similar to this everyday example in that each of the divine persons must be "something with reference to himself" - the Father must be some substance, as must the Son, as must the Holy Spirit. The trinitarian case is different from our standard predications in that the aliquid ad se ipsum of each of the three persons is the same - the divine substance. Yet this divine substance itself enfolds the relations of Father, Son, and Holy Spirit to one another, without requiring any division in essence. The person of the Father, defined by relations to the Son and Holy Spirit, exists in and as the simple substance of the one God; and the same may be said of the other triune persons. As Augustine has it, "each, Father and Son, is substance, and each is one substance (utrumque substantia et utrumque una substantia)." 47

Without question, our conceptual capacities are close to the point of breaking here. If Augustine's account is to offer us a real path forward in using our feeble human speech to talk about the eternal triunity of God, we need some assurance that our words at least have some aptitude for the task. Peter King offers an instructive analogy that may remove something of the suspicion of incoherence from Augustine's account, by showing how relative speech about the divine persons stands in some very limited continuity with the way we already employ relative attributions of identity. He writes,

Consider "teacher" and "student." These are commonly roles occupied by distinct persons, as for instance when Catherine teaches Julia to speak German, or to play the piano, or to do calculus. Yet Julia might instead have decided to teach herself how to play the piano, how to speak German, or how to do calculus. If she does, she is simultaneously teacher and student. On the one hand Julia sets herself the syllabus with lessons, goals, and homework exercises; on the other hand Julia studies her lessons and does her homework. In the end, she may well have

46 trin. 7.1.2; WSA I/5, 219-20.

47 trin. 7.1.2; WSA I/5, 220. 
succeeded as both teacher and student by mastering her subject. Hence we cannot infer that the object referred to by one of a pair of inverse reciprocal correlatives is not also the object referred to by the other member of the pair. This is the miraculous condition for "father" and "son" in the Trinity. In all other contexts, the object that is picked out by "father" is distinct from the object picked out by its inverse reciprocal correlative "son." Augustine, however, holds that God can stand in reflexive internal relations to Himself that can be described as "Father" and "Son," much as Julia can teach herself piano. How this happens is miraculous and beyond our powers to understand, but it is not contradictory to think that such a case might be possible, any more than self-taught learners are. The semantics do not rule it out. Whether metaphysics does is a question that Augustine is happy to leave aside, having faith that it does not. ${ }^{48}$

It is important to note here that King does not put forward Julia as a positive example how our predications relate to God's triune life; rather, the example is intended to short-circuit an inference that would have otherwise made our trinitarian predications impossible, viz. that when using inverse reciprocal correlatives like "father" and "son" we can infer that the terms do not refer to the same object. Julia can be both student and teacher because we can refer to two different activities she undertakes; but in the simplicity of God's life, there are no such distinctions that could ground the different identifications. Yet King has shown that we do have the semantic resources to use inverse reciprocal correlatives in a situation where reference is made to only one object, necessary if we are meaningfully to predicate "father" and "son" of the simple life of God.

Once we have at our disposal this grammar of relational predication, the key lines of Augustine's approach to God-talk are clear. All predications made of God must be made according to substance or according to relation. One predicates substantially when one calls God, e.g., great, good, wise, blessed, and so on; and because the substantial existence of each of the triune persons just is the one undivided divine substance, predicating Greatness, Goodness, Wisdom, or Blessedness of the Father are substantial rather than relative predications. Similarly, even though the Son's identity is relative to the Father and Holy Spirit, the Son's substantial identity just is the divine substance, and so when we say the Son is great, good, wise, or blessed, we are making a substantial predication of one and the same divine essence - and this against accounts that would hold that the Father is not wise without the Son, since Christ is the power of God and the wisdom of God (1 Cor. 1.24); or against accounts that would hold that only the three triune persons in relation may be validly considered to be great, good, wise, or blessed. On the other hand, there is a class of predications that are strictly relational and do not say anything at all about the substantial life of God, among which: Father, Son, Holy Spirit; Word, Paraclete; Father of our Lord, wisdom of the Father, Spirit of Christ; light from light, True God from True God; and more broadly, we can speak of the Father as the source of divinity, the Son and Holy

${ }^{48}$ Peter King, "The Semantics of Augustine's Trinitarian Analysis in De Trinitate 5-7," in Le De Trinitate de Saint Augustin: Exégèse, logique et noétique, ed. Emmanuel Bermon and Gerard O'Daly (Paris: Institut d'Études Augustiniennes, 2012): 123-135; 133. 
Spirit as the Father's two hands, and so on. There will be some cases that may be difficult to determine on a first pass; it is clear that "begotten" and "spirated" are relative terms, but "unbegotten" seems to be a substantial predicate that does not require an inverse reciprocal correlate. ${ }^{49}$ Yet upon closer inspection, we find even "unbegotten" to be a relational predicate: "when the Father is called unbegotten, it is not being stated what he is, but what he is not. And when a relationship is denied it is not denied substance-wise, because the relationship itself is not affirmed substance-wise." ${ }^{50}$ Strictly speaking, every divine predication must fall either into the class of substantial or of relational predications.

In a sense, then, Augustine does not give us an account of God's life such that we are able to "distinguish" Father, Son, and Holy Spirit in the divine Being, formally reconciling simplicity and triunity. Each of the divine persons stands on the divine side of the creator/creation divide, and so, the subsistence of each person is hidden in the simplicity of God's life - there are no fully comprehensible distinctions here we can draw that will allow us neatly to map on the triune persons. Even our language of modes of origination or relationships provide mere analogies of the sense in which what it is to be God eternally enfolds the relations of Father, Son, and Holy Spirit to one another. Both God's threeness and God's oneness stand on the far side of our apophatic reserve, and so the sense in which these three are one bears the mark of divine unknowability. ${ }^{51}$ The font of the doctrine of the Trinity thus cannot be any philosophical distinctions in God we have to offer - for us, as for Augustine, we should believe in God's triunity because it is the teaching of Scripture, and of the councils of the Church. Though we have no metaphysical story to tell of how it can be the case that God is both simple and eternally Father, Son, and Holy Spirit, such is the faith of the Church, and should be believed by all Christians. Indeed, it is the faith of the Church that secures the trinitarian relations as relations of origination, undergirding the important pro-Nicene account of the "monarchy" of the Father. Viewed strictly as a grammar of relational predication, Augustine's account would not require any inward "movement" within the Trinity, and could be viewed merely as logical distinctions. It is the teaching of the Church that leads us to view the triune Being and act of God as always a movement from the Father, through the Son, in the Holy Spirit, and to view the trinitarian relations as always beginning with the Father as fons deitatis, who eternally begets the Son and from whom the Spirit proceeds with and through the Son.

We must always remember, then, that asking after the Trinity is asking after the mystery of God's own life, and so we should expect a strict limit to our ability to comprehend it. Rather than seeking to render the doctrine of the Trinity coherent with the doctrine of divine simplicity, our more restrained aim should be to undermine claims of its incoherence - and this is precisely what Augustine does in offering a grammar of relational predication, showing us how our words can function to render sensible the notion of inverse reciprocal correlative predicates applying to

\footnotetext{
49 Precisely the argument of Augustine's opponents in trin. 5.6.7.

50 trin. 5.6.7; WSA I/5, 193.

51 These are the shoals on which all attempts within especially analytic philosophy of religion to render the doctrine of the trinity comprehensible run aground, and an error shared both by those who argue for the coherence and the incoherence of the doctrine of divine simplicity and the doctrine of the Trinity.
} 
one substance. Augustine has not provided a comprehensive understanding of God's way of being, but has given us enough of a linguistic and conceptual foothold that we can understand something of and reason about God's triunity.

At the same time, we need not careen into an epistemically-motivated attraction to modalism, as for example Schleiermacher seems to do. ${ }^{52}$ While we should renounce any aspiration of comprehending the metaphysics of the Trinity, the Church holds that God is tripersonal not only in the work of redemption, but even in God's eternal life in se. While our attempts properly to distinguish God from creation establish that God's life must lack composition, the doctrine of the Trinity informs us beyond the limits of reason's grasp that this simple life is eternally inwardly related as Father, Son, and Holy Spirit. These relations are neither logically prior to nor consequent upon the unity of the divine substance; rather, they are characteristic of it. If one were to imagine a divine substance abstracted from the three persons of the Trinity, one would necessarily be imagining something different than the Lord of Abraham, Isaac, and Jacob. ${ }^{53}$ Similarly, if one were to imagine three divine persons as separable godlets endowed with their own personal centers of knowledge and activity in abstraction from the simple Being of God, one would be imagining something other than the God who liberated Israel from Egypt and raised Christ from the dead. The end result is something close to mathematical relations: nine is three multiplied by three, but neither the unity of the number nine nor the relation of multiplication between its factors should be considered primary. ${ }^{54}$ Whether in theological reflection one considers the unity or the triunity first should thus be considered entirely a question of one's dialectical aims, and should in principle be rewritable beginning from the other perspective.

Let me pause for a moment and register a worry that I suspect has been for many readers around the edges of this whole discussion so far. My account of well-formed Augustinian utterances on the immutable, simple, and triune life of God has been spare, almost formalistic. Can such an account suffice as a description of the eternal triune life of the Creator of heaven and earth? By no means! Those whose hearts have been warmed by the fires of trinitarian piety are bound to find something missing - quite rightly - if they take what I have said so far as a complete trinitarian theology. Yet I believe there is an important lesson to be learned in the austerity of this trinitarian grammar.

As Linn Marie Tonstad has argued in her important God and Difference: The Trinity, Sexuality, and the Transformation of Finitude, the tendency in trinitarian theology in recent years has

\footnotetext{
${ }^{52}$ See the (in)famous conclusion on the Trinity in Schleiermacher's Glaubenslehre: Friedrich Daniel Ernst Schleiermacher, The Christian Faith, ed. H.R. Mackintosh and J.S. Stewart (Edinburgh: T\&T Clark, 1928), 738-51. But see also recent interpretations of Schleiermacher that emphasize his trinitarianism: Paul DeHart, "Ter mundus accipit infinitum: The Dogmatic Coordinates of Schleiermacher's Trinitarian Treatise," Neue Zeitschrift für Systematische Theologie und Religionsphilosophie 52, no. 1 (2010): 17-39; and Shelli Poe, Essential Trinitarianism: Schleiermacher as Trinitarian Theologian (London: Bloomsbury T\&T Clark, 2017).

53 Which is not quite the same as to say that if one referred to God as One without having knowledge of God as Father, Son, and Holy Spirit, that one would be referring to or knowing something different than the God of Abraham, Isaac, and Jacob.

54 Paul Griffiths compares the trinitarian relations to mathematical relations at Decreation: The Last Things of All Creatures (Waco, TX: Baylor University Press, 2014), 72.
} 
been to render the doctrine of the Trinity central for practical accounts of the Christian life. ${ }^{55}$ The trinitarian relations are taken to be paradigmatic of the relations obtaining between human persons, and so the Trinity is made the model for understanding the metaphysics of sexual difference, or the differences constitutive of political community, or the difference of erotic desire. The Trinity is thought to be a fruitful site even by those who wish to destabilize binary construals of these relations, in part because of the intimacy in differentiation that characterizes the mutual indwelling of the trinitarian persons. Tonstad argues, however, that the actual effect of this move has been to project our own experiences of difference mediated by sin into God. The result has been that the cross is imposed on the eternal life of God: the difference of the trinitarian persons is read as the estrangement of negativity, their mutual self-offering is taken to be a self-sacrificial kenosis, suffering is brought into the eternal life of God and read as standing at the origin of relation to the other, what Tonstad calls the "womb-wound." The original sin of this imaginary is the construal of the Father as the origin of the Trinity, with the Son and Holy Spirit both derivative of His original self-sufficiency. Through the doctrine of the trinitarian processions, heteronormative masculinity is inscribed in the heart of the Trinity, a fact which is covered over in the protestations that the Father is "father," but inconceivably different than any father with which we are familiar. What is truly inconceivable is that we might think of God as Father without this concept bearing for us the traces of patriarchy.

By contrast, Tonstad proposes that "If we put light together with dazzling darkness, we find our attempts to start with any one person of the trinity baffled. Instead, we encounter something like an ordered circle: an order in which each person has an irreversible relationship to the others but where relationships are not relationships of origin but of intensification or gift." 56 She suggests we construe God's inner life not through the model of modes of origination, but as "asymmetrical exchanges" and "triadic intransitive relations," 57 and the trinitarian community not according to the heterosexist logic of shattering interpenetration, but according to the queer logic of the clitoral touch that intensifies an enjoyment of mutual presence precisely by drawing bordered and integral selves into contact.

Tonstad is right, I think, to diagnose a tendency in contemporary trinitarian theology to project our sinful condition onto the eternal life of God, and to see too easy a connection between the sui generis difference proper to God's own life and the many differences that characterize our own lives as creatures. She is especially perceptive in calling attention to the way that trinitarian theology funds a defensive posture, neatly separating the wheat from the chaff, those whose theological approaches are sufficiently orthodox to be regarded from those who can be safely ignored. In beginning this dissertation in the way I have, I risk (and no doubt, to some extent, perform) precisely the moves Tonstad cautions against.

\footnotetext{
${ }^{55}$ Linn Marie Tonstad, God and Difference: The Trinity, Sexuality, and the Transformation of Finitude (New York: Routledge, 2016).

56 Tonstad, God and Difference, 228.

57 Tonstad, God and Difference, 229.
} 
Yet where I find her project most compelling, and where I hope the argument of this dissertation can be seen as pursuing a similar aspiration, is in Tonstad's attraction to what Karen Kilby has called an "apophatic trinitarianism." Tonstad cites Kilby as asking,

What if we were to suppose that how the three are one, how to relate the divine persons, what the inner relations between the persons are, are all questions which are quite simply beyond us?... What answers we may appear to have- answers drawing on notions of processions, relations, perichoresis - would be acknowledged as in fact no more than technical ways of articulating our inability to know. ${ }^{58}$

This ought not be read as undermining Christian confidence in God's triunity, or in the true revelation of God's life in the relation of Father and Holy Spirit to incarnate Son. Yet it suggests, as Augustine does too at least at some points in his trinitarian reflections, that we are drawn into a mystery that remains hidden to us, and will remain incomprehensible to us even when we see the triune Lord face to face. We ought not think we have too sure a grasp on this God who makes Herself known to us as both three and one. While I cannot follow Tonstad in dispensing totally with the language of processions - it is simply too deeply woven into the creeds of the Catholic Church, doctrinal statements which I believe to have been revealed authoritatively by the Holy Spirit - it nevertheless seems right to me to say that construing these as contentful descriptions of God's eternal life rather than as safeguards to mystery is a mistake. With Tonstad and Kilby then, and with at least some currents within Augustine's own thought, I suggest that christology begins with a persistent sense of God's radical otherness from the world of our experience, a presence of the triune God that constantly unsettles the categories of our reflection, and teaches us to receive the knowledge of God ever anew as the gift of the Holy Spirit.

\section{Conclusion}

Let me draw attention to three features of the preceding account. First, it is not incidental to my presentation that it begins with the words of Scripture. Scholars of early Christianity, and particularly of the fourth-century milieu that shaped Augustine's theological presuppositions, have drawn increasing attention in recent years to the significance of Scriptural interpretation in shaping doctrine. In many cases, this involved exegetical traditions surrounding important contested passages that were focal points for differentiating various theological approaches. More broadly, Patristic scholarship has emphasized that Scripture remained the starting-point and constant companion of early Christian theologians. Though my account here has been normative and constructive rather than historical in orientation, my hope has been to show that even seemingly recondite considerations about the eternal life of God can be motivated by reflection on the most basic Scriptural assertions about God. None of this is deductive, of course

${ }^{58}$ Karen Kilby, "Is an Apophatic Trinitarianism Possible?", International fournal of Systematic Theology 12, no. 1 (2010): 65-77; cited at Tonstad, God and Difference, 225. 
(Scripture is open to many different interpretations, as the history of doctrinal controversy in the early Church makes evident). Nevertheless, I believe that careful reflection on Scripture's predications of God as guided by core convictions about God's surpassing greatness render a picture of God's life indebted to fourth-century trinitarian theology (perhaps surprisingly) plausible. The Lord is Good; much else follows from reflection on this claim.

Second, by presenting this discussion as the introductory chapter to a study in Augustinian christology, I am staking out a position on the proper order of christological thinking. More specifically, I believe that attaining whatever clarity we can about the divine life in se productively focuses and constrains our discussions of how this God reveals Himself in the life of Jesus Christ. In this, I am placing myself alongside such recent theologians as Katherine Sonderegger, ${ }^{59}$ Sarah Coakley, ${ }^{60}$ and Thomas Joseph White, ${ }^{61}$ and against a host of theologians who hold that the person of Jesus Christ is the proper starting-point for theological reflection about both God and humanity. This difference in approach, though fundamental and affecting all that follows, certainly does not indicate that Christ is a secondary locus of theological interest (this is, after all, a work of christology), or deny that my approach and methodologically-opposed tacks can be placed in fruitful conversation. But it is, in part, an attempt to conform theological reflection to the history of revelation: God reveals Herself as the one God of Israel before assuming flesh in the person of Jesus Christ.

Third and finally, I have attempted here to conduct what most theologians would view as a thoroughly metaphysical discussion of God's life - making use of a range of concepts like being, participation, and the like - while nevertheless attending to the fact that Augustine's central arguments in De trinitate 5-7 concern our predication of attributes to God, rather than construction of a philosophical ontology. In this, I follow a number of recent scholars in attending to the role that language and the grammar of predication play in Augustine's thought, over-against accounts that seek to reconstruct a science of Being from Augustine. ${ }^{62}$ But I also situate myself within a broadly post-Wittgensteinian theological discourse, represented by thinkers loosely allied under the banners of "postliberal theology" and "grammatical Thomism," as well as individual figures like Rowan Williams, James Wetzel, and Stephen Mulhall. While the prominence of Wittgenstein in Christian theology has declined since the heyday of the Yale School, there remains a deep current of Augustinian studies shaped by his work, and with good reason. Wittgenstein, along with Augustine, was concerned with the way in which religious concepts take shape in the contexts of their use, and are therefore implicated in the concrete practices of daily life. Language is not a theoretical overlay that must correspond to the world; speech is action within the world. Inasmuch as we require discourse of the Good or of divine simplicity, then, or strategies of substantial and relational predication, these cannot simply be

\footnotetext{
${ }^{59}$ Katherine Sonderegger, Systematic Theology: The Doctrine of God, Vol. 1 (Minneapolis: Fortress Press, 2015).

${ }^{60}$ God, Sexuality, and the Self: An Essay 'On the Trinity' (Cambridge: Cambridge University Press, 2013).

61 Thomas Joseph White, O.P., The Incarnate Lord: A Thomistic Study in Christology (Washington, D.C.: The Catholic University of America Press, 2015).

62 I take Ayres, Barnes, King, and Morgan to offer different versions of such a perspective in the works of theirs I have cited in this chapter.
} 
posits of ontology, but must emerge from the everyday substance of the Christian life. Our technical vocabulary and distinctions are answerable to the conceptual problems of attempting properly to distinguish God from the world, or to speak of God as both three and one without compromising our patterns of speech about God's simplicity. In following Augustine's reasoning as I have, I have hoped to show that his theological reflections on the divine life are characterized by just these features. To the extent that our theological language is properly described as metaphysical, this metaphysics remains always tied to the language of faith. 


\section{Chapter 2}

\section{Day from Day: Time and the Incarnation}

This chapter turns, in light of the previous chapter's discussion of God's eternal life in se, to consider God's works directed to the created order, and particularly the act of the Word's assumption of flesh. The focus of this chapter, accordingly, is on what systematic theology has traditionally called "the person of Christ." Many theologians have come to see this doctrinal locus as unfortunately limiting, focusing on the metaphysical constitution of Christ's person to the exclusion of and in abstraction from God's redeeming work in Christ. Scholars like Hans Frei (and many following him) have sought to counter this distinction by writing "narrative christologies," generating an account of the union of divinity and humanity in Christ as both natures are seen working in the one person of the Incarnation. ${ }^{1}$ While such studies have made significant contributions to christological reflection, and while they have usefully troubled the person/work distinction, such an approach generally involves surrendering some of the philosophical precision observed in more classical christologies. In this chapter, I pursue a slightly different path - rather than attempting to bring clarity to the question of the union of divine and human natures in Christ through attention to his work, I try to view the Incarnation through the lens of the eternal work of God. I introduce the central problems of this chapter in an analysis of Augustine's sermo 187 on the Nativity, before turning in the heart of the chapter to a series of

\footnotetext{
${ }^{1}$ Cf. Hans Frei, The Identity of Jesus Christ. Eugene Rogers has extended this narrative treatment to pneumatology in Eugene F. Rogers, After the Spirit: A Constructive Pneumatology from Resources outside the Modern West (Grand Rapids: Wm. B. Eerdmans Publishing Co., 2005).
} 
questions designed progressively to narrow in concentric circles on the Word's particular action of assuming flesh into personal unity with the divine nature.

\section{Augustine on the Nativity: Sermo 187}

God became human: this simple confession of Christian faith still has the potential to be scandalous in the right context. God - the God who is unchanging, eternal-became human? The God who is exalted, matchless, exceeding all concepts or capacity for comprehension that we possess, became human? There is undoubtedly a temptation to render this claim more palatable, a temptation we might speculate as being the root of many anti-Nicene and anti-Chalcedonian christologies, both ancient and modern. Yet it is a temptation that Augustine largely resists in his homiletical works. When he is proclaiming the Christian faith to the congregations gathered at Hippo Regius or Carthage, his general preference is to ratchet up the paradoxical aspects of the doctrine of the Incarnation.

Sermo 187, a sermon preached on Christmas day in celebration of the Feast of the Nativity, ${ }^{2}$ opens with a dizzying rhetorical display of the tensions inherent in the Christian profession of God's assumption of flesh:

My mouth shall speak the praise of the Lord (Ps 51:15); of that Lord through whom all things were made (Jn 1:3), and who was himself made among all things; who is the revealer of the Father, creator of his mother; the son of God from the Father without mother, the son of man from his mother without Father; great as the day of the angels, little in the day of men; the Word, God before all times, the Word, flesh at the appropriate time; the maker and placer of the sun, made and placed under the sun; marshaling all the ages from the bosom of the Father, consecrating this day from the womb of his mother; remaining there, coming forth from here; producer of heaven and earth, appearing on earth under heaven; unspeakably wise, wisely speechless as an infant; filling the world, lying in a manger; directing the course of the stars, suckling his mother's breasts; so great in the form of God, so small in the form of a servant, in such a way that neither the greatness was diminished by the smallness, nor the smallness overwhelmed by the greatness. ${ }^{3}$

While we are likely to be drawn to the battery of striking characterizations of Christ's incarnation, we must not miss the crucial opening words of the passage. Augustine presents this high-flying rhetoric quite consciously as the language of praise. His purpose here is to provoke awe in his hearers at the reality of the Nativity, to offer them words that can express their own praise,

2 The date and location of the sermon are unclear.

${ }^{3}$ s. 187.1; WSA III/6, 27. 
or even to invite them to join in in offering words of praise. ${ }^{4}$ Yet this introductory encomium serves also as a map of many of the themes that appear over and over in Augustine's preaching on the Nativity, and his christology more broadly: the creator comes to dwell within creation; Christ is the one who manifests the Father; the God who is without time sanctifies one particular day by being born within it; the Word retains all the features of divinity while appearing in Christ within the limits of human flesh; Christ must be viewed both under the form of God and under the form of a servant, a characteristic use of the Christ hymn of Philippians 2.6-7; and finally, attention to the important typological role Mary plays, both nourishing the one who nourishes all creation, and signifying in her virginity both the integrity of human goodness in its created state and consecration to a chaste love of God that is the eschatological state of the redeemed. These themes appear over and over again within Augustine's thought, and will figure largely in our chapters to come.

Augustine is conscious, however, that his paradoxical language of praise - though it stands at both the beginning and (as we will see) the end of Christian proclamation of the Incarnation - can prove bewildering to those who have not learned how properly to relate divinity and humanity in the person of Jesus Christ, and so he once again reflects on how his own proclamation of the faith may serve as a model for the Word's assumption of flesh. "Why should all this surprise us about the Word of God," he asks, "seeing that this sermon I am addressing to you flows so freely into your senses, that you hearers both receive it, and don't imprison or corner it?"5 The initial question, then, is one of how the Word could be present both in the incarnate state and in the divine life's presence to all creation. One option might be to say that a part of the Word acts in the person of Christ, while the remainder continues to fill heaven and earth.

Against this, though, Augustine notes that as he speaks, all his words are heard simultaneously by all listeners - their being heard by one listener presents no problem for their being heard by others, and so, seemingly, it should be possible for the Word to be undividedly present both in the incarnate state and in the eternal glory of God. For if such presence without division is possible for the words Augustine speaks as he preaches,

How much more, then, could the Word of God, through which all things were made (Jn 1:3), and which while abiding in itself renews all things (Wis 7:27); which is neither confined in places, nor stretched out through times, nor varied by short and long quantities (quod nec locis concluditur, nec temporibus tenditur, nec morulis brevibus longisque variatur), nor woven together out of different sounds, nor ended by silence; how much more could this Word, of such a kind as that, make a mother's womb fruitful by assuming a body, while still not departing from the bosom of the Father; come forth from there to be seen by human eyes, from here to enlighten

\footnotetext{
${ }^{4}$ Carol Harrison has explored the role of the listener in early Christian preaching practices, noting how often preachers responded to the shouts of their hearers; cf. The Art of Listening, 145.

${ }^{5}$ s. 187.2; WSA III/6, 27.
} 
angelic minds; go forth from there to all the earth, from here to stretch out the heavens; from there become man, from here make man? ${ }^{6}$

While our examination of some of the philosophical implications of this passage will have to wait for a later section, the terms he uses here all relate to extension or partition. Given Augustine's commitment to divine simplicity, there are no such mereological distinctions to be drawn in the person of the Word, and so no possibility of attributing the Incarnation only to a part of the Word. Instead, the Incarnation must be understood as an act of the "whole Word," in its integrity as one of the three persons of God's eternal life.

At this point, Augustine turns to what we have seen is a more fundamental worry for him - the question of change in God. "None of you therefore should believe that the Son of God was converted and changed into a son of man; but rather we must believe that while remaining the Son of God he became the son of man, and that the divine substance was not consumed, while the human substance was perfectly assumed (sed potius credamus et non consumpta divina et perfecte assumpta humana substantia)"7 As expected, Augustine denies any mutability in God; yet this only intensifies the problem of how God could become human if there is no change in God. In what does the "perfect assumption" of human substance consist? Augustine turns to the familiar analogy of vocalized speech. On his reckoning, speech begins with an "internal word," an activity of the mind in which "the matter itself (res ipsa quae dicenda est), before any variety of expression in any language, is so to say naked to the intelligence in the bed-chamber of the mind, and which in order to come out from there is clothed in the voice of the speaker."8 In this context, the analogy is meant to display how a purely intelligible reality may be bound to material realities - the movements of lips, tongue, and vocal chords; the air waves that transmit sound; the vibrations of the hearer's eardrums ${ }^{9}$ - without undergoing any change qua inner word. At no point is the inner word transmuted into physical signs, even as it becomes manifest to other intellects by means of such signs. Similarly, the Incarnation occurs as the Word's assumption of flesh, rather than by any change in the Word itself.

Here, then, is the central point of sermo 187: "when from the world of time [the Word] took flesh, in order to come forth into our time-bound life, it did not in the flesh lose eternity, but rather on the flesh too bestowed immortality." 10 Without ceasing to be God, without

surrendering any of the qualities of divinity, the Son takes to Himself human flesh, raising it to an utterly unprecedented state of union with God. The eternal life of God is unchanged in any respect; yet the Word begins a new temporal existence in the human nature He assumes. And this assumed human nature is complete without any qualification: "All this, you see, that we are, whether in soul or in body, is our nature, but his condition; we, if we weren't this, wouldn't be at

\footnotetext{
${ }^{6}$ s. $187.2 ;$ WSA III/6, 28.

7 s. 187.3; WSA III/6, 28.

${ }^{8}$ s. 187.3: sed cum ante omnem linguarum diversitatem res ipsa quae dicenda est, adhuc in cubili cordis quodam modo nuda est intellegenti, quae ut inde procedat loquentis voce vestitur; WSA III/6, 28.

${ }^{9}$ On late antique theories of hearing, see Harrison, Art of Listening, 61-87.

10 s. 187.4; WSA III/6, 29.
} 
all; he, if he weren't this, would still of course be God." "Such statements may, at first glance, appear to advance little beyond the paradoxical constructions Augustine employs at the beginning of sermo 187, yet they serve an important clarificatory function within his christology. First, they rule out positing any change in God, even in the action of incarnation; and second, they make clear that the assumed human nature of Christ must be considered an "addition" to the Word in a sense yet to be explicated. The emphasis here is clearly on the contingency of the Incarnation on the divine will; the Word need not have assumed flesh, and would be complete in divinity without having done so. Yet we should not overlook the implications of Augustine's statement here for his christology: All this that we are has been taken up as the Word's condition in the Incarnation. Christ's humanity is full and complete, consisting in soul and body. While this is an obvious rejection of Apollinarian excesses, ${ }^{12}$ it also is an instructive moment in conceiving of how Augustine imagines the relation of divine and human natures. There is no need for the Word to "push out" any aspects of human nature in order for the Word to live fully in Christ's humanity; nothing in human nature must be compromised, or even presents any opposition, to its assumption by the Word. The Word may live fully in human nature without undermining its integrity in any way.

A final clarification near the end of this sermon specifies further, "He became man, you see, while remaining God, in order that the son of man too might rightly be called God with us; not one being God, another being man." 13 While this is not an explicit statement conceiving the unity of divine and human natures occurring in the one divine person, ${ }^{14}$ Augustine's purpose here is clearly to establish a unitary referent for locutions like "son of God" and "son of man"; while some predications of Christ may be true of him in virtue of his divine nature and some in virtue of his human nature, these are not to be understood as referring to two distinct subjects of predication, but to the one God who has become human. It is thus no surprise to see Augustine appeal in this same context to Philippians 2.6-7, making use of the forma Dei/forma servi motif to help resolve seeming contradictions in the predications we make of Christ. So, for instance, Christ's statement in John's Gospel that the Father is greater than he (Jn. 14.28) is true in virtue of the Word's incarnate state as forma servi, while his statement in the same Gospel that he and the Father are one (Jn. 10.30) is true in virtue of the forma Dei, the glory in which the Son is eternally equal to the Father. ${ }^{15}$ This exegetical strategy is one of the defining features of Augustine's interpretation of Scripture's statements about Christ, and figures prominently in all his mature christology. ${ }^{16}$

Having educated his hearers in this new strategy of christological predication, Augustine returns in the last words of the sermon to the paradoxical statements with which he began, and to the language of praise. He concludes

\footnotetext{
11 s. 187.4 ; WSA III/6, 29.

12 Cf. also conf. 7.19.25.

13 s. 187.4: Factus est enim homo, permanens Deus, ut et filius hominis recte vocetur Nobiscum Deus: non alter Deus, alter homo.; WSA III/6, 29, translation amended.

14 Though, as we will see below, Augustine comes to hold that the two natures are united in the person of the Word.

15 s. 187.4; WSA III/6, 29.

16 Ayres, Augustine and the Trinity, 142-7.
} 
And so let the world exult in the persons of all believers, for whose salvation the one through whom the world was made has come. The maker of Mary, born of Mary, the son of David, David's Lord (Mk 12:37), the seed of Abraham who is before Abraham (Jn 8:58), the maker of the earth, made on earth, the creator of heaven, created under heaven. He is the day which the Lord has made, and the Lord himself is the daylight of our minds. Let us walk in his light, let us exult and be merry in it ( $\mathrm{Ps}$ 118:24). ${ }^{17}$

Augustine has returned us, then, to where we began - but we are to hear these words with new ears. What had begun as contradiction and incoherence can be assessed in a new light, given by the affirmation of God's unchangeability and the strategy of Christological predication offered by the forma Dei/forma servi motif. Each side of the paired contradictory statements can now be read as speaking of Christ as under the form of God or form of a servant; while mystery and paradox remains, it is no longer to be located in the incoherence of Church teaching, but in the person of the Incarnate Lord. In point of fact, concluding sermo 187 in this manner suggests that Augustine's aim all along has been to help us understand the inner logic underlying the language of Christian praise - to guard against misapprehensions of the claim that the Word became flesh, to preserve the distinctness of divine and human natures even in the state of incarnation, yet to describe their union in such a way that Jesus Christ may be truly seen as God with us.

Sermo 187, and the nativity sermons more broadly, form a sort of overture of the concerns of this chapter. In concise form, heightened rhetorically by the liturgical context of Christmas, we find a preponderance of the central concerns that will occupy Augustine's reflections on the person of Christ throughout the body of his work. The sermon brings into light some of the key questions that will occupy us throughout this chapter, particularly questions concerning how the eternal God can unite Herself to human nature. Answering these questions will require an account encompassing not only the constitution of Christ's person, but an understanding more generally of God's action as it relates to the created order. Only when we have understood how God acts in relation to the world can we understand how God provides for its redemption in the Incarnation.

\section{The Work of Incarnation}

In the act of incarnation, the Second Person of the Trinity wills to assume human flesh and be born of Mary, an act of willing inseparable in the unity of the divine will from the Father's and the Spirit's act of willing that the Son should assume human flesh and be born of Mary. Several nested conceptual problems present themselves in this formulation. It will be useful to move through them in turn like a series of concentric circles, beginning with the widest scope of God's activity and narrowing down to God's act in the concrete person of Jesus Christ. Following

17 s. 187.4; WSA III/6, 29. 
this progression, then, we may ask: First, in identifying this act: what, if anything, differentiates this action of God from other divine actions in God's own life, marking off the Incarnation as distinct within God's work? Second, human flesh is a creation, utterly dependent for its existence on God's creative act; the Son's willing to assume flesh is therefore a work of God ad extra, and so an account of God's acts toward creation is needed. How are we to understand God's actions toward that which is not God? Third, we are told that the assumption of flesh is an act particularly of the Son; how are we to make sense of the attribution of particular acts to the trinitarian persons? Fourth, how are we to understand the content of this particular act, the assumption of human flesh into unity with the person of the Son? In the remainder of this chapter, I will consider each of these questions in turn.

\subsection{The Eternal Act of God}

What within the divine life marks off the act of incarnation as distinct among all the actions of God? In light of the preceding chapter's account of divine simplicity, this question can be dealt with fairly straightforwardly: nothing at all. Inasmuch as the Incarnation is distinguishable as an act of God separate from God's other actions, it is solely in virtue of the effects it brings about within the created order, namely the uniting of human flesh to the Word. In itself, the Second Person's assumption of flesh is identical to the one eternal act that is God's Being. In its classical Thomist statement, the identity of God's act and being are secured through a series of denials of composition: first a denial that there is any composition of act and potency in God (and so God must be actus purus, with no potency remaining to be actualized), and subsequently a denial that God is composed of essence and existence - what it is to be (the essence of) God is to be (the action) "to be."18 As James F. Anderson notes, however, "In Augustine, there is expressly no doctrine of 'potency-act' composition: the Bishop of Hippo was not an Aristotelian." 19 As a result, Augustine must take a different route to arrive at the same result. Returning to the notion of changeability that served as such an important starting point in last chapter's discussion, Anderson observes, “Augustine's mutabilitas functions as a kind of potency in the sense of an existential limitation, whereas his immutabilitas is simply 'act,' or as he himself often puts it, 'vere esse.' To be 'immutable' is to be incapable of not-being; to be 'mutable' is to be able not to be." 20 Rather than an act/potency distinction, therefore, it is a being/nonbeing distinction that animates Augustine's thought; and as for the Thomist, it is clear that it is in God's essence to be the verbal vere esse.

Consequently, when we approach the divine will which is conceived of as the action of God in all eternity, we are still answerable to the same considerations of simplicity that guided our discussion of God's life in se. The divine will cannot be composed of a set of volitional acts; neither can it change or develop. On the contrary, the divine will is identical to God's Being, full and entire from all eternity. And this is precisely what Augustine affirms on numerous occasions:

\footnotetext{
18 So David Burrell: "Aquinas is asserting: to be God is to be to-be"; Aquinas: God and Action, 26.

${ }^{19}$ James F. Anderson, St. Augustine and Being: A Metaphysical Essay (The Hague: Martinus Nijhoff, 1965$), 17$.

${ }^{20}$ Anderson, St. Augustine and Being, 17.
} 
You will surely not claim that everything Truth told me so loudly in my inward ear concerning the eternity of the creator was false? Can it be untrue that his substance varies not one whit throughout time, and that his will is not separate from his substance? From that I infer that he does not first will something, then something else; whatever he wills, he wills once only and all together and eternally, not in repetitive fashion, nor this today and that tomorrow, nor willing later what he did not will previously, nor going back later on what he wanted earlier. A will like that is subject to change, and anything changeable is not eternal; but our God is eternal... These are the truths I gather, and by combining them I discover that my God, the eternal God, did not bring creation into being by some new act of will, nor is his knowledge subject to any impermanence. ${ }^{21}$

Finally, then: "Your will is identical with yourself, and you made all things by no change of will whatsoever, without the emergence of any volition which had not previously been present."22 Here again, Augustine wishes to guard against the possibility of change, as well as the more abstract concern to avoid any notion of God's life including composition, with being as one part and will as another. The self-identity of God and God's will ensures that no change is conceivable in God's life. As a result, however, Augustine must claim that everything that God wills - from the creation of the world to its eventual resolution - is included in the divine will from all eternity. Augustine is thus led to affirm what Lewis Ayres identifies as one of the key principles of pro-Nicene theology: all God's operationes ad extra indivisa sunt - all God's actions toward that which is not God are indivisible. ${ }^{23}$ All God's actions, then - parting the Red Sea here, raising Lazarus there, striking down Ananias and Sapphira elsewhere - are rooted in the one simple and indivisible activity of God that is both eternal and eternally identical to God's Being. This activity is marked by the same incomprehensibility that characterizes all the perfections of God's essence, and contains all God's actions towards that which is not God - in it, God wills to create, sustain, and glorify the cosmos.

When applied to the specific act of assuming flesh, the following picture emerges: from all eternity, it is part of the content of the divine will that the Word should assume flesh and be born

${ }^{21}$ conf. 12.15.18; WSA I/1, 321-2. See also conf. 7.4.6 and 11.10.12, and the interesting exchange in David Bentley Hart, "The Hidden and the Manifest: Metaphysics after Nicaea," in Orthodox Readings of Augustine, ed. George E. Demacopoulos and Aristotle Papanikolaou (Crestwood, NY: St. Vladimir's Seminary Press, 2008), 191-226; and David Bradshaw, "Augustine the Metaphysician," in Orthodox Readings of Augustine, ed. George E. Demacopoulos and Aristotle Papanikolaou (Crestwood, NY: St. Vladimir's Seminary Press, 2008), 227-252, on the question of whether Augustine believes that God's eternal will includes all historical particulars, or if it is merely the faculty of divine will which is simple and eternal. As will be apparent, I side with Bradshaw on this issue, and cite also Katherin Rogers' observation that "Augustine says repeatedly that God foreknows the particular sins his individual creatures will commit", paralleling Augustine's statement in conf. 11.31.41 that "As you knew heaven and earth in the beginning, without the slightest modification in your knowledge, so too you made heaven and earth in the beginning without any distention in your activity" (WSA I/ 1, 311); Katherin A. Rogers, "St. Augustine on Time and Eternity," American Catholic Philosophical Quarterly 70, no. 2 (1996): 207-23; 209.

22 conf. 12.28.38; WSA I/ 1, 336.

${ }^{23}$ Ayres, Nicaea and its Legacy, 296-300. 
of the Virgin Mary. ${ }^{24}$ ("Being part of the content of the divine will" should be glossed in this case - though not in all cases - as "being a temporal effect of the one eternal act of God's being.") Insofar as we wish to speak of it as a particular act of God, we can do so only in virtue of our distinction of this effect (the uniting of flesh to the Word) from other effects of God's will (say, parting the Red Sea). But there is nothing in the divine will itself that corresponds to our marking off this act from other acts of God; the eternal will to become incarnate is therefore identical with the one simple act of God's Being. We must remember, however, that this one simple act is also internally structured; I will have more to say about the specifically Trinitarian character of the act of incarnation below.

We must, finally, say that this act is free: there is no internal necessity in God to create, God would be perfectly complete in beatitude without the existence of creation. Nevertheless, it is eternally part of the content of the will of God to create the world and assume flesh in the life of Jesus Christ: willing to do this freely is part of what it is for God to be God. The logic of this position can be discerned in Augustine's comment at civ. 5.10 that "we do not make the life of God and the foreknowledge of God subject to necessity if we say that it is 'necessary' for God to live forever and to foreknow all things. By the same token, His power is not diminished when we say that He 'cannot' die or err. For this is impossible to Him in such a way that, if it were possible, He would have less power." 25 If we were to say that God did not always possess the will to create the world and become incarnate in Christ, we would have to say that this volition arose in Her; but this would be to attribute mutability to God. Similarly, if God did not know from all eternity that She would create the world and become incarnate within it, we would have to say God attained this knowledge at some point. Here we might say with Augustine that if this were possible, God would be diminished. To attribute freedom to God is to say that God is under no constraint or compulsion to create, and especially that creation adds nothing to God. ${ }^{26}$

Nevertheless, God is always who God is; the character of God's Goodness is established from all eternity. God would not be less good had God not chosen to create, for this would imply some lack in God that is fulfilled through creation; or again, if we understood creation as some sort of mechanical emanation from God, God could not be God without creating. The eternity of God's will to create only comes to appear problematic or like the constraint of necessity if we view the Being of God as more basic than God's will, such that God's will should be constrained by God's Character. Similarly, the eternity of this will only appears like naked voluntarism if we view the will of God as more basic than God's Being, such that this will is construed as a motivationless choice between alternative possibilities in which God assigns content to God's Being. ${ }^{27}$ If Being

\footnotetext{
${ }^{24}$ Cf. trin. 2.5.9; WSA I/5, 103: "in the Wisdom of God, there was timelessly contained the time in which that Wisdom was to appear in the flesh. So while without any beginning of time in the beginning was the Word and the Word was with God and the Word was God (Jn 1:1), without any time there was in the Word the time at which the Word would become flesh and dwell among us (Jn 1:14)... The whole series of all times is timelessly contained in God's eternal wisdom."

25 Dyson, 204.

26 Sokolowski, God of Faith and Reason, 8-10.

27 One of the more interesting theological convergences in recent years has come between Barthians and Thomists reflecting together on the grounding of predestination in God's eternal life. Significant theological differences
} 
and will are viewed in the inseparability of divine simplicity, no threat of the necessity of creation arises even as we claim that God was never without the will to create and become incarnate.

\subsection{The Act of God in Relation to the Created Order}

\subsubsection{The Non-Competition of Divine and Greaturely Agency}

One of the central claims made in this study so far is that classical Christian speech about God holds that God must be distinguished from all else that is. There are many ways of marking off this distinction: we might say that God's essence is God's existence, that there is an infinite qualitative difference between God and all that is not God, that all terms we use to refer to God must be predicated analogically. What remains constant is that whatever we say of the created order, we cannot say about God's eternal life in precisely the same way.

When, then, we turn to the questions of agency or causality, our expectation is that the creaturely agency and causality with which we are familiar in our experience may exhibit some likeness to God's agency or causality, but that whatever likeness obtains will exist in the shadow of an infinitely greater dissimilarity. There must be some likeness between our agency and God's, or we will not be able to get any conceptual purchase on what it is like to act, but we must never make the mistake of thinking that what it is for us to act and what it is for God to act are the same.

What sort of relation thus obtains between our agency and God's? Can we do anything to fill in the exceedingly vague attribution of some "likeness" between them? In a series of publications which have become common currency among contemporary theologians, Kathryn Tanner has developed an account of the relation as being "non-competitive."28 Tanner writes, "God does not give on the same plane of being and activity as creatures, as one among other givers and therefore God is not in potential competition (or co-operation) with them."29 The crucial point to note for the time being is that not only does God not compete with creaturely action contingently - She does not even compete potentially. If it were possible under any circumstances for God's act to be in competition with our own, it would indicate that they operated on the same plane, that God could (if only potentially) elbow our freedom out of the picture by exercising Her own agency. So too, cooperation in a strict sense is out of the picture: for cooperation as Tanner intends it suggests a mutual contribution of agency, that we work together with God toward some common end, and that if either we or God were not to contribute our respective parts, that that end would not come about. If God's agency is simply on another plane than our own, however, God may be perfectly free in willing, and we may

remain, of course, but each side has seen in the other an instructive challenge. See especially Matthew Levering, "Christ, the Trinity, and Predestination: McCormack and Aquinas," in Trinity and Election in Contemporary Theology (Grand Rapids: Wm. B. Eerdmans Publishing Co., 2011), 244-73.

${ }^{28}$ Tanner's move from the language of a "non-contrastive" relation in God and Creation to that of "non-competitive" in later works seems to be a terminological innovation only.

${ }^{29}$ Tanner, Fesus, Humanity, and the Trinity, 3. 
similarly be perfectly free, without there being any conflict or competition: "The glorification of God does not come at the expense of creatures." 30 Tanner offers this account to head off precisely the worries that we discussed in the last chapter in our attempt properly to distinguish God from the created order. ${ }^{31}$

Yet there is a deeper motivation, as well. In viewing the relation between God's act and the agency and causality of the created order as non-competitive, Tanner means to suggest not merely that they run along parallel courses without interfering in each's proper activity, but that the agency and causality of the created order are founded upon God's agency. She writes,

This non-competitive relation between creatures and God is possible, it seems, only if God is the fecund provider of all that the creature is in itself; the creature in its giftedness, in its goodness, does not compete with God's gift-fullness and goodness because God is the giver of all that the creature is for the good. This relationship of total giver to total gift is possible, in turn, only if God and creatures are, so to speak, on different levels of being, and different planes of causalitysomething that God's transcendence implies. ${ }^{32}$

An understanding of the relation between divine and creaturely agency as non-competitive thus protects against certain sorts of theological error, but much more importantly teaches us to see all creation as founded on the act of God. All that is, is a gift, existing solely in response to God's originary act in which He grants the world existence.

Several implications follow from such an account. First, we ought not understand this non-competitive relation on the model of two self-contained spheres of activity, seeing divine and creaturely agency as insulated from one another. Though God's action cannot directly infringe upon our free agency, this is not because it is distant from us: as Tanner tells us, "Far from appearing to be incompatible with it, a non-contrastive transcendence of God suggest an extreme of divine involvement with the world - a divine involvement in the form of a productive agency extending to everything that is in an equally direct manner." 33 Because all creaturely agency and causality are founded upon the act of God, there is nothing that exists that is distant from God's action upon it; God's action must be understood as "immediate and universally extensive."34

Second, we should avoid any conceptual schemes that divide our agency and God's into mutually exclusive terms. So, for instance, "passivity with respect to God is not to be inserted into the usual contrast between passivity and activity that holds for creatures. Passivity before God is not the same as passivity as we understand it in relations among creatures; in relation to creatures, one cannot, as in relations with God, be active in virtue of being passive." ${ }^{35}$ Here, we

30 Tanner, Fesus, Humanity, and the Trinity, 2.

31 Tanner, God and Creation, 45.

32 Tanner, Jesus, Humanity, and the Trinity, 3.

33 Tanner, God and Creation, 46.

34 Tanner, God and Creation, 47.

35 Tanner, Fesus, Humanity, and the Trinity, 4. 
may introduce a slight terminological revision. As this contrast between activity and passivity makes clear, there is a sense in which we can (and indeed, should) say we cooperate with God, for God's activity does not and cannot preclude our own activity. It is better, on my view, to say that we can indeed cooperate with God, in that we can will the very same thing God wills, and play a part within our plane of agency in bringing it about - but we must also say that God's agency is irreducibly prior to our own. Thus, if God wills that St. Mark should write a gospel, there is nothing to prevent St. Mark from willing to write a gospel as well; and in fact, the Gospel of St. Mark is not written without St. Mark's writing it if that is what God wills. But this should never trick us into thinking that we cooperate with God in the strict sense that God requires our ratifying what She wills through our corresponding freedom in order to bring about Her purposes. God does not require our freedom - rather, God founds it. ${ }^{36}$

Finally, and perhaps most dramatically, Tanner tells us, "Christian talk of God's creative agency [must] be worked out in a genuinely radical way: God must be directly productive of everything that is in every aspect of its existence." 37 There is nothing that exists, in any of its particulars, that does not exist as God wills it to be. All that is, to the extent that it is, is the gift of God, and exists precisely as God wills it. And, to anticipate the account of divine timelessness I will provide presently, we should continue: the creative act of God exists irreducibly prior to any created temporality. As a result, we must understand the simple creative act of God as the one act in which God wills the entire course of created history, from beginning to end. "The divine will is radically transcendent, in other words, but necessarily efficacious: what God wills has to happen."38 This is a hard saying, particularly in light of the ravages of sin we see around us every day; and we should be careful to specify precisely what these claims entail in light of human sin. Tanner, in fact, explicitly leaves this question to the side in her fullest treatment of divine and creaturely non-competition. ${ }^{39}$

Augustine, however, goes somewhat further. In a letter of 428, Augustine writes of God:

of course nothing happens unless he himself does it or permits that it be done, and since he willingly does it and willingly permits it, absolutely nothing happens if he does not will it. Yet it is true to say that whatever is displeasing to him is done contrary to his will. Still, he permits evils to happen because he is powerful enough to produce good, which is his, out of evils, which are not his. ${ }^{40}$

Just what is going on in this puzzling passage, and how may it clarify the implications of God's non-competitive relation to created agency? Importantly, Augustine affirms that there is a true

\footnotetext{
${ }^{36}$ Cf. Tanner, God and Creation, 93: "Where created causes are operative, it is improper to claim that God's work is separately sufficient for a created effect to the exclusion of created causes. Such a statement is not well formed since God's creative intention includes in the instance the founding of created causes."

37 Tanner, God and Creation, 47.

38 Tanner, God and Creation, 73.

${ }^{39}$ Cf. God and Creation, 174n.12: "Questions of sin and evil are left out of account in what follows; the intelligibility of evil if a theologian follows our rules is a further question not addressed in this work."

${ }^{40}$ ep. 2*.8; WSA II/4, 237. Wetzel discusses this passage at Limits of Virtue, 209-10.
} 
sense in which the whole course of created history, inclusive of all the horrors sin wreaks on the world, is included within God's eternal will, with a priority to any created willing (sinful or otherwise). To put this in the starkest possible terms, God brings into being a created history that includes sin - a somewhat stronger statement than saying God brings into being a world knowing that there will be sin. We are pushed to this stronger formulation by two considerations: First, God brings the whole course of created history timelessly into being, and so there is no moment of that history that comes into being earlier than another with respect to God's life (a point to be developed below). Second, God not only "foreknows" what created agents will do, but knows what they will do as She brings them into being. Said differently, God's knowledge is itself creative. But if this is right, then God brings created agents into being knowing unquestionably that they will sin.

Does this not straightforwardly make God the author of sin? It does not. For as Tanner observes, "it is axiomatic that God creates only what is good," for Augustine no less than her. ${ }^{41}$ The appropriate question to ask is thus: what is the good that God wills in creating the creaturely agent who sins? There are two answers to this question. First, God wills the existence of the creaturely agent qua creaturely agent. Things exist by participation in God's life, and to the extent that they exist, they are good. For there to be any creature, whether sinful or no, it can exist solely by participation in God, and so there is some sense in which it is good, a claim that can be made of even the most vitiated creaturely agents. Furthermore, in willing it to exist, God wills it to exist as good. This is to say that God gives the creaturely agent all the agency it needs to will the good; if it goes on to sin, it is not as a result of the deficiency of God's gift, but as a result of a deficiency in its use of the agency God gives it. ${ }^{42}$ God wills the good, but the creature uses the true freedom that God grants it to sin. Yet there is still a problem: God still brings into a creature knowing that it will do evil. What can be the good in that? Second, then, God wills the good purpose that will be accomplished through and in spite of the sinful history that the creature wills. This is to say: the history of redemption is a history in which God wills the good of creation in spite of creaturely sin, and accomplishes that purpose perfectly.

This is bound to be an unsatisfying answer, and quite rightfully so. In fact, I wish to say that it is less an answer, and more a refusal of the possibility of answer to this question. ${ }^{43}$ Though this response bears the superficial features of solving a problem, it is far from a theodicy. It draws together a formal claim - that God can will only the good in creation - with a refusal to identify any conceivable good as the good that God wills in creating a history inclusive of creaturely sin. It says that, at present, there is no good we can possibly imagine that would account for the tragedy, the despair, the meaningless death we see all around us. It refuses to do anything that would mitigate the enormity of the world's sin, and refuses to place responsibility for this suffering anywhere but on the shoulders of God's permission that there should be a sinful

41 Tanner, God and Creation, 174n.12.

42 See Ch. 5 below.

43 I have been influenced on this point by Rowan Williams' response to the work of Marilyn McCord Adams, "Redeeming sorrows: Marilyn McCord Adams and the defeat of evil," in Wrestling with Angels: Conversations in Modern Theology, ed. Mike Higton (London: SCM Press, 2007), 255-74. 
creation. In saying that, in willing this devastated history, God wills some good purpose, I do not intend to say that we should not be anxious about whether God's justice will be vindicated; quite the opposite. To say that God permits a sinful creation is to lay a charge at God's feet: will He answer to it? Even the recognition of God's own suffering in the flesh of Christ can serve as no easy resolution here. Augustine's answer leaves us with the question of God's justice. In that light, responding that God wills some good in the course our broken cosmos follows can only be a profession of faith, a hope expressed that at the last day, what we have experienced here will be known as a happy fall. Until that day, the question remains open.

\subsubsection{Augustine on Eternity and Time}

The human flesh assumed by the Word is created; how, then, are we to understand the manner in which God is related to the created order? Any answer to the particular question of the relation of the Word to human flesh in Christ will be interwoven with a more general account of how God relates to creation as such; here, we find the question already broached in sermo 187 about how the eternal God can act within time.

A defining element of the Augustinian doctrine of creation is that time itself is created, or in the words of De civitate dei 11.6, "Beyond doubt, then, the world was made not in time, but simultaneously with time" (procul dubio non est mundus factus in tempore, sed cum tempore). ${ }^{44}$ Positing time's createdness clears up several thorny issues for Augustine: if time is not created, there is no reason in principle why the world could not exist eternally (a position which Augustine takes to be definitively proscribed by the Scriptural witness); and if time exists prior to creation, one must account for why God created at the moment that She did rather than some prior or later moment on the time-line, or surrender God's immutability in claiming that though formerly She had not desired to create, at a certain point She formed this volition. ${ }^{45}$ And further problems threaten the theologian who believes that time is not itself created by God: as is suggested by Augustine's rejection of any "distention in [God's] activity," positing the co-eternity of time alongside God might indicate that God is extended in time, that there are moments of time out of which the divine life is composed. Clearly, this is unacceptable on an Augustinian account of simplicity.

When Augustine describes the life of God as "eternal," then, what he means is that God's life is utterly prior to time, and therefore utterly lacking in temporal predicates. As he writes in his famous discussion of time in Confessions 11,

You have precedence over the past by the loftiness of your ever-present eternity, and you live beyond all the future, because future times are future, but as soon as they have arrived they will be past, where as you are ever the same, and your years fail not. Your years do not come and go. Our years pass and new ones arrive

\footnotetext{
44 Dyson, 456.
}

45 Cf. civ. 11.4. 
only so that all may come in turn, but your years stand all at once, because they are stable: there is no pushing out of vanishing years by those that are coming on, because with you none are transient. In our case, our years will be complete only when there are none left. Your years are a single day, and this day of yours is not a daily recurrence, but a simple "Today," because your Today does not give way to tomorrow, nor follow yesterday. Your Today is eternity, and therefore your Son, to whom you said, Today have I begotten you, is coeternal with you. You have made all eras of time and you are before all time, and there was never a "time" when time did not exist. ${ }^{46}$

And, in view of this description of God's life, God's creative act - which is to say, the one act encompassing all God's activity toward the created order - must exist eternally and timelessly:

Thus in that Word who is coeternal with yourself you speak all that you speak simultaneously and eternally, and whatever you say shall be comes into being. Your creative act is in no way different from your speaking. Yet things which you create by speaking do not all come to be simultaneously, nor are they eternal. ${ }^{47}$

At this point, it appears we are close to an account of God's relation to the created order; it is clear that on an Augustinian account temporal predications do not apply properly to God, and equally clear that God's activity may nevertheless have temporal effects. All that remains is to describe how an eternal act may have a temporal effect - yet it is precisely this point at which Augustine's thought loses the ability to go on. The main outlines of Augustine's position in relating God's eternity and temporal creation are clear, but instead of giving us one account of the metaphysics of time such that we could coherently describe how God's action can produce effects at a moment of time without actually acting at that time, he offers us a bevy of descriptions of the nature of. As Jason W. Carter has recently argued in a careful study, there are in fact "at least nine distinct views on the nature of time" in Augustine's thought. ${ }^{48}$

The attribution of timelessness to God can, I think, serve an incredibly important purpose in the course of christological reflection. In describing the Word as becoming incarnate in Christ, we are tempted to assume a somewhat mythological picture in which the Word departs from eternity and comes to dwell within the flesh of Christ. No one would be so crude as to hold this as a well-formed christological account, of course; what I am suggesting is something more subtle. When we think about the eternal life of God, we might just be able to imagine a life so different

\footnotetext{
${ }^{46}$ conf. 11.13.16; WSA I/ 1295.

${ }^{47}$ conf. 11.7.9; WSA I/1, 291.

${ }^{48} \mathrm{He}$ lists them as "time as (1) an infinitely divisible continuum, (2) a series of minimal temporal intervals, (3) composed of time numbers, (4) a non-extended present, (5) a distention of the soul (distentio animi), (6) subjective in nature, (7) the product of the world-soul or angelic motion, (8) an accident of an enduring substance, and (9) consisting only of past and future moments", concluding that this picture "can be made consistent under the definition of time as an order of accidental changes in created substances"; Jason W. Carter, "St. Augustine on Time, Time Numbers, and Enduring Objects," Vivarium 49, no. 4 (2011): 301-23; 302 (emphasis original).
} 
than our own that it does not seem totally devoid of content to speak of activity without succession or duration, immutable but not static, one and yet three. Yet when we claim that one of the three persons of that life became incarnate and lived in human flesh, walked among us, ate and drank, willed as we will, this task becomes even more difficult. We can easily lapse into thinking that the Word must exist in Christ in a manner other than in the simplicity of the divine life, that some part or aspect of God's eternity enters into temporality - and so, that behind and in addition to the temporal human willing of Christ, there is a divine willing that changes over the course of his life. So we might say: at one moment Christ wills as both God and human to eat a fish; at another moment, he wills as both God and human to deliver a sermon. But this is precisely the wrong picture. The divine will in Christ is none other than the will which is the eternal life of the World, atemporally perfect, complete, and one; the divine will of Christ as he wishes to eat the fish is utterly identical to the divine will of Christ as he preaches. What changes - all that changes in his willing - is the human will of Christ. All that is temporal in the life of Jesus Christ, vere Deus et vere homo, is the humanity of Christ, assumed into perfect unity without any change in the divine nature.

Attention to God's timeless serves as a sort of wedge for christology, forcing the issue of the relation of Christ's divine and human natures, and keeping us always attentive the persistent difference in natures that renders their true union in the person of Christ all the more remarkable. For if the Word is none other than the eternal and timeless Second Person of the Trinity even in the context of the Incarnation, we must reckon with the reality that this very flesh exists in utter dependence upon the eternal life of God, that it is in fact the Word's own flesh through which He lives in time. Tarrying with the contemporary analytic philosophy of time will provide us resources for understanding how God's eternity might be thought to relate timelessly to creaturely temporality, and in so doing, will help us explore how divinity and humanity are related in the one person of Christ.

\subsubsection{God and the Philosophy of Time}

The central division in the field of philosophy of time within the analytic tradition is between those positions (lamentably) denoted as A-theories or B-theories. The man responsible for this terminology is the Scottish philosopher J.M.E. McTaggart, who in 1908 distinguished between two ways of conceiving of time's order. ${ }^{49}$ The first way, what McTaggart called the "A series," looks out from the vantage point of the present moment and sees moments of time stretching back into the past in one direction, and moments of time stretching forward into the future in the other. The second way, the "B series," assumes a standpoint outside the temporal order itself and surveys the relations obtaining between moments of time of being earlier than, later than, or simultaneous with other moments of time. Both the A-series and the B-series will have all the same moments of time in the same order, of course; the question is whether there is a privileged moment of time - the present - that can divide the whole series into a past, a present,

${ }^{49}$ J.M.E. McTaggart, "The Unreality of Time." Mind, 1908: 457-74. 
and a future, or whether all moments of time are on equal ontological footing, with the only relevant temporal distinctions being the relations of earlier-than, later-than, and simultaneous-with. The division between A-theories and B-theories of time tracks which of these series a philosophy takes to be more metaphysically basic. An A-theorist of time will argue that the passage of time involves metaphysical change, specifically holding that (i) there is some unique objectively privileged time, the present; and (ii) that which moment of time is present changes. A B-theorist will hold that the present moment is ontologically just like any other moment, and that in fact all moments of time, whether past, present, or future, exist in some unrestricted sense. Ross Cameron states the distinction between A-theories and B-theories with a bit more precision when he writes that A-theories are committed to the conjunction of two claims that B-theories reject:

Privileged present: There is a unique objectively privileged time: the time which is present. No description of reality can be correct and complete without specifying which time is present.

....and

Temporary presentness: What time is objectively privileged changes: the time that objectively present either was or will not be present (or both), and some time that is not objectively present either was or will be (or both). ${ }^{50}$

Among A-theories of time, the dominant account is known as "presentism." Though it can be defined in various ways, Dean Zimmerman writes that presentism is "the doctrine that all reality is confined to the present - that past and future things simply do not exist, and that all quantified statements that seem to carry commitment to past or future things are either false or susceptible of paraphrase into statements that avoid the implication."51 The presentist holds, then, that all that exists is that which exists at the present moment. There is no sense in which anything past or future exists; perhaps it existed at one time, but that time has vanished utterly into nothingness. What exists, then, is constantly in flux: there are no triceratopses anywhere in existence; there are no colonies on mars, even if it may nevertheless be true that we will colonize mars at some future time; all that exists, exists now. We might contrast this with the "Growing Block" theory, an A-theory in which it is held that the present moment comes into existence but does not pass out of it as the present moment moves forward in time. Because the past continues to exist for the growing blocker, we might imagine the history of the times in existence as a fourdimensional block of spacetime, with one "growing edge" as newly present times continue to be added to the block; whereas for the presentist, all that exists is the present moment and its three familiar spatial dimensions. ${ }^{52}$ Completing the range of what are known as the "standard" A-

\footnotetext{
${ }^{50}$ Ross P. Cameron, The Moving Spotlight: An Essay on Time and Eternity (Oxford: Oxford University Press, 2015$), 2$.

${ }^{51}$ Dean W. Zimmerman, "The A-Theory of Time, The B-Theory of Time, and 'Taking Tense Seriously'," dialectica 59, no. 4 (2005): 401-57; 402. Trenton Merricks adopts a similar but slightly simpler formulation at "Persistence, parts, and presentism," Nous 33, no. 3 (1999): 421-38; 424, writing that "the presentist holds that the only objects that exist... are those that exist at the present time."

${ }^{52}$ G.D. Broad offers the classical statement of this position in C.D. Broad, Scientific Thought (London: Routledge \& Kegan Paul, 1923); but see Trenton Merricks' critique in "Goodbye Growing Block," Oxford studies in metaphysics 2
} 
theories is the "Moving Spotlight" view, which in its classical expression claims that all past, present, and future moments exist in some sense, but that which moment is present (and consequently, which moments are past and future) change throughout time; ${ }^{53}$ and there are also a range of non-standard A-theories that incorporate some account of metaphysical change over time, without clearly aligning with any of the classical models discussed above. ${ }^{54}$

Arguably the most important feature of A-theoretic accounts of time is that they seem to satisfy a fundamental phenomenological intuition rooted in our experience of the world - that time flows, that ingredient to the passage of time is true metaphysical change in what there is. Among the A-theories, presentism in particular exhibits clear theoretical virtues, chief among which is the answer it provides to the problem of temporary intrinsic properties. Consider this example: when I was young, I was three feet tall. At present, I am a little less than six feet tall. It seems, then, that both the properties of being three feet tall and being 5'9" can be predicated of me; but how can I hold both these conflicting properties? The presentist says that I am 5'9" simpliciter, that there is no part of me that is 3", because I exist wholly at the present moment and my present existence is 5'9". Another potential virtue of presentism (and the Growing Block theory) is that it allows for an "open future"-because the future does not exist, it seems wholly undetermined, thus allowing free decisions to play a role in bringing about one set of future states of affairs rather than another. Yet presentism also faces challenges that the other standard Atheories and the B-theory do not: consider that for the presentist, nowhere in existence are there any kings of England. What then makes it true at present that there have been six English kings named George? What makes it true that dinosaurs once ruled the earth, considering that there are no dinosaurs anywhere in existence? There are answers that presentists may give to these questions, of course, but they do involve some philosophical gymnastics.

Two considerations, I believe, should push the Augustinian theologian to reject presentism, and A-theoretic accounts of time more broadly - the first properly philosophical, the second rooted in the specifics of an Augustinian account of divine eternity. In the first place, presentism appears incompatible with the constraints set on our thinking about time by the theory of special relativity. ${ }^{55}$ The presentist, at least in her classical form, believes that there is a simultaneity relation that holds between all things in existence; all that exists, exists simultaneously, for the only things that exist are those that exist at the present moment. According to special relativity, however, there is no such globally-transitive simultaneity relation; simultaneity is instead relative to inertial frames. Suppose an observer standing still perceives two spatially distant events to occur simultaneously; an observer moving at some constant speed

(2006): 103-10. For a theological use of the Growing Block theory, see Hud Hudson, The Fall and Hypertime (Oxford: Oxford University Press, 2014).

${ }^{53}$ Ross Cameron has recently offered a forceful statement of the view in The Moving Spotlight, but see also Bradford Skow, "Relativity and the Moving Spotlight," The Fournal of Philosophy 106, no. 12 (2009): 666-78; and Daniel Deasy, "The Moving Spotlight Theory," Philosophical Studies 172, no. 8 (2015): 2073-89.

54 Two important recent non-standard A-theoretic accounts can be found in "Tense and Reality," in Modality and Tense: Philosophical Papers (Oxford: Oxford University Press, 2005), 261-320; and Oliver Pooley, "XVI-Relativity, the Open Future, and the Passage of Time," Proceedings of the Aristotelian Society 113, no. 3.3 (2013): 321-63.

55 Theodore Sider has argued this point extensively in the second chapter of Four-Dimensionalism; see Fourdimensionalism: An Ontology of Persistence and Time (Oxford: Oxford University Press, 2001). 
relative to the first inertial frame will see these events occurring at different times. Because there is no absolute inertial frame, there is no empirically observable fact of the matter about what is simultaneous with what; and so, there seems to be no candidate for the sort of temporal relation the presentist needs in order to say that all that exists is what exists at the present time. Special relativity thus pushes us toward a view of cosmic history as a manifold inwardly related through a variety of spatiotemporal distance relations, ordered into simultaneity relations relative to inertial frames - a view fully consistent with four-dimensionalism.

The most detailed and systematic recent argument for presentism's viability in the face of relativity can be found in Dean Zimmerman's "Presentism and the Space-Time Manifold," in which he draws extensively on Bradley Monton's defense of presentism from the perspective of quantum gravity. ${ }^{56}$ Yet philosophers with expertise in both metaphysics and relativistic physics have, for the most part, found Zimmerman's case unconvincing. Zimmerman and Monton both appeal to the fact that special relativity is not, strictly speaking, considered a true theory of spacetime, but has instead been superseded by general relativity; and even general relativity may yet be superseded by a quantum gravity model like string theory. Christian Wüthrich notes, however, that the special relativity's underlying account of inertial frame-relativity "is fantastically well confirmed in many disparate contexts and for many different phenomena"; rather than viewing special relativity as a superseded theory, then, "we should regard it as a 'second-order constraint' on...more fundamental theories" 57 like general relativity or quantum gravitation, requiring that any more complete theory incorporate the relativity of inertial frames.

Both Wüthrich and Oliver Pooley point out that special relativity leaves us with no physically definable feature of the spacetime manifold available to play the role of the absolute simultaneity relation, the defender of presentism must posit an additional metaphysical fact that "cannot possibly find expression in the physical realm." ${ }^{58}$ But if the metaphysical fact that we are using to define presentism is in principle unobservable, it seems difficult to imagine that this could answer to our intuitions that what exists is what is simultaneous with us in the present moment. To summarize this objection, then: presentism is the A-theory that has commanded the widest assent of those attracted to the notion of metaphysical change over time. Yet we have significant reason to think that presentism is incompatible with our best theories of fundamental physics, or would ramp the theoretical costs of holding presentism up so high that the theory would lose much of the attraction it holds in its more intuitive forms.

Second, Paul Helm offers a compelling argument that any A-theoretic account of time will entail surrendering either the doctrine of God's omniscience, or of God's unchangeability; for the Augustinian Christian, either of these options is clearly unacceptable. Helm, adapting an

\footnotetext{
${ }^{56}$ Dean W. Zimmerman, "Presentism and the Space-Time Manifold," in The Oxford Handbook of the Philosophy of Time, ed. Craig Callender (Oxford: Oxford University Press, 2011), 163-244.

${ }^{57}$ Christian Wüthrich, "The fate of presentism in modern physics," in New Papers on the Present-Focus on Presentism, ed. Roberto Ciunti, Kristie Miller and Giuliano Torrengo (Munich: Philosophia Verlag, 2012), 1-23; 20; see also Wüthrich, "No presentism in quantum gravity," in Space, Time, and Spacetime (Heidelberg: Springer Berlin, 2010), 25778.

58 Wüthrich, "Fate of Presentism," 10.
} 
argument found in Eleonore Stump and Norman Kretzmann's classic article "Eternity,"59 formulates the argument as a reductio:

(1) An eternal God is not subject to change.

(2) An eternal God knows everything.

(3) A being that knows everything always knows what time it is.

(4) A being that always knows what time it is is necessarily subject to change.

(5) Therefore an eternal God is subject to change.

(6) Therefore an eternal God is not an eternal God.

(7) Therefore there is no eternal God. ${ }^{60}$

The fundamental problem is this: if we conceive of time as the A-theory does - as metaphysical change in what exists simpliciter (as the presentist holds), as expansion in what exists over time (Growing Block), or as change in what existents are currently present (Moving Spotlight) - there will be substantive change in what is true over time, and therefore change in what God knows to be true over time. For example, when there are triceratopses that exist in the world, God knows that it is true that triceratopses exist; but at the present moment, if the A-theory is true, God knows that it is false that triceratopses exist. Similarly, God knows as I am writing this that it is now April 30, 2016, but God knows that it is now a different time whenever you are reading this. It is not enough to temporally index these claims, by saying (for instance) that it is eternally true that God knows triceratopses exist whenever triceratopses exist, and that God knows which moment is present at each moment of time, for the A-theory insists that there is change in what exists itself. Either God cannot know these temporally-indexed facts, or God must Herself occupy a changing position within the temporal order. For this reason, an Augustinian thinker committed to both omniscience and unchangeability should prefer a B-theoretic account of time; to such accounts we now turn.

The fundamental intuition of the B-theorist, or "four-dimensionalist," is that we should think of time as a fourth dimension on a relatively close analogy to the three spatial dimensions with which we are most familiar. I am currently writing this in Charlottesville, VA; on the other side of the world is Kathmandu, Nepal. I have never been to Kathmandu, and so my mental image of Kathmandu is radically underdetermined when compared to my ability to imagine my parents' home in Richmond, VA; and both of these are pale shadows of the vibrant sensory experiences I am having in this room. Nevertheless, the city of Kathmandu and its inhabitants go about their daily lives, no less real for my spatial separation from them. For the fourdimensionalist, time should be understood similarly; specifying that a time is present is an indexical statement, akin to saying that I am here in Charlottesville rather than there in Kathmandu. Our experience of the present is dramatically different than that of any of the times from which we are temporally separated; yet when we think about existence in an unqualified

${ }^{59}$ Eleonore Stump and Norman Kretzmann, "Eternity," The fournal of Philosophy 78, no. 8 (1981): 429-58.

60 Paul Helm, Eternal God, 2nd Edition (Oxford: Oxford University Press, 2010), 74. 
sense, it is true to say that other times exist, and that we bear various relations of closeness or distantness to them.

Imagine the whole course of created time, then, as a three-dimensional block extended before us, where a two-dimensional slice of the block represents all the things that are simultaneous with one another. Just as I have parts extended in space of which I am composed of the present moment, arms and legs and so on, so also I have parts extended in time of which I am composed - each of these is to be understood as all the spatial parts that are simultaneous with one another at any one of these time slices; and I myself am perhaps best understood as the four-dimensional object composed by all of these slices, stretched out like a spacetime worm through our block of existing times. This provides a ready solution to the problem of temporary intrinsics: I have a three-foot-tall temporal part located around 1991, and a 5'9" temporal part existing in 2016; and similarly, the problem of past truthmakers is easily resolved - it is now true that there have been six kings George because there are six kings George that exist in the past. And this accords nicely with relativistic thinking: as Theodore Sider notes, "Since the fourdimensionalist's part-whole relation is atemporal, the theory of that relation is unaffected by relativistic considerations (Of course, which parts of a spacetime worm count as temporal parts is a matter affected by relativity, but that is different)." ${ }^{1}$ Sider's point is that while relativistic considerations will have an affect on which regions of spacetime should be considered to exist simultaneous to with one another (and therefore counting as spatial parts, rather than temporal parts), the question of which points of spacetime compose an object is an atemporal matter, and therefore are unaffected by relativity.

On the four-dimensionalist account, then, each point of spacetime exists within the spacetime manifold already standing in all the spatiotemporal relations it bears to every other point of spacetime. There are a range of relations that the spacetime region occupied by my left arm bear to the region of spacetime occupied by the Westbrook Nebula; and individual relations between time-slices of both my arm and the Westbrook Nebula will be observable as either space-like simultaneity relations or as temporal relations depending on the inertial frame of the observer. Similarly, I and the spacetime region I encompass always bear fixed relations within the four-dimensional manifold to the Eiffel Tower, relations that are space-like between my timeslices and the time-slices of the Eiffel Tower that exist simultaneously with them, and a temporal relation between (for example) the moment of my birth and the tower's opening on May 6, 1889. Part of what it is for me to be the concrete physical being that I am is for me to stand in these spatial and temporal relations to the Eiffel Tower, the Westbrook Nebula, and in fact, all other points of spacetime.

Without providing us with a metaphysical account of God's timelessness, this model of the nature of time does help us sort between competing accounts of divine timelessness. A recent example of this can be drawn from Ryan Mullins' recent work The End of the Timeless God. Mullins observes that many defenders of divine timelessness opt for a four-dimensionalist account of time because they believe that it helps make sense of claims like God's eternally causing creation, or of

${ }^{61}$ Sider, Four-Dimensionalism, 84. 
God's eternal knowledge of all created truths. Because God's action is eternal, there is a sense in which creation is eternally present to God. But as Mullins notes, four-dimensionalism does not remove time entirely from the block universe. Time and temporal change are understood here on the model of spatial change - just as the same road can be smooth at one point become rough further down it, so also the same person can be three feet tall as a child and later in time be six feet tall. ${ }^{62}$ What it is for something to be temporal on this account is simply to occupy regions of time, and what it is to change is to instantiate different properties at different regions of time. While many defenders of timelessness attempt to differentiate between existing "at" a time and existing "in" time, it is not clear on the four-dimensionalist account what could provide the principle of distinction - quantification over what exists at a time is already what fourdimensionalists use to identify when something is temporally located, when something has a temporal part. But if it is part of God's eternity to exist simultaneous to all times, as some proponents of divine timelessness have wanted to say, the four-dimensionalist account of time suggests we should say that God exists at every time - but by the lights of four-dimensionalism, that is just to say that God is changelessly temporal, with a temporal part existing at every time. And we seem to reach this conclusion even if we opt for a simultaneity relation like that proposed by Eleonore Stump and Norman Kretzmann, in which an eternal reality can exist simultaneous with every moment of time without those moments of time existing simultaneously with one another. Adoption of a four-dimensionalist metaphysic of time should therefore lead the adherent of divine timelessness to deny with Paul Helm and Brian Leftow that God exists simultaneous to any time. ${ }^{63}$ As Helm writes,

to attempt to raise, in a strict and philosophical manner, questions about the simultaneity and non-simultaneity of the divine will and human wills (for example) is to be guilty of a category mistake. It is like asking for the physical dimensions of a thought. The eternally timeless God is not the sort of individual that can have temporal relations with anything distinct from him... The creation is not temporally present to God in his knowing it, nor is it distant. God knows, and that is all. ${ }^{64}$

Brian Leftow, operating from a similar intuition, develops a logic for claiming "that [the proposition] 'God exists' is true, but not true at any time." 65 Considerations like these push us

\footnotetext{
${ }^{62}$ R.T. Mullins, The End of the Timeless God (Oxford: Oxford University Press, 2016).

${ }^{63}$ Helm, Eternal God, Ch. 2; and Brian Leftow, Time and Eternity (Ithaca, NY: Cornell University Press, 1991$)$, Ch. 4.

${ }^{64}$ Helm, Eternal God, 37.

65 Leftow, Time and Eternity, 50. Though Leftow rejects Stump and Kretzmann's "E-T simultaneity" relation, he follows them in attempting to conceive of eternity as possessing duration in a position he describes as QuasiTemporal Eternity. Katherin Rogers has argued convincingly against both Stump and Kretzmann's position and Leftow's in Katherin A. Rogers, "Eternity has no Duration," Religious Studies 30, no. 1 (1994): 1-16, identifying her final position as one drawn from Augustine and Anselm's later development of the Augustinian position: "The temporal phenomenon with which we are familiar which is most like eternity is the present, durationless, instant... The analogy points out that eternity may be present to all time as the present instant is to all space" (15).
} 
toward a view of God's existence attentive to the radical disjunction between the temporally extended created order and God's timeless life.

How then, to return at last to the question that opened this section, are we to understand how an God - now understood even more stringently as a God who cannot properly stand in any temporal relations - can bring about and act within a temporal created order? In the first place, we must understand the creative act of God not as the first cause in the series of created causes, but rather as God's bringing into being the entire course of created history, in all its concrete particulars: from the formation of galaxy filaments, to Caesar's crossing the Rubicon, to the founding of the first Martian colony, to the fall of the sparrow. As Helm writes, "in creation God brings into being (timelessly) the whole temporal matrix. He knows (timelessly) all about it. In his mind all events are brought together, but they are not brought together at a time, but timelessly. God is time-free." 66 The act of creation thus brings about the entirety of the four-dimensional block (or again, all time-slices), constituting all the points of spacetime and ordering their relations into spacetime's relativistic topography. ${ }^{67}$ Inasmuch as this is an account of God as the "cause" of creation, it is an analogical use of causal language:

what the [four-dimensionalist] account of creation is maintaining is that the universe depends on God in that it has a relation of asymmetrical dependence upon the will of God. To be strictly accurate, what the view maintains is that the universe, considered as a whole, exists at no time, but is dependent on the eternal will of God. Events occur in time as a consequence of the exercise of the powers of created things. In addition, some events, such as miracles, may occur that have a direct eternal cause and a temporal effect. ${ }^{68}$

By understanding creation as God's bringing into being all of cosmic history in the one eternal act of His Being, we therefore avoid other problematic construals of the divine activity within the created order - the notion of miracles as God's reaching in to tinker with an otherwise-integral finite order, or (as in Schleiermacher) the restriction of God's activity to grounding the order of finite causes. ${ }^{69}$

On the timeless creation account, it is eternally part of God's will and creative act that the world should be such that the Red Sea parted before Moses and the Israelites, or that Lazarus should be restored to life at the command of Christ. No further act beyond the one activity of God's life is required, or conceivable. Furthermore, the language of four-dimensionalism gives us additional resources for understanding the Word's assumption of flesh: with respect to the physical element of Christ's flesh (more on the soul in section 2.2.iv of this chapter), what is

${ }^{66}$ Helm, Eternal God, 27.

67 The best scientific theories currently available suggest that we should conceive of these points of spacetime as actually existing, rather than these points being reducible to the spacetime relations between existing objects; on this, see Oliver Pooley, "Substantivalist and Relationalist Approaches to Spacetime," in The Oxford Handbook of Philosophy of Physics, ed. Robert Batterman (Oxford: Oxford University Press, 2013), 522-86.

68 Helm, Eternal God, 241.

69 Schleiermacher, The Christian Faith, §54. 
assumed is a spacetime region, a four-dimensional object composed of all the time-slices of Christ's life, beginning in Bethlehem and extending throughout the course of his life. ${ }^{70}$ The act of incarnation should thus be understood as the act of God's Being, identical with the creative act, considered in light of the effect of the human flesh of Christ being assumed into union with the Word.

Returning to Augustine, we may note (following Katherin Rogers) that while there are unquestionably passages in the North African bishop's writing that resist assimilation to a fourdimensionalist position, ${ }^{71}$ there are significant currents in Augustine's thought that push us toward a B-theoretic position. ${ }^{72}$ As Rogers notes, the four-dimensionalist position accords nicely with Augustine's claim in diu. qu. 17 that

Whatever is past no longer exists, and whatever is future does not yet exist. Both the past and the future, therefore, are entirely absent. To God, however, nothing is absent, and hence nothing is either past or future, but everything is present to God. 73

Similarly, the four-dimensionalist's claim that each point of spacetime comes into being already bearing its relations to all other points of spacetime is paralleled by Augustine's words in conf. 11.8.10 that "Everything which begins to exist and then ceases to exist does so at the due time for its beginning and cessation decreed in that eternal Reason where nothing begins or comes to an end." 74 While we should prescind from attributing a four-dimensionalist position to Augustine himself in the interest of avoiding anachronism, we are justified in adopting it as the most coherent account of time in a contemporary Augustinian theology, and in viewing it as a useful tool for thinking through the implications of Augustine's account of God's timeless creation of the world. ${ }^{75}$

In concluding this section, we may raise two potential worries or objections to the fourdimensionalist picture of time. First, the account of time's nature that I have given here, though it

70 There are, of course, some fascinating but knotty problems here surrounding the Ascension and Eucharist, including where Christ's body should be understood to exist physically now, and whether consecrated hosts should be understood as regions of spacetime that are parts of the spacetime continuant of Christ's physical existence. For a series of illuminating treatments of how these issues were approached in the medieval period, see Marilyn McCord Adams, Some Later Medieval Theories of the Eucharist: Thomas Aquinas, Giles of Rome, Duns Scotus, and William Ockham (Oxford: Oxford University Press, 2012).

71 "Anselm on Eternity as the Fifth Dimension," Saint Anselm fournal 3 (2006): 1-8; 3.

72 Rogers has developed this case in detail in "St. Augustine on Time and Eternity." One of the virtues of her reconstruction is that it gives significant attention to the "Heaven of Heavens" of conf. 12, and to the significance of angelic movement within Augustine's writings on time. While I do not believe that a contemporary Augustinian four-dimensionalist position requires either component of Augustine's own thought, they are important for interpreting him correctly. For a contemporary argument against the thesis that time's passage requires movement or change, see Sydney Shoemaker, "Time without Change," The Fournal of Philosophy 66, no. 12 (1969): 363-81.

73 diu. qu. 17; WSA I/12, 37. Cf. Rogers, "St. Augustine on Time and Eternity," 210.

74 conf. 11.8.10; WSA I/1, 291.

75 In addition for Rogers, Paul Griffiths has made impressive use of four-dimensionalism in his recent Decreation, written from a broadly Augustinian standpoint; see $\S \S 13-16$. 
accords well with modern physics, seems to many to conflict with our sense of the dynamic passage of time; for though we perceive the moments of time in ordered succession, nothing metaphysically changes in them. Second, we may worry that this account implies that the world is coeternal with God. ${ }^{76}$

In response to the first objection, the four-dimensionalist will encourage us to think back to the analogy between time and the three spatial dimensions. I experience the room where I am now with great vividness, but not places far removed from me- I simply am not the sort of creature that can perceive what is currently happening across the world, I have no faculty that would allow me to do so. Human creatures are similarly the sorts of things that can perceive things "close" to them in their spatiotemporal relations - the present moment - but not that which is past or future. Again, we are simply not the sorts of things that can perceive that which is separated from us temporally, rather than spatially. Nevertheless, we are the sorts of things who perceive our lives unfolding sequentially, moving from time to time in order - it is part of our creaturely existence that we should perceive those things that stand in close space-like relations to us, with memory of what we have previously perceived but is now past, and without memory or perception (except perhaps in rare occasions, with some sort of prophetic knowledge) of what is in our future. Four-dimensionalism is a theory about what time is, but is not intended to deny how we experience time, or to offer a substantive thesis about what it is to exist as a temporal creature rather than as time's creator. ${ }^{77}$

This brings us to the second point. As I have quoted Helm as arguing above, fourdimensionalism ought not be understood as arguing that creation as a whole exists eternally, but rather that it exists at no time, in an asymmetric relation of dependence on God's creative act. Creation does not exist eternally, but it is founded in eternity; when we attempt to view creation as a whole, what we are struggling for is precisely the vantage point of the eternal God. ${ }^{78}$ In the more technical language of existential quantification native to the analytic philosophy of time, we are attempting to quantify over an unrestricted domain, asking what exists simpliciter - in any way, at any place, at any time. ${ }^{79}$ Philosophers often speak as if this is a fairly easy theoretical move: just remove any of the limits we place on our thinking. It is by no means clear, however, that the limit of temporality is something we can remove, or think beyond.

When we ask whether there are any triceratopses anywhere in existence, it is clear that there are none that exist now, none that are present to me; but to ask whether there are any triceratopses simpliciter is to ask whether there are any included and participating in the eternal activity of God's creation - and here the answer seems to be yes. But we should not underestimate the difficulty or the spiritual peril of attempting to view creation from God's eternal standpoint on an analogy of our own ability to view a three-dimensional block before us.

\footnotetext{
76 This worry is exacerbated by the fact that four-dimensionalism or the B-theory are sometimes known as "eternalism" within the philosophical literature.

77 See also the literature on our sense of time's passage below at Ch. 5n.10.

78 Helm, Eternal God, Ch. 14.

${ }^{79}$ In brief, existential quantification is just what it sounds like - an attempt to "count" the entities that exist within a specified range (the "domain").
} 
James Wetzel points to Augustine's own attempt to imagine God's perception in conf. 11.31.41, wherein considers the sense in which he is able to know the entire psalm he is singing at once, to hold it integrally in his mind. Yet at the crucial moment of this imagining, Augustine pulls back from asserting that this is indeed how God knows creation: "But far be it from us to suppose that you, the creator of the universe, creator of souls and bodies, know all things future and past in this fashion! Perish the thought! Far, far more wonderful is your mode of knowing, and far more mysterious." 80 What turns him back, Wetzel tells us, is the recognition that Augustine has only gained this small degree of insight into how God might perceive creation by nearly taking himself out of time - limiting the domain of thought, cutting away from consideration all his life but the brief moments when he is singing the song. In order to gain some insight into how God perceives, he has attempted to abstract almost out of time one brief passage in his life, and in so doing, has become something radically different than the time-bound creature that he is, receiving his whole life as a gift from God. In refusing to rest comfortably with this model of divine knowing,

Augustine has here refused himself the consolation of an analogy. He will not let those brief times when he feels at one with his knowing shape his expectation of the divine intelligence... The closer I bring God to a mildly distended human mind, the more I am driven to trivialize my human awareness of time. I cannot be thinking about life and death, good and evil, when I have time only briefly in mind. Augustine is right. Not only am I nowhere near the mystery of God's time; I am running in the other direction. I am running by leaps and bounds away from incarnation. ${ }^{81}$

Where does this leave us? Four-dimensionalism offers us an analogy for understanding God's creative act, but because this activity is itself identical with the life of the unknowable God, it is not an analogy that can leave us comfortable in our knowledge of God's eternity. It is perhaps best understood as a tool for clearing away misunderstandings of eternity: the notion that God could perceive metaphysical change, as the A-theorist holds, or that eternity should be understood as having a duration, or that an understanding of God's life as timeless means that God's act cannot bring about effects within the created order. This theory gives us just enough of a glimpse of God's eternity to clear away our misconceptions - but we must never think this allows us to occupy the standpoint of eternity, to know as God knows.

\subsection{The Act of Assuming of Flesh as an Act of the Son}

It is essential to the proper description of the act of incarnation that it be understood as the Word's assumption of flesh. In the life of Christ, it is the Second Person of the Trinity that is

${ }^{80}$ conf. 11.31.41; WSA I/1, 311 .

${ }^{81}$ James Wetzel, Augustine: A Guide for the Perplexed (London: T\&T Clark, 2010), 125. 
born of the Blessed Virgin Mary and nourished at her breast; who receives baptism at the hand of St. John; who preaches throughout Galilee, heals and exorcises; who offers his Body and Blood to his disciples in the upper room; who is crucified, dies, and is raised on the third day; who appears to Mary, and to the twelve; and who is received into heaven after forty days. ${ }^{82}$ Though the Word acts inseparably from the Father and Spirit in the activity which is the life of the one who is idipsum (the selfsame), how are we to understand the act of assuming flesh as an act proper to the Son?

This question is the central focus of Augustine's sermo 52, likely preached between 410 and 412 at roughly the midpoint of the time he spent composing the De trinitate. ${ }^{83}$ The homily centers on Augustine's exegesis of the Baptism of Christ as recounted in the Gospel according to St. Matthew. This story shows us, Augustine tells us, "the three, somehow or other, clearly distinguished (distinctam quodam modo Trinitatem): in the voice the Father, in the man the Son, in the dove the Holy Spirit"; 84 and, in a statement the controversial nature of which Augustine is clearly aware, "I make bold to say (I say it timidly enough, but I still make bold to say it), we have the three apparently separable... These three are apparently separated by place, separated by function, separated by action." 85 Yet this apparently innocuous statement is enough to raise a question in the projected voice of his listeners; Augustine imagines his hearers urging him "Demonstrate that the three are inseparable. Remember you're speaking as a Catholic, speaking to Catholics." "86 Though the narrative of Christ's baptism displays three actors in voice, man, and dove, the Catholic faith holds "that Father, Son, and Holy Spirit are one inseparable trinity or triad; one God, not three gods; but one God in such a way that the Son is not the Father, that the Father is not the Son, that the Holy Spirit is neither the Father nor the Son, but the Spirit of the Father and of the Son." 87 The task of the sermon, then, is to answer a question "commonly discussed in the conversations of those who love God's word"88: "Does the Father do anything that the Son doesn't do, or the Son do anything that the Father doesn't do?"89 Telegraphing his conclusion, Augustine tells us that when God "has brought our efforts to a successful conclusion, we will have to understand that the Holy Spirit too is in no way excluded from the activity of the Father and of the Son." 90 It is perhaps worth noting that even here, where the explicit focus of

\footnotetext{
82 If I may be forgiven the rhetorical excess of long lists like this, my hope in multiplying examples of this sort is to emphasize the particularity and multiplicity of the aspects of the created order ordered in relation to Christ's flesh. My practice has been shaped by Ian Bogost's discussion of similar lists in the work of Bruno Latour, what he calls "Latour litanies"; see Ian Bogost, Alien Phenomenology, or What it's Like to be a Thing (Minneapolis: University of Minnesota Press, 2012), 38-9.

${ }^{83}$ Cf. Hill, WSA III/3, 62-63n.1. Lewis Ayres has written extensively and insightfully on this sermon in his "Remember That You are Catholic (serm. 52.2): Augustine on the Unity of the Triune God," Fournal of Early Christian Studies 8, no. 1 (2000): 39-82.

84 s. 52.1; WSA III/3, 50.

85 s. 52.2: audeo dicere (quamvis timide id dicam, tamen audeo) quasi separabilem Trinitatem... tria haec quasi separantur locis, separantur officiis, separantur operibus; WSA III/3, 51.

86 s. 52.2 ; WSA III/3, 51 .

87 s. 52.2 ; WSA III/ 3,51 .

88 s. 52.4; WSA III/3, 52.

89 s. 52.4; WSA III/3, 52.

90 s. 52.4: intellegitur etiam Spiritus sanctus ab operatione Patris et Filii nequaquam discedere; WSA III/3, 52.
} 
discussion is the threeness of the divine activity, when Augustine speaks of the activity of the Father, Son, and Spirit, he uses the singular ab operatione, rather than the plural ab operationibus.

Augustine's task, then, is to explore the sense in which the operation of the triune persons can be both inseparable and distinguishable in God's threeness, a task he pursues through considering a series of Scriptural texts concerning the activities of Father and Son. His first example, of the creation and ordering of all things through the Word, he takes to be uncontroversial: "The whole of creation made through the Son - we naturally understand that the Father made it through his Word, God made it through his power and his wisdom."91 And as an uncontroversial example, he takes it to establish the rule that he will apply to the more challenging instances he will proceed to examine, concluding: "Thus the Father does nothing without the Son, the Son nothing without the Father."92

This rule provides for an appropriate intensification of the difficulty in attributing particular acts to the trinitarian persons, and for the solution of this problem. On the face of it, the rule may seem to push us toward either modalism or Patripassianism: "If the Father does nothing without the Son and the Son nothing without the Father, won't it follow, presumably, that we have to say the Father too was born of the Virgin Mary, the Father suffered under Pontius Pilate, the Father rose again and ascended into heaven?"93 What is needed in cases like these is the proper disambiguation of the Father's and Son's (and, by extension and less commonly with explicit Scriptural support, the Spirit's) work in accomplishing these actions: "It was not indeed the Father, but the Son who suffered; yet the suffering of the Son was the work of both Father and Son. It wasn't the Father who rose again, but the Son; yet the resurrection of the Son was the work of both Father and Son."94 There follows Augustine's analysis of the Father's and Son's co-operation in working the Nativity, the Crucifixion, and the Resurrection, drawing attention in each case to the attribution of the same actions to Father and Son at various points in the Scriptural witness. So, for instance, we find in Philippians that "the Father raised up the Son by exalting him and waking him from the dead"; but, Augustine asks, "Doesn't the Son also raise himself up? Of course he does," as John's Gospel shows. ${ }^{95}$

My suggestion is that we interpret Augustine's attribution of the acts particular to the trinitarian persons on the model of his strategy of predication of substantial attributes, discussed in the last chapter. For any action of God, it is possible and appropriate to speak of it on the analogy of a substantial predication - that is, to ascribe the action to the one simple God, including it within the one activity that is identical to Her Being. At the same time, it is possible and appropriate to speak of any divine action on the analogy of a relational predication - to describe the activity of God as inwardly related in the trinitarian persons, and therefore to understand any action of God as the inseparable threefold activity of Father, Son, and Holy Spirit. Yet this threefold activity of the trinitarian persons is simply the same simple work of God

\footnotetext{
91 s. 52.5; WSA III/3, 52.

92 s. 52.5 ; WSA III/3, 52.

93 s. 52.6; WSA III/3; 52-3.

94 s. 52.8; WSA III/3, 54.

95 s. 52.13 ; WSA III/3, 55.
} 
under another description, and is therefore subject to all the same considerations explored previously in our discussion of God's act - it is timeless, unchanging, eternally complete, yet nevertheless able to bring about diverse effects in time - because these aspects of God's action do not have to do with the trinitarian relations, and are thus always predicated on the model of substantial predication rather than relational predication even when we are speaking of the acts proper to one or other of the triune persons. Moving to a discussion of the triune persons' acts ought not, therefore, encourage us to conceive of Father, Son, and Holy Spirit conducting different operations at different times as if the trinitarian persons lived within a time-bound creation, except in the loose sense that the constitutively related acts of the trinitarian persons bring about effects indexed to different times. The work of God toward and in creation may thus be validly understood either as one simple activity, or as an eternally related threefold activity, but always as the action of the timeless God who is Father, Son, and Holy Spirit. And similarly, the Word's assumption of flesh (and, in a point that we will return to below, the Word's ordering the relations obtaining within the created order) is to be understood as an act proper to the Second Person of the trinity, identical with all His other acts and with the timeless act of the Son's Being; eternally related to, inseparable from, and worked in unity with the act proper to the Father and Holy Spirit; and possessing in itself the fullness of the divine activity, though considered under the aspect of the particular temporal effect of the union of the humanity of Jesus Christ to the Word.

As this description should indicate, our ability to understand the act of the Word's assumption of flesh is radically limited, possible only by way of analogy with the sorts of individual temporal actions performed by created agents. It is unsurprising, then, that at precisely this point in sermo 52 we find one of the strongest statements of apophaticism in the Augustinian corpus, a judgment that both stands necessarily over our attempts to understand the one and threefold life of God, and that we must carry with us as we contemplate the union of divine and human natures in the person of Christ:

So what are we to say, brothers, about God? For if you have fully grasped what you want to say, it isn't God. If you have been able to comprehend it, you have comprehended something else instead of God. If you think you have been able to comprehend, your thoughts have deceived you. So he isn't this, if this is what you have understood; but if he is this, then you haven't understood it. So what is it you want to say, seeing you haven't been able to understand it?96

\subsection{The Act of Assuming Flesh as Constitutive of Christ's Person}

In light of this account of the Triune Lord's action in and toward creation, what are the effects brought about by the act of the Word's assumption of flesh (the effects which, let us recall,

96 s. 52.16: Quid ergo dicamus, fratres, de Deo? Si enim quod vis dicere, si cepisti, non est Deus: si comprehendere potuisti, aliud pro Deo comprehendisti. Si quasi comprehendere potuisti, cogitatione tua te decepisti. Hoc ergo non est, si comprehendisti: si autem hoc est, non comprehendisti. Quid ergo vis loqui, quod comprehendere non potuisti?; WSA III/3, 57. 
allow us to distinguish this act conceptually within the one simple act of God's life)? Or, said more simply, what does it mean for the Word to assume flesh, and how should we understand the person of Christ in light of this act?

As we might expect in light of what we have seen of Augustine's christology and trinitarian thought so far, a guiding principle here must be that the assumption of flesh cannot result in any change of the Word; as Augustine writes in his epistula 137, "The man, of course, was added to God; God did not withdraw from himself." 97 It is important to be clear about the nature of this addition to the Word. Anything that is not true of the Word essentially as God or relationally as one of the trinitarian persons necessarily falls on the created side of the distinction between Creator and creature; the flesh of Christ must therefore to be understood as a creature, ${ }^{98}$ and even in the particular case of the Incarnation, operates in the mode appropriate to the relation between Creator God and created effect. So, for instance, it is correct to say that the Word comes to possess human flesh in the Incarnation, assumed into unity with the Son. But how can the Word come to possess flesh without undergoing change? It would seem that there is (if not a time) a state of the Word prior to assuming flesh, and a state of the Word enfleshed; if the latter state comes to exist in time only with the Annunciation to Mary, isn't there some change in the Word? This cannot be the case. The predication of "being enfleshed" to the Word must be akin to that of "being the Creator" or "being the Lord of Israel" to God or "speaking over the waters of Jesus' baptism" to the Father. ${ }^{99}$ These are also relational predications of God's life, and are true (as are all true predications of God) in virtue of the divine life and God's eternal will, but change in their truth-value over time because one term of the relation is a changeable creature. So, for example, the Lord is not the God of Israel prior to Abraham's election, but is afterwards; this would not be true at all had this created effect not been included within God's eternal will, but becomes true in time because of the changes in creation that God's providential order brings about in time. Our substance changes; God's does not. Applied to the case of the Incarnation, then, the Word remains changelessly the same, and eternally includes the will and activity of assuming flesh; the change in Creation wrought by the creation of Christ's flesh from Mary makes it relationally true that the Word is incarnate.

It is in light of this feature of Augustine's christology that we can make sense of statement like those of ep. 187.9:

when we call Christ the Son of God we do not exclude the man, nor when we call the same Christ the Son of Man do we exclude God. For as man he was on earth, not in heaven where he is now, when he said, No one goes up into heaven except him who has come down from heaven, the Son of Man who is in heaven (Jn 3.13); though as the Son of God he was in heaven, as the Son of Man he was still on earth and had not yet ascended into heaven. Similarly, as the Son of God, he is the Lord of glory, but as the Son of Man he was crucified...And for this reason the Son of Man as God was

\footnotetext{
97 ep. 137.3.10; WSA II/2, 218.

98 As Augustine will note in c.s.Arrian. 8.6, as will be discussed further below.

${ }^{99}$ Cf. trin. 5.16.17.
} 
in heaven, and the Son of God as man was crucified on earth...in accord with the immutability of God he had never left paradise because he is always everywhere. ${ }^{100}$

As against some unfortunately unsubtle presentations of the so-called extra Calvinisticum which might (as Calvin himself did not) suggest that a part of the Word or Her activity becomes incarnate while the much greater part of the Word's life exceeds the incarnate state, here we must draw a much more radical distinction: the eternal life of the Word continues unchanged, while there comes to exist within time human flesh that is possessed by and united to the Word.

Augustine describes this union on the model of the soul's union with the body in the constitution of a human person: "just as the soul is united to the body in the unity of the person in order that a human being might exist, so God is united to the man in the unity of the person in order that Christ might exist." 101 Augustine is equally clear in both ep. 137 and ep. 187 that the "man" assumed was a "complete man" (homo perfectus), and "it is not a complete man if either a soul is lacking to the flesh or a human mind to the soul." 102 We can therefore give a bit more content to the Johannine "human flesh" that has figured so prominently in this discussion of the act of incarnation: the human flesh assumed by the Word is complete with body and soul, and the soul is complete with human mind (and as we will see, will). Yet even here, Augustine's language can give the mistaken impression that there is a preexisting subsistence of human nature, a "man that is assumed" (homo assumptus), ${ }^{103}$ who exists (even if only theoretically) as a person logically anterior to the act of incarnation. Augustine guards against this misunderstanding at Contra sermonem Arrianorum 8.6, writing, "Nor was he assumed in such a way that he was first created and then assumed; rather he was created in being assumed (nec sic assumptus est ut prius creatus post assumeretur, sed ut ipsa assumptione crearetur)." 104 Evidently, the humanity of Christ is not to be understood as a separate subject of predication or person, but exists anhypostatically - it is created only in virtue of the Word's act of assuming flesh, not as an existent creature in its own right. ${ }^{105}$

On the account of incarnation given in these relatively late texts of Augustine's, ${ }^{106}$ then, it is clear to Augustine that there is in Christ "one person in the two natures (Unam...personam in utraque natura), that is, God's and man's. For, if he were two persons, there would begin to be a foursome instead of a trinity." 107 In summary, "the one person who is Christ is the Word and

\footnotetext{
100 ep. 187.3.9; WSA II/3, 235.

101 ep. 137.3.11; WSA II/2, 218.

102 ep. 187.2.4; WSA II/3, 233.

${ }^{103}$ Herman Diepen, "L"Assumptus Homo' patristique," Revue Thomiste 71 (1963): 225-45, notes the problematic nature of some of early christological writings, in which he seems to suggest that a complete personal subsistence of humanity rather than unhypostatized human nature is assumed.

104 c.s.Arrian. 8.6; WSA I/18, 145.

105 The description of Christ's humanity as existing anhypostatically and enhypostatically has returned to contemporary prominence largely through the work of Karl Barth; for an exemplary discussion of this issue in Barth's thought, see Jones, The Humanity of Christ, 22-5.

106 Ep. 137 dates to $411-2$; ep. 187 to 417 ; and c.s.Arrian. to 419.

107 c.s.Arrian. 7.6; WSA I/18, 145.
} 
man, but man is soul and flesh; hence, Christ is Word, soul, and flesh. Therefore, we should understand that he has two substances, namely, divine and human, with the human substance composed of soul and flesh." 108 Augustine is not reticent here to use the language of substance, and it is clear that there is only one person of the Incarnation, Jesus Christ. Furthermore, and Augustine's occasional linguistic practice to the sometimes to the contrary, there is no sense in these later texts in which we should understand Christ's humanity as a preexistent human existing outside the concrete context of the Word's assumption of flesh; and so, the personal identity of Jesus Christ is rooted most properly in the Word - it is in virtue of human nature's union with the Word that Jesus Christ is a person, not in virtue of anything in his human nature itself.

What does this language get us? Certainly, it is interesting (and salutary for later theologians who take themselves to be bound by conciliar orthodoxy) that Augustine's description of the constitution of Christ's person significantly anticipates the Chalcedonian definition. Similarly, it rules out several christological positions that have come to be seen as undesirable or heretical: Apollinarianism, Eutychianism, Nestorianism (to the extent that any of these terms are useful as descriptions of general outlooks in fifth-century christology), ${ }^{109}$ and offers guidance about how we should and should not think of the independent existence of Christ's humanity. The analogy of the union between soul and body and God and humanity is at least suggestive here, and may go some way toward increasing the intelligibility of Augustine's account. Most importantly, it gives us a syntax with which we can judge some theological statements to be well-formed and others to be ill-formed, a syntax that has come to be known in the theological tradition as the communicatio idiomatum. We find Augustine explicitly noting this feature of christological discourse at c.s.Arrian. 8.6, for example:

on account of the unity of the person that we must understand in the two natures, the Son of Man is said to have come down from heaven, although he was assumed from the Virgin who was already on earth. So too, the Son of God is said to have been crucified and buried, although he did not suffer this in the divinity by which he is the Only-Begotten coeternal with the Father, but in the weakness of human nature... The blessed apostle teaches this unity of the person of Christ Jesus, our Lord, including both natures, namely, the divine and the human, so that each of

\footnotetext{
108 c.s.Arrian. 9.7: fateanturque Christum, non tantum carnem, sed animam quoque humanam Verbo unigenito coaptasse; ut esset una persona, quod Christus est, Verbum et homo: sed ipse homo, anima et caro; ac per hoc Christus Verbum anima et caro. Et ideo sic intellegendus geminae substantiae, divinae scilicet et humanae, ut ipsa humana ex anima constet et carne.; WSA I/18, 147. Cf. also Brian Daley, "The Giant's Twin Substances: Ambrose and the Christology of Augustine's Contra sermonem Arianorum," in Augustine: Presbyter Factus Sum, ed. Joseph T. Lienhard, et al. (New York: Peter Lang, 1993); 477-95. Augustine’s claim here cuts against the arguments of Harnack, TeSelle, and McWilliam Dewart that Augustine's christology bears the marks of significant influence by Theodore of Mopsuestia and the Antiochene tradition. On this, see Joanne McWilliam Dewart, "The Influence of Theodore of Mopsuestia on Augustine's Letter 187," Augustinian Studies 10 (1979): 113-132; and McGuckin, “Did Augustine's Christology Depend on Theodore?”

109 Perhaps the best overview of the christological controversies may be found in Frances M. Young and Andrew Teal, From Nicaea to Chalcedon: A Guide to the Literature and Its Background, 2nd Edition (London: SCM Press, 2010).
} 
them shares its attributes with the other, the divine with the human, and the human with the divine. ${ }^{110}$

In light of Christ's possession of all the attributes of humanity and divinity in the unity of his person, we are able to say that all his human attributes can be truly predicated of God in the context of the Incarnation (and vice-versa), because the one person Jesus Christ is God. This grammar is essential for the proper conduct of christological discourse, giving us language to speak of the one person who is both God and human, yet also observing the mystery of the Incarnation by marking off the limits of our ability to speak of this union.

In speaking of the person of Christ, then, Augustine displays a concern both to preserve the distinction between the divine and human natures in Christ, and also to describe the sense in which the attributes of God may rightly be said of a human in the context of the Incarnation. But this does not go terribly far in telling us how the Word is present in Christ, or what it might mean for human flesh to be the possession of and united to the eternal God. The question here is one of intimacy - how can we speak of the human flesh of Christ as the flesh of God? In his epistula 187, also known as the little treatise De praesentia dei, Augustine comes closest to answering this question. While Augustine takes pains to distinguish his position from those of the anti-Nicenes and Apollinarians, the treatise (written in 417) is marked especially by the controversy with the Pelagians. ${ }^{111}$ The text as a whole concerns the presence of God to the world, but takes particular interest in the unique manner in which the Word is present to Christ's flesh.

Augustine observes that our language of God's omnipresence is, in many ways, deeply puzzling. God fills all space, yet cannot be located at any point of it; God is present in many different places, yet wholly present at each of them; God is wholly in all things, yet is not said to dwell equally in all human hearts. Certainly, he is concerned to avoid any hint of materialism in his view of God; he offers the analogy of God being like the health of a body, which is present everywhere in it, yet without being material in any way. ${ }^{112}$ Yet even this analogy fails to the extent that it suggests that God's presence to creation might be understood as a quality of the world itself - that God might be a possession of the world, rather than the world existing only in God. In spite of this weakness, acknowledged from the outset, Augustine continues thinking through the analogy of health. In our common practice, we can speak of the health of a body as a whole, but we can also speak of the a person's body and the health of different parts of it: her heart is fine, but her kidneys are ill. We are able to speak of immaterial realities as obtaining in various degrees, even in material objects; perhaps, then, we may speak also of God's presence in creation in varying degrees, of some places being more saturated with the presence of God than others. ${ }^{13}$ The picture, then, is something like this: in contrast to a quality like health, which is not present at all if the material substrate it depends upon is destroyed, God is present everywhere in Herself; God is "in himself because he is not contained by those things to which he is present, as

\footnotetext{
110 c.s.Arrian. 8.6; WSA I/18, 146.

111 McGuckin, "Did Augustine's Christology Depend on Theodore?", 45-46.

112 ep. 187.4.12-3; WSA II/3, 236.

113 ep. 187.6.18; WSA II/3, 238-9.
} 
if he could not exist without them," and "if God is received less (si minus capitur) by one to whom he is present, he is not therefore himself less." 114 This presence of God to all things in virtue of the divine nature is thus rooted in creation's dependence upon God; if God were not present to a thing upholding it in being, it could not exist at all.

Nevertheless, God can also be present in creatures in varying degrees, to the extent that they "receive" Her. Augustine marshals another analogy here, likening God's intensive presence (that is, presence varying by degrees) to the manner in which light is present to eyes that are blind to a progressively greater extent. The light "floods sightless eyes" (oculos perfundat exstinctos) to no less a degree than it floods a healthy eye, "But eyes are rightly said to draw near to the light when by an increase in health they improve by recovering their keenness." 115 In like manner, then, we may say that "God is everywhere by the presence of his divinity but not everywhere through the indwelling of grace"; and this latter is to be identified with "the grace of his love" (gratia dilectionis). ${ }^{116}$ And this reference to grace makes the ultimate contrast of this view with the Pelagians clear: this capacity to receive God is created in humans by the very same activity that they then receive; as Augustine writes, "those in whom he dwells possess him in accordance with their different capacities, some more, others less, and he himself makes them a most beloved temple for himself by the grace of his goodness." 117

When he turns to the specific case of Christ's flesh, it is this same understanding of presence through received grace that Augustine has in mind. Certainly, we must say that by God's creation of the perfect humanity of Christ, Christ perfectly receives the presence of God, and that in him the fullness of Godhead dwells corporeally (Col 2.9). ${ }^{118}$ And in this, Christ is utterly unique: "For of no saint could or can or will it be able to be said, And the Word became flesh (Jn 1.14)...That assumption, then, is singular, nor can it in any way be shared by some human saints, no matter how outstanding in wisdom and holiness." 119 We should thus expect Augustine to place significant emphasis on the human faithfulness of Christ, and we see exactly this in the Contra sermonem Arrianorum, written just two years later. In this text, we see Augustine clearly guarding against the implication that there is in Christ's person only a divine will, while emphasizing also that what Christ wills as a human is a created repetition of what he wills as God. Discussing the Agony in the Garden of Gethsemane, Augustine clarifies the relation between the will of the Father, the will of the Son, and the human will of Jesus:

he did his own will and he died, because the judgment of God is just. The Son of God makes such a just judgment in not seeking his own will, although he is the Son of Man. It is not that his will is not involved in judging. Who would be so

\footnotetext{
114 ер. 187.6.18; WSA II/3, 238-9.

115 ep. 187.5.17; WSA II/3, 238. Augustine is interestingly modern in this moment, viewing light as flooding into the eyes instead of viewing the eye as emitting a ray that extends outwards to the object of sight.

116 ep. 187.5.16; WSA II/3, 237.

117 ep. 187.6.19; WSA II/3, 239.

118 Augustine references this text at ep. 187.13.39.

119 ep. 187.13.40; WSA II/3, 249.
} 
foolish as to say that? It is rather that his will is not his own in such a way that it is opposed to the Father's. ${ }^{120}$

Just as the Word receives Being and will from the Father, so also the human Christ receives being and will from the Word (and from the Father and Spirit); and because the humanity of Christ exists only in union with the Word, Christ humanly wills in the way proper to human creatures precisely what the Word wills. His human flesh perfectly receives the activity of God, becomes transparent to it so that God's action may be seen in it; and it is this perfection in Christ's reception of the Word's action and presence that describes the Word's indwelling in the humanity of Christ.

Does this, however, indicate a difference only in the degree of reception of God, but not in kind? Clearly for Augustine, Christ is categorically unique; though this is not yet to register the conclusion of his argument, only his intent. ${ }^{121}$ Careful reflection on Augustine's position, though, indicates the qualitative difference between the Word's manner of dwelling in Christ and God's dwelling in the holy. As John McGuckin notes of epistula 187, the fact is that Augustine "does not see the categories of 'substantial' or 'graceful' as mutually opposing descriptors in the Christology debate"122 and this, I suggest, because he is guided in these discussions by his awareness of the simplicity and unchangeability of the divine life. His preference for the language of essentia over that of substantia is yet another indication that the activity of the divine life is no other for Augustine than the substantial life of God; the life of God is as much verbal as it is nounal. ${ }^{123}$ From all eternity, it is part of the substance of God in the person of the Word to effect the union of divinity and human flesh. From all eternity, the concrete act of assuming flesh is, in unity with all God's acts, identical with God's Being. It is eternally part of this will to create the human flesh of Christ entirely for the purpose of being so assumed. There is no identity of Christ, no subsistent personhood, independent of this flesh's existence in union with the person of the Word; and so there is only one person that results from this union, the person of Jesus Christ. Because it has been created as the Word's, this flesh perfectly receives God's eternal act in a way unique within the created order: the Word eternally wills that as human He should will perfectly what God wills. The humanity of Christ is thus included within the divine will, and expressive of it, and it is in both sides of this that Augustine recognizes the indwelling of Christ. Without either side ceasing to be what it is, the divine essence is united to humanity. ${ }^{124}$

\footnotetext{
${ }^{120}$ c.s.Arrian. 18.9; WSA I/18, 155.

${ }^{121}$ Cf. ep. 187.13.40; WSA II/3, 249: "We believe that there is this difference between the head and the other members - that in any member, however eminent, such as some great prophet or apostle, although the divinity dwells in him, all the fullness of divinity does not dwell in him as it does in the head, which is Christ."

122 McGuckin, "Did Augustine's Christology Depend on Theodore?", 48.

${ }^{123}$ Roland J. Teske, "Augustine's Use of Substantia when Speaking about God," in To Know God and the Soul: Essays on the Thought of Saint Augustine (Washington, D.G.: The Catholic University of America Press, 2008), 112-130; 119-20.

124 The resonances of this account with the mature christology of Friedrich Schleiermacher should not go unnoticed, though the constraints of his theological method (and his Reformed and Kantian skepticism of metaphysics) pulls him up just short of describing his theology as the union of the substance of divinity with the substance of humanity. For an incredibly insightful reading of Schleiermacher's christology, see Kevin W. Hector, "Actualism and
} 


\section{Conclusion}

In the preceding account, I have intentionally avoided drawing a distinction between a so-called "immanent" and "economic" Trinity, in favor of a distinction between the activity of God in se and ad extra. In my judgment, an immanent/economic distinction obscures more than it illuminates; instead of understanding the act of God to be identical with God's Being in the simplicity of the divine life, and understanding creation as the temporal effects produced by this very same act, it suggests a distinction in the divine life where there is none. Speaking of an immanent and economic Trinity need not be theologically distortive; one could ground such a distinction in the attributions of God we make on the basis of God's relation to the created order, such as God being the Creator, or God being the Lord of Israel. Nevertheless, in contemporary theology, I believe that an immanent/economic distinction tends to authorize an unwarranted mythologization of God's life. We can lapse into thinking of God as a fellow-inhabitant of time, of understanding the "economic Trinity" as the aspect of God's life that reacts to us, that follows us through the changing present moment and decides to enact different events at different moments. So, too, in the context of the Incarnation. In the most dramatic cases, we imagine that the Word sloughs off some of the qualities of divinity. More commonly, I fear, even we who strive for fidelity to the creeds imagine the Word as the holy ghost in the machine: infusing the life of Christ, the divinity in him guiding and empowering the humanity, the divine will willing each action in unison with the human will - never conscious of the implicit Nestorianism of such a picture, even as it strives to articulate the union of two natures in one person. All this emerges from a properly Christian piety, I think - it is ingredient to Christianity to believe that God hears and responds to prayer, that God acts in history and particularly in the intertwined histories of Israel and the Church. But conceiving of God domesticates these mysteries. If God has elected Israel - which She has - it is because this people has been chosen from before the foundation of the world. If God hears our prayers - which She does - it is because the desperate prayers of Her children have a home in Her life from all eternity. Too often, we have made the mistake of thinking that God is like us.

The truth of the Incarnation is far more radical than this: the human life of Christ is exhaustively the mode of God's existence in time. God brings about effects in time, to be sure, and God makes Herself known in time through manifestations like the burning bush or the dove of the Holy Spirit, but it is only in the flesh of Christ that God comes to exist in time. And there is no change in God as a result: even in the person of Christ, the Word exists timelessly, wills timelessly, acts timelessly; yet this same Word exists in time, wills in time, and acts in time in and through the flesh it has assumed. This existence, willing, and action of the Son within the created order occurs not by the change or reduction of divinity, but by adding to divinity created nature - and so the only temporal life of the Word is in and as a created nature, in the humanity

Incarnation: the high christology of Friedrich Schleiermacher," International fournal of Systematic Theology 8, no. 3 (2006): 307-22. 
of Christ. When, then, we try to contemplate how the divinity and humanity were both willing Christ's actions in, for instance, Jesus' response to the confession of St. Peter, we must say: the one person both God and human, wills; as God, Jesus Christ wills his own response Jesus timelessly in the simplicity of the divine life; as human, Jesus Christ wills his response temporally, as any other human person does (though perfect in love of God, and therefore without sin). And similarly, when we ask about Jesus' sufferings, we must say: the one person, both God and human, suffers; as God, Jesus Christ's sufferings are included eternally in the divine life, not as suffering in the divine nature itself, but as part of the history lived by the flesh that the Word assumes; as human, Jesus Christ suffers pains and weaknesses as does any other person. Though Christ suffers neither the corruption of the will nor the ignorance that accompanies all sin, his life is like ours in every other way. Though I will have more to say on these matters in coming chapters, particularly concerning how Christ comes to be who he is through his relations with other human persons, the central point for the moment is that when we think of the temporal existence of the divine-human Jesus Christ, we should think of human flesh just like our own, different only in that it is the Word's human flesh.

Our discussion of the B-theory of time does allow us to say more, though. As we have seen in our discussions of Augustine's writings on the personal constitution of Christ, the human flesh assumed by the Word consists in the fullness of human nature, soul and body. Yet if the assumption of flesh is a timeless act directed to four-dimensional spacetime, then we must also say that included in what is assumed is a region of spacetime - the region occupied by Christ's body through the course of his life. The whole course of Christ's life is intended and assumed in the act of incarnation, and Christ's human life has a wormlike spacetime "shape," just as do our own lives. Far more interestingly, however, this region of Christ's spacetime and the points in which it consists stand in relations to every other moment of spacetime, from the creation of the cosmos to its end. While it would go too far to say that the flesh of Christ is, on this basis, somehow "present" in itself to every moment of spacetime, it is correct to say that all things are intrinsically related to the materiality of Christ. We are distant from it in time, yet there remains a sense in which all times exist as upheld by the eternal act of God's life; and so the moments of Christ's boyhood at home in Nazareth, or of his teaching by the Sea of Galilee, or even his suffering on the cross and glorious resurrection, persist in being and bear spatiotemporal relations to us.

A B-theoretic account of time therefore provides for relations to Christ's flesh unavailable to those who view metaphysical change over time as intrinsic to the created order. For the presentist, Christ's material existence (as past) has either passed utterly into nonbeing, exists presently ascended to the right hand of God, or exists on the altars under the aspect of bread and wine; but what does it mean for us to relate now to the crucified flesh of Christ, raised on a rocky hill overlooking Jerusalem two thousand years ago? For the presentist, there is no such thing to adore; one may bear relations to the same flesh now glorified, or to that flesh in its sacramental presence, or to a memory or image of that event, or most abstractly to the present state of affairs of Christ's having been crucified, but the very body of Christ on the cross is nowhere in existence, it is absent to us. For the B-theorist, that flesh is not present to us, but it exists; and this grounds 
our ability to bear cross-temporal relations to it - not only spatiotemporal ones, but relations of contemplation or adoration, precisely the sorts of relation to Christ's flesh that Augustine holds will purify and redeem the hearts of believers. Four-dimensionalism teaches us that however distant in the spacetime manifold we may be from the flesh of Christ, it nevertheless exists for us as a relatum to which we are intrinsically related through bearing our own spacetime location, but more importantly, that it exists for us as an object of our loves - it seems that finally, even time cannot separate us from the love of God in Christ Jesus our Lord.

On the B-theory, of course, every point of spacetime is related to every other point; the flesh of Christ is not unique in this. In themselves, these temporal relations may not, at first glance, seem terribly interesting theologically - after all, it does not tell you much about me to know that I presently stand in a set of spatial and temporal relations to the Eiffel Tower. Yet I believe the situation is rather more interesting when we turn our attention to the flesh of Christ. It is a standard feature of Augustine's thought, and of Patristic and later medieval thought in general, that the Word as the wisdom (sapientia) of God is the principle of divine rationality that orders all things within their proper created limits and sets them in relation to one another. As we have already seen in conf. 11.8.10, the Word orders the coming into and passing out of being of all things, and Augustine never tires of reminding his readers or listeners, the Word has set all things in measure, number, and weight, a synecdoche for the Word setting the limits of all finite creatures. ${ }^{125}$ As we will see in the next chapter, the participation of all things in the Word constitutes what we might call the "architecture" of Augustine's account of creaturely signs pointing to God: all things are signs of God by virtue of their participation in Him, yet much of their effectiveness as signs comes from the relations they stand in to the other created signs around them. The order of creation, and of the particular histories of Israel and the Church within creation, are integral parts of creation's ability to lead us to deeper knowledge of God. What the B-theory tells us, then, is that not only do all things bear an intrinsic relation to the Word by participating in Him - all things also are ordered by the Word into spatiotemporal relations to the flesh of Christ. From the perspective of intra-worldly causality, there is nothing necessary about these relationships; if Christ had been standing three feet to the left of where he in fact stood while preaching the Sermon on the Mount, he would have a different spacetime shape and would stand in different spatiotemporal relations to all other points of spacetime, but he would still be a human person.

Yet these relations to particular places and times are more soteriologically freighted than they may seem. No doubt, he would still be a human person, but would Christ still be the Messiah had he not preached in the Temple and thrown out the moneychangers? Would Christ have still been the Redeemer if he had been born at the same time in southern Gaul and lived his whole life there, never setting foot in the land of Israel? Would Christ still be the hinge of God's saving work were he not worshipped in the present day, by people all around the globe? My point is not that it is impossible to imagine other histories of salvation; far from it. If salvation is a work of grace, it is wholly dependent upon God's good pleasure, not upon anything intrinsic to

${ }^{125}$ See W.J. Roche, "Measure, Number, and Weight in St. Augustine," The New Scholasticism 15, no. 4 (1941): 350-76. 
the created order. Yet if God's saving work is a work in history, then the particularities of the relations within the created order become charged with significance. Neither the lives of Augustine or Ambrose would have been the same had they not existed in close proximity within spacetime. Peter's life is unimaginable without having lived with Christ. And Christ's life is unimaginable without standing in the midst of God's long history with the people He has chosen.

My claim is that, when we are speaking of the flesh of Christ, all these relations are at least potentially significant in God's saving work - not only the relations to the people that surround Christ, or the history preceding him, or even the history of the community formed in response to his death and resurrection; but also the relations Christ's flesh bears to the olive trees in the Garden of Gethsemane and the fig tree outside Bethany, to the Buddhist lama whose whole life passes without ever encountering the name of Christ, to the porpoise now swimming merrily in the warm waters of the Atlantic, to the lepton which exists only seconds after the Big Bang. These relations are not incidental, but are ordered by the Word, and our question is whether these relations are ordered to some end. Might it be the case that even these relations can uniquely reveal something of God to creation? If this is the case, then not only might all things serve as created signs of the Word through their participation in Him, but the relations that all created things bear to the flesh of Christ might themselves serve as signs of God. On this account, the whole of creation in its internal ordering to the flesh of Christ might serve as an icon of the participation of all things in the Word: the ordering of all things to the flesh of Christ would serve as a repetition within creation of the order the Word grants to all things by their participation in Him. As all things are ordered to Jesus Christ in his divinity, all things are ordered to Jesus Christ in his humanity - and in this, he is revealed in his humanity as the very one who orders all creation in his divinity. Arguing the truth of this claim will be the task of my next chapter. 


\section{Chapter 3 The Regime of Signs}

Hoc sacramentum, hoc sacrificium, hic sacerdos, hic Deus antequam missus veniret factus ex femina, omnia quae sacrate atque mystice patribus nostris per angelica miracula apparuerunt sive quae per ipsos facta sunt similitudines huius fuerunt ut omnis creatura factis quodam modo loqueretur unum futurum in quo esset salus universorum a morte reparandorum.

This sacrament, this sacrifice, this high priest, this God, before he was sent and came, made of woman - all the sacred and mysterious things that were shown to our fathers by angelic miracles, or that they themselves performed, were likenesses of him, so that all creation might in some fashion utter the one who was to come and be the savior of all. ${ }^{1}$

Anyone who has seen me has seen the Father. ${ }^{2}$ If we find these words credible, it necessitates a revolution in our understanding of how God teaches us of Herself. If these words are true, the God who is invisible and incomprehensible, who permits of no representation or depiction, may be lovingly gazed upon in the flesh. If God Herself has a human form, then that form may be carved into stone and wood, painted in oil, stamped in metal, and molded into resin - other created things may be taken as pointers and reminders of that form, for it is visible to us. ${ }^{3}$ Where previously beholding the face of God was understood to bring only death, we now turn to this face in the hope of finding new life.

\footnotetext{
1 trin. 4.7.11; WSA I/5, 160.

2 The title of this chapter is a rather loose rendering of Augustine's dispensatio similitudinum as a description of the present age at trin. 1.8.16, rendered by Hill at WSA I/5, 76 as: "It is when he cancels all sovereignty and all authority and all power that the Son will reveal the Father, that is, when there is no more need for the regime of symbols [dispensatio similitudinum] administered by the angelic sovereignties and authorities and powers."

3 This is the argument of John of Damascus, at least; see John of Damascus, Three Treatises on the Divine Images, trans. Andrew Louth (Crestwood, NY: St. Vladimir's Seminary Press, 2003).
} 
This chapter continues the incarnational movement of this dissertation. Where in the first chapter, we were concerned with God's eternal act that is the triune life, and in the last chapter considered the relation of that eternal act to temporal creation culminating in the specific act of the Word's assumption of flesh, this chapter focuses on God's work of redemption, centered upon and effected through the unified divine-human activity of Christ's life. I attempt here a first answer to the question that will occupy us through the remainder of this dissertation: how does the life of Christ reconcile us to God? Modern theology commonly answers this question in schemas of justification and sanctification, of "theories" of atonement and the like, but these doctrinal divisions are for the most part quite alien to Augustine's thought. Instead, we see him appealing to notions of sign and signification, to the intellect and the ordering of loves, to categories of justice and power. As on the other topics considered in this dissertation, Augustine's thought on these matters develops considerably over the course of his life, and it would be a grave error to proffer one interpretive frame sufficient to account for all the many different statements he makes throughout his corpus. Rather than pursue this ill-considered course, I have let my own systematic concerns guide my presentation here. The central question of this chapter is how the life of Christ comes to serve as the preeminent sign of God's redemptive work, the manifestation of God Himself in time. Through the training of our intellects and affections on this sign, we come to understand something of the God who remains hidden to us in our sin, and we come to desire deeper intimacy with Him. Yet the implications of the Word's visibility in Christ are vast on my Augustinian account: for if the Word of which all things are signs by virtue of their participatory likeness in Him itself becomes a sign within the world, then all creatures must also come to serve as signs of the flesh in which the Word becomes manifest. This will push us to an expansive account of the telos of all things as being not only signs of the triune God by virtue of their participation in Him, but as signs of Christ's human life.

The argument of the chapter proceeds in several steps. First, drawing upon Michel René Barnes's interpretation of the early books of the De trinitate, I highlight the importance of God's persistent invisibility even in the context of the Incarnation. Christ's human flesh comes to serve as the key site of mediation between our intellects and God; only there does God become visible to us. I then turn to a discussion of Christ's redemptive significance as the sign that draws our hearts and minds back to God through a discussion of the central christological books of the $D e$ trinitate, namely books four and thirteen. Book four presents Augustine's first presentation of how Christ's life reveals God to us and redeems us; but at the same time, his account of Christ's flesh as the manifestation of God raises key questions about the nature of signs and signification more broadly. Before turning to De trinitate 13, then, I turn back to one of Augustine's earliest texts, the De magistro, which is notable both for its christological richness and its concentration on the Word's presence to our intellects and the sort of knowledge that can and cannot be attained from signs. Armed with a more textured understanding of how signs relate our intellects to what is signified, I thus return to De trinitate 13 to develop my Augustinian account of all creation as pointing us not only to the invisible God for whom we long, but to the human flesh of Christ itself which focuses and intensifies our desires. While this procedure is undoubtedly questionable as a historical account of Augustine's thought and development - there is, of course, significant 
development in Augustine's thought from De magistro to De trinitate (and indeed, within the De trinitate itself) - it will become clear that, for all their insight, I believe that Augustine's account of signification in De magistro will require significant modifications in light of the insights of contemporary philosophy of language. When so modified, however, I believe that a basically Augustinian outlook provides a powerful depiction not only of how the life of Christ serves as a redemptive sign of God, but of how all material culture, all art and production of human craft, is meant to serve for us as signs of the human flesh of Christ.

\section{The Invisible God}

One could imagine salvation occurring in a very different way than has been wrought by the Lord Jesus Christ. Leaving aside the question of whether the union of divinity and humanity is necessary in order for God to redeem us, or of whether it is necessary for God to redeem us at all, ${ }^{4}$ nothing in what I have said so far precludes the possibility of a very different sort of incarnation. Imagine a true deus incognito: a baby born in an anonymous village, the union of human flesh with an unknown god; a sinless life lived in obscurity until an unfortunate run-in with the law; an execution unmarked and unattended; a resurrection unwitnessed, and unwitnessed to. ${ }^{5}$ On some accounts of atonement, at least, the conditions seem to be in place here for a complete (if unsatisfying) account of redemption: though no one ever knows about it, or even knows the god that works it, one can imagine this sinless divine-human bearing in her death the weight of all human sin, substituting her own death for that of all people (or conquering death in her death, or tricking the devil into surrendering his right to sinful humanity, etc.), and being exalted in heaven with the rest of humanity being none the wiser.

The point of this thought-experiment is to mark off how dramatically different our situation is, here in this last age on the far side of Christ's death and resurrection. Christ is not anonymous: though the form of God is in him veiled in human flesh, obscuring his glory from plain view, his life is the pivot of all God's acts of self-communication to creation - their source, center, and final referent. Christ's life and redemptive work only assumes its proper significance when it is set within the whole history of revelation, commencing even before the calling of Abraham and finding an end without end in the Spirit's work in the Church. While the life of Christ is the point to which each of these other signs is ordered, Augustine's soteriology is capacious enough to accord each of them a place within Christ's redeeming work.

The first four books of the De trinitate are primarily concerned with the relation between the Word and the signs that preceded the life of Christ in the economy of salvation. This feature of the work should alert us, as recent scholarship has forcefully argued, to the polemical context

\footnotetext{
4 Anselm discusses these questions at Cur deus homo 1.14; see Anselm of Canterbury, The Major Works, ed. Brian Davies and G.R. Evans (Oxford: Oxford University Press, 1998), 287.

5 The allusion to the incognito refers to Kierkegaard's reflections at Søren Kierkegaard, Practice in Christianity, ed. Howard V. Hong and Edna H. Hong (Princeton: Princeton University Press, 1991), 127-33.
} 
in which the work was written; ${ }^{6}$ but it also brings to light one of the defining features of Augustine's account of Christ's redemptive work, the centrality of Christ's human nature as the point where God is most fully revealed within the created order. Though Augustine takes up the series of Old Testament theophanies - for instance, the three men appearing to Abraham at the Oak of Mamre, ${ }^{7}$ or Moses's encounter with the burning bush ${ }^{8}$ - these exegeses are, for the most part, inconclusive in identifying any of these theophanies as revelatory of a particular trinitarian person. Why, then, does Augustine dwell at such great length on these texts? The answer can be seen in the fairly modest claim that Augustine is most concerned to establish in each case: "All these visions... were produced through the changeable creation subject to the changeless God, and they did not manifest God as he is in himself, but in a significatory manner as times and circumstances required." 9

Though they are instructive on the broader christological patterns of his thought, these exegetical questions were broached in significant part due to Augustine's polemical concerns. As Michel René Barnes has argued, the first four books of the De trinitate are written as a response to

the Homoian argument that the Son's character as revealer - or the Son's 'noetic visibility' - constitutes the Son's inferiority to the Father...[B]y the year 400 one of Augustine's primary tasks in de Trinitate (and in his Trinitarian writings generally) is to articulate an understanding of the Son's revelatory role which supports a theology of the Son's equal divinity with the Father. ${ }^{10}$

For both pro-Nicene and Homoian Christians, the invisibility of the Father is taken as a given on the basis of both Scriptural evidence (Augustine at trin. 2.8.14 offers 1 Tim 1.17 and 1 Tim 6.15 as examples) and the prevailing philosophical climate. ${ }^{11}$ Where the anti-Nicene Christians depart from Augustine is in claiming that the Son is essentially visible, thus marking the Son's existence off as different than that of the Father and relegating the Son to a lower grade of divinity. ${ }^{12}$ In showing the difficulty in ascribing the Old Testament theophanies to the Son alone, whether through pointing to events that indicate a revelation of God's tripersonality (as at Mamre) or events that seem impossible to ascribe to any particular person of the Trinity (as in the burning bush), Augustine hopes to short-circuit the move from a recognition of the Son's being revealed

\footnotetext{
${ }^{6}$ See Barnes, "The Arians of Book V," but also Cavadini's argument in light of trin.'s indeterminacy of readership that the apologetic purposes of the text should not overshadow its speculative and meditative aspects: "Trinity and Apologetics in the Thought of St. Augustine," Modern Theology 29, no. 1 (2013): 48-82.

7 trin. 2.11.20.

8 trin. 2.17.32.

${ }^{9}$ trin. 2.17.32; WSA I/5, 120 (modified).

${ }^{10}$ Michel René Barnes, "The Visible Christ and the Invisible Trinity: Mt. 5:8 in Augustine's Trinitarian Theology of 400," Modern Theology 19, no. 3 (2003): 329-55; 330.

${ }^{11}$ Se especially Part III of Rowan Williams, Arius: Heresy and Tradition, Revised Edition (Grand Rapids: Wm. B. Eerdmans Publishing Co), 2001.

${ }^{12}$ Cf. trin. 2.9.15, where Augustine writes that his opponents "say that the Son is visible not merely in the flesh which he took of the virgin, but even before that in himself. For it is he, they say, who showed himself visibly to the fathers" (WSA I/5, 107).
} 
to a general exegetical principle suggesting that the Son is always the person being revealed, and is therefore more intrinsically perceptible than the Father. Augustine's counterargument is that if the Father is invisible and both Son and Spirit are true God, then each of the trinitarian persons must be essentially invisible.

There are important points here in situating the De trinitate within its proper historical context, but for now I wish to call attention to a persistent christological temptation that finds expression in these passages. Unquestionably, Augustine's anti-Nicene opponents are attempting to secure the uniqueness and transcendence of God in ascribing invisibility to the Father alone; what is less commonly noted is that in attributing visibility to the Son, they are securing also the possibility of an immediate experience of God. This is bought, of course, at the price of restricting this experience to that of a less transcendent divinity, but the implications remain profound. Knowledge of God - or at least, knowledge of what is knowable of God - is set on sure epistemic footing; the Son of God is immediately available to our perception, and so we may be confident that our concepts and noetic faculties are up to the task of building a theology on the basis of the Son's revelation. No modern theologians would be so rash as to attribute visibility (especially physical visibility) to the Son's essence, yet the attraction to an immediacy of revelation seems more seductive.

The temptation I am trying to isolate is this: the tendency to see the life of Christ as establishing the starting-point for a stable theological discourse, of viewing revelation as offering a range of concepts well-suited to christological reflection without any need for their constant revision. On such an account, the life of Christ would serve as an epistemic ground for theology, a beginning through which all else could be understood, rather than as a sign standing against the closure or ultimate stability of any theological discourse. For Augustine, God's revelation in Christ offers not the solid ground of epistemic fundament, but a telos toward which all theological language is ordered that can only hope to be fully known eschatologically. Within Augustine's thought, reflection on Christ is always preparatory, designed to move us deeper into the mystery of the Word's assumption of flesh. ${ }^{13}$ A true theological understanding of the theological claim that the Word has assumed flesh is necessarily ordered to praise, for truly understanding this claim would require understanding the eternal act of the triune life wherein the Word wills to take on human nature in threefold unity with the Father and Holy Spirit. For the moment, our christological language can only describe the life of Christ as pointing to and existing in unity with a God whom we cannot yet understand.

As Barnes observes, central to Augustine's christological outlook are the words of Matthew 5.8: Blessed are the pure of heart, for they shall see God. There will be a vision of God, Augustine assures us, but only for those who are pure of heart - which is to say, only at the end of God's redemptive work, only when our love has been perfected. Augustine avoids the crass materialism of the Homoians by affirming that the Son is essentially invisible, yet avoids too the modern hope of setting revelation as a sure foundation for theology by setting the vision of God

\footnotetext{
${ }^{13}$ John G. Cavadini, "The Structure and Intention of Augustine's De trinitate," Augustinian Studies 23 (1992): 103-23,
} argues especially that the De trinitate should be viewed as spiritual exercise. 
as the eschatological endpoint of salvation history. Prior to the final consummation of all things, the Son remains invisible to us. Barnes is precise in describing just how thoroughgoing the implications of this are in Augustine's thought:

the Son is not a revelation of the divine in any direct, available-to-the-senses, way; the Son is not divinity-insofar-as-it-may-be-perceived; the Son, as divine, is not the occasion of human faith (the Son, as human, is). The divinity of the Son is, until the eschaton, unseen and unseeable, although it can be symbolized or signified by some created artifact, just as the divinity of the Father and Holy Spirit can be, and is. ${ }^{14}$

While the first two denials in this passage are to be expected in countering a crude Homoian position, the third is more far-reaching; the Son, as God, is not directly known, even in the incarnate life of Christ. This third denial is not attributable to the essential nature of God; were that the case, then the vision of God would be impossible even eschatologically. The Son (along with the Father and Holy Spirit) are invisible in this last respect as a result of human sin, and the vitiation sin works on our capacity to behold God's perfect truth. We are impure of heart, therefore we cannot see God. We will have more to say below about precisely how sin corrupts our ability to see God, and how Augustine understands this damage to be healed.

For now, the essential claim to draw from Augustine's argument is that all that is known to us in the life of Christ is the humanity of the Son - what we know of the Word is what we know of the man Jesus, the sort of knowledge we can possess of any human person. Barnes is again helpfully lucid on this point:

The most important fact about the identity of Jesus of Nazareth cannot be known, for it is not available to any kind of sight, material or noetic. Obviously this is true for those who live "now" (an era which includes both Augustine and ourselves), since Jesus the Son of God is not available to be seen. More importantly, this was true for those who lived when Jesus was available to be seen: all that could be seen was the human, Jesus of Nazareth. ${ }^{15}$

This is, at one level, a claim that might naturally be drawn from the Scriptural witness; after all, how could the Pharisees or Pilate reject Christ as Messiah and Lord if the divine nature were somehow perceptible in his very flesh? The only explanation for the way others treat Christ in the Gospels is that there was nothing remarkable in his appearance- he was despised, and we esteemed him not. At the same time, Barnes notes that this claim cuts against some deeply-rooted traditions of interpretation surrounding especially the Transfiguration: the Augustinian position leaves no room for the direct perception of divinity even in the radiance of Christ's visage,

14 Barnes, "The Visible Christ," 335.

15 Barnes, "The Visible Christ," 343. 
whether in the restrained presentation given prior to Augustine by St. Hilary of Poitiers or in the later development within the Orthodox tradition of the doctrine of God's uncreated light. ${ }^{16}$

More important than this denial for my purposes here, though, is the affirmation contained therein: before the beatific vision, knowledge of God in Himself is impossible to us. ${ }^{17}$ In the present dispensation, we always come to know God through the mediation of created things, being directed to God through the humble things that He has made. Because this vision of the invisible Lord is presently inaccessible to us, however, we cannot ascribe any sort of finality to the understandings of God that we now possess. Our knowledge remains always open to correction, correction brought not through a new and purer sight of God, but through further created signs that resituate what we thought we had known before. And as with the two edges of the Homoian position above, both degrading the divinity of the Son while setting revelation on surer footing, this broadly Augustinian position both unsettles our confident grasp on knowledge of God even as it dignifies created reality and makes of it the path by which we encounter God. In this dialectic, the human flesh of Christ emerges as the definitive sign of God's self-revelation, both in the manner that all other signs point to it and in the invisible dwelling of God within it.

It is important to note that nothing in this account should suggest that we cannot believe true things about God. On the contrary, it is precisely through our knowledge of created signs that true knowledge of God is mediated to us; but this is the sort of knowledge proper to faith, rather than sight. What precisely constitutes the difference between the knowledge in faith that we can possess of God now and the direct perception of God that will be ours eschatologically remains to be seen, and along with an account of the difference between faith and sight, we will require also an understanding of how signs can provide us with knowledge of the things to which they refer. Much of the rest of this chapter will be concerned with setting out these distinctions; yet before turning to these questions, we will need a more expansive view of Christ's place within salvation history.

\section{The Mission of the Word}

The fourth book of the De trinitate is Augustine's first sustained discussion in that work of the redemptive significance of Christ's life. His exposition there is undeniably skeletal, as mine will be in this section. In both Augustine's text and in this dissertation, the purpose of the account is to set out the range of concepts and their interconnections so that they may be investigated in more depth elsewhere. Rather than offering a systematic overview of the place of Christ in God's order of creation, Augustine begins us in medias res, telling the reader about his own situation, and ours: "I am struggling to return from this far country (Lk 15:13) by the road he has made in the

\footnotetext{
16 Barnes, 347. See Hilary of Poitiers, De trinitate 11.37-8; The Trinity, trans. by Stephen McKenna (Washington, D.C.: Catholic University of America Press, 1954); and Gregory Palamas, "The Uncreated Glory," in The Triads, ed. John Meyendorff (Mahwah, NJ: Paulist Press, 1983), 71-92.

17 A possible counterexample to this claim is knowledge of mathematical truths; I will have more to say on this in Chapter 5, below. Briefly, I believe that to know any particular mathematical truth as it subsists in God rather than as reflected imperfectly in our weakened intellects would entail knowledge of that truth in its intrinsic relation to all other mathematical truths - and that, suffice it to say, we do not currently possess.
} 
humanity of the divinity of his only Son; and changeable though I am, I breathe in his truth the more deeply, the more clearly I perceive there is nothing changeable about it."18

Just what has brought us to this sorry state remains, for now, in the background of Augustine's presentation. More important is to describe the condition in which we find ourselves, and the provisions that God has provided for our reclamation. It is clear that while we have fallen far from our original beatitude, traces of our original righteousness remain in our natures, providing for the possibility of a restored union with God. Augustine tells us that "we were exiled from this unchanging joy, yet not so broken and cut off from it that we stopped seeking eternity, truth, and happiness even in this changeable time-bound situation of ours - for we do not want, after all, to die or to be deceived or to be afflicted." 19 Our desires can only be satisfied by God, yet our eyes are turned elsewhere; as a result, "God sent us sights suited to our wandering state (missa sunt nobis divinitus visa congrua peregrinationi), to admonish us that what we seek is not here, and that we must turn back from the things around us to where our whole being springs from - if it did not, we would not even seek these things here." 20 This last phrase is somewhat elliptical. Augustine claims here that we search for the stability of eternal beatitude because our existence derives from the unchanging blessedness of God's own life, but the suggestion is underdeveloped: either we possess in our nature a memory of our original righteousness that generates in us a longing to return to our source, or a desire to return to the source of our being is simply hardwired into us. Whatever the case, it is clear that our origin in divine beatitude establishes the possibility of our being drawn back to God by means of created signs, without requiring that these signs coupled with our desire will be sufficient to lead all people back to the love of things eternal.

Augustine marks out both a Scylla and a Charybdis along the route of our return in despair and pride: "First we had to be persuaded how much God loved us, in case out of sheer despair we lacked the courage to reach up to him. Also we had to be shown what sort of people we are that he loves, in case we should take pride in our own worth, and so bounce even further away from him and sink even more under our own strength." 21 To learn hope, without our hoping in ourselves: this is the first step on our path back to God. ${ }^{22}$ Augustine will maintain the emphases of this passage throughout his account of redemption: God appears for us preeminently as a lover, one who humbles Himself in order to pull us out of our desperate situation, while we appear over and over again as those inclined to pride and self-regard, tempted to ascribe righteousness to ourselves even as God works to perfect us. Indeed, one of the

\footnotetext{
18 trin. 4.1.1; WSA I/5, 153.

${ }^{19}$ trin. 4.1.2; WSA I/5, 153.

20 trin. 4.1.2; WSA I/5, 153.

21 trin. 4.1.2; WSA I/5, 153.

22 One might note here a distant anticipation of the opening words of Calvin's Institutes, wherein we are told that theology begins with a twofold knowledge of God and of oneself; cf. John Calvin, Institutes of the Christian Religion, ed. John T. McNeill, trans. Ford Lewis Battles (Louisville, KY: Westminster John Knox Press, 1960), 35 and the discussion of this central Reformed theme in Serene Jones, Calvin and the Rhetoric of Piety (Louisville, KY: Westminster John Knox Press, 1995).
} 
predominant themes in De trinitate 4 is the need for purification before we can see God. In an important passage early in the book, Augustine writes,

The darkness is the foolish minds of men, blinded by depraved desires and unbelief. To cure these and make them well the Word through which all things were made became flesh and dwelt among us (Jn 1:14). Our enlightenment is to participate in the Word (illuminatio quippe nostra participatio Verbi est), that is, in that life which is the light of men (Jn 1:4). Yet we were absolutely incapable (prorsus inhabile) of such participation and quite unfit for it, so unclean were we through sin, so we had to be cleansed. Furthermore, the only thing to cleanse the wicked and the proud is the blood of the just man (sanguis iusti) and the humility of God; to contemplate God, which by nature we are not, we would have to be cleansed by him who became what by nature we are and what by sin we are not. ${ }^{23}$

Immediately apparent in the passage is the extent to which Augustine's theology is shaped by the language and concepts of St. John's gospel, yet we also see Augustine introducing his own native categories - perhaps most noticeably in this passage, those of participatio and illuminatio. ${ }^{24}$

Augustine treats "participation" here as a description of the relation properly obtaining between the purified intellect and the Word, whereas "illumination" is the state of the intellect when it bears this proper relation to the Word. As Barnes has taught us to expect, we are utterly unable (prorsus inhabile) to attain to this state of beatific illumination prior to the coming of Christ; ${ }^{25}$ we require purification before we are capable of participating properly in the Word. Yet the final lines of this passage remain, as of yet, opaque. To this point, Augustine has appealed primarily to noetic categories; how could the blood of the just or the humility of God effect the cleansing of sinful minds? Augustine's concluding suggestion, that the soteriological weight is borne by Christ assuming our nature, remains at best cryptic. Though Augustine leaves us no doubt that we have drawn close to the mystery, he has so far given us little indication of how the life (and more particularly the blood) of Christ can be considered the needed sights suited to our wanderings in separation from God.

Unfortunately, Augustine seems at this point to become only more obscure. The passage continues:

By nature we are not God; by nature we are men; by sin we are not just. So God became a just man to intercede with God for sinful man. The sinner did not match the just, but man did match man. So he applied to us the similarity of his

\footnotetext{
23 trin. 4.2.4; WSA I/5, 154-5.

${ }^{24}$ Jonathan Teubner has written on the importance of participatio in trin. 4 at Jonathan D. Teubner, "Prayer in the Latin Tradition: a study in the development of Augustinianism" (Unpublished D.Phil. Thesis, University of Cambridge, 2013), 90-7.

25 Though, as Teubner notes, Augustine will elsewhere speak of illumination as an intensive term increasing in the measure that one is purified; see Teubner, "Prayer in the Latin Tradition," 142.
} 
humanity to take away the dissimilarity of our iniquity, and becoming a partaker of our mortality he made us partakers of his divinity. It was surely right that the death of the sinner issuing from the stern necessity of condemnation should be undone by the death of the just man issuing from the voluntary freedom of mercy, his single matching our double. ${ }^{26}$

The notion of the Christic "single" matching our "double" is quite puzzling, and receives no direct explication in the text of the De trinitate. John Cavadini has helpfully interpreted these passages as referring to the differences between Christ's death and our own: though in our sin we die a twofold death, the first being the separation of soul from body and the second the separation of God from the soul, Christ dies only a single death in the body, by which we are redeemed. ${ }^{27}$ While Augustine is clearly concerned with the relation between Christ's single death and our double through trin. 4.3.6, however, he soon extends the scope to a much broader discussion of the importance of proportion and harmony itself in understanding how Christ's life is redemptive. In this register of conversation, the "single" and "double" refer less to particular theological construals of our death, and more to the mathematical qualities of oneness and twoness in their interrelation. He writes, "This match - or agreement or concord or consonance or whatever the right word is for the proportion of one to two - is of enormous importance in every construction or interlock (coaptatione) ${ }^{28}$ - that is the word I want - of creation. What I mean by this interlock, it has just occurred to me, is what the Greeks call harmonia." 29 He clearly means this to be an intuitive concept for us; he points to the sense of fittingness we find in voices singing in harmony, and the initial recoil at tonal dissonance. Whatever the difference is between a chorus singing Tallis, and one of the more outré compositions of Schönberg - that is the difference Augustine attempts to point us to in talking about Christ's single and our double. So too, we may think of the compositional harmony that governs much medieval and renaissance art and architecture, the "divine proportion."

Augustine is, I believe, pointing us to something like an aesthetics of redemption. As puzzling as his discussion may be, I believe it is essential to understanding how the life of Christ serves as a redemptive sign, and how other creatures may be redeemed through being related to him. It is the harmonia, the proportion obtaining between the two terms, that sets and marks the single and double as what they are through their relation to one another - the question is how our lives may be ordered to Christ's own such that a new harmonia obtains between them, one in

${ }^{26}$ trin. 4.2.4: Deus enim natura non sumus; homines natura sumus; iusti peccato non sumus. Deus itaque factus homo iustus intercessit Deo pro homine peccatore. Non enim congruit peccator iusto, sed congruit homini homo. Adiungens ergo nobis similitudinem humanitatis suae abstulit dissimilitudinem iniquitatis nostrae, et factus particeps mortalitatis nostrae, fecit participes divinitatis suae. Merito quippe mors peccatoris veniens ex damnationis necessitate soluta est per mortem iusti venientem ex misericordiae voluntate dum simplum eius congruit duplo nostro; WSA I/5, 155.

${ }^{27}$ John C. Cavadini, "Jesus' Death Is Real: An Augustinian Spirituality of the Cross," in The Cross in Christian Tradition: From Paul to Bonaventure, edited by Elizabeth A. Dreyer (New York: Paulist Press, 2000), 169-191; 176-7.

${ }^{28}$ Hill notes that coaptatio is an Augustinian neologism at WSA I/5, 177n.12.

${ }^{29}$ trin. 4.2.4: Haec enim congruentia, sive convenientia vel concinentia vel consonantia commodius dicitur quod est unum ad duo, in omni compaginatione vel si melius dicitur coaptatione creaturae valet plurimum. Hanc enim coaptationem, sicut mihi nunc occurrit, dicere volui, quam graeci à puovía vocant; WSA I/5, 155. 
which Christ is our redeemer and we are restored to the original perfection of our nature. This coaptatio stands at the heart of Augustine's account of redemption: "what has to be explained as far as God permits is how the single of our Lord Jesus Christ matches our double, and in some fashion enters into a harmony of salvation with it (quaemodum simplum Domini et Salvatoris nostri Iesu Christi duplo nostro congruat et quodam modo concinat ad salutem)." 30 Without yet clarifying how this consonance between Christ's life and our own actually functions salvifically, Augustine continues to emphasize its importance, writing that "his body served as a sacrament of our inner man and as the model of our outer man (et in sacramento interioris hominis nostri et exemplo exterioris), by a kind of curative accord or symmetry." 31

The moment in trin. 4 where Augustine seems to run furthest afield of his soteriological concerns is in fact the point at which he provides the clearest indications of what he understands the harmony of salvation to be. Immediately following the lines just quoted, Augustine launches into an extended discussion of mathematical relations and sacred numerology, telling us at the outset that "This proportion of the single to the double arises from the number 3 ; for 1 and 2 make 3. But all this I have just mentioned comes to the number $6 ; 1$ and 2 and 3 make 6", \&c. ${ }^{32}$ While we need not be detained by the specifics of this discussion - the woman with a hemorrhage suffered for 18 years, which is 3 times 6 (trin. 4.4.7); the number of days from the Annunciation to the Nativity is 276, a period within which 46 days have the number 6 in them (trin. 4.5.9)Augustine places a great deal of emphasis on them, but rejecting as "foolish and inept" the suggestion that these numbers serve no purpose. ${ }^{33}$

These proportions serve for Augustine as a marker of the way that God has ordered the providential course of history, and set each creature in its proper place within that order. We should have in mind my last chapter's discussion of God setting all things within their proper bounds of measure, number, and weight and ordering the coming into and passing out of being of each creature when we read that the number 6, which stands in for Augustine for the proportion obtaining between Christ's single and our double, is "in some sense symbolic of time in that other tripartite division, by which we reckon one age before the law, another under the law, and the third under grace." 34 In fact, atypically for Augustine, all of the numerological explanations he attaches to these Scriptural numbers through three extended chapters of trin. 4 refer to periods or divisions of time.

What we are meant to learn through this excursus into numerology is that the divine wisdom by which God orders all things in their created bounds at the same time sets all things into relation with one another in a redemptive history. ${ }^{35}$ God not only orders all things intrinsically as what they are, but orders them to Christ - and this harmonia with Christ in which God

\footnotetext{
30 trin. 4.3.5; WSA I/5, 155.

31 trin. 4.3.6; WSA I/5, 157.

32 trin. 4.4.7; WSA I/5, 158.

33 trin. 4.6.10; WSA I/5, 160.

34 trin. 4.4.7; WSA I/5, 160. Augustine refers here to the three stages preceding our eschatological existence in pace found in his commentary on Romans at exp.prop.Rm. 13-8: ante legem, sub lege, and sub gratia.

35 The Word as the Sapientia of God ordering the universe is a theme Williams develops in On Augustine, Ch. 10.
} 
providentially sets us occupies an important role within God's economy of salvation. As Augustine concludes his discussion of the coaptatio between Christ's single and our double:

This sacrament, this sacrifice, this high priest, this God, before he was sent and

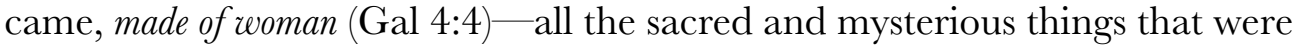
shown to our fathers by angelic miracles, or that they themselves performed, were likenesses (similitudines) of him, so that all creation might in some fashion utter the one who was to come and be the savior of all who needed to be restored from death (ut omnis creatura factis quodam modo loqueretur unum futurum in quo esset salus universorumm a morte reparandorum). ${ }^{36}$

The question is ultimately how we may see created things in their proper relation with Christ, such that they become intelligible to us as likenesses of him. The theophanies granted to the people of Israel as recorded in the Old Testament are particularly clear, particularly significant examples of what is potentially true of all created things. God has used them to reveal Herself, to make Herself known to a particular people in a particular place and time; yet in principle, at least, all creation is meant to serve in a parallel role, to tell us not only of the God who has created it, but of the savior who has conquered death. God has arranged the whole of the created order into a consonant harmonia, as if in ordering history She had scored a polyphonic setting with as many voices as there are moments of time. As history unfolds, new voices enter or fall silent, swell or diminish, repeat familiar phrases or push the melody in a new and surprising direction-and each tonal rise or fall, each harmonic interval, is meant to point us to the human flesh of Christ, the one point at which the invisible God can be seen in the changeable creation.

While it is a standard claim of Christian theologies influenced by Platonism that all things are likenesses of God inasmuch as they exist by participating in Him, this account of similitudines, particularly in light of Barnes' argument, goes further. If all things exist as similitudines by virtue of their coaptatio with the human life of Christ, then they serve as likenesses not only of the transcendent Word in which they participate but also of the human life that Word assumes. Augustine draws clearly on his Platonic inheritance here, telling us that we have fallen "away from the one supreme true God into the many, divided by the many, clinging to the many."37 Yet instead of advising withdrawal from the world in the contemplation of the One, Augustine points us back to the world - God has mobilized the many on His behalf, and "it was fitting that at the beck and bidding of a compassionate God the many should themselves acclaim together the one who was to come, and that acclaimed by the many together the one should come, and that the many should testify together that the one had come, and that we being disburdened of the many should come to the one."38 In the redemptive harmonia, the multitude of created things serve as likenesses not principally of the invisible God, but of the One in whose fleshly life we see God and are redeemed. Calling us from the incoherence of our desires, which are many because

\footnotetext{
36 trin. 4.7.11; WSA I/5, 160.

37 trin. 4.7.11; WSA I/5, 160.

38 trin. 4.7.11; WSA I/5, 160-1.
} 
they are directed to the many things of the world, Christ calls us back to God, making us "many members preceded by the one head" in order that "we may be able to cling to the one, enjoy the one, and remain for ever one." 39 We are to be united to Christ and one another

not only by virtue of the same nature whereby all of them from the ranks of mortal men are made equal to the angels, but even more by virtue of one and the same wholly harmonious will (concordissimam voluntatem) reaching out in concert to the same ultimate happiness, and fused somehow into one spirit in the furnace of charity (in unum spiritum quodam modo caritatis igne conflatam)...that just as Father and Son are one not only by equality of nature but also by identity of will, so these men, for whom the Son is mediator with God, might be one not only by being of the same nature, but also by being bound in the fellowship of the same love. ${ }^{40}$

It is finally the case, then, that this coaptatio or harmonia of salvation is not only the divine plan of reconciliation, but resolves into the blessedness of everlasting life. In being ordered in common to Christ as our one center, our wills are to be ordered in relation to one another, each willing as the creatures that we are, but all desiring together the vision of God through the flesh of the Son. Not only are worldly signs ordered to draw us back to God, but we find that we ourselves are ordered by God's work - we are the many that is being drawn into the oneness of life in Christ.

The hinge of this redemptive work is the Crucifixion, the self-offering of Christ that purifies both our knowledge of God and our desire for Her. The cross is the tonic note of Christ's "single," the root tone that allows our lives to be set in their proper harmonic interval through relation to his: "being clothed with mortal flesh, in that alone he died and in that alone he rose again; and so in that alone he harmonized with each part of us by becoming in that flesh the sacrament for the inner man and the model for the outer one." ${ }^{11}$ Pride of place is given in $D e$ trinitate 4 to the language of exemplum, sacramentum, and sacrificium: ${ }^{42}$ in both his death and resurrection, the great mystery of Christ's sacrifice serves as sacrament of the inner human and model fort the outer. For the outer human, Christ's death teaches that we need not fear the sufferings that others may inflict on our flesh. As a result of sin, we come to value fleeting temporal goods more highly than eternal goods; but in addition, we fail properly to evaluate the deaths that we face as a result of sin. Sinful humans "shrank more from the punishment than from what deserved the punishment. Few, after all, care - or care very much - about not sinning; but they make a great fuss about not dying, though it is in fact unobtainable." 43 In giving himself willingly to death in service of God, Christ "came to show us how little we should really fear death, which in our human condition cannot now be avoided anyway, and how we should rather

\footnotetext{
39 trin. 4.7.11; WSA I/5, 161.

40 trin. 4.9.12; WSA I/5, 161 (modified).

41 trin. 4.3.6; WSA I/5, 156.

42 As Studer notes, the pairing of the terms sacramentum and exemplum is relatively rare in Augustine's thought outside the De trinitate; "Sacramentum et Exemplum chez saint Augustin," Recherches Augustiniennes 10 (1975): 87-141; 101. 43 trin. 4.12.15; WSA I/5, 163.
} 
fear ungodliness which can be warded off by faith."44 And if Christ's willing acceptance of death may serve as an exemplum for us, then so too is his resurrection a model of our own: in the disciples "being shown the complete integrity of his flesh" through being able to touch the risen body of Christ (cf. Lk 24.39, Jn 20.28), they receive "a demonstration of what he had said elsewhere to encourage them, Not a hair of your heads will perish (Lk 21.28)."45 There are, of course, many other senses in which Christ's life serves as a model for Augustine's "outer human," gathered mostly around acting in our own flesh in a manner springing from love of God and love of neighbor, yet the exemplarity of Christ's crucifixion itself centers for the most part on assuaging our fear of death and suffering. ${ }^{46}$

For the inner human, it is the sacrament of Christ's humble self-offering that is primary, though Augustine is under no illusions about the difficulty involved in tearing ourselves away from the worldly things to which we have attached ourselves through our sinful desires. He tells us, "By the crucifixion of the inner man is to be understood the sorrows of repentance and a kind of salutary torment of self-discipline, a kind of death to erase the death of ungodliness in which God does not leave us", and this is complemented by an understanding of the Resurrection as a "sacrament of our inner resurrection" in which we learn to seek eternal things by means of Christ's flesh. ${ }^{47}$

In each case, then, Christ's death as sacramentum of the inner human and exemplum of the outer have a twofold purpose, both teaching us about our present condition and calling us to a new one. As Basil Studer writes,

The sacrament of the inner man refers to the fact that in baptism man dies to sin and recalls at the same time of the obligation to take up a new life. Likewise, the example of the inner man invites one to rise above the fear of bodily death and announces at the same time the resurrection of the body. Sacrament and example are thus both signs which demonstrate and oblige. ${ }^{48}$

The distinction between sacramentum and exemplum thus has nothing to do with two separate actions of Christ, such that some of his behavior would apply to the inner human and some to the outer - it is the one death of Christ, the unified action of his self-offering, that is referred to in each case. The distinction is rather one in the application of Christ's death to our lives, on the one hand teaching us a new model for our embodied action as exemplum, and on the other, teaching us a new possibility of giving up our worldly attachments and humbling ourselves before God as sacramentum. Most importantly, it is in the concrete materiality of Christ's life - in the

\footnotetext{
44 trin. 4.12.15; WSA I/5, 163-4. At trin. 4.3.6, Augustine references a passage that will become increasingly important in this dissertation, suggesting that the lack of our fear of suffering is modeled in St. Paul's statement, "That I may make up what is wanting from Christ's afflictions in my flesh (Col 1.24)" (WSA I/5, 157).

45 trin. 4.3.6; WSA I/5, 157.

${ }^{46}$ Cf. Robert Dodaro, "Christus iustus and Fear of Death in Augustine's Dispute with Pelagius," in Signum pietatis. Festgabe für Cornelius P. Mayer OSA zum 60 Geburtstag, ed. A. Zumkeller (Würzburg, 1989), 341-61.

47 trin. 4.3.6; WSA I/5, 156.

48 Studer, "Sacramentum et Exemplum," 102. Translation mine.
} 
lashes he receives, the sundering of soul from body in death, in the embodied nature of his resurrection appearances - that these mysteries are made known to us. These visible events point to the new life to which we are called, but beyond even that, to the work of God that creates this new life in us. It is in this sense that we should understand the death of Christ as both signum and similitudo. ${ }^{49}$

It is the material visibility of the signs of Christ's life that connects the key terms exemplum and sacramentum to the purificatory resonance of the term sacrificium. The sign of Christ's life and death is give to us in accordance with our need:

we were incapable of grasping eternal things, and weighed down by the accumulated dirt of our sins, which we had collected by our love of temporal things, and which had become almost a natural growth on our mortal stock; so we needed purifying. But we could only be purified for adaptation to eternal things by temporal means like those we were already bound to in a servile adaptation. ${ }^{50}$

Only the example of Christ's death could cure us of our fear of death, and only the sacramental manifestation of Christ's humility could break the snares of concupiscence and purges us of our sinful desires. They teach us of realities that we cannot yet see, and enable the possibility of placing our trust in a God who remains invisible to us: "Useless temporal things just delude the sick and disappoint them; useful ones help them to get well and lead them, once they have got well, to eternal things. Now just as the rational mind is meant, once purified, to contemplate eternal things, so it is meant while still needing purification to give faith to temporal things." 51

Augustine's description of our present state therefore places us squarely within a series of contrasts between the present age and the age to come. We cannot yet see God, but we have been given sights to trust in faith. We have not yet suffered the death which we owe as a result of sin, yet we find life already being renewed in us. It is a movement from the old to the new that we find ourselves along, and critically, Augustine understands the union of divine and human natures in Christ as the key presupposition of the redemptive efficacy of these signs. In coming to know the concrete events of Christ's life, we see a temporal manifestation of the God who remains invisible to us: Christ's humanity serves as "a bridge to his eternity." 52 He comes "to capture our faith and draw it to himself, and by means of it to lead us on to his truth." 53 In a manner still unspecified, these signs come to serve as the pathway by which we return to God; the work of the next section will be to offer an account of Augustinian signa such that placing faith in them will actually refer our hearts and minds back to God.

\footnotetext{
49 Studer connects the terms sacramentum and exemplum to his use of signum and similitudo throughout Augustine's work at "Sacramentum et Exemplum," 103-4.

50 trin. 4.18.24; WSA I/5, 169.

51 trin. 4.18.24; WSA I/5, 169.

52 trin. 4.18.24; WSA I/5, 170.

53 trin. 4.18.24; WSA I/5, 170.
} 
But before turning to that discussion, we must note the startling window into God's eternity that Augustine believes Christ's life provides. In contrast to all the Old Testament theophanies, the Word's project of reclamation in assuming flesh is not only God communicating to us, but God communicating Himself to us. As Augustine lyrically remarks, "There you have what the Son of God has been sent for; indeed, there you have what it is for the Son of God to have been sent (Ecce ad quod missus est Filius Dei; immo vero ecce quod est missum esse Filium Dei)." "54 The Incarnation is the first of the "missions" of the triune Lord, to be complemented with the outpouring of the Holy Spirit at Pentecost and throughout the life of the Church. Yet Augustine is careful to note that the Word's mission teaches us not about the eternal life of the Son in relation to the Father, but about the action properly attributed to the Son in relation to the created order. The mission of the Son cannot be taken as an indication that He is any more properly visible or comprehensible to us than is the Father:

the Son of God is not said to be sent in the very fact that he is born of the Father, but either in the fact that the Word made flesh showed himself to this world...Or else he is sent in the fact that he is perceived in time by someone's mind... That he is born means that he is from eternity to eternity - he is the brightness of eternal light (Wis 7:26). But that he is sent means that he is known by somebody in time. ${ }^{55}$

Yet it would not be quite right either to claim that the sending is something that applies solely to the humanity of Christ rather than including the Word also: "we should understand that it was not just the man who the Word became that was sent, but that the Word was sent to become man." 56 What it is for the Word to be sent is for the invisible God to enter into visibility, for God Himself to become a sign for us. The missions show us not only how to return to God, but show us already who God is. While the begetting of the Son from the essence of the Father cannot be directly identified as the sending of the Son, the fact that it is the Son (alongside the Spirit) who is sent is a signification of His eternal source in the Father: "just as being born means for the Son his being from the Father, so his being sent means his being known to be from him." 57

In describing the mission of the Son as the Word's becoming visible in the flesh of Christ, Augustine makes an important distinction in the ways that created signs may refer to God. As he tells us, "Everything that has taken place in time in 'originated' matters which have been produced from the eternal and reduced back to the eternal, and has been designed to elicit the faith we must be purified by in order to contemplate the truth, has either been testimony to this mission or has been the actual mission of the Son of God." 58 All temporal things are alike in that they are "originated" in the eternal act of God, and at least some of them have been designed to

\footnotetext{
54 4.19.25; WSA I/5, 171.

55 trin. 4.20.28; WSA I/5, 173.

56 trin. 4.20.27; WSA I/5, 172.

57 trin. 4.20.29; WSA I/5, 174. Ayres stresses the importance of the monarchia of the Father within Augustine's thought at Augustine and the Trinity, 263-8.

58 trin. 4.19.25; WSA I/5, 171.
} 
lead us to faith. The crucial difference here, what separates the missio of the Son from all other temporal signs (and paradigmatically, the theophanies that began this discussion), is the end to which these signs refer: while the theophanies and other created signa point to the missions of the Son and Spirit, the missions themselves point directly to God's eternal life and the modes of origination of the trinitarian persons. ${ }^{59}$ Through these signs, our intellects are purified in hopeful expectation of seeing Father, Son, and Holy Spirit in eternal blessedness.

This discussion of De trinitate 4 has added three key insights to our account of Augustinian christology. First, one of the defining features of this account is the claim that all created things are ordered by the Word into a harmonia of salvation, and meant to serve for us as signs of God's redeeming work in Christ. Second, these signs - and especially the sign of Christ's flesh, its death and resurrection - are meant to purify our minds in preparation of the beatific vision of God; by giving us objects of faith, they are to ready us for sight. Finally, these signs are not only a curative dispensation serving the functional role of bringing us back to health, but they open to us the very life of God, teaching us in time who God is from all eternity. Several outstanding questions remain, however - preeminently, the questions of how these signs actually work to purify the inner human, and of how all things are ordered to serve as signs of the Son's mission. Answering these questions will require dwelling on Augustine's account of signs and signification; to this task I now turn.

\section{Faith in Things Unseen}

Within the Augustinian corpus, the De doctrina christiana and the later books of De trinitate stand as the high-water mark of nuance and precision in Augustine's thinking on signs and signification; yet even these texts cannot match the christological richness of signification proposed in his early work, De magistro. Writing of this slim book in the Retractationes near the end of his literary career, Augustine's only comment is, "I wrote a book entitled The Teacher [in 389]. There it is debated, sought, and found that there is no teacher giving knowledge to man other than God. This is also in accordance with what is written by the Evangelist: Your teacher, Christ, is unique (Matthew 23:10)."60 We should not, of course, read into Augustine's relative silence on this text the wholesale approval of the arguments contained therein. Most important for our purposes here is what Augustine identifies as the central argument of the De magistro, though the point only becomes explicit in its final pages: that Christ is in some sense the only true teacher of humanity, that all learning and knowledge is to be attributed to Christ's instruction. That this is the sole comment Augustine offers on De magistro suggests the continuing relevance of this claim to Augustine's later christological reflection. Attentive, then, to the dangers of flattening the development of Augustine's thought, I will nevertheless focus the discussion of this section on this early dialogue, hoping to situate these later writings on signification within the christological

\footnotetext{
${ }^{59}$ The mission of the Son is further distinguished as unique by His assumption of a created sign into unity with the person of the Word; cf. trin. 4.20.30.

60 retr. 1.12; Augustine, Against the Academicians and The Teacher, ed. Peter King (Indianapolis: Hackett Publishing Co., 1995), 94 (editorial comments original).
} 
context that Augustine believed to be their proper home from even the first years of his life as a catholic Christian.

De magistro takes the form of a dialogue between a young Augustine and his teenage son Adeodatus, set in the period of his post-baptismal retreat at Cassiciacum. ${ }^{61}$ The work focuses especially on the ways in which language can signify, though it is clear at points that ultimate point about Christ as the unique teacher applies to all signs (including gestures and material objects) rather than to words alone. ${ }^{62}$ Leaving aside for the moment the conceptual distinctions Augustine uses to structure De magistro (e.g., signs that signify things versus signs that signify other signs), the work can be broken neatly into two parts. The first is a traditional dialogue between Augustine and Adeodatus, wandering down a somewhat tortuous logical path in order to determine whether anything can be taught without the use of signs. The second is a monologue beginning near the end of mag. 10.32, in which Augustine turns to arguing his claim about the inner teacher; Adeodatus reappears only in the final lines of the dialogue, showing he has learned the lesson Augustine hoped to teach by denying that his earthly father has taught him anything at all (mag. 13.46). This division has been remarked upon commonly enough; what has been less frequently noted is that the first part of the text is a reductio ad absurdum of the claim that all teaching occurs through signs, pointing us instead to an embodied account of learning already "in touch" with the world, and occurring within linguistic communities. Clarifying the relation between the two parts of this work - our learning from the world and our learning from Christ, the inner teacher - will be the purpose of this section. My hope is that, by clarifying how signs direct our minds to realities beyond them, we may gain a deeper understanding of how all creaturely similitudines direct us to Christ's flesh, and how Christ's flesh directs us to the invisible God.

Just what are signs supposed to do? To signify, of course - but this can hardly serve as an answer. Slightly better, if still a naive account of signification, would be to say that a sign is something that points us to something else; or, (what may not be quite the same) something that calls something else to mind. This is definitionally true for Augustine: if a sign doesn't signify anything, it cannot be a sign, even though the signified may sometimes be obscure to us. ${ }^{63} \mathrm{We}$ use signs in order to remind ourselves or someone else of something already known to us, or to teach another something as yet unknown to him or her. ${ }^{64}$ Augustine is concerned in De magistro primarily with linguistic signs, but the claim seems more widely applicable: I might tie a string around my finger to remind myself to buy detergent at the grocery store, or leave a coded marking on a wall to teach my friend that I have passed that way. In cases of reminding, the signification seems to be relatively straightforward: in the course of my life, I have previously

\footnotetext{
${ }^{61}$ Augustine references this period in conf. 9.6.14, telling us that the ideas attributed to Adeodatus were really the boy's, and expressing wonder at his intellectual gifts.

62 Cf. mag. 4.9; King, 108: "if I were to say to you that just as every horse is an animal but not every animal is a horse, so too every word is a sign but not every sign is a word, I think you wouldn't hesitate to agree."

63 mag. 2.3; King, 97.

64 mag. 1.2; King, 95. Cary discusses pre-Augustinian semiotics, and especially the Greek perspective that words were not signs, at Phillip Cary, Outward Signs: The Powerlessness of External Things in Augustine's Thought (Oxford: Oxford University Press, 2008), 18-21.
} 
learned something; say, the fact that there is no more detergent, and the dishes are piling up. The sign that reminds points most properly not to something in the world, but to something in us the knowledge that we already possess. ${ }^{65}$

How, then, are signs supposed to teach? Here, things get more complicated. Suppose I know the word "wall," but do not know what a wall is; how am I to learn? ${ }^{66}$ I ask a friend, and she points in the direction of the wall. But if I don't already know the referent of the word "wall," how am I to know what she intends with her pointing? Perhaps "wall" refers to the shade of paint used to decorate the wall; or to the sort of material out of which the wall is constructed, rather than to the wall itself; or even to the general direction of her pointing itself. If the referent of the word "wall" is unknown to me, how am I to decide that these other possibilities are incorrect, and that she intends one flat side of the room I am in, abstracted from the rest of the building's construction? It seems that something in excess of the sign itself is needed to fix the sign's referent; but it is thoroughly unclear what could possibly serve that purpose. All that seems available for further specifying the referent of the sign already given - my friend's pointing - are themselves signs, requiring in turn that their own referents be fixed somehow.

Though Augustine articulates this problem with particular clarity, he is not alone in doing so. Indeed, Augustine's discussion of this point resonates strongly (as so often) with one of the twentieth century's most important philosophical voices, Ludwig Wittgenstein. Wittgenstein famously opens the Philosophical Investigations by quoting what is ostensibly Augustine's account of how he learned to speak from Confessions 1.8.13, and Wittgenstein's use of this passage has generally been the focus of those who wish to place the two thinkers in dialogue. ${ }^{67}$ Wittgenstein and Augustine are often taken (arguably, Wittgenstein saw himself this way) as offering two answers to the same problem, that of ostensive definition, the definition of meaning through display or "pointing" that we have been discussing so far. Augustine is read as holding that language is fundamentally a matter of naming and describing our relations to the objects of our experience, and thus, that the bedrock of language is our knowledge of the world around us what we lack is simply an agreed-upon language of signs that will map onto those objects and make clear to others what we mean. ${ }^{68}$ Wittgenstein, by contrast, is conscious of a far broader scope of linguistic acts, and accordingly holds that language receives its meaning (and particular linguistic signs their referents) through the patterns of how we use language, patterns that do not

\footnotetext{
65 It should go without saying that this account is hardly adequate by the lights of contemporary semiotics, and even by Augustine's developed thought on signs. At the outset, we should note that the relation of signification must always be triadic, consisting of the sign, the thing signified, and the interpreter; and we must attend also to the Derridean insight that even the referents of signs intrinsically refer beyond themselves in virtue of the concepts that pattern our experience of the world. Even so, it will be useful to follow the naïve account of signs a little longer, in order to determine what really animates the argument of De magistro.

66 The example comes from mag. 3.5.

${ }^{67}$ See, for instance, Myles F. Burnyeat, "The Inaugural Address: Wittgenstein and Augustine De Magistro." Proceedings of the Aristotelian Society, Supplementary Volumes 61 (1987): 1-24.

${ }^{68}$ Cf. Ludwig Wittgenstein, Philosophical Investigations, 4th Edition, ed. P.M.S. Hacker and Joachim Schulte, trans. G.E.M. Anscombe, P.M.S. Hacker and Joachim Schulte (Oxford: Wiley-Blackwell Publishers, 2009), 19 (§32):

"Augustine describes the learning of human language as if the child came into a foreign country and did not understand the language of the country; that is, as if he already had a language, only not this one."
} 
map straightforwardly onto the world but are rather determined by our linguistic communities. ${ }^{69}$ There is some truth to each of these depictions, I think; Wittgenstein's careful attention to the wide variance in the way we use language helpfully complicates some of the more incautious moments in Augustine's philosophy of language. At the same time, I believe Augustine's theological attention to the life of God as Truth itself and the source of the truthfulness of all finite truths requires a slightly different grammar of truth-attributions than Wittgenstein might have preferred. In this section, then, through reading the De magistro and the Philosophical Investigations in light of one another, I hope to develop a modified Augustinian (and Wittgensteinian) account of linguistic signs that will emphasize both the Word's internal agency in teaching us through created signs, and the work of linguistic communities in fixing the referents of temporal significations. ${ }^{70}$

In $\S 28$ of the Philosophical Investigations, Wittgenstein recapitulates the problem Augustine has already seen:

The definition of the number two, "That is called "two"" - pointing to two nuts is perfectly exact. - But how can the number two be defined like that? The person one gives the definition to doesn't know what it is that one wants to call "two"; he will suppose that "two is the name given to this group of nuts! - He may suppose this; but perhaps he does not. He might make the opposite mistake: when I want to assign a name to this group of nuts, he might take it to be the name of a number. And he might equally well take a person's name, which I explain ostensively, as that of a colour, of a race, or even of a point of the compass. That is to say, an ostensive definition can be variously interpreted in any case. ${ }^{71}$

It seems that we have come to the same impasse we met in Augustine; what is to stand surety for our intended meaning, preventing misunderstanding on the part of the person I am trying to teach? Instead of offering a theory of how words come to correspond to things in the world, however, Wittgenstein asks us to dwell in the circumstances of my student's misunderstanding. Imagine, Wittgenstein asks us, that you actually were in the situation of trying to teach someone the number "two" by pointing at two nuts, only to have your student fail properly to understand along one of the lines mentioned above; how would you try to correct your student? Wittgenstein continues in $\$ 29$ :

\footnotetext{
69 This is a particularly brutish characterization of each thinker; for a far more insightful and stimulating accounts, see Stephen Mulhall, Inheritance and Originality: Wittgenstein, Heidegger, Kierkegaard (Oxford: Oxford University Press, 2001), 29-36; and Wetzel, Parting Knowledge, Ch. 13 ("Wittgenstein's Augustine").

70 As will be increasingly apparent over the course of this dissertation, my preferred solution to this problem will emphasize the priority of the divine action but also the true and necessary contribution of finite agency and causality. In particular, we might observe how the fixing of the referent of signs through linguistic communities parallels my understanding of the interdependence of Christ with other creatures, and that Christ's own human agency and the agency of those who shape his agency stand in a place similar to the pedagogical effectiveness of creaturely signs, always dependent on the prior action of the inner teacher.

71 Wittgenstein, Philosophical Investigations, 17.
} 
Perhaps someone will say, "two" can be ostensively defined only in this way: "This number is called 'two'." For the word "number" here shows what place in language, in grammar, we assign to the word. But this means that the word "number" must be explained before that ostensive definition can be understood. - The word "number" in the definition does indeed indicate this place - the post at which we station the word. ${ }^{72}$

Very likely, I would attempt to correct my student's misunderstanding of the word "two" by attempting to inform them what sort of thing it is that I am attempting to define for them: "No, I'm trying to tell you what the number is." And, if this effort were unsuccessful - if, perhaps, I was teaching a child who did not know the concept of "number" at all-I would attempt to communicate the concept of "number" to them by presenting a series of objects in an effort to get them to understand what is common to each group: two nuts, three toys, four pencils, and so on. Yet, as Wittgenstein points out, there is nothing in these further attempts to teach the concept of "number" that ensures the success of my teaching, any more than my attempt to teach the number "two" will meet with success. Nevertheless, only one option is really available to us: "Explain, then, by means of other words! And what about the last explanation in this chain? (Don't say: 'There isn't a 'last' explanation.' That is just as if you were to say: 'There isn't a last house on this road; one can always build an additional one.')"73 The last definition, in this sense, is the one that succeeds in correcting my student's misunderstanding; but if the misunderstanding persists, another attempt to explain is always possible.

In itself, this may seem like a thoroughly unsatisfying answer to the question of how we may guard against misinterpretation of our utterances - it only succeeds in resolving the problem by sacrificing the aspiration of theoretical completeness in grounding the meaning of our speech. But this is, in fact, one of the central points Wittgenstein hopes to make: the ideal of a language incapable of being misinterpreted is itself the problem. The search for some occult linguistic surplus that might fix the meaning of our language in accord with our intention in speaking is bound not only to be fruitless, but draws us away from the situations in which we learn to distinguish between correct and incorrect uses of language, and in which we learn to correct our own or others' misunderstandings of the words we have spoken. Successful ostensive definition therefore requires that the person we are trying to teach already be familiar with the related sorts of words - the concepts - that we will be employing in our linguistic "pointing":

[O]ne could say: an ostensive definition explains the use - the meaning - of a word if the role the word is supposed to play in the language is already clear. So if I know that someone means to explain a colour-word to me, the ostensive definition "That is called 'sepia"" will enable me to understand the word. - And

\footnotetext{
72 Wittgenstein, Philosophical Investigations, 18.
}

73 Wittgenstein, Philosophical Investigations, 18. 
one can say this, as long as one does not forget that now all sorts of questions are tied up with the words "to know" or "to be clear."

One has already to know (or be able to do) something before one can ask what something is called. But what does one have to know? (§30)

The answer to this final question comes shortly thereafter, in $§ 31$ : "We may say: it only makes sense for someone to ask what something is called if he already knows how to make use of the name." 74

Wittgenstein's central point is that not only our usage of language, but even our capacity to learn it, comes from our being implicated in the sorts of shared human activities that make such language intelligible to us: "to imagine a language means to imagine a form of life" (§19). ${ }^{75}$ These shared forms of life are, in significant part, plastic and socially adapted; yet we should not underestimate the extent to which our forms of life are shaped by physical and biological realities. Various groups of persons may vary widely in how particular colors are differentiated, grouped, and correlated according to similarity or dissimilarity; yet color distinctions would not be possible at all were the human eye not capable of perceiving differences in the light-reflecting properties of various surfaces. So also, concepts of number and practices of counting would be impossible were the world not the sort of place where medium-sized objects could be handled in relative isolation from one another, marked off from other such objects, grouped, and used. One can count two nuts; but imagine how different our concepts would be were all space like a bowl of water, and were all objects like drops of ink within that water spreading and interpenetrating one another. Language-speakers learn to count and the concept of number by being taught to differentiate between objects in the world, and to manipulate them in various ways. It is only when we know what to do with a word - when we know that the sort of thing answering to our word "wall" is an architectural feature; or that it is a thing answering to this word at all, in contrast to a connective word like "but" which seems not to have any thing which seems to answer to it - that our linguistic signs become meaningful to us. Learning to use language, and therein learning the proper referents of our linguistic signs, cannot be abstracted from the world, from the concrete events and physical (and arguably, spiritual) realities of our lives. Language is thought of wrongly if it is believed to be an abstract and ideal structure corresponding to the world; rather, to speak is to act within the world.

Augustine and Adeodatus seem conscious of a similar anxiety. Throughout their dialogue, they return over and over to the question of whether or not anything can be taught without the use of signs. A range of possibilities is canvassed. Certainly any teaching employing words can be passed by, as words are themselves signs. Perhaps a material object close by (a wall) can be pointed to wordlessly, but as we have already seen, this sort of ostensive definition can easily fail; and more importantly, it seems that the gesture of pointing at the wall is a sign. ${ }^{76}$ Two more attractive possibilities are “( $a$ ) things we aren't doing when we are asked [about them] and yet can

\footnotetext{
74 Wittgenstein, Philosophical Investigations, 19.

75 Wittgenstein, Philosophical Investigations, 11.

76 mag. 3.6; King, 101.
} 
do on the spot; (b) the very signs we happen to be 'doing' [when asked about them]."77 The cases Augustine has in mind are a stationary person being asked what it is to walk beginning to walk in response, and a person asked what it is to speak while they are already speaking and responding "Why, it's the thing I'm doing right now." Yet Augustine acknowledges at the close of the dialogue that even these examples seem to require signs to guard against misunderstanding: my pupil might think that "walking" refers to the precise number of steps I have taken as a demonstration of the general concept, and in order for the speaking teacher to communicate to her student that what she is presently doing is called "speaking," it appears that she needs to make use of the very signs she is producing. Augustine and Adeodatus seem to have reached an impasse, with Augustine tentatively summarizing that "it has been established that nothing is taught without signs."78

It is at this point in the text, the culmination of the dialogue between Augustine and Adeodatus and the hinge between this first section and the long concluding monologue on Christ the inner teacher, that Augustine offers us a puzzling little narrative meant to undermine the sweeping conclusion into which he and his son had been forced, that nothing can be taught without signs:

Suppose that someone unfamiliar with how to trick birds (which is done with reeds and birdlime) should run into a birdcatcher outfitted with his tools, not birdcatching but on his way to do so. On seeing this birdcatcher, he follows closely in his footsteps, and, as it happens, he reflects and asks himself in his astonishment what exactly the man's equipment means. Now the birdcatcher, wanting to show off after seeing the attention focused on him, prepares his reeds and with his birdcall and his hawk intercepts, subdues, and captures some little bird he has noticed nearby. I ask you: wouldn't he then teach the man watching him what he wanted to know by the thing itself rather than by anything that signifies? ${ }^{79}$

As Adeodatus immediately notes, this situation seems to present difficulties directly parallel to that of the man who is displaying what it is to walk: "Here, too, I don't see that the whole of birdcatching has been exhibited." 80 In fact, the example seems decidedly worse as an occasion for proving the falsity of the claim that nothing is learned without signs: the activity described here is certainly more complex than walking, and missing is even the initial communication in which one person asks another what it is to walk. Yet Augustine tells Adeodatus, "It's easy to get rid of your worry. I add that he's so intelligent that he recognizes the kind of craft as a whole on the basis of what he has seen. It's surely enough for the matter at hand that some men can be taught

\footnotetext{
77 mag. 4.7; King, 102.

78 mag. 10.31; King 133.

${ }^{79}$ mag. 10.32; King, 134.

${ }^{80}$ mag. 10.32; King, 134.
} 
about some things, even if not all, without a sign." 81 This is, perhaps surprisingly, accepted by Adeodatus as a sufficient response, and he excitedly declares that as long as that person is "sufficiently intelligent," one person observing another walking could similarly "know the whole of what it is to walk, once walking has been illustrated by a few steps." 82

But what has been argued here? The passage threatens non sequitur in the context of $D e$ magistro; Augustine has elided the explanation of his reasoning so thoroughly that M.F. Burnyeat, for instance, can dismiss the argument and its conclusion as merely "a temporary dialectical concession." 83 On the contrary, I believe it is essential to explaining how and why Augustine puts forward the radical thesis in the conclusion of De magistro that Christ is the only true teacher. To this point in the text, it has been a fundamentally skeptical question motivating Augustine's and Adeodatus' discussion: is it possible to teach anything without necessitating the use of signs to fix the meanings of my words and actions? The skeptical conclusion is no - there is always a way that my words and actions can be misunderstood, and so all occasions of teaching will require signs to specify just what I intend to teach. On this way of thinking, teaching requires that knowledge be effected in the learner without possibility of miscommunication, or it is no true teaching at all.

Rather than finding some decisive theoretical move that would answer the skeptic's worry, Augustine (in a fashion we could anachronistically call Wittgensteinian) deflates the picture that had created the worry for us in the first place. What's more, he does so by returning us to the concrete situations in which we learn. You come across a man with strange tools, marching off toward an unknown purpose; you see him set up his reeds (a type of plant already known to you), take out an instrument that makes a sound familiar to your ears as a birdcall, uncage a type of bird you know as a hawk, and use these tools to capture a smaller bird in a way analogous to your own practice of capturing rabbits. You are able to recognize the "kind of craft" - the genus artis - of the birdcatcher, because you are familiar with similar crafts of this kind. And Augustine does not take this example to be exceptional, concluding with Adeodatus that "what seemed apparent to us a little earlier - that there is absolutely nothing that can be shown without signs - is false. These examples suggest not one or another but thousands of things that are exhibited through themselves, without any sign being given." ${ }^{4}$ Misunderstanding of course remains a possibility, but this is no longer seen as a threat to the sort of teaching that Augustine has in mind; we may learn new techniques, new activities, in virtue of the fact that these practices take place in a world within which we already know how to act.

While the example of the birdcatcher may return us to a world in which we are truly capable of learning as embodied knowers, it also is representative of a tendency that Phillip Cary believes will lead Augustine to great error in the "inner teacher" thesis he will develop through the remainder of the De magistro. Cary writes,

\footnotetext{
81 mag. 10.32: Facile est hac cura te exuere; addo enim, si ille ita intellegens esset, ut ex hoc quod vidit, totum illud genus artis agnosceret: satis est namque ad rem, et de quibusdam rebus tametsi non omnibus, et quosdam homines doceri posse sine signo; King, 134. 82 mag. 10.32; King, 135.

83 Burnyeat, "Wittgenstein and Augustine De magistro," 14.

${ }^{84}$ mag. 10.32; King, 135 (emphasis mine).
} 
the birdcatcher's wordless art illustrates the same point as the other, more wordy examples of things taught without signs: in every case, to show something without a sign is to do it in plain sight, so that the learner can perceive the thing itself the res ipsa). It turns out that far from being the exception, this is how all learning really works: unless you see the thing itself, you have not learned a thing. ${ }^{85}$

For Augustine, something can be learned without signs only if the thing itself is present to you; and as we will see, Augustine also holds this to be true of things learned through the use of signs. Yet the flaw a Wittgensteinian will identify in this picture is the notion that there is a clearly distinguishable res ipsa there, waiting to be defined. To use two of Augustine's examples, what is the res ipsa signified by our word "walking," as distinguished from the res ipsa signified by our word "hurrying"? Augustine's presupposition seems to be that naming is simply the mind's act of attaching labels to discrete objects or activities out there in the world; but as our discussion of Wittgenstein's account of ostensive definition showed, the reality is much more complicated, and much more deeply dependent on our receiving words and habits of naming from others who can correct us when we are wrong.

Augustine is conscious of the embodied nature of our learning, and conscious too of the contingency and contextual relativity of the particular words we employ as linguistic signs; i.e., he believes that in order to know what snow is, we must have encountered snow in our experience, and he knows that there are differences in language-use of the sort that we see when comparing the words "snow" and "neige." What is arguably less apparent to him is that some of our linguistic distinctions are contingent all the way down - that "walking" and "hurrying" may not refer to two clearly-definable res ipsae, but our drawing this distinction may simply be a community-specific habit in our performance of linguistic acts. We need a philosophy of language that does not require every linguistic utterance to point at some thing in the world of our experience.

Wittgenstein, in a sense, usefully demystifies our language-use at precisely the point where Augustine's account seems to falter. We are biologically capable of making certain sounds and gestures; we have the power to act in the world and learn to expect certain consequences from our actions on the basis of what we have experienced in the past; we learn in making certain sorts of utterances how to produce reliably some desired effects.

Consider the following picture of linguistic development, a picture of human growth and education that we would do well to keep in mind throughout ensuing chapters: We begin our lives wholly dependent upon those around us, unable to provide food for ourselves, unable to speak or think conceptually, unable even to determine the boundaries between the objects of our experience or distinguish between what is me and what is not. Nevertheless, my biological existence is (for most human persons) such that I either possess or will develop the capacity to recognize patterns in my experience: the faces of my parents become familiar to me, and

${ }^{85}$ Cary, Outward Signs, 94. 
associated with the provision for my sustenance; I become aware of my hands and feet as directly responsive to my urges in a way most things in my experience are not; I come to see in my experience distinct objects that I can manipulate; I learn to recognize basic correlations of cause and effect, as when I knock the glass of juice off the table. I also instinctively act in certain ways: I cry when I am hungry, or when I am scared, or when I am in pain; and I begin to recognize the pattern that when I cry, others respond to me. Gradually, I begin to learn more patterns of behavior that shade indefinably from natural evolved responses into more and more culturallyconditioned forms of response: when adults play with me, they smile, and so I come to smile when I am happy; I come to cry not only in response to external stimuli, but to produce reactions in others; I make noises mimicking the songs my parents sing to me; and increasingly, I begin to form with my own mouth the sounds I hear others making as they speak. More advanced language-users encourage and correct me in this, telling me what to call them and what to call the things around me, correcting me when I wrongly say "cow" instead of "cat." I come to recognize the consistent ways in which others respond to my utterances, that when I say "ball", others roll the ball to me. As I come to be a more and more confident language-user, I become better able to recognize the subtleties in the way others speak, and they begin holding my speech to higher standards. I learn that words are not only used to name objects or persons, but that there are different sorts of words - even if I do not yet know how to call them by their names, I find that some sorts of words are nouns, others adjectives, others prepositions. And importantly, I am taught not only to cry when I am sad or in pain, but to use language in response to sadness or pain; I am taught to answer the question "Where does it hurt?"

At each step of my learning to be a language-user, it is essential that my acts of speaking are integrated within the concrete circumstances of my life and my place in the world - both abstractly, in the specific way of living I share to a greater or lesser extent with those around me, and more concretely in the physical realities of my body, my environment, and those around me. It is also important in my language-acquisition that I have teachers who, by their approval or disapproval of the way I use speech, instruct me to be a user of a particular language (or several particular languages). To repeat a point made above: to speak is to act within the world. As such, our speech is open to the approval or reproval of others, allowing us to be instructed as more and more confident speakers; but also, this is to say that our speech is enabled and constrained by the sorts of concrete, material lives we live. Language does not float free from the world, and the material realities of our lives exert pressure on the sorts of linguistic practices it will make sense to us to employ. ${ }^{86}$ So also, we do not need to find a way for our words to correspond to the world, for our words are already within it - they are already enmeshed in circumstances that have to do with both me and the object under consideration.

In their emphasis on the embodied nature of learning, we see a point of contact between Augustine's account of the birdcatcher and the Wittgensteinian account of language offered

\footnotetext{
86 Wittgenstein notes, for instance, that our practices and language concerning weighing pieces of cheese are dependent on the world being such that blocks of cheese do not unexpectedly grow larger or smaller. If they did, it would soon become meaningless to mark and sell cheeses by their weight. Cf. Wittgenstein, Philosophical Investigations, 62 (§142), and Mulhall, Inheritance and Originality, 99-102.
} 
above. Where these two pictures differ is that Augustine took the birdcatcher example to show us a case of learning without signs, while Wittgenstein is showing us precisely what it is to use and learn from linguistic signs; what has been removed is the suggestion that learning to speak is different than learning acts like birdcatching. In learning to speak, as in learning to catch birds through the silent observation of someone else, we gain new knowledge by watching, recognizing patterns, connecting our observations with activities in which we are already adept, mimicking the behavior of others, and if necessary, being corrected by more able practitioners of the art. While this account surrenders the arguably Augustinian claim that each sign corresponds to some one particular res significata, it preserves what I take to be a central feature of Augustine's early semiotics: the claim that the significatory function of signs is grounded in the material circumstances of our lives - our place in the world, and our relations to the things in it. We learn first and fundamentally by coming into contact with the world in which we find ourselves, through reaching out and manipulating the things that constitute our environment, through experiencing the world's responses to our actions (whether causal chains, or the conscious responses of those around us). For us to come to know something is for it to occupy a place in our form of life - it is this crucial insight that forms the background to Augustine's discussion of the "inner teacher" at the conclusion of De magistro.

Following immediately on the heels of the birdcatcher narrative, De magistro takes an unexpected turn: Adeodatus drops out of the conversation entirely, only to reappear in the final words of the text; and the topic shifts radically from the question of whether anything can be learned without signs to the question of whether anything can be learned through them. Augustine introduces this new line of questioning almost casually: "Well, if we should consider this more carefully, perhaps you'll discover that nothing is learned through its signs. When a sign is given to me, it can teach me nothing if it finds me ignorant of the thing of which it is the sign; but if I'm not ignorant, what do I learn through the sign?"87 His argument for this claim is fairly straightforward: I come across an unfamiliar word (the example he gives is sarabarae, a word that appears in Daniel 3). ${ }^{88}$ I am able to read the sentence around it; I know roughly what "post" in the sentence this word is manning (to repurpose Wittgenstein's metaphor); I can even read and speak this word; yet I still have no idea what it is meant to signify. If one placed some sarabarae in front of me one day, I would have no idea that these things are called sarabarae. Augustine takes this fact to be deeply illuminating of both the nature and limits of signification:

The first time the syllable "head" struck my ears I was just as ignorant of what it signified as when I first heard or read "sarabarae." Yet since "head" was often pronounced, I discovered that it was the term for a thing already familiar to me by sight. Before I made this discovery, the word was a mere sound to me; but I learned that it was a sign when I found out of what thing it is the sign... Therefore,

87 mag. 10.33; King, 135.

${ }^{88}$ King notes that even today, "the form and meaning of the word are extremely unclear"; 135n.78. 
a sign is learned when the thing is known, rather than the thing being learned when the sign is given. ${ }^{89}$

Clearly the import of the sarabarae example is to show that if a thing does not enter into my form of life, the sign has no power itself to communicate knowledge of the thing to me. If I have not already come across a sarabara, and if I do not already know that the word "sarabara" refers to it, the sign itself is powerless to teach me what it signifies. Even if the res significata is already known to me, as in the case of "head", unless someone informs me that this word refers to the head, the sign itself communicates nothing. Augustine concludes, therefore, that we learn nothing from signs themselves, but only from the things to which the signs refer.

Imagine another case, though: say that I have never seen the Great Wall of China (as, indeed, I have not). Nevertheless, I am acquainted with many signs that refer to it: I have seen photographs of it; I have seen documentaries about it; I have read about it in books. And not only do I (seem to) know things about it, but I myself can refer to it, as I just did in the preceding sentence and as I continue to do with pronouns in this sentence. I know that it was built largely in the Ming Dynasty to defend against the Mongols, and I could conceivably learn enough to become an expert teacher on the Wall without ever having seen it myself. As stated, then, Augustine's argument appears to be on shaky ground. ${ }^{90}$

Augustine is not, however, innocent of what we might call "Great Wall" cases. He imagines an interlocutor asking him whether or not we know anything of Nebuchadnezzar and the three young men thrown into the furnace in Daniel 3; for one who takes this narrative to be a true record of events by virtue of its inclusion in Holy Scripture, do not the words themselves communicate knowledge? Augustine's response is instructive:

I reply to this objection that everything signified by those words was already known to us. I'm already familiar with what three boys are, what a furnace is, what fire is, what a king is, and finally what being unharmed by fire is, and all the other things that those words signify. Yet Ananias, Azarias, and Mishael are just as unknown to me as the sarabarae, and these names didn't help me at all to know them, nor could they help me. ${ }^{91}$

\footnotetext{
89 mag. 10.33; King, 136.

${ }^{90}$ It is perhaps worth noting that at times, Augustine seems to limit the force of his argument to linguistic signs, as at mag. 10.34, where he says, "Most of all I'm trying to persuade you, if I'll be able to, that we don't learn anything by these signs called words (Et id maxime tibi nitor persuadere, si potero, per ea signa quae verba appellantur, nos nihil discere)" (King, 137). Throughout the remainder of the text, uses of verbum and its cognates vastly outnumber use of signum and its cognates. It is interesting to ponder what he would make of something like a photograph. If I have seen a photograph of the Great Wall, have I come into contact with the res ipsa, or only a sign of it? While Augustine's "inner teacher" thesis undoubtedly has profound implications for his understanding of how all signs function, we should be cautious about too hastily committing him to the claim that no sign or representation teaches us anything at all about a thing. If it is true, as Augustine claims, that "words have force only to the extent that they remind us to look for things; they don't display them for us to know" (mag. 11.36; King, 137) then perhaps types of signification that come closer to displaying their res significata - photographs, for instance - have greater power to teach.

91 mag. 11.37; King, 138.
} 
I can attain some sort of imperfect knowledge about something I do not directly perceivewhether the Great Wall of China or the fiery furnace- by words pointing me to remember things I already know; but reading the story in Daniel does not give me a direct connection to the three young men themselves. The Wittgensteinian can go some distance down this road: that I have not directly perceived the Great Wall of China limits the sorts of knowledge about it that can be attributed to me. I could potentially read phenomenological descriptions of the Wall, and so learn how to describe its texture, the way its shadows fall as the sun moves across it throughout the day, whether the wind whips especially strongly over the top of it. What's more, had I read such descriptions, I could teach you about them as well. However many accounts I read of what it is like to be at the Great Wall, though, I cannot (without being a liar) tell you what it was like for me to see the sun striking the Wall's face, or whether it was warm to my touch. This is not because this knowledge is in principle incommunicable - if I had been there, I could tell you all this - but the Wall has not yet entered into my life in this way. In this sense, the Wittgensteinian can even affirm Augustine's statement about the fiery furnace that "I believe rather than know that everything we read in the story happened then just as it is written," and therefore some version of the knowledge/belief distinction. ${ }^{92}$

Where the faithful Wittgensteinian must finally part ways with the Augustinian is in describing what it is for something to be a belief rather than knowledge. For the Wittgensteinian, knowing can be glossed as "being able to go on." "Judging something to be true, on this account, is akin to being such that you would respond "Yes" if asked whether something were the case. Some sorts of truth-predications are of the sort that they should be affirmed as true always by everyone (it is true that $2+2=4$ ); some are dependent on contingent cultural forms but no less universally true for that (it is true that the President of the United States in 2016 is Barack Obama); others change based on contingent circumstances (it is true that I am sitting; but it will not be true in a few minutes). Here again, we should not ignore our biological realities - it is true that the sky is blue, in part because our eyes have evolved to differentiate between different wavelengths of light, and because we have relatively consistent practices of identifying things according to the wavelength of light they reflect off their surface; but our account of what it is for a statement to be true or false stops at the horizon of these conventions of judgment. The farthest a Wittgensteinian might go toward Augustine's knowledge/belief distinction would run roughly as follows: to know something is to hold it to be true on the basis of direct experience or rational necessity, while to believe something would be to hold it to be true without sufficient justification to count as knowledge.

By contrast, for the Augustinian (as should be held, I think, by all Christian theologians), the central feature of ascriptions of truth is that God is Herself the fullness and source of all Truth. While Augustine draws the knowledge/belief distinction based on the sources of one's

92 mag. 11.37; King, 138.

93 Cf. Philosophical Investigations, $§ 150-1$. 
knowledge, it is clearly the personal nature of Truth that is the motivation and most significant feature of his account of truth predications. This leads Augustine to a striking conclusion:

Regarding each of the things we understand, however, we don't consult a speaker who makes sounds outside us, but the Truth that presides within over the mind itself, though perhaps words prompt us to consult Him. What is more, He Who is consulted, He Who is said to dwell in the inner man, does teach: Christ - that is, the unchangeable power and everlasting wisdom of God, which every rational soul does consult, but is disclosed to anyone, to the extent that he can apprehend it, according to his good or evil will. ${ }^{94}$

When we believe things about the Great Wall of China that we read in books or see in documentaries, we place our trust in the signs and representations presented to us - we trust that the author has done her research thoroughly, or that the documentarian has not deceived us through computer-generated effects. This trust in external signs or people is characteristic of belief, even if what we believe is true. When, however, we come to understand something, we can see its truth plainly - we perceive the thing known directly with our senses, or we recall it in memory, and see these images in the light of the Truth; or, if the thing known is an intelligible rather than a sensible thing, "we look upon [it] immediately in the inner light of Truth," demonstrating it to ourselves through reason. ${ }^{95}$

This is not, of course, to say that we cannot be mistaken if we believe ourselves to know or understand something, for as Augustine notes, our ability to perceive the Truth and other realities in its light is very imperfect. ${ }^{96}$ But it is to say that linguistic convention should not be considered the final arbiter of judgments of truth or falsity. It is important to be clear on this point: my claim is not that because we may know some things in the light of the Truth, there are some truths we may know beyond any possibility of doubt. While Augustine's account tends in this direction, and while mathematical and some logical truths seem likely contenders for such a distinction, our difficulty in perceiving the Truth opens the possibility of doubting even these. ${ }^{97}$ The affirmation of the personal identity of Truth and the possibility of perceiving sensible or intelligible things in that Truth does not deny the linguistic mediation of all statements we wish to judge as true, but rather gives us a different way of understanding of what it is to judge something to be true. To know something as incontrovertibly true (or close to it) is to come into contact not only with the thing perceived, but through it, to the Truth itself. It is, as Cary noted, akin to the example of the birdcatcher - just as we learned what it is to engage in birdcatching by watching him conduct the activity, so also we learn the truth of judgments about the world by

\footnotetext{
94 mag. 11.38; King, 139.

95 mag. 12.40; King, 140.

96 Cf. mag. 11.38

97 Though it seems impossible to imagine any form of life in which basic mathematical truths can be doubted in a sustained way without sacrificing rational thought entirely; cf. Ludwig Wittgenstein on "hinge propositions" in $O n$ Certainty, ed. G.E.M. Anscombe and G.H. von Wright, trans. Denis Paul and G.E.M. Anscombe (New York: Harper \& Row, 1969), 86 (§341).
} 
encountering Truth itself, present to the intellect. If our ability to learn of the world and speak about it depended upon the fact that we are already in contact with the world, something similar is the case with knowing Truth: we learn it more and more fully as we encounter it in the world, perceive it in the mind, and are corrected by it.

On the basis of this account, we may see why Augustine claims that signs are powerless to teach us - to communicate knowledge in themselves. As the example of the sarabarae taught us, words have no necessary or even evident connection to the things of which they are signs. So also, words can communicate falsely: the person speaking to us may be lying, or merely mistaken. In many cases, the best I can do is to believe the person speaking to me, to trust that what she says is true. For something to attain to knowledge, however, it is necessary that learners should "consider within themselves whether truths have been stated. They do so by looking upon the inner Truth, according to their abilities. That is therefore the point at which they learn."98 And so, the conclusion runs, we should understand the one truly responsible for the learning not to be the speaker or the linguistic signs, but the Truth itself, present within the learner. This Truth, Scripture teaches us, is the eternal God, the one whose mission is to communicate knowledge to us, and who therefore becomes incarnate in Jesus Christ, "Who is the Teacher of all." 99 At best, words can direct our minds to look for something in God's Truth.

When, then, a much older Augustine turns back to De magistro in his Retractationes and describes it (as we saw above) as a work in which "it is debated, sought, and found that there is no teacher giving knowledge to man other than God," we should take him at his word. ${ }^{100}$ While his argument that the Word is the only true teacher occupies only the end of the treatise, Augustine's whole argument is governed by the aim of rendering this conclusion convincing. Determinative for him is the claim that in order to learn anything from signs, we must consult the Truth that dwells mentally within us, the Truth who is Jesus Christ. This does not, of course, suggest that one is unable to reason properly or be directed by signs to new knowledge without first coming to know God's revelation in Christ; many people have understood mathematical truth quite effectively without having ever come across the name of Jesus. The suggestion is rather that, whether we are able to recognize it as such or not, every act of thought in which we come to perceive some truth depends on the Word's presence to our intellects. The Word's illumination should not be understood as an act in which God beams knowledge into us from beyond, converting belief into knowledge, but as the deepened intimacy with the Truth that results from knowing the world truly. ${ }^{101}$ From our very constitution as rational creatures, the Word dwells

\footnotetext{
98 mag. 14.45; King, 145.

${ }^{99}$ mag. 13.46; King 146, citing Matthew 23.10.

100 retr. 1.12; King, 94.

101 So Lydia Schumacher, Divine Illumination: The History and Future of Augustine's Theory of Knowledge (Oxford: WileyBlackwell, 2011), 65: "the illumination of Christ does not bear on cognition in any way that undermines the autonomy or integrity of the intellect but in a way that reinstates it, at least for the intellect that stokes rather than extinguishes His light through a decision to work with faith in Him. On Augustine's account, all that comes to the intellect from the outside is the power to be renewed on the inside; this is the power to illumine the divine being that is received through divine illumination - the power to know like God and thus know God...unless God gives the capacity to know Him and it is used to the end of knowing Him, there is no such thing as knowing or knowledge at all." Augustine's writings on illumination are especially knotty; in addition to Schumacher's book, see Gerard
} 
within us, and the truth we encounter as we learn about the world draws us into contact with it, returning us to the source of our capacity to know the world and confirming our knowledge of the world as knowledge. ${ }^{102}$

In fact, we may worry that Augustine's account has gone too far, raising the question of how our direct perceptions of the world can be thought to produce knowledge in us, rather than belief. After all, can't our senses lie to us just as effectively as our friends? Why, then, should the sensible objects of our perception be considered more trustworthy than signs? Burnyeat's suggestion that the birdcatcher narrative presents only a "temporary dialectical concession" to the view that we can learn some things from observation of the world indicates that he interprets Augustine along just these lines. Augustine does not discuss this point directly in De magistro, and his terminology of "looking upon the inner Truth" remains suggestive but vague. In order for perceptions of the world to count as productive of knowledge, there must be an intrinsic connection between the things of the world and the Truth that is known in them. The most likely candidate in Augustine's thought seems to be the relation of participation: created things are and are true because they participate in the Word's Truth; as a result, our perceptions of created things may give rise in us to true knowledge about them. Creatures depend for their existence on a relation of likeness to God, and so they exhibit a likeness to God's Truth. What's more, each creature exists within the one Truth of God, known and ordered from all eternity by the divine Wisdom; all truths about creaturely realities are therefore eternally included within the Truth that is God's own life. Without the Word's presence to the intellect interior intimo meo, preceding and enabling all our acts of knowing, knowledge of the world would be impossible for us; so also, what it is for our knowledge to be true is for our intellects to be conformed to the world, knowing it as the Word gives it to be through participation in Him. In this sense, it is true to say that all created things are signs that point us to the Word in our knowing them, that knowing the referent of any sign draws the intellect into deeper contact with the Word. The crucial difference between perceptions of the world and significations is that the sign points finally to a truth wholly external to it, while a perception points to the truth proper to the creature itself; that neither sort of intellective act can occur without the mind's illumination by the Word does not invalidate the knowledge of finite truth proper to perception of creatures.

To summarize my adaptation of Augustine's account of signs: we are born into the world, and through repetition and a biological capacity to recognize patterns in the world, learn practices of giving and receiving signs alongside other actions like manipulating physical objects, moving by crawling and walking, feeding at regular intervals, and so on. Some of these recognized patterns are natural (for instance, smoke signifying fire, as Augustine famously discusses in De doctrina christiana 2.1.1), but many more have no essential connection between the sign and signified, and are learned through interaction with other people. In either case, the sign

O’Daly, Augustine's Philosophy of Mind (London: Gerald Duckworth \& Co., Ltd., 1987), 199-207; and Robert Dodaro, "Light in the Thought of St. Augustine," in Light from light: scientists and theologians in dialogue, ed. Gerald O'Collins S.J. and Mary Ann Meyers (Grand Rapids: Wm B. Eerdmans Publishing Co., 2012), 195-207.

102 Mark D. Jordan, "Word and Words: Incarnation and Signification in Augustine's De doctrina christiana," Augustinian Studies 11 (1980): 177-96; 196. 
does not necessarily announce itself as such: we only come to recognize smoke as a sign of fire after we have learned that smoke generally accompanies fire, and we must already be aware of the social conventions concerning some particular sign (or more broadly, the giving and receiving of signs) to recognize something as a sign in the first place. For something to function as a sign, therefore, it must be implicated in a broader linguistic community; nothing is essentially a sign. Signs function by pointing away from themselves, and consequently, they are not themselves sufficient to produce knowledge in the one who perceives the sign; this can be seen in the fact that signs are capable of representing as true what is untrue. Most of what we gain by perceiving signs should thus be regarded as beliefs, rather than knowledge. Inasmuch as signs are involved in our attaining to real knowledge, it is because signs can prompt us to remember something we had already learned, or to consult the Truth itself which is always present to our intellect. Though our perception of this Truth is limited, we can on some occasions come to know things directly in its light. Learning such knowledge is not to be attributed to the sign itself, but to the Word who teaches us inwardly. This Truth is the very one who assumes flesh and becomes incarnate in Jesus Christ; by the communication of attributes, it is thus proper (indeed, if one accepts the rest of this account, christologically necessary) to affirm that the inner teacher who communicates all knowledge through signs to us is Jesus of Nazareth.

Augustine errs in holding (or at least, errs if he holds) that the referent of signs is fixed by correspondence to some one res ipsa in the world. This assumes that the world of our experience comes neatly pre-sorted into objects to which we can subsequently attach any number of signs. But as Wittgenstein shows us, our recognition of these res ipsae is itself conventional. Even to identify what is signified by the sign depends upon dividing the world up in a certain way, and we learn to this in linguistic communities which vary widely between each other in just how they divide the world up into things to be signified. Nevertheless, Augustine's fundamental point is that signs depend for their significatory power on their participation in the Word who is present in our intellects as the inner teacher, showing us the truth of the thing signified as the sign directs our minds to it. This fundamental structure can be preserved, even on the other side of our Wittgensteinian critique. Though signs can signify in any number of different ways as a result of linguistic convention, they nevertheless still point us to different features of the same world, a world that exists in dependence on the Word. Any truths knowable about the world will be dependent upon features of that we encounter in our experience of it, the experiences that ground our ability to signify things within it and make truth-claims about those things within our various contingent languages of signification. Any language that allows us to make truth-claims about the world will be developed through life within the world, and so will point us to features of the world that exists in dependence on the Word. So, for instance, if our language has many different words for different sorts of snow, it will respond to the feature of the world that snow consistently and repeatably falls in many different varieties; if our language has only one word for snow, it will be because there are features like coldness and solidity that are shared by all these different sorts of snow. Though these words signify the world to us differently, they point us to the very world that exists in dependence on the Word; and to the extent that our words point our intellects to a deeper knowledge of the world's truths, it is because our intellects too participate in 
the Word who is the source of all truth. All signs, to the extent that they signify truly, point us to the world God has made, and - finally and non-competitively - to the Word that is the source of their existence.

With this understanding of Augustine's semiotics in mind, we return to the second extended christological section of the De trinitate in book thirteen, with the hope of appreciating more fully how the sign of Christ's flesh serves to draw our desires and intellects back to the Triune Lord.

\section{Reading Christ in the World}

Let me briefly rehearse the argument of this chapter to this point. In section one, we saw that as a result of our sinful condition, we cannot yet see God; at present we see only in a glass darkly. Only the pure in heart may see God. Because the Word is and exists in substantial unity with God, He too remains invisible to us even in the context of the Incarnation. Yet the flesh of Christ is visible, and it is to the preeminent sign of God in Christ's human life that we must turn if we desire the restoration of our vision of God.

In section two, we saw that the Christ is indeed the sign of God in the world par excellence, the point toward which those who desire reconciliation with God should turn in contemplation and adoration. It is his life that serves as both the sacramentum of the inner human and exemplum of the outer; in him, we learn the proper spirit of dependence upon God in humility, and trust that his victory over death will be made our own. As we turn to Christ as both the mystery of our inner renovation and the example of our life in the world, we find our hearts gradually purified and turned back to God. It is this purificatory effect of Christ's life that is emphasized when we call Christ sacrificium, God's self-offering to the world that cleanses us of our sinful desire. More than this, however, Christ's life serves as the center of all creation's signification of God. All things are signs of the eternal Word as a result of their participation in Him, the likeness to God that establishes them in their being.

In section three, then, I attempted to develop an Augustinian account of signs and signification that might fill in some of the gaps in our preceding discussion. In the course of reading the De magistro and Wittgenstein's Philosophical Investigations alongside one another, I offered an understanding of signification that attended to two principal emphases: first, the embodied and community-dependent nature of all our language-use; and second, the grounding of the pedagogical potential of all signs in the direct presence of the Word to and within the intellect. Though the referents of signs are fixed by linguistic convention, it is only possible for us truly to learn from them inasmuch as they draw our minds into more intimate relation with the Word who dwells within us, and who grounds our life and knowing through our participation in Her. 
In light of all this, we are prepared to consider with more specificity how the human life of Christ serves as a redemptive sign, a question to which Augustine himself returns in De trinitate 13. My presentation makes four central claims. ${ }^{103}$

103 Though my presentation in this chapter focuses upon Augustine's account of Christ's life as a redemptive sign, it would be a mistake to think that the cross possesses for Augustine a significatory importance alone. John Cavadini, for instance, has outlined the many different metaphors Augustine employs to describe the work of the cross in addition to sign, including mousetrap, lampstand, classroom, boat, and "tree of silly fruit"; cf. John C. Cavadini, "'The Tree of Silly Fruit': Images of the Cross in Augustine," in The Cross in Christian Tradition: From Paul to Bonaventure, ed. Elizabeth A. Dreyer (New York: Paulist Press, 2000), 147-68. So also, one of the major themes of both De trinitate 4 and 13 is Christ's sacrifice as the event which liberates us from the power of the devil.

The cross transforms not only our intellects and desires, but also our relation to other parts of God's creation, particularly the spiritual realm. Adam and Eve were not alone - or even original - in their fall; Augustine tells us that "The devil was the mediator of this road, persuading to sin and hurling down into death; he too brought his own single death to bear in order to operate our double death." 103 Interwoven with the inner cleansing effected by the sacramentum of Christ's offering is an account of the breaking of the devil's power over humanity, "who had yielded to his seduction, and whom he had thus as it were acquired full property rights over, and being himself liable to no corruption of flesh and blood had held in his thrall in his weakness and poverty and the frailness of this mortal body, like one seemingly rich and powerful, and all the prouder for that, lording it over a wretched ragged slave" (trin. 4.13.17; WSA I/5, 165). Clearly, this does not occur outside the purview of God's providence: as Augustine goes on to write in De trinitate 13, "As for the way in which man was handed over into the devil's power, this should not be thought of as though God actually did it or ordered it to be done, but merely that he permitted it, albeit justly. When he withdrew from the sinner, the author of sin marched in" (trin. 13.12.16; WSA I/5, 355-6). The crucial link forged here is the one between the devil's mediation of sin to us and his right over us. In the relationship between Satan and humanity, we see a perversion of our relation to God and Christ. We are, at root, created to be receivers of God's gifts; our creation and all God's action toward us are grace, and our lives are ordered to respond in gratitude and praise. In teaching humanity to sin, the devil offers us a sort of deceptive gift - not quite a new pattern of action, so much as a pattern of inaction. Even so, the devil teaches us to behave as he does - proudly, maliciously, slothfully, and so on - and in so doing, mediates to us the nothingness that increasingly characterizes his and our lives. We become bound to him in a twisted image of the gratitude we ought show to God, and come to resemble him ever more fully. As the author of sin, the devil is the head of a degenerate and degenerating community; the civitas terrena is also civitas diaboli. Inasmuch as the devil has rights over us, it is because he is the model of our sin, and he will pursue this advantage over us until this power is broken.

The account of our justification Augustine offers in De trinitate 13 hinges on a contrast between power and justice. God is, of course, all-powerful, and had God wished simply to break the power of the devil over us by claiming us as His own, no creature could resist. Yet Augustine seems to think that effecting salvation in this way would serve as a final confirmation of what we might call the "satanic impulse": "The essential flaw of the devil's perversion made him a lover of power and a deserter and assailant of justice, which means that men imitate him all the more thoroughly the more they neglect or even detest justice and studiously devote themselves to power, rejoicing at the possession of it or inflamed with the desire for it" (trin. 13.13.17; WSA I/5, 356). This desire for domination will be familiar to readers of $D e$ civitate dei as the libido dominandi; but here Augustine ventures to imagine what it would be like if God were also characterized above all by the will to exercise power, irrespective of the justice of His actions. Had God liberated humanity from Satan's tyranny through coercive force, God would begin to appear to us uncomfortably similar to the devil, only incomparably more powerful. And this revelation of the ultimacy of power would, in itself, seem to confirm us in our lust for domination, rather than loosening its grip on us. Instead of God's redemptive work serving as an attractor to desires rightly-ordered in love of God and neighbor, this conquest of hell would only reinforce that power is the final word, and that we are justified in pursuing it over all other things. The problem is not that redemption would be impossible - another act of power would undoubtedly be sufficient to convert our hearts forcibly — but rather that God's saving acts would be a stumbling block, deepening us in sin before freeing us from it.

As a result, Augustine tells us that "it pleased God to deliver man from the devil's authority by beating him at the justice game, not the power game, so that men too might imitate Christ by seeking to beat the devil at the justice game, not the power game. Not that power is to be shunned as something bad, but that the right order must be preserved which puts justice first" (trin. 13.13.17; WSA I/5, 356). This is what Christ's death accomplishes: a just judgment against the devil that strips him of his right to exercise power against us. One of the most significant 
First, Christ's life comes to be intelligible to us as a sign of God through an embodied history wherein God teaches and corrects the speech of one particular linguistic community, makes them capable language-users of signs directed to God through correction of their errors in sign-use, and enables them to extend this linguistic community by teaching these patterns of language-use to others. This linguistic community is, in the first place, the people of Israel, and derivatively the Church guided by the bishops that the Holy Spirit has called to teach within it.

This chapter began with the words of Christ to St. Philip in John 14.9, Anyone who has seen me has seen the Father; but it will be useful to remember the context of these words. In the midst of teaching his disciples, Philip expresses just the desire that has been at the heart of our reading of Augustine: Lord, show us the Father, and it sufficeth us. Fesus saith unto him, Have I been so long time with you, and yet hast thou not known me, Philip? Confronted face to face with the Christ, the sign of God, Philip can see nothing. He that hath seen me, hath seen the Father seems a promise, not a description of what it is like to see Christ. We can think also of the many leaders in synagogues dotting Galilee and Judea, the temple authorities, the Roman officers: all these meet Christ in the flesh, yet few see God in him. These features of Christ's life should suggest to us that nothing about Christ's life is self-evidently a sign of God. It is entirely possible to miss the intended significatory referent of his life, just as the word sarabara means nothing whatsoever to me.

We must be taught to see the life of Christ as a sign of God: we must be made capable users of what we might call the "language of divine signification." In speaking of divine signification as a sort of language, I have in mind a communicative history between God and God's people that Cora Diamond describes as "a kind of conceptual reorientation" that occurs through the "recognition of God as genuinely giving himself in revelation, and of revelation as thereby involving the 'inner conversion' of our former concepts, through its, as it were, saying 'Nay' to them." 104 Diamond asks us to imagine a religious believer who "describes the language game she plays as one in which God speaks and is responded to":

She might be asked what, in the game, counts as God having spoken; when do we say that he has spoken? The questioner insists that she should provide a form of description in which we are the ones who speak and who determine what counts as God's speaking; but that form of description seems to her to deliver God's speaking into our hands. Whatever might be the conventions of the game, the

features of Christ's death in De trinitate 13 is that it was a travesty of justice, an offering that the devil had no right to accept. The miscarriage of justice that the devil allows removes, as it were, the legal standing by which he was granted to have power over sinful humanity. This stripping of the devil's right over us is the heart of Augustine's description of justification in this text: "this blood of his, of one who had no sin at all, was shed for the remission of our sins, and the devil, who once held us deservedly under the sentence of death as we were guilty of sin, was deservedly obliged to give us up through him he had most undeservedly condemned to death, though guilty of no sin" (trin. 13.15.19; WSA I/5, 358) Once this power is broken over us, "it is therefore perfectly just that he should let the debtors he held go free, who believe in the one whom he killed without being in his debt. This is how we are said to be justified by the blood of Christ"(trin. 13.14.18; WSA I/5, 357).

104 Cora Diamond, "Wittgenstein on Religious Belief: The Gulfs Between Us," in Religion and Wittgenstein's Legacy, ed. D.Z. Phillips and M. von der Ruhr (London: Ashgate, 2005), 99-137; 125. The Barthian resonances of this passage are unmistakable. 
ways we take what people say, and correct them, and so on, the game has (as she sees it) a kind of openness to God's actions, an openness which means that it is not for her or others to lay down rules for what counts as God's speaking. ${ }^{105}$

In language that will be familiar to readers of Wittgenstein or postliberal theology, Diamond presents us with a grammatical investigation: what is the grammar for identifying something as the communication of God? We might rather say, what is the feature of Christian speech that identifies something as a sign of God? We might even develop it in more rarified theological air by presenting theological claims themselves as rules for Christian speech, and the truth of Christian claims as fundamentally a matter of coherence with the other well-formed utterances within that language. ${ }^{106}$

Yet this philosophical inquiry is derailed by the introduction to Diamond's scenario of an otherwise unremarkable woman of piety. This woman tells her philosophical interlocutor that what counts within her grammar of revelation as God's speaking is not something that can be fully and finally anticipatable in advance: it is God who sets the terms of Her speech to us, and our account of the grammar of divine speech will need constantly to be revised in light of future events in which God speaks to us. Diamond is pointing us back to the rough ground of our experience, rather than the frictionlessness of our theories; our understanding of what it is for God to speak must - if it is part of our understanding of revelation to say that God is the one who superintends the process - be reassessed as we continue living lives thoroughly dependent upon the world in which we find ourselves, passing linguistic signs back and forth with those who share our patterns of speech to a greater or lesser extent. Our language, especially about God, is not closed and fixed, but always responsive to the new ways God is communicating to us. Through the history of this communication, God is teaching us to speak about Her in certain ways, correcting us when our responses are inappropriate, giving us new words that expand our vocabulary of signs that refer to Her.

Consider: the God of Abraham, Isaac and Jacob; who becomes the God who liberates the slaves from Egypt; who names Himself as "I am that I am"; who becomes the Lawgiver; who punishes those who represent Him in the form of a golden calf; who dwells first in the Tabernacle, and then in the Temple; who rules through judges and kings; who speaks through the prophets; who sends His people into exile, and restores them to the land of Israel. Each of these communicative acts enriches the significatory lexicon of this people: the bush that burns without being consumed; the bread of heaven; justice that rolls down like waters. Any one of these new acts of God's speech may require a reevaluation of what we understood to be the grammar of God's self-communication to be, as when the people who worshipped a nameless

\footnotetext{
105 Diamond, "Wittgenstein on Religious Belief," 128; see also Mulhall's discussion of this essay and Diamond's creative development of Wittgenstein more generally at Stephen Mulhall, "Realism, Modernism, and the Realistic Spirit: Diamond's Inheritance of Wittgenstein, Early and Late." Nordic Wittgenstein Review 1 (2012): 7-34.

106 The first of these is something that I will certainly wish to do in certain contexts; the latter seems to me a misapplication of the grammar of Christian truth-claims, which (as I argue above) necessarily include reference to the Lord whose life is Truth and the source of all truths.
} 
Lord are given a name too holy to utter. We thus come to recognize creaturely things as signs of God as these things are included within a developing history of God's self-communication. We are like the boy Samuel: in order to hear the voice of the Lord as the Lord's, we require tutelage from those who are already proficient in recognizing these signs as signs. ${ }^{107}$

When we turn to Augustine's thought, we can see a clear anticipation of this outlook both in his theology of the Jewish people and in his typological exegesis of Scripture. Paula Fredriksen writes of Augustine's christological interpretation of Scripture and the place of the Jewish people in God's historical work as "radically innovative":

This orientation enabled him to assert not only that the Law itself is good, but also, and much more boldly, that the Fewish understanding of the Law as enacted by Israel and as described in the Bible was also good. Ancient Jewish behavior, asserted Augustine, with all its purification rituals and blood offerings and food restrictions and pilgrimage holidays and codes of conduct for the Sabbath, was also praiseworthy. ${ }^{108}$

These rituals of the people of Israel were not mere misunderstandings of God's speech or perversions of Her commands, as earlier Christian writers like Tertullian had thought. ${ }^{109}$ These were irreplaceable moments in which God communicated Her character to the Jewish people, and equipped them to recognize future acts of divine speech. Where the Jews have erred, on Augustine's account, is in failing to recognize Christ when he appeared. They possessed all the tools that they needed to see Christ as the sign of God, but responded ineptly to God's selfcommunication in human flesh. Augustine fails to consider the possibility that the Jewish people might, in light of their role within God's redemptive work, have a different "dialect" within the language of divine signification in God's speech to them and their response to God, an understanding that would view the continuation of the Jewish people and their continued observance of the law as precisely what God commands within the broad arc the world's reclamation. Nevertheless, he continues to view the Scriptures both Old and New as a treasury of images, all of which refer finally to the human flesh of Christ. As he wrote at Contra Faustum 12.8 with reference to the Book of Genesis, "Everything that we read there, when it is considered clearly and piece by piece, foretells Christ and the Church."110

Summarizing this first point, we may say that signs come to be recognizable as referring to God as they are implicated within the history of God's speech to Israel, and later the Church. It is part of the grammar of the language of divine signification that it is always open to revision in light of God's further communication, communication recognizable in light of the revelatory

\footnotetext{
${ }^{107}$ Part of what makes Abraham a model of faith is that he trusted without a history of communication with this unknown God.

108 Paula Fredriksen, Augustine and the Fews: A Christian Defense of Jews and Judaism (New Haven: Yale University Press, 2010), 243.

109 Fredriksen, Augustine and the Fews, 224.

110 WSA I/20, 130; cited by Fredriksen at Augustine and the Fews, 263.
} 
speech of God with which we are already familiar. Though meditation on the Scriptures, the teaching of the Church, the lives of the Saints, and so on, we are enabled to recognize novel signs or novel connections between old signs, ${ }^{111}$ pointing us more deeply into the mystery of God's life. As it is interpreted through the types and anticipations especially of the Hebrew Bible, and as it is encountered in the sacramentum and exemplum of Christ's life, we may say with Augustine that "faith has been given actual definite content in Christ (hanc autem fidem in Christo esse definitam), who rose in the flesh from the dead to die no more." 112

Second, we should say in light of the preceding three sections that the sign of Christ's life produces in us faith, not sight - and it is faith in these worldly signs that open for us a pathway back to God. The question of how our agency and God's relate to one another in the course of this return will need to wait for Chapter 5, below; for now, we may simply note the interrelation of external signs and our interior homo in this affective and intellectual pilgrimage. "Faith," as Augustine writes at the beginning of trin. 13, "is needed by which to believe what cannot be seen." 113 At various points of his writing, it is clear that faith is an act of both intellect and will, the intellect entertaining a thought and the will assenting to belief in it. ${ }^{114}$ How does the will's assent to belief in the redemptive signs proffered by God, preeminently the sign of Christ's life, lead our hearts and minds to rise to God?

To answer this question, it will be necessary to look briefly at the account of the intentionality of our knowing that Augustine offers in De trinitate 11 and 12. In our experience of our intentional perception, we may understand the will as that which directs our eyes to certain objects, which focuses our attention and struggles to make out details in what we see with greater precision. In at least those voluntary acts of perception in which the will directs sight to perceive some object in the world, "Perhaps we can say that sight is the end and resting place of the will" - the will desires knowledge of something in the world, and sight is the vehicle by which the soul is united to the object of the will's desire. ${ }^{115}$ Yet this process can quickly become more complicated: "the will to see the window has as its end the sight of the window; the will to see passers-by through the window is another will joined onto this one, and again its end is the sight of passers-by." "16 If I wish to see the people walking by outside, I know I must look through the window; yet it is the window to which I turn my eyes, not to the passers-by who may or may not even be outside. Nevertheless, in this process, the window becomes epistemically (as well as, to a greater or lesser degree, physically) transparent to me; in many cases, I am not even conscious of

\footnotetext{
111 This is characteristic of the allegorical exegetical method employed by most of the early Fathers of the Church; see Robert Louis Wilken, "In Defense of Allegory," Modern Theology 14, no. 2 (1998): 197-212; and Mark Randall James, "Learning the Language of Scripture: Origen, Wisdom, and Exegetical Inquiry" (Unpublished Ph.D. Dissertation, University of Virginia, 2016).

112 trin. 13.20.25; WSA I/5, 364. Translation lightly amended.

113 trin. 13.1.2; WSA I/5, 343.

114 praed.sanct. 2.5 ; WSA I/26, 151: "although certain thoughts fly quickly, even most swiftly, before the will to believe, and the will follows so soon afterward that it accompanies it as if it were united to it, it is, nonetheless, necessary that thought precedes everything which we believe. In fact, the very act of believing is nothing other than to think with assent."

115 trin. 11.6.10; WSA I/5, 311 .

116 trin. 11.6.10; WSA I/5, 312 .
} 
perceiving the window, only of perceiving the objects I desire to see through it. In such cases, the window figures in my sight as a sort of weigh-station, simply passing my vision on to its eventual objects. As Augustine describes this process,

if the will is still referred to something else, its resting place which we call its end is rather like what we could call the resting place of the foot in walking, when it is set down in a place from which the other foot can be supported as it takes another step. If however something pleases the will in such a way that it rest in it with a certain delight, and yet is not the thing it is tending toward but is also referred to something else, it should be thought of not as the home country of a citizen but as refreshment, or even a night's lodging for a traveler. ${ }^{117}$

Yet it is the will - the soul's activity of desiring - that directs our sight from one object to the next. If I desire to see the tree through the window, under normal circumstances I am able to do so. But this desire can be subtly derailed; if the window is so dirty as to be a distraction, the window itself can fill the horizon of my sight, drawing my attention to itself and derailing my intent to look at the tree. Augustine conceives this as a series of steps in which the will may (or may fail to) be referred from one to the next:

Now all wills or wishes are straight, and all the ones linked with them too, if the one to which they are all referred is good; but if that is bent then they are all bent. And thus a sequence of straight wishes or wills is a ladder for those who would climb to happiness, to be negotiated by definite steps; but a skein of bent and twisted wishes or wills is a rope to bind anyone who acts so, and have him cast into outer darkness (Mt 8.12). ${ }^{118}$

As is quite clear from the conclusion of this passage, Augustine's account of this is already opening beyond simple perception to the spiritual significance of sight; we can imagine him addressing a congregation on how our wills may bend our perceptions away from the good things of the world and toward the seductions of temporal luxury.

Accordingly, the way that we love temporal things stands in continuity with our love of eternal things. Just as, in perceiving the dirty window, I can be distracted from my desire to see the people walking outside and settle on the window itself as the object of my attention, so also attachment to worldly things can prevent us from rising through the similitudines of finite creation to contemplation of the God who is their source:

With bodily sensation, after all, bodily things are sensed; but eternal, unchangeable and spiritual things are understood with the reasoning of wisdom.

117 trin. 11.6.10; WSA I/5, 312.

118 trin. 11.6.10; WSA I/5, 312. 
But the appetite is very close to the reasoning of knowledge, seeing that it is the function of this knowledge to reason about the bodily things that are perceived by bodily sensation. If it does this well, it does it in order to refer them to the highest good as their end; if badly, in order to enjoy them as goods of a sort it can take its ease in with an illusory happiness. ${ }^{119}$

All that is presently possible for us, therefore, is knowledge of the temporal objects of our experience, and fragmentary glimpses of the eternal realities underlying them in, for instance, meditation on mathematical truths or in brief moments of illumination like that described at Confessions 7.17.23 - nothing like the stable contemplation that would allow us to persist in beatific knowledge of God. ${ }^{120}$

On the basis of this account of the defection of our intellect as a result of a sinful will, Augustine draws a distinction between two types of knowledge. The first, that which is almost entirely impossible for us in the condition of $\sin$, is the contemplatio rebus aeternorum that Augustine calls sapientia, or wisdom. ${ }^{121}$ The sort of knowledge proper to our present state is scientia, the "action by which we make good use of temporal things" (actio qua bene utimur temporalibus rebus). This is the knowledge that we attain through faith in the temporal signs God has given us, and which gives us the object of assent that the will moves toward. As we assent to the truth of what God has taught us in these signs, our wills gradually begin to climb the ladder back to the contemplation of eternal things. Our wills move first in belief, and as we believe in what God has done, so we are taught to long for the one who has accomplished these things but remains invisible to us now. Yet, to anticipate the account of the reformation of our wills I will give in Chapter 5, even these signs are not sufficient in themselves to draw our hearts back to God. Knowledge of the Word's acts in the life of Christ must be matched by the Holy Spirit's presence enlivening our affections, as we find that the work of God presented to us in external signs is the same activity present within us and purifying our affections.

That both scientia and sapientia can be considered species of a broader sense of "knowledge" is seen in Augustine's quotation of 1 Corinthians 13.12 immediately after introducing the distinction: "Now I know in part, but then I shall know even as I am known."122 It is important to note that both these senses are knowledge as viewed in the light of De magistro, which is to say, both are to be counted as forms of direct knowledge. This is clear enough with respect to our eschatological contemplation of God - whatever we go on to say about what it means to see God, our hope is that we will see Her face to face. Inasmuch as our scientia of temporal things is direct knowledge, it is knowledge of the created signs, not of God. In coming to know these created signs, however, we are able to make use of them because they point beyond themselves and back to God; our direct knowledge of these signs enables our belief in the God still invisible. Here again, we see the importance of faith, for some of the most important

\footnotetext{
119 trin. 12.12.17; WSA I/5, 331-2.

120 Cf. Luigi Gioia, The Theological Epistemology of Augustine's De Trinitate (Oxford: Oxford University Press, 2008$), 224$.

121 Cf. trin. 12.14.22.

122 trin. 12.14.22; WSA I/5, 334.
} 
signs established within the temporal order to point us to God cannot themselves be directly known, but only believed. I can only believe that Deborah was judge over Israel, or that Solomon built the temple from the cedars of Lebanon, for these signs are not present to me. Nevertheless, to the extent that I am conscious of my belief in these realities, the presence of faith in me comes to serve as an object of direct knowledge, similarly focusing our affections. As Augustine writes, "every man sees [it] to be in his heart if he believes, or not to be there if he does not believe."123 Comparatively rarer (if perhaps still abundant) are the signs of God that I am both able to discern and know directly: the icon on the church wall; the face of my neighbor; the chanted psalm; perhaps paradigmatically, the consecrated eucharistic host; and most intimately, the faith created in my heart by the Holy Spirit. ${ }^{124}$

Once again to summarize: as we come to recognize the signs of God's selfcommunication, we are given the opportunity to assent to what God teaches us in faith. This faith must be distinguished from the sight that we hope for in the eschaton, but it too creates in us the true knowledge of scientia even in the absence of sapientia. Nevertheless, this knowledge offers us an object of assent that may begin referring our affections back along the long way to God. As we come to know more of who God is and how God has worked, even if this knowledge is only in faith, our desire for God may grow.

Third, and perhaps most importantly, the central importance of Christ's life as a redemptive sign is that he is both the object of scientia and sapientia - though we cannot now know him with the intimacy of contemplation, in knowing and loving him as the object of faith, we have to do with none other than the one we will adore in eternity. Christ is for Augustine the clearest and most complete image of who God is possible within the created order. Christ teaches us truths about God we could not know apart from these signs, preeminently God's triunity. But more directly relevant to our reconciliation with God, Christ offers us a focal point for our desires. If we wish to love God, we are told to love this one, to trust in him and long for his presence within us; and we are taught to believe that, by turning our loves to this one point in history, all our other loves will slowly come to be ordered around him, and so properly ordered to God. The more we turn our desires to this one, the more we find him lovable, and inexhaustibly so; he is the one created thing that we stand in no risk of loving inordinately, because he is to be loved absolutely. In the humility of incarnation and crucifixion, the Word gives us signs teaching us that the man Jesus is to be loved as God; and throughout the Christian life, we find that the more we love him, the more our deepened knowledge of him calls forth an even greater measure of love from us.

Christ is, in the words Goulven Madec draws from Augustine, both la Patrie et la Voie - the homeland towards which we journey, and the way that leads there. ${ }^{125} \mathrm{In}$ our weakened condition, it is the significatory effects of Christ's life to which we must cling; Augustine reminds

123 trin. 13.1.3; WSA I/5, 343.

${ }^{124}$ Karmen MacKendrick offers a helpful discussion of the conversion of knowledge of the sign to love of the sign's referent using the category of the "seductiveness" of signs; see MacKendrick, Divine Enticements: Theological Seductions, (New York: Fordham University Press, 2013).

125 Madec, La Patrie et la Voie. 
us that "all these things that the Word made flesh did and suffered for us in time and space belong, according to the distinction we have undertaken to illustrate, to knowledge (scientia) and not to wisdom (sapientia)." ${ }^{\prime 26}$ All the moments of Christ's life - his birth in a stable, his first tentative steps, his teaching at the temple, through to the devastation of the cross and the bewildering event of Resurrection - all this has been for the purpose of turning our eyes heavenward, giving us the end toward which we can direct our desire in the confidence that our loves will carry our minds back to God. In the life of Christ, we find tangible signs of God's mercy, God's forgiveness, God's desire to heal our broken bodies and wounded souls. In meditating upon his acts recorded in Scripture, we come to know in faith truths that are not yet manifest in sight, because they are hidden with the invisible Word: the triune life of God, as the man Jesus relates to Father and Holy Spirit through the course of his life; the true union of both divine and human natures in the one person of Christ; the duality of his divine and human wills in his one incarnate life; even, as the Seventh Ecumenical Council declared, the representability of his flesh, the shocking fact of God being able to be depicted without idolatry. All these are truths held in faith, known as scientia in order that we might come to know God and desire Him more.

What stands on the other side of this course, as our faith is converted to sight? Augustine's answer is decisive:

Our knowledge therefore is Christ, and our wisdom is the same Christ (scientia ergo nostra Christus est, sapientia quoque nostra idem Christus est). It is he who plants faith in us about temporal things, he who presents us with the truth about eternal things. Through him we go straight toward him, through knowledge toward wisdom, without ever turning aside from one and the same Christ, in whom are hidden all the treasures of wisdom and knowledge (Col. 2.3). ${ }^{127}$

By now, it will be apparent the extent to which this conclusion depends upon the personal unity of divine and human natures in Christ - only if the sign of Christ's flesh is in unity with the person of the Word can we truly say that the same one is both knowledge and wisdom. At the heart of Augustine's piety is the sense that Christ can be trusted to draw us back to God: that he dwells within us as the inner teacher, enabling us to see any truth that we can glimpse in this world; that he has disposed all things in such a way that they point from the constitution of their being to God, if only we can learn to see it; and that, when all these signs have served their purpose and we behold the face of God, Christ will remain with us. Faith and hope pass away, but love does not, for Love is Christ Jesus. As Augustine writes at trin. 4.18.24: "now we accord faith to the things done in time for our sakes, and are purified by it; in order that when we come to sight and truth succeeds to faith, eternity might likewise succeed to mortality." 128

\footnotetext{
126 trin. 13.19.24; WSA I/5, 362.

127 trin. 13.19.24; WSA I/5, 363-4.

$128 \mathrm{WSA} \mathrm{I} / 5,169-70$.
} 
Fourth and finally, I believe that this christological account of signification should lead us to a dramatic reevaluation of the way we understand the world in relation to Christ. Simply put, I believe that it is the telos of all things to be made signs of Christ's flesh - to be written into the language of divine signification in such a way that they point us to the human life of Jesus. It is a Platonic commonplace to say that all creation serves as a likeness of God by virtue of participation in Her, that in receiving form from the Word, the things of the world intrinsically exhibit some likeness to Her that could potentially serve as a vehicle of ascent to eternal things. The decisive question is whether we may say in addition that things are signs of Christ's humanity, such that, when we read in the passage that serves as an epigraph to this chapter, that "all the sacred and mysterious things that were shown to our fathers by angelic miracles, or that they themselves performed, were likenesses (similitudines) of him, so that all creation might in some fashion utter the one who was to come and be the savior of all," we might say that all creation points to the life of this one man. ${ }^{129}$

We can imagine a symbolic order so constituted as existing along both a vertical and a horizontal axis. Along the vertical axis, we may first say that all things exist as likenesses of God inasmuch as they receive their being and form through participation in Him: each thing reflects God differently through the specific mode of participation proper to its nature, the proper limits of its being and activity determined as a particular way of reflecting its source in the Word, represented in Augustine's theological shorthand as the Sapientia of God determining all things in measure, weight, and number. These things are meant to serve as signs of the Word, but their ability to point us to God has been compromised by darkening of our intellects through sin. As a result, we require a sign capable of drawing us out of our sin, and back to the knowledge and love of God; this sign is the life of Christ, and the mission of God is accomplished by the Son as He becomes visible in Christ's flesh, pointing us upward along the vertical axis of signification. Yet there are also innumerable signs that refer along the horizontal axis, created particulars serving as signs of other created particulars, smoke signifying fire, the word "apple" signifying an apple. In light of the preceding discussion of De trinitate 4, it also seems correct to say that the mission of the Son has implications for this horizontal order of signification. One example Augustine explicitly raises is that the death and resurrection of Christ come to serve as exempla of our own anticipated death and resurrection, creating a horizontal relation of signification between the actions Christ performs in his outer human life and the consequences we hope will take place in our own outer life. Other examples are the Old Testament theophanies, which all point, Augustine tells us, to the coming sign of Christ's flesh which will signify not simply another temporal reality, but the eternal reality of the Word.

At issue here is the relation between the Word's providential ordering of created history, and the harmonia of creaturely signs that centers on Christ as the ultimate manifestation of God's eternal life within the created order. As we discussed in the last chapter, the eternal act of God's self-relation, the act in which God creates and providentially orders the course of created history, and the act in which the Word assumes flesh are all identical, each none other than the simple

129 trin. 4.7.11; WSA I/5, 160. 
internally related life of the triune Lord. From all eternity, this is what God's Being is and who God wills to be in the creative freedom of the divine nature. If the human life of Christ manifests to us the Word in time, it can be none other than this life, this act that is manifested. If it is part of the act proper to the Word to grant the form to each creature in measure, weight and number, and to order all things in their historical relations to one another, then there must be a sense in which this very act is revealed in the sign of Christ's flesh, some sense in which he is manifest to us as the one in whom all things participate for their being. To put it simply, if all things are intrinsically related to the Word, and the Word becomes manifest in Christ, then the intrinsic relation of all things to the Word must become manifest as an intrinsic relation to Christ.

I presented the first draft of this proposal in the last chapter by suggesting that all things are constituted in their proper spatiotemporal relations to all other creatures by virtue of being spatiotemporally related to the spacetime of Christ's life. This is a theoretically satisfying but ultimately rather thin portrayal of this relation. True, there is a sense in which Christ is the center of all physical history, but this cannot bear much soteriological weight. By contrast, Augustine holds that it is through the signification of God in Christ's human flesh that our minds are directed back to God over the course of our redemption. If all creaturely things are meant to be signs that point us to the flesh of Christ, it suggests both that all our creaturely knowing and loving are meant to carry us back to the flesh of Christ, on the one hand, and on the other, that all creatures have a potential role to play as redemptive signs in focusing our hearts and minds on him. We can push further: it may be that we cannot be perfected in the knowledge of God, brought to true sapientia, until each particular creation is known to us as a sign ordered to Christ's flesh. On this proposal, it is the flesh of Christ as it is semiotically related to all creatures that is the perfect image of God's eternity, and we will only see a part of the one who is the image of the invisible God until we know him as the one in whom all things hold together.

If I am right, it suggests a new use for the metaphor of a "language of divine signification" to describe God's progressive acts of revelation: all things are to be written into this language, a work in which we may take part as we become skillful users of it. Already, we possess images of God's speech that suggest something along these lines to us: I think of a gothic cathedral, in which nearly every square inch is carved or painted, adorned with signs of Christ and his Saints, beautifications visible solely to the angels yet no less communicative for that; I think of a countryside dotted with crosses, and small roadside shrines built to house holy images; I think of a Purim celebration in which not only the name of Haman, but virtually every word of the Book of Esther is met with a different shout or repeated gesture, a communal annotation of the text meant to be added to forever. ${ }^{130}$ Through books we write, the material culture we produce, the way church bells sanctify the very air we breathe, ${ }^{131} \mathrm{I}$ believe that Christians are quite familiar with the work of writing the world into the life of Christ.

\footnotetext{
${ }^{130}$ I am grateful to Peter Ochs for this way of viewing our custom, and to Rebecca and Sarah Epstein-Levi for some remarkable hamantaschen.

131 Alain Corbin has studied the religious and political significance of church bells through the French Revolution in Village Bells: Sound and Meaning in the 19th Century French Countryside (New York: Columbia University Press, 1998).
} 
To take one example in a bit more detail, I think of Auden's poem "In Praise of Limestone." 132 From its first line, the poem indicates its restlessness and the longing that animates it: "If it form the one landscape that we the inconstant ones/Are consistently homesick for, this is chiefly/Because it dissolves in water." The poem takes shape as a meditation on a limestone landscape of "rounded slopes," "caves and conduits," and "weathered outcrop." The poem tightens as the poet begins the third stanza, pondering the sorts of person drawn to landscapes other than the one before him. Limestone is a "stone that responds," not one that can withstand the elements or resist the tools of the stonemason: "That is why, I suppose,/The best and worst never stayed here long but sought/Immoderate soils where the beauty was not so external." The call of several other landscapes sound in turn:

"Come!" cried the granite wastes, "How evasive is your humor, how accidental

Your kindest kiss, how permanent is death." (Saints-to-be

Slipped away sighing.) "Come!" purred the clays and gravels,

"On our plains there is room for armies to drill; rivers

Wait to be tamed and slaves to construct you a tomb

In the grand manner: soft as the earth is mankind and both

Need to be altered." (Intendant Caesars rose and

Left, slamming the door.) But the really reckless were fetched

By an older colder voice, the oceanic whisper:

"I am the solitude that asks and promises nothing;

That is how I shall set you free. There is no love;

There are only the various envies, all of them sad."

Limestone equivocates, where these terrains offer a proving-ground for the consuming ambitions and nihilistic impulses of those who are drawn to them: "They were right, my dear, all those voices were right/And still are; this land is not the sweet home that it looks, /Nor its peace the historical calm of a site/Where something was settled once and for all." The hope of those who find themselves drawn to limestone is similarly unfocused:

Not to lose time, not to get caught,

Not to be left behind, not, please! to resemble

The beasts who repeat themselves, or a thing like water

Or stone whose conduct can be predicted, these

Are our Common Prayer

132 W.H. Auden, Selected Poems, expanded 2nd Edition, ed. Edward Mendelson (New York: Vintage International, 2007), 189-191. 
The limestone seems a place of frivolity, of novelty for novelty's sake; which is to say, of dissipation and boredom. The poet knows that setting out each day in search of the new is a lost cause - the best he can muster is the grim pronouncement that it makes a great deal of sense to seek change up to the moment when death steals this possibility away from us. Yet as he considers the finality of death, the limestone before him takes on new significance:

\section{But if}

Sins can be forgiven, if bodies rise from the dead,

These modifications of matter into

Innocent athletes and gesticulating fountains,

Made solely for pleasure, make a further point:

The blessed will not care what angle they are regarded from,

Having nothing to hide. Dear, I know nothing of

Either, but when I try to imagine a faultless love

Or the life to come, what I hear is the murmur

Of underground streams, what I see is a limestone landscape.

This unassuming landscape has taken on, unmistakably, the aspect of grace. What had been the weakness of the stone is precisely what fits it for the purpose of carving into objects of aesthetic delight; what remain the anxieties and self-consciousness of the poet can be seen in new light as the possibility of a new life, relating to others without shame. It is a life, as-of-yet, only hoped for; yet the changeability of limestone is a sign of it even now. The transformative power that will bring about this new life moves quietly within us even now, like the streams slowly but not quite silently shaping the limestone in its hidden depths.

I cannot see a limestone landscape anymore without thinking of this poem. And so, I cannot see a limestone landscape anymore without my mind being drawn to the secret workings of grace, shaping me in ways of which I am not conscious but hope for nevertheless. The poem has accomplished, for me at least, the work I have proposed, of writing very stone itself into the life of Christ such that I am moved to contemplation of him in seeing this created sign. The limestone itself points me to his body that rises from the dead, and the modifications of matter that will, I hope, someday pull me from the grave. All the world is meant to signify Christ in this manner: every blade of grass, every wave, every misplaced pen or dented car door. If we could see these clearly, if we could see them as ordered within the history God has created and see them as they draw their life from the triune Lord, would be transfigured in our view, signs of Christ no less dazzling than the burning bush.

But not only that which is beyond us - we too, in our very flesh, are to become living signs of Christ, truly incorporate in him. This is basic to Christian theology, I think: in our prayers and worship, our feasts and fasting, our care for the widow, orphan, and prisoner, we are marked as Christ's own. In our very being, in the most minute determinations of our creaturely existence, we may serve as unique signs of Christ's flesh. And as we stretch our visions to the farthest reaches of the cosmos and the whole of spacetime, we find that all creation is destined to serve as 
one all-encompassing sign: the whole, with both physical processes and creaturely agency working together to shape its unfolding comes to serve as a sign of one child, born in a stable in Bethlehem. Christ's flesh is the center of creation; in every word, every gesture, we are already ordered as likenesses to it in a manner not yet visible to us. I say móre:

the just man justices;

Keeps grace: thát keeps all his goings graces;

Acts in God's eye what in God's eye he is -

Chríst - for Christ plays in ten thousand places,

Lovely in limbs, and lovely in eyes not his

To the Father through the features of men's faces.

$* * * *$

All the world? Blasphemous. Signs of Christ: war; mass starvation; the extinction of untold numbers of species; the exploitation of the powerless for personal profit; the murder of children; betrayal of trust; abuse; hydrogen bombs; death camps; the slavemaster's lash; virus and plague? Obscene.

These are all the good things of God's creation; yet they are so vitiated by sin that they are almost unrecognizable as the creatures of God. The existence that has been granted to them in God's creative act has become so corrupted, that these things seem to collapse in on themselves, grotesque and misshapen as they pull themselves back toward the nothingness from which God originally drew them. They are the signs of a world groaning under the weight of sin; they are human acts using the power of God to refuse the life She gives. As we gaze at the world, we see not the face of Christ, but a death mask.

Yet these, too, are signs of Christ's flesh. He stands over them in judgment; he is the one who refuses their ultimacy. These horrors, we have seen and hope to see one day, are to be written into the history wherein Christ conquers death, judges the wickedness of sinful humanity, purifies the world with fire, and draws it renewed into his embrace. These are signs of Christ's flesh, in that they are signs of what is defeated in his flesh. For these acts, as directed toward the nothingness of evil, can have no place in the light in which there is no darkness. They can only be intelligible within the history God has created as they are overcome, as they find their place within the history of the one whose body rises on the third day. For them to be signs of Christ's flesh is for us to hope that his life is what determines history, rather than our death. For them to be signs of Christ's flesh is for us to hope that these deaths may be conquered in our lives, too. 


\section{Chapter 4}

\section{Completing Christ}

I have resolved to know nothing among you but fesus Christ, and him crucified. The work of my last chapter was to offer an account of how all creaturely signs are ordered by and to the human flesh of Christ in the "regime of signs" (dispensatio similitudinum) we have been given in the course of our earthly pilgrimage. All true knowledge, inasmuch as it participates in the Word who is Truth itself, is inwardly related to and bears the potential to reveal Christ; and so, coming to see Christ in this world enables us to see Christ in all things, to know nothing but Christ and all things in him. In this chapter, I turn to the particular sign of the cross. If the whole dispensation of creaturely likenesses to the Word centers on the human life of Christ, the life of Christ is itself ordered by and to his crucifixion and resurrection. It is the sign that includes all the other signs of Christ's life, for we are to know nothing but Jesus Christ, and him crucified; and so it should be regarded on an Augustinian account as the center of all creation, the sign in which all other signs are included, the revelatory moment at which the intimacy of all things with their creator is most extensively revealed.

Yet, for all this, it is a curious sign. It speaks of love and humility, but also of violence and degradation. It asks us to find beauty in blood unjustly spilt, and salvation in our attempt to annihilate the God who wills to walk among us. It is a sign that speaks in the silence of Christ's lifeless body. As Rowan Williams writes, "The Word incarnate and crucified represents the absence and deferral that is basic to signum as such, and represents also, crucially, the fact that absence and deferral are the means whereby God engages our desire so that it is freed from its 
own pull towards finishing, towards presence and possession." "This absence and deferral is seen nowhere more clearly, or unsettlingly, than in Christ's words from the cross: My God, my God, why have you forsaken me? In his exegesis of the twenty-first psalm, ${ }^{2}$ Augustine offers not only some of his most extensive and moving reflections on Christ's redemptive work, but a startling vision of his union with the condition of sinful humanity. Stated simply, Christ's cry of dereliction expresses not his own state of beatific intimacy with the Father, but the godforsakenness that characterizes our lives in the wake of human sin; or, better (if more paradoxically), it expresses that Christ's beatitude is not exclusive of his being united to our desolation. But how can this be? How can it possibly be appropriate for the Second Person of the Trinity, incarnate in human flesh, to cry out as one abandoned by God?

Previous accounts of Augustine's thought on this score have centered on the rhetorical tools and pedagogical significance of Christ's speaking in the persona of humanity in process of redemption, ${ }^{3}$ and on the hermeneutical significance of Christ's plurivocal speech in both sinless head and sinful body. ${ }^{4}$ While deeply indebted to these studies, I suggest that reflection on Augustine's exegesis of the cry of dereliction and on Christ's unity with the Church pushes constructive christological reflection to an even more capacious sense of the work of redemption. In his teaching on the "whole Christ" (totus Christus), Augustine suggests a realist union between Christ and those included within his redemptive work. Perhaps more surprisingly, he suggests that there is a sense in which Christ, though complete in divinity by the eternal life of the Word and wholly human by virtue of the Word's act of assuming flesh, is only fully himself as he is united to his body. To offer an account of this realist union between head and body, I will need to examine more closely the ways in which human lives unfold through their relations to one another and to the world around them - using Judith Butler's categories, the "exposure" of human life that establishes human persons as interdependent, vulnerable, and singular. ${ }^{5}$ Attention to these features of human life, I will argue, pushes toward an understanding of the Incarnation that recognizes the implication of Christ's flesh within innumerable relations to the created order. These relations not only give shape to the human life that Christ leads, but are incorporated into Christ's redemptive work itself. On an Augustinian account, then, the theology of the cross is intimately related to and completed in the theology of the totus Christus, and the life of Christ may only be seen in the fullness of its redemptive significance inasmuch as he also lives in the bodies of the redeemed. The doctrine of the totus Christus tells us that, even now in the lives we lead, we may find Christ in us and ourselves in him. We should begin, then, by looking more carefully at the sort of life we live - and the sort of life the Word assumed.

\footnotetext{
${ }^{1}$ Williams, On Augustine, 55

${ }^{2}$ Here and throughout this chapter I here follow Augustine's own numbering of the Psalms, so as to facilitate reference to Augustine's texts.

${ }^{3}$ Cf. Babcock, "The Christ of the Exchange"; and Drobner, Person-Exegese und Christologie bei Augustinus.

${ }^{4}$ Cf. Michael Fiedrowicz, Psalmus Vox Totius Christi Studien Zu Augustins Enarrationes in Psalmos (Freiburg: Herder, 1997), and Cameron, Christ Meets Me Everywhere.

${ }^{5}$ Judish Butler, Giving an Account of Oneself (New York: Fordham University Press, 2005), 31-38. Butler draws these terms from Adriana Cavarero. Butler puts these terms to substantially different use than I do here, though see Chapter 6 below for a more thoroughgoing engagement with the accounts of moral philosophy and ethical subjectivity Butler presents in Giving an Account of Oneself.
} 


\section{The Shape of Human Life}

How have I become the person that I am? It is not, of course, clear to me just who I am; I do not mean to imply any fixity or settledness in the identity, or self, or self-representation presupposed by this question. I am quite happy to admit that even in asking it, I am asking for a narrative that fashions for me a picture of myself, a narrative that is bound to be provisional, selective, and distortive in its avoidance of a truth to my life that my wounded eyes cannot yet bear.

Even so. I act in the world; I know parts of it, I speak and listen, I deliberate and judge, I desire things within it - and I seem to do all this in a manner particularly my own. What's more, I am conscious at times that my experience of all these aspects of life changes: I become aware of having misunderstood something, I learn a new word, I find that I no longer enjoy the music I once did. How have I come to this unstable moment between who I have been and who I will be, this present constellation of experiences and desires that is no less singular for all its transience?

My aim here is not a philosophical cartography of the self; I have no desire to enumerate the steps by which self-consciousness dawns in us whether in the language of philosophy or of developmental psychology. Nor do I wish to provide a descriptive account of the soul and its operations. These may be useful things to do sometimes; or, at any rate, they may be stimulating diversions. My purpose here is rather to recognize the inescapable materiality (which is also to say sociality) of our lives. Particular accounts of these features of human life might be (and have been) given in the vocabulary of a theology or anthropology of relation, or of the other-in-thesame at the heart of subjectivity, or of the mutual participation or chiasmus of I in you and you in me. Each of these formulations might do quite nicely depending on the ends one pursues in giving such an account, though each would require a greater or lesser degree of baptism to pass muster in theological discourse. ${ }^{6}$

For the moment, I am concerned only with the bodily reality of my dependence on others for existence and survival in its barest and most untheorized form. Our bodies come into being only as they are drawn from the flesh of our parents; as they develop, they require many months of dependence on the circulatory system, digestive system, renal system, and uterus of our mothers before they have any possibility of sustaining our lives in the world. Once we are born, we possess little facility at perceiving or moving within our surroundings, and are utterly reliant on others to provide us sustenance, shelter, and protection from predators. The survival of new human life is, in a very literal way, impossible without the presence of other people (or in very remarkable cases, other animals) around us, providing for us, inducting us into the bodily practices of sociality. In some cases, adequate provision of food and shelter is inadequate, and survival requires extensive use of culturally-specific knowledge and technological arts: ventilators that assist a newborn in breathing, understandings of bacterial infections, hospital architecture

${ }^{6}$ I have drawn these examples from, respectively, Keller, Cloud of the Impossible; Emmanuel Lévinas, Otherwise than Being: or, Beyond Essence, trans. Alphonso Lingis (Dordrecht: Springer Science and Business Media, 1991); and Graham Ward, Christ and Culture (Oxford: Blackwell Publishing, 2008). 
that establishes certain spaces as neonatal intensive care units. The contingency of our lives is only underlined by the fact that virtually all human persons who have lived have done so without the availability of this knowledge and technology. While our biological dependence on things outside ourselves can be seen with particular clarity in the case of newborns, it does not end with our births - we have only to consider the central role that bacterial ecosystems within our bodies play in our digestive and immune systems to see that the very continuance of our lives is made possible through our relations to that which we are not.

The case of a parent (or caretaker) and child offers a particularly poignant instance of the interweaving of our lives with others, but the example points to our deeper implication within a causal order marked by unpredictability and contingency. ${ }^{7}$ Our lives unfold within this network of confluences of an unimaginable number of events and in response to them, events which establish the very conditions in which our lives take place. Never mind the incomprehensible number of microphysical processes at play in the cosmological origins of the universe, the gravitational attraction of the universe's matter into the lumpy distribution of superclusters of galaxies, the production of heavier elements in the nuclear fires of suns, the accretion of matter orbiting these suns into a disk and eventually into satellites, all necessary in order for at least one of these satellites to produce life at all. Our lives are decisively shaped by events occurring outside the agency of any finite creature: the rainstorm that causes me to stay inside and read a book that will change the way I think about a friendship; the landslide that extinguishes the life of the brilliant nine-year old who might have pioneered a new agricultural method for feeding impoverished communities; the diminished fish stocks that force me to move away from my parents' home and way of life to find employment in an urban center. The point is not, of course, that we are simply subject to the vicissitudes of a natural order unshaped by human agency - no one living through this time of rapid climate change can afford to believe that the processes of nature are unresponsive to our agency - or that our lives are unknowingly determined by these events. The point is rather that the fields in which our lives are lived out are not entirely, or even mostly, under our control. The world in which we learn and exercise our agency, the world which we come to understand with the concepts we are given and develop, impinges on us - it constrains and enables the ways in which we are able to exercise agency, it provides for us and pushes back on us.

Likely even more important than the simple physical constraints of our bodies (though, as we have seen, inextricable from them) are the social realities of our lives. The newborn does not stay thus forever, and from the moment of her birth she is plunged into a world that is inescapably structured by the lives of others. Here again, philosophical accounts abound of the constitutive openness to others and the world that informs our sense of ourselves as subjects, as agents in the world, and as speakers able to converse with one another. ${ }^{8}$ Here again, my point is

\footnotetext{
${ }^{7}$ A causal determinist would, of course, disagree with this description; nevertheless, it is clear at the very least that our experience of the causal order is characterized by unpredictability and contingency.

8 Three compelling accounts of these phenomena may be found in, respectively: Jean-Luc Marion, The Erotic Phenomenon, trans. Stephen E. Lewis (Chicago: University of Chicago Press, 2007); John McDowell, Mind and World
} 
a basic one: in all our actions, in all the concepts we employ to make sense of the world, in our very sense of ourselves as selves, we are dependent on others and the world we share with them. As Rowan Williams writes, both the language we learn from other speakers and the "friction" with which the world pushes back on and corrects our language use are integrally related to our ability to view our lives as a unified whole in which we are able to exercise agency within the world:

We need linguistic and conceptual tools that allow us to see a continuing identity over time in what confronts us, and a 'schematic' consistency in clusters of phenomena. Refining these tools is a matter of learning, trying out schemata, exposing them to be tested; and that testing is not only in terms of practical success but also and inseparably in terms of recognizability in the exchange of speech with other speakers - what we colloquially and significantly call 'making sense' to others. ${ }^{9}$

This process of refinement does not, Williams notes, march mechanically toward the ideal of one perfect language adequately representing the world, but is a movement in which we work out within blurry-edged linguistic communities the patterns of speech that help us make sense of our environments and relations to one another.

Williams writes that "to understand how language works, we have to understand its riskiness, its unstable connection with what it engages with." ${ }^{10}$ And in this instability, we find the precondition not only of language's ability to help us make sense of the world, but of our concepts to distort our relations to the world and one another. We can lie, and we can lie against our place in the world and in relation to others through misrepresentation of our environments and the creatures with which we interact; and in the inherently interpersonal character of our language, these misrepresentations can also come to pattern our social relations, the concepts we use to describe others, and even the narratives that others adopt to make sense of their own lives. For better or worse, we come to understand ourselves only alongside others, and with the language they give us and we extend. My view of the goals and aspirations available to me, of the value and dignity society does or does not afford my body, of my perception of my body as unthreateningly normative or menacingly aberrant (or then again, in some spaces, menacingly normatizing) - all this is worked out in a complex negotiation between the narratives and past experiences that have shaped my understanding of who I am on the one hand, and the narratives, ways of thinking, and social orderings of those around me on the other. Our lives are at all points an interplay of what Stephen Mulhall has identified as "inheritance" and "originality" - the ways that we are indebted to others in our ability to understand the world and

(Cambridge: Harvard University Press, 1996); and Rowan Williams, The Edge of Words: God and the Habits of Language (London: Bloomsbury, 2014).

${ }^{9}$ Williams, The Edge of Words, 44.

${ }^{10}$ Williams, The Edge of Words, 44. 
act within it, and the distinctive ways that we freely draw upon this inheritance: changing it, extending it, and reciprocally influencing the way others think and act in the process. ${ }^{11}$

These considerations point to a view of human life as both singular and interdependent with those around me and my environment more broadly. My singularity consists (in my experience, at least) in my sense of myself as a distinct agent in the world, able to learn, deliberate, and act in novel fashion, and inhabiting a body that is related to me in a way different than the other things I encounter. My particular experience of all this is, of course, deeply conditioned by contingent and culturally-specific assumptions, yet it does not seem possible to me for anyone to deny utterly our phenomenological distinctness - that there is some sense in which my experience seems mine to me in a way that nothing else is. Even a Buddhist metaphysic committed to the illusory nature of all separate existence begins with the phenomenological problem that it seems to me that there is, and this is all that is needed to establish the sense of singularity I intend. In practice, it is undeniable that it is (at best) immensely difficult to distinguish that which I am from that which I am not. Doing so successfully will require a more fine-grained account of the way the world is, and though offering such an account is not my purpose in this project, I will approach the question below with reference to the singularity of Christ's life.

More central to my purposes here is the recognition of the interdependence of our lives. Even if we wish (as I do) eventually to affirm that our singularity is reflected in the order of being - that you and I are distinct existences, each participating separately in the Being of the triune Lord - it is nevertheless the case that our lives are nearly unimaginable apart from our interdependence. I can imagine my life being very different than it is (if, say, I had joined the military at age eighteen), and I can perhaps just barely imagine my life taking place under radically different circumstances (growing up in medieval China, or on a colony on the other side of the Milky Way). I cannot, I think, imagine the life of anything I would be able to identify as "me" absent an evolutionary history or other creative act of God that grants me capacities and frailties much like those I now possess (one implication of which is that I cannot now imagine the resurrected life we are promised in Christ; but more on that later).

What this suggests is that much of what I think of as "me" is not provided by my bare metaphysical constitution or self-experience, but by what I will call the "shape" of my life. The shape of my life is my life as it is lived in relations of interdependence: the physical, biological, and social histories that have conditioned my environment, and that I will in turn influence through my action within them; the relations I bear to those around me, the people who teach me to speak a particular language, the friends who play a role in fashioning my moral and aesthetic judgments, the relationships that will last through the course of my life allowing for unmatched depths of intimacy and responsibility; and the events that turn the course of my life, the decisions I make that ramify through the rest of my days, the accident or chance encounter that forever reconfigures the possibilities of my life. Apart from these concrete histories, relationships, and events, I may still be a person, but I am not me. The shape of my life, inclusive

\footnotetext{
${ }^{11}$ Mulhall, Inheritance and Originality.
} 
of my own exercise of agency in the course of my life, is inseparable from my becoming the person who will one day stand before the judgment seat of God bearing a determinate history and an unsubstitutable way of existing as a human person. The shape of my life is what makes me the person that I am, as opposed to someone else. To the extent that my life is not yet complete, it is not yet clear what the shape of my life will be - it does not yet appear what we shall be when Christ appears.

If our lives are built substantially out of the relations of dependence we bear to the world and those in it, it is also the case that we are often broken by these relations. Our exposure to the world cuts both ways. Our flesh is the site of our worldly availability for the relations of interdependence that play a role in constituting the shape of our lives. In it, we are drawn into particular forms of life that may involve driving automobiles to large air-conditioned spaces wherein we will coordinate the shipping of goods across the world, using our vocal chords and the electronic devices we have manufactured to communicate with partners across the world in several different languages we have been taught through formalized educational practices; or, very differently, we may awake each day in the same remote village in which we were born, humming to ourselves songs passed from parent to child over many generations as we go to fetch water from a well dug miles away. In each of these cases, our bodies make us available for the interdependent relations that mark us as members of particular ethnicity or culture, that teach us the habits and customs of a (or, often, several different) social groups, that render us capable of speaking particular languages, making certain sorts of art, learning particular ways the world is. Our flesh is the site, too, of more intimate relations to one another: we learn, and are able to express, pleasure or displeasure on our faces or with our limbs, to signal relaxation or tense anxiety; we exchange embraces to comfort one another in our sorrow or pain; we offer touches that communicate desire and love.

Yet our flesh also makes us available for the bodily wounds that we suffer through the course of our lives, a vulnerability that is no less important in giving our lives their shape. Just as our agency is enabled by the cultural formation we undergo, so also it is constrained: even as children, we will be punished corporally for engaging in certain sorts of proscribed action, though what precisely counts as taboo can be as contingent as whether we greet one another with a handshake or a bow. We will be corrected and reproved when we do not follow local conventions, punished with labor or confinement. We will find that we are excluded from certain paths of action solely by virtue of our bodies, told that there are certain people we ought not touch, that there are certain careers for which we are not fit, that there are certain social spaces where we are not welcome. In dramatic (though not uncommon) cases, we will find our bodies treated by others as objects - bought and sold, used to gratify another's desire with little or no consideration of my own, valued solely for its capacity to produce for another's profit. And our flesh is literally vulnerable: vulnerable to weather and hunger, able to be restrained physically by others, susceptible to corruption by disease, easily damaged through accident or malice. We tire from overexertion, we bleed when we are cut. Vulnerability shapes our lives no less than our interdependence, and in fact, these two categories shade into one another. The vulnerability of my parents causes me to grow up an orphan, or the course of my life is changed by a spinal cord 
injury suffered while playing sports. I am abducted and tortured by a madman, a trauma that leaves scars both physical and psychological. I suffer violence at the hands of one I trust, or lose a child in the midst of war. These, no less than the meals we share with friends or the embraces we receive from family, constitute the fabric of our lives. To live as vulnerable in this world is, very often, to live with tragedy and injustice. It is, finally, to live in a body that will die, losing all bodily availability to those we love and all the worldly goods that we love.

This is the flesh that we are: formed biologically in and through natural processes stretching billions of years into the cosmic past; formed socially through the material and linguistic relations we bear to those around us; exposed to others and the world around us both for intimacy and violence. And, if the Word has joined Herself to humanity in Jesus Christ, this is the very flesh She has assumed.

\section{The Shape of Christ's Life}

Christian theology has traditionally held that Christ is like us in all things, excepting sin. Such an affirmation seems necessary if we are to hold, with Chalcedon, that Christ is vere homo. Yet this tells us very little about the shape of Christ's life, or about how the human flesh of Christ functions within God's redemptive work. While Augustine himself offers profound resources for describing each of these aspects of Christ's life, I will seek in this section to sharpen the lines of my Augustinian christological proposal by extending his thought in conversation with contemporary theological interlocutors. I will proceed with particular attention to the exposure of Christ's flesh, considering in turn his life as interdependent, vulnerable, and singular.

\subsection{Interdependence}

Christ is, like any other human person, born in a determinate time and place. He is cared for by his mother and father, speaks the Aramaic dialect that is predominant in his region among his ethnic group, dresses according to the needs of his environment and, we might speculate, according to the fashion of the day. His body is marked as a member of a particular community, the people of Israel, as he is circumcised and presented at the temple. Here already, we see that the interdependence that constitutes us is inseparable from the vulnerability of our flesh; the first drops of Christ's blood are shed as he enters the covenantal promises made to Abraham. These facts are rarely explicit objects of christological reflection — we might raise Christ's implication within some local custom when interpreting a puzzling verse of Scripture, as when we appeal to what we know of Jewish agricultural practices to underline the strange farming techniques represented in the parable of the sower; or, likely more commonly within formal theology, we might reflect on the importance of Christ being born to the people of Israel within the redemptive economy of God's work. The words of salvation we hear pronounced on his lips are inescapably Jewish words, communicated in the language of the apocalypticism characteristic of the Second Temple period, and this context is not finally separable from the content of the proclamation of the coming of God's Kingdom. Christ's life is shaped with particular intensity by 
the Jewish context into which he is born, for (as I argued in the last chapter) it is here that the world learns the language of divine signification through which God will teach us to see the incarnate Word in an executed peasant teacher. Yet our attention to Israel's importance should point us to an even broader context that is determinative of the shape of Christ's life, a context full of fishing boats and mustard shrubs, of highway bandits and occupying armies.

What's more, he is surrounded by people who shape his life: the father who teaches him carpentry, the cousin who pronounces the advent of the Kingdom of God, the friends and followers who spur his teaching through both their insight and misunderstanding. However we wish to understand these incidents, it is undeniable that Scripture presents much of Christ's ministry as response to the words and actions of others. Whether friends or strangers, the manner in which Christ conducts his ministry is inseparable from the presence and actions of the people in whose company Christ lives. Christ is, I suggest, dependent upon all these contextual features of his life in much the same way we are - the most significant difference being that the Word has providentially ordered these created realities and set them in the relations by which they will shape the life of the flesh He assumes.

One of Augustine's favorite images to express the state of dependence that the Word takes on in assuming flesh is that of Christ nursing at Mary's breast. To take just two of many examples, his sermo 191 on the Nativity finds him telling his congregation, "The maker of man, he was made man, so that the director of the stars might be a babe at the breast," 12 while sermo 239, preached within the Easter octave, employs the fact of the God becoming a helpless infant to convince his listeners to give up their own wealth on behalf of the poor:

Consider his wealth; what could be wealthier than the one through whom all things were made? And yet he, though being rich, took flesh in the virgin's womb. He was born as a baby, wrapped up in baby clothes, laid in a manger; patiently he awaited the successive ages of life; patiently he endured the succession of times, the one through whom all times were made. He sucked the breast, he cried, he was manifestly a baby. But he lay there, and reigned; he was in the manger, he held the universe together; he was nursed by his mother, and worshiped by the nations; nursed by his mother, and announced by angels; nursed by his mother, and proclaimed by a shining star. ${ }^{13}$

The power of this image, formalized within the iconographic tradition as the Galaktotrophousa and in later Western art as the Madonna lactans or Madonna allattante, stems from its depiction of the Lord of all creation receiving sustenance from the breast of his mother. ${ }^{14}$ It dares

12 s. 191.1; WSA III/6, 42.

13 s. 239.6; WSA III/7, 62.

14 The image is ancient, yet relatively uncommon; see John Cotsonis, "The Image of the Virgin Nursing (Galaktotrophousa) and a Unique Inscription on the Seals of Romanos, Metropolitan of Kyzikos," Dumbarton Oaks Papers (Dumbarton Oaks, Trustees for Harvard University) 65/66 (2011-12): 193-207; 194. The properly Christian image of Mary and Jesus enjoys a long pagan prehistory concentrated particularly in Egypt, where images of Isis nursing Horus can be found as early as the eighth century before Christ, with devotion to Isis lactans intensifying in 
to tell us that this one, dependent on the body of another, is properly worshipped as the eternal God. Augustine's insistence at en.Ps. 64.6 that Christ's body is "first-fruits of our flesh that he took from the Virgin's womb" 15 is further developed in the medieval tradition as explicit reflection on the depiction of the Madonna lactans. As Beth Williamson writes, such representations implicitly drew on and reinforced not only theological claims about the Incarnation, but about the bodily functions of their viewers:

Medieval physiological theory, usually based on the teachings of Soranus of Ephesus (96-138 C.E.), taught that the mother's menstrual blood formed the fetus in the womb and continued to feed it while it grew. A further element of this theory was that the womb-blood went by a special vein to the breasts and was then converted into milk to feed the newborn infant. This biological theory had several implications for an image of the Virgin Lactans. First, it meant that the image could be seen as symbolizing the very physical nature of the Virgin's motherhood and emphasizing her part in the Incarnation. It also linked the Virgin's milk with Christ's blood, not only in the biological sense - where the blood and milk were thought to be two forms of the same substance- - but also in a sacrificial and eucharistic sense. For if the Virgin's blood formed the body of Christ in the womb and his blood was thus one with hers, then the Virgin's milk, being nothing more than her own converted blood, was also one with the saving blood of Christ. ${ }^{16}$

In appealing to the image of the Madonna lactans as an icon of Christ's fleshly interdependence on the context in which he lives his life, I intend to draw on the full tangled history of this artistic tradition, both in its christological and Marian significances. Most directly, the image is a reminder of the forma servi assumed by the Word, the powerlessness and humility in which the invisible God becomes manifest. Rather than appearing in the incomprehensible glory proper to the divine nature's creaturely manifestations - a glory too holy to look upon without bringing about the death of our intellectual capacities and of our biological existence, a glory that brightens the faces and whitens the hairs of those who gaze upon it, ${ }^{17}$ a glory seen in the whirlwind and thunder and tongues of fire - the Word appears to the world He has made first in the need, the uncontrolled movements, and the muteness of an infant. Yet this image is also and at the same time a sign of the Word's assumption of human dependency, Life receiving life at his

the first through the fourth centuries of the common era (cf. Gale Patterson Corrigan, "The Milk of Salvation: Redemption by the Mother in Late Antiquity and Early Christianity," The Harvard Theological Review 82, no. 4 (1989): 393-420; 398.) The formal iconography of the Galaktotrophousa seems to have developed in the Coptic church in the sixth to seventh centuries, as seen in the chapel frescoes of the Egyptian monasteries of Bawit and Saqqara; cf. Martin Werner, "The Madonna and Child Miniature in the Book of Kells: Part I," The Art Bulletin 54, no. 1 (Mar 1972): 1-23; 4.

15 WSA III/ 17, 272.

${ }^{16}$ Beth Williamson, "The Virgin Lactans as Second Eve: Image of the "Salvatrix"," Studies in Iconography 19 (1998): 105-138; 111.

17 As Cecil B. DeMille would have it. 
mother's breast. It is this resonance of the Madonna lactans that I hope to bring to the fore, because I believe it to have been scandalously underemphasized in the christological tradition to this point. This passing over of the human Word's dependence on creation no doubt reflects a pious anxiety: even if uttered in accordance with the linguistic patterns of the communicatio idiomatum, statements that the Word stands in reciprocal relations with the created order by virtue of the Incarnation bear great potential to mislead, exacerbated by the incautious theological speech of much twentieth-century theology.

Yet the christological conclusion is inescapable: without at all questioning the union with and determination of Christ's humanity by the Word from the moment of his virginal conception, and even in recognition of the way that the humanity of Christ exists only as it is united to the person of the Word, it is nevertheless human flesh that is assumed, and so Christ is dependent biologically on the milk he drinks, the mother who provides him food, the bacteria that aid his digestive process, the swaddling clothes that prevent his early death from cold, the strangers and relations who shelter him first in Bethlehem and then in Nazareth, and on the proper functioning of his organs and organism as his body grows and develops. What's more, the flesh of Christ is dependent upon a long evolutionary history moving backward from early hominids to smaller mammals and finally through to the watery primal origins of life on Earth; without this history, no man Jesus Christ. Even as he grows in stature from child to man, he is dependent on his environment and especially the people around him for the words and language with which he makes sense of the world, for the metaphors and images of the people from which he comes, for their Scriptures, for his understanding of what it is to be a teacher or his sense of who requires healing, for the dust in which he writes to signify forgiveness and judgment.

An objection may be raised at this point, however: is it appropriate to speak of dependence here, when humanity is assumed by the Word who is creator of all? More specifically, should we speak of Christ learning from those around him, when his human intellect is at all moments of his life perfectly united to the Word? Three questions may be distinguished here. First, we may ask whether Christ possesses in his divine nature the full knowledge proper to Godhead; and here we should answer with an unqualified yes. Augustine returns to this point time and again in his In Iohannis evangelium tractatus CXXIV, and it occurs frequently also in his exegesis of troubling passages like Mark 13.32, in which Christ professes that even the Son does not know the hour of his return. It is simply a non-starter on an Augustinian perspective to suggest that the Son kenotically empties Himself of knowledge in His divine nature, what would be a clear abrogation of any number of aspects of Augustine's trinitarian logic, from God's changelessness to God's simplicity.

Next, we may ask whether the human intellect of Christ possesses the beatific vision promised to the saints in the eschaton. On this point, the evidence in Augustine's own texts are inconclusive. Conversation on this topic became particularly intense among Roman Catholic interpreters of Augustine in the first half of the last century, and has recently been revived in relation to Augustine by Fr. Simon Francis Gaine, O.P. in his careful and illuminating study Did the Saviour See the Father?: Christ, Salvation, and the Vision of God. On Gaine's telling, most texts scholars have attempted to marshal as evidence of Augustine's belief that Christ experienced the 
beatific vision (e.g., div.qu. 65 and en.Ps. 15.10) are inconclusive. ${ }^{18}$ Following Van Bavel, Gaine holds that the clearest support for such an interpretation comes from the Conlatio cum Maximinum, in which Augustine interprets John 6.46 in a way that seems to suggest Christ has seen the Father in his human nature:

His words, Not that anyone has seen the Father, but he who has come from God has seen the Father, can refer to human beings, because it said, Anyone. Because he was a man who was then speaking in his human condition, he said it in this way as if to say, "Not that any man has seen the Father except me."19

While this passage certainly is suggestive, I do not believe the matter is as clear-cut as Gaine and Van Bavel seem to think. Minimally, we should read Augustine as saying here that, first, Jesus' use of the word "anyone" implies that it is possible for humans to see God by denying the actuality of this state of affairs; secondly, that Jesus is not including himself among this denial; and thirdly, that he has clarified this point because though he has seen the Father, he is presently speaking in his human condition. Absent is the explicit claim that Jesus has seen the Father in his human condition, which is what Gaine would need to prove the point.

In determining as best we are able what Augustine actually thought, then, we are probably best left with the estimation Gaine gives of Patristic thought on this question: "The general tendency among the Fathers was to exclude all ignorance from the human mind of Christ and regard it as endowed with knowledge of all things, the human mind benefiting from the divine knowledge of the Creator." 20 Yet the later scholastic tradition and doctrinal pronouncements like Pius XII's Mystici Corporis Christi tilt the scales of the tradition significantly in favor of the belief that Christ did behold the beatific vision, even if many contemporary Catholic theologians remain unconvinced. ${ }^{21}$ As Thomas Joseph White notes, however,

the vision of God is not conceptual or notional, but immediate or intuitive.

Consequently, it cannot be 'assimilated' by Christ's habitual, conceptual manner of knowing and willing in any direct fashion. As Aquinas and many Thomists after him have rightly insisted, then, the knowledge of Christ's vision is 'communicated' to his ordinary human consciousness through the medium of a so-called infused prophetic science. ${ }^{22}$

\footnotetext{
${ }^{18}$ Simon Francis Gaine, Did the Savior See the Father? Christ, Salvation and the Vision of God (London: Bloomsbury T\&T Clark, 2015), 54-6.

${ }^{19}$ c.Max. 2.9.1; WSA I/18, 272.

${ }^{20}$ Gaine, Did the Savior See the Father?, 63.

${ }^{21}$ Pius XII. Mystici Corporis Christi [Encyclical of Pope Pius XII on the Mysical Body of Christ]. June 29, 1943. http://w2.vatican.va/content/pius-xii/en/encyclicals/documents/hf_p-xii_enc_29061943_mystici-corporischristi.html (accessed May 30, 2016).

22 Thomas Joseph White, O.P., The Incarnate Lord, 257.
} 
It is not clear, then, that ascribing the beatific vision as such to Christ would present any obstacle to holding that Christ truly learns from those around him. As Aquinas argues in ST III.10.2resp., Christ must know all things in the Word, because "no beatified intellect fails to know in the Word whatever pertains to itself," but "to Christ and to His dignity all things to some extent belong, inasmuch as all things are subject to Him." 23 But, as ST I.12.4-5 makes clear, this is a form of knowing improper to human nature, and therefore requiring a gracious elevation of the natural powers of the intellect, and the assistance of the "supernatural disposition" of created light that allows the essence of God to be not only seen but understood (though never comprehended). This created light is necessary for God's essence to be visible to the intellect at all (and so beatific), but as White points out, it is not clear how this new elevated knowing relates to our more familiar conceptual knowledge.

For this, Aquinas suggests that we need also the infusion of knowledge in our passive intellects (ST III.11.1) and acquired knowledge gained through perception of the world (ST III.12.1). It is not the doctrine of the beatific vision as such that results in the picture (worrisome to some) of the boy Christ possessing conceptual knowledge of, for instance, the fundamental physics captured by the equations of quantum mechanics, but rather Thomas' dogmatic insistence that "it was fitting that the soul of Christ should be wholly perfected by having each of its powers reduced to act" (ST III.11.1 resp.). It is this account of the necessity that all the potentialities of Christ's intellect be actualized that results in his claim in ST III.12.3resp. that Christ learned nothing from other human persons: "Christ is established by God the Head of the Church - yea, of all men, as was said above, so that not only all might receive grace through Him, but that all might receive the doctrine of Truth from Him...And thus it did not befit His dignity that He should be taught by any man." So long as we reject the claim that all the powers of Christ's soul must be perfected even prior to the glorification of the Resurrection and Ascension, there does not appear to be any incoherence in denying that conceptual knowledge corresponding to the intuitive knowledge of the beatific vision is infused in Christ. Such an approach would depress in Christ the significance of infused conceptual knowledge prior to the glorification of his flesh while amplifying the importance of Christ's learning from those around him, without undermining the claim that Christ possesses throughout his life the beatific vision of God. It seems, then, that we need not deny the beatific vision to Christ in order to affirm that he truly learned from others - only to hold that the forma servi is a far greater state of humility than Thomas realizes.

Third and finally, then, we may ask directly whether Christ learned from those around him, and here we seem to meet open theological terrain. Again, Augustine offers little explicit guidance on this point; the closest we get is a brief discussion in conl.Max 2.7 of Luke 2.52: "We read that Jesus advanced in age and wisdom, and the grace of God was upon him, but this was according to the form of man which he took from us and for us, not according to the form of God in which he did not think it robbery to be equal to God." 24 While this cannot be thought to give us insight

${ }^{23}$ All citations to the Summa Theologiae (hereafter, ST) drawn from Thomas Aquinas, Summa Theologica, trans. Fathers of the English Dominican Province. 3 vols. (Westminster, MD: Christian Classics, 1948).

${ }^{24}$ WSA I/ $18,315$. 
into what it meant for Jesus to advance in wisdom, it at least establishes that Augustine's theology of the forma servi opens the possibility of his growth in wisdom. There is also unquestionably present in Augustine, as Gaine noted above, the claim that Christ possesses knowledge far more expansive than what can be known to an average person; this may be seen in his anticipation of his crucifixion and resurrection, in his knowledge of the Samaritan woman's five husbands, in his perception of Nathaniel under the fig tree. Whether through the infusion of knowledge in the intellect or through the prophetic ministrations of the Holy Spirit - if we do not wish simply to identify these two gracious acts of God, which would seem reasonable - we may suggest as a general rule: he who eternally knows all things as God, knows humanly - which is the only way the Word knows in time - only that which it is right that he should know within the economy of salvation. As seen in the Scriptural examples above, this knowledge should be thought to be quite capacious, certainly including if the accounts of all four Gospels are to be believed knowledge of himself as God (before Abraham was, I am) and knowledge of his crucifixion and resurrection. But this rule nevertheless secures wide latitude both for God providentially disposing history such that Christ acquires a great deal of what he knows from those around him, as well as the possibility that some things in the economy might remain obscure within Christ's natural conceptual human knowing, alongside the immediate and intuitive beatific knowledge of God.

On this presentation, the matter of Christ's conceptual knowledge runs parallel to that of the capacity of Christ's flesh to experience injury and pain: though the decay of Christ's flesh under Roman lashes is not, strictly speaking, proper to the incorruptible state of flesh united to God (as, again, our flesh will be incorruptible when it reaches eschatological union with God), in assuming flesh the Word wills that this flesh should be susceptible to injury and pain in its preresurrected state. Similarly, we might think that though it is proper to a perfected human intellect to have conceptual knowledge of all things, the Word wills in an act of power that the intellect of Christ should exist in a state of humility, not knowing all things conceptually even as it enjoys the beatitude of the intellect's union with God. Something like this account is necessary in order to hold alongside Augustine that Christ enjoys the blessedness of union with the Father even as he truly experiences the emotions of fear and sorrow and the anguish of physical pain. In relation to those around him, then, we may claim that Christ fully inhabits the language and cultural conceptualizations of those who teach him how to walk, how to speak, how to dress, and so on. Christ speaks as a first-century Jew, with the intellectual thought-forms and understanding of the world around him that he inherits as a first-century Jew; and-again, allowing room for special illumination by the Holy Spirit, which the Gospels give us reason to think affords him significant knowledge of his own place within God's work and the vocation to which he is called - we may even hold that in the forma servi the scope of Christ's conceptual knowledge abides within the limits of what could be known by a first-century Jew. On this account, Christ receives the language and concepts through which he communicates with others from the world around him, just as he receives the material substance of his body from Mary. 


\subsection{Vulnerability}

In Act V.2 of Othello, the maid Emilia arrives just as Othello has dealt a fatal wound to his wife (and Emilia's mistress) Desdemona. In her anger and grief, Emilia refuses to keep silence, though speaking in judgment of Othello's murderous deed will place her own life in danger. She is uncowed: "Thou hast not half that power to do me harm as I have to be hurt." 25 This line, one of the most Christian insights in all of Shakespeare, ${ }^{26}$ does much to illuminate the way Augustine understands the vulnerability of Christ's flesh. Christ's weakness and susceptibility to violence are, on the one hand, a work of divine power. Christ's flesh is profoundly unlike our own in that it is without sin, and so is not properly subject to the corruption and death that characterize our experience of our bodies. He experiences bodily damage, suffering, and death only because he wills to do so for our salvation. On the other hand, however, fleshly vulnerability is precisely the tool the Word uses to effect the salvation of the world. The world's power to harm Christ and those in him shrinks before the cross; his power to be hurt, a power he shares with us, is the source of our redemption.

Augustine is clear throughout his writings that Christ's flesh is not properly subject to corruption and death. At en.Ps. 86.5, Augustine asks of his listeners:

Could any kind of pain be lacking in that man himself, the man that the Word of God became, the man who was born of the virgin Mary? He suffered what it was appointed to him to suffer, and he did so of his own volition, not under any necessity flowing from $\sin .$. Who is this, who departs from life in the way that Christ went forth from his body? Who ever could? He alone who had first said, I have the power to lay down my life, and I have the power to take it up again. No one takes it away from me; but I lay it down of my own accord, and I take it up again (Jn 10.18,17). He laid it down when he willed, and took it up when he willed; no one took it away, no one wrested it from him. ${ }^{27}$

On Augustine's understanding, the little signs of corruptibility and death with which we are all so familiar - a skinned knee, a chest cold, a sore back - are all marks of sin's effects upon us. They are signs of a body improperly enlivened by the soul, because the soul itself is improperly enlivened by God. As the soul suffers the death of its withdrawal from God, so also the body suffers the death of the withdrawal of the soul. This "first death" of the separation of soul and body (contrasted to the "second death" of the soul's separation from God) is fully accomplished when we reach the terminus of our earthly lives, yet each sign of bodily corruption is an anticipation of this promised end. ${ }^{28}$ As Augustine notes of our experience of ourselves, "from the

\footnotetext{
${ }^{25}$ William Shakespeare, The Oxford Shakespeare: Othello, The Moor of Venice (Oxford: Oxford University Press, 2008), 384.

${ }^{26}$ A point I owe to Ashley Faulkner.

27 WSA III/18, 250-1.

28 Cf. civ. 13.2.
} 
very beginning of our existence in this dying body, there is never a moment when death is not at work in us." 29

By contrast, the flesh of the saints "will be subject to the spirit with a supreme and marvelous readiness to obey, and will fulfill its will in the most assured knowledge of indestructible immortality, with all distress, all corruptibility and all reluctance gone." 30 In fact, the resurrected body "will not only be better then than it was here even when in perfect health; it will also be better than those bodies which the first human beings had before they sinned. For, though they were not to die unless they sinned, they nonetheless made use of food as men do now; for their bodies were not yet spiritual, but animal and earthly only."31 Death or corruption will be utterly improper to those bodies, because the entire existence of the saints will be perfectly received as the gift of God, the Life in whom there is no death. They "will need no tree to guard them against death from sickness or old age, nor other corporeal food to protect them from any kind of hunger or thirst. For they will be endued with the reward of an immortality so certain, and so inviolable in every way, that they will not eat except when they wish, having the power to do so, but no need." 32 This incorruptible body is the sort of flesh appropriate to the condition of humanity without sin, though it is a flesh we possess only in hope. Such flesh so far exceeds our experience that it is difficult to imagine life in it; at best, we can imagine the absence of the sorts of death that figure prominently in our lives, the pains and frailties to which we are subject. What the eschatological hope for incorruptible flesh does indicate to us, however, is that vulnerabilitythe capacity to be wounded - is a contingent feature of human life. We will one day be without it, and Christ might have lacked it and nevertheless been fully human.

That Christ was born in vulnerable flesh is therefore a great mystery, and of great importance to his redemptive work. As Augustine writes at civ. 13.23, "the animal body is the first: the kind of body that the first Adam had, although it would not have died had he not sinned...It is also the kind of body which Christ Himself deigned to assume for us at first: not, indeed, of necessity, but of choice." 33 It is clear, too, that there is a transition in the quality of Christ's flesh between its state in the period of his ministry and the glorified flesh he receives in the Resurrection: after this animal body "comes the spiritual body, which Christ Himself, as our Head already has; and this is the kind of body which His members will have at the final resurrection of the dead." 34 Christ's vulnerability must therefore be understood as a state entered into willingly. In contrast to we who suffer corruption and death necessarily on account of the sinful condition in which we enter life, Christ's assumption of a body capable of death is an act of power, a condescension to the forma servi. As Michael Cameron notes, "In willing to take up human death, the man Jesus paralleled, replicated, complemented, and fulfilled the humble

29 civ. 13.10; Dyson, 550.

30 civ. 13.20; Dyson, 566.

31 civ. 13.20; Dyson, 566-7.

32 civ. 13.22; Dyson, 569.

33 Dyson, 572.

34 civ. 13.23; Dyson, 572. 
divine will of the Word who condescended to take up mortal flesh." ${ }^{35}$ He even goes so far as to speak of Jesus" "humble will-to-death." 36

When we approach the narratives of the Passion, then, there is no reason to suppose that Augustine's identification of Christ's vulnerability as a work of power in any way compromises the reality of his suffering. When he asks, "What did he gain by suffering so terribly? What was it that cost him all that pain?", ${ }^{37}$ we need add no qualifications: Christ suffered the pain of death fully, anguishedly, in the same way that you and I feel pain - though he suffered this on our account and to provide a model for our hope in God's victory over death, as we saw in Chapter Three. Though we differ in that Christ enters this state willingly, Christ's vulnerability is our own.

We may offer a similar account of the affections Christ undergoes in the Passion. In his second exposition of Psalm 30, he asks

Surely we cannot attribute fear to Christ as his passion loomed, when we know that was what he had come for? When he had reached that suffering for which he had come, was he afraid of imminent death? Surely even if he had been human only, not God, he could have been more joyful at the prospect of future resurrection than fearful because he was about to die, couldn't he? ${ }^{38}$

It is important to note that, even when addressing this possibility, Augustine is careful not to separate Christ's experience from what is possible for other human persons. It is at least conceivable that if someone were to face death knowing that they would be revived on the other side, that expectation of their new life would overcome the fear they might otherwise face.

Augustine does not rest, however, with this more comforting possibility of a Christ who does not face fear:

But in fact he who deigned to assume the form of a slave, and within that form to clothe us with himself, he who did not disdain to take us up into himself, did not disdain either to transfigure us into himself, and to speak in our words, so that we in our turn might speak in his. This is the wonderful exchange, the divine business deal, the transaction effected in this world by the heavenly dealer. He came to receive insults and give honors, he came to drain the cup of suffering and give salvation, he came to undergo death and give life. Facing death, then, because of what he had from us, he was afraid, not in himself but in us. When he said that his soul was sorrowful to the point of death, we all unquestionably said it with him. Without him, we are nothing, but in him we too are Christ. ${ }^{39}$

\footnotetext{
35 Cameron, Christ Meets Me Everywhere, 154.

${ }^{36}$ Cameron, Christ Meets Me Everywhere, 154.

37 en.Ps. 21(2).8; WSA III/ 15, 232.

38 en.Ps. 30(2).3; WSA III/15, 322.

39 en.Ps. 30(2).3; WSA III/15, 322-3.
} 
Two interrelated questions emerge in light of this passage: first, how are we to understand Augustine's statement that Christ experiences fear not in himself but in us? And second, what sort of relation between Christ and humanity is created in this "wonderful exchange," such that this transferal of fear is possible? An answer to the first question remains murky in this passage. It is clear that Augustine intends his words here as a response to the possibility that Christ felt no fear at his imminent death. Knowing that he will not be left in death, Augustine believes that it would make little sense - and in fact, would show Christ to be deficient in comparison to the martyrs and to St. Paul, who seemed to exhibit no fear in wishing that he could leave this life and reside with Jesus - if he had been terrified simply by the prospect of the passage from life to death. Christ is Lord over all, including death; surely the one who is all-powerful should fear nothing? If, then, Christ is to experience any fear at all, it must not be on his own account, but on ours. What we lack in this passage is any unequivocal statement of the quality of Christ's emotional experience. This may be part of the point: rather than dwelling on the content of Christ's psyche, Augustine wishes us to reflect on our own incorporation, and the incorporation of all our experience and emotions, into Christ's own life. But at this crucial point, a Christ who is utterly emotionless seems so fantastically far from our own experience that the idea gives us pause, and calls into question just how fully God has united Himself to humanity. Clearly, the most important claim for Augustine here is that Christ has been united to our fear; but what does this tell us about his own life?

While no answer is forthcoming in Enarratio in Psalmum 30, Augustine returns to this question in De civitate dei 14.9. Drawing a contrast to those philosophers who take growth in wisdom to lead to the stilling of the soul and its perturbations, he writes that "We Christians, on the other hand, are citizens of the Holy City of God, living according to God during the pilgrimage of this present life. Such citizens feel fear and desire, pain and gladness, but in a manner consistent with the Holy Scriptures and wholesome doctrine; and because their love is righteous, all these emotions are righteous in them." 40 The life of the saint in her pilgrimage through this world is richly emotional, fearing that she will lapse into sin, hoping that grace will preserve her in love of God, weeping tears of compunction. Yet this pilgrim life is also deeply communal; Augustine tells us, "it is not only for their own sakes that the citizens of the City of God are moved by these feelings. They also feel them on behalf of those whom they desire to see redeemed and fear to see perish. They feel pain if these do perish, and gladness if they are redeemed." ${ }^{41}$ Here we have edged closer to the way Augustine has described Christ in en.Ps. $30(2)$; there is a sharing of emotional life proper to all the redeemed, a feeling of fear on account of others. Augustine has not gone so far here as to describe the saints feeling the actual fear of others in themselves, but has established that it is human (perfectly human, in fact) for those whose desires are rightly ordered to experience emotions like fear on behalf of others. This sort of fellow-feeling, and perhaps especially fellow-suffering, is woven into the fabric of interpersonal

40 civ. 14.9; Dyson, 597.

${ }^{41}$ civ. 14.9; Dyson, 598. 
life for Augustine. Instead of the noble philosopher, secured by the wisdom he alone has attained against all the harms that the world can inflict upon him, Augustine's finds the paradigm for Christian life in the apostle Paul, who is aware at all times of his dependence upon God's gift, who grieves over the separation of the community of the Church from the people of Israel, and who desires above all else union with Christ. ${ }^{42}$ It seems for Augustine that our redemption and trust in God's grace, far from drawing us away from worldly relations, breaks us open to one another in a new sort of vulnerability - it is only when we have begun to be knit into the body of Christ that we find how deeply our emotional lives are dependent on one another.

It is in the context of this rethinking of the place of emotion in the lives of the redeemed that Augustine turns to consider Christ's own life. ${ }^{43}$ He writes,

when the Lord Himself deigned to live a human life in the form of a servant, though having no sin, He displayed these emotions in circumstances where $\mathrm{He}$ judged that they ought to be displayed. For human emotion was not feigned in Him Who truly had the body of a man and the mind of a man... Truly, he accepted these emotions into His human mind for the sake of His own assured purpose, and when He so willed, just as He was made man when He so willed. ${ }^{44}$

There is a risk of a sort of mythologizing in passages like these that does indeed suggest in Christ's humanity a quality perilously dissimilar to our own. We can imagine a reader of Augustine concluding that, at various moments in the course of his temporal life, Jesus Christ chooses to open himself to certain emotions, deliberating and deciding whether or not to experience sorrow or fear, and appropriating to himself the true emotions of some poor soul. In such a reading, we see again the danger of a picture that I have consistently attempted to avoid throughout the course of my exposition, a picture that imagines the Word as mythologically present in time acting behind or alongside the humanity of Christ. Such an account sees the Lordship of Christ as exercised moment by moment, the divine willing in time what the human wills in time; but this is also to imagine the Word as dwelling within created history in some way other than in the humble flesh of Christ. By contrast, I have consistently affirmed that the life of the Word in time is found exhaustively in the humanity of Christ, which is itself the human flesh of the Second Person of the Trinity. The Word is present to all creation as its source, principle of order, and in the created effects the Sapientia of God creates to manifest Herself, but only in and as a (divinehuman person is the Word properly said to live in time. Though it may be possible to offer an account of Christ's assumption of fleshly vulnerability to both injury and affection that understands him as humanly willing to permit each pain or emotion, it is better, I think, to view

\footnotetext{
42 Robert Dodaro directs attention to Augustine's framing of Paul as the ideal Christian disciple in "Augustine's Revision of the Heroic Ideal." Augustinian Studies 36, no. 1 (2005): 141-157.

${ }^{43}$ John C. Cavadini offers a careful reading of this passage with reference to Christ's emotions at "Feeling Right: Augustine on the Passions and Sexual Desire," Augustinian Studies 36, no. 1 (2005): 195-217; 202.

44 civ. 14.9; Dyson, 599.
} 
Christ's will to assume the forma servi as itself a will to assume the vulnerability proper to our bodies of $\sin ^{45}$

As we interpret passages like this one in De civitate dei, then, we must remember that the act of will in which the Word assumes not only the materiality of human bodily existence but also the experience of emotions like sorrow and fear is the very eternal act that is the divine life of the Word. The determination in which the Word is pleased to experience emotion is the same determination in which the Word assumes human nature - various in temporal effect, but integral in the eternal life of God. The emotions of Christ are true and of the same quality as those of other persons, but here again, are assumed by the Word as an act of power. Our "tears come...from the infirmity of our human condition; but this was not true of the Lord Jesus, Whose very weakness came from His power." ${ }^{6}$ Without reaching too deeply into speculations on Christ's self-experience and mental states, we can make the formal claim that Christ's emotional states differ from our own not in their character or intensity, but in their necessity as determinations of the humanity of the Word. It would be in perfect accordance with the power of God to assume from the first perfected and glorified human flesh: deathless, incorruptible, possessing a beatitude untroubled by sorrow or fear and resting in loving contemplation of the Father - but, as civ. 14 suggests, this would only be possible had the Word remained aloof from the sorry condition of sinful humanity. As seen in the Apostle Paul, a righteous person experiences "emotions and affections, which come from love of the good and from holy charity," and "when they are exhibited in the proper circumstances, these affections are the consequences of right reason." 47 It is appropriate, it is entirely natural, for a righteous human person to feel these emotions in connection to and on behalf of others; and they are the inescapable result of a life lived in loving contemplation of the Father on behalf of others. While Christ's power thus leads us to consider the possibility of a divine-human person who is not subject to affective perturbations, the mission of Christ reminds us that to imagine this possibility is to imagine a very different Word than the one who has come to us in humility, subjecting Himself to the weakness of human life on our behalf.

This account of Christ's power in weakness forms the crucial context for Augustine's discussion of the cry of dereliction: in translation from Augustine's Latin, "O God, my God, look upon me, why have you forsaken me?"48 As modern readers, we cannot help but be puzzled at the thought of God crying out in godforsakenness; what might this possibly mean? Augustine would not have perceived a wide-open field of possible answers to this question (though he may have perceived more acutely than us the potential dangers of many of the sorts of answers given by many modern theologians). For him, the faith of the Church offers clear guidance on this point: as soon as he asks the question "What did the Lord mean?", he answers, "God had not abandoned him,

${ }^{45}$ In his forthcoming Christian Flesh, Paul Griffiths offers such an account of occasionalist vulnerability with respect to bodily injury, though he studiously avoids any discussion of Christ's affective life.

46 civ. 14.9; Dyson, 599.

47 civ. 14.9; Dyson, 599.

48 en.Ps. 21(2).3; WSA III/15, 229. 
since he himself was God." 49 It is, for Augustine, simply inconceivable that God should have abandoned Christ on the cross - even temporarily, even in the economy of salvation, even in the order of signs that draws our hearts and minds back to God. As he shows in his quick citation of the prologue to John's gospel, the question is simple: "let us see if Christ is God." 50 That he is, entails that there can be no godforsakenness in God, no abandonment of the Son by the Father. That Christ should utter on the cross words so spectacularly unsuitable to his own sinless life and fullness of deity should direct us to pursue a deeper interpretation of this text:

For what other reason was this said than that we were there, for what other reason than that Christ's body is the Church? Why did he say, My God, my God, look upon me, why have you forsaken me? unless he was somehow trying to catch our attention, to make us understand, "This psalm is written about me"?51

It is not Christ that has been abandoned by God, but we ourselves in the sin that merits the second death. In forsaking God, we have become bereft of God; though, as we saw in Chapter Two, this can suggest no change in God's own loving disposition toward us. It is rather that the same disposition of God that was perceived as loving when our hearts and actions were properly ordered to God (and thereby, to the world) appears to us now as a countenance of wrath, and worse, of abandonment. Christ's words reflect the godforsakenness that we have brought upon ourselves - but in being uttered by the incarnate Lord, Christ shows us that God has not left us in our wretchedness, but has joined Himself to our condition. In walking among us, Christ experiences not his own abandonment by God, but horror at our abandonment of God. As one with emotions ordered by justice and righteous mercy, he experiences in time the outrage of a good creation that has mutilated itself in setting itself against its creator. His cry expresses the pain and despair of knowing the world as it should be, and seeing everywhere around him the tragedy that is. These words are a moment of excess in Christ's speech, something that cannot be accounted for strictly by attention to the unity of divinity and humanity in the Word's assumption of flesh, but which push us to see the whole shape of Christ's life, the way his life unfolds in vulnerability and relations of dependence to others.

This is not yet to say that Christ experiences himself to be abandoned by God, but at least he experiences himself as aligned with our God-abandonment - and, we may perhaps say, experiences also and humanly his alienation from us as the God that we have abandoned. It is worth noting that if the account of Christ's affections offered above is correct, Christ's pain at the world's separation from God would not begin at the Crucifixion, but would extend as far back toward the beginning of his life as his developmental capacity permits. Every drop of Christ's blood shed throughout the course of his life is an anticipation of the cross, and a recognition of the suffering at the state of the world he bears throughout his life. We may think here of John Everett Millais' Christ in the House of His Parents, as the boy Jesus suffers a wound in his palm

49 en.Ps. 21(2).3; WSA III/ 15, 229.

50 en.Ps. 21(2).3; WSA III/15, 229.

51 en.Ps. 21(2).3; WSA III/15, 229. 
sustained by assisting his father's carpentry; the Crucifixion is more than a three-day affair. From his youth, Christ would be able to hear the world's groaning; we can imagine that such pain would be utterly debilitating. It perhaps does not go too far to say that Christ, above all people, required with him the presence of the Holy Ghost, the Comforter - the one who, acting inseparably from the Word, inspires and sustains Christ's ministry, who fits and strengthens him for the work he is to do. We may even speculate that as he approached the place of the skull, the Spirit's work of comfort receded, allowing Christ to experience the undiluted intensity of the world's separation from God, the cup that he was to drink. This does not indicate any caesura in the Trinity, though does suggest a sense in which the Spirit's economic relation to the incarnate Son exposes his human flesh to the world's abandonment by God, a counterpoint to the Baptism of Christ in which the Spirit rests on Christ's flesh and impels him to the desert with particular force. But as Augustine shows, even in Gethsemane the suffering Christ experiences is our own: "Do you suppose, brothers and sisters, that when the Lord said, Father if it is possible, let this cup pass from me, he was afraid to die?": "Why did he make that prayer, then, except because he was bearing our weakness, and made it for those members of his body who still fear death? That was where the words came from; this was the voice of his members, not of the Head."52

The cry of dereliction is, then, a sign of divine misericordia, an indication to us that Christ has assumed human flesh in an act of love for the purpose of healing the condition afflicting us. Without undermining the true quality of the sorrowful affection Christ experiences as a fellowsufferer alongside us, there is thus also a pedagogical function of Christ's words from the cross. In Christ's cry of dereliction, we come to a twofold knowledge of ourselves, both in the godforsakenness that characterizes our fallen state, and in the working out of our salvation that is currently in process. We are perched perilously between these two realities; in the cross, they join as one, our abandonment made the very sign of God's redemptive purpose. In speaking our own words to us at the extremity of death, Christ shows us that God has taken the part of humanity, and will bring those elect in him to reconciliation and eventual glorification.

It is here we encounter most fully the redemptive significance of Christ's vulnerability, and indeed, the power of our own vulnerability. When Emilia tells Othello that her capacity to be harmed far outstrips his ability to wound her, she insists that the grief she feels at Desdemona's death is a deeper, truer reflection of human life together than our ability to harm one another. Her cry protests the sundering of her relationship with her friend, the reality of death unjustly dealt, the complicity she finds in her husband's responsibility. Emilia refuses to accept the brokenness of our relations to one another as basic, a refusal that ultimately closes her possibility of living in this world. In her rejection of the forces that led to Desdemona's death, we may see also a rejection of all the wounds we give and receive in our fleshly vulnerability, all the violence, misrecognition, and betrayals that shape our lives. Our power to be harmed tells against the ultimacy of war, of racism, of patriarchy, of heterosexism, of economic and environmental injustice. It tells against our pettiness, our insecurity, the unknown sleights that deeply harm our neighbor. We are not meant for the devastation in which we live; we are meant for one another,

52 en.Ps. 21(2).4; WSA III/ 15, 230. 
and for God. In his cry of dereliction, Christ illumines a beacon in our darkness, teaching us that God Herself has joined us in the state of our fleshly abjection. God is with us, suffering the consequences of our attempts to dominate and exterminate one another; God is with us, suffering our suicidal attempt to live otherwise than as Her creatures. In bearing our wounds without dealing any of his own, Christ teaches us that our vulnerability is truer than our pain - that we are meant for one another, and will live in blessed life together even when our flesh has been rendered incorruptible; that even in the suffering of this world, a new community in Christ can offer a glimpse of the home toward which we make our pilgrim way. In his death, Christ permits his life to be fully determined by those around him, surrendering himself utterly to their attempts to destroy him; and at the moment of his death, as vulnerability and interdependence become one, he opens to us new life in him.

\subsection{Singularity}

In the claims I have made thus far - that the Word's assumes a flesh necessarily implicated in and dependent upon a long cosmic and evolutionary history alongside the linguistic and cultural histories that shape first-century Palestine, that the reconciliation between God and creation is effected through our vulnerability and interrelation - I am coming quite close to a position Danish theologian Niels Gregersen has described as "deep incarnation." While I am sympathetic to the theological aims of Gregersen and the "deep incarnation" school, they show the theoretical dangers of a christological approach that favors the language of interdependence and vulnerability without a corresponding emphasis on the singularity of Christ's flesh. Though I do not intend to offer an exhaustive account of Christ's singularity, engagement with deep incarnation shows that even as it emphasizes the interdependence of the created order, christology must appeal also to a metaphysics of human persons.

First coining the phrase "deep incarnation" in 2001, ${ }^{53}$ Gregersen has in a series of recent essays described deep incarnation as the claim that "the divine Logos (which can be translated as creative 'Word' or the formative 'Pattern') has assumed not merely humanity, but the whole malleable matrix of materiality." 54 The notion, a christological adaptation of Norwegian philosopher Arne Næss' concept of "deep ecology," 55 is meant to convey especially the evolutionary and ecological context and significance of the Incarnation. Pointing to the Johannine prologue's claim that Christ assumed flesh rather than specifying human flesh, Gregersen argues that

we can now also say that the divine Logos, in the process of incarnation, unites itself with the very basic physical stuff. In other words, the flesh that is assumed in

\footnotetext{
53 Niels Henrik Gregersen, "The Cross of Christ in an Evolutionary World," Dialog: A Fournal of Theology 40, no. 3 (2001): 192-207; 205.

54 Niels Henrik Gregersen, "Deep Incarnation: Why Evolutionary Continuity Matters in Christology," Toronto fournal of Theology 26, no. 2 (2010): 173-188; 176, emphasis original.

55 Næss coined the term in Arne Næss, "The shallow and the deep, long-range ecology movement. A summary," Inquiry 16, no. 1-4 (1973): 95-100.
} 
Jesus Christ is not only the man Jesus but also the entire realm of humanity, animality, plant life, and soil...In Christ, God is conjoining all creatures and enters into the biological tissue of creation itself in order to share the fate of biological existence. God becomes Jesus, and in him God becomes human, and (by implication) foxes and sparrows, grass and soil. 56

This fascinating but rather wooly set of claims is given a measure of specificity in a later article in which Gregersen distinguishes between "strict-sense," "broad sense," and "full-scope" registers of discourse concerning the Incarnation, or "modes of incarnation." In referring to the "strict sense," or "As-incarnation," ${ }^{57}$ Gregersen has in mind the unique way that God is present in the body of Christ. Even at this first level, however, Gregersen pushes us to a more capacious sense of incarnation: he tells us that "this classic or strict notion of incarnation always includes reference to the body of Christ as present in the cosmic story before as well as after the historical incarnation in Jesus, ${ }^{\prime 2}{ }^{8}$ by which he means both God's antecedent will to become incarnate (the Logos incarnandus) as well as the "notion of an extended body of Jesus - comprising his social and biological relations in deep time and space." ${ }^{59}$ The material body of Christ is the locus of God's redemptive work in history, and is irrevocably assumed into unity with the life of God. The second "broad sense" of incarnation, what Gregersen calls "In, With, and Under incarnation," 60 picks out the sense in which the Word's creation and preservation of all things can be understood as "Christ co-inher[ing] throughout the world of creation." 61 This second sense of incarnation is required by the fact that not all of created reality manifests the life of God to the world. Since nothing exists without the life-giving power of the Word, there is a sense in which the violence of natural selection or unloving human relations like "child abuse, idle gossip, hidden economic deals, or family-like relations in gangs and Mafias" bear an intrinsic relation to the Son; but "The point of Christology is that the living Christ is always co-present in such relationships, calling for transformation, but exactly not present as enacting these self-same relationships." ${ }^{\prime 2}$ In this broad sense, then, we may say that creation with all its suffering and evil exists in a relation of intimacy to the Word, without sanctifying all this as revealing to us the character of God. Finally, the "fullscope" notion of incarnation, which Gregersen also refers to as "soteriological incarnation," is most basically the claim that "Christ co-suffers with and for all suffering creatures," "compassionately suffering with and for others while working out on [sic] their salvation."63

What to make of this proposal? Gregersen is clearly animated by what seems to me a valuable theological insight: the Word's assumption of flesh implicates not only the physical body

\footnotetext{
${ }^{56}$ Gregersen, "Deep Incarnation: Why Evolutionary Continuity Matters in Christology," 182, emphasis original.

${ }^{57}$ Niels Henrik Gregersen, "Cur Deus Caro: Jesus and the Cosmic Story," Theology and Science 11, no. 4 (2013): 370-393; 385, emphasis original.

58 Gregersen, "Cur deus caro," 384-5.

${ }^{59}$ Gregersen, "Cur deus caro," 385.

60 Gregersen, "Cur deus caro," 385-6; emphasis original.

${ }^{61}$ Gregersen, "Cur deus caro," 386.

${ }^{62}$ Gregersen, "Cur deus caro," 386; emphasis original.

63 Gregersen, "Cur deus caro," 386.
} 
of Christ, but the historical, biological, and social conditions that produce such flesh. ${ }^{64}$ Yet within this broader note of appreciation for the spirit of Gregersen's theology, his account suffers from a number of problems. There is a lingering ambiguity about just what distinguishes God's presence in Christ from God's coinherence in creation. Gregersen pushes hard at the boundaries of theological language in order to convey the scope of the Word's assumptive act, as when he writes, "In the depths of incarnation, God does not just conjoin with the ecosystem of Gaia in its totality. God also unites himself with the individual, vulnerable creatures." 65 Gregersen's intent is clearly not to claim that the Word is identically incarnate in both Christ and every hare or guppy. Rather, he wishes us to see that "in Jesus Christ the entire matrix of materiality is assumed in his blood and body." 66 In his blood and body - this is the crucial part of this statement, and it leads Gregersen to a clear statement that "deep incarnation does not suggest that God is simply incarnate in all that happens and takes place at any moment in the history of creation." 67

Yet it remains unclear just what is supposed to account for the uniqueness of Christ's human flesh. The closest we get is Gregersen's claim that "Deep incarnation aims to identify who the God is who is present in, with, and under the many events, processes, and experiences in the world of creation: it is the forever incarnated and resurrected Jesus Christ,"68 but while this identification of God with Christ clearly suggests the centrality of the man Jesus in God's work, it tells us nothing about the principle and limits of this identification. Say, for example, we understand (as Gregersen seems to) the human person as an inherently fuzzy concept, picking out not a composite of matter and form or an individual subsistence of a form eternally inhering in God's mind, but an ever-changing collection of particles governed by physical processes - where do we draw the boundaries of a human person? It would seem that it is insufficient to say that just the physical constituents of Christ's body are assumed in the strict sense, because these are always changing; and anyway it is hard to say that they constitute a human person without the attendant physical processes. This seems to be the motivation for Gregersen's repeated statements to the effect that "the whole matrix of materiality is assumed" - we need both physical material and material process. Yet if the material processes are also assumed, there lies an intrinsic connection between Christ and all other aspects of reality in which those material processes are implicated; and this ends up being the whole of created history. This is, of course, the whole point for Gregersen, precisely the christological result he is looking for; but such an account makes it exceedingly difficult to differentiate the sense in which Christ's body is assumed by the Word from the broader sense in which Gregersen believes all creation can be said to be assumed.

\footnotetext{
64 Though Gregersen does not discuss the issue, it should be clear that acceptance of the doctrine of Christ's virginal conception does not exempt him from implication in the evolutionary processes that have produced the present biological form of homo sapiens - his flesh is miraculously drawn from that of his mother. It is, in my view, a profound mistake to imagine the Holy Spirit contributing any genetic matter or other physical material to the formation of Christ's body.

65 Gregersen, "Deep Incarnation: Why Evolutionary Continuity Matters in Christology," 184.

66 Niels Henrik Gregersen, "Deep incarnation and kenosis: In, with, under, and as: A response to Ted Peters," Dialog 52, no. 3 (2013): 251-262; 252.

67 Gregersen, "Deep Incarnation and Kenosis," 252; emphasis original.

68 Gregersen, "Deep Incarnation and Kenosis," 252.
} 
The difficulty is deepened by Gregersen's discussion of internal and external relations. Gregersen contrasts his position with what he calls 'the common-sense idea of all 'things' being individual 'substances' with corresponding 'qualities' (including relations), while the substances themselves are presumed to have a simple location," 69 where this last point is the (non-relativistic) claim that a thing's location entails no intrinsic relation to any other place or time. Instead, he tells us that

The other possibility is to understand the relations of Christ to the cosmos as internal. In this case, the cosmic relations are co-constitutive of Christ. In this view, the incarnate Christ cannot at all be the incarnate Logos, unless he is internally related to the cosmos at large; one cannot make a division between Christ and the cosmos, once they have obtained their internal relations. Expressed in theological language, Jesus could not be savior without actually being there for those who are to be saved by him. Just as a message cannot be a gospel, unless it is actually good news for people, so the body of Christ cannot be genuinely incarnate apart from the entire nexus of the world of Energy, Matter, and Information. ${ }^{70}$

There is much in this passage I will eventually wish to affirm, but it is important to stress the radical metaphysical implications of such a posture in a strictly relationist picture lacking underlying substances in which qualities inhere. Long ago, G.E. Moore argued against F.H. Bradley that, if all relations are internal, the result is a thoroughly deterministic view of the world. ${ }^{71}$ As John Heil writes,

a view of this kind implies that objects have all of their properties essentially: if Socrates has a bruise on his left shin, he could not have failed to have a bruise on his left shin. Why? A change in a single property of a single object changes relations among every object. Objects in Socrates' world would no longer be related in endless ways to bruised Socrates. So, whatever is, is what is of necessity and could not have been otherwise. ${ }^{72}$

Better, Heil thinks, to distinguish between internal and external relations: it is an internal relation that the number 6 be greater than 5, but it is an external relation that Simmias is taller than Socrates. Had Simmias failed to exist (with the relation of Simmias' being taller than Socrates consequently failing to obtain), Socrates himself would be no different. Gregersen has an answer to this objection; he can with some justice point out that he is not merely trying to change our

69 Gregersen, "Cur deus caro," 389.

70 Gregersen, "Cur deus caro," 389.

${ }^{71}$ Cf. G.E. Moore, "External and internal relations." Proceedings of the Aristotelian Society 20 (1919): 40-62; and F.H. Bradley, Appearance and Reality (London: Swan Sonnenschein \& Co., 1893).

${ }^{72}$ John Heil, "Relations," in The Routledge Companion to Metaphysics, ed. Robin Le Poidevin, Peter Simons, Andrew McGonigal and Ross P. Cameron (London: Routledge, 2009), 310-321; 313. 
account of relations, he is trying to do away with the philosophical discourse of object/substance/quality altogether. But in this case, it is unclear how he can account for either the distinctness of Christ within creation, or his continuity over time. Say that we accept the claims that all relations are internal, and that relations do not require objects to serve as relata (difficult as this may be). What picks out one term of the relation from the other, such that a relation can obtain between them? Perhaps the relation itself is basic, but even in this case we would still require an answer to the question of what is being related. Perhaps we should view the relata as relational "nodes" - merely one position within or confluence of the infinite set of relations. But if each node necessarily entails all the relations, and if we have no objects in which these relations inhere substantially, then what is to pick out some nodes as being the ones that constitute Christ? What's more, what secures his identity over time? Christ's human flesh is constantly changing, growing from three feet tall to five feet tall, for instance, or his skin darkening seasonally under the Galilean sun. There cannot be a relation of strict identity between the parts of Christ's life that exist at these times, for they are comprised by different relations; but then, how are we to say that there is one continuous life stretching across these times, rather than a plethora of disconnected relation-states? Some notion of underlying continuants (whether described as object, substance, or some other form of substratum in which qualities inhere and which can serve as a relational term) seems needed here to save the account from incoherence - as Whitehead saw, and as Gregersen faults him for. ${ }^{73}$

Gregersen seems alive to this worry, yet his attempt to distinguish Christ from the rest of creation is deeply unsatisfying. As we have noted, he intends that when we speak about God's incarnation in Christ, we are discussing incarnation in the "strict sense," a distinct "mode" of theological speech about incarnation. While God coinheres with all creation "in, with, and under" it, only in Christ's human life (and, seemingly, the biological processes that have produced it) can we say that God's life and transformative power appear "as" incarnate. Yet when pushed, the point seems merely to be one about the degree to which God is manifest in creation, a fundamentally epistemic category. Gregersen tells us that the distinction between strict and broad senses of incarnation is required by "the problems of natural evil and sin"74consequently, what distinguishes the "co-presence" of Christ in all things (the in-with-and-under from the as) is that some parts of creation "[do] not reveal the nature of God" or "[express] the kind of love exemplified in the life of Jesus." 75 This revelatory aspect of Christ's life is marshaled as a gloss on the sense in which God may be said to be particularly present in Christ:

"Incarnation, in the strict sense of the term, includes both God's self-embodiment and God's selfidentification. Even if God is omnipresent in creation, God is not omnimanifest there."76 And in fact, the deep currents of Gregersen's theology militate against his ability to acknowledge the distinctiveness of Christ within creation as anything more than a difference in the degree to which the part of the created order comprising his life reveals God. He is resolutely opposed to

\footnotetext{
73 Gregersen, "Cur deus caro," 389.

${ }^{74}$ Gregersen, "Cur deus caro," 386.

${ }^{75}$ Gregersen, "Cur deus caro," 386.

76 Gregersen, "Deep Incarnation and Kenosis," 253.
} 
any notion of "a disembodied divine Logos existing alongside creation and incarnation," and tells us in regard to our own humanity that "we never find clear-cut boundaries between ourselves and the nexus of Energy, Mass and Information, of which we are part." 77 What seems ultimately lacking here is any affirmation - or philosophical conceptuality that will make it meaningful to affirm - that the human flesh of Christ exists in contrast to the rest of creation only in its unity with the person of the Word. Lacking any account of object or substance, it seems impossible for Gregerson to describe the flesh of Christ as anhypostatic considered apart from personal union with the Word, which as we have seen, is essential to both Augustine and the later Chalcedonian tradition.

In developing a constructive Augustinian christology, then, we require conceptual resources for discussing the Word's flesh both in its materiality and in its soul, the instantiation of human form. Leaving his panrelationism aside, the physical existence of Christ is much as Gregersen describes it: providentially established in measure, weight, and number, and ordered in its movement and relation to other physical objects in relations describable (with varying adequacy) by physical laws; shaped by long histories of physical and evolutionary development; participant in many series of finite causality stretching back to the first moments of the cosmos and continuing into the eschatological consummation of time; and, to the extent that Christ's flesh is not yet glorified in the course of his life prior to the Resurrection, dependent for the maintenance of his body on biological processes drawing nutrients from the food he eats, as well as on physiological needs like sleep. Gregersen is right that these aspects of Christ's human life are not sufficiently emphasized in most christology, and right as well that assumption of any position within the physical order necessarily bears relations to all other creatures within that order; we have seen this already in our discussion of the relations obtaining within fourdimensional spacetime. But this cannot entail that the assumption into unity with the Word of any region of spacetime constitutes an assumption of all of spacetime, and neither should we think that all relations are intrinsic in the way that spatiotemporal relations are. Some relationssay, your being taller (or shorter) than me- have no bearing whatsoever on who I am essentially, and I would still be the person that I am even if you had been quite different, or failed to exist entirely. Complementing this awareness of the physical implication of Christ's life within the material order, then, must be the affirmation that Christ's humanity exists anhypostatically considered apart from the Word. This is to say, apart from the context of the Incarnation, there is no antecedently-existing human person that is Jesus of Nazareth. The human person is a composite of body and soul, and while an identical series of material processes might be sufficient to produce a human body susceptible to union with the Word, there is no subsistent person without the ensoulment or in-forming of that body; and the soul of Christ exists only in union with the person of the Word, and as a hypostatization in human nature of that person. Indeed, the birth narratives of Luke and Matthew suggest to us that even Christ's bodily existence cannot adequately be accounted for through our standard assumptions and understandings of mere physical process. There is thus no conflict in affirming both that Christ's body stands in the midst

77 Gregersen, “Cur deus caro,” 389-90. 
of the material processes and causal series of the created order and bears intrinsic relations to the whole of that order, and that the flesh of Christ as a composite of body and soul is uniquely assumed into personal union by the Word. Christ is a uniquely divine-human person, but his flesh is our flesh.

\subsection{The Body of Christ}

In light of the preceding discussions, and building upon the christological epistemology outlined in Chapter Three, I believe we are led to a simple conclusion: it is not simply the fact of the Word's union with human flesh that redeems us, but rather the shape of Christ's life - and this is a shape that includes our lives, our actions, our sins and faithful responses to the work of God among us. We may see in this the lingering utility as well as the limits of a distinction between Christ's person and work; his complete personhood describes him as noncompetitively vere deus and vere homo, but tells us nothing else of the shape of his life, the work by which we are redeemed. We are reconciled to God not by the state of a metaphysically-complete humanity being assumed by the Word, but by the life that Word lives in human flesh - a flesh that sucks at Mary's breast, plays games with other children, is taught woodworking by Joseph, learns from the doctors of the temple. Christ is, through the action of the Word in inseparable unity with Father and Holy Spirit, true God and true human; but he learns to be Messiah from those around him. The action and influence of those around him are not dispensable to the work of redemption, but are providentially included within it; and while this has no bearing on the metaphysical completeness of his humanity, it is integrally related to Christ becoming the person that he is, the one who reconciles all creation to God. Indeed, if we speak of the Incarnation as the timeless act in which the Word assumes into unity with Her person the life of Jesus, we may speak also of the "work of incarnation" - the embodied history in which Christ learns the language and cultural practices of the people of Israel under Roman occupation; in which he undergoes experiences that shape the ways he talks to others, his sense of humor, his skill as a storyteller, his love of the law and sense of the commitment it requires, his vocation as a teacher; in which he encounters the vulnerability of human life and the weight of desire, teaching him anger at those who would profane the temple, and fear at his suffering and death. All this occurs within a life perfectly ordered by the love of God, the one truest love that allows him to love as human all things in the particularity with which he created them as God.

In sum, Jesus is the union of divinity and humanity in virtue of the Word's act of assuming flesh, but he is not Christ without us. ${ }^{78}$ In assuming flesh, the Word assumes the dependence and vulnerability of human life - on others, on our environment, on the long

\footnotetext{
${ }^{78}$ In saying this, I affirm and, I hope, extend the claim Graham Ward makes at Christ and Culture, 106: "Redemption is the fulfillment of the economy of the incarnation, and incorporation into Christ in and through partaking of the eucharist is fundamental to that economy...Jesus is the Christ only in relation to other human beings; the act of redemption is a relational act; Christology needs to pay more attention not only to the identity of the God-man, but to the redemptive operation effected in and through this complex co-abiding." Cf. also Christ and Culture, 149: "Jesus Christ as God incarnate can of himself only reveal to the extent he is recognised; he can only reconcile and redeem all to the extent he is responded to. Christology begins with the operation of Christ 'between."'
} 
physical and biological processes and causal chains that have made our human lives possible in the first place. And it is only Christ who redeems us, the human life of the Word made possible and given shape in its interaction with the people and things around him. In the work of incarnation, Jesus becomes who he is by receiving and learning from his world and the people in it, and so our lives and agency are providentially included within God's redemptive acts. Without those around him, there is no proclamation in the synagogue of the year of the Lord's favor; no call to repent in view of the coming of the Kingdom of God; no betrayal, crucifixion, and death. All these acts require a human world shaped by language, religion, kinship bonds, political authority - and it is precisely by these acts of the man Jesus that we are saved. These are not simply the environment within which the God-man acts, they are the forces that shape the divine-human life that he leads, the life that is the perfect created manifestation of the invisible God. We should be careful here; it is easy to lapse into imprecise statements suggesting that the mere fact of Christ's life existing within the series of finite causes counts as some form of unification of all creation with the Word. This is a puzzling claim - it is difficult to see, for example, how the bare fact of Christ's standing in a spatiotemporal relation to the construction of the Harmandir Sahib grounds the sort of incarnational intimacy between Christ and all creation that Gregersen and the deep incarnation school propose. Even if Christ's possessing a body requires that the spacetime region his body occupies be related to all other points of spacetime, this is an external relation; the whole of the star Vega could have been shifted ten meters to the left of its actual location without altering Christ's metaphysical constitution or any of the particular events of his life.

Yet, as seen with particular clarity in the people and places with whom Christ interacted in the course of his life, there are some aspects of the created order that $d o$ seem intimately related to the person that he is; even if these relationships contribute nothing to the completeness of both his divinity and humanity, it is impossible to imagine Jesus as existing without being the son of Mary. Even if we attempt to imagine a scenario in which the Second Person becomes incarnate from a different mother and is born as a different child, ${ }^{79}$ we would still say that in assuming flesh the Word lives in time as a divine-human person, but would live a different human life - different experiences, different family relations, and (plausibly at least) different reactions to the world around him. It thus seems that there is a way in which the lives of some people - among them Mary, Joseph, Peter, John, but including many of the people in the Gospel narratives and likely many people not included in them - may be considered co-constitutive not of Christ's divine-human personhood, but of the concrete historical life he leads. He would not be who he is without the presence of these people in his life, and without the events for which they are present and undergo with and alongside him. Widening the scope somewhat, Christ's life is shaped by the decisions of those quite distant from him by our common reckoning in space and time; his life would have been unthinkably different absent the long history of Roman warfare and expansion, and particularly absent the Roman imperial occupation of Judea. These social realities were shaped over hundreds of years by the decisions and cultural formation of

\footnotetext{
${ }^{79}$ Let us call her Mandy, and him Brian.
} 
untold numbers of people creating and inhabiting the Greco-Roman world. While it is impossible here to assign particular responsibility for forces impinging Christ's life to individuals here with very few exceptions (Herod the Great, perhaps, or Caesar Augustus), we must nevertheless say that the confluence of these exercises of created agency made the world that shaped the life of Christ. Expanding our circle still farther beyond the role of finite agents, we should recognize that any number of non-agential phenomena provided the material conditions of Christ's life and could have decisively altered it. Had geological processes proceeded differently, the boy Jesus might have been killed in an earthquake, or given different meteorological conditions his family may have been forced to leave Nazareth by drought; and the physical processes that produced the relatively stable land and temperate climate of Christ's life are implicated in causal series stretching back to the beginning of creation.

We tend to take all these factors conditioning the life of Christ for granted, and with some justice; we cannot imagine a human life that is not shaped by interactions with others, or by the social and political orders that we inhabit, or by the environment in which we dwell. But this is precisely why such factors must be accorded a central place within christology. God does not assume flesh in isolation from a sinful world, but in and through it; and in the same way, God redeems the world in a life that bears the marks of both creation's goodness and its sin. God makes a place within His reconciling work for all the inanimate, animal, and human histories that shape the life of Jesus, determining in concert with Christ's own divine-human agency the particular events and encounters that manifest the invisible God to the world. This is the humility of God: that the eternal Word lives out and is known through a human life just like any other, dependent upon and receptive to those around him and his environment.

Even here, we must remember that the eternal will that is itself the life of God remains irreducibly prior to the finite causality and agency exercised within the created order, encompassing both Christ's human will and the other creatures that inform the course of his life. Though the particulars of Christ's life are not deterministically plotted as the necessary consequence of causal chains within the creaturely order, the will of God is non-competitively related to created and finite causality. But because God is the giver and source of all things, created agency and causality exists always in and as response to the divine will; and because God is the creator of time rather than existing within it, we should understand this one simple will of God to include within it the whole course of created history, the entirety of four-dimensional spacetime. This is why it makes sense for us to speak of the creaturely factors shaping Christ's life as "included within" the work of incarnation: God has, from all eternity, appointed these humble means - the life of Andrew, or Herod, or Jesus' swaddling clothes - as the creaturely tools through which Jesus' life will be sustained and given shape. In assuming flesh, the Word wills to live a particular life in the midst of other lives, and wills that these others should inform the history of Her humanity. The way these lives (and other animal and inanimate creaturely histories) shape Christ's own life is as varied, textured, and impossible to define as the way our own lives are shaped by the people, places, and things to which we are connected. We catch some glimpses of Christ's dependence on others and his environment in Scripture- John the Baptist's apocalyptic preaching seems to have been an influence on Christ's own conception of 
the coming Kingdom of God, for instance, and scholars are increasingly conscious of the constructive engagement between Jesus' teaching and the other contemporary schools of Palestinian Judaism - but much of this remains hidden from us. Still, pious reflection on the circumstances of Christ's life and the way they shaped Jesus have been a part of the Christian tradition from its earliest days, seen with particular clarity in the literature and art of the Church. We may think here of apocryphal texts like the infancy gospels of Christ; hagiographic tales of SS. Joachim and Anna, the grandparents of our Lord; and the details inevitably added to visual representations of Biblical narratives and events like the Dormition and Assumption of Mary. All these, I suggest, may fruitfully be considered as attempts to attend to the manner not only in which Christ shapes the lives of those around him, but in which their lives shape his own. These literary and artistic depictions of Christ's life and the lives of those important to him call our attention to the particularity of the human relationships that made him who he is, asking us to imagine him not only as an archetype or holy symbol, but as one who has shared our world with us. Tentatively, we may even hope and trust that, to varying degrees, these literary and artistic traditions are "over-ruled" by the Holy Spirit such that they communicate to us historical truth of Christ's life unknowable to us by historical method. ${ }^{80}$

But we must go farther. All these encounters and relations that Christ bears to the world around him help constitute what I have called the shape of his life; but as created similitudines ordered by the Word to the flesh of Christ, they come to serve also as redemptive signs of the invisible God. As we saw in the last chapter, not only is Christ's every word and gesture a sign of the living God, but it is the telos of all creatures that they should be seen to be signs of Christ, written into God's revelatory work. This doubles or harmonizes within the order of creaturely manifestation what is already true in the order of being; all things are established and ordered in their particularity by their participation in the Word, and so all things are established and ordered as signs of Christ's flesh when that Word is revealed in creation. We see this in the typological relations patterning Scripture, as for example when the binding of Isaac or the bronze serpent come to serve as signs of the crucifixion, as well as in Christian preaching and poetry as all contemporary events or particular moments are seen to be enfolded in Christ's life. The argument of this chapter pushes us to an even more radical claim: not only do these people, things, and events reflect Christ's life, they are co-constitutive of it, playing a role in making it what it is. But it is Christ's life that is redemptive for us, in the act of self-giving in which he breaks the devil's power over us but even more importantly in serving as the one true mediator whose human flesh is the sign that draws our misshapen loves back to God. It is not simply the physical body of Christ that manifests God to us and comes to serve as the object of our loves, therein reordering all our other desires, but his whole history, all the interactions he has with his environment and those around him. We are taught to love Christ by contemplating his humility in learning from the doctors of the temple, his mercy to the woman caught in adultery, his unjust death at the hands of Roman soldiers; and these others are not incidental to God's revelation in

${ }^{80}$ John Henry Newman, "Remarks on Certain Passages in the Thirty-Nine Articles [No. 90 of Tracts for the Times]," in The Via Media of the Anglican Church, Vol. 2 (London: Longmans, Green, and Co., 1908): 259-356; 292. 
Christ, but included within it. Jesus is not the Christ who has redeemed us without these interactions, with these people - God has chosen them to manifest Himself to all creation. In a very real sense, then, finite creatures are granted an unsubstitutable place within the work of incarnation; our reconciliation does not occur without them, even if their own ability to serve as signs of God is always and only in Christo.

This is not, of course, to say that God would be powerless to save without the particular creatures that do in fact bear historical relations to Christ. One can attempt to imagine the life of Jesus proceeding very differently without him being any less a divine-human person, and the infinity of God's life suggests that there is no one definitive creaturely order in relation to the incarnate Word that exhaustively manifests the invisible God. Nevertheless, the people and world that actually have existed are necessary constituents of the life that Jesus does live, and of the way that Christ's life actually reveals God to us. Only imagine what would have been lost - or at least strangely different - to Christian piety and devotion had the nameless bleeding woman of Mark 5 remained home instead of joining the crowd and reaching out to touch Christ's robe. More dramatically, imagine how different our understanding of the Triune Lord would be had the Word been born not in a stable, but in a royal palace. Christians have not traditionally expressed their piety by meditating on different courses that the Word's human life might have taken, and with good reason: to imagine the Word other than as revealed in the actual life of Christ is to imagine a different God entirely. ${ }^{81}$ While Christ's relations to his environment and those around him thus bear (excepting Mary) no necessary role in his constitution as a human person, they are essential to the redemptive significance of the life that Christ leads.

What are the limits of this incorporation into Christ's redemptive work? I have grounded my discussion in the lives of those closest to Jesus, and in the Scriptural narratives that are the privileged site at which we learn the language of divine signification. These are the moments when we encounter the contributions of other creatures to the redemptive significance of Christ's flesh in a relatively familiar manner, through the sorts of influence we know others to have exerted on our own lives, and through symbolic and typological identifications well-rooted in the theological and exegetical tradition. These are the heart of God's revelation in history, the life of Christ and the creatures and histories most clearly ordered as responsive manifestations of that life: the sacraments of the Church, the lives of the saints, the experiences of confession and forgiveness we can only attribute to the work of the Holy Spirit. If this age is the "school of eternity," 82 these are our grammar-books, teaching us how to discern the presence of God in the world. But we are capable now of learning only the first halting phrases in this language. If I am right, every gesture of Christ, every relation he bears to all points of spacetime, every hair of one's head and the fall of every sparrow, are destined to be enlivened as signs of Christ's flesh,

\footnotetext{
${ }^{81}$ A notable exception to this restraint is the persistent question of whether, absent the fall, the Word would still have become incarnate. It should be clear that my account would caution against taking this theological puzzle very seriously. We should also disambiguate attempts to imagine other possible courses of Christ's life, and to imagine possible courses of Christ's actual life that are otherwise unsupported in Scripture. The former is almost entirely absent in the tradition; the latter is present in every age of the Church, even if it too sometimes leads to theological excesses.

82 civ. 1.29; Dyson, 43.
} 
and thereby made into tools which God uses to draw us into deeper love of Him. As our desires are perfected, as our ignorance of God's presence in our lives is purged away, we will learn to see even the most insignificant corners of our lives and the world as visible signs of Christ's humanity, the true sign of the invisible God. This is, I think, virtually impossible for us to imagine now; so far have our intellects fallen from the vision of God as a result of sin. It may even seem faintly silly to hold that my lunchtime sandwich bears the capacity to be transfigured as a sign of Christ's body - but ah! what God can make of bread! In his bodily existence, Christ bears determinate (if nevertheless extrinsic) relations to all of the created order, and, crucially, all of this is intended in the Word's assumption of flesh - each relation, all its significatory potential, all the many avenues by which our hearts are drawn back to God. Christ is a man like any other, but he sits at the heart of creation, and only reconciles us as the one in whom all things hold together. All things in created history are granted a place in this work, made instruments of redemption by their ordering to Christ; but it is no less true to say that Christ lives the life that he does only in relation to the rest of this created order. The world shelters the life of Christ, upholding it and giving it shape as surely as Jesus' body was knit together in Mary's womb.

This returns us to the image of the Madonna lactans, and to Augustine's theology of the cross. In an instructively challenging development of this Marian and incarnational iconography, the late-fifteenth and early-sixteenth centuries see this motif tied specifically to depictions of St. Augustine, reflecting a counter-Reformation legend of Mary and Christ appearing to the doctor of grace. ${ }^{83}$ In most of these images, as in that from Dutch artist Adriaan Helmischz, Augustine kneels between a vision of the Crucifixion on one side, and Mary on the other; a stream of blood pours from the wound in Christ's side on the one hand, and on the other a stream of milk flows from Mary's breast to the saint. Often, the image is accompanied by the inscription hinc pascor a vulnere, hinc lactor ab ubere; positus in medio quo me vertam nescio: from this side, I am nourished by the wound; from that, I am suckled at the breast; I am placed in the middle and I do not know which way to turn. Though rooted in the polemical context of the sixteenth-century and legends that did not appear until a thousand years after Augustine's death, I believe this hagiographical iconography offers a compelling vision of a christological approach developed from the Augustinian tradition. The image, in putting the cross at the same vertical level as the Mother of God, risks falling into deep error in suggesting that Mary's role in God's redemptive work is equal to that of Christ, rather than as a responsive site at which the grace of Christ is mediated to us. Yet we can, I believe, read this image more productively as a guide to the dynamics of an Augustinian christology that I have attempted to develop throughout this section. The depiction of Augustine kneeling between cross and nursing mother gives us a picture in which Mary's action to sustain Christ's life has been included within the work of the cross, in which her own life is seen as playing an essential role in shaping the life wherein Christ will give himself over to suffering and death for the sake of our redemption. As we noted in Williamson above, Augustine need not fear turning either to the wound or to Mary's breast: the milk that nourishes Christ is the same as the blood by which he sustains us.

83 Thanks to Grażyna Jurkowlaniec for conversation on this iconographic tradition. 
Our puzzlement with this tradition of representing Augustine derives, I suspect, from the suggestion that the saint does not know which way to turn when placed between these two mysteries. Of course he should turn to the cross; it is the center of christology, the heart of God's redemptive work, the site where the humility of God is seen in its clearest form. But as the prevalence of reference to Mary nursing Christ in the Nativity sermons alongside the appearance of this imagery in Augustine's sermons on the Resurrection shows, the two moments of birth and death cannot be neatly separated. For Augustine, both the suckling Christ-child and the suffering of the cross are paradigmatic images of the Word's humility in assuming flesh, yet each carries with it a slightly different resonance. Augustine's theology of the cross shows us the extremity of our own situation: we have fallen so far away from God that we are threatened not only with biological death, but with the "second death" in which the soul is bereft of God's presence. Christ is willing to bear the sufferings inflicted on him by the devil and the sinful world in order that the power of death over us might be broken, and that we might begin the arduous therapy by which our desires are chastened, our souls and bodies healed, and by which we return to the stability of love for God.

In Christ's sacrifice, we see our own death nullified. The nursing Christ displays what is, from a certain vantage point, an even deeper humility: not that of a man reduced to powerlessness, but that of the vulnerability and dependence that characterizes the early years of every human life. The image of Christ being nursed by Mary emphasizes, for Augustine, the incongruity of the one who is the source and creator of all things receiving life from his mother. While Augustine may not have drawn the connection quite so clearly, we can see complementing what Robert Dodaro has called "Augustine's revision of the heroic ideal" a corresponding revision of the ideal of maternity: here, a young woman powerless in her society, with no grand home to order, slaves to command, or husband to command her, is the one who nourishes the one who sustains the cosmos. ${ }^{84} \mathrm{We}$ should be careful on this point, however; I have no desire to suggest that the image of the Madonna lactans offers us some window into "the true nature of womanhood," or even worse, "the feminine in God." The divine life is certainly reflected in the life of Mary, as in all people of whatever gender; and while it is surely reflected in motherhood, it is no less reflected in the care and nursing that father's provide, and for that matter, in the wrath at injustice, the rationality, the power, and the agency that we see women display every day. What is significant about the Madonna lactans on my account is not the example of Mary as ideal mother, but the fact that all human persons begin in wombs, knit together in the bodies of others and dependent on them, and continuing in their dependence on others for survival well past the point of their biological individuation. In christological terms, what this image emphasizes and what Augustine uses it to underscore is the receptivity of Christ to those around him, the one who possesses all things being deprived even of the ability to feed himself. This, just as much as Christ's suffering and death, displays to the world the humility of the Word.

When we turn to Augustine's account of the cry of dereliction with this theology of the infant Christ in mind, I believe we may observe in it deeper shoals than might be suggested by

\footnotetext{
${ }^{84}$ Cf. note 42 above.
} 
assessing it as simple exegesis of Psalm 21. Though the expression of godforsakenness is not appropriate to the divine-human person of Christ considered in himself, Christ's life in fact is interwoven with the lives of those around him, and inextricable from them. Jesus never exists in personal isolation from us, but lives in the world and receptive to it, the events of his life worked out in constant tension and negotiation with a sinful world. The cry of dereliction is neither playact nor indication of the Father's abandonment of the incarnate Word. It is, rather, a sign that Christ offers using the language he has received from those around him to show us how deeply he has united himself to the station of sinful humanity, exposing himself to the fear, suffering, and finally death that is the inheritance of all those born into sin. It is a synecdoche of how thoroughly Christ has received who he is from those around him, both those encountered in his life and in the great cosmic history within which his thirty years are situated. At the moment of his death above all, Christ takes our words and makes them his own in order to show us God's redemptive love in our extremity. As Augustine writes at en.Ps.15.10 in the voice of Christ, "this flesh which I have taken on, instructed me even to the point of death, that I might experience the darkness proper to mortality, a darkness which the understanding does not know." ${ }^{85}$ Christ has entered the place of the godforsaken in order to show that God has not abandoned us even here. He has done so in assuming flesh, willing to relate to us not only as the God to whom we can add nothing, but as a man whose life is unthinkable without the creation that sustains and shapes it.

Yet we should note one final feature of Helmischz's depiction of Augustine between Christ and Mary before moving on: the infant Jesus is absent from this picture. Instead, even as he gazes upon the crucified body of our Lord, Augustine occupies the place of Christ, receiving life as Mary nurses him. If the image threatens to run together Mary's and Christ's contributions to our redemption, it also takes the risk of affirming an identity between Augustine and Christ. If Christ includes us within the work of incarnation as seen in his infancy and passion, there must be a corresponding sense in which we are incorporated into the life of Christ. With this, we turn to the final section of this chapter, and to Augustine's theology of the totus Christus.

\section{The Whole Christ}

While deeply rooted in the Pauline language of existence in Christ or description of Christ as head and Church as body, at times Augustine attributes his theology of the "whole Christ" directly to the exegetical need occasioned by the cry of dereliction. At Enarratio in Psalmum 37.6, for instance, Augustine tells us,

The need to make sense of this forces us to recognize that 'Christ' here is the full Christ, the whole Christ; that is, Christ, Head and body (plenum et totum Christum, id est caput et corpus)...Now we are quite certain that Christ was sinless and free from all faults, so we might begin to think that these psalm-words are not his. Yet it would be very difficult, indeed wrong-headed, to maintain that the earlier psalm

85 WSA III/15, 184. 
[i.e., Ps. 21] does not belong to Christ, when it describes his passion so plainly that it might almost be reading from the gospel...Let us hear them as one single organism (Sic audiamus tamquam unum), but let us listen to the Head as Head, and the body as body. The persons are not separated, but in dignity they are distinct, for the Head saves and the body is saved. May the Head dispense mercy, and the body bemoan its misery. The role of the Head is to purge away sins, the body's to confess them. Wherever scripture does not indicate when the body is speaking, when the Head, we hear them speak with one single voice. We have to distinguish as we listen, but the voice is one. ${ }^{86}$

The metaphor of the relation between Christ and the Church as head and body is omnipresent throughout the Enarrationes in Psalmos, appearing in the exegesis of nearly every psalm. Yet most commonly, Augustine uses it as an expression of the intimacy with the Church wrought by Christ's redemptive work, without becoming the direct focus of theological or philosophical reflection. On some occasions, Augustine reflects on it or commends it as a strategy for resolving interpretive issues through the attribution of some statements to Christ, and some to the Church still in process of being redeemed; and on some occasions, as above, he offers particular thoughts on proper and improper ways of relating head and body. We see in en.Ps. 37.6 that the Church is not merely absorbed into Christ in a way that would compromise our own personhood and volition; ${ }^{87}$ that securing this distinction between head and body is a difference in "dignity," a recognition of the fact that the flesh of Christ is assumed into a unity with the Word qualitatively different than the union with God that is our eschatological hope; that a further mark of this distinction, related to the first, is the role they play in God's redemptive work, with the flesh of Christ occupying the place of priority as he dispenses mercy and purges sin; that the place of the body is to respond to this work in Christ in grief over sin and confession; and that, finally, even in this distinctness, there is an inner unity between Christ and the Church that allows us to treat them as one in their speech and historical reality. This is all tremendously suggestive and unquestionably rich for theological reflection, as has been borne out by the long history of Christian reflection on the totus Christus or on the Church as the extension of the Incarnation; yet it remains also maddeningly imprecise. Just what sort of union is being described here, and how is it being effected?

Arguably Augustine's fullest treatment of this question may be found in his sermo Dolbeau 22 (known also as s. 34 laugm., and in a shorter version as s. 341), likely preached in Carthage on December 12, 417.88 The sermon aims to disambiguate the "three ways" in which Christ is named in Scripture:

\footnotetext{
86 WSA III/16, 150-1.

${ }^{87}$ David Vincent Meconi, S.J. reflects helpfully on this point at The One Christ: St. Augustine's Theology of Deification (Washington, D.C.: The Catholic University of America Press, 2013), 158.

88 WSA III/ 1 1, 305n.1. What Hill calls a "truncated" version of the texts published by the Maurists as $s .341$ may be found in translation in WSA III/10.
} 
One way is: as God and according to that divine nature which is coequal and coeternal with the Father before he assumed flesh. The next way is: how, after assuming flesh, he is now understood from our reading to be God who is at the same time man, and man who is at the same time God, according to that preeminence which is peculiar to him and in which he is not to be equated with other human beings, but is the mediator and head of the Church. The third way is: when he is preached to believers and offered for their approval to the wise as in some manner or other the whole Christ in fullness of the Church, that is, as head and body, according to the completeness of a certain perfect man (Eph 4.13), the man in whom we are each of us members.

We have already discussed at length the first two ways in which Christ is known - as eternal Word and in the union of human flesh with that Word - and Augustine's treatment in this sermon rehearses many of the points we have seen him make elsewhere. The Word is present fully in both glorious unity with the Father and in the humility of Mary's womb, without any possibility of extension or division; ${ }^{89}$ the Word's existence both in glory and in life of Christ is compared to a spoken word not being divided in being heard by multiple listeners; ${ }^{90}$ any suggestion of inferiority to the Father given in Christ's human life (the "second way") is to be referred to the human nature he has assumed in the forma servi, rather than to the glory proper to the Son's divine nature..$^{91}$

Even in these familiar claims, though, Augustine adds a note framing these first two ways as forms of God's self-communication. In the course of meditating on the Incarnation, he points to the inner unity of the action of Word and Spirit in our coming to know and love God:

O one and only Word, delightful Word, may he breathe his love into us! Now he breathes with the Holy Spirit...In order that this most delightful and surpassing and inexpressible Trinity may be loved, soaring beyond the universal creation which it initiated, completed, arranged, soaring beyond it altogether, the Spirit desires the hearts of lovers. It is quite right to say he desires, because he makes us desire. ${ }^{92}$

Augustine imagines what human life would be like did not God desire to communicate Herself to us: "if your creator, than whom you can find nothing better, were not to give himself to you, you should rather spend your entire time bewailing the fact than go seeking something else."93 It seems that, even in a counterfactual situation in which we possess a desire for the ultimate Good but God wills not to give us the Good that is Herself, we would not be justified in letting some

\footnotetext{
89 s. Dolbeau 22.8.

90 s. Dolbeau 22.9.

91 s. Dolbeau 22.13-15.

92 s. Dolbeau 22.7; WSA III/11, 288.

93 s. Dolbeau 22.7; WSA III/11, 288.
} 
other more proximate desire order our loves and provide us with a life whose ends are intelligible to us. Even in the absence of God, the desire for God is the only thing that properly integrates us as selves, a point which will become increasingly important in my next chapter. Happily, and tragically, this is not our condition: "Now though, he is in fact offering himself, and you there are looking for something else; he is asking somehow or other to be loved by one whom he is not loved by. Oh, it's you that are wretched, not he!"94 In a manner that we have yet to specify but which is attributed here to the work of the Spirit, the movement from the first through the second and to the third ways of speaking about Christ is described as God giving Herself - to the world She has created, to the human flesh She assumes, and to all those who in this self-giving are integrated into the body of Christ.

When Augustine turns to the "third way," his first aim is to describe a relation of unity in persistent difference: "the third way is how the whole Christ is predicated with reference to the Church, that is as head and body. For indeed head and body form one Christ."95 Yet Augustine immediately guards here against possible misunderstandings based on this language, continuing,

Not that he isn't complete without the body, but that he was prepared to be complete with us as well, though even without us he is always complete, not only insofar as he is the Word, the only-begotten Son equal to the Father, but also in the very man whom he took on, and with whom he is both God and man together. ${ }^{96}$

What sort of completeness is being affirmed here, and what incompleteness rejected? I suggest that Augustine intends here to affirm the completeness of Christ's person, or metaphysical completeness. The Word requires the cooperation of no creature in order to assume human flesh and hypostatize the divine and human natures in one divine-human person. This is suggested by Christ's virginal conception: God does not require the familiar processes of biological reproduction to produce human flesh, and it would be within the divine power to sever all ties with biological reproduction by creating true human flesh de novo without taking it from Mary, crafting flesh from the dust of the earth (though this would of course dramatically reshape how we understand the role of human history prior to Christ, and specifically, the history of Israel in God's redemptive work).

We can push the question a bit: is the divine-human person of Jesus Christ essentially the son of Mary? A Kripkean account of modality would lead us to think the answer is yes, as it seems to me that there are no possible worlds in which I exist but am not the child of my parents (and you, yours). ${ }^{97}$ But if we were to answer yes in the case of Jesus, we would be suggesting that (to use the later Thomist language) some particular suppositum of human nature is assumed, and

\footnotetext{
94 s. Dolbeau 22.7; WSA III/1 1, 289.

95 s. Dolbeau 22.19; WSA III/11, 298.

96 s. Dolbeau 22.19; WSA III/11, 298.

97 Saul Kripke, Naming and Necessity (Cambridge, MA: Harvard University Press, 1980), 110-1.
} 
could therefore fail to be assumed in favor of some other suppositum. ${ }^{98}$ By contrast, we should affirm that the "personality" or "hypostaticity" of the divine-human person of Christ is grounded solely in the one suppositum of the Word's person, and consequently, affirm that any other life in human flesh lived as assumed by the Word would be the same divine-human person hypostatized by the Word, and accordingly that being the son of Mary is not essential to Christ's person. This not to deny the unsubstitutable role that Mary plays in the actual life of Christ, which is the life through which God redeems us; but just to say that even assuming flesh from Mary should be considered a part of God's being "prepared to be complete with us as well" in addition to being complete without us. Mary is Queen of Heaven, but only by grace.

As this discussion has shown, dwelling on the sense in which Christ is rightly said to be "complete without us" very swiftly takes us away from anything recognizable as the life through which God reveals Himself in history and draws us back to the love of Him; and far from leading us away from the particulars of Christ's life, it shows us how integral the relations with other created particulars are to the life he actually leads. Only in the barest metaphysical sense should we view Christ's life as complete without us; much more determinative of the life he leads is God's gracious will to be complete with us. Augustine is quite aware of this fact, as well as the expansive cosmic scope to which such a claim soon pushes us. As he notes, the basic logic of his account of Christ's relation to his body is that

There seem to be two, and there's one. Otherwise, how are we the members of Christ, with the apostle saying as clearly as can be, But you are the body of Christ and its members (1 Cor 12.27)? If we are the members of Christ and all of us together are his body, then it's not only those of us who are in this place, but throughout the whole world, and not only those of us who are alive at this time, but - what shall I say? - from Abel the just (Mt 23.35) right up to the end of the age, as long as people beget and are begotten, any of the just who make the passage through this life, all that are here now - that is, not in this place, but in this life - all that are going to be born after us, all these constitute the one body of Christ, while they are each individually members of Christ. ${ }^{99}$

When Augustine speaks of the totus Christus, then, he speaks of all those who will be redeemed by Christ's work, and suggests that this work does not remain extrinsic to them but that their very lives are incorporated within it. By virtue of their relation to the head, the man Jesus Christ, those saved by him themselves become Christ. There is no necessity in this - "Christ is one with his body because he graciously consents to be, not because he has to be"100_ but neither is this

98 ST III.4.3; I have also benefitted from Rowan Williams' first Hulsean Lecture, "The Hulsean Lectures 2016: Christ and the Logic of Creation: Lecture 1. A Mediaeval Excursion: Aquinas' Christology and its Aftermath." University of Cambridge Faculty of Divinity. Jan 12, 2016. http://www.divinity.cam.ac.uk/events/the-hulsean-lectures2016-christ-and-the-logic-of-creation (accessed Feb 8, 2016).

99 s. Dolbeau 22.19; WSA III/11, 298.

100 s. Dolbeau 22.19; WSA III/ 1 1, 299. 
merely a metaphor or figurative claim. There is a real and objective sense in which Christ's relation to the City of God fulfills and completes his identity.

Throughout this chapter, I have given one account of how we might develop this strand of Augustine's theology. On my telling, Jesus includes the life of creation in his own life through his dependence on it: quite literally when we are speaking about the sustenance of his bodily existence as an infant, but dependent also for the "shape" of his life on all the personal relations, social and cultural contexts, and environmental causal chains that play a role in making him who he is. Who he is, most fundamentally, is the Christ, the Redeemer, the one in whom all things hold together and through whose blood God has reconciled all things to Herself. He is who he is to the extent that God's saving will has been accomplished in creation. ${ }^{101}$ But as we have seen, Christ's life is not the sole sign by which God draws our hearts back to Her; indeed, it is ingredient in the telos of all created things to come to serve as signs of Christ's flesh, to be "written into" the language of divine signification. Just as all things - from the beginning to the end of cosmic history - are ordered by their participation in the Word and point to it in our halting attempts at mystical ascent, so also all things are ordered to Christ's flesh as signs of the human life assumed by the Word. The ordering of all things to the human flesh of Christ reflects their ordering by the eternal Word of God. As, very gradually, we learn to see Christ in the things of this world, our hearts are drawn back to the love of God, and we come to participate more fully in our reconciliation; but if that is right, then the relations between other created particulars and the flesh of Christ has come to serve for us as an instrument of redemption. As my gazing at the windhover or the limestone outcropping comes to remind me of Christ and draw my loves back to him, I am (progressively) redeemed - and so, not only do I come to be more fully the creature I have been made to be as I draw my life more completely from God, but Christ becomes more fully the Redeemer as I am redeemed. These other created signs are included within the life of Christ, and his redemptive work is accomplished through them. In Augustine's claim that Christ wills to be "complete with us," we can see a claim that his life as Redeemer only finds its full significance as all those whom God wills are redeemed, and this only occurs for us inasmuch as we are drawn to the love of Christ and God in him by the sacraments, the words of Scripture in their allegorical and typological significance, the lives of the saints; indeed, the lives of those on whom our lives are dependent.

Yet even within the cosmic scope of creation's inclusion within the life of Christ, the Church is a unique site of reconciliation, something Augustine acknowledges in referring to those being joined to Christ as the totus Christus. The Church - or more properly, "this Church which is now on its pilgrimage...joined to that heavenly Church where we have the angels as fellow citizens (Eph 2.19)"102 - is unique in what we know of creation in that it is able not only to serve as an instrument of salvation, but to know that it is serving as a sign of Christ and to desire the redemption of one's neighbor. The Church is granted the possibility not only of being included within God's plan of salvation, but of one's loves being conformed to Christ's own and one's

101 This should not be taken to imply the necessity of universal salvation, only an Augustinian affirmation that if any are damned, it is because God has not willed to include them within Her redemptive work.

102 s. Dolbeau 22.19; WSA III/ 11, 298. 
actions being conformed to God's will in the occasional awareness that the Holy Spirit is using one's own life to lead others back to God. In becoming followers of Christ, we are made also coworkers with Christ, serving the one who became a servant alongside us. In this way, we come to be not only included within the redemptive work of Christ but truly his body in the world, repeating and extending his life in our own. Our hope is to become Christ, not having our individuality or created particularity absorbed into his, but finding our own particularity fully realized by our inclusion in him. We become more fully ourselves, and more fully a community recognizing our dependence on one another, as Christ becomes more fully himself, the head of his body. We only truly exist in Christ - participant in the Word who is Christ, ordered historically in our relation to Christ's flesh, intelligible to ourselves only to the extent that our lives are understood in relation to Christ's own, and conformed in our love of God and neighbor to Christ's loves by the work of his Spirit.

While the next two chapters will focus on this process of incorporation into Christ, and particularly the role of the Holy Spirit in it, the end of Augustine's discussion of the "third way" of referring to Christ as totus Christus in sermo Dolbeau 22 instructively points out to us the way forward. Having described for us the sense in which Christ may be seen as the union of head and body, Augustine launches into a concatenation of Scriptural verses that regularly appear alongside one another in the Enarrationes in Psalmos: Philippians 2.6-8, Genesis 2.24, Ephesians 5.31-2, Matthew 19.5-6, and the verse that signals to us the reality of the totus Christus perhaps more clearly than any other, Christ's question Saul, Saul, why are you persecuting me? (Acts 9.4). At this point, however, Augustine concludes this series of verses tracing the teaching of the totus Christus through the Biblical witness with a verse that appears very infrequently in his writings. Showing us how radically the life of the Apostle Paul had been changed by its encounter with Christ, Augustine writes that "when as a preacher of Christ he was now suffering from others what he had done himself as a persecutor, that I may fill up, he said, in my flesh what is lacking from the afflictions of Christ (quae desunt pressurarum Christi in carne mea) (Col 1.24), thus showing that what he was suffering was part and parcel of the afflictions of Christ." 103 We will return to this verse in the conclusion of this dissertation; for what can be lacking from the sufferings of Christ? But for now, we should note that the movement of inclusion within Christ indicates for Augustine a corresponding movement from being a persecutor to being one who suffers under the persecution of others. Though we will need to be quite careful in specifying the implications of this claim, incorporation in Christ involves also a repetition of Christ's sufferings and humility in the world. As Augustine writes of the Church,

This is the bride of Christ, not having stain or wrinkle. You don't want to have any stain? Do what is written: Wash yourselves, be clean, remove the wicked schemes from your hearts (Is 1.16). You don't want to have any wrinkle? Stretch yourself on the cross. You see, you don't only need to be washed, but also to be stretched, in order to be without stain or wrinkle, because by the washing sins are removed,

103 s. Dolbeau 22.20; WSA III/11, 299. 
while by the stretching a desire is created for the future life, which is what Christ was crucified for. ${ }^{104}$

The Christian life, I will suggest, is a life in which we are joyfully taught to recognize the dependence of our lives on one another, and our mutual implication. In order for this to happen, though, the Spirit must break the patterns of domination and exploitation that characterize all our relations with one another, tearing us away from our distorted ways of loving the good things of the world and teaching us the true humility perfectly expressed in the life of Christ. We repeat in ourselves the crucifixion of Christ, so that God may also repeat in us his resurrection. In this reconciliation we find that not only are we made whole, but Christ is too.

104 s. Dolbeau 22.21; WSA III/ 11, 300. 


\section{Chapter 5 A Broken Body}

This chapter tells a story of dissolution and repair. Where preceding chapters have focused on the activity of the Word in assuming human flesh, this chapter turns to the question of how our lives are included within that incarnational work. As we shall see, this too is the action of God, properly attributed to the Holy Spirit who works with the Father and Son in inseparable unity. As the Love of God shed in our hearts, the Holy Spirit works within us to convert our desires from their present state of incoherence to God alone as final referent. By this activity of the Holy Spirit, we are drawn into the pattern of Christ's life and enlivened by his own presence, made one with God and our neighbor in the body of Christ.

In order to understand the Spirit's sanctifying work, however, we will need to look more carefully than we have so far at sinful condition in which we now find ourselves. If our desires are the vehicle by which we are united to Christ's body and returned to the love of God, they are also the root of our sin and of all the wicked actions we perpetrate on one another. The chapter thus begins with an investigation of the role of desire in all the operations of the soul, among which perception, intellection, memory, and willing. Sin's turning of our desires away from God not only creates improper attachments of worldly goods, but begins in us a degenerative process by which our lives become unintelligible to ourselves and others - a process by which we move ever more surely to the final incoherence of the nothingness from which God drew us in creation. Sinful affections decompose us into the state of distentio animi that Augustine describes so perceptively in Confessions 11, vaulting us into the panicked quest to secure ourselves the coherence of our lives, rather than receiving that coherence as the gift of God. Ultimately, we 
find that the Holy Spirit's work does not bring us to a restored sense of self-presence and selfpossession, for this has always been the aspiration of sinful humanity rather than redeemed humanity. Instead, we are absolved of the desire to discover who we are in ourselves, and liberated to receive ourselves as the creatures we are, dependent always on our relations to God and our neighbor.

While Augustine's discussions of the vagaries of sin and the perils of self-knowledge span his literary corpus, his considerations of these topics reaches a particular intensity and intimacy in the Confessions. This work portrays a thinker trying to make sense of the history that has brought him to the bishop's chair of Hippo Regius, and of God's providential ordering of that history. It gives us too a master rhetorician self-consciously cultivating his public image within the Church, even as he is uncomfortably aware that he is not in control of the distortions that sin continues to introduce into his confession. The Confessions are Augustine's attempt to render his life intelligible to himself and others, overcoming as much as possible the self-deceptions that prevent him from seeing himself as the particular creature God has made him to be.

This chapter thus begins with Augustine's account of his own incoherence. Where his soul is meant to reflect the life of the triune Lord in interrelated activities of remembering, knowing, and willing, disordered loves have stretched the canvas of the soul on which this image was painted into something grotesque. If we wish to understand the restoration of God's image in us through the work of the Holy Spirit, we must begin first with this distentio animi, and with the enigma we have become to ourselves.

\section{Confessing Oneself}

Great are you, Lord, and exceedingly worthy of praise. ${ }^{1}$ These are, quite famously, the words with which Augustine begins the Confessions - words learned from his mother, or from Ambrose as he prepared for baptism, or in his study of the Psalms as a young priest of the Church. They are also, less commonly noted, words quoted again at the beginning of the eleventh book of the Confessions: ${ }^{2}$

Eternity belongs to you, O Lord, so surely you can neither be ignorant of what I am telling you, nor view what happens in time as though you were conditioned by time yourself? Why then am I relating all this to you at such length? Certainly not in order to inform you. I do it to arouse my own loving devotion toward you, and that of my readers, so that together we may declare, Great is the Lord, and exceedingly worthy of praise. ${ }^{3}$

\footnotetext{
${ }^{1}$ conf. 1.1.1; WSA I/1, 39.

${ }^{2}$ Charles Mathewes, "The Liberation of Questioning in Augustine's Confessions," Journal of the American Academy of Religion 70, no. 3 (2002): 539-560; 554; and James J. O'Donnell, Augustine Confessions: Volume III: Commentary on Books 813 (Oxford: Oxford University Press, 1992), 250-4.

${ }^{3}$ conf. 11.1.1; WSA I/1, 284.
} 
Why has Augustine returned to this text, at this moment in his writing? The beginning of Book Eleven is, of course, a stylistic hinge of the text: where the preceding ten books are mostly occupied with narrating Augustine's own life and God's work in it, the ensuing three books will take the form of philosophical exegesis of the creation narratives in Genesis. Perhaps the psalmic reference appears here as a marker of this shift - a sort of "re-founding" of the text of the Confessions, a recognition that there are many styles available to us as we over and over begin our confession anew? Or again, perhaps returning to these words indicates a broadening of scope: where previously Augustine's confession had focused on God's work in his own life, now Augustine invites his readers to confess alongside him as they consider God's work in their lives and in all creation. By tracing God's action in his own life, Augustine has displayed the way the Holy Spirit has opened him from the privacy of sin and freed him for true community bound together in praise of God.

Both sorts of answers have evident merit and offer rewards for interpreting the Confessions; even so, neither seems fully sufficient to account for the unity of the text. The former approach threatens to present the first ten books and the last three as two different confessions stapled together, licensing the widespread practice of teaching Confessions 1-10 in separation from Books 11-13. The latter is at risk of underestimating the extent to which the Confessions' first ten books are already public, ignoring both the extensive use of the first-person plural at the psalm's first appearance in conf. 1.1.1 (and throughout books 1-10), and the extent to which the form of the Confessions has been shaped by literary, apologetic, and polemical concerns. ${ }^{4}$

The repetition of the psalm's words seems to me a reminder, both to himself and the reader, of the nature of the story he has tried to tell in the first ten books - and, I would argue, is still trying to tell in the final three. We may even read in it an implicit judgment of the story he has just told; or better, a confession of its flaws and limitations. The pedal-tone underlying the narrative portions of the Confessions is the dawning acknowledgment that God has been at work in Augustine's life in ways that have become clear only retrospectively. Even when Augustine manages to recognize that he has attained a new awareness of the Good or of God's activity within creation (as, for instance, when exposure to the philosophical works of Cicero stokes the fire of his love of wisdom), ${ }^{5}$ the moment is subsequently rewritten into a different narrative. The love of philosophical wisdom leads him through a series of hopes and disappointments that only snap into focus when Augustine realizes his need for the Wisdom who has entered into human flesh in the life of Jesus Christ.

As we can see in the Retractationes, Augustine never loses this sense of the revisability of his thought and understanding of his personal and intellectual history. In a certain light, we may see the first ten books of the Confessions as a series of failures in the attempt to share his life truly with

\footnotetext{
4 Two recent studies of Augustine taking the artifice of his self-presentation as a central theme are James J. O'Donnell, Augustine: A New Biography (New York: HarperCollins, 2005); and the two volumes to appear so far of Jason BeDuhn's projected three-part series: Augustine's Manichaean Dilemma, Volume 1: Conversion and Apostasy, 373-388 C.E. (Philadelphia: University of Pennsylvania Press, 2010); and Augustine's Manichaean Dilemma, Volume 2: Making a "Catholic" Self, 388-401 C.E. (Philadelphia: University of Pennsylvania Press, 2013).

${ }^{5}$ conf. 3.4.7.
} 
God and with his readers. Precisely in confessing the incompleteness and distortions in his selfnarration as a younger man, Augustine teaches us to attend to the inadequacy of the account he offers as bishop of Hippo Regius. It is quite possible to approach Augustine's confession cynically as little more than self-serving propaganda, and this spirit is not entirely alien to Augustine's own hopes for his readers. Augustine is aware that the story he tells us in middle age bears the marks of his sin no less truly than the stories he told in youth. What has changed by the early years of his episcopacy is that he knows he is not - and indeed, cannot yet be - aware of the precise ways that his account of his life has been distorted by the sins as yet unseen, and therefore, unconfessed. As he writes at Confessions 11.2.2, he hopes to "confess to you both what I know and what I still find baffling, your dawning light in me and the residual darkness that will linger until my weakness is swallowed up by your strength." ${ }^{6}$ His text is an attempt, offered principally to God, but also to his reader, to amend and correct his self-presentation - and in so doing, to effect and participate in his sanctification. The Confessions is in part, as many interpreters have noted, an attempt at self-justification; but by as it is written in full awareness of this fact, it is also a plea for forgiveness.

Augustine confesses because he knows he is not yet capable of telling the story of his life truly, and in returning to the opening words of the Confessions at the beginning of Book Eleven, he teaches us to see who has ultimate responsibility for crafting the narrative of his life. Only God may make Augustine's life entirely intelligible, and to know himself as God's is to know himself as created. Contrary to our expectations, Augustine's theological outlook suggests that Books Eleven through Thirteen, his exegesis of the creation narratives in Genesis, are the most truly "autobiographical" books of the Confessions. They are Augustine's attempt to tell the story of his life not as he experienced it, but as situated within God's own telling of the world's story, communicated to us in Scripture. It is here, in the language God Himself has revealed, that Augustine believes he can offer the most genuine account of his relation to "the Word through whom you made all things, and me among them"; ${ }^{7}$ of who he was created to be, who sin has made him, and the person into whom God is fashioning him.

Why does Augustine find it so difficult to confess his own life truthfully? The answer is intimately bound up with the sort of creatures we are: namely, temporal ones. Our temporality is, as in the passage opening Confessions 11 above, one of the most significant marks distinguishing the sort of lives we lead from the Life that is proper to God, yet it is also one of the defining features of our attempts to understand ourselves. We grow, we change, we act; most basically, we begin to exist — we are brought into being, where previously there had been nothing. Any attempt to understand ourselves will thus need to reckon with the temporal extension of our lives, with our changeability and impermanence; and for Christians, with the fact of our createdness. Our attempts to render our lives intelligible are, in significant part, attempts to narrate the history of the changes we undergo, to describe the experiences we have undergone and the way

\footnotetext{
6 WSA I/1, 285.

${ }^{7}$ conf. 11.2.4; WSA I/11, 287.
} 
they fit together in such a manner that our motivations and actions become intelligible to ourselves and others. The shape of our lives is irreducibly narrative. ${ }^{8}$

Yet our experience of our lives as temporal (and thus narratable) is deeply puzzling. In our everyday experience of things, of course, our temporality is the most natural thing in the world. One moment slips into another seemingly by its own motion, the future slipping into the past through the gate of the present. The present appears to us as our window into our lives: I may have some vague sense of what I will be doing two hours from now, or may still be able to recall the sensation of walking from a dark room into the bright sun that I experienced just a few minutes ago. For the most part, however, all that is available for me to experience is that which is present to me now: the sour tang of the coffee I am drinking, and the heat I feel as I swallow it; the image of my hands typing on the keyboard in front of me, the sensation of touching its smooth plastic, the resistance it offers as I press each key. I can try to imagine a vivid sensation that I experienced in the past, or summon a mental image of something I may or may not have seen previously, but even these cases do not really challenge the point that I can only experience in the present. It would be nonsensical, or at best a very odd use of language to tell you that I feel something five minutes ago. I might say that I felt it then, or that I feel it still - but such cases only underline the point that we only experience in the present. (There are important questions to answered here about, e.g., what it is to experience a star which may have gone supernova by the time its light reaches our eyes; but what I am concerned with at the moment is the phenomenology of experience - what it seems like to us to experience something - rather than an epistemology that would tell us what it is to experience something.)

I experience in the present then, and the brief sliver of time in which things are available to my experience is bounded on one side by the past of what I have already experienced and the future of what I will experience. At any one moment, something may be entering into my experience (a fly buzzes into view) or passing out of it (a dog exits, stage left), and other things will persist in my experience (the face of the friend with whom I am conversing, or the screen that displays a movie I am watching). Each of these last two examples show the important role that my ability to recognize both persistence and change plays in my ability to perceive the world around me: my ability to hear my friend's words depends upon a series of sound waves striking my eardrums, and much of the information she communicates to me in conversation comes through minute changes in facial expressions or body language; my ability to watch a movie depends on my brain's ability to process and relate to one another a series of static representations, a point made especially clear by unspooling a reel of printed film. Plausibly at least, each of these sensations is only perceptible to me inasmuch as it becomes present for a time; and it usually seems to me that my experience of my life is just such a series of present moments experienced in succession. If it were not, I would be left with the same problem we observed

8 The literature on the place of narrative in theology is voluminous, but three important points of entry remain $\mathrm{H}$. Richard Niebuhr, The Meaning of Revelation (New York: MacMillan Publishing Company, 1941), 43-81; Alasdair MacIntyre, After Virtue, 3rd Edition (Notre Dame: Notre Dame University Press, 2007), 204-225; and Stanley Hauerwas, A Community of Character: Toward a Constructive Christian Social Ethic (Notre Dame: University of Notre Dame Press, 1991). 
earlier, of trying to make sense of experiencing something five minutes ago. It thus appears to me that I experience my world, and myself within it, only in an ever-shifting present moment.

The problem, as Augustine famously notes, arises when we attempt to understand what this present moment could possibly be. He writes,

If we can conceive of a moment in time which cannot be further divided into even the tiniest of minute particles, that alone can be rightly termed the present; yet even this flies by from the future into the past with such haste that it seems to last no time at all. Even if it has some duration, that too is divisible into past and future; hence the present is reduced to vanishing-point (praesens autem nullum habet spatium).$^{9}$

Our problem, then, is this: we seem to need a present moment to experience the world at all, yet when we look for the present, it seems to lack all temporal extension. There does not seem to be any "time" in the present for us to have any experience at all - for us to perceive both the changes and the persistence in what we experience that allows us to order things into an intelligible narrative structure. We may note in passing that such a judgment is wholly compatible with the B-theoretic account of the metaphysics of time canvassed in Chapter 2; there is, on a four-dimensionalist account of time, no objectively present moment of time, no one time that is metaphysically different in that it is the one time that is present right now, while all other moments are past or future.

What, then, accounts for our phenomenal experience of time's passage, of our lives as emerging from the past, existing in the present moment, and moving into the future? This is, quite understandably, a popular subject of inquiry among B-theoretic philosophers of time, but we need not be detained by the specifics of any one proposal. ${ }^{10}$ Augustine's preferred way of speaking about our sense of time's passage is to describe the soul as "stretched out" over the period of the changes we experience. At Confessions 11.26.33, he tells us, "I have therefore come to the conclusion that time is nothing other than tension: but tension of what, I do not know, and I would be very surprised if it is not tension of the soul itself (inde mihi visum est nihil esse aliud tempus quam distentionem: sed cuius rei, nescio, et mirum, si non ipsius animi)."11 The soul's ability to perceive the world is, we might say, intrinsically temporal — we do not experience the world as a series of static instants, but rather perceive our world only in its created changeability, spread out over time. There is an important sense, then, in which we must see our distentio animi as a feature of our original created goodness, rather than of our fall. While I will have more to say presently about our experience of distentio animi under the conditions of sin, we should not lose sight of the good

${ }^{9}$ conf. 11.15.20; WSA I/11, 297.

${ }^{10}$ See, in a classic presentation, Donald C. Williams, "The Myth of Passage," The Fournal of Philosophy 48, no. 15 (1951): 457-472; and in more recent treatments, Robin Le Poidevin. The Images of Time: An Essay on Temporal Representation (Oxford: Oxford University Press, 2007), Part II; Natalja Deng, "Our Experience of Passage on the BTheory," Erkenn 78 (2013): 713-26; and Lisa Leininger, "Presentism and the Myth of Passage," Australasian Fournal of Philosophy 93, no. 4 (2015): 724-739.

${ }_{11}$ WSA I/ 1, 306 (modified). 
that is our temporal extension. Our experience is defined not by exhaustive self-presence, but by the capacity to understand change across time, to see narrative continuities. In the language the Husserlian phenomenological tradition would employ centuries after Augustine, our perception of lived time and the present moment is structured by its relations to past and future through retention of what we have already perceived and anticipations of what we expect to perceive in the future. ${ }^{12}$ It is not possible for us to achieve God's manner of knowing the world, knowing all of created history as present; ${ }^{13}$ what it is for us to experience the world is for us to stretch across multiple times, for our soul to hold these times together with one another and experience them as interrelated. What it is for us to perceive, is for our soul to recognize the narrative continuities in God's creation - something it is possible to do well, or poorly.

This temporality of our experience of the world will have significant ramifications for the shape of Augustine's understandings of both human nature and our redemption; it is after all the case that Augustine believes we are reconciled to God through the narrative sign of Christ's life. At the moment, however, I am most interested in Augustine's account of how our distentio animi goes wrong - in the effects that sin has on our ability to understand our lives coherently, and to perceive the world around us rightly. As Augustine remarks, it is in memory that "I come to meet myself." 14 If my ability to hold together the temporally-distended moments of my perception in memory is compromised, the troubling implication is that I will meet only a shade of myself. In order to understand how sin undermines our ability to experience our lives as coherent, it will thus be important to specify how our perception across times is supposed to work.

Augustine offers what is arguably his most sustained discussion of our perception in the later books of the De trinitate. While his discussion is wide-ranging, I will focus here on the role of temporality in our perceptions of the world, and more specifically, on the necessity of memory, intellect, and will to function inseparably as we perceive the world stretched across times. These three are necessarily interrelated in perception precisely because we are changeable creatures, and know a changeable world; it is no coincidence that the three activities of mind that give the world in experience also come to serve as the clearest analogy of the Trinity when our minds are turned to God. ${ }^{15}$ As Augustine suggests, our memory, intellect, and stand close to the heart of who we are as persons and how we interact with the world around us, functioning together to define each person's dispositions, range of knowledge, and habitual practices. ${ }^{16}$ That which opens

\footnotetext{
12 A focused presentation of Husserl's thoughts on time-consciousness and the role of recollection and anticipation in object syntheses may be found at Edmund Husserl, Analyses Concerning Passive and Active Synthesis: Lectures on Transcendental Logic, trans. by Anthony J. Steinbock (Dordrecht: Kluwer Academic Publishers, 2001), \$\$26-31. ${ }^{13}$ Cf. conf. 11.10.12; WSA I/1, 293: "in eternity nothing passes, for the whole is present, whereas time cannot be present all at once."

${ }^{14}$ conf. 10.8.14; WSA I/11, 246.

${ }^{15}$ Rowan Williams has convincingly argued that the mind serves as the imago Dei in its active contemplation of God in the classic article "Sapientia and the Trinity: Reflections on the De Trinitate," now printed as Chapter 10 of On Augustine.

${ }^{16}$ Cf. trin. 10.11.17; WSA I/5, 298: "when one talks about these three things in a person, disposition (ingenium), learning (doctrina), practice (usus), one judges the first according to what he can do with his memory, his understanding, and his will; one estimates the second according to what he actually has in his memory and understanding, and where he has got to with his will to study; the third however is to be found in the use the will now
} 
us to the world also opens us (in our original created nature) to God - and we are most like God when we are most open to both God and world. As we shall see, the obverse also holds: as the relation between memory, intellect, and will in perception is damaged, we lose God, our world, and ourselves.

In De trinitate 11, Augustine begins his discussion of the interrelation of memory, intellect, and will with a discussion of simple sense perception. ${ }^{17}$ I see a stone before me:

First of all there is the thing we see, a stone or a flame or anything else the eyes can see, which of course could exist before it was seen. Next there is the actual sight or vision, which did not exist before we sensed that object presented to the sense. Thirdly there is what holds the sense of the eyes on the thing being seen as long as it is being seen, namely the conscious intention (id est animi intentio). ${ }^{18}$

The paradigm case that Augustine has in mind here is the intentional act of looking at a stone, an act in which I direct my attention to the stone I am seeing. ${ }^{19}$ In such acts of perception, it seems necessary to say at least that the mind is active both in its intellectual and its volitional activity. We need not subscribe to all the particulars of Augustine's (or any other classical or medieval) account of mind or soul to affirm this; I have no desire to build in an overly-developed account of what the soul is like. Whatever we want to say about the soul, it seems that two of the activities in which we engage that are (at least plausibly) irreducible to our body's physical processes are intuit some things (by which I mean, perceive non-physically) and will some things (by which I mean, even more roughly, a movement of the soul toward some desired end). ${ }^{20}$ My will directs my attention to the stone I wish to view, and whatever is perceptible of the stone is in some sense present to my intellect. Augustine, using an analogy popular in his day, will refer to the form of the stone being imprinted on the intellect as hot wax receives the seal of a signet ring. ${ }^{21}$ In even the most basic acts of sense perception, then, we seem justified in saying that at least two of the three activities Augustine takes to be central and constitutively interrelated in the soul - intellect and will-are operative.

What of memory? This seems a slightly more complicated case. Augustine points to some instances of our experience when it seems that we perceive something, without remembering it at all: "I find that I have read a page or a letter and have not the slightest idea what I have read, and have to repeat it. The will's interest has been intent on something else, and so the memory

makes of what the memory and understanding hold, whether it refers them to something else or whether it takes delight in them as ends in themselves."

${ }^{17}$ O'Daly provides a detailed discussion of Augustine's theory of sense-perception at Augustine's Philosophy of Mind, 80105.

18 trin. 11.2.2; WSA I/5, 304.

19 O'Daly emphasizes the active nature of sense-perception in his discussion of intentio at Augustine's Philosophy of Mind, 84-87.

20 The definition of the will as motus animi can be found at lib.arb. 3.1.2. See also Marianne Djuth, "Will," in Augustine through the Ages: An Encyclopedia, ed. Allan D. Fitzgerald O.S.A. (Grand Rapids: Wm. B. Eerdmans Publishing Co, 1999), 881-5.

${ }^{21}$ Cf. trin. 11.2.3. 
has not been applied to the sense of the body as that sense has been applied to the letters." 22 Or again, how are we to understand incidents where I misremember something - surely the possibility of remembering something I have perceived incorrectly suggests a degree of independence in the mind's activities of remembering, perceiving, and willing? Augustine is aware of these complications, and his response to them is instructive. He writes,

if we only remember what we have sensed, and only think what we have remembered, how is it that we often think false things though we do not of course remember falsely what we have sensed? It must be that the will, which I have been at pains to present to the best of my ability as coupler and separator of this kind of thing (nisi quia voluntas illa quam coniunctricem ac separatricem huiuscemodi rerum), it must be that the will leads the thinking attention where it pleases through the stores of memory in order to be formed, and prompts it to take something from here out of the things we remember, something else from there, in order to think things we do not remember. ${ }^{23}$

His suggestion seems to be that, rather than understanding the memory to be simply inoperative in what appear failures to remember or to remember properly, we should understand the will as failing to join our intentio animi to what we retain in memory. It is not that I have failed to perceive the page I was reading too cursorily, or that my intellect was malfunctioning in perceiving what I now misremember; it is that, in the act of perception, my will failed to join my intellective act to my remembering in such a way that I would be able to remember correctly. I was distracted by my thoughts while reading, or was so focused on the prize I desired that I failed to pay attention to the other relevant information I was perceiving, and so the impression left on my intellect and translated into memory does not match what was there for me to see.

An account like this seems to accord with many of the features of our experience: in some cases, I can recover some features of what I had forgotten by directing my attention to it, searching the depths of my memory for, say, the departure time of the last train home. What's more, if memory were not operative in all acts of perception, even if very imperfectly so, it would be difficult to understand how we could later recall the content of any of our perceptual acts. As popular understandings of the subconscious or of the perception of the presence of loved ones at one's side while in a coma suggest, we may retain in memory far more than we think. ${ }^{24}$

In mental activity more complicated than mere sense perception, Augustine seems to think it is only more evident that memory, intellect, and will are each at issue. When I am actively perceiving the stone in front of me, the stone exists independently of me as the end toward which my perception is directed. By contrast, when I later attempt to recall what the

\footnotetext{
22 trin. 11.8.15; WSA I/5, 316.

23 trin. 11.10.17; WSA I/5, 317.

${ }^{24}$ Cf. O’Daly, Augustine's Philosophy of Mind, 87: “Augustine seems to be saying something like the following: the awareness implicit in any perceptive process is guaranteed by the instantaneous operation of memory. An infinite series of memory-impressions is stored in the mind in the course of any perception."
} 
stone looked like, my intentio animi is directed to the memory of the stone that is contained in memory. My intellect is joined to my memory by my will, and it is precisely this interrelated threefold operation of my one soul that Augustine takes to be a distant but real analogy of God's triune life.

The upshot of this discussion is that, in all acts of perception, in all the mental activities by which we sense the world, understand something of it, and are intelligible to ourselves, the activities of memory, intellect, and will are necessarily co-operative; and even more specifically, the will serves a particularly important function as "coupler" (coniunctrix) and "separator" (separatrix), drawing together and drawing distinctions within that which is disparate and unformed in both sensual perception and memory. It is our will, our own intentional acts, that draw connections or distinctions within our experience and understanding; said slightly differently, the categories and concepts through which we understand the world are intimately related to our agency, to our action within the world and the way our agency is shaped both by our biological realities and the agency of others around us. I intend this account of the will's operation within our mental acts to be in accordance with the broadly Wittgensteinian account of language and sign offered above in Chapter 3.

The central claim I wish to make here is that, in every mental activity through which we attempt to make sense of the world, whether simple sense perception or the more byzantine recesses of memory, what we perceive and what we understand cannot finally be separated from our will - from the movements of our souls conducted in accordance with that which we desire. Here again, I believe our everyday experience makes such a claim plausible. If I am afraid of snakes, I do not come to a considered judgment that the snake on my porch is threatening $-I$ perceive it as being terrifying. ${ }^{25} \mathrm{My}$ affective disposition toward the snake - whether my desires draw me to it or make me recoil from it - is inseparable from my actual perception of it; in fact, my sense of a snake as being something dangerous is integral to my concept of what it is to be a snake, that through which I understand what a snake is at all. So much can be seen in the fact that even harmless garter snakes can provoke quite intense reactions in those who come across them.

Yet the importance of this claim extends, of course, far more broadly. The will as coniunctrix and separatrix shapes all my acts of intellection and memory, sifting what I experience and recall through the sieve of my concepts and desires: my eye is drawn swiftly to the anticipated sight of the Empire State Building as I cross the Verrazano Bridge; I pick out the face of a friend in the midst of a large crowd, the rest of the faces there blurring together; my experience as a forester easily allows me to identify and avoid the poison ivy along the edge of the

\footnotetext{
${ }^{25}$ O'Daly disambiguates helpfully here between the bare fact of sensation and our assent (consentire) to our perceptions, noting that "There is a close connection between such assent, and the activity of the will displayed in emotional behavior" (Augustine's Philosophy of Mind, 89). As evidence, he points to civ. 14.6: "what is desire and joy but an act of will in agreement with what we wish for? And what is fear and grief but an act of will in disagreement with what we do not wish for?" (Dyson, 590). I am pushing Augustine in a direction slightly more indebted to the phenomenological tradition, arguing that our intention is involved in the conceptual constitution of our perceptions. In viewing our perception as intrinsically conceptual, I am also indebted to M.G.F. Martin, "The Transparency of Experience," Mind E Language 17, no. 4 (2002): 376-425.
} 
trail. Only slightly more abstractly than these instances in which my will and affections seem to structure my sense perception itself, are those examples of how our understanding of what we perceive are shaped by our affections: my affection for my friend leads me to take his side, even when he is wrong; I find my own biases and expectations confirmed in my experience, even when the facts on the ground raise deep challenges for me; my social formation leads me to encounter another person as threatening, simply on the basis of their cultural difference. Each of these are instances in which our desires come to shape not only our actions within the world, but how we perceive and understand it. My claim is not that we simply choose what we want to see, as if I could simply desire not to see the chair in front of me and so have it vanish from view, but rather that the volitional movements that guide our attention, that lead us to place certain concepts in relation to one another, and that guide the formation of our concepts themselves through our social patterns of language-use, all impinge upon every act of intellection or memory - and that, similarly, every movement of the will is shaped by the history of what we have perceived and the memory of what we have found delightful or repulsive in the past. I perceive the chair as chair, something I can sit upon; the enemy as enemy, one of whom I should be wary; the keys for which I have been frantically searching as that which I had lost. And, as we have already heard Augustine say, we meet ourselves in memory - we come to understand our own lives, to develop a sense of who we are and what motivates our action, what we like and dislike, what we care about, whom we love, as we draw together and distinguish various acts of our perception and memory. We say to ourselves: I am a good person; my life is divided into the time before and after that experience; that betrayal doesn't reflect who I really am.

What happens to our understanding of ourselves, and of our world, when our affections are compromised by sin? Put simply, we become bad at putting the pieces of our experience together. We perceive, we remember, but we join together and separate the wrong things in our experience: we ignore the evidence to the contrary, we deceive ourselves about the desires that really motivate our actions, our biases and preconceptions become the horizon beyond which we cannot see, and into which we force our experiences of those we meet. ${ }^{26}$ We can still put together the pieces of our experience, most of the time, we can still render a sort of intelligibility to our perception of ourselves and our world; but it will never quite correspond to the truth of the matter. Our attempts to understand ourselves and our world will always be a bit forced; we will need to smooth out some rough edges of our experience that do not accord with our expectations or desires. There will always be an extent to which, in order to fit our experience within the categories we have, shaped by our collective agency and the individual histories of our desires, we will need to suppress the parts of us, our relationships, and our world that challenge the distorted and incomplete stories we tell of ourselves. The fit will be off: to the extent that our experience does not accord with the world God has made and the people God has made us to be, the stories we tell of ourselves, the understandings we bear with us, will fail to be coherent, and will always threaten to collapse.

${ }^{26}$ M. Shawn Copeland discusses racialized skin as "horizon" at Enfleshing Freedom: Body, Race, and Being (Minneapolis: Fortress Press, 2010), 12-15. 
In many situations - gazing at the stone again - these distortions will likely be wholly imperceptible. Perhaps we might perceive some affective disorder in one who looks at a mountain and sees only a resource to be strip mined, but we will have a difficult time saying that a person fails to perceive a pebble in her hand truthfully. Yet just at the edges of our imagination, we might imagine the difference between how the pebble looks to me now, and how it will look when the ordering of my loves to God enable me to see the blessed presence of the Lord as every rock cries out - we will praise alongside the limestone. But in other situations, the distortions in our perception and understanding of the world are tragically apparent to us even now. One has only to read the stories of those who have spent years in prison as a result of faulty eyewitness testimony - disproportionately leading to the convictions of racial minorities in the United States - to recognize how deeply the results of our social formation shape what we see, and how we remember it. ${ }^{27}$ Our ability to understand our own lives will, if anything, suffer even deeper and more pervasive distortions than our understanding of the world around us.

It is this sense of incoherence as a result of sin that shapes Augustine's experience of his life and temporality. Because his affections are not properly ordered by the love of God, and because he is unable to will the good as his soul stretches out to the Good that is God, he finds that his life is not ultimately intelligible to him; he does not understand why he does what he does, how he has become the person he is, or the end toward which his life is moving. Thus in Confessions 11, we find Augustine lamenting, "I have been dispersed into times of which I do not know the order (ego in tempora dissilui, quorum ordinem nescio). In the most intimate depths of my soul my thoughts are torn into fragments by tempestuous changes until that time when I flow into you, purged and rendered molten by the fire of your love." 28 The problem is one of form: Augustine does not know how to put the pieces of his life together in a manner that is truthful to the creature God has made him. At times, we experience this inability to order our lives in quite literal fashion: I vividly remember an afternoon passed in conversation with a friend, but am unable to recall whether or not this event took place before or after his wife died. We do not know the order (nescimus ordinem) of the times across which our lives are spread, and so we are unable to see truly how our lives have unfolded, how the experiences we have undergone have shaped our anxieties and fears, our habits and desires, the ways that our vulnerability, dependence, and agency constitute us in relation to one another.

Because our wills are corrupted, we cannot draw the right connections within memory such that we understand ourselves and our world rightly. We are left with either the falsehoods we can cobble together, or with total incoherence. All Augustine possesses are the scattered experiences of his life, and the conviction that any attempt to bring the semblance of order to them can provide only a distorted understanding of himself. The situation appears hopeless: any intelligibility we can bring to our histories will be a lie we tell to ourselves, and any lie will be unable finally to recover a sense of our wholeness. Either we will expunge a part of ourselves from the narrative through which we understand our lives, or the narrative will collapse

27 Cf. Gary L. Wells and Elizabeth A. Olson, "Eyewitness Testimony," Annual Review of Psychology 54 (2003): 277-295.

28 conf. 11.29.39; WSA I/11, 310 (modified). 
completely; and if we have learned anything from the modern masters of suspicion, it is that even what we attempt to repress will return with unexpected and destructive force. In one of the most moving passages of the Confessions, Augustine offers this nearly hopeless state both to his divine and human listeners: ecce distentio est vita mea; as James Wetzel powerfully renders it, "Look and see, the distension is my life."29

Yet a challenge can be raised at this point: if memory, intellect, and will are co-operative in all our acts of knowing, all three must be active too in our perception of intelligibilia, objects of knowledge like mathematical relations or (arguably) the forms that are instantiated in many different created particulars ("humanness," for instance). If all three operations of the mind are not at issue in the perception of intelligibilia, there is an important counterexample to the account I have given - a counterexample that would call into question much in what I will go on to say about the inseparability of our memory, intellects, and affections in our sanctification and knowledge of God. For the question to be a problem for my account, we will need to presume a certain account of intelligible realities as existing primarily in God, and in our intellects through the participation of our minds in God; while I believe much in the account I have given so far stands even without making these presumptions about intelligibilia, I will grant these presuppositions for the sake of addressing this objection to my approach.

Clearly, on Augustine's account, the intellect is active in our coming to know intelligible realities. In such acts of knowing, one's mind comes into contact with and is informed by the Word, the eternal Truth in which both number and form subsist as the archetype of their created exemplifications. Memory, too, seems to be involved in such acts of perceiving intelligibilia: though Augustine considers the possibility that all knowledge of forms is contained in the memory, the conclusion that Plato draws in the Meno from Socrates' discovery of geometrical knowledge in a servant boy through directed questioning, he rejects the explanation that such cases indicate memory of past lives or a past integral unity of human knowledge. ${ }^{30}$ Instead, he proposes the

conclusion...that the nature of the intellectual mind has been so established by the disposition of its creator that it is subjoined to intelligible things in the order of nature, and so it sees such truths in a kind of non-bodily light that is sui generis, just as our eyes of flesh see all these things that lie around us in this bodily light, a light they were created to be receptive of and to match. ${ }^{31}$

This light is external to us, and so would seem not to be an operation of memory. Yet it is clear also that encountering intelligibilia in this intellectual light produces real knowledge in us, and must therefore be communicated to memory in a manner analogous to a sensual perception. We do not relearn the truth of four being two's square every time we think about it, as would be the case if knowledge of this truth remained extrinsic to memory; instead, we retain in memory our coming to know that four is two's square, the encounter with the Truth in which we came to

29 conf. 11.29.39; James Wetzel, "Time after Augustine," Religious Studies 31, no. 3 (1995): 341-357; 354-5.

30 Cf. trin. 12.15.24.

31 trin. 12.15.24; WSA I/5, 336. 
perceive this fact as true. This "non-bodily light" must therefore be understood to illuminate both the intellection of this truth and its retention in memory.

The question turns, then, to whether the will is involved in knowledge of intelligible truths, and here we seem to be on shakier ground. As we saw in Chapter 3, Augustine's account of Christ as a redemptive sign presumes that the answer to this question is yes; but is it plausible to think that our knowledge that $3+4=7$ is dependent on - or even informed in any meaningful sense - by our will? In a first attempt at answering, we may ask what is being "coupled" or "separated" in such instances. In the most basic acts of knowing, as for instance in knowing the number three, Augustine's account suggests that the will is functions to connect us to the Word as it eternally knows, reflects, and is the source of threeness. On one classical way of speaking of the relation of numbers to God, we may say that the number three eternally subsists in God; as we contemplate the number three, then, our will joins us to the Truth of the Word as the number three exists in it. Our intention picks out this particular number as it subsists in God - our minds are joined to the number three in contemplation, rather than the number seven, as our intentio animi reaches out to the number three as it subsists in God. We can see this too phenomenologically as we rise from the instantiation of threeness in creation to the idea of threeness itself: we are presented with a set of three apples, a set of three pencils, a picture of three puppies; and it seems plausible to say that we want to know and be able to give an answer to the question when asked of how many there are of each, and what each of these examples has in common. Even if it seems (as I think it does in many cases) that the answers to these questions simply "come to us" rather than being produced as the result of intellectual labor, it also seems to me true to say that we desire to know even these basic truths. The analogy for the conjunctive work of the will at this level in the physical realm would be the will's direction of our attention in our perception of the world.

As we get to more complex relations and knowledges of the world, the operation of the will becomes manifest to a greater and greater degree. Desiring to know the answer to the sum of three and four requires that we bring our knowledge of these numbers in relation to one another in order to discover the eternal relation obtaining between these numbers in their essences (and in the essence of "seven"); only think of the frustration of the child not yet adept at arithmetic, who wishes to add three and four properly but continues making mistakes. As we turn to higherlevel mathematical proofs, we can even see the difference that one's desire makes in how we are joined to the Word's Truth: we can imagine two mathematicians arriving independently at proofs for the same theorem, one desiring to prove the theorem which had until then only been considered hypothetical (and therefore desiring to join together what is already proven mathematically with the postulated theorem), and another simply following out the implications of what is already mathematically proven without having any knowledge of the theorem (and therefore desiring to join together only the mathematical terms at each level of the proof, wondering "what would happen if I did this..." and continuing to spin out the implications until she realizes that she has just constructed a proof for a new theorem).

The situation seems even more dependent on the will's work of conjunction and separation as we turn away from strictly mathematical realities and turn to properly metaphysical 
knowledge, insofar as it is accessible to us in this life. Recognition of causal relationships requires us intellectually to join together diverse phenomena, like one billiard ball moving across the table and coming to a quick stop, as another billiard ball begins moving swiftly in another direction. As Hume ably showed, it is possible to contest the theoretical adequacy of joining even these two events together in a causal relationship - if one desires to do so. ${ }^{32}$ In fact, if we should regard the will not only as a coupler but also as a separator, we must identify the will as operating even in the judgment that there are two entities there on the table, separating them from the rest of their environment as distinct objects; and the will is at play in recognizing these two objects as two billiard balls, objects of a certain kind distinct (that is, separated intellectually) from objects of other kinds. Just as in our perception of sensibilia, the intellect makes use of categories and concepts that have been shaped through the agency employed in linguistic acts; even - perhaps especially!our metaphysical concepts have histories, and are used in pursuit of particular sorts of desired knowledge. Plausibly then, even our perception of intelligible realities are possible only through the interrelated activity as the mind remembers, knows, and wills.

For Augustine, the soundest evidence for the claim that even our most abstract acts of knowing are shot through with desire is the mind's inability to persist in contemplation even when one has raised one's mind to the Truth. Augustine himself famously recounts an experience of this instability in conf. 7.10.16, as he finds himself unable to maintain the contemplation of eternal realities arrived at by attempting the path of Platonic ascent. The cause of his inability to persist in contemplating the Truth, Augustine tells us, is a failure of desire: his affections have wrongfully attached him to the things of the world, meaning that his will cannot successfully conjoin him to the Truth, or what he often describes as cleaving to the Word. His illness is revealed by the remedy God has provided: as Augustine will go on to write in conf. 7.18.24, Christ's work opens to us the eschatological possibility of a stable contemplation of Truth in that "He heals [sinners'] swollen pride and nourishes their love, that they may not wander even further away through self-confidence." 33 What I am arguing here is that this same failure of love is not limited to producing the sinful patterns of action and damaging consequences that we regularly inflict on others, but cuts to the quick of all our acts of remembering, knowing, and willing. Our distorted loves compromise to a greater or lesser degree even our most abstract acts of knowing, and the more that our wills are involved in drawing together the remembered objects of past experience or present objects of perception into synthetic judgments, the more damaged - and damaging to others — we can expect our knowing to be. ${ }^{34}$

\footnotetext{
${ }^{32}$ David Hume, A Treatise of Human Nature, ed. David Fate Norton, Vol. I. (Oxford: Clarendon Press, 2007), 27-31 (1.2.3).

33 WSA I/11, 178.

${ }^{34}$ Cf. Dodaro, Christ and the Fust Society, 74-5: "Enlightenment of the intellect and healing of the will are not separate operations performed within the soul; nor, therefore, do they occur as distinct steps in a process. Grace heals the will of its weakness concerning justice in the same act in which the intellect is enlightened about the nature and content of justice, as both are understood in Christ's example...for the full effects of Christ's example and grace to be perceived by both intellect and will, the obstacles to understanding and loving virtue represented by ignorance and weakness must simultaneously be overcome... approached in this way, ignorance and weakness do not constitute two distinct defects of the soul, but two alternative explanations of the same defect."
} 
If there is to be healing in our lives, if there is to be a restoration of our created integrity, the medicine will need to treat the root of the problem; we will not be able to know ourselves as creatures of God, or be able to confess our histories of sin and grace truthfully, until our affections are healed. Neither will we be able to refrain from acting sinfully until the desires moving our will toward sinful action are directed properly to God, as I will discuss more fully in the next section. This is the conclusion to which Augustine is led in Confessions 11, as he cries out to God, "I will stand still, then, and find firm footing in you, in your Truth who is shaping me to himself." 35 We must learn to surrender our fruitless struggle to render our own lives intelligible, and receive our lives as the gift of God; as we will see, the only possibility of our reclamation lies beyond us, in the grace of God.

Yet at the outset, we should correct against a possible misinterpretation. The problem that sin introduces to our attempts to understand ourselves and our world is one of fragmentation and incoherence, but its resolution does not come through a renewal of our ability to fashion a new crystalline unity of ourselves. The Augustinian aspiration is not to the well-defined (and policed) borders of self-possessed subjectivity, or to the achievement of finality in our attempts to understand ourselves. The integral self-understanding for which Augustine teaches us to hope is not ultimately closed, but rather finds its coherence precisely in being related to God and one's neighbor. I will have much more to say about this below, but for the moment, I am content to note the increasing skepticism with which scholars of Augustine have come to regard the project of finding in his thought an anticipation of modern discourses of the "self." 36 As John Cavadini has written, "Someone who is self-aware is aware not of 'a self' but of a struggle, a brokenness, a gift, a process of healing, a resistance to healing, an emptiness, a reference that impels one not to concentrate on oneself, in the end, but on that to which one's self-awareness propels one, to God."37 This is the fundamental character of the Christian life on an Augustinian account: a continual turning back to God, a recognition of the failure properly to love God and the world, a deepening awareness both of one's sin and of the goodness of one's created nature, a halting journey through which we are opened to the presence of God and the others with whom God has placed us in relation.

Two aspects of this "interruption" of the self may be distinguished in the course of our reformation, though in the context of the Christian life they are inseparable from one another. ${ }^{38}$ In the first place, God's gracious activity serves to correct the effects of sin, reordering our loves

\footnotetext{
35 conf. 11.30.40; WSA I/11, 310.

${ }^{36}$ Charles Taylor and Phillip Cary offer classic presentations of Augustine as the progenitor of the modern "self" at Charles Taylor, Sources of the Self: The Making of the Modern Identity (Cambridge: Harvard University Press, 1989); and Phillip Cary, Augustine's Invention of the Inner Self: The Legacy of a Christian Platonist (Oxford: Oxford University Press, 2000). Contrasting proposals emphasizing the instability of any notion of the self in Augustine may be found at Hanby, Augustine and Modernity; John C. Cavadini, "The Darkest Enigma: Reconsidering the Self in Augustine's Thought," Augustinian Studies 38, no. 1 (2007): 119-132; James Wetzel, "The Force of Memory: Reflections on the Interrupted Self," Augustinian Studies 38, no. 1 (2007): 147-159; Matthew Drever, "The Self Before God? Rethinking Augustine's Trinitarian Thought," Harvard Theological Review 100, no. 2 (2007): 233-242 and Image, Identity, and the Formation of the Augustinian Soul; Rowan Williams, On Augustine, Ch. 9; and Jean-Luc Marion, In the Self's Place.

37 Cavadini, "The Darkest Enigma," 123.

38 The description of the self as "interrupted" comes from Wetzel in the article cited at n.32 above.
} 
and thereby healing us of the ignorance and weakness that so determine our lives in this saeculum. ${ }^{39}$ Though the primary locus of God's redemptive activity is the human soul as it is both taught to love properly and illumined by the work of the Holy Spirit, we should not underestimate the corporate effects of this process; as Robert Dodaro ably shows, and as we will explore more fully below, Augustine's christological reflection is deeply interwoven with his political theology. ${ }^{40}$ Our incorporation into the body of Christ not only reshapes our hearts in relation to God, but offers us new resources for understanding our life together, and inaugurates new possibilities for the ordering of our social life to the end of catechizing us in the love of God.

Yet this first register of grace's work may be distinguished from a second, in view of the fact that this curative work of God comes to an end, while the self's ecstatic movement to God does not. Even eschatologically, we never arrive at a settled self-presence and exhaustive selfunderstanding. If I understand myself truly, I understand myself as one to whom God is interior intimo meo, ${ }^{41}$ and so the perfection of my life's intelligibility can occur only as an understanding of my createdness, my constitutive participatory relation to a God who is essentially incomprehensible. I cannot fully understand myself without knowing myself to be essentially related to a God who exceeds my capacity to understand. The Augustinian conception of perfect self-knowledge therefore involves a surrender of one picture (final and comprehensive intellectual self-presence) and its replacement with another: coming to find the intelligibility of our lives in the life of the Incarnate Son, learning to see each moment of our experience and all the relations we bear to the created order as charged with meaning as signs ordered by the Word. The point is not that we fail to attain wholeness or that our restlessness persists into the eschaton, but that what it is for us to be whole is, in part, to understand that we exist only inasmuch as God continues to grant us being through participation in Him. Understanding ourselves truly cannot then mean a static finality in our knowledge, but rather the movement of our intellects through ourselves and to the endless contemplation and praise of God. ${ }^{42}$ We find our rest not in ourselves, but in the incomprehensibility of God.

It is, finally, through coming to know ourselves as finite, as changeable, as located in particular places and particular times surrounded and influenced by particular people and events that we learn to see God. More than this, it is in learning to see our particular creaturely histories as written into the life of Christ, made intelligible in our relation to him, that we understand whom God has made us. Augustine, recognizing his own inability to bring order to his life and memory, tells us that he stakes his claim on the "Truth who is shaping me to himself" - but, as we have seen, this is a Truth who enters into the changeability of time alongside us, assuming to Herself human flesh. We come to know ourselves most truly as creatures reconciled to God and called to union with Her as we learn to see the world (and us in it) as rendered meaningful in

\footnotetext{
39 Dodaro's description of ignorance and weakness as two of the principal effects of sin may be found at Christ and the Fust Society, 27-32.

40 This is the central focus of Dodaro, Christ and the Fust Society. Eric Gregory has also drawn attention to the ethical significance of Augustine's christology at Politics and the Order of Love; see especially pp. 255ff.

${ }^{41}$ conf. 3.6.11.

42 Rowan Williams has written extensively about this aspect of our creaturely self-knowing at, for instance, On Augustine, Ch. 1 ("A Question to Myself": Time and Self-Awareness in the Confessions").
} 
relation to God's life; and - alongside and inseparable from this knowing - to love the world as Christ loves it, and to remember created history truthfully in both the horrors sin has wrought in it and in the goodness over which no evil can finally triumph. As God stitches together the distension we have made of ourselves, we are not made exiles from the world, but rather learn how to inhabit it properly as the creatures we are. The only worlds we must flee are those we have made for ourselves, the worlds generated by our misrememberings, misunderstandings, and misbegotten loves. These worlds must collapse back into the nothingness from which they issued in our corrupted hearts, in order that we may receive anew ourselves and the world God has made.

To the extent that we come truly to inhabit our creaturely histories, we are conformed to the only one who has remembered, known, and loved the world perfectly; we repeat in ourselves, by God's grace, the life of Christ in new times and in new places, and so are made the body of Christ. As Augustine writes in en.Ps. 86.5 (and again drawing on the puzzling passage of Col. $1.24)$,

You are Christ's body, Christ's members. Because the apostle was among his members, he said, That I may fill up what is lacking to the sufferings of Christ in my own flesh. We are traveling to the place whither Christ has gone before, but it is equally true to say that Christ is making his way to the place where he has already gone in advance, for though Christ has gone before us as head, he follows in his body. And Christ still labors here... ${ }^{43}$

We must follow this movement from Christ to Christ if we are to learn to see ourselves as his body, and it is only in understanding ourselves as knit into Christ's own life that we come to know ourselves truly. And not only ourselves - we exist in Christ only as members of a body, and so the reformation of our remembering, knowing, and loving requires the sanctification of our historical memory, knowledge of our world, and love of our neighbor. Only as we learn to love our neighbor in Christ and Christ in our neighbor can we come to know ourselves as his body. In the remainder of this chapter, I explore the character that this twofold movement into Christ's and our own particularity affords to the Christian life. As we will see, ours is a halting progress to greater knowledge and love of God and neighbor - but one that requires we follow our own way of the cross, completing in ourselves Christ's suffering so that we may share in his resurrection.

\section{The State of Sin}

To this point, my account of sin's disintegrating effects has focused on the damage we inflict on our ability to know God, ourselves, and our world truly. I have been concerned with supporting two claims: that sin compromises all our acts of knowing, and that our misdirected affections are the root of this malfunction of our intellective acts. Our sinful loves deceive us

43 en.Ps. 86.5; WSA III/ 18, 251. 
about the world, and we act in the world sinfully on the basis of our deceptions - where the preceding section centered on the first of these two interrelated claims, this section turns to the second, focusing our action within the world. The basic claim of this section is that sinful loves are compounding; that action on the basis of disordered affections leads inevitably and inescapably to ever more thoroughly disordered affections. The section traces the waves of incoherence that radiate outward from the originary act of human sin, sundering first God's relation to the soul, then the soul's relation to the body, before turning to the broken relationships as our lives are separated from those of our neighbor. All aspects of our life together are damaged by the consequences of sin; all of them will require healing in the course of our redemption.

One of the presuppositions of Augustine's anthropology, and indeed of his doctrine of creation in general, is that all that is not God exists solely by virtue of the dependent participatory relation that creation bears to God. Without the creative act of God, we are nothing whatsoever, and we both come into being and are maintained in being as the creatures that we are only by continually receiving existence and form as the gifts of God. As Augustine writes, "it is when [each creature] turns, everything in the way suited to its kind, to that which truly and always is, to the creator that is to say of its own being, that it really imitates the form of the Word which always and unchangingly adheres to the Father, and receives its own form, and becomes a perfect, complete creature."44 Augustine imagines a creature turning here to the source of its existence; but how can that which is in itself nothing turn to God? We are invited to imagine the creature's turning to God not as an act undertaken by some creature that has been granted independent existence as its own possession, but rather to imagine the creature's own proper activity as the manner by which it turns to God, always and at each moment, for as long as it exists. The stone, simply by existing as a stone, reflects its likeness to the divine life, and its actus essendi (to use the later Thomist idiom) in a "stony" way is the manner by which it adheres to God. Similarly, a cat adheres to God and is fully what it is and reflects the life of God in living its own life: as its blood circulates through its body, as it rubs itself against a table leg, as it drinks the saucer of milk set before it. The question of whether hunting mice is natural to the cat is an important one, and the answer must be, all experience to the contrary, no. This would be to make death part of the goodness of creation, and to suggest that there is something like death in God's own life - a well-trodden path from Hegel onwards, but one that compromises the Christian convictions that God is Life and the source of life; that death and corruption enter the world God has made solely through creaturely sin; and that death will be no more in the heavenly Jerusalem, our final enemy having been swallowed up in Christ's victory.

Like stones and cats, humans have a proper manner by which we turn to God, receiving our existence from her; and indeed, we bear some likeness to stones and cats in the way we reflect the life of God in our own existences. Like stones, it is proper to us to be extended in spacetime; like cats (and plants, and insects, but unlike stones), our physical existences are animated by their own proper activity, our vitality drawing the material world into new and ordered configurations

${ }^{44}$ Gn.litt. 1.4.9; WSA I/13, 171. 
as we move, eat and digest, grow, and reproduce. In fact, as warm-blooded creatures, there are even more ways in which we are like cats than other animate life, and we can speculatively identify other species (chimpanzees, dolphins, elephants) as being even more like us than cats as we find in them some more-or-less distant reflections of social behaviors in response to death, or behaviors that seem like rudimentary language-use. It seems likely that many of the animals whose lives we take to be most like our own also possess memory and desire, qualities both suggested by Pavlov's experiment with his dog. We are unlike them (as best we can tell) in that we are not only animate, but rational: we are capable not only of sensing and responding to what is around us, but of knowing the truth of things as they participate in the Truth of the triune Lord. Our minds can contemplate the truth of number, for instance, or (dimly) the truth of natural forms like "catness" or "humanness"; in this, our knowing is capable of manifesting a closer likeness to the knowing that is God's life than is whatever sort of intellection may be possible for a cat or gorilla. Though we are unique (so far as we know; and for now, at least) in being both rational and embodied, we are not unique among creation in being rational: the angels, too, know and contemplate God's Truth in the manner proper to their existence.

Because we are capable of knowing God, the activities proper to our souls take on a particular form: we are most fully ourselves, we are living in the way that adheres us to God, as our minds turn to God in loving contemplation - the threefold action of memory, intellect, and will whereby we know God as we are united to Her in desire. And, because it is proper to our lives to be embodied, we may expand this point beyond the more limited question Augustine harbored about what in us most reflects the triune life of God to say that just as our souls are meant to be rapt in contemplation, so also our bodies are to be employed in worship. It is essential to our humanity in its ideal state that we should glorify God in our bodies, each movement reflective of a soul animated by the love of God. Embodied, loving contemplation of God: this is the life God gives us, the life in which we reflect Her life most truly.

Sin is, ultimately, a refusal of this life. Rather than living the life God gives us, defined by being ordered to the embodied loving contemplation of His own life, we attempt to live in a manner ordered by something other than the love of God. Though we can tell the story of our defection from God, there is no intelligible story to be told that would explain why we do this. Though we might identify in narrative scheme the goods Adam and Eve thought they were pursuing in sinning, we can offer no satisfactory account of why they forsook highest good of God Himself to pursue some other created good. There can be no sufficient reason to render an evil action intelligible, but only an insufficient one. ${ }^{45}$ Augustine displays this logic with clarity in $D e$

\footnotetext{
${ }^{45}$ In this, I follow Charles Mathewes, Evil and the Augustinian Tradition, 78-80 and 92-3. Wetzel also offers a perceptive analysis of the causa deficiens at Parting Knowledge, 92-4, yet also notes an equivocation (or at least tension) in the idea at 55: on the question of whether the causa deficiens is "a pure love of evil or always some deluded way of pursuing the good," he responds, "My suspicion is that Augustine needs it (impossibly) to be both. A desire for pure evil (i.e., a deliberate rejection of God) is what makes the first sin solely a matter of human culpability; a grossly misshapen, but still salvageable, desire for the good (i.e., an ignorant love of God) is what makes the first sin redeemable" (55n.14). Wetzel develops this insight in Chapter 1 of Parting Knowledge, where he describes Adam's sin as a decision not to live without Eve: "He chooses to disobey because he cannot imagine her getting along without him-'she would wither away without his care' (Gn. Litt. 11.42.59) — and because he assumes that God will forgive him for having made, in
} 
civitate dei 12, in discussing whether we might find an efficient cause of a sinful will. The underlying presumption of Augustine's discussion there is that all that exists is created and ordered by God; for a sinful will to have an efficient cause would be for there to be some created good that, in acting as the good creature it is, to bring about a sinful will as the proper effect of its activity. This would indicate, however, that sin emerges naturally and necessarily as a result of the world God has created, and in this case God would unquestionably be the author of the evil that is defined as such by being that which God does not will. One is led to incoherence, or worse, to a diabolical God. Augustine concludes, "Let no one, then, seek an efficient cause of an evil will. For its cause is not efficient, but deficient, because the evil will itself is not an effect of something, but a defect. For to defect from that which supremely is, to that which has a less perfect degree of being: this is what it is to begin to have an evil will." 46

These are the hallmarks of the Augustinian account of sin: evil as a privation or corruption of some good thing God has made; the sinful will as a will moved by desires not properly ordered by the love of God; the description of our desires as being disordered, directed to a lower rather than the highest good as their final referent; enjoying what is properly to be used; ${ }^{47}$ or, perhaps most famously, love of self to the contempt of God rather than love of God to the contempt of self. ${ }^{48}$ The literature on Augustine's doctrines of evil and sin is voluminous, so I wish to focus here on question of how sinful willing affects our capacity to turn to God as we receive life and form from Her.

The first notable feature of our sinful condition is a formal one: in failing to live a life of embodied loving contemplation, we are not living the life proper to the sorts of creatures God has made us. We do not turn to the Word as the source of our life in the manner suited to the nature in which God has constituted us, and so we do not appropriately reflect in our own lives the life of God. We become, literally, de-formed: our lives are no longer fully ordered by the Word who establishes each creature as the kind of thing that it is and sets them in relation to one another, and so we become imperfect exemplifications of what it is to be human. While I will further specify the effects of this privation of our created goodness below, what is essential to not is that in being de-formed, we drift back toward the nothingness from which we were originally called by God's creative act. As creatures, we exist only as we participate in the life of God, existing as likenesses of Him to the extent that we live as the creatures He has made us. In sinning, we begin

some respect, a faithful choice (civ. Dei 14.13)" (23). While Wetzel's case is exceedingly thought-provoking, it still seems to me to make our originary sin to be too intelligible a decision, and thus to build at least ignorance of God's good (and arguably sin itself) into the created order as a good. In this, Wetzel seems to follow what we might call a more Irenaean than Augustinian account of sin wherein the Fall is understood as a misguided course resulting from our imperfect understanding of God's good will, and as a necessary step in humanity's spiritual maturation. Wetzel acknowledges many Augustinians may have this worry with his account at "Splendid Vices and Secular Virtues: Variations on Milbank's Augustine." The Journal of Religious Ethics 32, no. 3 (2004): 271-300; 298.

46 civ. 12.7; Dyson, 507. Jesse Couenhoven has offered a helpful reading of Augustine's account of the causa deficiens and its importance within Augustine's later works. He especially calls attention to the condition of possibility of our fall away from the good in the fact that we are created from nothing; cf. Jesse Couenhoven, "Augustine's rejection of the free-will defence: an overview of the late Augustine's theodicy," Religious Studies 43 (2007): 279-298; $286-90$.

47 doctr. chr. 1.3.3.

48 civ. 14.28. 
to live outside the bounds of the life we have been given; and this "outside" can only be a diminishment of ourselves, as there is no life at all outside God. The more we depart from the embodied loving contemplation for which we were made, the more incoherent our lives come to be - the more we recede into the utter formlessness of the nihil.

The second thing to note is the inescapably degenerative nature of our condition. As Rowan Williams helpfully comments, "To see evil as privation is to see it as something that affects my own perception of what is good for me: if evil is the absence of good, it is precisely that misreading of the world which skews my desires" - or, in the case of original sin, the skewing of our desires that produces our misreading of the world. ${ }^{49}$ Consequently, "if evil itself is never a subject or substance, the only way in which it can be desired or sought is by the exercise of the goods of mental and affective life swung around by error to a vast misapprehension, a mistaking of the unreal and groundless for the real." 50 These claims straightforwardly follow from the account of the interaction of memory, intellect, and will that I have offered above. As our desires defect from the love of God and are turn toward the things of creation as their final referent, our knowing and remembering are compromised as well; if one aspect of this threefold activity of mind malfunctions, the three in their interrelation will suffer damage as well. We no longer love the world as it is, but as we desire it to be, and so we fail to know the world as it is, but rather know only a deformed image of it. As we seek knowledge of the world in our sinful condition, our knowing misses the mark; and as we reach out to the world in desire, we set our loves not on what God has made, but on the phantasm we have imagined. ${ }^{51}$

It is in at least this sense that we should say that all sinful desires are directed toward nothingness itself. While it may be comforting to think that our error is not so grave, that we have only set our desires on lower goods instead of higher ones, this truth must be joined by an awareness of the end to which our sinful desirings move us. We do indeed love lower goods instead of the highest Good that is God; but in loving these created goods as something they are not - as something that might be validly enjoyed in themselves rather than as something that is lovable precisely in that it reflects and manifests the life of God - we love an object of our own making rather than God's; and this can only be an illusion, as we have no power of ourselves to create. In loving the world other than as God has made it, we turn our desires to nothing in particular, to the void from which we came. This is, in the end, why no object of our creation can satisfy our desires. In loving wrongly, we end up loving only our self-deceptions; the world can never satisfy our desires, because it is not really the world God has made that we love, but the world as we misguidedly imagine it to be.

As we persist in the habit of loving what cannot be, our desires become more and more skewed. Just as the original distortion of our loves subtly undermined our true knowledge of what God has made, so also our misapprehension of the world presents us impossible objects of desire that further distort our loving as our souls are moved toward them. The end result is a slow but

\footnotetext{
49 Williams, On Augustine, 83.

50 Williams, On Augustine, 88.

${ }^{51}$ Couenhoven offers a more textured account of Augustine's account of will, differentiating between voluntas, libertas, and liberum arbitrium at "Augustine's rejection of the free-will defence," 284-5.
} 
steady lapse back into the nihil, as our lives become less and less informed by our participation in the Word. Yet there is reason to think this slide into nothingness is not a straightforwardly linear process; Augustine regularly expresses appreciation for the ostensible virtues of pagan Rome, comments that have been developed both into accounts of "splendid vices" or of the continuity between the moral goods of those who appear redemptively animated by the work of the Spirit and those who appear not to be. ${ }^{52}$ It is, by Augustinian lights, undoubtedly true to say that there is no difference in kind between the actions (considered in themselves) of those in process of redemption and of those who are perishing; though we must, of course, maintain a great deal of skepticism about our ability to attribute membership in either set. Moreover, there is reason to think that some sinfully ordered desires may actually restrain other vices, as Augustine believed the Roman thirst for glory tempered their more hedonistic impulses for many centuries. ${ }^{53}$

Yet the most determinative feature of these splendid vices is the instability of the constellation of desires that produce them. Though the lust for glory may restrain for a time other vicious impulses, providing for even an apparent growth and even heroism in virtue, the incoherence of these orderings of desire only increases underneath the placid surface. What is most important from the standpoint Augustine offers in De civitate dei is the orientation of one's desires, not the snapshot of one's affective order that could be made at any particular moment: do your desires draw you into deeper intimacy with God, or do they release you into incoherence and the nihil? For Augustine, the answer for any sinful heart not turned to the love of God by grace must always and only be the latter, regardless of whatever apparent virtues might be otherwise manifested, and even if those virtues might be of such a quality that they can inspire even those in process of salvation to greater acts of heroic devotion to God. ${ }^{54}$ As Augustine notes at De natura et gratia 23.25, the "death of the soul leads to sin, since its life, that is, its God, abandons it, and it necessarily produces dead works until the grace of Christ brings it back to life." ${ }^{55}$ Rather than understanding the slide into nothingness as an unrelenting plunge downward, then, we might take instead the image of a satellite's degenerate orbit: at any one moment, the satellite might be moving at a velocity and course that are closer or farther away from those that would be appropriate to a stable orbit, but the inner trajectory of the system considered as a whole leads inexorably to orbital decay. So it is with the love of self to the contempt of God, qualitatively distinguishable from the proper ordering of one's desires to God as their final referent; and, though in our experience they are always mixed, two cities are founded on these loves.

What is life like in this city ordered by the incoherent love of that which God has not made? I have already discussed the breakdown of our ability to make sense of our own lives that sin effects, as we are dispersed into the distentio of our temporality. We must note, too, the

\footnotetext{
${ }^{52}$ Jennifer Herdt has recently explored Augustine's place in the history of theologies of "splendid vice," and noting importantly that this is a term Augustine himself never uses, at Putting on Virtue: The Legacy of the Splendid Vices (Chicago: University of Chicago Press, 2008); see especially Chapter 2 for her account of Augustine's thought on the possibility and impossibility of pagan virtue.

53 civ. 5.12.

$54 \mathrm{civ} .5 .14$.

55 WSA I/23, 229.
} 
incoherence that emerges in the relation of our souls to our bodies. Our bodies are meant to be enlivened by the soul just as the soul is enlivened by God; as the soul suffers the death brought about by its withdrawal from God, so also the body ceases to receive life from God by the soul's mediation. ${ }^{56}$ The first moment of our lives is, at the same time, the beginning of the slow death of our bodies. ${ }^{57}$ To this progressive dying of the flesh we must attribute all the physical wounds we suffer: bones broken by a fall; swelling and bruises that form as we are struck; the tearing of flesh as the bullet or knife passes through it. But not only these instances of accident or violence: the bodily corruption that results from sin is seen also in the ravages of aging, in congenital heart defects, in processes of cellular degradation itself. This is, for most, a very strange way to think; such processes seem to us like the most natural thing in the world. What's more, given the evolutionary history of human life, it seems impossible to imagine how human persons could come into existence without these processes of death.

While it may, for some, depart implausibly from our experience of embodied life to see all corruption and death as a result of creaturely sin, doing so maintains a resolute insistence on God as the one who gives life with no trace of death, for there is no death in Her. It also reminds us that created materiality enters into a cosmos already fallen, unfolding in light of and already damaged by the angelic fall. Creation itself groans under the weight of sin, both human and angelic; our corporeality itself, and the corporeality of our environment, bears the marks of sin even though it is intrinsically good without exception. In all our celebration of our embodied life, and even as we recognize that our materiality opens to us new possibilities for encountering and praising God, it is good to remember that we will often seem alien, even hostile, to ourselves no less in body than in soul. Our self-destructive urges and lack of self-intelligibility will be matched by our body's revolt against the soul and itself: our bodies will fail us with age; we will suffer illness; we will suffer spasms and other involuntary movements; we will be overwhelmed by bodily desires; we will suffer corruption in the natural processes of our body's development such that we are incapable of any communication or movement, rendering us incapable of participating actively in social commerce. This last example of profound developmental disability should underline the point that our bodily corruption cannot be categorically attributed to the consequences of personal sin: just as original sin describes our being born into the world without our affections properly ordered to the love of God, so also we are born into an embodied existence wherein our flesh bears already the effects of sin's corruption, manifested to varying degrees. This fact should accordingly make us wary of identifying any particular features of human life or development as the consequences of sin that are not straightforwardly involved in processes of death: because we cannot imagine what a life embodied in sinless flesh is like, much that we now regard as damage or disability may in the City of God come to be seen properly as the glorious diversity of what God has made.

Deeply implicated in both sin's effects upon our self-understanding and our bodily life are sin's effects upon our relation to the world, and our life together in community. As I have argued,

\footnotetext{
56 civ. 13.2.
}

57 civ. 13.10 . 
our lives are meant unfold in response to God's creative gift as embodied loving contemplationessentially, our lives are to be praise. Yet it would be a mistake to see this as the task of isolated individuals. As we will see below, our entry into this life of praise comes only as members of the communion of the body of Christ; our embodied loving contemplation is necessarily communal. In undermining our relation to the world and to those with whom we share it, sin fractures our ability to relate to one another as the creatures God has made us.

As Augustine sees, our inward disintegration both stands at the root of our social fracture, and is itself hastened by that social fracture. The inner and outer effects of sin are mutually reinforcing; nevertheless, it makes sense to begin here by moving from a consideration of how our inward disorder creates a disordered communal life. Robert Dodaro has noted the consequences of sin visible in our ignorance (the "incapacity to know oneself, others, and God with utter moral clarity"), weakness in willing the good, ${ }^{58}$ and fear of death (timor mortis). ${ }^{59}$ The three are, in fact, related: as Dodaro writes, "the moral object of knowledge is also in some respect an object of love, and, conversely, that which is not known cannot be loved,"60 while the fear of death both stems from our inability to understand ourselves as the creatures of God and produces in us an inability to see our own lives included in Christ's death. Our lives are lived in ignorance of the true value of things, leading us to value some created goods (say, wine or food) more highly than they deserve, and other goods (the virtues, for instance) less highly than we should. As we continue to make these misguided judgments, we become habituated to them, developing an undue attachment to wine or an aversion to those who are too honest. Not only, then, are our evaluative judgments compromised, but in many cases even when we correctly identify the higher good our habits chain us to the objects of our inordinate loves, leaving us powerless to will the good that we perceive. ${ }^{61}$ This weakness of will is, as we have seen, thoroughly tied to our ignorance, the corruption of our acts of intellection.

Perhaps most perniciously, the anxiety that the ever-present fear of our death produces in us makes us always fearful of the loss of that which we possess. We are aware of the impermanence of the goods that we possess, and thus attempt to secure them from a world that threatens on every side. Our lives become a sustained effort in crisis management, seeking to safeguard that which we always imperfectly know and value as good. This is the logic of empire, as Augustine traces throughout the De civitate dei under the rubric of the libido dominandi, ${ }^{62}$ the lust for domination that also dominates our lives. ${ }^{63}$ Yet the libido dominandi also functions significantly in our attempts to understand one another, enter into social relations with one another, and come to understand ourselves in light of these interactions. In being (mis)directed to, for instance, glory, wealth, or safety as the ultimate end of our love, our other desires are brought into alignment with this telos; we come to desire other subsidiary goods inasmuch as we take them to

\footnotetext{
58 Dodaro, Christ and the fust Society, 28.

${ }_{59}$ Dodaro, Christ and the Fust Society, 30.

60 Dodaro, Christ and the Fust Society, 29.

61 This is a central theme of Wetzel's, Augustine and the Limits of Virtue; see especially pp. 135-9.

62 Dodaro, Christ and the Fust Society, 32-43.

63 I owe this observation to Chuck Mathewes.
} 
bring us greater glory, wealth, or safety. These evaluative judgments grant a provisional intelligibility to our lives: we are able to narrate the goals we are pursuing in acting the way we do; we can give an account of what the world is like, and what we value within it; we can give an account of what might make our own lives meaningful. Yet this intelligibility is inherently unstable; no finite good can ultimately stand in God's place. We will find that glory in the eyes of our peers is fleeting and easily lost, that the accumulation of wealth is insufficient to satisfy the deeper needs of our souls, or that we cannot predict and plan against all the dangers that threaten our safety. More subtly, we will find that we have over- or under-valued some goods, that things do not satisfy our desires in the way we had hoped or that we feel the losses of some goods (a friendship, a broken family heirloom) more deeply than we had anticipated. These losses and unsatisfied longings are the cracks in the self-understanding we have forged of our sin; they are the moments when the world pushes back on our misshapen desires, when God's creation pushes through the lies we tell to reveal the falsity of the desires, the perceptions, and the histories we have made for ourselves.

Either the lies we tell fall apart, leaving us only in the state of distentio and in desperate need of grace; are replaced by new lies, replacing one provisional intelligibility of our lives with another that is destined to suffer the same fate; or we double down on our mistake, attempting to shore up the broken foundations of our identity against one another and the world. The libido dominandi and the violence it produces are born of the fragility of our distorted understandings of ourselves and the world. The world - including my neighbor - is too rich, too surprising to fit into the patterns of judgment and understanding that are available to my sinful intellect. Either I will be drawn up short by the particularity of the people and things I encounter, or I will need to force their conformity to my expectations. Instead of receiving my neighbor and my world as the good creation of God, my need to protect my unstable self-understanding or to secure the goods I believe will bring me happiness forces me to receive them as enemy, as obstacle, as tool, as resource. And I begin to seek out others who will assist me in the project of ordering my life such that my desires will not be challenged, my understandings of myself and the world will not be threatened, and I may maintain the intelligibility of my life and history in the light of the finite goods I pursue.

It is thus the fear of death - the fear of losing the goods I have come to value and the selfunderstanding I have constructed in light of valuing them - that most directly comes to undermine and dissolve the social relations we are meant to bear to one another as created by God. The destructive social orderings of racism, patriarchy, heterosexism, and unrestrained environmental depredation exist precisely as the product of a sinful attempt to overcome the effects of sin, my effort to secure the goods I possess and the borders of my identity against that which might challenge me. Similarly, these hegemonies are aligned (and the struggles against them are necessarily intersectional) not only because they together function to the benefit of a racist ableist colonialist hetero-patriarchy, but because that form of life is produced and maintained by the same lust for and logic of domination. This is not, of course, to claim that the struggles against these hegemonies does not require tools of analysis and strategies of resistance particular to each cause; resisting colonialism and patriarchy are intimately related, but very 
different tasks. But neither can the redemptive work of overcoming evil and healing our sinful natures be reduced to attaining justice in any of these realms. Without the reconciliation to God of the whole person, body and soul, even real advances in justice or equal provision for the material conditions of one's life is bound to be fleeting and unstable, eventually devolving into a substantially different but no less dominative social order.

The libido dominandi is thus, first and foremost, an attempt at self-possession. Yet because it is ingredient to our created natures to be open to the God who is interior intimo meo, as well as to the neighbors and contingent events that grant our lives their shapes, this attempt at selfpossession is directly called into question by the relations we bear to God and the world around us. To maintain the illusion we have crafted for ourselves, we must attempt to keep these challenges in check through careful circumscription of the ways we relate to one another. Our interactions pass through the filters of race, gender, sexuality, and civilization, with our social institutions, personal habits, conceptualities, and deployments of coercive power functioning to insulate us from any challenge our neighbor might pose to our self-understanding. These social realities are not merely tools we have carefully wrought through the mechanisms of law, custom, and constant formal and informal policing of our behavior according to communal norms, but take on a life of their own, continuing to shape our desires and entrench in us estimations of what is good and praiseworthy or aberrant and threatening. The logic of the libido dominandi is one of stasis: our hope is that we may preside over our lives as the mechanics of our own providential ordering, keeping the machine we have fabricated moving frictionlessly in perpetuity. Our aim, most basically, is not to be surprised.

We do not begin, then, by viewing others simply as mere objects of our desire, or as instruments or obstacles that can enable or hinder our pursuit of what we love. Nevertheless, those who become habituated to the misapprehensions that enable us to see those who bear the image of God only as threats or tools will, in some cases, cease to view others as challenges to their agency at all. My suggestion that domination is most basically about insulating oneself from surprise at encountering another may give the impression that even the most oppressive relationships bear within them a recognition of common humanity, an implicit recognition that the life of another may really call my own life into question. This may, however, give us too much credit. While I think something like this account is necessary to describe how we come to see one another as threats or instruments in the first place, it also seems true to say that as we become increasingly fixed in our wicked desires and ignorant of the created order in its relation to God, our relations to (some) others less and less come to exemplify the mutuality that is proper to our created natures and that will be restored in the Kingdom of God. Though the goods inherent in our relations to one another cannot be fully eradicated without our being subsumed entirely in the nothingness toward which sin pushes us, the libido dominandi not only distorts our sociality, but tends ever to its dissolution. Hell is not only privation, but privacy. ${ }^{64}$

${ }^{64}$ Sean Larsen has perceptively developed an Augustinian account of the relationship between privacy and sin in his forthcoming Naked and Unashamed: Rethinking Sex and Politics with Augustine. 
While this dominative tendency is the product of the sinful orientation that is common to all people, it is at the same time important to note that the power to dominate others is not evenly distributed. What's more, domination itself becomes a habit: as I find that I may bend others to my will, any resistance to my will seems more and more to merit violent reprisal. The history of the world that Augustine offers in De civitate dei is one of war, conquest, enslavement, and empire: these histories mark off particular configurations of the power to dominate, configurations that nurture the violent impulses of some and condemn others constantly to bear the consequences of injustice. It is important to keep in mind that there is no "perfect dominator" or "perfect dominated" here; history offers abundant examples of those who are profoundly oppressed by one set of social realities nevertheless occupying a standpoint where they are oppressors in relation to others. Contemporary intersectional politics and theologies aiming at the liberation of oppressed peoples have quite skillfully shown how, for instance, the voices of women of color have been marginalized both within the struggles for racial and gender equality. ${ }^{65}$ Even so, it is undeniable that as the libido dominandi functions at an expansive scale to enable the dominance of some members of a community, so also it works to place others consistently in the role of the dominated. And just as this social location supports the selfpossession of some, it leaves those oppressed in a state of enforced dispossession.

Analysis of particular instances of oppressive social orders show that they function precisely to control the humanity of those dominated, undermining their humanity and capacity for social relations so they cannot challenge the agency, self-understanding, or social world of the dominator. M. Shawn Copeland has mapped these processes with devastating clarity in her recounting of the way American slavery directly attacked the embodied social existence of black women. Slavery challenged black women's "freedom for God" in making white Christianity a pillar of white racial domination in preaching that God had willed the institution of slavery; it attacked their "freedom for being human" in subverting their agency and responsibility for their lives; it compromised their "freedom for loving without restraint" in destroying the relationships of loving mutuality within the marital bond; it "devalued motherhood and mother-love" by tearing apart the families of the enslaved for economic gain; it undermined "freedom for community and solidarity" in strictly policing the social interactions and assemblies of slaves; it attacked not only the soul's agency, but with particular force the black body through pervasive violence, sexual and otherwise; and finally, in its aspiration of structuring the entire life of the enslaved, American slavery challenged the possibility of "psychic healing and growth," the selflove ordered to God that is intended for us as creatures. ${ }^{66}$

When, therefore, Copeland writes that "Slavery sought to desecrate and deform black bodies," 67 we must see in this assertion the mirror image of the libido dominandi's task of selfpossession. In order for that lie to be preserved, those who bear the weight of domination must

65 One of the classic statements of womanist christology noting how black women's voices have been marginalized within both the struggles for gender and racial equality may be found at Jacquelyn Grant, White Women's Christ and Black Women's Jesus: Feminist Christology and Womanist Response (The American Academy of Religion, 1989).

66 Copeland, Enfleshing Freedom, 47-50.

67 Copeland, Enfleshing Freedom, 51. 
be stripped as thoroughly as possible of the spiritual and bodily dignities that make us human; they must be rendered unthreatening by removing, as much as possible, true reciprocity in their interactions, the interdependence and vulnerability that I have argued is at the heart of human life in the world. In contrast to the oppressor's attempt at dominative self-possession, the one who is oppressed finds her life hemmed into a forced incoherence to the extent that her agency and humanity have been torn away. Though much of the oppressed one's life is defined by its position as the one trodden down by the social order, she paradoxically finds no place within that social order for herself or the full recognition of her humanity. Her place within this social order is defined as the site where her humanity cannot appear, where her agency cannot be manifested - for the social order itself is predicated on the ability of others to control the way her humanity might challenge that of her oppressors. One may think here of the forced incoherence of "double-consciousness" as described by W.E.B. DuBois, or of his sense that his existence itself constitutes a problem for society. ${ }^{68}$

This analysis of the different standpoints that people occupy within dominative social orders, and the recognition that the burden of sin's consequences are not born in the same way by all, should make any Augustinian approach wary of identifying one sin as standing at the root of all others. In particular, such an account need not claim that all sin is at base pride or self-love. It is easy enough to see why Augustine might see in prideful self-love a particularly clear image of sin: trading our love of God for self-love, we substitute the truth of God's creation and His ordering of all created goods for our own estimation of what can satisfy our desires, therein losing our grip on the world and coming to see things only through the distorted glass of our sinful wants. On this reading, the sinner seeks to found his existence and desires on himself alone, suicidally renouncing God as the source of his life and the end to which all his loves must be ordered, attempting to claim sovereignty for himself. Yet it is debatable whether Augustine himself ever held that pride is the source of each sin (though it is clear for him that pride was the source of the first sin - namely, that of the devil) ${ }^{69}$ Over-against Augustinian accounts like those of Reinhold Niebuhr that take pride as the fundamental sin of all humanity, Valerie Saiving notes the very different forms that sin assumes in the lives of many women habituated into patriarchal society: their characteristic temptations

are better suggested by such items as triviality, distractibility, and diffuseness; lack of an organizing center or focus; dependence on others for one's own selfdefinition; tolerance at the expense of standards of excellence; inability to respect the boundaries of privacy; sentimentality, gossipy sociability, and mistrust of reason - in short, underdevelopment or negation of the self. ${ }^{70}$

\footnotetext{
${ }^{68}$ Brian Bantum insightfully notes the way that interracial bodies are themselves made problematic within societies ordered by white supremacy at Redeeming Mulatto: A Theology of Race and Christian Hybridity (Waco: Baylor University Press, 2010), Ch. 2.

${ }^{69}$ Cf. Jesse Couenhoven, "'Not every wrong is done with pride': Augustine's proto-feminist anti-Pelagianism," Scottish Journal of Theology 61, no. 1 (2008): 32-50.

${ }^{70}$ Valerie, Saiving Goldstein, "The human situation: a feminine view," The Fournal of Religion 40, no. 2 (1960): 100-12; 109.
} 
Saiving's presentation, of course, bears the marks of her own time and the limits of her experience: it shows little awareness of the very different experiences characteristic of women in poverty, women of color living under white supremacy, women living under colonialism, or of the very different temptations to which these experiences might expose them. Yet even to raise this point is to acknowledge the truth of Saiving's central argument: it is a mistake to view all sin through the prism of prideful assertion of one's own desires against the will of God. Some - in our present social context, women especially - experience not an active of their own will against what God wills, but an acquiescence to another's attempt to determine one's own will. As Susan Nelson Dunfee notes, our "hiding" can also be sinful, as we avoid the call to exercise our agency and assert our own value in the face of those who would question it. ${ }^{71}$ Sanctification will surely require some to renounce their sinful ambitions and submit their wills to God; but for others, it will involve renunciation of the lies they have been told about their lack of competence or value, and will require their speaking and acting boldly. If we wish to offer any universal description of sin, then, we would be wise to avoid searching for one sin exemplified by all people, and focusing rather on the fact that every sinful will is moved by desires improperly ordered to God as their final referent. This is what defines every heart suffering the consequences of original sin; and whether our contingent social orders and one's own agency shape one's loves into prideful selfassertion or paralyzing self-doubt, all alike find our own misapprehensions of the world substituted for the truth of God's creation. If we do not all live in fantasies of our own making, we nevertheless all dwell in worlds crafted by $\sin$.

In sum, the state of sin is not a positive state at all, but one of compounding fractures: the soul from God, the body from the soul, my life from that of my neighbor, the world's truth from my understanding, the oppressor from the oppressed, one society from another. To the extent that any provisional unities emerge apart from the grace of God in this rolling catastrophe, they are illusory and unstable. Without being enlivened by the presence of God, we begin a descent toward disorder and chaos, moving ever more swiftly to our desired end in the utter formlessness of the nihil.

\section{The Work of the Spirit}

In forsaking God, the sinner loses the source of its own life - the source of its ability to will the good, and persist in the love of God. As Augustine writes, "Deprived of that light and, therefore, blind, he will necessarily stumble more, and in falling, he will be injured, and once

\footnotetext{
${ }^{71}$ Susan Nelson Dunfee, "The sin of hiding: A feminist critique of Reinhold Niebuhr's account of the sin of pride," Soundings 65, no. 3 (1982): 316-27. Saiving's insights have also been developed by, inter alia, Daphne Hampson, "Reinhold Niebuhr on Sin: A Critique," in Reinhold Niebuhr and the Issues of our Time, ed. Richard Harries (Oxford: Mowbray, 1986), 46-60; Judith Plaskow, Sex, Sin, and Grace: Women's Experience and the Theologies of Reinhold Niebuhr and Paul Tillich (Washington, DC: University Press of America, 1980); and more recently (and critically) Jodie L. Lyon, "Pride and the Symptoms of Sin," Journal of Feminist Studies in Religion 28, no. 1 (2012): 96-102.
} 
injured, he will not get up."72 What remedy is there for this condition? How, lacking the power to turn our hearts to God, can we be restored to the proper ordering of our loves?

As Patout Burns argues, Augustine increasingly comes to believe that only direct divine action to create the true love of God in our hearts, what Burns calls "operative grace," can resolve our predicament. On Burns' telling, while the crucial insight that God's will alone is responsible for our salvation comes in 396 with the letter Ad Simplicianum, ${ }^{73}$ Augustine's account of how God effects the conversion of our hearts was a more gradual process:

In De diuersis quaestionibus ad Simplicianum, Augustine explained that God moves an individual to faith by providing motives which appeal to his prior dispositions, his unfulfilled desires for good. Twenty years later, in Epistula 194 to Sixtus of Rome, he developed a theory of conversion as a reversal of evil tendencies by an interior grace. A decade later, in De correptione et gratia, he combined the two explanations to assert that God maintains the elect in good to the end of their lives by a combination of environmental and interior graces. ${ }^{74}$

The movement is, generally speaking, one from an account centered on "congruous vocation" to one of "operative grace." A theory of congruous vocation holds that the same call to conversion is issued to each person in the course of their lives, but that the call is made efficacious (or not) by the manner in which it is issued, and the ways that our experiences and habits in willing have prepared us to receive the call in the moment it is issued.

It is important to note here that the question is not about whether or not God assists us by grace: on a theory of congruous vocation, God's grace is active both in His providential ordering of our lives such that we will be disposed to receive the call favorably, as well as in God's decision to issue the call at a moment in which we will be receptive to it. Without such a call being issued, the external influences are insufficient to draw our loves to God; but without God preparing us through these influences over the course of our lives, we will not respond to the call God issues with faith. Both the call and our preparation for it must be considered gratuitous if we respond in faith by the conversion of our loves to Christ, but we should note the radical situationalism that this position accords to God's redemptive work. Suppose that God providentially orders my birth and upbringing in a seaside town, disposes the events of my life such that I am nurtured in the love of the ocean, and then issues a call to conversion in a time of peril on the water or as I am meditating on the beauty of the ocean's crashing waves. Had the events of my life been

\footnotetext{
72 nat. et gr. 22.24; WSA I/23, 227.

${ }^{73}$ A standard presentation of a significant shift in Augustine's understanding of God's elective purposes can be found in Peter Brown's description of Augustine's "lost future"; see Augustine of Hippo: A Biography, 2nd Edition (Berkeley: University of California Press, 2000), 139-50. While such a shift does seem present to me in Augustine's thought, particularly on the question of whether our intellects are capable of driving our ascent to union with God or whether our desires take precedence as they are animated by grace, Carol Harrison offers important reminders on the continuity of Augustine's thought from early to late at Rethinking Augustine's Early Theology: An Argument for Continuity (Oxford: Oxford University Press, 2006).

${ }^{74}$ J. Patout Burns, The Development of Augustine's Doctrine of Operative Grace (Paris: Études Augustiniennes, 1980$), 7$.
} 
different - perhaps a traumatic experience on a boat in my youth instead cultivates in me an aversion to the sea-I might respond quite differently to God's call to conversion, feeling no pull on my desires strong enough to break me away from the objects of my sinful willing. Or again, suppose that God had issued the call the day before, when work left me stranded in a gray windowless building; without being prepared for the call, I do not respond in faith. God, providentially ordering the moments of my life and infallibly knowing the circumstances under which I will or will not respond to the call with conversion, issues an effectual call to some, and an ineffectual call to others. Thus some are converted and some are not, according solely to the good pleasure of God; those who God wishes to save will receive a vocation that is congruous with God's preparation of their affections, such that our hearts will respond in charity to God's call.

Increasingly, however, Augustine comes to see the need for a more thoroughgoing account of grace's work, one that not only shifts the emphasis on who is active in turning our hearts to God, but pushes us to reconfigure our understanding of the interaction of divine and creaturely agency entirely. Some of this is attributable to Augustine's increasing confidence that even an understanding of congruous vocation will be insufficient to convert our hearts; as James Wetzel writes, "He has to move to an ever more radical internal operation for the simple reason that grace must answer an ever more radical condition of perversity." 75 When viewed in light of the account of sinful willing I have offered above, the problems with a theory of congruous vocation are apparent. On the theory of congruous vocation, he manner in which grace works leaves some doubt as to whether redemption itself is accomplished by God's will, or by the will of the one being saved. Certainly conversion is not effected without God's will: God disposes the influences that shape our wills and issues the effective call, and these together draw our wills to the love of God. The "motive force" of this conversion is provided by the human will itself; this is precisely what distinguishes it from an account of operative grace, in which God Herself works to create charity in our hearts. ${ }^{76}$ On the theory of congruous vocation, the will is responding to the lure of God's goodness made irresistible in the moment of conversion by providence, but requires no further assistance to love God properly. ${ }^{77}$ Yet the account of sinful willing I have offered above suggests that no external conditions, no history of the will's preparation to receive the call, can of themselves result in the conversion of our hearts to the love of God. It is not simply that

\footnotetext{
75 Wetzel, Limits of Virtue, 188-9. Wetzel offers this as a gloss on Burns' interpretation.

${ }^{76}$ Cf. Burns, Operative Grace, 141: "The theory of congruous vocation and the accompanying understanding of the function of charity built upon the foundation of a natural desire for God and protected the autonomy of the human will. The call to faith presupposed dispositions which would, in appropriate circumstances, lead a person to ask God for assistance; charity strengthened a prior decision which had proven inadequate to perform the good works of the law. In neither case did God actually bestow a new orientation of the will or direct a person in a way which he was not himself already incipiently willing."

77 At Limits of Virtue, 191, Wetzel disputes Burns' belief that Augustine unambiguously held to an understanding of congruous vocation that assumes grace's operation is solely external even in the texts like Ad Simplicianum where Burns finds such an understanding articulated most clearly. While it seems to me that, on this point, Burns has the more convincing interpretation, I am content to let the exegetical question go unanswered; my principal aim in articulating the sort of account of congruous vocation that Burns attributes to Augustine is to render with greater clarity the logic of Augustine's later theology of grace, where I believe Wetzel serves as a particularly insightful guide.
} 
we lack the ability to see the way to God, and so to set our loves upon Her, but that our willing in our condition of sin is constitutively defective. Lacking the vitality of a soul that is already ordered by the love of God, all we are capable of is the reiteration of our sin - all we can produce are dead works.

More and more, Augustine comes to realize that only the operation of grace producing in us a charity in excess of what we ourselves can generate is sufficient to convert our hearts to God. On Burns' account, prior to the year 418 - and thus inclusive of his early anti-Pelagian works like De spiritu et littera - Augustine's account of grace's work "manifests an instability. He asserted the necessity of grace and urged the inadequacy of natural freedom to will properly and to perform consistently the commanded good. At the same time he sought to maintain human autonomy, at least in the roles of accepting, activating and preserving the power God gives."78 As Augustine becomes progressively aware of just how deeply debilitating sin is of our capacity to will the good, this balance shifts decisively toward the side of grace at the expense of human autonomy. After the year 418, a period in which he composed the important texts De gratia Christi, epistula 194, and Contra duas epistulas Pelagianorum, Augustine comes to believe that, as God grants those whom He chooses the "grace of conversion,"

The divine operation reverses a contrary disposition towards evil in bringing a person to faith in Christ. Moreover, it actually produces the consent of faith. Those whom the Father teaches, who hear Christ's words of life, who receive the Spirit of faith invariably repent and receive the gift of charity. ${ }^{79}$

In fact, Burns identifies three actions of God's operative grace: first, converting our hearts, and "produc[ing] human willing and consent"; second, creating in us "the charity which...makes a person seek and ask from God," a gift perfected in the beatific vision; and third, the grace of perseverance, "by which those elected to glory are maintained in the willing and performance of the good so that they reach salvation." 80 Augustine recognizes each of these aspects of grace's work in a distinct but interrelated process, coming to see the importance of grace in producing charity in the Ad Simplicianum of 397, the operative grace of conversion in the texts of 418, and the grace of perseverance finally in De correptione et gratia in response to the monks of Hadrumentum in the late 420s. This last advance, Burns tells us, is "modeled on the grace of conversion developed in 418." 81 What Burns views as the final iteration of Augustine's doctrine of operative grace is thus defined by a sort of perpetual dwelling within the moment of conversion. Our hearts are, because always sinful until fully restored to union with God, never able to produce anything but dead works, and so must at each moment be drawn by the operation of grace beyond their own capacities. This work of grace persists throughout our lives, strengthening our wills with as much consistently as God desires, but always in excess of what we could will on our own. To the extent

\footnotetext{
78 Burns, Operative Grace, 126.

79 Burns, Operative Grace, 157.

80 Burns, Operative Grace, 158.

${ }^{81}$ Burns, Operative Grace, 158.
} 
that we come to desire God's renovating work, this too is a product of grace's direct activity within us.

This is, I suspect, a depiction of Augustine's later anti-Pelagian thought familiar in its main outlines to many, though Burns has mapped with unparalleled subtlety and insight the contours and development of this Augustinian outlook. It is an account that we may call "soteriologically determinist": it avoids the hard determinism of claiming that all our actions are unfree solely in light of God's sovereignty, but suggests that in our bondage to sin our postlapsum "freedom" will always move us to sin. The operation of grace must pull us against our obstinate resistance to love of the good, progressively breaking our sinful habits and strengthening our ability to act morally. As James Wetzel recognizes, Burns' "final picture of grace's operation depends on viewing the scope of grace as the temporal extension of its means," essentially making the Christian life a series of repetitions of the moment of conversion; "in this," Wetzel holds, "Burns oversimplifies." 22 Burns' account functions by taking the moment of conversion and the operation of grace that produces it as a clear line dividing the life of the one converted into a before and after. Before, the pursuit of our loves moves us solely toward evil; after, God's grace slowly enables us to will the good. Before, we are autonomous in our sin; after, we are moved irresistibly by an interior activity of God. Before, we are sub lege; after, we are sub gratia. Each moment after grace's advent defines a before and after, in fact, as each new intervention of grace creates a capacity to will the good in excess of what had been possible to us before. Pointing to Burns' comment that the 'logic of Augustine's interpretation of Romans 9,16 which attributes salvific effects to the divine mercy rather than to human effort would eventually require that he eliminate all human autonomy," 83 Wetzel concludes: "Given the moment-bymoment intrusiveness of grace upon human willing, it is no wonder that Burns comes to view Augustine's reconciliation of grace and free choice as a zero-sum game."84

Is there any possibility of retaining a positive role for human freedom in light of grace's operation, or must we view grace as a merciful divine constraint placed upon our will? "The alternative response comes into view," Wetzel tells us,

when we no longer assume that the anachronism of conversion is merely an accidental feature of human appropriation of grace. Taking it as a necessary feature would mean that no change in the operation of grace could be interpreted to give human beings the opportunity to anticipate their conversion. ${ }^{85}$

This requires some explanation. As I have stated, Wetzel's worry with Burns' account is that, by contrasting the external summons of the congruous vocation with the interior gift of operative grace, Burns allows us to locate the moment when grace first becomes active in turning our hearts to God. This framing both reflects and reinforces a contrastive account of divine and

82 Wetzel, Limits of Virtue, 190.

83 Burns, Operative Grace, 169.

${ }^{84}$ Wetzel, Limits of Virtue, 190.

${ }^{85}$ Wetzel, Limits of Virtue, 194. 
human willing: before the gift of operative grace, our will leads us only to sin; after the moment of conversion, our will still resists God, but we can feel the oppressive weight of sin lifting as we are strengthened by grace. Such an account is needed, Burns reads Augustine as saying, in order to avoid any suggestion that we are responsible for the change in orientation as our hearts are turned back to God.

Yet Wetzel notes another feature of Augustine's changing reflections on grace's work: the more he stresses our powerlessness to turn our loves to God, the more hesitant he is to identify the beginnings of grace's work in our hearts. "Once he finds himself in the midst of redemption, the beginning of the process will elude the reach of his memory, much in the way that its completion extends beyond his expectation." 66 God's grace is experienced as "anachronistic": rather than seeing a qualitatively new operation of grace at work in the moment of our conversion, we come to see grace as always preceding our activity, without being able to isolate any moment of our lives when this work began. On Wetzel's telling, Augustine's account of grace is intended to rule out any suggestion that our own activity might come prior to God's act in our redemption. Burns' solution is to isolate the moment at which God's saving work begins to function, and to regard everything before this moment as either our own sinful will or as what comes to be seen as the ineffective external work of the congruous vocation (still gracious, of course, but not salvific). This reading ensures that the only actions of ours prior to operative grace will be thoroughly beholden to concupiscent desire; salvation will begin unquestionably with God.

Wetzel's account, on the other hand, sees the anachronism of grace not as a contingent feature of our experience - a mere inability to isolate the moment when grace did, in fact, begin working within us - but to view grace's anachronism as a structural feature of the relation between divine and human activity. On such an approach, we must see God's gracious activity as irreducibly prior to our own working, whether our wills remain in bondage to sin and thus tending to our dissolution or whether our wills are drawing us back to the love of God. In either case, our will must be seen only and exhaustively as called into being in response to God's gracious act; "The logic of divine anticipation consequently rules out human anticipation of the divine."87 This account answers the same Augustinian worry that Burns had set out to do, as there can no longer be any suggestion that any features of our own willing can precede the enlivening effects of God's grace, but it does so by redescribing the proper relation of divine and human willing itself. The upshot of Wetzel's presentation is that our whole lives, and all our willing, come to be seen as dependent upon the grace of God and included within God's redemptive work. No firm distinction can be drawn between God's use of external realities to draw us back to Him and God's work enlivening our desires through operative grace. The God who offers us creaturely signs pointing us back to Him is not separate from the one who is interior intimo meo, and so God's gracious work through these things is also the work in which God operates within. Though the moment in which our hearts are converted to the love of God

${ }^{86}$ Wetzel, Limits of Virtue, 194.

87 Wetzel, Limits of Virtue, 195. 
instead of a desire for the nihil does indeed indicate a qualitative shift in the ordering of our desires, the work by which God accomplishes this conversion need not be seen as more internal or more external than the work by which God had prepared us for this reorientation from the time of our birth onward.

It is important to note that Wetzel's account does not constitute a break with the necessity of grace's operation that Burns identifies: our condition when desirous of the nihil is as dire as Burns believes, and our conversion really is as dependent upon grace as his presentation claims. What changes in Wetzel's telling is the relation of grace to human freedom. Where Burns saw grace's operation as removing autonomy in a position I have described as soteriological determinism, Wetzel argues that the work of grace only intensifies human freedom. In light of this, we may describe his position as a compatibilist one (though with some reservations about how this description may misleadingly be taken to accept the terms within which the determinist/compatibilist/libertarian conversation is usually conducted within the analytic philosophy of religion). ${ }^{88}$ At the base of Wetzel's understanding of human freedom is a simple claim: "If God's power always lies at the bottom of ours, then we must cease trying to mark selfdetermination at the point where unadulterated human power begins to assert itself." 89 It is not our ability to resolve an inward indeterminacy between willing good or willing evil that marks our creaturely freedom. On the contrary, we are most free when we will in the way God has created us to will - when our wills are perfectly in accordance with the divine will, when we will what God wills that we should will. In sinful willing, we see the bondage of our incapacity to will according to our nature; in our freedom, we are able to will the good perfectly, and are thus most fully ourselves. We should note, however, that this compatibilist notion of freedom does not make us any less dependent upon grace than Burns' account does: we are still unable to will the good without being preceded by God's gracious work. What has changed is that on Wetzel's telling, rather than this work being described as pushing human freedom out of the picture, the operation of grace liberates us into true freedom. This is, fundamentally, a logic of noncompetition between divine and creaturely agency, one that teaches us to see all our willing and indeed our very existence as a response to the ever-prior work of God. ${ }^{90}$

Such an account will undoubtedly remain troubling for many, for it still holds that we are incapable of doing the good without being strengthened by grace - that we are only able to will the good that it is given to us to will. Even the attempt to preserve a place for our independent self-determination in a choice to accept or reject the promptings of grace must be ruled out; as

\footnotetext{
${ }^{88}$ Compatibilist presentations of Augustine's thought may be found at Lynne Rudder Baker, "Why Christians should not be Libertarians: An Augustinian Challenge," Faith and Philosophy 20, no. 4 (2003): 460-78; Katherin A. Rogers, "Augustine's Compatibilism," Religious Studies 40, no. 4 (2004): 415-35; and Couenhoven, "Augustine's rejection of the free-will defence." As Wetzel writes at Limits of Virtue, 216, however, "the issue of contention is not whether grace and freedom are compatible, but whether freedom is even intelligible apart from grace."

89 Wetzel, Limits of Virtue, 126.

90 Couenhoven has carefully marked how this shift from a libertarian to a compatibilist understanding of freedom led him to abandon the free will defense against the problem of evil, and to focus instead on the deficient cause of a sinful will and the condition of possibility of the fall in our changeability; see "Augustine's rejection of the free-will defense," 286-90.
} 
Wetzel writes, "Freedom to resist grace is not...genuine freedom but bondage to sin." 91 We must make the leap of viewing freedom as being defined by the freedom to do what God wills. As Augustine notes in a letter at the end of his life,

entrust yourself without delay not to yourself...but to that powerful one who is able to do all things. Do not wait until he wills it, as if you were going to offend him if you willed it first. For, whenever you have willed it, you will be willing it with his help and by his working. His mercy, of course, anticipates you so that you may will it, but when you will it, you yourself will it. For, if we do not will when we will, then he does not give us anything when he makes us will. ${ }^{92}$

It is God who creates us, and God who creates a new will in us as we are redeemed. Only grace can draw our desires back to God, enabling us to will the good, know the world and our histories truly, and receive our lives and world as gift.

In concluding this section, however, I wish to draw to the fore one aspect of Burns' account that we have not yet considered. Burns argues that, as Augustine becomes more and more aware of the importance of grace in both conversion and the Christian life, he comes to see this grace as ever more fully identified with the dwelling in us of the Holy Spirit. ${ }^{93}$ Romans 5.5, which had long occupied an importance place in Augustine's thought, comes to occupy an even more determinative role in his account of grace: "is not the love of God, without which no one lives a good life, poured out in our hearts not by us but through the Holy Spirit who has been given to us?"94 In the important epistula 194, the Holy Spirit is presented as the source of all right desire, all right willing, all true knowing:

Just as no one, then, is truly wise, truly understanding, truly endowed with counsel and fortitude, just as no one in knowledgeably pious or piously knowledgeable, just as one fears God with a chaste fear, unless he has received the Spirit of wisdom and understanding, of counsel and fortitude, of knowledge, piety, and fear of the Lord (Is 11.2-3), so no one has any true courage, sincere love, or religious continence except through the Spirit of courage, love, and continence (2 Tm 1.7). And in the same way no one is truly going to believe anything without the Spirit of faith or to pray in a salutary manner without the Spirit of prayer. It is not that there are so many spirits, but one and the same Spirit produces all these things, distributing the appropriate gifts to each one, as he wills (1 Cor 12.11), because the Spirit breathes where he wills (Jn 3.8). ${ }^{95}$

\footnotetext{
91 Wetzel, Limits of Virtue, 206.

92 ep. 2*.7; WSA II/4, 236. Cited at Wetzel, Limits of Virtue, 195.

93 Cf. Burns, Operative Grace, 145ff.

94 ер. 194.3.10; WSA II/3, 293.

95 ер. 194.4.18; WSA II/3, 296.
} 
Grace is not, for Augustine, an abstract quality that inheres in the soul, but the eternal life of God producing temporal effects in our changeable hearts. It is the power of God active in creation; and as we saw in Chapter 2 above, with respect to the eternal Word's presence in the created flesh of Christ, this power is appropriately understood as God's dwelling within creation. The Holy Spirit dwells in us in a very different manner than the Word dwells in Christ, of courseChrist's flesh is singular in existing solely by virtue of its assumption by the Word. Yet the same God who is in Christ comes to dwell in our hearts in the person of the Holy Spirit. It is the Spirit who acts in us irresistibly to turn our loves away from the nihil; who creates in us the love of God; who enables us to remember, know, and will rightly; and who, in doing all this, makes us members of the body of Christ through love of God and neighbor. We must understand the internal operation of grace and our incorporation into Christ in their relation to one another; and so, we need to understand God's work in us as the activity of Christ's Spirit.

\section{Binding us Together}

In the midst of Augustine's epistula 194 to Sixtus, he includes a reminder in the course of interpreting Christ's discourse in John 6:

And he said, For this reason I told you that no one can come to me unless it has been given to him by my Father (Jn 6.66). This is why some of those who heard him speaking of his flesh and blood went away scandalized, but some remained because they believed, because no one can come to him unless it has been given to him by the Father and, hence, by the Son and by the Holy Spirit. For the gifts and works of the inseparable Trinity are not separate. ${ }^{96}$

In describing the operation of grace in the heart of the elect as the work of the Holy Spirit, we must always remember that the Spirit's activity is inseparable from that of the Father and the Son. Yet this is far more than a formal reminder of the eternal triunity of God's life, even in the heart of the believer. In recognizing the trinitarian shape of the Spirit's action, we affirm that the love of God poured out in our hearts is none other than the love of Christ.

In the life of Christ and the gift of the Holy Spirit, we find two temporal manifestations of the eternal life of God. The life of Christ offers us the true image of God, a human life exhaustively determined by the love of God - in fact, a human life which finds its distinct subsistence solely in being the human life of God. In the work of the Holy Spirit, we find that this very same power of God comes to dwell within us, creating in us the love of God and conforming both our desires and the actions that proceed from them to the will of God. Throughout the writings of the anti-Pelagian period, Augustine increasingly comes to describe Christ as the only just human person. ${ }^{97}$ Christ is unique in his perfect love of God, a love that properly orders all his

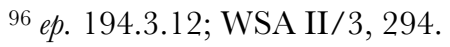

${ }_{97}$ While the description of Christ as uniquely just may be found throughout Augustine's work, Dodaro underlines its importance within the anti-Pelagian works at Christ and the fust Society, 78: "When considering Christ's person and
} 
other desires as referring finally to the summum bonum. In the integrity of his person, the divine will is perfectly united to a human will. Christ's human will is God's will, no less than the will of the Word is one with the will of the Father and the Holy Spirit; and to the extent that it is possible within the created order, the human will and desires of Christ reflect and perfectly express all that is contained in Christ's divine will. Christ's human will and desires thus exist as intrinsically related to the will of the Holy Spirit, just as Christ's divine will does. We see moments of this interrelation in the Scriptural witness, as when Christ is driven into the wilderness by the Spirit, or preaches in the synagogue at Nazareth the year of the Lord's favor. ${ }^{98}$ Throughout his ministry, the Holy Spirit empowers Christ's human nature as a reflection of the Spirit's differentiated identity with the Son who is incarnate in Christ. ${ }^{99}$ The Son and Spirit (along with the Father's act of sending, expressed temporally as the Father's commanding of Christ) therefore operate inseparably not only in eternity, but also in enabling the responsive and perfect human love of God in Christ. Christ's human desires exist not only as those of the human life assumed into unity with and dependent for its personal subsistence upon the Word, but as human desires answering to the indwelling of the Holy Spirit.

In a very real sense, then, the desires created in us by the power of the Holy Spirit are Christ's own desires. Inasmuch as we will what the Spirit wills - an always-imperfect identity on this side of the eschaton - we will the content of Christ's divine-human will. Inasmuch as our loves are ordered properly by and to the love of God, our loves correspond to Christ's own human loves enlivened by the presence of God in him. It is perhaps not too misleading to imagine that, as our wills come to be shaped ever more fully by the gracious activity of the Spirit, our wills come to reflect (again, always imperfectly) what Christ himself would have done had the circumstances of his life been exchanged with our own. Just as Christ's will is the Word's perfect human repetition in time of what She wills eternally, so also our wills come to resemble more and more a responsive human willing of the Spirit that dwells within us - a Spirit which is the Spirit of Christ, willing none other than Christ wills. The relevant difference is that what we will by grace, Christ wills by nature; or, more precisely, we will by grace what Christ wills necessarily in his humanity by virtue of that human subsistence being the humanity of the Word, united to the gracious activity of the Holy Spirit working in Christ inseparably from the Word throughout his life. The Spirit enables us to will what Christ wills. Indeed, because Christ reigns in heaven even now united to his human flesh, we must say that in drawing our loves to God and teaching us to will what God wills, the Spirit conforms us to what Christ actively does will for any particular

work in an anti-Pelagian context, Augustine at times draws a parallel between the two pairs 'just and justifying' and 'ignorance and weakness'. In so doing he asserts that, as a truly just man, Christ offers the only perfect example of justice that can cure ignorance, while as the God-man he offers the grace by which the soul is enabled to understand and imitate his example."

98 Eugene Rogers' constructive pneumatology is centered on those moments of the Scriptural narrative when the Spirit appears in Her work of resting upon Christ's body; see After the Spirit, Part II.

${ }_{99}$ Bruce L. McCormack has highlighted the importance of the Spirit's ministrations to Christ's human nature at "Karl Barth's Christology as a Resource for a Reformed Version of Kenoticism." International Journal of Systematic Theology 8, no. 3 (2006): 243-251. 
situation. In this way, the lives are the saints are lived not only in imitation of Christ, but as an extension of Christ's own life, his will becoming ours through the Spirit's activity.

It is in this sense that we must speak of the love of God as the means of our union with Christ. The Spirit creates in us the love of God; but we cannot come to love God without loving also the man who is God. Though the perfect Good of God in Herself remains invisible to us, in the Spirit's direction of our loves to the human flesh of Christ, we are graciously made to love the temporal manifestation of God's perfect Good. As our hearts direct our minds to him in loving contemplation, we find an intelligible image of God's justice, and come to understand haltingly but ever more deeply the character of God's love, judgment, and mercy. As we come to understand God's life in Christ, we find the true intelligibility of our own lives. Leaving aside the self-deceptions that characterize our experiences as sinners, we learn to see the purposes of God threading through our lives, God's gracious activity always preceding our own. In this new understanding of our lives in God, we find that our own judgments about our lives come to reflect ever more deeply God's own - we see our sin as sin, and our flailing desires as inchoate longings for God. We come to recognize Christ's own desires taking root in us, his words made ours, paradigmatically in recitation of the Lord's Prayer. Similarly, because our desires and judgments are shaped by the Christ's own through the activity of the Holy Spirit, we learn to see our actions as proceeding from Christ's own heart - we become his hands and feet in the world, our acts of justice and mercy being referred back to him as their source. As our hearts and minds are sanctified, we come to find a new coherence of our lives in God's providential ordering of created history, and a new stability in our desires as they are ordered ever more fully by the love of God. Christ's life is repeated in our own, novel in circumstance, and in that we are free to live our own lives fully the more he lives in us. Though Christ remains unique in that his human flesh exists only as the human life of the Word, we find in our own lives a movement towards the same perfect responsiveness of our human wills to the will of God working within us. Our lives become an extension of the Incarnation.

Yet even this is not a sufficient description of the intimacy of union with God we find in the life of Christ. For while the love of Christ that the Spirit creates in us provides an account of how Christ's actions, words, and desires become our own, they do not yet help us understand how our actions, words, and desires become Christ's. Here again, we face the question, how can God cry out in godforsakenness? How can the ascended Christ ask "Saul, Saul, why persecutest thou me?" In coming to be his body, we define more precisely what it is for Christ to be head, what it means for him to have willed to be complete with us. We have discussed already how Christ's assumption of flesh, the Word's will to occupy in a human life a determinate position in space and time, necessarily relates him to every moment of spacetime (Chapter 2). We have discussed also how God's providential ordering of created history - the relativistic relations obtaining between these moments of spacetime and the events that they contain - serves to make each created particular and the relations between them into signs of Christ's flesh (Chapter 3). Finally, we have seen how Christ's life is given its redemptive shape, serving as the perfect created sign of the divine life, through the relations he bears to the rest of the created order: most evidently to those persons that influenced him directly, through his childhood, adult friendships, 
ministry, and sacrifice, as well as through the events that formed the context of his life; in more cosmic scope, through the fact that created particulars distant from Christ's human flesh in spacetime are nevertheless made redemptive signs for us, thus serving as instruments through which Christ's salvific work is accomplished and by which his reign over creation is made fast. Only as situated within his history, bearing determinate relations to the rest of the created order, is Christ's humanity complete (Chapter 4). Yet in attending to the Spirit's activity of creating Christ's own desires in us, we find that we are given the will to participate in Christ's work. As Christ desires the redemption of the world, so we too come to desire it through the Spirit's work. Our lives not only begin to reflect a likeness to Christ's as his loves take root in our hearts - we are empowered to desire that our lives be made signs of Christ's own. In uttering the cry of our dereliction, and indeed, in suffering our godforsakenness through his perfect misericordia, Christ teaches us that our lives are bound to his even in his resurrection; in taking on the sufferings of his body as his own, he teaches us that his redemptive work is made ours.

Christ's life is only fully intelligible in the light of God's desire to redeem the world; we know him as he truly is precisely as he comes into focus as our redeemer. But it is also true that we come to know him as redeemer as other created signs teach us about him, and most fully as we see Christ in the lives of others and find that they meet Christ in us. Christ redeems us by using the things of creation to teach us about himself - and his life is only fully intelligible as the center of all God's redemptive work insofar as that redemptive work is actually accomplished in us, and with the activity of creaturely mediators. As Christ desires to redeem the world by including our lives in his own, so also we come to desire that God should accomplish the salvation of the world by making us Her instruments. We see an early New Testament intimation of this in St. Paul's words to the Church of Rome, "I could wish that I myself were accursed and cut off from Christ for the sake of my own people, my kindred according to the flesh."100 The possibility is entertained as a counterfactual, and there is no hint that St. Paul actually means to propose his own damnation for the sake of the Jewish people. Even so, the text expresses the stirring of a desire to repeat in his own life the work of Christ; the translation perhaps mutes some

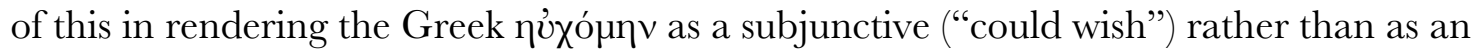
imperfect indicative ("was wishing"). Are we to understand Paul's expression of this desire as his coming close to error by wishing to enact a work accomplished only properly by Christ, or are we to see in this desire his being conformed to the love of Christ, willing to become a curse as Christ did? Here again, we may turn to the suggestive passage in Colossians 1.24: "in my flesh I am completing what is lacking in Christ's afflictions for the sake of his body, that is, the church."101 This passage points to a mystery, I will argue below, that is at the heart of our union with Christ. Perhaps the high-water mark of the theological outlook I am commending can be found in the for many scandalous identification of the Blessed Virgin Mary as "co-redemptrix." 102 This,

100 Romans 9.3. The HarperCollins Study Bible: New Revised Standard Version, Including the Apocryphal/Deuterocanonical Books, ed. Harold W. Attridge, Wayne A. Meeks, and Jouette M. Bassler (New York: HarperOne, 2006). Hereafter NRSV. 101 NRSV.

102 A brief history of the development of this motif may be found in Aidan Nichols, O.P., There Is No Rose: The Mariology of the Catholic Church (Minneapolis: Augsburg Fortress Press, 2015.), pp. 67-85. 
of course, goes beyond anything Augustine himself said, though Pope John Paul II pointed to a comment in Augustine's De sancta virginitate as one of the clearest Patristic anticipations of the idea:103 "she was born spiritually from him, as everyone who believes in him, including her, is rightly called a child of the bridegroom. On the other hand, clearly she is the mother of his members, which is ourselves, since she has cooperated with charity (quia cooperata est caritate) for the birth of the faithful in the Church." 104 Aidan Nichols points to a passage from St. Ambrose that emphasizes Mary's cooperation in redemption even more than Augustine had done:

While the apostles were in flight, she stood before the Cross, animated by sentiments worthy of the Mother of Christ. She contemplated with love the wounds of her Son, for she was less preoccupied with the death of her child than with the salvation of the world. Perhaps indeed, knowing that by the death of her Son the redemption of the world was worked, she hoped to be able by her own death-to-herself to contribute some little to what was accomplished for the profit of all. ${ }^{105}$

Even in Augustine's own day, then, the teachers of the Church had begun to see in Mary's life an activity corresponding to, and even cooperating in, Christ's redemptive work. And, as this quotation from Ambrose shows, this activity proper to Mary's life is inextricably related to her own embodied loving contemplation of Christ's own redemptive life.

But can the language of "cooperation" - or worse, "co-redemption"-be appropriate here? Does this not force us to say that Christ's own self-offering is insufficient for redemption? Mark Miravelle offers a helpful reminder here: "The prefix, 'co-' derives from the Latin term 'cum,' which means 'with' (and not 'equal to'). Although some modern languages, such as English, sometimes use the prefix 'co' with connotations of equality, the true Latin meaning remains "with." 106 Referring to Mary as "co-redemptrix" is thus entirely compatible with viewing her redemptive work as secondary to, indeed entirely derivative of, Christ's work. What this title emphasizes is instead the coincidence of this work: though Mary's contribution to God's redemptive work is never found apart from (or apart from its dependence on) Christ's activity, neither is Christ's redemptive work ever found without Mary's fiat, without her feeding her son from her own body, without the sword of grief piercing her heart at his crucifixion. ${ }^{107}$ Indeed, Mary's place as theotokos ensures that she is uniquely qualified to be called co-redemptrix: because Christ's flesh is drawn from her own, and with her cooperation, there is no act that Christ

\footnotetext{
103 General Audience, April 9, 1997, L'Osservatore Romano, English edition, April 16, 1997, p. 7; cited at (Miravelle 2003), p. 75n.25.

104 virg. 6.6; WSA I/9, 70.

105 Ambrose, Expositio evangelii secundum Lucam 10.132; cited and translated by Nichols at There Is No Rose, 72. 106 Mark Miravelle, With Jesus: The Story of Mary Co-redemptrix (Goleta, CA: Queenship Publishing, 2003$), 9$.

107 As should be clear, I do not mean to imply that Mary's sole redemptive contribution is in her fiat - what some have called a "subjective" interpretation of Mary's status as co-redemptrix. Far closer to my approach is E.J. Cuskelly, M.S.C.'s account, which holds that the division of Marian theologies into "subjective" and "objective" approaches occludes more than it illuminates; see E.J. Cuskelly, M.S.C., "Mary's Coredemption: A Different Approach to the Problem," Theological Studies 21, no. 2 (1960): 207-20.
} 
performs in the flesh that is entirely separable from her work. In this, Mary's co-redemptive work too is qualitatively different than our own; yet this co-redemptive act serves for the Church as a model of how we should understand the incorporation of our own lives and actions into Christ's redemptive work. In the course of our reconciliation with God, the Spirit of Christ creates Christ's own desires in our hearts, making our lives extensions of the Incarnation. This occurs both through the inward operation of grace and through the gift of external signs, something (as we saw in Wetzel's argument against Burns) possible through the non-competition between divine and creaturely agency. As we are made signs of Christ, our lives are offered to others as the redemptive signs through which the Spirit will create the love of Christ in them, just as their lives are offered to us. We become signs of Christ to one another, and so Christ uses us - our bodies and agency - to accomplish his redemptive work. Jesus Christ cannot be head without his body, and is not our redeemer without us; he becomes complete in our lives.

None of this is to be referred to the individual, but is meant to illuminate the pervasive structure of God's work: God's absolutely prior giving, and our irreducibly posterior response. Even in the eschatological life of the saints, when our loves will be perfectly conformed to Christ's own, our agency will always and only follow upon the grace of God. There can be no question here of the ultimate merit of our actions accruing to us, for God's work always precedes our own. In speaking of the Blessed Virgin Mary as co-redemptrix, or of our own lives as redemptive signs of Christ, we are appealing to the same style of paradoxical language that characterizes Augustine's sermons on the Nativity, and to a similar end: to convey the dazzling mystery of the unity of divine and human action, in Christ's life and in the lives through which he walks in the world even now.

This shocking theological language in fact does nothing more than follow to its end the charge given to all Christians in relating to their brothers and sisters: to love one another even as Christ has loved us. In ordering our hearts by the true charity that is the love of God, we are drawn necessarily to the love of our neighbors. In fact, in Augustine's account of the totus Christus, we find the love of God and neighbor inseparably drawn together. ${ }^{108}$ This occurs at several related levels. First, in creating the love of God in us, the Holy Spirit draws us to love all persons without exception. The ordering of our loves by charity teaches us to love things as God loves them, and so, to the extent that our own hearts are properly directed to and by the love of God, we will love all persons in God. In fact, we may say that the Spirit creates Christ's own desires in us, infusing in us the love with which Christ loves all persons. This first level sense in which the love of God and neighbor are brought together ought not, therefore, be perceived as a general and indeterminate charge to love those around us, but as command given content and normed by the life of Christ. To love our neighbor in this unrestricted scope is to love the enemy and the one who persecutes us; to love the widow, the orphan, and the stranger; to lay down our lives for one another. Indeed, as our hearts are conformed to the heart of God, not only are we called to the love of our human neighbors. Our relation to the whole of the created order is transformed,

108 This theme is the topic of Raymond Canning, The Unity of Love for God and Neighbor in St. Augustine (Louvain: Australian Historical Institute, 1993); see also Tarcisius van Bavel, "The Double Face of Love in Augustine," Augustinian Studies 17 (1986): 196-181. 
as we learn properly to love things as God has made them, to value them in all their natural distinctiveness. The love of God thus accomplishes a transformation of all our affective relations to the world, teaching us to know each thing as the unique creature it is, enabling us to love every created particular in God.

Second, the love of God and neighbor are bound together in the love of our particular neighbor Jesus Christ, who is also God. ${ }^{109}$ As the object of our devotion and contemplation, as the one whose life we are told lives in us, in loving Christ we love the visible sign of the one who is also the inner teacher. Through loving Christ's flesh, our hearts are ordered ever more fully to the love of the invisible God who is the highest Good, and our minds are purified and granted the scientia which is ordered to the eschatological fulfillment of sapientia. Yet in loving this individual, the finite creature who is the man Jesus Christ, we love the one who is Alpha and Omega, who is the firstborn of all creation, in whom all things hold together. Our love of this neighbor who is God again draws our love to all our neighbors, because this one is made known to us as Lord of all things. In loving Christ's determinate historical life, we love all that which made him what he is: the parents who taught him to speak, the doctors of the temple with whom he conversed, the friends who accompanied him through his ministry, the political and religious authorities who cannot see his kingship and over whom he sits in judgment. We come to love Christ as Lord over all of created history, and so we are made to love all of created history as that which is ordered to Christ. We are drawn to love each creature in gratitude as a unique sign of Christ, opening to us more deeply the mystery of his life and inspiring (literally, breathing in the Spirit) in us a fuller understanding of God's commands or a new power for acting in response to the call of God.

Third and finally, in loving other members of the body of Christ, we love our neighbors in whom the Christ who is God has come to dwell. Here, the divine love that God has put in our hearts for our neighbor is met with the divine love that God has put in our neighbor's heart for us. We are made one: I love my neighbor as Christ and am loved as the same Christ. Commenting on the statement of the first Johannine epistle that This is how we know that we love the sons of God (5.2), Augustine asks,

Which sons of God? The members of the Son of God. And he himself also becomes a member by loving, and through love he comes to be in the structure of Christ's body, and there shall be one Christ loving himself. For, when the members love each other, the body loves itself...But, if you love your brother, perhaps you love your brother and don't love Christ? How can that be, when you love Christ's members? When you love Christ's members, then, you love Christ;

109 Augustine preaches on Christ as our neighbor at s. 41.7; WSA III/2, 231: 'Take the word 'neighbor' as meaning the name 'Christ,' and take it so in humility. In humility, after all, you will match the humble and lowly one; in humility you will grasp him as the exalted one. Take him humbly and understand him as neighbor; for the Lord is near to those who have crushed their hearts (Ps 34.18), so that you may say in your prayer, As a neighbor, as our brother, so I accepted $\operatorname{him}(\mathrm{Ps} 35.14) . "$ 
when you love Christ, you love the Son of God; when you love the Son of God, you also love his Father. Love, then, cannot be separated. ${ }^{110}$

The unique relation between Christ and the Church, and the unique relation that members of Christ's body bear to one another, is thus derived from the fact that the same love exists in each of them. ${ }^{111}$ To the extent that the same Spirit illuminates their minds and sanctifies their desires, members of the Church perceive the same hurts in the world, and desire the same justice in it. The members of Christ's body desire as one that their individual lives and their lives together should be made into signs of God's love for the world, and that God will use their words and actions to draw those outside the community of the Church into the new life shared by those who have entered into Christ. Just as the individual believer is united to Christ through the work of the Holy Spirit, so also the whole Church exists as an extension of the Incarnation, the propagation of Christ's divine-human will far beyond the limits of one life and into a new community animated by his desires. The love of Christ's members for one another display that the work of the Holy Spirit is always unitive, in contrast to the destructive power of sin: the love of God knits together our lives to God, our self-understandings to the world, and our life to that of our neighbor. What sin has torn asunder, the Spirit of God mends, and love is the instrument through which God accomplishes this healing.

Here, as in the other two registers we have discussed, the unity of love of God and neighbor pushes toward a cosmic scope and yearns for eschatological fulfillment. Just as we are not yet perfect in the love of God in Herself or in the love of the man Jesus Christ our neighbor, so also the love of God has not yet fully determined the communal life of Christ's body, and the membership of the City of God has not yet reached its full complement. Many who are predestined to be united with Christ have not yet been enlivened to the love of God by the Holy Spirit; the creation through which the Church travels on its pilgrimage still groans in expectation of Christ's renewal of all things. The end of the Church is the same as that of creation - that God may be all and in all. Yet in the midst of this long wait for Christ's return, the Church has a distinct vocation: it is the one part of creation that is empowered self-consciously to will what Christ wills, to desire what Christ desires, to love as Christ loves. The Church is unique in that, by the gracious work of the Holy Spirit, it is enabled not only to conform to the love of God, but to desire that it be conformed to the love of God, and to know this as its telos. The Church not only serves as a sign of Christ (as does all of creation), but wills that it may serve ever more fully as a sign of Christ. The Church not only plays a role in Christ's redemptive work, as did the ground on which Christ trod or the fish that nourished his body; it is given the power to participate in this work, to become in its own life the completion of Christ's life. For only through our discipleship has Christ willed to be Lord; only in our redemption is he Redeemer; only with our humanity has he become flesh.

110 ep.Io.tr. 10.3; WSA I/14, 148.

111 Cf. Philippians 2.2. 


\section{The Way of the Cross}

Such is the life of the saints in glory - but we are far from saints. This perfect love of God in Christ and in our neighbor is the eschatological hope held out by the Church, but it is undeniably far from our present experience. We cannot now see the world as God sees it, or love it as He loves it. In God's eyes, even the defaced goodness of creation is ordered to restoration, and moved toward it by His loving acts of wrath, judgment, forgiveness, and mercy. Because we can now see God's goodness only imperfectly, we cannot reliably see even the misshapen reflections of it that lie at the heart of each creature. We cannot, in fact, even see the full extent of the violence we do to one another, for we do not truly understand how deeply our acts mar a goodness we do not know. That God is making of created history a story of healing and repair depends solely on grace, not on any inner logic submerged beneath the sheen of our suffering, or on the engine of history itself. In our hands, as the sinners we are, our histories are defined by bloodshed, inattention to suffering, self-interest, institutionalized subjugation, cowardice, and betrayal. To the extent that our lives are not yet clearly seen as an unrelenting campaign to extinguish those who might threaten the bastions of our self-understandings, it reflects God's gracious work in our hearts well beyond our calling into the community of Christ - but also, how much deeper a fall remains possible for us. Created goods are signs of God in virtue of their participation in God, their existence itself; but they are signs of Christ's flesh inasmuch as they participate in the woundedness of his flesh and in God's victory over death and corruption. Each moment of time, each created particular in some deeply compromised way reflects its transcendent source in the God who is the fullness of the Good. Yet precisely as a history, as the course of the world God has made, the horrors we have carried out on one another and our world signify Christ's flesh in that they are the death he overcomes and the hell from which he redeems us. The broken bones and unattended graves of the hominids slaughtered by the newlyascendant homo sapiens, the Mesopotamian plains damp with the blood of ruined armies, the pervasive violence inflicted on the bodies especially of women and children, the claustrophobic darkness of the slave hold, the crematoria of Treblinka - these manifest the same death that is worked by imperial violence on Christ's body; this is the history of which Christ becomes a part; these moments are signs of Christ's flesh in his suffering alongside the afflicted, and as his resurrected body proclaims God's victory over death. It is in Christ's humanity that he is made judge of all things, and given power to root out the forces of $\sin .{ }^{112}$

If we hold that the Holy Spirit has called and bound together even the local manifestations of the Church in which we worship today, they are nevertheless marred by the same sin that retains an influence on our desires. Our parishes are places of redemption, but in that very redemptive work are places also of racism, patriarchy, heterosexism, classism, nationalism, and abuse. ${ }^{113}$ To the extent that our churches are the Church at all, this can be

\footnotetext{
112 Christ's judgment of humanity in his human flesh is a major concern of trin. 1.13.28-31.

113 The language of individual congregations as "places of redemption," as well as a subtle analysis of the difficulties involved in identifying flawed human communities as such, may be found at Mary McClintock Fulkerson, Places of Redemption: Theology for a Worldly Church (Oxford: Oxford University Press), 2007.
} 
referred only to the work of the Holy Spirit - to the beginnings of Christ's charity that She creates in our hearts, and to Her willing to work through the rites and liturgies of the Church. The question of this section is how this indwelling of the Holy Spirit is manifested in the Christian life, of how the Spirit's work gives to Christian life a particular shape. If our lives may be described as the histories in which the Holy Spirit writes us into Christ's life, creating his own desires in us and enabling us to act as his hands in the world, how is sin overcome in us?

Augustine offers an answer in the sixtieth of his Enarrationes in Psalmos: "Christ has made himself a pattern for the life you live now by his labors, his temptations, his sufferings, and his death; and in his resurrection he is the pattern for the life you will live later." 114 If we wish to enter into the new life promised by Christ's resurrection, it is necessary that we be joined to his cross - that we repeat in our own lives the pattern he establishes in his teaching, sufferings, and death. This call to suffering is complicated both by Augustine's understanding of the dynamics of both sin and Christ's redemptive work. Our condition is one of infirmity, and as one of Augustine's favorite christological images would have it, Christ is our doctor (Christus medicus): "he is a physician, and there is still some diseased tissue in you. You cry out, but he goes on cutting, and he does not stay his hand until he has done all the cutting he knows to be necessary. In fact it is a cruel doctor who listens to the patient's cries, and leaves the festering wound untouched."115 We must note first here that, on Augustine's rendering, we are already trapped within suffering we cannot escape. This is, in significant part, the suffering brought about by our own sinful acts and desires: because we place our loves in transient goods, we are constantly disappointed when we inevitably lose them; or we attain the object of our desire, and suffer disappointment that it cannot fulfill the outsized love that we held for it. More expansively, our misshapen loves have left us bereft of God, and separated from our neighbor: we either attempt to dominate others, treating them as objects rather than humans and so closing off the opportunity to relate to them as fellow humans; or we find our lives riven by the domination of others, constraining our agency and freedom to share fellowship both with our oppressor and with those oppressed alongside us. Yet in speaking of the suffering in which Christ our physician finds us, Augustine has a wider sense than even this in mind. Whether out of a desire to focus on the sorts of suffering caused by sinful human actions or institutions and therefore able to be resisted by liberatory struggle, or out of a desire to conform our understanding of human finitude to the data of empirical science and common experience, contemporary theology rarely understands so-called "natural evil" as being a consequence of sin's entry into creation. By contrast, Augustine understood (and I believe we should understand) experiences like disease, the weakness of age, natural disasters, and death itself to be features of our experience that display the effects of sin upon us, a reflection of the disaster that sin has brought upon creation. These purportedly natural evils in fact show precisely how unnatural our present condition is, and how great is our need for a healer.

It is in light of these facts that we must interpret statements like that at en.Ps. 37.16: "Just as he willed to take our sufferings on himself, because we are his body, so we too must will his

\footnotetext{
114 en.Ps. 60.4; WSA III/17, 195.
}

115 en.Ps. 33(2).20; WSA III/ 16, 39. 
sufferings to be ours, because he is our Head." 116 It is not simply that we must suffer because Christ suffered, a claim that has served to authorize abuse and undermine Christian resistance to the work of injustice. ${ }^{117}$ Rather, Christ has first taken on our suffering: for our redemption, he has exposed himself to the violence of others; he has experienced the betrayal of his friends and the death of those close to him; he has felt his body torn by the lash, and abandoned himself to the inescapability of our death. Yet in assuming our condition, Christ has created a new possibility for us in the suffering that still inevitably marks our lives - instead of being encountered as sheer loss, a bare reflection of our self-destructive desires and the wickedness of the world in which we live, the pains of this life can now themselves be known as signs of Christ. This is emphatically not to say that these sufferings in themselves should be considered good, but rather that in the evils we encounter in our lives, we are now able to see the very same evil that Christ overcomes in his resurrection. To the extent that this pain draws us away from our sinful desires and to the love of Christ, even these sufferings may be considered redemptive. This can be no counsel to seek out worldly pain and loss, for our suffering only serves as a sign of Christ inasmuch as it too is meant to be overcome in resurrection. Only that suffering is redemptive for us which leads to new life, which shows in our own lives the power of Christ's victory over death. To the extent that Christian faith leads us into suffering we might otherwise escape, it is as a result of a life lived as testimony to the Resurrection. As Augustine continues in the passage from en.Ps. 37 above, "To certain disciples who aspired to a place close to him in his heavenly kingdom he replied, Are you able to drink the cup I am to drink? (Mt 20:22). Those sufferings of our Lord are our sufferings. If anyone serves God loyally, keeps faith, pays his debts, and lives justly among his fellow men and women, I should be surprised if he does not suffer, and even suffer what Christ here recounts of his own passion." 118 Being joined to Christ's cross thus entails being joined also to his resurrection; separating two moments of the Triduum can lead only to a masochistic spirituality, or a complacent one that feels no need to suffer in resisting injustice.

Though Augustine certainly holds that the unavoidable sorrows of our lives may at times provide a spur to contemplation of God, the dominant note of his meditations on our union with the suffering Christ is that we must imitate in our own lives the humility of the cross. As Augustine notes at sermo 360B.17, "Christ's humility is the remedy for your pride," 119 or what at trin. 8.5.7 he calls our "tumor of pride" (tumor superbiae). ${ }^{120}$ Our pride is healed as we "follow the ways he has shown us, especially the way of humility, which he himself became for us. He showed us the way of humility by his teaching, and he constructed it by suffering for us."121 Augustine's discussions of Christ healing our pride through humility is often joined to medical metaphors, as the imagery of the Christus medicus allows Augustine to clarify the precise sense in

\footnotetext{
116 WSA III/ 16, 159.

117 As argued by Joanne Carlson Brown and Rebecca Parker, "For God So Loved the World?", in Christianity, Patriarchy, and Abuse: A Feminist Critique, ed. Joanne Carlson Brown and Carole R. Bohn (New York: The Pilgrim Press, 1989), 1-30..

118 en.Ps. 37.16; WSA III/16, 159.

119 WSA III/ 11, 376.

120 WSA I/5, 247.

121 s. 23A.3; WSA III/2, 69.
} 
which we are to repeat Christ's sufferings in ourselves. The way of humility is, ultimately, the way of confession: "he gave us the way of humility. If we keep to it we shall confess to the Lord, and not without reason shall we sing We will confess to you, $O$ God, we will confess and call upon your name (Ps 75.1)."122 Indeed, humility is the essence of confession: "What does confessing to God mean, but humbling oneself before God, not arrogating to oneself any merits?"123

Confession is, finally, the implement that Christ our physician employs to treat our diseased hearts - though the nature of our malady ensures that this remedy will be painful. Even here, though, we see that the sufferings brought about by God's redemptive work are ordered to and accompanied by the thrill of new life in Christ. In a vivid passage, Augustine writes,

Let the Gentiles be glad and exult. Over what? Their confession itself. Why? Because he to whom they confess is good. He demands confession only so that he may free the humble; he condemns the one who refuses to confess only because he must punish the proud. You must therefore be sad before you confess; but once you have confessed, dance for joy, because now you have the prospect of healing. Your conscience has accumulated morbid matter, and a boil swelled up. It caused you agony and allowed you no rest. The physician applies the poultice of his words, and eventually lances it. He uses a medicinal knife to correct the trouble, and you must acknowledge the doctor's hand. Confess. Let all the pus come out and flow away in your confession; then dance for joy and be glad. Any residual sore will heal easily. Let the peoples confess to you, O God, let all peoples confess to you. ${ }^{124}$

On this presentation, confession is the sharp edge of God's gracious activity, separating that which is healthy in us from what is diseased. Confession painfully treats the worldly sufferings in which we were already enmeshed, in part because of our improper attachments to the transient goods around us. Augustine's recognition of the pain of our redemption indicates the double edge of our redemption: even our misshapen acts of love are nevertheless love, and therefore imperfectly but no less really reflect the creative love with which God calls the world into being. The misplaced objects of our desire are nevertheless the good things of God's creation, and offer a true if necessarily fleeting happiness when our loves unite us to them. These loves must be broken before they can be healed. In learning to love God properly, we must lose much that we currently value, a reality made no less painful by the fact that in cleaving to God we eventually receive back a restored relation to all things.

In confession, we find the heart of our incorporation into Christ. Augustine tells us that "There is a holy spirit in everyone who confesses, for it is already due to a gift of the Holy Spirit that you are disgusted by what you have done," 125 and that "The first grace that God in his kindness confers on us is to bring us to confess our weakness, to confess that whatever good we

\footnotetext{
122 s. 23A.4; WSA III/2, 70.

123 s. 23A.1; WSA III/2, 68.

124 en.Ps. 66.7; WSA III/ 17, 318.

125 en.Ps. 50.16; WSA III/ 16, 424.
} 
can do, whatever strength we have, is ours only in him, so that anyone minded to boast may boast in the Lord." "126 If confession stands at the beginning of our faith, it is also the activity answering to the work of the Holy Spirit that forms us into the body of Christ, for it is "when we have confessed and invoked him, and he has begun to take possession of us, then is formed the whole Christ, head and body, one from the many." 127 Confession for Augustine underwrites the whole of the Christian life, and is meant to accompany all our activities in the world.

This unrestrained scope is best seen in Augustine's well-known distinction between two sorts of confession, both necessary components of the life of faith: in a characteristic statement, he notes at en.Ps. 29(2).19 that "Confession is twofold; it can be of sin or of praise. When things are going badly for us, in the midst of our tribulations let us confess our sins; when things are going well for us, in our joy at his righteousness let us confess praise to God. Only, let us never give up confession." 128 This is, for Augustine, precisely the aim: never to give up confessing, but to let our confession of sin be transfigured into the confession of praise as we are sanctified by the work of the Holy Spirit and bound together as Christ's body. While we are in the midst of this saeculum we are to move ceaselessly between these foci of the Christian life, confessing our sins as we become aware of them or are granted the humility to turn away from sin, and confessing our praise as we come to know and love God more intimately. Our confession is never solitary, being offered first to God, but extending necessarily outward with the same love of neighbor that knits us together as the Church. We are to confess to our neighbors when we have wronged them, and to praise God alongside one another and in recognition of the work God is accomplishing in both our own hearts and that of our neighbors. Confession draws us out of fearful privacy into community, opening the possibility of forgiveness for wounds given or received, and leading us even now into the heavenly chorus in which we will everlastingly offer praise to God. We are creatures built for confession, and to the extent that we learn now how to confess our failures and our need for grace, we are prepared for a confession without end.

In discussing the "confessional mode" of Augustine's writings in the Confessions, James Wetzel remarks, "The basic imperative of confession holds constant throughout Augustine's thirteen tries at self-recollection and knowledge of God, and that is for him to face the great question of himself. Part of what it means for him to face this question is to suffer the death of his straying self; the other part is to surrender to the life that works through this death." 129 What is true here of Augustine's act of literary confession is no less true of his thought, and his understanding of the Christian life, as a whole. Our lives are lived confessionally, caught in a cyclical movement of dispossession, reception of God's gift, and responsive self-offering. ${ }^{130}$ On Wetzel's account, Augustine's meditations on his own life reveal sin to be fundamentally an avoidance of the flesh, a desire to live a life other than the one God gives us. It is not that we love

\footnotetext{
126 en.Ps. 38.18; WSA III/16, 189.

127 en.Ps. 74.4; WSA III/18, 42.

128 WSA III/ 15, 313.

129 Wetzel characterizes Augustine's writings as taking place in a "confessional mode" at Parting Knowledge, 61; the quotation is found at Parting Knowledge, 60.

130 Wetzel brings these three terms together at Parting Knowledge, 262.
} 
the material world too much, but that we have substituted our love for God's creation with a love for illusions of our own making. We attempt to find an intelligible life we can lead apart from the one we are in God, but this is an inherently self-defeating task: there is nothing to us that does not come from God, and so no life in us apart from God's gift. Confession, by contrast, returns us to ourselves, allowing us to see ourselves (for better or worse) in the finite, fleshly, presently-broken state that we inhabit; and, most importantly, to see that very life as the object of God's love. Grace teaches us not to flee the world, but to accept it, and to accept our dependence, our need for companionship, our sufferings, even the death we experience as a result of our separation from God. In surrendering our distorted projections and receiving our lives from God, we receive the whole world back, and are able to find ourselves marked by the same vulnerability we saw in Christ's own life: we enter into this world nursed by the bodies of others, labor in an environment dependent on innumerable creatures, and love in caressing the skin of another. All the quirks and idiosyncrasies of our existence, all the particularities and contingent events that have shaped who we are - all of this is woven into Christ's life; all of this is the life Christ lives in us. One of the particular graces of human life is that we are permitted to know God's work in Christ, and Christ's work in us. By the work of the Holy Spirit, we are enabled to offer our lives to God in response, desiring to become what Christ has already made us. Freed from self-deception, we learn and accept who God has made our neighbor in all her bodily particularity and with her own unsubstitutable history, and are liberated to love her accordingly, and to love God in her. In trees, in rocky shores, in birds lazily drifting overhead, we are finally able to receive the world for what it is: the work of God.

This, finally, is why an Augustinian theology must be resolutely and joyfully sacramental. God is spirit; yet God is present to us in flesh. In drawing all creation into union with God, She is not content to remain distant from the materiality of the world, choosing to dwell in the very signs through which She manifests Herself to us: in the flesh of Christ; in the Church; in water, bread, and wine. In baptism and eucharist, the sacraments by which we are made members of Christ and fed by the same body which we are, we find a repetition of the same confessional logic at work in Augustine's thought. In baptism, we are united to Christ's death, being dispossessed of both the selves and the worlds we have fashioned in our misguided refusal of the life God gives us. In the eucharist, we receive ourselves anew, but find ourselves incorporated within the body of Christ, living members charged to serve as signs of God's presence in the world. In receiving Christ's body, and as his body, we are made limbs by which God tends the sick, gives rest to the weary, blesses the dying, soothes the suffering, pities the afflicted, and shields the joyous. In baptism and eucharist, we are stripped of the lives we think we are leading and clothed in Christ, and in the light which is his life, we find ourselves and our worlds newly intelligible. We find, above all, that we are who we are most truly in him, and in relation to one another. Our particularities are not subsumed in Christ, but he becomes who he is - our Redeemer - by completing his life in and through our particularity.

So also, the particularity of water, bread, and wine (as well as oil, the laying on of hands, and all the other sensible elements of the sacraments) are incorporated into God's redemptive work, reaching their deepest intimacy with Christ as the Holy Spirit makes bread and wine his 
body and blood. ${ }^{131}$ Augustine is attentive to both the semiotic import of the sacrament, and to the realism of this transformation. In an Easter sermon, Augustine calls attention to the mystery of the Spirit's sacramental action, telling his listeners (among them the newly baptized), "What you can see here, dearly beloved, on the table of the Lord, is bread and wine; but this bread and wine, when the word is applied to it, becomes the body and blood of the Word." 132 Just as each moment of our own lives become newly intelligible as signs of Christ's flesh as we are drawn into his life, even the history of the bread can teach us of God:

Call to mind what this created object was, not so long ago, in the fields; how the earth produced it, the rain nourished it, ripened it into the full ear; then human labor carried it to the threshing floor, threshed it, winnowed it, stored it, brought it out, ground it, mixed it into dough, baked it, and hardly any time ago at all produced it finally as bread. Now call yourselves also to mind: you didn't exist, and you were created, you were carried to the Lord's threshing floor, you were threshed by the labor of oxen, that is of the preachers of the gospel. When, as catechumens, you were being held back, you were being stored in the barn. You gave in your names; then you began to be ground by fasts and exorcisms. Afterward you came to the water, and you were moistened into dough, and made into one lump. Wit the application of the heat of the Holy Spirit you were baked, and made into the Lord's loaf of bread. ${ }^{133}$

While it is in our loves that we are bound to Christ, and in our lives that we serve as signs of him, the realism of the eucharistic transubstantiation is matched by the reality of our incorporation into Christ. Our being made part of the totus Christus, Christ's becoming complete with us as an extension of the Incarnation, cannot be reduced to mere metaphor. In assuming flesh, Christ lives a human life that is affected by and dependent upon those around him, and enters into the

\footnotetext{
131 Aaron Stalnaker helpfully cautions against too neatly realist a reading of Augustine's sacramental theology, pointing to s. 229 as what we might call a particularly Catholic Augustine, and doct.chr. 3.9.13 for a more Protestant reading (cf. Stalnaker, "Spiritual Exercises and the Grace of God: Paradoxes of Personal Formation in Augustine," Fournal of the Society of Christian Ethics 24, no. 2 (2004): 137-70), 168n.69). My own thinking on the sacraments is deeply shaped by later Medieval thought, and thus while I am happy to draw on points where Augustine seems to write in a realist sense about Christ's presence in the eucharistic host, I am hesitant to lean on Augustine too much as a source for this position. Classic treatments of Augustine's expansive understanding of the sacraments may be found at Gerald Bonner, "The Church and the Eucharist in the Theology of St. Augustine," Sobornost 7, no. 6 (1978): 448-61; J. Patout Burns, "Christ and the Holy Spirit in Augustine's Theology of Baptism," in Augustine: From Rhetor to Theologian, ed. Joanne McWilliam (Waterloo: Wilfrid Laurier University Press, 1992), 161-71; and above all, Studer, "Sacramentum et Exemplum." One of the most provocative recent assessments of Augustine's sacramental thought may be found in Phillip Cary, Outward Signs, particularly pp. 155 on. It should be clear from the account I have offered in this chapter that understanding the noncompetitive relation between divine and creaturely agency in the operation of grace should present no difficulties for a true and robust Augustinian sacramentalism. What Cary sees as the inward operation of grace to the exclusion of any place for external signs should rather, I suggest, be reconfigured into a schema of the irreducible priority of God's action in the sacraments and a place being made for created signs as the means by which God mediates that grace.

132 s. 229.1; WSA III/6, 265.

133 s. 229.1; WSA III/6, 265.
} 
same course of finite causality in which we also have a place; in living his life, he occupies a region of relativistic spacetime that bears relations to every other point of cosmic history. We are made signs of his life, our existence itself ordered by the Word who Christ is, but in our redemption find our lives also transfigured as signs of Christ's suffering, death, and resurrection. Most intimately, by the work of the Holy Spirit, our hearts and minds are conformed to those of Christ, teaching us, to the extent we are sanctified, to know and love ourselves and all around us as Christ knows and loves them. The human life of the Word is repeated in our own humanity, by the power of the Holy Spirit; we are made one with Christ. In assuming flesh, the Word wills to be our Redeemer, and wills to draw us to Her through the redemptive sign of Christ's life. As this work is completed in us, as our lives too shine forth as signs of God, the man Jesus Christ becomes who the Word has willed him to be: his life is given its shape in his human will's perfect reception of his divine will, but also in the relations he bears to us. Christ accomplishes what he desires through us, showing himself to us in and through our own lives and those of our neighbors. He is perfected as Redeemer in our redemption, and this is complete only as the totus Christus is completed in us. 


\section{Chapter 6 Rising with Christ}

Christians live in the wake of the Resurrection, but also in that of the Ascension. Between these two poles - of Christ's resurrected presence, God with us in flesh even now; and of the hiddenness of that flesh, calling us to our eschatological home in worship at the throne of Godour stories unfold: this is the saeculum in which we struggle to discern the Good and act justly, in which we sin against God and our neighbor in ways known and unknown to us, and in which we confess each day both our sin and God's grace. To ask how we might live in light of the Resurrection and Ascension is to ask: what form of life follows from the confessional logic of dispossession, reception, and responsive self-offering that we discerned in the preceding chapter? What basis does Augustine's christology offer for reflection on moral theology; and less abstractly, what practices and patterns of action ought life in the Church inculcate, what demands of justice and sacrifice for my neighbor are placed upon me by the recognition of Christ's presence in all creation? This chapter has four aims: First, I describe in conversation with Augustine's texts how the Christian life is framed by the two moments of Christ's Resurrection and Ascension, the former showing us a possibility of a life no longer determined by the death we see all around us, the latter teaching us that we can only reach this goal by seeking Christ's presence in the world around us through humility, confession, and works of justice and mercy. Second, and in the longest section of the chapter, I attempt to sketch out an Augustinian ethical outlook that begins and ends with confession, returning us always to the acknowledgment of our own moral failures so that we may learn our utter dependence on grace for any possibility of knowing the world truly or acting justly within it. Third, I offer an account of how we are to seek the ascended 
Christ in the world, and, in light of the argument of the preceding section, how it is possible for us to recognize him in spite of the corruption of our knowing by sin. Fourth and finally, I offer a few words on the beatific vision of God to which Christ will bring us, asking especially whether the flesh assumed by the Word continues to mediate God's presence to us in the eschaton. This chapter constitutes the incarnational endpoint of this dissertation: while we began by discussing the eternal and immutable act of God's life in which She wills to assume flesh, here we arrive at the full extent of the totus Christus - Christ made concretely and perhaps surprisingly present among us in our lives, our cultures, and our shared search for just community in him.

\section{The Glorification of the Body}

The resurrection of the Lord Jesus Christ is the distinctive mark (forma) of the Christian faith. After all, that he was born as a human being of a human being at a particular time, while being God from God, God apart from any time; so, that he was born in mortal flesh, in the likeness of the flesh of sin (Rom 8.3); that he endured infancy, passed through boyhood, reached young manhood and lived through this until his death - all this was at the service of the resurrection. I mean to say, he wouldn't rise again unless he had died, unless he had been born; and thus the fact that he was born and died led up to the resurrection. Many people, both alien to us and godless, have believed that the Lord Christ was born a human being, of a human being. Although they didn't know that he was born of a virgin, still both friends and enemies have believed that Christ was born a man; both friends and enemies have believed that Christ was crucified and died; that he rose again, only his friends have known. ${ }^{1}$

So begins one of Augustine's richest sermons on the Resurrection, preached on the Tuesday after Easter sometime after 412. ${ }^{2}$ The Resurrection provides the forma of Christ's life - its shape or pattern, the moment toward which his whole life is leading, the end that gives the whole its intelligibility - and in so doing, serves also as the forma of the life that is being created in the hearts of those being made into Christ's members. From the standpoint of God's timeless eternity, all Christ's childhood interactions, all his travels throughout Galilee and Judea, all the moments when he spoke an Aramaic word or ate a simple meal or drank at a well, are leading to the moment in which new life is made from death. Belief in Christ's resurrection sets apart Christians from non-Christians descriptively, and understandably: "there are two things we had always been familiar with: being born and dying... To rise again, though, and to live for ever, who was ever familiar with that?"3 Belief in this shocking new fact is itself faith in Christ, the evidence of the Spirit's work. It not only marks off people who accept a certain description of historical events, but indicates God's creation of a new relationship: only his friends have known.

${ }^{1}$ s. 229H.1; WSA III/6, 295.

2 WSA III/6, 295.

${ }^{3}$ s. 229H.1; WSA III/6, 295. 
To trust that Christ has been raised from the dead is already to be united to his life, to trust that God is bringing new life in our death as well.

Augustine sees in the Resurrection the guarantee of our particularity. This is, perhaps, surprising; we are accustomed to thinking of death as the ultimate mark of finitude, the limit through which we recognize all the other limits of our lives. Yet the situation is precisely the opposite for Augustine:

Nothing, after all, is so certain for anyone and everyone as death. Start at the beginning. People are conceived; perhaps they come to birth, perhaps they don't. They are born; perhaps they grow up, perhaps they don't. Perhaps they go to school, perhaps they don't; perhaps they marry, perhaps they don't; perhaps they'll have children, perhaps they won't; perhaps they'll have good ones, perhaps they'll have bad ones; perhaps they'll have good wives or husbands, perhaps bad ones; perhaps they'll be rich, perhaps they'll be poor; perhaps they will be of no account, perhaps they will be highly honored. Among all the other things, can this be said about them: "Perhaps they'll die, perhaps they won't"?4

In its universality, death threatens to bring all our particularities to naught, making us indistinguishable from all else that has passed from life. In the true death to which sin is leading us, this universality is realized exhaustively, as we pass into an identical nothingness. But against this, resurrection tells us that God will restore us to life. Christ exists in all the determinateness of his life, the very same one, the very same flesh that had been laid in the tomb; and if Christ, than possibly us in Christ. In manifesting to us the invisible God who he is and who raises him from the dead, Christ shows us also the new life in him that we cannot yet see. These are not two revelations, but one, for the God that Christ signifies is the God who draws us into Her own incarnate life. In another Easter sermon, Augustine dramatizes this action by which we are included in Christ's body: 'I'm inviting you to my life, where nobody dies, where life is truly happy, where food doesn't go bad...that's where I am inviting you, to the region of the angels, to the friendship of the Father and the Holy Spirit, to the everlasting supper, to be my brothers and sisters, to be, in a word, myself. I'm inviting you to my life." 5 The Resurrection shows us for the first time that God triumphs over the blank universalizing force of death, and truly does defeat death by infusing in a human life for the first time the power of incorruptibility. This victory

\footnotetext{
${ }^{4}$ s. 229H.3; WSA III/6, 298.

${ }^{5}$ s. 231.5; WSA III/7, 22. Cited by O'Collins at Gerald O'Collins, S.J., Saint Augustine on the Resurrection of Christ:

Teaching, Rhetoric, and Reception (Oxford: Oxford University Press, 2017). O'Collins identifies seven characteristic emphases of Augustine's preaching on the Resurrection: as the heart of Christian faith; as the active work of God in all three trinitarian persons, and thus a work of Christ's own agency; as the raising of the true substance of flesh to a new condition of spirituality and immortality; as, in concert with the Ascension, a glorification of Christ that nevertheless does not compromise his ability to perform embodied actions like eating and drinking; as the revelation of our own hope; as the mediation of new life to us; and as enabling Christ's intercession and high priestly ministry at the heavenly altar. See O'Collins, Augustine on the Resurrection, Ch. 1, with a summary of his conclusions on pages 2931.
} 
becomes ours too, as the work of the Holy Spirit creates in us the love of Christ, incorporating us into this body that has overcome death.

Central for Augustine is the claim that Christ rises in the same body with which he died. This is, over and over again, the primary emphasis of his preaching on the Resurrection; "It is only occasionally that Augustine notes that 'the very same body' was also a different kind of body, one that was no longer constrained by the normal limits of human bodies." 6 Christ's body is transformed by a new divine operation: made incorruptible, able to pass through closed doors; yet still able to be touched, still able to eat and drink. The Resurrection broadens dramatically our understanding of what is possible for human flesh made "spiritual" in that it is enlivened by souls themselves enlivened by the Spirit. Yet the dominant note here is that the body that the followers of Jesus encounter following the Resurrection is the very same flesh in which Christ had lived before his death. The clearest indication of this continuity are, for Augustine, the wounds of Christ: "He insists that Jesus could have 'risen again without his scars,' but 'wished to adapt himself' to the disciples and show them 'his scars': 'true flesh' had risen from death. 'The scars are evidence for this...the hands [of the disciples] touch and feel, to rescue their minds from doubt." "7 That we will be raised in our same bodies, as well, is confirmed in Augustine's famous remarks on the wounds of the martyrs:

I do not know why this is so, but the love we bear for the blessed martyrs makes us desire to see in the kingdom of heaven the marks of the wounds which they received for Christ's name; and it may be that we shall indeed see them. For this will not be a deformity, but a badge of honor, and the beauty of their virtue - a beauty which is in the body, but not of the body - will shine forth in it...It may be that, in the world to come, it will be fitting for them to exhibit some marks of their glorious wounds, still visible in their immortal flesh. ${ }^{8}$

This emphasis on the continuity of both Christ's flesh and our own in the resurrected state indicates that our histories and experiences continue to matter in our eschatological lives. Sins are forgiven, wounds are knit into scars, yet we continue to bear within us the marks the world has left upon us. Our bodies are not merely the dispensable vessels through which we act in the world, but are - as united to the soul — who we are.

This will come as no surprise to readers of poststructural thought and theologies selfconscious of the contexts of their authorship: these traditions of inquiry have been exemplary in their attention to the ways that our bodies are sites of discipline and habituation, thoroughly integrated into the social orders that enable and constrain our agency, mediating all our encounters with others and exposing us both to intimacy and violence. Our bodies carry the marks that our histories have left on us in their scars, piercings, and tattoos, and in turn shape our particular lives as they are sexed, raced, valued according to abilities or disabilities, regarded

${ }^{6}$ O'Collins, Augustine on the Resurrection, 8; O'Collins quotes here s. 362.10.

7 O'Collins, Augustine on the Resurrection, 12; citing s. 362.12-13.

8 civ. 22.19; Dyson, 1149-50. 
as healthy or ill. We may be unconscious of the way these marks structure our lives, or we may be made constantly and painfully aware of them. What is essential is that, if Augustine's description of the wounds of the martyrs may be extended to all the redeemed, these histories continue to be ours in the Kingdom of God: our sins and their bodily consequences overcome by grace, our wounds (self-inflicted or otherwise) healed and restored, our histories judged and redeemed, our flesh made incorruptible as the power of the Holy Spirit comes to dwell in our hearts. Our existence is made secure as the particular creatures we are, with all our tastes and quirks and eccentricities, and we are finally liberated to embrace the flesh that God gives us.

Rather than fleeing from our bodies into a new spiritual condition, our very same flesh is brought to a new spiritual state as the relation between soul and body is healed by grace. As Augustine writes, "The flesh will then be spiritual, and subject to the spirit; but it will still be flesh and not spirit, just as the spirit, even when carnal and subject to the flesh, is still spirit and not flesh." "This "subjection to the spirit" is not a coercion or subjugation of the body, but the body's being fully enlivened by the soul, even as the soul is fully enlivened by the indwelling of the Spirit. As mediated by the soul, the Spirit comes to dwell in our flesh, banishing death from it and rendering it incorruptible.

We can have little more than a formal understanding of what this might entail, for the flesh of our experience comes close to being defined by its corruptibility: remember you are dust, and to dust you shall return. Yet one clear implication of the flesh's spiritualization is the perfection of our embodied relations. Augustine writes that in the City of God, "we shall enjoy each other's beauty without any lust: an enjoyment which will specially redound to the praise of the Creator." 10 Susannah Cornwall comments on this passage,

More than the libidinal lust to which Augustine refers, I propose, the lust which will not affect appreciation of one another's beauty in the new creation includes the patriarchal-capitalist lust to perfect, correct, regulate, manage, dominate and homogenize...We shall be freed from the apparently insatiable lust to know definitively what constitutes a good body, what bodies are "supposed" to be likeand freed to embrace the fact that scars and stretch marks testify to the processes which have happened in and through bodies: pregnancies, injuries, fluctuations in weight and all. These stories tell of changed states, not unequivocal loss or gain. ${ }^{11}$

As for Christ, these same bodies of ours become the loci of God's sanctifying presence, united to Her as surely as our souls. Indeed, they become Christ's members; and without undermining the particularity of our own existence, we become members of one another in the same risen body of Christ. Cornwall very helpfully issues a reminder that what many take at present to be the obviously natural order of the world may be quite thoroughly overturned in this new life

\footnotetext{
${ }^{9}$ civ. 22.21; Dyson, 1152.

10 civ. 22.24; Dyson, 1164.

11 Susannah Cornwall, Sex and Uncertainty in the Body of Christ: Intersex Conditions and Christian Theology (Oxford:

Routledge, 2014), 192.
} 
together. Discussing the implications of the resurrection body for those with intersex conditions, she writes, "Just as impairments will not necessarily be impairing in the new creation, so atypically-sexed bodies will not be at a disadvantage. If there is to be no marriage in heaven, and no procreation either, there is no need for gametes to mean what they have meant in this realm, or for particular gender roles to reinscribe procreative sexed norms." 12 Though this new flesh will be in continuity with the embodied lives we now lead, it may be that we will find our own resurrected bodies as shocking and novel as the apostles experienced Christ's body to be in the days between Easter and Mt. Olivet.

It is no great surprise that the Resurrection figures so prominently in Augustine's thought; perhaps more striking, particularly when compared to the contemporary theological landscape, is the central place the Ascension occupies in his thought. Though it is relatively rare for the Ascension to take center-stage in current discussions of Christ's redemptive work, it figures quite prominently in Augustine's writings, and is one of the key facts determining the shape of the Christian life. ${ }^{13}$ As William Marrevee observes, the Ascension serves for Augustine as the theological complement of the Incarnation: in assuming human nature, Christ assumes the forma servi, foregoing the manifestation of the divine glory that is properly his due; in the Ascension, Christ displays in his flesh the forma dei, his example of humility completed in the glorification of his body. Marrevee writes, "The mystery of the Ascension consists in this, that Christ's human nature was lifted up into heaven. As far as His divinity is concerned the Incarnation did not mean for Christ a leaving of the Father, neither did His Ascension include a departure from us. Both events must mainly be understood as referring to Christ's humanity." 14 John 3.13 serves as the crucial Scriptural passage establishing this link between Christ's descent into flesh and the Ascension. ${ }^{15}$ Augustine accepts the Lukan narration of Christ dwelling bodily with the disciples for forty days, a period Augustine takes to be necessary for confirming their belief that he still leads a fleshly life as he converses with them, breaks bread, and eats alongside them. ${ }^{16}$ The Ascension is thus understood to complete the glorification that began with the Resurrection; in rising from the Mount of Olives in full view of his disciples, Jesus is revealed fully and finally as the incarnate Lord, "mak[ing] the hidden divinity of Christ manifest for us." 17 With his glorification complete, Christ dwells in heaven and intercedes for us, serves as Great High Priest in the true sanctum sanctorum, and mediates between us and God.

\footnotetext{
12 Cornwall, Sex and Uncertainty, 192. See also the discussion of Cornwall's interpretation of Augustine at Morwenna Ludlow, "Augustine on the Last Things," in The TET Clark Companion to Augustine and Modern Theology (London: Bloomsbury T\&T Clark, 2013), 91-112; 105-8.

${ }^{13}$ Two very different exceptions to this trend are Tonstad, God and Difference, Ch. 7, and Douglas Farrow, Ascension Theology (London: T\&T Clark International, 2011). Perhaps the most fascinating recent treatment, however, may be found in Anthony J. Kelly, Upward: Faith, Church, and the Ascension of Christ (Collegeville, MN: Liturgical Press, 2014). In Chapter 4 particularly, as Kelly discusses the "The Body of the Ascended Christ and the Expanded Incarnation," Kelly anticipates some of the arguments of this dissertation to the effect that the Church exist as an "extrametaphorical" extension of the Incarnation; see pp. 74-5.

14 William H. Marrevee, The Ascension of Christ in the Works of St. Augustine (Ottawa: University of Ottawa Press, 1967), 67.

15 Marrevee, Ascension of Christ, Ch. 2.

${ }_{16}$ O'Collins, Augustine on the Resurrection, 13-4.

17 Marrevee, Ascension of Christ, 68.
} 
Yet the Ascension's manifestation of divine glory is at the same time - and necessarilyan occlusion, the disappearance of Christ's flesh from our vision. On Augustine's account, Christ's departure removes from us what might have been a stumbling block: "it was necessary for the form of a servant to be removed from their sight, since as long as they could observe it they would think that Christ was this only which they had before their eyes." 18 Augustine understands both Christ's injunction to Mary "Noli me tangere" in the garden on Easter morning and Thomas' need to see himself the wounds of the cross as symptoms of our inability to love properly even the resurrected flesh of Christ: we are liable to hold to these physical signs too tightly, content to remain in sight without passing over to belief in the God who remains invisibly present in Christ's body. Even in the resurrection appearances, God remains hidden in Christ: "what had arisen was flesh, because it was flesh that had died; the godhead which could not die still lay concealed in the flesh of the Risen One. His human shape could be seen, his limbs grasped, his scars felt, but could anyone see the Word through whom all things were made? Could anyone hold onto that?" 19 Here too, the work of the Holy Spirit is essential in creating faith in us. Not the empty tomb, not even seeing the resurrected flesh of Christ with our own eyes offers us a sign sufficient to break sin's hold over us and begin the therapeutic reordering of our desires back to God. Our knowledge of these signs must be enlivened by the presence of the Spirit. Yet even as this process of reordering begins, our loves remain bound by habit to the changeable things we have learned to desire inordinately. We are accustomed to seeing the world around us as the objects through which we seek the satisfaction of our desires, rather than as signs of God. On this score, Christ's flesh is no different; for his disciples, their habit was to view him as a teacher, a friend even, but certainly not as their creator. Augustine recasts Christ's statement in John 14.28 as his explanation of the need for the Ascension: "This is why I must go to the Father, because while you see me like this you assume from what you see that I am inferior to the Father, and thus with all your attention on the creature and on the adopted condition, you fail to understand the equality I enjoy with the Father." ${ }^{20}$ In ascending from the Mount of Olives, God assists our movement from unbelief to faith, preventing Christ's flesh from serving as a distraction.

Framing the Ascension in these terms may make it seem that Christ's flesh serves a merely instrumental purpose in our redemption, and if Augustine left things there, ${ }^{21}$ these suspicions would be well founded. Alongside the suggestion that seeing Christ with our own eyes might serve as an obstacle to faith, however, is the claim that the Ascension is necessary precisely because his resurrected flesh is the fullest possible creaturely sign of God. At trin. 1.9.18, Augustine writes, "His ascension to the Father signified his being seen in his equality with the Father, that being the ultimate vision which suffices us"; 22 and similarly, at en.Ps. 49.5, he says that the disciples "went on gazing after him whom they had known; but it was in his lowly condition that

\footnotetext{
18 trin. 1.9.18; WSA I/5, 78. Cited at Marrevee, Ascension of Christ, 98.

19 en.Ps. 49.5; WSA III/16, 384. Cited at Marrevee, Ascension of Christ, 94.

20 trin. 1.9.18; WSA I/5, 78.

${ }^{21}$ As Marrevee comes close to doing, at points.

22 WSA I/5, 78.
} 
they had known him and they did not know him yet in his radiant glory." 23 These passages suggest that the Ascension is not the end of God's revelation through the flesh of Christ, but rather the intensification of it. In being raised to heaven, the flesh of Christ receives to the greatest extent possible for a creature the glory that the Word has possessed from all eternity. This does not entail any deeper or more intimate unity with the Word than it possessed throughout his life, but it is the converson of the forma servi to the forma dei. Christ's flesh is no longer presented to us as milk in actions and wonders that we can interpret, but is the solid food for which we are not yet ready. While in the forma servi, Christ's flesh was for us a visible sign of the God who is invisible to us on account of our sin; ${ }^{24}$ in the Ascension, it becomes a sign without any accommodation for the weakness of our eyes, and so Christ's flesh too becomes invisible to us. In being occluded from our view, Christ shows us that he is the very one who we have lost in our sin, who serves as the end of our desires, for whom our hearts long. Our eyes are dazzled by the glory of God in him, and he vanishes in our blindness; we are left staring where we had seen him just a moment ago. If we stand looking at the same place, hoping to see him again, we only show that we do not understand properly. Only our being perfected in faith will allow us to see the overwhelming glory of God, present in his flesh to the greatest extent possible for a creature. In disappearing from view, then, Christ teaches us to long for the deity manifested in the flesh no longer visible to us. We do not lack for signs of Christ, of course, from the obvious icons, statues, and paintings, to - as we have seen - potentially any creature. Yet after the Ascension, these signs point us to an invisible referent. Even the eucharistic host - fully and truly Christ's flesh - is marked off as the bodily presence of Christ that is visible only as bread; here, above all, we learn that only faith will allow us to see Christ in the world under the guise of bread and wine, and that this same faith is required if we are to see the glory of God fully manifest in his flesh eschatologically. In order to attain to this vision, we must set our loves on Christ, believing in what he taught and did in the forma servi, and letting our desires carry us to heaven where the bodily sign of God's presence now dwells. Augustine captures this dynamic well at en.Ps. 58(1).10, asking, "What does he mean that he ascended to the Father? He ascends when he makes himself known to us as the Father's equal. We ascend by making progress until we have the capacity to see this, to understand it, in some degree to take it in." ${ }^{25}$ Augustine characteristically (and as guided by Scripture) speaks here of Christ ascending "to the Father," understanding this as his now being manifest with the same glory that the Father has possessed from all eternity, but which was hidden for the Word in the form of the servant. Matching Christ's final manifestation in the forma dei is our own adequation to God: as we make progress in faith and in setting our loves on Christ, we "take in" this mystery to the extent that we are able. Even at the Last Judgment, only those purified by charity will behold Christ in the form of glory. ${ }^{26}$ In light of the argument of this dissertation, we are warranted, I think, in seeing here not only as epistemic claim (that we take in

${ }^{23}$ WSA III/ 16, 385.

${ }^{24}$ To be distinguished from God's essential incomprehensibility, which persists eschatologically.

25 WSA III/17, 157.

${ }^{26}$ Cf. Io.eu.tr. 21.14; WSA III/12, 386: "The form of a slave will be shown to slaves; the form of God will be reserved for sons." 
the mystery of the Incarnation as we ascend to Christ, our minds being conformed to the truth of God's work in Christ), but that we actually take this mystery into ourselves. As Christ is manifested as God, so also we are made Christ; the Ascension begins to pattern our lives, too, as we rise to union with God. We are being drawn to a vision not only of Christ's flesh, but of our own - restored, transfigured, made everlastingly into the dwelling place of God.

In his theology of the Ascension, then, Augustine desires from us a fundamental reorientation of our view of the world and our understanding of our own lives. Drawing on one of the most prevalent christological metaphors of the Enarrationes in Psalmos, that of Christ as the cornerstone, ${ }^{27}$ Augustine tells us that "God's Church, though established here below, strains toward heaven, and so our foundation is laid there, where our Lord Jesus Christ sits at the Father's right hand."28 The Church is a temple founded upside down, its chief cornerstone laid in heaven rather than on Earth. We are meant to understand our lives on that basis, seeing our lives and our life together in the Church as beginning from Christ. We are called to act not on the basis of what we are, but on the basis of that into which we are being made.

The City of God on its earthly pilgrimage is thus caught between two realities: Christians are meant to understand the world and act within it on the basis of Christ, knowing the world and loving it as Christ does; yet Christ himself has disappeared from view, showing us that we lack at present the restored relation to God that would allow us to do so. Our efforts at seeing Christ in the world are compromised from the start, and so the Church is meant to be a community in movement, carrying lightly all the understandings of the world and temporal goods it now possesses, but holding fast to the savior it cannot now see but nevertheless pursues. The Church's life at any one moment of history is inherently provisional, a community committed both to its own revisability, and to the belief that any progress in its life is attributable to the Holy Spirit who animates this community. All the Church's work is ordered to the end of reconciliation with God - which is to say, it is meant to fit us for the vision of God in Christ's ascended flesh. This dynamic informs Augustine's approach to the images offered to the Church by Scripture, an account of creaturely similitudines that I have argued extends to the significatory potential of every created particular:

Whatever likenesses have been proposed to you, if you find them in Scripture, believe them (Et si quae tibi similitudines datae fuerint; si inveneris in Scripturis, crede). If what you find there is no more than a reflection of popular belief, do not put too much faith in that; it may accord with reality, or it may not. What matters is that you progress, and a likeness (similitudo) is meant to help you along to salvation. You do not find this particular image helpful? Very well, take another; the point is that you must act on it. ${ }^{29}$

\footnotetext{
27 Augustine's deployment of this metaphor is often tied to the Ascension, and is based primarily on two passages of Scripture: Psalm 117.22 ("the stone rejected by the builders has become the headstone of the corner") and Ephesians 2.20 ("with Christ Jesus himself as the true cornerstone").

28 en.Ps. 29(2).10; WSA III/15, 310.

29 en.Ps. 66.10; WSA III/17, 322-3. I have lightly revised Boulding's translation here.
} 
Scripture serves as the bedrock of the language of divine signification, yet all created likenesses may assist us in our journey back to God. Our charge is to attempt to discern God's presence in the world, and to act on what we understand God's will to be; in all this, we are to be guided by our love for Christ. Yet we live in this way knowing that our understandings are flawed, our actions will be sinful, and our love is imperfect; we live in the constant awareness of our failure. The Augustinian hope is that through our failure, we may learn to depend ever more fully on the power of the Holy Spirit uniting us to Christ; and that as the Spirit's work makes us aware of our failure, we will be led to confess both to God and our neighbor. To make a step toward God in this life is always and at the same time to discover a new way of missing the mark, yet if we set our loves on Christ, we may trust that God will eventually draw us to union with Her. As we seek to discern Christ in worldly similitudines, we move from misunderstanding to misunderstanding, in the hope that we may eventually be brought to the Truth. Lest this process seem too cheerful, we should not underestimate the difficulty of finding our view of ourselves and the world constantly broken apart as we recognize the sinful distortion that pervades it, nor should we forget the suffering that we inflict on others in the midst of our moral blindness. In the next section of this chapter, I will sketch out the starting point of an Augustinian moral theology in confessionbeginning from the acknowledgment, too late, that we have misunderstood, that we have done violence to others, that we must be remade if we are to see God.

\section{An Ethic of Confession}

Of Augustine's moral theology, James Wetzel has remarked, "Augustine is teaching us to grieve in the vale of tears." 30 The humility that Augustine describes as standing at the heart of the Christian life, the humility that unites us to the cross of Christ, cannot be left as an abstraction or a general disposition of those who seek to be Christ's followers. It is a continually unfolding grief, a dawning awareness that I have failed, and failed with disastrous effect. Do not let yourself push this fact away, or sequester your consideration of it as an intellectual claim from your awareness of your life. We have said things that have hurt people we love; we have acted in ways that directly harmed people both near to me and far away. I have, in my speech and action, called into question the worth, agency, and insights of people marginalized along any number of

\footnotetext{
30 Wetzel made this comment at a manuscript workshop on June 20, 2014 at Duke University on what would become Joseph Clair, Discerning the Good in the Letters and Sermons of Augustine (Oxford: Oxford University Press, 2016). Cf. en.Ps. 83.10, and perhaps more centrally in light of its position as the introduction to the Psalms of Ascent, en.Ps. 119.1. Wetzel has reflected on Augustine's understanding of grief more extensively at Augustine and the Limits of Virtue, 104-5: "Marcia Colish is right to observe that Augustine's sharpest break from the Stoic ideal of apatheia comes with his recognition that virtue and grief are compatible. Often, in fact, grief is the necessary and appropriate affective form of virtue... He differentiates grief from potential synonyms in pain (dolor) and affliction (aegritudo) in order to highlight the cognitive component of the affection in question. Grief must incorporate our judgment that something of value to us has been lost. Depending on the nature of our recognition of loss, our grief sometimes modulates into related forms of affection, such as compassion, sympathy, sorrow, anger, and remorse. The life of virtue without this range of affections, without grief in particular, is either blind or insensitive... Christian wisdom proportions grief to the hope of redemption beyond time, and fortitude prevents the affection from modulating into despair."
} 
different social vectors, viewing them as threats, or "less than," or merely "other"; and though you have done all this differently than I have, you have done it too. I hope that the vast majority of the times I have done these things, I have done them unknowingly, but I am suspicious of myself on that score. There are certainly times I am needlessly harsh with others, or intend to assert myself over them in some way, and am conscious of it; yet most of the time, I recognize the harm I have already done only retrospectively.

This is, I think (and I think Augustine thinks), one of the defining features of the Christian life. We are slowly sanctified by the work of the Holy Spirit, but it is only as our loves are conformed to Christ's loves and as our minds are illumined to see the Word's Truth that we are able to see what we have done, and to understand the gravity of our sin. If we are enlivened by the love of God, the only response to our sin can be grief, and our only words can be confession. Michael McCarthy has instructively desanitized this confessional outlook by describing Augustine's thought as giving us an "ecclesiology of groaning" 31 - we are to feel our regret and outrage rising from deep within us, wracking our bodies as everything in us aches at the knowledge of my and the world's sin. Perhaps most of all, we are to strain under burden of knowing that we have only begun to understand, that there are untold reserves of harms we have done but still cannot yet see. Indeed, it may be that we will not have understood the horror of sin itself, both essentially and in the devastation it introduces into creation, until we know the full truth of Newman's statement that

it were better for sun and moon to drop from heaven, for the earth to fail, and for all the many millions who are upon it to die of starvation in extremest agony, so far as temporal affliction goes, than that one soul, I will not say, should be lost, but should commit one single venial sin, should tell one wilful untruth, though it harmed no one, or steal one poor farthing without excuse. ${ }^{32}$

This cannot, I think, be discounted as hyperbole, and appears to us as callous only if we forget or dispute that all these evils (the corruption of the natural order, starvation, death) enter into God's good creation through sin. Until we have learned - not just to say, but learned the truth of the words - that even our most minor sins carry in them the seeds of all the world's sufferings, we will not yet grieve properly. To come even close to understanding the gravity of our sin would require an intimacy with God proper to sainthood. Until we are purged of our sin, we must strain under the knowledge that even our confession is a failure.

How are we brought to this grief characterizing the Christian life? It is the work of the Holy Spirit, to be sure; yet this is not quite an answer. The Holy Spirit surely works within our hearts, yet properly speaking, the work of the Holy Spirit is just the one triunely-related eternal

\footnotetext{
${ }^{31}$ Michael McCarthy S.J., "An Ecclesiology of Groaning: Augustine, the Psalms, and the Making of Church," Theological Studies 66 (2005): 23-48.

${ }^{32}$ John Henry Newman, Certain Difficulties Felt by Anglicans in Catholic Teaching, Vol. 1: In Twelve Lectures Addressed in 1850 to the Party of the Religious Movement of 1833 (London: Longmans, Green, and Co., 1918), 240. (Originally published 1850.)
} 
act that is identical to God's Being. The divine life is incomprehensible, and so the work of the Holy Spirit in our hearts is, in itself, incomprehensible. We can recognize the effects in us of the Spirit's work, a new awareness of how we have sinned against God and our neighbor, or a new power to resist sin that we did not possess before; but we are always too late to identify the Spirit's action itself. ${ }^{33}$ By the time we can identify a change, the Spirit has already acted. Rather than attempting to catch the Spirit red-handed, we should attend instead to the creaturely means by which the Spirit teaches us we have failed. Though the Spirit of course blows where it will, and is therefore utterly unconstrained in the means He may use as participants in the communication of grace, this ought not suggest that there is no regularity in where we should look for the Spirit's action. What we are seeking, then, are the situations in which we become newly aware of our inability to know truly, act justly, and love well- the circumstances in which our failures become manifest to us, leading us (ideally) to deeper humility and greater dependence on God's grace. In describing the dynamics of this passage through failure to humility, my hope is that we might understand more deeply why confession stands at the heart of Augustine's moral theology. If we desire to act justly, if we seek the beginnings of an Augustinian ethic in light of our dependence upon God's grace, my suggestion is that we must begin with confession.

This cannot be reduced to the simple injunction to participate in ecclesial practices like the sacrament of confession, the Reconciliation of a Penitent. While such practices are key supports of the Christian life and avenues by which God's grace is communicated to us, and can indeed serve as situations in which we not only confess our sin but become aware of it, for the most part such practices presume that we are confessing failures of which we are already conscious. Much closer to the mark are Sarah Coakley's discussions of contemplative prayer as the practice in which we are exposed to the presence of God and find our repressed desires brought to light and opened to transfiguration. ${ }^{34}$ What I hope to identify are specific experiences in which we become aware of ethical failures, that uncover for us deeper challenges that pervade all our moral action; and in so doing, to draw attention to the ways we are disciplined and habituated into deeply sinful patterns of life to disastrous effect. My aim is not a comprehensive

\footnotetext{
${ }^{33}$ Jean-Louis Chrétien develops his phenomenological account of our life in the world as responsal in Jean-Louis Chrétien, The Call and the Response, trans. Anne A. Davenport (New York: Fordham University Press, 2004).

34 See especially Powers and Submissions and Coakley's more recent development of these ideas as part of her théologie totale in God, Sexuality, and the Self. I am significantly in agreement with Coakley's practice, and believe along with her that contemplative prayer can serve as a key site of sanctification. Andrew Prevot, another fellow-traveler, notes with some justice that focusing on the category of doxology rather than contemplative prayer ascribes this transformational potential to prayers beyond the wordless, a salutary modification of Coakley's account for an Augustinian committed to the importance of confession; see Andrew Prevot, Thinking Prayer: Theology and Spirituality among the Crises of Modernity (Notre Dame: University of Notre Dame Press, 2015), 343n.45. Yet if we are describing Augustine's confessional practice as a movement of dispossession, reception, and responsive self-offering, Coakley's focus on contemplation offers a compelling model and recommendation of concrete practices by which our spiritual and moral failures are brought to our awareness. I include it here, rather than discussing it more fully in the subsections below, both because Coakley herself has developed the place of contemplation in our moral lives in such compelling fashion, and because of the unpredictability of what is uncovered for us in contemplative prayer. On Coakley's account, we stand utterly open before God in wordless prayer, and as a result, any aspect of our lives may be called into question, any register of failure can be brought to light.
} 
accounting of all the registers of our moral failure, but the inculcation of what I take to be an Augustinian outlook on ethical reflection that begins from the awareness of our own weakness.

In pursuing this task, I will make use of an idiosyncratic cast of philosophers, critical theorists, and theologians to describe our failures of responsibility, will, representation, and imagination. This is, in part, a judgment on the (in)sufficiency of Augustine's thought as a guide to moral reflection. Augustine of course has far more to offer to Christian ethics than shallow misreadings of him might suggest; and in fact, over the last twenty years especially Augustine has served as a resource for many careful and stimulating studies especially within the realm of political theology and moral theology more broadly. ${ }^{35}$ Yet it must also be said, as contemporary Augustinian ethicists would also affirm, that Augustine himself saw only in part. While he serves the crucial theological role in putting confession at the center of the Christian life, critical theorists and liberation theologians have in recent years greatly expanded our ability to recognize some types of violence and social death that Augustine could not have acknowledged in his own time. It is likely also the case that there are aspects of our own wickedness that Augustine might have seen much more clearly than we can. ${ }^{36}$ In the present work, I have erred on the side of drawing contemporary theoretical resources into a basically Augustinian confessional framework.

Through all of it, my goal is to point to a moral theology lived in light of the Ascensionone that admits of movement toward the incarnate Good, and therefore demands judgments about the relative justice or injustice of our actions; but one that recognizes the invisibility of Christ's flesh, and so remains painfully aware that even our best attempts at acting justly are undermined by a sin that we cannot even identify. In this, I hope to describe a humility that does not debilitate our moral action, but empowers it in teaching us to rely on the work of the Holy Spirit in us.

\subsection{Failures of Responsibility}

By "failures of responsibility," I have in mind our failures to understand ourselves as moral agents, and more specifically, to understand the social factors that have shaped our moral agency. ${ }^{37}$ In Giving an Account of Oneself, Judith Butler has written, "The 'I' is the moment of failure in every narrative effort to give an account of oneself." 38 To understand why this should be so,

\footnotetext{
35 There are, of course, a vast number of appropriations of Augustine's thought within political theology and ethics, but I am thinking particularly here of the trajectory represented by Charles Mathewes, A Theology of Public Life (Cambridge: Cambridge University Press, 2007); Eric Gregory, Politics and the Order of Love; Joseph Clair, Discerning the Good in the Letters and Sermons of Augustine; and Sarah Stewart-Kroeker, Pilgrimage as Moral and Aesthetic Formation in Augustine's Thought (Oxford: Oxford University Press, 2017), what has sometimes been grouped together (for better or worse) under the rubric of "Augustinian liberalism." For a critical engagement with this trajectory, see Peter Iver Kaufman, "Christian Realism and Augustinian (?) Liberalism," Journal of Religious Ethics 38, no. 4 (2010): 699-724. 36 Work I hope to pursue through detailed study of Augustine's own ethical writings in future publications.

37 This is, of course, an idiosyncratic use of the word "responsibility" pulled from Butler; much of the extension of that term in contemporary moral theology collapses together many of the other sorts of failures I discuss in later subsections. For a now-standard account of responsibility within Christian ethics, see H. Richard Niebuhr, The Responsible Self: An Essay in Christian Moral Philosophy (New York: Harper and Row Publishers, 1963).

38 Butler, Giving an Account, 79.
} 
we must attend to her account of our moral subjectivation. In the spirit of Butler's intent to foreground "infancy, dependency, relationality, [and] primary impressionability" within moral philosophy, ${ }^{39}$ think of how children are drawn into practices of moral accountability. As an infant grows, she is enmeshed in any number of patterns of behavior designed to regulate what she does or does not do, where she does and does not go: before she can even talk, doors to certain rooms are closed to protect the fine china, and gates are placed to protect her from dangerous stairs. As she grows, these physical obstacles are internalized as commands: do not run inside the house, use the toilet when you need to relieve yourself. Each of these commands instills certain behavioral norms in us, communicating to us that one should be careful with the possessions of others, or that certain bodily functions should not enter into public spaces. The reflexivity about one's actions and motivations that Butler takes to characterize a moral subject only appears, however, when I am called to give an account of my actions: I have broken a family heirloom, and I am asked to explain why I was running through the living room when I knew that this was prohibited. As Butler notes, "I begin my story of myself only in the face of a 'you' who asks me to give an account." 40 One of her great insights on this score is that any answer I give to such a question will have to draw on the very same norms and moral categories that conditioned my behavior in the first place. Being asked why I was running through the house when I knew better creates a communicative situation in which I am asked to justify or express regret for an action I have committed - but this is to say that in order to answer the question I have been asked, I must accept the legitimacy of the question, and the legitimacy of my questioner. Even were I to respond angrily that I have no need to justify my action, I would share with my interrogator a set of moral categories that would make my protest against a moral norm recognizable as protest. Butler thus concludes, "There is no making of oneself (poiesis) outside of a mode of subjectivation (assujettisement) and, hence, no self-making outside of the norms that orchestrate the possible forms that a subject may take." 41

It is another crucial step to note that these same norms function also to make people recognizable as moral agents. As she writes, "The norms by which I recognize another or, indeed, myself are not mine alone. They function to the extent that they are social, exceeding every dyadic exchange that they condition." 42 While we might have thought that the situation of a parent asking a child for an account of her actions is an ethical relation that obtains solely between these two moral agents, it is plainly visible that this relation is implicated within any number of broader social factors that shape this interaction: think of the historical contingency of parenting practices in the United States, over-against more thoroughly communal approaches to parenting; or of the economic norm that imagines each family will have their own house, with a common living space full of family mementos, and that we should desire a space large enough that a child could run around in it (even if, perhaps confoundingly, they are regularly told not to do so). As Butler notes, then,

\footnotetext{
${ }^{39}$ Butler, Giving an Account, 102.

40 Butler, Giving an Account, 11.

${ }^{41}$ Butler, Giving an Account, 17.

42 Butler, Giving an Account, 24.
} 
though I might think of the ethical relation as dyadic or, indeed, as presocial, I am caught up not only in the sphere of normativity but in the problematic of power when I pose the ethical question in its directness and simplicity: 'How ought I treat you?' If the 'I' and the 'you' must first come into being, and if a normative frame is necessary for this encounter, then norms work not only to direct my conduct but to condition the possible emergence of an encounter between myself and the other. ${ }^{43}$

The significance of this move to a fully social account of moral subjectivation should be apparent. It is not only the emergence of children as moral agents that is governed by communal practices and orderings of power, but that of all people. These configurations of power determine, for instance, whether one is called to account for an act of domestic abuse, or whether such an assault is considered within one's rights as paterfamilias; whether the inmate's charge of inhumane living conditions at his for-profit prison is judged worthy of a public investigation and response; whether social spaces are designed in such a way to provide equal access to those with difficulty climbing stairs, or whether labor practices allow for those with chronic sudden episodes of debilitating pain to maintain steady employment in the midst of regular unexpected absences. The contingent historical orderings of our moral norms not only constrain way we talk about such considerations, but govern the appearance of these phenomena as moral problems in the first place. We are dependent on our relations to others for the very categories that allow us to render judgments about the good.

Yet the insight of Butler most relevant to my present purpose is her recognition of our inability, in giving an account of ourselves, to give a full account of the social and historical factors that have shaped these influences on our moral norms. It is this that she describes as the constitutive failure of our ability to give an account of ourselves, to render ourselves intelligible as moral subjects: "my effort at self-summarization fails, and fails necessarily, when the 'I' who is introduced in the opening line as a narrative voice cannot give an account of how it became an 'I' who might narrate itself or this story in particular." 44 We can attempt to give an account of the conditions that have shaped our moral agency, but there can be no hope in the success of this endeavor. We simply lack the knowledge truthfully to describe all the particular and contingent actions and events that have shaped the social world we inhabit. Describing the state of power and culture in the present day is a task we can accomplish only in broad brushstrokes, and the further we move away from the current state of things, the more unwieldy the history of these forces and flows of power becomes. We can certainly give better or worse genealogies of the social forces shaping our moral agency, but any such story we offer is bound not only to illuminate but to conceal. As we try to give accounts of ourselves that encompass these social histories, allowing us to recognize ourselves as moral agents, we hide aspects of ourselves and our

\footnotetext{
43 Butler, Giving an Account, 25.
}

44 Butler, Giving an Account, 66. 
relations to one another from view. So Butler: "Not all of [my] past is gathered and known in the act of recognition; the act alters the organization of that past and its meaning at the same time that it transforms the present of the one who receives recognition." 45 And so, we find that even in trying to account for the histories that have shaped our ability to be recognized as moral agents, we obscure certain features of those histories that may make it more difficult to recognize the moral subjectivity and claims of others in the present. In the terms of my previous chapters: even our attempts to render our lives intelligible may obscure the interdependency of our agency.

The moment of failure that Butler brings into view for us is therefore our inability to account for our own moral formation - we know that we have been shaped by factors far exceeding our own lives and awareness, but because we do not understand them we cannot give an account of how they have shaped us. What may such an account of our agency give to an Augustinian moral theology? Butler herself describes the upshot of her position in terms quite congenial to an Augustinian approach: she writes that an awareness of "one's own opacity...can, by the way, constitute a disposition of humility and generosity alike: I will need to be forgiven for what I cannot have fully known, and I will be under a similar obligation to offer forgiveness to others, who are also constituted in partial opacity to themselves." ${ }^{46}$ She seeks

an ethics based on our shared, invariable, and partial blindness about ourselves. The recognition that one is, at every turn, not quite the same as how one presents oneself in the available discourse might imply, in turn, a certain patience with others that would suspend the demand that they be self-same at every moment. Suspending the demand for self-identity or, more particularly, for complete coherence seems to me to counter a certain ethical violence, which demands that we manifest and maintain self-identity at all times and require that others do the same. $^{47}$

Perhaps most dramatically in light of the command to love one's neighbor, Butler notes that the social nature of our moral agency puts us in a relation of mutual dependence with others: I cannot give an account of myself without the moral categories I have been given, yet I am called to give an account of myself and the other is called to give an account of herself in a relation where neither of us are reducible to the moral norms we to some extent share. In our particularity, we are capable of revealing our opacity to one another; and in virtue of our shared moral language, we find our place in a social order that places moral obligations on us for one another. At the end of Giving an Account of Oneself, Butler writes,

we must recognize that ethics requires us to risk ourselves precisely at moments of unknowingness, when what forms us diverges from what lies before us, when our willingness to become undone in relation to others constitutes our chance of

\footnotetext{
45 Butler, Giving an Account, 28.

46 Butler, Giving an Account, 42.

47 Butler, Giving an Account, 41-2.
} 
becoming human. To be undone by another is a primary necessity, an anguish, to be sure, but also a chance - to be addressed, claimed, bound to what is not me, but also to be moved, to be prompted to act, to address myself elsewhere, and so to vacate the self-sufficient 'I' as a kind of possession. ${ }^{48}$

Butler has neatly described the self-dispossessive moment that I take to be at the heart of Augustine's account of our being incorporated within the body of Christ; it should come as no surprise that it is precisely in the relation to our neighbor that we are fit for the love of God.

In closing this section, I wonder if it might be possible to read Butler in the direction of the longing for transcendence that Sarah Coakley has identified in her work. ${ }^{49}$ Butler takes our failure of responsibility - the failure to give a true account of our moral agency - to be a constitutive feature of our existence; it is inconceivable on her account to imagine anything other than or beyond this failure. During the world, ${ }^{50}$ an Augustinian may surely agree with the inevitability of our defection - we are never purged of sin in this life, and even if we were, the finitude of our lives would prevent us from offering an account of the sort Butler describes. Yet if we read Butler as describing what it would be like to give a successful account of ourselves, an interesting theological point emerges: to understand ourselves truly, our account would need to encompass the whole history of the created order, viewing ourselves in all our debts to one another, and as situated in the midst of unfathomably complex social relations, decisions, and chance occurrences. Only God could, in fact, give such an account of us, and we could only give this account responsally, having first received it from Her. We may perhaps see Butler as describing our eschatological hope, giving an account of ourselves as the very creatures God has made us, embracing the whole histories and all the relations to all other histories in which God has set us. Yet even here, we do not return the self-possessed subject that Butler attacks, but rather to the constitutively open, constitutively receptive creatureliness that Rowan Williams and John Cavadini see in Augustine's thought. ${ }^{11}$ We do not succeed in the project of self-making to which we have so damagingly committed ourselves in our sin, but rather learn the folly of that aspiration, finally accepting ourselves as the creatures we have always been.

\subsection{Failures of Will}

\footnotetext{
${ }^{48}$ Butler, Giving an Account, 136.

${ }^{49}$ See Coakley, "The Eschatological Body: Gender, Transformation, and God" at Powers and Submissions, Chapter 9, pp. 153-167.

${ }_{50}$ Mathewes uses the evocative phrase "during the world" throughout A Theology of Public Life: "To endure our life in this way is to be attentive and wakeful, patient and long-suffering, to refuse to let the world have the last word on what it means, and yet to refuse also to presume to know what that last word will be. It is to live in the world, without accepting its immanent self-presentation. It is to live eschatologically within the world - to live during the world" (15).

51 See above, Ch. 5n.36.
} 
We are unable to give an account of how we have been formed as moral agents; nevertheless, we do possess moral agency, able (as informed by the social world into which we are inducted) to make judgments about the relative goodness of possible objects we desire, about the goodness of our desires themselves, and about the best course of action to pursue in light of our evaluations of the good. Yet, in the course of exercising this agency, we regularly experience a different sort of failure, a failure of will. As St. Paul writes in Romans 7.19, "I do not do the good that I want, but the evil I do not want is what I do." 52 James Wetzel has analyzed this as the problem of "involuntary $\sin , " 53$ a failure to will the good even if one has discerned it relatively well. We experience this as the presence in us as two opposed wills: one seemingly under our control, moving to act on the basis of our judgments of the good; another resisting that which we consciously will, even overcoming the will with which we identify ourselves and leading us to act against our better judgment. The culprit here, on Wetzel's telling, is habit: "The history of how we have desired and acted on desire, registered in our present experience as the cumulative force of habit, will have an obstructing influence on our ability to allow new kinds of desires, for example, ones framed by beatific knowledge, to determine our willing." 54 We carry with us the habits acquired in our histories of sinful willing even as the Holy Spirit works to renovate our desires, drawing them back to the love of God and beginning to reorder our loves of temporal things. The presence in us both of the Spirit's illuminating and empowering work, and of the habits that continue to constrain our willing of the good, create in us a particular sense of powerlessness: we recognize that we are acting sinfully, we wish to act otherwise, but find ourselves unable to do so. Wetzel describes this condition: "Thrown upon our own efforts, we cannot abstain from pursuing inferior objects of attraction, even when we recognize and condemn how our pursuit violates the order of creation. Involuntary sin becomes the premier symptom of the impotence of knowledge." 55

These failures of will need not be (in fact, are usually not) the grand conflicts of a divided will that Augustine describes in his conversion. ${ }^{56}$ They are familiar to us: lashing out at someone we love, simply because he or she is an available target; a self-protective lie uttered in fear; a relapse into addiction. In these moments, we discover the limits of our ability to will the goodwe discover that even when we know what the good is, we cannot always act on this knowledge. It is tempting to view this simply as the condition of the flesh, to dismiss these moments with a recognition that no one is perfect. Yet if we keep our eyes trained on these moments and what they reveal about our moral life, and if we heed Christ's injunction to be perfect as our Father in heaven is perfect, two options seem available to us: despair; or a humility that recognizes both the necessity of the Spirit's work in us and our continued resistance to that work. We find in these moments a failure that we have not yet been entired, that we do not yet experience the wholeness we will find in being knit into the body of Christ. Even absent determinations of whether or not

\footnotetext{
52 NRSV.

53 Wetzel, Limits of Virtue, 97.

54 Wetzel, Limits of Virtue, 94.

55 Wetzel, Limits of Virtue, 97.

56 The locus classicus for Augustine's discussion of the divided will is conf. 8.9.21.
} 
we have successfully discerned the good, attention to our experience of willing itself serves as a reminder that all our ability to act justly depends upon the prior activity of the Holy Ghost in us.

\subsection{Failures of Representation}

We cannot give a full account of what has shaped our understandings of the good; even when we think we have discerned the good in a situation, we do not reliably act on this knowledge. Yet a further - and on Augustinian terms, more basic, as the source of the other two - failure looms, and pervades all our moral action: we are incapable of knowing the true Good that is God, and therefore incapable too of knowing the particular good that should motivate our action in any situation. It is true that our love and knowledge of God vary in the degree of their error, and so recognition of this third species of failure should not be taken for a claim that all possibilities in a situation are equally bad; but we must say that all of our acts of willing are failures to a greater or lesser degree. These failures are not harmless: to the extent that I fail to perceive both the good creatures of God as God has made them in any particular situation, and in so doing fail to discern the good that motivates my action in drawing my desire toward it, I will act in a way that harms myself and my neighbor. I will demand more of my neighbor than she is able to provide, or I will pursue my own self-interest in my relation to the environment, rather than acting in a way that preserves a healthy ecosystem in view of my desire to uphold the common good. Yet, worse than this, the failure of my action will in many cases be unknown to me: I will be as lenient with my neighbor as possible, seeking of her only the minimum that I perceive justice to demand, even as I drive her into penury; I will engage in patterns of action precisely with the aim of environmental preservation, even as I introduce toxins into the ecosystem that I will not realize have devastated the ecosystem until decades later. These are failures of representation because I cannot see the world or my action as it is, and so I am powerless to will the good. I have unknowingly substituted my own flawed understanding of the world and my own erroneous notion of the good for the truth of God's creation and the justice of God's command; I have traded my own representation of the world for the knowledge of it I might have possessed absent sin's corruption.

Both in her awareness of the violence inherent in misrepresentation, and in her belief that this violence is ingredient in any ethical attempt to act in pursuit of a good social order, the late Gillian Rose has been identified by many thinkers as a forceful theoretical ally in developing an Augustinian moral philosophy. ${ }^{57}$ Rose seeks to cultivate in her readers a commitment to "the work of mourning," which she describes as

\footnotetext{
57 Among the Augustinian thinkers who have drawn upon Rose's work are Rowan Williams, John Milbank, and Lewis Ayres; see "Between politics and metaphysics: reflections in the wake of Gillian Rose," in Wrestling with Angels: Conversations in Modern Theology, ed. Mike Higton (London: SCM Press, 2007), 53-76; John Milbank, Theology and Social Theory: Beyond Secular Reason (Oxford: Basil Blackwell Ltd., 1990); and Lewis Ayres, "Representation, Theology, and Faith," Modern Theology 11, no. 1 (1995): 23-46. But see also Vincent Lloyd's cautions that Christian theological interpreters of Rose (he examines Tony Gorman, Graham Ward, and Rowan Williams) often err in overlytheologizing Rose's work, too easily resolving the work of the middle; or (in Williams' case) by focusing on her
} 
experience which comes to learn that will, action, reflection and passivity have consequences for others and for oneself which may not be anticipated and can never be completely anticipated; which comes to learn its unintended complicity in the use and abuse of power; and hence to redraw, again and again, the measures, the bonding and boundaries between me and me, subject and subjectivity, singular and individual, non-conscious and unconscious. ${ }^{58}$

Rose operates with a basically Hegelian account of rationality, in which our patterns of reasoning are constantly called into question and modified on the basis of our experience. Rose understands our histories and the histories of our reasoning as "the drama of misrecognition which ensues at every stage and transition of the work - a ceaseless comedy, according to which our aims and outcomes constantly mismatch each other, and provoke yet another revised aim, action and discordant outcome." 59 This misrecognition is based initially on "the act of imposing... a pure and hence destructive, totalitarian universal." 60 The universal to which Rose refers is nothing but the notion of the good, or of justice - that standard by which we judge the relative merits of various courses of action, and commit ourselves to the one which seems best to us. Yet it is destructive and totalitarian precisely because we cannot see the world clearly. We have each been shaped by histories that exceed us, and occupy particular locations within those histories that render us conscious of or blind to the power we possess, and the needs of justice that obtain. We are unable also to anticipate all the consequences of our actions, producing effects well in excess of what we had desired, or dealing injuries that we had not predicted. None of this serves to exculpate us; indeed, our becoming aware of our blameworthiness is one of Rose's primary aims. Yet it does not seem that there are any other options open to us. Any action in pursuit of some good that we engage in must necessarily presume some understanding of the way the world is, and some notion of the good that we are striving to bring about. These are, in each case, representations of the way things are, and no intentional action would be possible without them. Prior to our action, though, these representations are normed only by our histories, pure products of our reasoning on the basis of those histories. To the extent that they are constructs of reason, they are totalitarian; only action in the world on the basis of these representations allows the world to "push back" on our thought, exposing our creations as misrepresentations. We come to learn that the world is as we expected it to be, and are forced to represent it to ourselves anew in light of what we have learned. "Reason," Rose writes, "is full of surprises, unanticipated happenings, so that comprehension is always provisional and preliminary." 61 Action affords us the opportunity of discovering where we have misrepresented things, and of attempting to correct

metaphysics at the expense of her own ethical appropriations of the theological virtues of faith and love; cf. Vincent Lloyd, "On the Use of Gillian Rose," The Heythrop fournal 48, no. 5 (2007): 697-706.

58 Gillian Rose, Mourning Becomes the Law: Philosophy and Representation (Cambridge: Cambridge University Press, 1996), 122.

${ }^{59}$ Rose, Mourning Becomes the Law, 72.

${ }^{60}$ Rose, Mourning Becomes the Law, 122.

${ }^{61}$ Rose, Mourning Becomes the Law, 72. Emphasis removed. 
our errors. But by then, the damage has already been done - we have inflicted violence on the basis of our misrepresentations that we did not anticipate, but for which we unquestionably bear guilt.

If we may hold with Augustine that virtually all evil acts pursue some deeply disfigured notion of the good, Rose gives us a language to describe the moral blindness induced by wicked desires. Representations of the complementary differences between masculinity and femininity coupled with the perceived good of a rationally-ordered household result in the domination of women and the establishment of a heteronormative ideal of the family, blinding many men and indeed women in patriarchal social orders to the possibilities of exercising moral agency foreclosed by (for instance) barring women's admission to higher education. So also, members of the society cannot see the injustice perpetrated on women barred from careers as public servants, or gay and lesbian persons imprisoned for moral deviance. Those conducting these actions know what they are doing, of course: maintaining appropriate admission standards to educational institutions, or punishing those who might corrupt the moral status of others; but they cannot see these actions as the profound violence, the profound injustices that they are. Only when the world pushes back, when a young woman displays intellectual skills unmatched by her male peers or when one's own life is enriched by a same-sex relationship, are one's concepts and representations of the world called into question, allowing one to see the wounds that have been inflicted.

Such an approach risks, of course, rendering what we tend to view as the subject-position of the oppressor normative in descriptions of political change, but one of Rose's fundamental claims - and one to which an Augustinian account of sin should lead us - is that there are no truly innocent parties (indeed, one recent study of Rose's work is titled Against Innocence). ${ }^{62}$ This is certainly not to say that all bear equal guilt; it would be abhorrent to think that the slave and the slaveowner occupy morally comparable positions, and in fact, would nullify Rose's aspiration for a social order in which the desires and demands of each party are negotiated in mutual recognition. But it is to say that even those who are dominated along various social vectors retain a circumscribed agency (as all agency is), and pursue representations of the good that themselves blind them to the harms they do to others. To take a theological example, one may think of James Cone's belated recognition after being pushed by younger black women scholars that his early black theology of liberation remained deeply and unconsciously patriarchal. ${ }^{63}$

On Rose's account, then, "the struggle for recognition is a drama in which the good (full mutual recognition) and the means (the varieties of misrecognition) engender each other and may

\footnotetext{
62 Andrew Shanks, Against Innocence: An Introduction to Gillian Rose (London: SCM Press, 2008.).

63 See Cone's words in the 1989 preface to his Black Theology E Black Power: "With the recent development of womanist theology, as expressed in the articulate and challenging voices of Delores Williams, Jackie Grant, Katie Cannon, Renita Weems, Cherl Gilkes, Kelly Brown, and others, even African-American male ministers and theologians are learning how to talk less offensively about women's liberation. Many seem to have forgotten that they once used exclusive language. Amnesia is the enemy of justice. We must never forget what we once were lest we repeat our evil deeds in new forms. I do not want to forget that I was once silent about the oppression of women in the church and the society. Silence gives support to the powers that be." James H. Cone, Black Theology E् Black Power (Maryknoll, NY: Orbis Books, 2006), xi.
} 
be negotiated but only by acknowledgment of mutual implication in the violence of misrecognition." 64 If we desire justice - the good of full mutual recognition - we cannot simply avoid acting. Pursuing the good engenders the necessity of representation, even if we know in advance that our understanding of the world in which we act will inevitably be some species of misrecognition. Yet only when we venture action can our misrecognition be exposed, hopefully leading to a more adequate representation, enabling us to act more justly. This cannot be understood as a mechanical process of advance; our action, and our misunderstanding of how we have acted wrongly (for we misrepresent to ourselves that, too), may lead us into deeper error just as much as it may lead us to deeper truth.

While we cannot trust that our action will lead us to a just society, seeking full mutual recognition opens for us a possibility for justice that acting on the basis of self-interest does not: "politics does not happen when you act on behalf of your own damaged good, but when you act, without guarantees, for the good of all - this is to take the risk of the universal interest." 65 This risk is, for Rose, the "risk of positing and failing and positing again," 66 and is essential for any possibility of understanding the world more truly and so (to the extent we are able, in light of failures of the will), to act justly within it: "Learning in this sense mediates the social and the political: it works precisely by making mistakes, by taking the risk of action, and then by reflecting on its unintended consequences, and then taking the risk, yet again, of further action, and so on." 67 Yet this requires that we act in the knowledge that we will err, and that our error will implicate us in violence against others. It comes as cold comfort that any action on their part will implicate them too in violence against us; and this is hollowed even further by the knowledge that power is not evenly spread through our social orders, and that the violence brought about by the actions of those who presently possess power - even actions done in what they believe to be service to the good - will dramatically exceed the consequences of the misrepresentations of those under the boot of an unjust society.

Rose is unwilling, even in light of this knowledge, to surrender the hope of a just society, and so does not counsel quietism. Still less does she trust in the bare messianism of the dream that we might simply step out of the present social order (through an undefined event, or an advent of the multitude, or simply by "blowing up" the contemporary order of things) and into a new, unaccountably more just one. The claim is not that such transformations are impossible, but that we have no reason to think these new social orders will be more just without an account of the material conditions and conceptual histories that have produced the notion of justice that orders life within them. Any different social order that does not pass through the history of learning by which our errors are exposed and corrected will, Rose thinks, inevitably suffer from the misrepresentations that keep us locked into the violence of our present relations to one another. Even as "the recognition of our failures of full mutual recognition"68 - a clear-eyed

${ }^{64}$ Rose, Mourning Becomes the Law, 98.

65 Rose, Mourning Becomes the Law, 62.

66 Rose, Mourning Becomes the Law, 13.

67 Rose, Mourning Becomes the Law, 38.

68 Rose, Mourning Becomes the Law, 76. 
accounting of our failures and violence - constitutes an essential part of her understanding of the moral life, it is merely one aspect of the "work" that is incumbent upon us: "a working through, that combination of self-knowledge and action which will not blanch before its complicities in power." If there is any possibility of a just society in which all find recognition, we will need to find it through the mutual contestation of desires and competing notions of the good. "For power is not necessarily tyranny, but that can only be discovered by taking the risk of coming to learn it - by acting, reflecting on the outcome, and then initiating further action." 69

On an Augustinian account, then, we may say that failures of representation are, most basically, failures to see the good creation of God as it is; failures to love it properly, failures to act justly toward it. We will love things too much or too little, or better, we will love not the thing God has made, but a forgery of our own fabrication. In failing to recognize our neighbor as who she is, we will treat her wrongly, often to violent end. This is simply the state of all sinful willing, and sinful willing is the only sort possible for us until we are able to behold all things in the light of our perfected vision of God. What Rose teaches the Augustinian reader is not a sure way out of $\sin$-we act always "without guarantees" — but a disposition toward our own sinful willing. In every action, we should be training ourselves to look for the moments when the world surprises us, moments when we discover that our neighbor is different than we thought she would be, or that something we had hoped would bring us fulfillment leaves us empty. In seeking out the failures of our own representations, we are taught humility, becoming newly aware of the limits of our knowledge and of the pain we have already unknowingly inflicted on others. This knowledge serves to train our eyes on the good; it serves to focus our love on the good that we seek. For Rose, this is the good of a polis permitting full mutual recognition, of a moral agency that is not necessarily tyranny.

We may take one step further: the good toward which our failures train us is the grace of God, the Good incarnate in the life of Jesus Christ. To identify the standard of our justice with the man Jesus is, however, to locate this Good not in a knowable transcendental that can serve as a ready guide to action, but in a human life, lived alongside us and in the midst of our ethical contestation. The Incarnation returns our notion of the universal good (though, not, of course, that Good itself) to the realm of the ethical, making it something that must be achieved through negotiation of the claims we make on our neighbors, and that our neighbor - Christ - makes on us. If we hold that this particular neighbor is the God who places an absolute claim on us, and that our own claims for justice and the fulfillment of our desires are not compromised but rather fully realized in acknowledging Christ's ethical demands of us, these assertions must station a post rather like (in fact, including) Rose's "full mutual recognition." Christ's ethical claim on us, and the realization of full mutual recognition in him, are formal posits whose meaning can only be determined through learning justice, and so must be learned as we contest with one another over what it means to follow Christ, what it is to do good. There are no guarantees in this process, but we may hope that our life together is enlivened by the Holy Spirit, and that She will create in us the love of Christ.

${ }^{69}$ Rose, Mourning Becomes the Law, 121. 
In learning our failure over and over again, we learn of our need for forgiveness from both God and our neighbor, and we learn that our sinful condition will be cured by no work of our own. Relatively better or relatively worse social and political orders may be open to us, but each will inevitably obscure from us the violence that persists in them. We cannot break ourselves out of bondage to sin, and even the humility we learn from our failures will not in itself heal us. All it can do is teach us where to place our hope, and train us, if we find ourselves spared from sins tomorrow from which we suffer today, to give thanks for this work to the Spirit of Christ.

\subsection{Failures of Imagination}

By "failures of imagination," I mean failures to imagine how our world might be very different than it is now, and how our actions might assist in bringing those possibilities about. There is reason to fear that Gillian Rose's account of rationality may lead us into failures of just this sort. Vincent Lloyd, undoubtedly one of Rose's most perceptive readers, sees dangerous shoals in the course set by many of her Christian interpreters. ${ }^{70} \mathrm{He}$ identifies those attracted to Rose's "broken middle," the realm of ethical contestation, as "broadly Hegelian in outlook. They do not see isolated subjects but rather subjects constituted in relation to other subjects, to communities, to histories, and to themselves - and to the absolute."71 Yet the temptation is to a moderate, purportedly sensible pragmatism that serves primarily to avoid radical challenge to the status quo. "Who embraces the middle? Obviously, it is those who reject extremes. It is those who are sensible, respectable, whose judgment is sound. It is those who think carefully and critically. In short, the middle is a very comfortable place for scholars; it matches the scholarly disposition."72 The rhetorical privileging of "the middle" threatens permanently to defend the world as it presently is: white, colonialist, patriarchal, ableist, heteronormative, bourgeois, largely unconcerned with just relations to the nonhuman environment. As Lloyd forcefully puts it,

This method of the middle presumes that our view of things is distorted a bit here and a bit there; with work, it can be clarified (even if some opacity will always remain). Yet from the perspective of the least fortunate, of the African American prisoner or the Haitian earthquake victim or the Palestinian refugee, an entire epistemological regime may need to come to an end, and it is unclear what resources the middle has for that. ${ }^{73}$

\footnotetext{
${ }^{70}$ Lloyd's first book is for the most part a detailed interpretation of Rose's thought, and a development of it in conversation with contemporary legal theory; see Vincent Lloyd, Law and Transcendence: On the Unfinished Project of Gillian Rose (New York: Palgrave-McMillan, 2009). His second book (Vincent Lloyd, The Problem with Grace: Reconfiguring Political Theology (Stanford: Stanford University Press, 2011)) offers a contribution to political theology through a secular Rose-inspired articulation of the theological virtues.

${ }^{71}$ Lloyd identifies Rowan Williams, Andrew Shanks, and Gavin Hyman among those who share this outlook. See Vincent Lloyd, "The Rhetoric of the Middle," Syndicate 1, no. 3 (September/October 2014): 58-63.; 58.

72 Lloyd, "The Rhetoric of the Middle," 58.

73 Lloyd, "The Rhetoric of the Middle," 61.
} 
Lloyd offers this as a critique of a particular species of theologian rather than of Rose herself, and so we may hope with some right that she possesses deeper resources for avoiding these problems than we might initially suspect. Yet Lloyd has identified a hazard into which those following after Rose could easily stumble. How are we to avoid it?

As a first response, we should note that the account of failures of representation I have offered assumes far greater defects in our ability to recognize the good than Lloyd's critique supposes. In light of the pervasive effects of sin, there are more than minor distortions at issue, and so we should expect that mere adjustments to our present sense of the demands of justice will be required. If, when he raises the possibility of "an entire epistemic regime" coming to an end, Lloyd means a fundamental revision of our categories of knowing and of our evaluations of what justices requires, I am in agreement with him; if he is pointing to the advent of a set of categories of knowing genealogically unrelated to those we now employ, I am not quite sure what he means. At a deeper level than this initial offering, I believe that Lloyd is pointing to a deficiency in the theological and philosophical method of those who take themselves to dwell in the broken middle. We might express it as a worry about triangulation: the rhetoric of the middle can devolve into a sense that in any encounter between different representations of the world and the good, each side will correct the other to a greater or lesser extent, but always in the direction of truth. Commitment to encounter with the other becomes a good in itself, but with a proviso: the other can trouble and change my understanding of the good, but cannot call me to conversion from my representation of the world to her own. In this way, fidelity to the middle safeguards the concepts I use to make sense of the world, even if these concepts limit the possibilities of justice I am able to imagine.

To this, I can only say yea and amen; though we do well to remind that both epistemological regimes imagined here emerge from the same material conditions and the same social orders, leaving the description of one of these regimes coming to an end rhetorically powerful but potentially misleading. It is better, in my judgment, to avoid the image of seamlessly-interlocking postmodern "conceptualities" or "epistemological regimes," in favor of a more deeply Wittgensteinian notion of concepts (and indeed, of representations) as fuzzily-related patterns of language-use appearing in many different particular discursive acts. Just as we never change our habits of speaking or judgment all at once, so also we never simply trade in one way of viewing the world for another in toto. Nevertheless, change in how we deploy one concept in discursive acts, or ceasing to use a concept entirely, can have widespread consequences in how we speak about the world and judge the good in particular situations, shifting our use of other concepts and substantially revising what we take to be good.

Lloyd points us, then, to a recognition that not all representations of the world are equally positioned with respect to the good of full mutual recognition, and that these variances are in significant part indexable to particular communities. One who is routinely exposed to the injustices of the contemporary American criminal justice system - who has suffered the constraints on her possibilities for living that that system unequally enforces, who has regularly experienced the failure of that system to recognize her desires and claim to justice - is epistemically better-positioned to see the inequity of that system, and to recognize that pursuit of 
the good of full mutual recognition will require fundamental changes to it. At the very least, belief that our representations of the world are deeply compromised by sin coupled with knowledge that those systemically oppressed by the present social order see the world very differently than we do should give us significant reason to doubt that our representations of the world are accurately allowing us to act toward the good, and to fear that they might be actually hindering our just action. It is precisely at this point where our failures of imagination come into focus; for even when confronted with the inadequacy of our ways of understanding the world, we often can imagine little more than superficial changes to our habits of acting within it. If failures of representation look backward, identifying our inability to understand rightly in the first place, failures of imagination are prospective, and pick out the limits of our ability to envision possibilities for living otherwise. It is important to note that not all defects in acting justly should be considered failures of imagination; some people simply prize self-interest to the exclusion of justice, not seeking any good beyond their own. What I have in mind are those times when one is earnestly seeking justice, but fails to imagine a world where justice might be done - or fails to recognize a relatively more just representation of the world offered by another. These sorts of failures are, I think, commonly seen in those times when a dominant social group cannot recognize the claims of justice when presented with them by those who are oppressed, though failures of imagination may also be seen among oppressed communities when members lose hope that a relatively more just social order is possible.

In recent years, queer theorists Judith Halberstam and the late José Esteban Muñoz have undertaken a thorough critique of failures of the imagination, alongside reflection on the broader ethical significance of what Halberstam calls "the queer art of failure."74 Muñoz's chief insight, developed in conversation with and subsequently further expanded upon by Halberstam, is that failure is the inevitable judgment that heteronormative society renders on queerness - and in turn, many in the LGBT movement have taken on failure as a particular mode of resistance to the constraints of straightness. While Muñoz presents his project as utopian, he means this in a very particular sense; though Muñoz does not directly engage Gillian Rose's work, he presents Cruising Utopia as emerging from the same theoretical trajectory passing from Hegel through the Frankfurt School, ${ }^{75}$ with Muñoz's utopianism being particularly indebted to Ernst Bloch. ${ }^{76}$ In contrast to the "abstract utopias... untethered from any historical consciousness," Muñoz's account centers on "concrete utopias," which he describes as "relational to historically situated struggles" and "the hopes of a collective, an emergent group, or even the solitary oddball who is the one who dreams for many. Concrete utopias are the realm of educated hope."77 Through analyses of a dizzying array of contemporary art emerging from the struggle for queer identity,

\footnotetext{
${ }^{74}$ See José Esteban Muñoz, Cruising Utopia: The Then and There of Queer Futurity (New York: NYU Press, 2009); and Judith Halberstam, The Queer Art of Failure (Durham, NC: Duke University Press Books, 2011). Muñoz refers to the "failures of imagination" of both the pragmatist gay rights movement as well as the antirelationalism of theorists like Lee Edelman at Cruising Utopia, 18.

${ }^{75}$ Rose's first book was, of course, on Adorno; cf. Gillian Rose, The Melancholy Science: An Introduction to the Thought of Theodor W. Adorno (London: Verso Books, 2014); (originally published 1978).

${ }^{76}$ Muñoz, Cruising Utopia, 2.

${ }_{77}$ Muñoz, Cruising Utopia, 3.
} 
Muñoz identifies the emergence of particular aesthetic practices that maintain the destabilizing hope of living outside the bounds of straight society's normative expectations. The recognition of failure constitutes a key moment in the formation of queer identity and its ethical significance.

Muñoz writes,

Utopia's rejection of pragmatism is often associated with failure. And, indeed, most profoundly, utopianism represents a failure to be normal...Utopia can never be prescriptive and is always destined to fail. Despite this seeming negativity, a generative politics can be potentially distilled from the aesthetics of queer failure. Within failure we can locate a kernel of potentiality. ${ }^{78}$

One should not underestimate the complexity of the dynamics of queer failure that Muñoz identifies here. On one level, Muñoz notes that the social order has linked together our concepts of queerness and failure by judging queer existence as a failure to live according to the dominant social script. As Judith Halberstam articulates this claim, "Heteronormative common sense leads to the equation of success with advancement, capital accumulation, family, ethical conduct, and hope. Other subordinate, queer, or counter-hegemonic modes of common sense lead to the association of failure with nonconformity, anticapitalist practices, nonreproductive life styles, negativity, and critique." 79 As judged by the normative assumptions of straight society, choosing not to secure a well-paying job and assume one's place in the middle class, choosing not to marry and have children, choosing to live the unpredictable life of an artist, can only be read as failure. This is what Halberstam calls "straight time," the regulated movement from childish preoccupations to responsibility and reproduction - of one's own genes, of course, but in so doing also of the dominant social order. ${ }^{80}$

In accepting the mantle of failure, however, Halberstam argues that those who are judged inadequate by a heteronormative society receive a powerful tool of critique. Drawing on James C. Scott's and Saidiya Hartman's arguments that "subtle resistances to slavery like working slowly or feigning incompetence" should be identified as "weapons of the weak," Halberstam suggests,

The concept of "weapons of the weak" can be used to recategorize what looks like inaction, passivity, and lack of resistance in terms of the practice of stalling the business of the dominant. We can also recognize failure as a way of refusing to acquiesce to dominant logics of power and discipline and as a form of critique. As a practice, failure recognizes that alternatives are embedded already in the dominant and that power is never total or consistent; indeed failure can exploit the unpredictability of ideology and its indeterminate qualities. ${ }^{81}$

\footnotetext{
${ }^{78}$ Muñoz, Cruising Utopia, 173.

${ }^{79}$ Halberstam, Queer Art of Failure, 89.

${ }^{80}$ Muñoz, Cruising Utopia, 25.

${ }^{81}$ Halberstam, Queer Art of Failure, 88.
} 
Failure is thus an ambivalent aspect of queerness, at once imposed and adopted; in speaking of queer failure, we must recognize both the "legacies of failure and loneliness as the consequences of homophobia and racism and xenophobia," 82 but also that the queer art of failure "quietly loses, and in losing it imagines other goals for life, for love, for art, and for being." 83

When I speak of "failures of imagination," then, I mean the sort of failures that issue from judging queerness as failure rather than as presenting alternative possibilities for human life. Heteronormative society cannot imagine being queer, and in so doing, subjects LGBT individuals to profound violence. Similarly, it cannot imagine not desiring to become a productive member of capitalist society, or not desiring to raise children, and judges these desires to be outside the bounds of a good human life. In evaluating queer lives and queer aesthetic productions as failures, heteronormative society blinds itself to these alternative possibilities as possibilities for its own life, and in so doing, fails to receive the neighbor as who she is. It is a failure to love one's neighbor, to treat her justly, or even to be sufficiently gripped by the challenge that her life issues to the pattern and assumptions of one's own. This is not to say that every possibility of human life must be uncritically affirmed when encountered in another; but they must be acknowledged as possibilities of human love that question the self-evident goodness of our own loves, and bear the potential to teach us new and better ways of loving that we had not previously seen. The danger of the pragmatist ${ }^{84}$ commitment to what seems politically viable to me is that the range of what is actually possible is likely very different than what seems possible to me. In some cases, I might dramatically overestimate my ability to participate in bringing about a different social order; but in others, I will have an unnecessarily constrained view of things. What queer theoretic accounts of failure underline is the way that a commitment to what we judge to be presently possible circumscribes our ability to hope. As Muñoz writes, the problem with the pragmatism of the gay and lesbian rights movement, which he reads primarily as seeking inclusion within the assumptions of heteronormative society, is that it "in and of itself hamstrings not only politics but also desire." By contrast, "Queerness as utopian formation is a formation based on an economy of desire and desiring. This desire is always directed at that thing that is not yet here, objects and moments that burn with anticipation and promise."85

In attending to experiences of failure both positive and negative within the queer experience, Muñoz and Halberstam teach us to dwell with failure - to view it not as one step, whether regrettable or necessary, within a larger narrative of progress and success, but to view it as a condition of life. It is precisely this notion of failure that an Augustinian account of Christian life in the world requires. For both thinkers, failure is ineradicable; as we recall, "utopia is...always destined to fail." 86 Yet attention to, and even aesthetic celebration of this failure cultivates a disposition that remains open to critique of whatever social norms prevail at any

82 Halberstam, Queer Art of Failure, 99.

${ }^{83}$ Halberstam, Queer Art of Failure, 88.

${ }^{84}$ By "pragmatist," I do not intend any connection to the school of American philosophy that goes by that name.

85 Muñoz, Cruising Utopia, 26.

86 Muñoz, Cruising Utopia, 173. 
particular time. It maintains a desire for utopia, and a sense that some glimpse of it may be apprehended in that which is strange to us, that which is novel and perhaps even set against that which presently is. In embracing our own failures, we recognize the unlivability of the world as it stands, and are taught to hope for something more. Moments when we realize that our imaginations have failed, that we never considered that one could live so differently, may if greeted with delight rather than scorn become moments when we both receive our neighbor more truly than we had before, and learn that life in the City of God also exceeds anything we can presently imagine.

In closing this section, I offer one word of caution about our failures of imagination and alternative ways of living. Both Muñoz and Halberstam valorize the sense that the world could be much different than it is, but neither lingers on the possibility that our actions could bring about a world that is significantly worse. Halberstam comes closest in a chapter on gay appropriations of fascist aesthetics, but the message there is merely that we must be alive to the complexities of history and avoided the misguided sense that there are "linear connections between radical desires and radical politics." 87 The possibility that goes unacknowledged in all this is that in our pursuit of utopia, we might bring about horrors. The persistently critical posture Muñoz and Halberstam advocate against the self-evidence of social norms likely inculcates the disposition most capable of receiving the difference of my neighbor, and so helps us see and oppose consciously doing wickedness to others. Yet we should remember that our wills are weak, and that many great evils have been done in the knowledge that they were evil, whether out of fear of another or out of self-interest. Imagining different and more just possibilities for human life does not correct the viciousness of the human heart. Even beyond this, we must recognize that we quite regularly fail to imagine what the consequences of our actions will be. Just as Muñoz and Halberstam laud queer aesthetics as displaying possibilities beyond what pragmatism can imagine, so also we must recognize that we often significantly underestimate just how bad we can make things. We may think that just a few seconds reading a text message received while driving cannot do any harm, only to result in the loss of one's own life or the life of another. We might imagine that quite radical change is needed in the political order, and anything that ends the current regime of power is a step in the right direction, only to issue in an entrenched totalitarianism. Most unsettlingly, incredible violence can result even from our attempts to pursue the good: few remember that it was Robespierre's ardent opposition to the death penalty and commitment to universal human rights that led to the Terror. ${ }^{88}$

More proximately, we might recall the example of Jean-Bertrand Aristide, the first democratically-elected president of the Republic of Haiti. ${ }^{89}$ Aristide was ordained as a Roman

\footnotetext{
${ }^{87}$ Halberstam, Queer Art of Failure, 171.

${ }^{88}$ Maximilien Robespierre, "'On the Death Penalty" (Speech at the Constituent Assembly, June 22, 1971), trans. Mitch Abidor." Marxists.org. 2004.

${ }^{89}$ Alex Dupuy, widely regarded as the authority on this period of Haiti's history among scholars of the region Alex Dupuy, The Prophet and Power: Fean-Bertrand Aristide, the International Community, and Haiti (Lanham, MD: Rowman \& Littlefield Publishers, Inc., 2007), describes the "mafia-like corruption network set up under the second Aristide presidency" (161). "It is clear," Dupuy writes, "that Aristide, as well as his Fanmi Lavalas party in power, relied on intimidation, violence, and corruption to maintain themselves in power, had become discredited, no longer
} 
Catholic priest in the midst of the tyranny of the Duvalier regime, and quickly became one of the most prominent liberation theologians of the Afro-Caribbean Church. ${ }^{90}$ Less than two years after Aristide's preaching and leadership had contributed to the ouster of "Baby Doc" Duvalier, his church of St. Jean-Bosco in Port-au-Prince was attacked by the paramilitary Tonton Macoutes in the midst of Sunday mass on September 11, 1988. At least a dozen people were killed, though the number is likely much higher; many of the dead were incinerated as the burning church collapsed on top of their remains. In 1990, still a Salesian priest, Aristide was elected President of Haiti. Aristide endured significant political opposition throughout his political career, including several assassination attempts and successful coups-d'etat, as well as the renunciation of his orders in 1994 after conflict with the ecclesiastical hierarchy boiled over. While Aristide remains a controversial figure in Haiti, ${ }^{91}$ his administrations were marred by widespread corruption at even the highest levels of government, with allegations including embezzlement of hundreds of millions of dollars from public funds, drug trafficking, money laundering, kickbacks from lucrative government contracts, and the use of violence against political rivals. ${ }^{92}$ Charges against him and more than thirty family members and associates continue to work their way through the Haitian and United States legal systems. ${ }^{93}$

In bringing up this example, I have no intention of suggesting that all theopolitical struggles for justice are doomed to failure, or that there is no possibility of real and lasting advances in social goods. My point is that, even in pursuing what seems to us an unquestionable good, even in striving for what appears clear to us as the cause of justice, we cannot reliably anticipate what will result from our actions. It is quite possible that supporting Aristide brought about more overt and systemic violence than some other course of action would have, though it is impossible to know for sure (and this is exactly the point). Indeed, we have no reason to think that Fr. Aristide himself was acting in bad faith; in his case, it seems clear that acting as he believed Christ to demand in pursuit of justice opened him to temptations he was not able to overcome. Aristide surely never imagined such a path for himself as he sought to respond to the grave injustices done against his people, and this is precisely what should terrify us. Yet quietism

represented the interests of the majority of Haitians who brought them to power, and were a major obstacle to the democratization of Haiti" (168).

90 See, for instance, the collection of Aristide's writings in Jean-Bertrand Aristide, In the Parish of the Poor: Writings from Haiti (Maryknoll: Orbis Books, 1990).

${ }^{91}$ Kerlens Tilus, "Quand le Roi des Rats Jean Bertrand Aristide Evoque le Déchouquage," Radio Television Caraibes, December 11, 2016.

${ }^{92}$ Komisar, Lucy. "Follow Aristide’s Money Offshore: How Haiti was looted with the help of tax haven shell companies \& secret bank accounts and U.S. citizens \& corporations." The Komisar Scoop. November 10, 2005. http:/ / www.thekomisarscoop.com/2005/11/follow-aristides-money-offshore-how-haiti-was-looted-with-the-helpof-tax-haven-shell-companies-secret-bank-accounts-and-us-citizens-corporations/ (accessed February 22, 2017). 93 The lawsuit filed in the United States District Court for the Southeastern District of Florida by the Republic of Haiti against Aristide on Nov. 2, 2005 may be found at http://haitipolicy.org/Filed\%20Complaint.pdf, and alleges that "Aristide and his accomplices converted to their own use millions of dollars of public funds" (2). It likely goes without saying that, as with most of Haitian politics for the last several centuries, the United States has been intimately involved with the goings-on around the Aristide administrations, sometimes on behalf of both the proAristide and opposition parties; cf. Paul Farmer, "Who Removed Aristide?", London Review of Books, April 15, 2004. https://www.lrb.co.uk/v26/n08/paul-farmer/who-removed-aristide (accessed February 22, 2017). 
can offer no solace: we do not know what the consequences of our inaction will be, either, and cannot trust that we will be more likely to avoid torture and bloodshed if we do nothing. Our failures of imagination reveal that there is no safe place for us, no course that we can trust will leave our hands unstained by blood. This too should teach us the depth and tragedy of our failures to know and desire the good, and should form in us the desperate hope that new life may come to this body of death.

\subsection{The Failure of Humility}

The end of life found Augustine painfully reminded of his own failures. While the attraction in his earliest days as a Christian to the possibility of retreat into a community ordered by the love of incarnate Wisdom persists in his desire to live a cloistered life as priest and bishop in Hippo Regius, Augustine had a dimmer view of the possibilities for spiritual advance than most of his contemporaries. As Conrad Leyser writes, "The monastery for Augustine was a site in which to practice and to perfect charity: this was far more important, in his view, than the performance of feats of asceticism, or in physically separating from 'the world." "94 Even if Leyser is correct that he had long before his death given up "[confidence in] his abilities to make moral progress and to inspire it in others," 95 his final years found even his hopes that his monastery might serve as "a window onto the City of God" dashed. ${ }^{96}$

Several notable events brought scandal to his community. In the mid-410s, Augustine had secured the ordination of a member of his community, Antoninus, to the bishopric of Fussala. ${ }^{97}$ Antoninus had grown up in the monastery on account of his parents' indigence, and Augustine believed him to be "prepared" (paratus) for the responsibilities of ecclesiastical office. ${ }^{98}$ As Leyser describes, "Initially overawed by his promotion, Bishop Antoninus soon overcame his inhibitions. Summoning two associates from the monastery at Hippo, he embarked on the fullscale exploitation and depredation of his flock... The episcopal court records at Hippo carried the doleful list of grievances of 'poor men and women, and worse still, widows." "99 Even as he was dealing with this crisis through the early 420s, matters did not improve: "the fabric of thirty years of monastic practice in the Church at Hippo and beyond seemed to unravel before the eyes of its ageing bishop." 100 There was a struggle for power among the nuns over who would succeed Augustine's sister as superior of the abbey she and Augustine had founded; "An 85-year-old man lived in continent marriage for twenty-five years... and then bought a 'music-girl"'; one of the priests resident at the monastery in Hippo was discovered at his death to have maintained private

\footnotetext{
${ }^{94}$ Conrad Leyser, Authority and Asceticism from Augustine to Gregory the Great (Oxford: Oxford University Press, 2000$), 10$.

${ }^{95}$ Leyser, Authority and Asceticism, 6.

96 Leyser, Authority and Asceticism, 4.

${ }^{97}$ Jane E. Merdinger, "Antoninus of Fussala," in Augustine through the Ages: An Encyclopedia, ed. Allan D. Fitzgerald O.S.A., John Cavadini, Marianne Djuth, James J. O'Donnell and Frederick Van Fleteren (Grand Rapids: Wm. B. Eerdmans Publishing Co., 1999), 47-8; ер. 209 and 20*.

98 ep. 209.3.

${ }^{99}$ Leyser, Authority and Asceticism, 21; citing ep. 20*.6.1.

100 Leyser, Authority and Asceticism, 23.
} 
property, rather than selling all he had upon entering the community. ${ }^{101}$ He responded by undertaking an inquiry into the rest of the priests in Hippo; "A month or so later, at Epiphany (426), Augustine reported that no other infraction had come to light. Within the year, however, he effectively abdicated as bishop, passing episcopal business onto the priest Eraclius." 102 Such incidents brought the effectiveness of Augustine's moral guidance into sharp relief. Though the bishop was capable of calling together a community devoted to the service of Christ, he was insufficient to the task of assuring the faithfulness of that community. He could not ensure that the members of his community would persist in the love of Christ and be numbered among the elect; he could not trust that the counsel he intended to edify those in his responsibility would achieve the desired result. "To wield the knife of correction was, effectively, to stab in the dark." 103

What sort of ethic is possible under such conditions? What hope for moral progress is available to us when so many fall unexpectedly into such grave sin, and when even the saints among us are incapable of preventing our (or their own) ruin? Our incorporation into Christ begins to conform us to the truth of our lives; but this is a hard truth. Our lives are pervasively and catastrophically marked by $\sin$. This sin, far more often than we realize, shoots our lives through with death. Our own mortality, yes, though this is also a means by which we are joined to Christ in hope of resurrection, a gift we receive from God. More terrible are the deaths we deal to one another, the grim cycles of war, and instrumentalization, and exclusion. We are acquainted with all these evils; yet perhaps most incapacitating in our attempts at moral progress, we cannot even see clearly where we fail. Every recognition of our sin is bounded by the simple truth that there is more wickedness in us than we know. Every recognition of that fact should be accompanied by an awareness that we do not know what we do not know about ourselves. Any judgment that we have advanced in love of justice may be a misrecognition of splendid vice, an occasion when our misdirected loves give the appearance of virtue. While it is true on an Augustinian account to say that even our splendid vices are misconfigured desires of some good or other, and therefore open to further reordering to the Good, the decisive fact is the direction of our loves. Either the present configuration of our loves iterates in orderings farther and farther removed from the proper ordering of desire by the love of God - splendid vices be damned - or our loves are drawing us closer to God, animated by the presence in us of the Holy Spirit. There is no Manichaean difference here: the world would be dramatically more violent, incapable of sustaining even the rudiments of human community, was not the Holy Spirit active in the hearts of even the most wicked persons. Neither can we be confident that we (or anyone else) falls on one side of the other of this distinction: the murderer on pilgrimage back to God may still commit grievous sin en route, and the moralist who is plunging into the abyss may emit the whiff of holiness. Between those who are being saved by the power of God and those who are perishing stands a gulf bridgeable only by grace.

\footnotetext{
101 Leyser, Authority and Asceticism, 23.

102 Leyser, Authority and Asceticism, 24.

103 Leyser, Authority and Asceticism, 27.
} 
In light of all this, Augustinians should be profoundly skeptical of all self-directed programs of moral advance - though not, we shall see, of the possibility of moral advance itself. It is a mistake to think that we can reorder our loves, or act in such a way that the reordering of our loves to God will reliably follow. Two people may pass their lives together regularly performing the same spiritual practices: one may become a saint, while the other is filled with pride and becomes scornful of others. It is a mistake, too, to think that the notion of reordering our loves can function ethically in anything but the most barren sense. We may say at a formal level that inasmuch as any order of loves are the loves of a creature of God, and so are not irredeemably wicked; similarly, we may say that any order of loves will be sinful just to the extent that it is misdirected, and holy to the extent that it refers all loves finally to God; and both claims pertain to all people, and in fact, to all amative beings. But as soon as we venture any judgments about our own or others' affective constellations, as soon as we speculate about how our loves might be brought to a more virtuous state by pursuing any particular course of action, we overstep our capacity.

It is not simply that our opacity to ourselves prevents us from knowing whether any moral program will be successful, but rather that no renovation of our desires is possible apart from grace's work, and God's gracious work is largely hidden from us. This did not, of course, prevent Augustine from enjoining spiritual practices among his monastic brethren and his congregations as a whole, as Aaron Stalnaker helpfully reminds us. ${ }^{104}$ Yet, as can clearly be seen in the correspondence with the monks of Hadrumentum, by the end of his life Augustine was clear that neither the summons to holiness nor the struggle to act righteously are sufficient in themselves to restore us to the love of God. At De correptione et gratia 2.3, Augustine writes,

the apostle does not say: We warn, teach, exhort, or reprove; rather, he says, We pray to God that you may do no evil, but that you may do what is good. And he was, nonetheless, speaking to them and doing all those things which I mentioned: He warned, taught, exhorted, and reproved. But he new that all these things which he was doing in an obvious way by planting and watering did no good unless he who gives the increase in a hidden way heard him praying for them. ${ }^{105}$

Why, then, undertake to exhort or reprove at all? Certainly, the reproof of others can serve as an occasion in which God distributes grace; for as we saw in the last chapter, God's work and the work of external signs are not exclusive of one another, but rather are non-competitively related. ${ }^{106}$ Yet even here, whether or not one is moved to holiness depends not on the mere fact

104 Stalnaker, "Spiritual Exercises and the Grace of God," 143-4.

105 WSA I/26, 110.

106 Cf. also corrept. 9.25; WSA I/26, 126: "Let no one, then, say that we should not rebuke someone who wanders from the right road, but that we should only ask of the Lord for his return and perseverance...For, if this person has been called according to his plan, God undoubtedly makes his being rebuked also to work for his good." 
of the rebuke, but on God's work in it. ${ }^{107}$ The answer, it seems, is so that our actions may come to serve as a reminder of the grace we have received or still require:

they are shown what they ought to do so that, when they do it as they should, that is, with love and the delight in righteousness, they may rejoice that they have received the sweetness which the Lord gave in order that their earth might bear its fruit. But when they do not do it, either by doing nothing at all or by not doing it out of love, let them pray that they may receive what they do not yet have. For what will they have that they have not received? Or what do they have which they have not received? ${ }^{108}$

In listening to the apostle, we should "recognize (cognosce) in his command what you ought to have; recognize in his rebuke that you do not have it through your own fault; recognize in his prayer the source from which you may want to receive what you want to have." ${ }^{109}$ As in the Confessions, the grace that draws our hearts to God comes upon us mostly unawares, and is best seen retrospectively - our task is one of recognition. Even in those moments when we can trust on the basis of the Church's teachings that grace is communicated to us sacramentally, the particular work of the Spirit is hidden from us, and so ought not be taken to direct us to any particular course of action beyond continuing to receive the sacraments. We may hope to grow in virtue, but these hopes may founder; when they do not, it will come not as a result of our moral exertion, but on account of grace. Attempting to make prudential judgments about which courses of action may nudge the constellation of our desires marginally in the direction of the good, opening our hearts to further renovation, but may also misidentify the source of our return to affective health. Left to our own devices, any attempt to make our desires an object of techne and to reorder them in the direction of justice can only produce a differently-constituted affective order that will sink us deeper into sin; yet as assisted by grace, moral struggle may indeed move us to the good. The point is not that we should renounce all moral struggle, but that we should

\footnotetext{
${ }^{107} \mathrm{I}$ am substantially in agreement with Paul Kolbet when he writes of corrept. that "It is a fundamental theological misunderstanding of God's relationship to the world to see divine agency as competing in history with human agency and art. No matter how robust one's notion of divine grace is, its transcendent quality prevents it from being a simple substitute for human effort" (Paul R. Kolbet, Augustine and the Cure of Souls: Revising a Classical Ideal (Notre Dame: University of Notre Dame Press, 2010), 137). Two qualifications, however. First: as Kolbet has framed the issue through grace's "transcendent quality," he is entirely right to say that grace cannot replace effort; indeed, the whole purpose of grace is to activate effort, the desire for good and the just action that follows from it. Yet this must not be taken to compromise the priority of grace's operation, or the feedback-loop in which sin holds us: our effort is powerless if we understand it to anticipate grace, or even to be cooperative in any way that imagines grace and our will to each contribute a part of what is needed in order to produce some result in our willing. Second: I am convinced by Leyser that, by the end of his life, and without modifying the non-competitive framework of grace's operation to which Kolbet directs our attention, that Augustine had a fairly dim view of his own ability to discern what words might move his congregants and monastic brethren toward the love of God. This need not imply any crisis of confidence in his ability to preach words of correction, rebuke, or exhortation, precisely because Augustine understood preaching to be so deeply shaped by the language of Scripture. When one doubts that one can effectively choose the right words to lead another to faith, it is best to rely on the words God has given us.

108 corrept. 2.3; WSA I/26, 110.

109 corrept. 3.5; WSA I/26, 111.
} 
renounce all claim to the effectiveness of our moral struggle. Whether or not we strive for the good, it is God who pulls our hearts back to Him. Only the Holy Spirit can create in us the true charity that teaches us to long for the God who is Justice.

When Augustine famously preaches to his congregation "Love, and do what you will" (dilige, et quod vis fac), ${ }^{110}$ then, it is as much an utterance of tragic resignation as it is a confidence that the God who is Love will eventually draw us to Herself. ${ }^{111}$ We will, at best, do what it seems good to us to do. Often, the good will be hidden from us, and we will not be able to act upon it. Sometimes, we will manage to see the good clearly, but our desire to act in accordance with it will not be sufficiently strong to bring about a good action, a result of the concupiscent habits that chain us to our sin. Our intellects are darkened, and our wills are weak; one way or another, we will do what we love, even if it is against our better judgment. The closest we can come to moral advance is to recognize our situation - to recognize, that is, our powerlessness, and our dependence upon God's grace. This is humility. Included in this is the recognition that, definitionally, nothing we can do will help us merit grace, even our humility. Humility is not selfabasement so that we may solicit God's favor, merely another species of moral program. It is a recognition of what we are and what we have always been: God's creatures, utterly dependent upon Her for all we are, both for the possibility of willing at all and for the possibility of willing rightly. We are no less dependent on grace for being humble, but it is nevertheless a good - and a good through which grace can work - to recognize ourselves for who we are.

It is the knowledge that we are creatures of God meant to love Him that rescues us from a quietism that suggests it is meaningless to desire the good or to attempt to act justly. At every level of our willing, sinful or no, we find our willing to be the good gift of God. In any particular situation and in our lives as a whole, we may deceive ourselves that we truly desire justice rather than our own interest or some other misdirected end; even our altruism may be splendid vice. Nevertheless, to the extent that we will at all, our willing is the action of a good creature exercising the volitional capacity God has given us, even if improperly. Though such vitiated willing necessarily draws us closer to nonbeing, to the extent that it is creaturely action, it is founded on the gift of God. Similarly, if we are capable of truly desiring the good and drawing closer to God, this is solely by the power of the Holy Spirit; even if we are gravely mistaken about our motivations for acting or the consequences of our actions, God remains free to enliven us with His own presence in our hearts. These two states of affairs - splendid vice and persistent sin in the midst of our reclamation - are impossible to distinguish in any case on this side of the Final Judgment, and so we are given no license for either despair or inaction. ${ }^{112}$ True, we may be mistaken about the justice we pursue; true, our pursuit of justice may bring about disaster; true, we may be mistaken in thinking that we desire justice at all: the answer is not retreat into moral lassitude, for failing to act on the basis of love when that is what our neighbor's pain requires is as

\footnotetext{
110 ep.Io.tr. 7.8.

${ }^{111}$ I am grateful to Jim Wetzel for this formulation.

112 This is the central Augustinian claim animating the thesis of R.A. Markus, Saeculum: History and Society in the

Theology of St. Augustine (Cambridge: Cambridge University Press, 1988).
} 
worthy of condemnation as trying but failing on account of our sin. That we sin (and sometimes to devastating effect) even when we attempt to do good should inspire us only to greater humility.

The ethical posture cultivated by this approach centers above all on the love of God and of our neighbor, and attempts to cultivate a receptiveness to God's work by keeping our own moral failures always in view. It places little confidence in efforts to know or sculpt our own desires, and recognizes the deep uncertainty we should have about the consequences of our actions. It attempts to dwell within this self-opacity, this knowledge of our past failures, this uncertainty of future success, and in so doing, it seeks to respond in humility to the work we hope the Holy Spirit is accomplishing in our own heart and that of our neighbor. If it is true that we cannot know just how deeply compromised we are by sin, it is also true that we cannot know the extent to which the Spirit has already liberated us from sin. Our vocation, then, is to love God and our neighbor in fear and trembling: to act as we believe that love requires, refusing to let our imaginations for a just society be constrained by the fear of failure; but also to act in the abiding awareness of the violence to which we are disposed by sin, and that any good issuing from our action is attributable to the work of the Holy Spirit in us. It is in pursuing the good that we fail, and in failing that we are reminded of our dependence upon God; there is a sense in which, on this side of the eschaton, we are meant to strive for justice in order to fail. Our failures are a tool through which the Holy Spirit deconstructs our distorted images of the world, the painful medicine through which God creates humility in us. We will love what we love, and act on the basis of those loves; this is beyond question. We may even learn something about what we love on the basis of how we act. The best we can do in the midst of this is to pay attention to the rough ground of our moral lives, to look for where the world pushes back on our expectations or resists being loved in the way we try to love it. When I recognize my failures, I recognize that I have loved poorly, and while this in itself cannot teach me to love properly, the very fact of my recognition opens for me the possibility that the Holy Spirit has already made in me the capacity to love better. Our aim is not to create the conditions for the Spirit who needs nothing from us to restore us to life, but rather to focus our attention on the gifts the Spirit has already given us.

We see at this point the deep connection between the humble self-knowledge we gain from attending to our moral failings, and the blessed life toward which the Holy Spirit is drawing us. In coming to know ourselves as the deeply sinful creatures we are, we also come to know ourselves as the beloved children of God who are even now being written into the body of Christ. Only when we understand just how thoroughly we have disfigured ourselves by sin can we understand the utter gratuity of God's love for us. This recognition is not only a personal one that pulls our hearts to the love of God, but a deeply social one, allowing us to receive not only ourselves as who we our but our neighbor as who he is. It is to acknowledge both the love and the wounds that pass between us, the histories of pain and the possibilities for true communion, to acknowledge as Gillian Rose writes, "that to live, to love, is to be failed, to forgive, to have failed, to be forgiven, for ever and ever." 113 In this saeculum, our love and our failures to love are inextricable from one another. If attention to our failures cannot itself create in us the holy love

${ }^{113}$ Gillian Rose, Love's Work (New York: New York Review of Books, 2011), 105. 
that we desire to share with one another and to direct to God, what it can do is keep us riveted on the possibilities of love and desire available to us now.

That I am able to know my failure as failure indicates that the Spirit has already been at work in me- I am able to recognize the ways that my loving is, at present, limited. But in this very recognition, I become aware of the absence of some health in me, and some good beyond me. My failure shows me that the Holy Spirit has enabled me to long for God, and for communion with my neighbor. This long is always responsive to God's work, always comes to us as gift, and is itself always imperfect on this side of the eschaton. Yet the desire for God and for our neighbor in God to which our humility directs us is unique among all that will persist and be transfigured in the New Jerusalem. What is now our longing for God and for restored relations within the created order is itself the love produced in us by the Spirit's action, true caritas; at present, it is something we suffer, a desire that is constitutionally unmet as a result of our sin, an open wound constantly reminding us that we lack the full embrace of ourselves, one another, and our God for which we were created. Humility tends the fire of this longing that the Spirit has created, leading it (we hope and pray) to be the defining feature of all our experience of the world - the reception of the world as gift, but a gift that points beyond itself to a fullness that we can only desire, not yet see. Augustine's more untethered moments of world-denial should, I think, be read in this direction, as indicating that loving the creation and our finite lives teaches us that the very worldly goods in which we delight are not yet fully themselves to us, that we will not be able to love them as what they are until we love them in the perfected love of God.

The loves and acts of love we share with one another are thus, as Rose indicates, profoundly ambiguous things. The defining difference in our present experience between our love of God and of our neighbor is that the flesh of our neighbor is unveiled and present to us, while the flesh of God is in heaven, available to us only hidden in bread and wine. We can hold one another, comforting one another in grief. We can share knowing glances, or raise our eyebrows in challenge to another's actions or words. We can hold one another's bodies, feeling the warmth of skin against skin or of flesh within flesh. We can kiss the forehead of one we love as she lays dying. And we can bruise; we can linger on the pain and fear visible in another's face; we can force another's body to conform to our will; we can render skin ragged with the pocked iron of shackles or the crack of a whip. We write our desires on one another's bodies. We know them either as objects to be controlled and made available to our whims, or as signs that even our best ways of loving are not yet adequate to receiving our neighbor as the unsubstitutable life God has made him. We will wound one another; this cannot be seriously questioned. We will continue to wound one another even in our best efforts at receiving the other faithfully. Training my attention on those moments when my expectations of my neighbor are confounded preserves her in her particularity as best I am able, and allows me to be surprised by a new awareness of who God has made my neighbor to be. Yet as we have seen, this process will often be quite painfulpainful both because we expose ourselves to another who, because sinful, will inevitably wound us; but also because we will be forced to come to terms with the ways we have already harmed others. We are too late to prevent the damage we have done, but our hope is that the Holy Spirit will grant us the grace to see our sins as sin, and the strength to avoid sinning likewise in the 
future. Facing ourselves as those who have caused others to suffer - even (especially) those we love- continually teaches us our dependence on God.

Yet in attending humbly to my failures in love, I attend also to the desire not to fail that the Spirit has created in me, and am taught to pray for an even greater longing. I come to desire what God desires, with the very desire God has created in me: that I should know the gravity of my sin, and the damage I do in refusing my neighbor as who she is; that I should repent, turning to Christ alone as the one who can restore me to health; that I should not insulate myself from the inescapable tragedies of the world or the harms others inflict on me, but even in suffering them feel in them a hope for something more; and that, in response to God's work and empowered by it, I may take the risk of loving others, knowing that I will fail but committed nevertheless to the work of justice. This last moment should not be passed over too quickly; we are not taught to revel in our sufferings, or to seek them out, or to avoid acting in such a way that we might correct injustice (even if we should maintain a skepticism about our ability to know what the consequences of our actions will be). We are taught to love, and we will not love at all if we do not learn to bind the wounds that lie open before us. We must work to correct injustices, because our love teaches us to desire just life together. ${ }^{114}$

Our failures in love thus open the world to us, teaching us with painful clarity who we are, and teaching us also to desire something beyond the world of our experience. As Charles Mathewes writes, "The hope we can barely stand is indeed what we must endure; and it is God's hope, not primarily ours at all. In hope, we refuse to cease suffering, and look instead to find ways to deepen our attentiveness, both to hope's tantalizing visage and the reasons we need it so desperately." 115 In the words Rose quotes from the modern saint Silouan the Athonite, "Keep your mind in hell, and despair not." 116 We must suffer the world, learning hope precisely in our regret and longing as we fail others and are failed by them. In clinging to our weakness, we may yet become, and are even now, the body of Christ.

\section{Seeing Christ with Wounded Eyes}

\footnotetext{
114 We should recognize, too, that not all wounds are capable of redress. We will inevitably be failed by those we love, or harmed by the wickedness of others, or bear in our bodies the corruption of injury and disease. At the last, each of us will die; our flesh will be reduced to dust, we will lose all possibility of bodily embrace, we will lose all those corporeal goods that have brought us delight. Throughout our lives, we will experience the death of others, losing them perhaps in a steady drip punctuated by unexpected seasons of tragedy, or if we are lucky, with increasing frequency as we approach the natural limit of our lives. It is the pain of this pervasive loss that teaches us to hope for the restoration of all things, but even here we should avoid glibness: some harms are so overwhelming, undergoing some evils so debilitating, that those who are subjected to them may find themselves utterly unable to hope. Such situations approach tragedy without reserve. The best we can do in them is to commend the wounded to God, to comfort without expectation that they will return to health, and to cherish our own hope that God's work and the distance of time will one day brighten their darkened skies. While such horrors may be unique in their effects, they are like the other harms we suffer in many ways. Perhaps most significantly, they are thoroughly unnecessary, in that they are the result of the damage that sin does within the created order; but also, in that we can rarely escape them.

115 Mathewes, A Theology of Public Life, 257.

116 Rose, Love's Work, 105.
} 
All this sketches out the main lines of an Augustinian disposition that attempts to think from our knowledge of our pervasive moral failure - yet it remains, at this point, vague. My actions toward an unnamed neighbor are to be guided by my love for a God whom I do not yet see clearly. The demands of love are themselves uncertain, and the rhetoric of love can be (and has been) used as justification for profoundly wicked acts.

The natural move at this point is, of course, to turn to Christ. Surely it is in the life of Christ that we find the Good made concrete? Surely here we may find determinate guidance on how we should act in light of the charity that the Holy Spirit sheds in our hearts? This is no doubt correct, but we must remain attentive to the difficulties in responding in this manner. First, as we have noted, one of the defining features of Christian life before the eschaton is the occlusion of Christ's flesh; though he remains present to us veiled in the eucharistic host, he does not now dwell with us in a manner that would enable us to see clearly what belonging to his Kingdom might entail. He reigns even now over all the earth, but the law he has given us is love. Second, the manner in which Christ was present to his disciples and those close to him in the course of his ministry did not prevent dramatic misunderstanding of who he was and the significance of his actions. As Augustine writes at en.Ps. 90(2).13, "Christ was not seen in the way that we shall see him. He was seen in such a way that it was possible for those who saw him to crucify him."117 The Scriptural witness demands that we claim that Christ's divinity was not visible such that anyone who gazed on his flesh would see and worship the God who has made all things, though Christ might have appeared in this way. ${ }^{118}$ This is, possibly, the reaction that any creature might have had to beholding Christ's transfigured flesh, and a theophany of this sort is likely what is presumed of Christ's flesh at the Last Judgment, where both those to be reconciled to God and those to be damned (if any such people there be) will behold alike Christ's coming in majesty. The vision of Christ enjoyed by those who met him in Galilee or Jerusalem, and which we possess mediately through the witness of Scripture and through other representations of Christ, is of a different sort: it is susceptible of misrecognition, capable of being abused and distorted in the same ways as our representations of one another. Those who crucified Christ likely viewed him as any other religious dissident executed within ancient Palestine: as a threat to the projection of Roman sovereignty, as a religious extremist who might incite the people to rebellion, as an illiterate peasant, as an occasion to publish the consequences of any attempt to challenge the rule of Caesar or his vassals. Christ is represented here not as the incarnate Lord, but through the darkened lens of the conceptual vocabulary of Roman rule. But if the image of Christ held by those who encountered him directly could be so pervasively distorted, how can we hope that our own vision of Christ can serve as a sure guide to us? Shouldn't we fear that we, too,

117 WSA III/ 18, 343.

118 Coakley explores a similar set of issues in Powers and Submissions, Ch. 8, through discussion of Origen, Gregory of Nyssa, and Ludwig Wittgenstein. She argues that, "Just as 'referring' has no one ('essential') meaning from a 'family resemblance' perspective, so too 'perceiving' seemingly has no one meaning either. We 'perceive' at different 'levels', according to the development of our 'devoutness'. If this is indeed Wittgenstein's meaning (and it does seem to be the 'plain sense' of the text), then we are extraordinarily close to the central insight of the spiritual senses tradition" (145). 
will mislead ourselves even as we attempt to follow Christ, that our pieties may themselves authorize our self-deceptions, our misdirected loves, our desires for domination?

Well yes, quite. Christian history is littered with anti-Jewish Christs, imperialist Christs, colonialist Christs, patriarchal Christs, racist Christs, homophobic Christs, and many others besides. What's more, we should expect and lament there to be many other compromised and damaging representations of Christ, against our best efforts; we cannot avoid substituting idols for our God enfleshed, though this fact does not absolve us of responsibility for manufacturing these counterfeits. There is, again, no simple solution here. Augustine continues the passage above, "Think of it: those who saw him crucified him, whereas we did not see him but have believed in him. Those others had eyes, and have we none? Far from it; we have the eyes of the heart, but for the present we live by faith, not by sight."119 This is indeed a contrast between the faithful and those who have not set their trust in Christ, but it is not one conducive to untroubled reflection. What differentiated those who were able to see Christ's divinity from those who were not? As we have already seen, only faith, which is itself a gift of the Holy Spirit; and though we can, indeed must, trust the Spirit, we cannot be confident of its work in us. Our faith may prove impermanent; the trust we seem to ourselves to place in Christ may be trust in a deity of our own making. Even here, our representations may fail us imperceptibly.

We run up against a familiar problem. Only the work of the Holy Spirit can correct the distortions in our view of Christ; only the Spirit's enlivening presence can conform our lives to the pattern set in Christ's own life. Only the Spirit can make us members of Christ, giving us his own life lived now in us. And so the question again must be converted from that of how we can correct our misapprehensions of Christ, to how we may attend responsively to the work the Holy Spirit has already accomplished in us. We must focus on the moments when we become aware of our failures to see Christ. As I have noted above, such recognitions presuppose that the Spirit has already acted in us, and are usually brought about by encounters when we experience the world as pushing back against our expectations of it, bringing to light the awareness of a new capacity for seeing God that has been granted to us. Here again, the Ascension stands as the insuperable fact rendering impossible the modes of fleshly engagement through which our misconceptions are often chastened; if we will see Christ, it will need to be elsewhere than in the body of the Resurrection. If we are to love Christ who is both God and neighbor under these circumstances, it will mean seeking him out.

At this point we return to the quotation from the Enarrationes in Psalmos with which I ended section one of this chapter, and to Chapter Three's concluding discussion of the proliferation of creaturely likenesses (similitudines) of Christ. As Augustine wrote at en.Ps. 66.10, "What matters is that you progress, and a likeness (similitudo) is meant to help you along to salvation. You do not find this particular image helpful? Very well, take another; the point is that you must act on it." 120 Seeking the ascended Christ, focusing our desires on him even in his absence, will lead us to seek signs that direct us to him; as we saw in Chapter Three, this is

119 en.Ps. 90(2).13; WSA III/18, 343.

120 WSA III/ 17, 323, revised. 
precisely the logic of Augustine's account of the ordering of redemptive signs to Christ's flesh. And as we saw there, nothing is, in principle, excluded from potentially serving as a sign of Christ. It is the telos of all things, and of all moments of created history, to be written into the language of divine signification, eschatologically revealing to us new depths of the mystery of all creation's ordering to the flesh of Christ. In the absence of his unveiled flesh, our action should be directed to the end of seeing Christ in all things: paint is to be set on wood and canvas in surprised gratitude that God may now be depicted; gold is to be set in leaves embellishing these images, or crafted into the form of his body and placed on altars or carried in procession as his people make their pilgrim way through the world; stones are to be set together as church buildings; plates and cups are to be made eucharistic vessels; jewelry is to be marked with the sign of the cross; bells are to call God's people to prayer and mark out time itself as sanctified; lambs are to be roasted on Easter morning, and dough is to be baked into hot cross buns; rearview mirrors are to be adorned with images of the saints who themselves are signs pointing to Christ.

The point of such a list is to gesture at its endlessness, and it could (and should) be pushed even further out of the realm of what we imagine as the proper bounds of "Church practice": fish fries, green beer on St. Patrick's Day, the cartoon Christ of South Park, Hallmark Christmas movies. It is not that any of these are perfect images; indeed, they are all necessarily imperfect, some perhaps tending to profanation of sacred things. Though not, I think, as many as we might expect; Christ has set the pattern for what it is to depict God by assuming flesh beaten, spat upon, naked, profaned, and the sight of his bloody, violated, spent body on the hill of Golgotha is the measure of all other depictions of God far more than the sanitized versions that hang in our churches. Here, as always, the standard by which we are to adjudicate an image of Christ as holy or profane is whether it disposes us to love Christ or to despise him - if it is useful in directing our hearts to God, very well; if not, find another. Though here, as always, we should maintain a healthy skepticism about our judgment of these matters, and should attend as best we can to the fruit that contemplation of these images bear in our action. Such images of Christ, whether directly depicting his body or drawing upon the infinitely extendable language of divine signification to point to Christ in a windhover, or a limestone coast, or a gnarled old table, or (let us say it) a dead dog, ${ }^{121}$ serve a central role in the life of faith, showing all aspects of our experience to be sanctifiable, and Christ to be in all things.

Yet for precisely this reason, such images (or such a way of considering images) make poor checks on our capacity to distort Christ. If all things are likenesses of Christ that can serve as signs of him, nothing is excluded - but this recognition by itself offers little purchase for critique if I am holding to an image unhelpfully, taking it to be a truer image than it is helpful for me to do. The pacific image of Christ the Good Shepherd is very comforting if I feel myself walking through the valley of the shadow of death, but it may be substantially less helpful if my trust that Christ will take care of others leads me to absolve myself from feeding them or clothing their nakedness. We most commonly become aware of our failures when the world pushes back on us,

${ }^{121}$ Karl Barth, Church Dogmatics I/ 1, ed. G.W. Bromiley and T.F. Torrance, trans. G.W. Bromiley (Edinburgh: T\&T Clark, 1975), 55. 
confounding our expectations of it, as in interpersonal relations. If, then, we wish to follow after Christ's ascension, seeking him in the world, we will need images of him that can draw us up short, showing us where and when we have neglected his presence among us. Static images can serve this purpose at times, particularly when we come across them for the first time, or most commonly when they are situated within communities that promote dialogue about interpreting them. We may think of images like the Blazon of the Five Wounds adorning the banners of those marching in the Pilgrimage of Grace, or of depictions of Oscar Romero in city murals. Though they require instruction about how they connect to other more familiar Christian signs, they display the potential of static images to serve as icons not only of Christ but of particular understandings of the proper conduct of Christian love: that Christian subjects in sixteenthcentury England should resist Henry VIII's encroachment on the work of the Church, or that the twentieth-century Church in Latin America must stand against political violence and on the side of the oppressed poor. These are particular (and thus fallible) judgments about the actions that should issue from love in particular times and places, and communicated through particular images.

Yet once again, static images seem ill-suited to this task. ${ }^{122}$ Che's likeness can be put on a t-shirt, while Che himself would (likely) strongly resist such commodification. ${ }^{123}$ The correction we require can only come from images capable of actively challenging the sinful distortions in our representations of Christ, living signs that can expose our moral blindnesses, correct our misapprehensions of who Christ is and how he dwells among us now, and teach us what justice demands in the present moment. In pointing to these living images, we must guard against two possible errors or misinterpretations of this approach. First, what is of ultimate significance is the extent to which these lives have been conformed to the life of Christ. There is no difficulty here in affirming that the self-understanding of those lives so conformed may be as pervasively mistaken as my own. My claim, then, is not for a special sort of epistemic access to what is holy or what is just that would protect those conformed to Christ's life from significant errors; those lives do not serve as living images for us because they understand more about Christ, and can communicate that knowledge to us, but rather because their lives themselves set Christ before us in our own time and place, opening the possibility that our misconceptions of who Christ is may be corrected by encountering his body through my neighbor. Second, we should not understand these encounters as serving a primarily utilitarian role, thus instrumentalizing our neighbor. It is true that meeting Christ in our neighbor has the potential, as provided by the Spirit, to emend our mistaken understandings of who Christ is and what loving him requires, but we do not love our neighbor merely because our relation her may further our redemption. Rather, it is the content

\footnotetext{
122 The powerlessness of static images should not be overstated; as Caroline Walker Bynum has spent a career arguing, material images played a lively, agent-like, and even threatening part in the significatory systems of the Middle Ages. Bynum writes that it was "extraordinarily difficult for people in the later Middle Ages to see any matter as truly dead, in the sense of inert, rather than rotten or fertile - that is, percolating with threatening, yet glorious physicality" (Caroline Walker Bynum, Christian Materiality: An Essay on Religion in Late Medieval Europe (New York: Zone Books, 2011), 122).

123 This does, however, point us to one of the situationally-relevant advantages Che's likeness bears over Che himself - it can serve an iconic role long after Che has died.
} 
of redemption to behold Christ ever more fully in our neighbor, and in doing so, to behold God in Christ. The Christian life is one of receiving our lives from God and living in response to the Spirit's action. What our existence as living images to one another shows is that we live in responsive self-giving to our neighbor, as well, that we receive our lives also from our neighbor, learning how to see ourselves and act as Christ by seeing Christ in her own life. Just as our sin ensures that we cannot perfectly receive the gift of ourselves that God gives us on this side of the eschaton, so also we must say that no such encounter is unmarked by forces of domination; yet even in their compromised present state, the moments when we share the living image of Christ teach us to long for our relations to come, in which we will give Christ to one another without loss to ourselves, becoming Christ ourselves as we show him to one another. Rather than using my neighbor, I find that I only become who I am as I love my neighbor for who she is, written into the life of Christ.

Who, then, is my neighbor? As what I have already said indicates, those who have been incorporated into Christ's body through baptism and the work of the Holy Spirit have a particular vocation to serve as living images of Christ, offering models of Christ's life today that can correct our misapprehensions of where he dwells and what he commands. It is the essence of the Church's life not only to serve as an icon of Christ, but to know itself as such an image and desire for one's own life to be patterned on that of Christ; as Augustine writes, "we are being changed from form to form, and are being passed from a blurred form to a clear one." 124 Christians serve as images of Christ to the extent that their lives are in-formed by his, and it is this gift of new life in Christo that allows the lives of Christians to model Christ for others, and to correct our misapprehensions of who Christ is today. We measure our lives against the holiness that we see in the lives of others; we learn that we must care for the poor by seeing Christ in others as they care for the poor, we learn how selfish and impatient we are with others as we see others model Christ's generosity. Often, those who help correct our misunderstandings of Christ will have no idea they are doing so; our sin will simply become apparent to us as we see the work of sanctification God has worked in another. At other times, however, this act of correcting us in the direction of Christ is a self-conscious work of those within Christ's body: we may think of the pastor who is aware that her congregation is insufficiently welcoming of visitors or refugees and teaches a Bible study on Christian care for the stranger, or who sees her congregation's idolatry of wealth and security and preaches on sacrifice and risk as ingredient to the Christian life, or who sees the sinfulness of her community and calls her congregation to display the possibility of new life in Christ by resisting injustice together. And these corrections are seen not only in relations between clergy and those whose souls are in their cure; we see it too in friends within the Church who support one another in hard times or tell difficult truths to one another, thus allowing one another to enter more deeply into the pattern of Christ's life. Because all this is premised on the recognition of Christ in one another by the work of the Holy Spirit, the Church is necessarily visible; to the extent that the members of the body of Christ do not recognize Christ

124 trin. 15.8.14; WSA I/5, 406. 
in one another in Catholic unity, this community contradicts its vocation within the economy of redemption.

It is of course ludicrous to think that this is what life in the Church is always like. Often we do not show Christ to one another, or do not see it when someone offers Christ to us; often, our calls to repentance can cloak calls to bigotry and exclusion. This is the presently inescapable consequence of $\sin$. In these moments, the Church fulfills its vocation by correcting one another in love. This correction may have no effect whatsoever, leaving the sinner in her darkness; if it does, if it enables her to see her sin as a failure, it may be a moment in which the sinner learns more deeply what it is for her to be a member of Christ, a lesson she learns as the Spirit enables her to see Christ in another. Living within the community of the Church thus regularly exposes us to those who, in their own lives, may challenge our expectations of what it means to be Christ in the world, correcting us often in ways even they do not recognize, calling us to enter more fully into the pattern of Christ's life. That they do so alongside being - and sometimes in the very act of being - petty, fearful, uncharitable, and thoroughly of this world is part of the miracle of God's redemptive work. So too, it is a mistake to think that these relations that teach us what it is to live in Christ today are only found within the Church. We should expect that our misapprehensions of Christ will be corrected by those outside the Church with no less frequency than by those within it. What is different about the community of the Church is that those relating within it know themselves to be common members in the body of Christ, and so are freed to worship together in a shared response of gratitude to the Lord who they know to be the source of their reconciliation with God.

Within this broader context of the Church's communal life, two sites especially are held up as revelatory of Christ's life, the points where we should return again and again in the hopes that our now-obscure image of him will become progressively more clear to us. The first of these is the sacramental ministry of the Church, the point at which Christ is presented to Christ by the Spirit of Christ with greatest intensity. Through the sacraments, Christ unites us to his death, nourishes us with his body, and opens to us a new life shaped by the pattern of his own; a life entered into by baptism, sustained by the eucharist, and structured by the rites of confirmation, marriage, ordination, the reconciliation of penitents, and the anointing of the sick and dying. These sacraments are unique in that they effect what they signify to us: the waters of baptism really do plunge the old human into death; the bread and wine really are the body of Christ broken for us and offered for our consumption. The fact that these signs require both outward sign and word ${ }^{125}$ makes them essentially liturgical acts - they are marked by their repeatability, their ability to be and be recognized as the same act in vastly different cultural and historical circumstances, and so require common features of performance to be recognized as the signs they are (water, the invocation of the triune name of God, etc.). Yet we approach these signs in the belief that they have been given to the Church by Christ and are animated by the work of the Holy Spirit, trusting that in being baptized, in communing each week, in marking the important moments of life by the Church's blessing, that we will come to understand ever more deeply what

${ }^{125}$ Cf. Io.eu.tr. 80.3. 
it is (and is not) to live as the body of Christ. The sacraments communicate to us a grace we cannot immediately see, but hope will work in us to create the love of God. In receiving these gifts together from the hand of those called to stand in persona Christi, one member of the body shows Christ to another, and in so doing, both the one administering the sacrament and the one receiving it (and the community as a whole) become more fully one body.

The second site at which we find Christ's life revealed to us with particular clarity is in the lives of those acknowledged by the Church to be saints. As the creed's profession of faith in the communion of saints has been interpreted within the Catholic tradition, Christians hope that even death cannot separate us from fellowship with those who live in Christ. As we trust that those living with us can show us Christ and mediate his redemptive work to us, so also we express that God may communicate Himself to us powerfully through our veneration of the saints, our meditation upon the witness of their holy lives, the power of God still active in their relics, and through their intercession for us. In the saints, we see human lives made transparent to the power of God through the work of grace, Christ's own life extended with shocking clarity into new times and places. If there is anything we learn from the deposit of saints' lives accumulated over two millennia, however, it is that being conformed to Christ is a messy, surprising, costly, and often transgressive work, far from the safe narratives of the holy we imagine for ourselves. As God communicates holiness to the saints, their lives come to be marked with the same strangeness and unfamiliarity of holiness that prevents us from seeing God's perfect holiness. As Elizabeth Sutherland observes, the mode of visibility of the saints is as much apophatic as kataphatic, chastening our presumption that we yet understand what it might mean to life a life conformed to Christ's. ${ }^{126}$

Indeed, the saints' ability to discompose our mistaken representation of who Christ is reflects an essential feature of the forma servi, something that is true of all those occasions in which our misapprehensions of Christ are exposed to our view. Christ comes to us as one unregarded, and in so doing, challenges our sense of what is worthy of regard. This case has been forcefully argued by Brian Bantum, who calls attention to what he calls the "mulattic" or hybridized existence of Christ. Bantum's analysis begins with a consideration of the processes of racial subjectivation and the special problem those of mixed race posed to the maintenance of the white supremacist social order under and in the wake of American slavery. In their very presence, they made visible and tangible a history of enslavement and rape, at once a testament to the white desire forcibly to gratify their desires upon black flesh, and a challenge to the law of paternal recognition and inheritance that maintained black flesh as property. Bantum tells us that this contradiction could only be covered over by an attempt to exclude racially-mixed bodies from white consciousness entirely. The slavemaster's children would grow up alongside one another, some as legal heirs, others as property; the continuance of this system of inheritance was predicated on legally covering over the fact that these dark-skinned children were equally his

${ }^{126}$ Elizabeth Sutherland, "Saints in Sight: Representations of Holiness in Late Medieval English Literature" (Unpublished Ph.D. Dissertation, University of Virginia, 2017), 19ff. See also Jean-Luc Marion, "The Invisibility of the Saint," in Saints: Faith without Borders, ed. Françoise Meltzer and Jas Elsner, trans. Christina M. Gschwandtner (Chicago: University of Chicago Press, 2011), 355-62. 
offspring. Thus, Bantum writes, "by denying mulatto bodies as a fruit of white desire and maintaining that the mulatto was essentially a black body, white identity would be created and maintained in the New World."127 The mulattic body occupies the position of the "neither/nor": able at times to "pass" as white, visible to whites as the product of their own desire, and so not fully assimilable to the racial categories imposed upon black bodies; yet excluded from the dominant social location of whiteness as something impure. ${ }^{128}$ Interracial bodies exist within white habits of conceptualization as that which must remain unthought, and in this very exclusion, find that their existence itself stands as a challenge to the constructions of the social order: "They disrupt because they are."129

In so doing, they also become a sign of possibilities for human lives conducted otherwise than the systems of power of white domination require: "the sheer hybridity of those bodies confound the logic of such constructions making a space where all are free to 'become." 130 The central anthropological insight here is that "The examination of mulatto/a bodies makes visible the participation of all bodies within modernity's interpretive racial gaze." ${ }^{131}$ It is not only interracial bodies that are worked upon by the technologies of racial formation, but all bodies; whiteness is no less an artifice of culture than blackness or mulattic existence. Bantum points to the same sociality of our self-understandings and moral agency that we saw in Butler when he notes, "The neither/nor that gives birth to and inheres within the interracial body in the modern west is but an iteration of the deeply 'inter' character of all human lives." 132 The notions of “"Mixture or 'hybridity' or 'mulatto,' are thus all confessions of the reality of a personhood born of two realities, yet... a personhood without divisions." 133

On the basis of all this, Bantum claims that "Christ's body and life inhabit the neither/nor that marks all human lives, but that is particularly resonant in mulatto/a bodies. Yet Jesus inhabits this space in a different way. His presence as mulatto recreates the space around him. He is neither/nor - but." ${ }^{134}$ Bantum has in mind here the negations of the Chalcedonian definition: the two natures in Christ are neither confused, nor changed; neither divisible, nor separable. In the divine-human life of Christ, we find both our concepts of God and humanity broken open - the transcendent God who is incomparably other than the created order lives a finite life; the humanity that we know to be little more than a breath and a fleeting shadow is made incorruptible and assumed into identity with God. As the human who is also God, Christ shows us not one more possibility for inhabiting a socially-constituted life, but shows us the possibility of all human life: "in the Creator becoming the Created One, humanity's claims concerning purity and possibility only become intelligible within Christ's body. In subjecting himself to the discursive limitations of human language regarding themselves or God, Christ

\footnotetext{
127 Bantum, Redeeming Mulatto, 9.

128 Bantum, Redeeming Mulatto, 41.

129 Bantum, Redeeming Mulatto, 43.

130 Bantum, Redeeming Mulatto, 80.

131 Bantum, Redeeming Mulatto, 83.

132 Bantum, Redeeming Mulatto, 90.

133 Bantum, Redeeming Mulatto, 98.

134 Bantum, Redeeming Mulatto, 99.
} 
renders such poles incoherent through his birth, life, death, and resurrection." 135 Analogously to the function of the mulatto/a body within American racialized society - indeed, in and as his own mulattic human life - Christ challenges all our presumptions of defining our own identities through practices of inclusion and exclusion. "Christ's life is a demand upon the disorientation of our lives that we have so long presumed to be oriented."136 In this "redemptive disruption," and in the particular life he lives, Christ opens to us a new possibility of life lived in the Spirit, inviting us "to enter into an identity of desire and dependence" upon one another. ${ }^{137}$

Bantum's discussion draws to light a central feature of the christological approach for which I am advocating: "Jesus is a body that confronts us and the assumptions we make about ourselves, each other, and the world." 138 To cast this point in the Augustinian terms that I have employed throughout this dissertation, we may say that the sinful constellations of our loves find tragic expression in material practices of exclusion, leading to orderings of social power that enact domination and violence. These social orderings operate at many different levels that interact both predictably and unpredictably with one another, from the broadest forces like globalization, patriarchy, and racism to more local expressions like regional caste systems or family, clan, or tribal feuds. These social forces and material practices cultivate our affections, giving shape to what we will love and what we will despise, whom we will recognize within relations of mutual openness, and whom we will ignore, banish, or dominate. ${ }^{139}$ In these relations, we are taught to love ourselves wrongly, either thinking ourselves to be the masters of those around us, or internalizing the oppression that is forced upon us by the social world that constitutes our subjectivity; and these loves shape our moral vision in particular ways, obscuring from our vision the injustices in which we participate, or devaluing the created goodness of our lives. It is true that we are each unique individuals and occupy a unique place within our social environment, and we will each have a particular affective constitution: some will refuse the social performance expected of them, and will resist the oppression society inflicts upon them; some will be particularly malformed, delighting in their cruelty; others will actively seek to undermine the social order that grants them the power to dominate their neighbors. Yet it will be possible in many (but not all) cases to map out the patterns of oppression that characterize a social order, noting for instance the systemic disadvantaging of people of color, of women, of the disabled, of those who do not conform to the gender binary.

\footnotetext{
135 Bantum, Redeeming Mulatto, 100.

136 Bantum, Redeeming Mulatto, 112.

137 Bantum, Redeeming Mulatto, 131.

138 Bantum, Redeeming Mulatto, 111.

${ }^{139}$ Jesse Couenhoven, in the course of presenting a view of responsibility grounded both in Augustine's thought and contemporary analytic moral philosophy, observes that "Patriarchy, for example, is not simply a choice individuals make but a way of seeing and being in the world; for those raised in it, sexism becomes second nature. Thus, the dynamics of patriarchy parallel those of original sin - both can be transmitted through social means and enslave persons involuntarily" (Stricken by Sin, Cured by Christ: Agency, Necessity, and Culpability in Augustinian Theology (Oxford: Oxford University Press, 2013), 202). Couenhoven's point is precisely that those whose agency is structured by patriarchy are nevertheless responsible for their patriarchal actions, even without having ever decided that one's will should be structured patriarchally.
} 
What Bantum teaches us, and what the way of humility demands, is that the body of Christ necessarily challenges the distorted sinful visions through which we see one another. Just as my representation of the world is challenged when I am surprised by something my neighbor does, teaching me that I have misrecognized his hopes, aspirations, competencies, so also my understanding of the world is challenged when Christ appears to me in a body that the order of things has taught me to reject and regard as other or impure. I may see anew the beauty of my flesh, which the world has told me is repugnant; or I may see my Lord in the one I have rejected, learning the enormity of my sin. As black theologians have long recognized, Christ's life in unveiled flesh manifested the God of Israel in poverty, in imperial oppression, in a community of religious minority; and the necessary corollary of this is that God is today manifested in black flesh (or in the bodies of women or members of the LGBT community, as seen in Edwina Sandys' Christa, or in Doug Blanchard's The Passion of Christ: A Gay Vision). ${ }^{140}$ The approach for which I am arguing insists that, as powerfully as and inseparably from the witness of the Church's life, these oppressed bodies are the living images of Christ in the world, the presence of God among us that is capable of challenging our misrepresentations of Christ, exposing our failures in love, teaching us humility, and shaping our loves such that we may act more justly. As Christ appears in the lives of our oppressed neighbors, he shows us the failures of love that enable that oppression, as well as the perfection of his own love to which we are being conformed. Whatever it is that has been excluded from our vision by sin, that is where Christ appears, the one who constantly disrupts our constructions of what it is to be human in order to show us that he alone creates the world and gives us who we are.

In his chastening, humbling presence, we learn to see Christ precisely in what we have been taught to despise. Those whose lives are defined by the "neither/nor" of oppression display to the world the forma servi, and in so doing, invite both the oppressor to enter into the pattern of Christ's humiliation and the one who is oppressed to see in their Lord the resurrection of their own flesh. There is no mystification in this; Christ appears to us as our neighbor in need of assistance, our neighbor who calls our attention to the injustice to which she is submitted, our neighbor whose flesh looks much like ours and who thus teaches us to reject the lies by which the world has taught us we are unlovely, and unlovable. The Holy Spirit manifests Christ in such a way that the ignorance in which sin leaves us is exposed, and we are able to see the world more truthfully than we could before. In this theophany, we are called to love our neighbor who is Christ: to feed the hungry, clothe the naked, make room for the stranger, visit the prisoner.

Encountering Christ in this way is nothing other than the work of the Spirit active in the logic of confession, as we are dispossessed of our misrepresentations of ourselves and the world, receive ourselves and our neighbors anew in Christ, and are empowered to act more justly toward our neighbor in response to the Spirit's work. While the Church forms a unique (because self-conscious) locus for gazing at living images of Christ, it does not constitute the only, or even incontestably the most important such manifestation of Christ. We are incorporated into the

140 A claim developed most systematically by James Cone in God of the Oppressed, Revised Edition (Maryknoll, NY: Orbis Books, 1997). 
pattern of Christ's life, in which glorification comes only to the one in forma servi; in assuming flesh, the Word has manifested Herself not in those exalted by the world, or even in those who renounce their high station in solidarity with those suffering injustice. The forma of Christ's human flesh is rather that of one born without wealth, in a land occupied by a foreign army, to a people historically enslaved and stripped of self-rule, and all those who suffer under such oppression, whether Christian or not, are by the very fact of these material conditions forced to live under the pattern of Christ's life. God has united Herself to the conditions of the least of these, and so all those who are marginalized find room within Christ's life, whether they are aware of this fact or not. Just as in the context of the Church, the relation in which my neighbor reveals Christ to me cannot properly be instrumentalized: the encounter with Christ in those who are oppressed is directed to the same end of delight in one another in the full mutual recognition of Christ's body. The oppressed do not simply serve a functional role in correcting the sin of their oppressors - they are made (and, if members of the Church, desire to be made) signs of Christ which draw all people toward a new eschatological existence, in which all will be loved and embraced as the creatures God has made them.

Yet we must go further. If the downtrodden of the world are conformed to Christ by undergoing the suffering wrongly inflicted upon them, then their desire for liberation participates in and repeats Christ's own desire for the coming of the Kingdom of God. To the extent that the poor, marginalized, and oppressed desire that the proud should be scattered in their conceit, the mighty should be cast down from their thrones, the humble should be exalted, and the hungry should filled with good things, they repeat in themselves Christ's own present and eschatological desire. The point is formally analogous to our description in the last chapter of Mary as coredemptrix, signifying and fulfilling the life of the Church itself as co-redemptive. The relevant difference in the case of those bearing the oppression of sin is that they do not necessarily know themselves to be the body of Christ, and thus understand their suffering as Christ's own only to the extent that they are also united to the visible community of his body, the Church.

Nevertheless, their groaning in hope of liberation and their longing for a just society in which they can relate to their neighbors indicates that the same desire that was in Christ is in them also; and this can only be the work of the Holy Spirit, dwelling among those who bear the weight of the world's sin. Just as the Church's co-redemptive work is found in their desire for their lives to become the redemptive signs that God is making them, so also the poor and marginalized desire in the midst of their suffering to participate in the concrete work of bringing about a just social order - and this work is always and everywhere the work of Christ. In the midst of the death that their neighbor has brought them, they desire new life, truly if always imperfectly; and this desire manifests to the world the pattern of Christ's life as surely, if not as reflexively, as does the life of the Church. The oppressed enact in their flesh Christ's own longing for justice and perfect love between all people, and so in the Spirit's power present a sign to the world capable of directing the world's hearts and minds to the love and contemplation of God. By their lives, they actively participate in the world's redemption.

Perhaps the most perceptive theological voice pointing us to the co-redemptive significance of the poor was the Jesuit martyr Ignacio Ellacuría, who wrote of the "crucified 
people." 141 This phrase marked off for him not only the politically and economically oppressed of his own Salvadorean context, but "that collective body, which as the majority of humankind owes its situation of crucifixion to the way society is organized and maintained by a minority that exercises its dominion through a series of factors, which taken together and given their concrete impact within history, must be regarded as sin." 142 On Ellacuría's presentation, true Christian faith must hold not only that the liberation of the crucified people stands historically as "the main object of the effort of salvation," but that "it might also in its very crucified situation be the principle of salvation for the whole world." 143 Ellacuría is aware of the controversial nature of his proclamation of "humankind's active participation in... salvation"144 in the lives of the poor:

It is indeed scandalous to hold the needy and the oppressed as the salvation of the world in history. It is scandalous for many believers who no longer think they see anything striking in the proclamation that the death of Jesus brought life to the world, but who cannot accept in theory, and much less in practice, that today this life-giving death goes by way of the oppressed part of humankind. It is likewise scandalous to those who seek the liberation of humankind in history. It is easy to regard the oppressed and needy as those who are to be saved and liberated, but it is not easy to see them as saviors and liberators. ${ }^{145}$

Indeed, we may express some sympathy with the scandalized at this point. Does this not suggest that the oppressed necessarily suffer, and that God desires their suffering as the means of salvation? Does this not justify their suffering, teaching them to view it as a good, and undermining their desire for their suffering to come to an end? These worries are important, but fundamentally misunderstand Ellacuría's account of how the life of the crucified people is redemptive. The "necessity" of the crucified people's suffering derives not from God's will, but from the reality of sin. Sin necessarily brings about violence, but precisely because it is the result of $\sin$ this violence is not willed by God. Indeed, the true necessity of the crucifixion is that God should stand on the side of the victims of violence, assuming their part in order to bring about the redemption of the world. Ellacuría does not commend as redemptive sheer passivity in the face of $\sin$, but rather the active resistance to sin that presupposes violence. ${ }^{146}$ Humans are essential

141 The link between Augustine's theology of the totus Christus and Ellacuría's theology of the "crucified people" has been previously acknowledged in Michael J. Iafrate, "Jesuits, The Totus Christus and the Crucified People: ReReading Augustine's Christology from Below with the Salvadorean," Fournal of Postcolonial Theory and Theology 2, no. 4 (2011): 1-49. Less explicitly, Robert Lassalle-Klein calls attention to the way that both Ellacuría and Jon Sobrino position themselves as interpreters of Augustine, particularly in light of Ellacuría's semiotics; see Robert LassalleKlein, "Jesus of Galilee and the Crucified People: The Contextual Christology of Jon Sobrino and Ignacio Ellacuría," Theological Studies 70 (2009): 347-376.

142 Ignacio Ellacuría, S.J., "The Crucified People," in Mysterium Liberationis, ed. Ignacio Ellacuría S.J. and Jon Sobrino S.J., trans. by Phillip Berryman and Robert R. Barr (Maryknoll, NY: Orbis Books, 1993), 580-603; 590.

143 Ellacuría, "The Crucified People," 591.

144 Ellacuría, "The Crucified People," 580.

145 Ellacuría, "The Crucified People," 582.

146 In his words, "it is necessary to go through death to reach glory, but glory need not follow death". Ellacuría, "The Crucified People," 587. 
partners in this act of God: "Although God gives the growth, the effort of human beings is not excluded but in fact is required, especially for destroying the objective embodiment of sin, and then for building up the objective embodiment of grace. Otherwise, necessity would not have any historic character but would be purely natural." 147

The life of Christ serves as the clearest sign that the reign of God stands opposed to the reign of $\sin$, and is the standard by which all judgments of standing on the side of Christ or opposed to him are (provisionally) rendered. Ellacuría is no less attentive than Augustine to the conformation of human life to the forma Christi. He identifies certain marks of Christ's life that fulfill the prophecies of Isaiah's servant songs, marks that also characterize the life of the crucified people: among others, the suffering servant "is a figure shattered by the concrete, historical intervention of human beings," appears as a sinner and is reckoned among them, "accepts this lot, this destiny," and, though "crushed in his sacrificed life and in the failure of death, triumphs." "148 Indeed, in words reminiscent of Bantum's, Ellacuría writes that in being conformed to Christ, the crucified people must share Christ's likeness in determinate social circumstances: "it will have to become what the worldly have cast out, and its appearance will not be human precisely because it has been dehumanized." 149 In the extension of this pattern of Christ's life to the crucified people, Ellacuría clarifies his understanding of how their life is redemptive:

The Son of Man is he who suffers with the little ones; and it is this Son of Man, precisely as incarnate in the crucified people, who will become judge. In its very existence the crucified people is already judge, although it does not formulate any theological judgment, and this judgment is salvation, insofar as it unveils the sin of the world by standing up to it; insofar as it makes possible redoing what has been done badly; insofar as it proposes a new demand as the unavoidable route for reaching salvation... Thus the crucified people has a twofold thrust: it is the victim of the sin of the world, and it is also bearer of the world's salvation. ${ }^{150}$

In the terms of the present study, the crucified people serve as living images of Christ, correcting all humanity's misapprehension of its Lord and rendering the claims of love concrete, precisely in the twofold thrust Ellacuría identifies: they are made signs of Christ in bearing the violent effects of the world's sin, and redeem the world in their struggle for justice. Though we regularly fail to see the suffering we inflict on others, and cannot always see the violence others inflict on us, the very moments in which we recognize our failures to love or to be loved are graces that show us God's judgment upon sin. Though this recognition is a feature of individual encounters, attention to the crucified peoples of the world shows us that it is also a political reality. The crucified people cries out at injustice, insisting that our action is sin. As in interpersonal relations, we often deafen ourselves to their voices - as, for instance, is necessary to maintain a global economy that

147 Ellacuría, "The Crucified People," 587-8.

148 Ellacuría, "The Crucified People," 597-8.

149 Ellacuría, "The Crucified People," 601.

${ }^{150}$ Ellacuría, "The Crucified People," 603. 
depends on working conditions close to if not indistinguishable from slavery. But in those moments when we hear their cry, the voice that comes to us is Christ's own, because it issues from those who are conformed to his life. It comes to us as a demand, teaching us little by little how we must love one another if we are to inherit together the Kingdom of God.

It is important to note, however, that this account of the crucified people does not presuppose any one particular course of political action as adequate to answering this call, nor does it assume any special ability of the crucified people to bring about the justice of God's reign. We may expect that advances in social justice will be much like advances in personal holiness: we will move along haltingly, without confidence that our present course of action will actually further the goal of the justice we seek; we will regularly become aware of the grave errors we have made, and the need for confession to one another and to God; we will proceed in the awareness that though redemption assumes determinate historical shape in our lives and activity, any capacity we realize to love one another rightly is attributable in its entirety to the work of the Holy Spirit. Though our ability to recognize the crucified people will be inconsistent (even if we ourselves are part of this body, marginalized by the social order) we can trust that it is among the oppressed, among those whom society teaches us to despise (again, even if we are ourselves the one society teaches as worthy of being despised), that we will hear the voice of Christ. Ellacuría is aware of the tentative nature of laying claim to the mantle of the suffering servant, yet he believes that Christ's life gives us sufficient definition to make some provisional judgments:

To mention some examples with two sides: the First World is not in this line and the Third World is; the rich and oppressive classes are not and the oppressed classes are; those who serve oppression are not, no matter what they undergo in that service, and those who struggle for justice and liberation are. The Third World, the oppressed classes, and those who struggle for justice, insofar as they are Third World, oppressed class and people who struggle for justice, are in the line of the Suffering Servant, even though not everything they do is necessarily done in the line of the Servant. ${ }^{151}$

This is quite far from offering a determinate political program, yet ensuring the accomplishment of justice is not our task. It is God, God alone, who gives any growth in justice that might come about, even if our work is given a responsive role in bringing about this growth. It is our task only to desire it, to long for it, and to express these longings as best we can in material practices and just actions no less concretely than our sinful desires are expressed in the discipline of contemporary social orders. We cannot see our ills clearly enough to believe that we may bring about liberation, but we can see those in whom Christ lives, and we can work assiduously toward the end of true loving communion with those we have been taught to reject. We will continue to wound one another even as we strive toward this goal, until our love is perfected; but we are nevertheless called to this work by the redemptive voice of the crucified people. For those of us who find

${ }^{151}$ Ellacuría, "The Crucified People," 602. 
ourselves sitting comfortably on the dominative side of any of the numerous vectors of social oppression of which we have some awareness, the present situation is asymmetrical. The oppressed are already the crucified people; Christ shines with particular clarity in our lives. If we are to make Christ visible to them in turn, allowing the mutual love in which we exchange Christ with Christ in mutual recognition, then our lives will need to be conformed to the pattern of his life. We will need to put ourselves and our bodies on the line, rendering the same judgment on our sin that the crucified people has already passed, revealing sin by resisting it. That we will fail one another, over and over again, should only lead us to deeper humility, deeper awareness of our dependence upon Christ, and a deeper desire to love one another in the power of the Spirit.

To the extent that we are not united, and actively uniting ourselves, to the crucified people, then, we fail to display Christ to the world. This entails that the Church's own life is intrinsically united to the life of the oppressed; the degree of its separation from them is the measure of its failure to be what it is, and to fulfill the co-redemptive work to which Christ has called it. Integral to the Church's serving as a sign of Christ's life to the world is it's identity with the poor. Augustine himself suggests that actively working for justice is inseparable from our understanding of Christ's presence among us, telling us, "Our justice is Christ, as the apostle Paul says. And so whoever is hungry for this bread is hungry for justice - but for the justice which comes down from heaven, the justice which God gives, not the sort which human beings fashion for themselves." 152 In distinguishing the justice that God gives from that which we achieve, Augustine does not mean to suggest that this justice exists apart from the material conditions of our lives, but rather indicates the source of this justice. The human justice he rejects is "That for which they presumed on their own strength, claiming that they, with their own virtue, perfectly fulfilled the law." The justice of God, by contrast, is "that justice which [God] gives to someone so that he might be just with his help." 153 We must affirm, then, that our justice is always a gift of God; but we must also affirm that we live together as the body of Christ only to the extent that our lives together are ordered by this justice. As we long for the forgiveness of our sins and the vision of God and strive to live holy lives, so also we must thirst for justice and act on the basis of whatever we can perceive of justice's demands, trusting that our action will be empowered by the Spirit. To imagine a Church separated from the crucified people is to imagine Christ at disunity with himself; it is a scandal akin to the sundering of the Church's visible unity. Christ wills to be complete only with us; Christ accomplishes salvation in and through us. Only as the Church seeks to love those who are banished from or degraded within the various orderings of our livesthe foreigner, the peasant, the culturally or racially hybridized - is it the body of Christ, a community through which love courses without loss, returning always to God. Only as it becomes a sign of Christ in joining the crucifixion of these peoples does it become what it is: Christ himself, accomplishing the redemption of the world.

152 Io.eu.tr. 26.1; WSA III/12, 449.

153 Io.eu.tr. 26.1; WSA III/12, 449-50. 


\section{Beholding God}

If in this life the wounds of sin prevent us from beholding the glorified flesh of Christ, our hope in resurrection is that we will be made fit for this vision. We will see Christ finally in the forma dei, the knowledge we possess by faith (scientia) converted finally to that attained by sight (sapientia). God guides us through our journey, granting us at each moment the grace that accords with Her providential ordering of created history. Christ is active in this history not only as the Word which sustains all things in being and sets them in their relations to one another, but also in the assumed flesh: "our head is at the Father's right hand to intercede for us; some of his members he welcomes, others he chastises, others he is cleansing, others he consoles, others he is creating, others calling, others recalling, others correcting, others reinstating." 154 His work is to create a longing in us for himself, and so Augustine instructs his listeners,

Call upon God as God, love God as God; nothing is better than he is, so desire God himself, hunger for God...If you want to be a lover of God, then, choose him from the bottom of your heart and with the utmost sincerity, love him with chaste longing, burn for him, thirst for him. You will find nothing better, nothing more joyful, nothing more lasting, than God. ${ }^{155}$

Through Christ, we will, God willing, come to see Her face to face, no longer through a glass darkly. In this life in a new Jerusalem, we will be perfected in our ability to love one another, finally able to meet our neighbor face to face as well, without the deceit and self-deception that characterize our experience now, without the misrecognitions and wounds that we pass one to another. We will be fully written into Christ's life, our lives conformed to his, and to his glory. Our every thought will be Christ's, our every desire his own, our very bodies made perfect signs of his flesh, and God in it. We will be the body of Christ: Christ will finally be complete, the head united to his body, wholly our Redeemer as all are wholly redeemed, Christ made totus Christus. The Word will have accomplished in the body his mediatory end; what relation will we then bear to the flesh of Christ?

There is in Augustine reason to worry that our eschatological relation to Christ will be functionally discarnate. At times, he seems to suggest that because grace has made us fit for the unmediated vision of the invisible God, we will leave Christ's flesh behind as a pedagogue no longer needed. In his first homily on the Gospel of John, for instance, he tells his listeners, "Feed on milk, so as to be able to take solid food. Do not withdraw from Christ born in the flesh, until you reach Christ born of the one Father (A Christo per carnem nato non recedat, donec perveniat ad Christum ab uno Patre natum), the Word God with God, through which all things were made; because that is the life which, in him, is the light of all." ${ }^{156}$ In what sense could we speak of our eschatological destiny as a withdrawal from Christ's flesh? More worrisome still, in the De trinitate

154 en.Ps. 85.5; WSA III/18, 225.

155 en.Ps. 85.8; WSA III/18, 228-9.

156 Io.eu.tr. 1.17; WSA III/12, 53. 
Augustine speaks in a manner that might suggest an eschatological caesura between the human nature of Christ and the divine life. Interpreting the puzzling words of 1 Corinthians 15.24, Augustine writes,

we shall contemplate God the Father and Son and Holy Spirit when the mediator of God and men the man Christ Jesus (1 Tm 2.5) has handed over the kingdom to God and the Father (1 Cor 15.24), and hence no longer intercedes for us as our mediator and priest, son of God and son of man, but is himself subject as priest, in the form of a servant he has assumed for us (Phil 2.7)... So inasmuch as he is God he will jointly with the Father have us as subjects; inasmuch as he is priest he will jointly with us be subject to him. ${ }^{157}$

As written, this passage suggests that the flesh of Christ is essentially, and exists everlastingly as, forma servi. We are not, in the City of God, to worship the glorified flesh of Christ, precisely because it is flesh; instead, we are to worship the triune God that stands over-against it. What are we to make of this?

Augustine seems to me in these moments to stray from his best insights concerning the Incarnation. He seems concerned to emphasize the difference in our relation to God that begins as we are enabled by grace to see the incomprehensible essence of God, but in so doing portrays the flesh of Christ as irrelevant to our beatitude. Augustine's logic at this point lapses into placing the divine and creaturely planes in competition with one another: we can only pass to an unmediated encounter with the Lord to the extent that Christ's flesh recedes from view. We need not follow him here.

Even so, we should not dismiss too easily the consideration that leads Augustine to such a position. If we are in resurrected life rendered capable of perceiving the very nature of God, then Christ's humanity ceases to serve as the necessary mediator that our present sinful condition requires. As Augustine writes in De trinitate 1, "It is when he cancels all sovereignty and all authority and power that the Son will reveal the Father, that is, when there is no more need for the regime of symbols (dispensatio similitudinum)"158; "We will not seek anything else when we reach that contemplation of him, which is not yet ours as long as we are rejoicing only in hope." "159 If we should we take Christ's flesh to be in the eschaton a necessary mediator of our vision of God, we would find ourselves still needing faith to see the invisible God in the visibility of Christ's human nature, as is the case for us now. Our desire to see God face to face would go unfulfilled, persisting throughout our everlasting life. We should thus affirm, with Augustine, that Christ's human nature ceases to serve as a necessary mediator of the beatific vision of God. In this sense, we do indeed pass from the milk of Christ's flesh to the solid food of contemplating the divine nature, and it is true to say that the incarnate Son carries us to sight of the Father. Though the

\footnotetext{
157 trin. 1.10.21; WSA I/5, 80.

158 trin. 1.8.16; WSA I/5, 76.

159 trin. 1.8.17; WSA I/5, 77.
} 
Word remains everlastingly united to flesh which is Her own, it no longer plays for us the role it once did in our relation to God.

The question thus becomes, what significance does the flesh of Christ bear for us when our redemption is accomplished, and the answer here is easy: it is, in the end without end, the body of our Lord, and is worshiped and adored as He is. Rather than the object of our longing, the flesh of Christ becomes for us in glory an object of delight, the material presence with us of the God whom we know also in the immaterial life which is properly and eternally His own. The Word's resurrected human life is no longer necessary to bring us to some end, for we have already arrived at our end, and it is him. His incarnate life with us is sheer gratuity, a creaturely re-giving of what is already given to us in the beatific vision, God enabling our communion with Him not only as He draws our souls into union with Him, but also as he enfolds our bodies in his own.

This dynamic can be observed in Augustine's treatment of how we will see God in the body more generally. Christ's flesh will no longer be the unique revelation of the divine life within the material world; in the heavenly Jerusalem, all creaturely reality will be made transparent to the vision of God. As Augustine tentatively advances in the De civitate dei,

in the world to come, we shall see the bodily forms of the new heaven and the new earth in such a way as to perceive God with total clarity and distinctness, everywhere present and governing all things, both material and spiritual...in the world to come, wherever we shall look with the spiritual eyes of our bodies, we shall then, by means of our bodies, behold the incorporeal God ruling all things. ${ }^{160}$

He tell us that our bodily eyes, made spiritual as the soul is united to God, will even see God when they are closed - that is, even the backs of our eyelids will reveal the divine nature to us in high definition. ${ }^{161}$ In all things, we will behold God's Truth; and consequently, we will see creation without misrecognition, in all the particularity and unsubstitutability with which God has created it: "No one will wish to have what he has not received, and he will be bound in a bond of uttermost peace to one who has received it; just as, in the body, the finger does not wish to be the eye, since both members are contained within the ordered composition of the whole body." 162 Even language will be unnecessary for us, as our very bodies will communicate our intentions perfectly and without need of interpretation. ${ }^{163}$ Yet in accord with the argument I have advanced throughout this dissertation, we should affirm that even eschatologically the material world will reveal God precisely in being ordered by and to the flesh of Christ. What had been true in the economy of redemption, that a creature becomes a redemptive sign of God to the extent that it is recognized in its relation to the flesh of Christ, will be constitutively true of all

\footnotetext{
160 civ. 22.29; Dyson, 1177.

161 civ. 22.29.

162 civ. 22.30; Dyson, 1179.

163 civ. 22.29.
} 
material reality in the City of God. Just as each thing is made what it is by its participation in the Word, so also the materiality of the heavenly Jerusalem will reveal the triune God by being ordered to the flesh that Word has assumed. His body will be the Lamb on the throne at the center of the City of God; we will stand together around it, offering praises to him as God; we will receive his body in an unending eucharist. In this new creation, "everything there will be seemly in its form, in motion and in rest, for anything that is not seemly will be there,"164 and to say that these movements are ordered by the Word requires that we say also that they are ordered in relation to the flesh in whom that Word lives. Even eschatologically, he remains the one in whom all things hold together, and we are glorious only in likeness to him: As Augustine quotes the First Epistle of St. John, "we are God's sons, and it has not yet been manifested what we shall be; we know that when he is manifested we shall be like him, for we shall see him as he is (1 Jn 3.2)."165

More than this, Jesus continues as our Great High Priest, no longer interceding for us (for we have been brought to the Father), but existing as who he always was: the one who assumes flesh in sheer gratuity, and then lives a human life as a perfectly responsive self-offering in his human will to his divine will. This is, perhaps, the limited sense in which we can say with Augustine that Christ is "subject" in his human flesh to his triune life: even in Christ, the divine agency is always irreducibly prior to the response of the created order. Christ's human flesh serves as the paradigm of the responsal existence that all creation will possess eschatologically. While in the forma servi, this meant that it was appropriate for Jesus to pray to his Father, to suffer, die, and be raised. We can only imagine what his fleshly life will be like in forma dei. The fleshly life he will live as creaturely response to his divine nature will reveal him to us as the very one who give us our own lives in the priority of the divine action. In his glorified flesh, we will know him as the same one who accomplishes our glorification in his own human life. As the divine action comes always before us, so also we will know his human responsiveness to God to be irreducibly prior to our own; we will find that our own unmediated response to the gift of our existence God gives us is also and at once a response to his human life. In this sense, he will remain the celebrant at our everlasting eucharist, the one who both leads our prayer and is prayed to as God, but will not stand between us and an immediate encounter with God. Whereas now we meet God first in the flesh of Christ, then our life with God shall inseparably issue in communion with the human Jesus Christ.

As we relate to one another - as we behold the beatific vision of God in one another, and in our own flesh - we will find that each movement and act of praise presents us with Christ. We may even hope that a new language will be available to us, one born not of the necessity to relate to one another in the midst of an opaque world, but rather springing from the glory of God radiating through this renewed and spiritualized materiality. The words of such a language would themselves be utterly gratuitous, existing solely as objects of delight, offered in and as response to God's transfiguring presence, ever the same, ever new. And our lives together will bear, all together and each in its own unique manner, the seal of Christ's life: "Nothing will give

164 civ. 22.30; Dyson, 1178.

165 trin. 1.8.17; WSA I/5, 77. 
more joy to that City than this song of the glory of the grace of Christ, by Whose blood we are redeemed. Then shall these words be fulfilled: 'Be still, and know that I am God."'166 All creation will have been written into the flesh of Christ; all that will remain to us will be to live, to love, to set the air trembling with words of praise offered to the Lord.

166 civ. 22.30; Dyson, 1181. 


\section{Conclusion}

What happens when we are given troubling words? Throughout this dissertation, I have sought to emphasize the extent to which our lives are given to us - given to us as founding our own agency and spontaneity in the world, to be sure, but given to us all the same. God is the first giver, the one who gives creation principally and in a manner incomparable and so without needing to compete with any other givers; but given also from a world that shapes us as particular sorts of biological entities, with particular relations to others who support and provide for the continuance of our lives, and who enrich it by teaching us particular languages, introducing us to particular tastes and habits of delight and disgust, who shape our expectations of the world around us and, in so doing, provide us opportunities to question, affirm, and reject what we have been given. We are, very often, unaware of how much we have received from others, and how pervasively it has structured our lives.

I have at times, and in the interest of challenging the assumption that we are masters of our self-understanding, resisted some of the practices of cataloguing our debts that are current in the theological academy: most obviously, I have sought to engage Scripture (among a few other poetic sources) not as a source to be quoted exactly and cited assiduously, but as the communication of God meant to be read, marked, learned, and inwardly digested - meant to shape our habits of thinking and praying, meant to nourish break unevenly to the surface of our speech and writing. This is, to my mind, one way for Christians to use the words God has given the Church, and one way that we may begin learning and speaking what I have called the language of divine signification. The utterances of Scripture are meant not only to be studied and 
memorized, but to be reproduced in new and unlikely settings, to be woven together in novel ways, to serve as the rudiments of a new way of speaking about God that can be extended indefinitely. If my words have failed at various points in this text, as they no doubt have, it is due in part to the ignorance accompanying sin, but also to the fact that even in our best theological language we can only now speak as children. Only by failing to speak well and receiving correction from both God and our neighbor can we develop the facility with the language of divine signification that will allow us to see God spoken in every creature.

Yet precisely because we are at best rudimentary speakers of this language, the words of Scripture can be extremely vexing. Even the plain sense of these words can be obscure, and our perplexity may only deepen as we encounter narrative inconsistencies, seemingly contradictory viewpoints on God's work in history, and prima facie conflicting theological outlooks - not to mention texts that prove morally troubling to modern readers (and not a few ancient ones), whether legal texts, stories of conquest and ethnic cleansing, straightforward reflections of patriarchy, imprecatory prayers, and all the other "texts of terror" which have been used against the vulnerable. ${ }^{1}$ Augustine's famous rule of interpretation is that we cannot go too badly wrong if we measure our readings by whether they produce both love of God and love of neighbor in our hearts; but if this is our safest practical criterion, more than a few texts of Scripture are bound to leave us utterly bewildered.

We may hope that the Holy Spirit works in this puzzlement, that our incomprehension when faced with God's speech in human words is a crucial step in learning to speak the language of divine signification, even as the words of Scripture continue to unsettle and provoke us. One of the implications of my argument in this dissertation is that God employs our lives, actions, and productions in the work of redemption, that we are granted our own proper (and properly noncompetitive) place within God's work of salvation. If this is right, then much of what God uses to reveal Herself in the world bears the deep wounds of sin, in process of being healed, but not yet fully purged, and we have little reason to exempt Scripture from this description even as we claim that its words have been providentially ordered to communicate the truth of God to us. We ought not think that the plain sense of every text of Scripture is edifying, a point Augustine well understood; ${ }^{2}$ yet we may trust that even where it seems most troubling, meditation on the words of Scripture may speak truly to us of God. As Augustine wrote, "Magnificent and salutary, therefore, is the way the Holy Spirit has so adjusted the holy scriptures, that they ward off starvation with the clearer passages, while driving away boredom with the obscurer ones."3

\footnotetext{
1 The phrase "texts of terror" comes from Phyllis Trible, Texts of Terror: Literary-Feminist Readings of Biblical Narratives (Minneapolis: Fortress Press, 1984); Ellen Davis has written carefully on the Psalms of imprecation at Ellen F. Davis, Getting Involved with God: Rediscovering the Old Testament (Lanham, MD: Cowley Publications, 2001), Ch. 3.

${ }^{2}$ Cf. doct. chr. 3.10.14; WSA I/ 11, 176: "To this warning against treating figurative expressions, that is, metaphorical ones, as though they were meant in the literal, proper sense, we also have to add this one, to beware of wanting to treat literal, proper statements as though they were figurative. So first of all we must point out the method for discovering if an expression is proper or figurative. And here, quite simply, is the one and only method: anything in the divine writings that cannot be referred either to good, honest morals or to the truth of faith, you must know is said figuratively." Cameron has given an overview of Augustine's approach to Scripture at "Augustine and Scripture," in A Companion to Augustine, ed. Mark Vessey (Oxford: Wiley-Blackwell, 2012), 200-14.

${ }^{3}$ doctr. chr. 2.6.8; WSA I/11, 132.
} 
This dissertation emerges in part from my persistent bafflement with a verse of the extended Pauline corpus, Colossians 1.24, and I hope that the dissertation as a whole may be read as a sort of commentary on the verse. Just prior to Colossians 1.24, we find perhaps the richest theological description of Christ in the New Testament:

He is the image of the invisible God, the firstborn of all creation; for in him all things in heaven and on earth were created, things visible and invisible, whether thrones or dominions or rulers or powers - all things have been created through him and for him. He himself is before all things, and in him all things hold together. He is the head of the body, the church; he is the beginning, the firstborn from the dead, so that he might come to have first place in everything. For in him all the fullness of God was pleased to dwell, and through him God was pleased to reconcile to himself all things, whether on earth or in heaven, by making peace through the blood of the cross. ${ }^{4}$

This is the very foundation of a cosmic christology, language so all-encompassing and inclusive that the man Jesus Christ comes to serve as the center of the entire created order. His life seems to be the single most determinative fact both of our creation and reconciliation to God; nothing seems to stand outside his presence, and all things find their place in him. Yet just a few verses later, we read St. Paul (or the epistle's author, writing in the Pauline tradition) telling his readers, "I am now rejoicing in my sufferings for your sake, and in my flesh I am completing what is

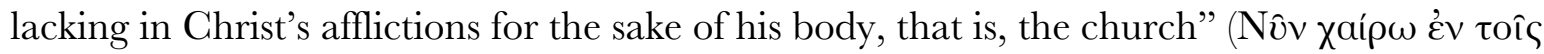

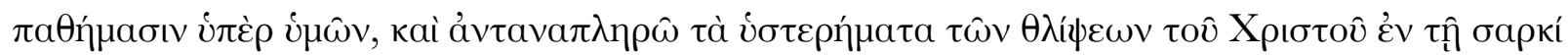

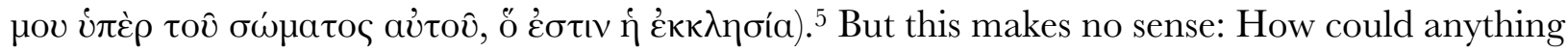
be lacking in the sufferings of the one in whom all creation hangs together? How could Paul complete the work in which God has already reconciled to Himself all things through the blood of the cross?

The verse only becomes more confounding on closer inspection. Several of the key terms in the verse are used in ways unparalleled in the rest of the New Testament: Andrew T. Lincoln notes that

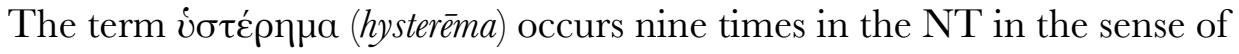
'need'/'want'/'deficiency,' but this is the only place where it is associated with Christ. Similarly, this is the only place in which the noun $\theta \lambda \hat{i} \psi \iota$ (thlipsis), used elsewhere of the tribulations of the last days and of the afflictions experienced by various humans, is employed for the sufferings of Christ. ${ }^{6}$

\footnotetext{
${ }^{4} \mathrm{NRSV}$

${ }^{5}$ NRSV; The Greek New Testament, 3rd Edition, ed. Kurt Aland, Matthew Black, Carlo M. Martini, Bruce M. Metzger, and Allen Wikgren (Münster: United Bible Societies, 1975).

${ }^{6}$ Andrew T. Lincoln, "The Letter to the Colossians," in The New Interpreter's Bible, Volume XI, 551 1-670 (Nashville: Abingdon Press, 2000), 613.
} 
It is, importantly, the only place in either the New Testament or the Septuagint where the crucial

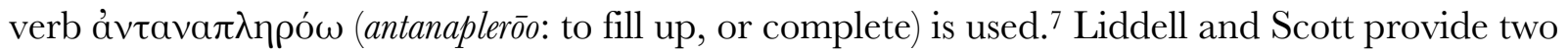

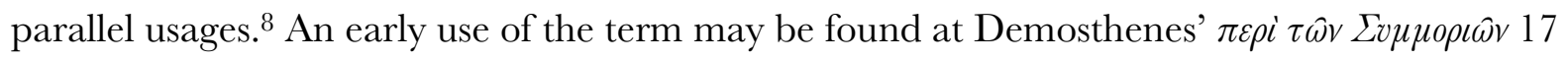
(On the Navy-Boards, 354 B.C.), where, in the context of dividing naval conscripts into battle sections, he says that the number of wealthy men in the unit should be filled up

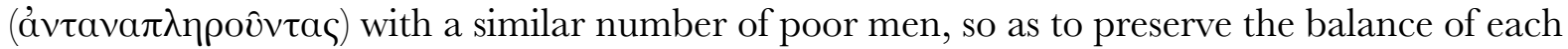

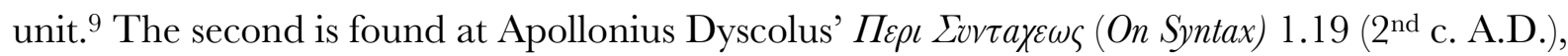
where he uses the term to describe the way that pronouns complete and render determinate the sense of verbs, as in the difference between "I write" and "you write." 10 It is interesting that the

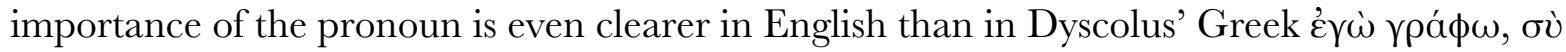

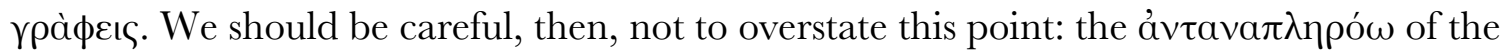
pronoun does not make the entire difference in the Greek that it does in the comparison between "I write" and "you write," but rather serves as a kind of repetition or confirmation that makes the subject of the word newly concrete in the grammar of the sentence. Each of these is instructive for our reading of Colossians, emphasizing on the one hand the sense in which the verb

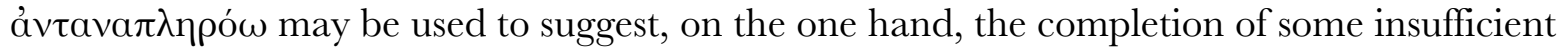
quantity, and on the other, completion as informing something in its particularity. Yet these uses only deepen the exegetical difficulties, for how could the quantity of Christ's afflictions be insufficient, or how could it lack determinateness as he suffers and dies on the cross?

As might be expected, contemporary critical scholarship is not of one mind in responding to this conundrum. In an article that remains a significant point of reference for contemporary scholarship, Roy Yates mapped the interpretive proposals on offer; ${ }^{11}$ condensing Yates, Jerry Sumney outlines the positions as follows: ${ }^{12}$

1. Christ's sufferings may be supplemented from the treasury of merit earned by saints and martyrs. Yates identifies this position as indicating "deficiencies in those sufferings He endured for the redemption of his people," "impl[ying] that Christ's sufferings are insufficient and therefore require supplementing," and as "totally unsupported by the verse in its context." 13

\footnotetext{
${ }^{7}$ Lincoln, "Colossians," 613.

${ }^{8}$ Henry George Liddell and Robert Scott, A Greek-English Lexicon/with a supplement 1968 (Oxford: Clarendon Press, 1985), 149

${ }_{9}^{9}$ Demosthenes 14.17: Demosthenis Orationes, ed. S.H. Butcher (Oxford: Clarendon Press, 1903).

10 Apollonius Dyscolus, De Constructione Libri Quattuor (Peri Suntaxeos), Vol. II.2, in Grammatici Graeci, ed. Gustav Uhlig (Leipzig: B.G. Teubner, 1910), 21.

${ }^{11}$ Roy Yates, "A Note on Colossians 1:24." The Evangelical Quarterly 42 (1970): 88-92

${ }^{12}$ Jerry L. Sumney, "'I Fill Up What Is Lacking in the Afflictions of Christ": Paul's Vicarious Suffering in Colossians," The Catholic Biblical Quarterly 68, no. 4 (2006): 664-80; 665. The portions of the offset text in italics are direct quotations of Sumney.

13 Yates, "A Note," 90.
} 
2. There is a distinction between suffering as a sacrifice for sin and suffering for edification. Yates presents this as the outlook of J.B. Lightfoot, ${ }^{14}$ in which believers do not undergo any salvific sufferings in satisfaction of sin, but rather experience "those sufferings endured for the building up of the Church and for the confirmation of believers in the faith."15

3. The passage illustrates the mystical union between Christ and Christians. Here, Yates places the interpretations of Chrysostom, Calvin, L.B. Radford, and L.S. Thornton. Calvin, for instance, writes in his commentary on Colossians, that "we know that there is so great a unity between Christ and his members, that the name of Christ sometimes includes the whole body...As, therefore, Christ has suffered once in his own person, so he suffers daily in his members, and in this way there are filled up those sufferings which the Father hath appointed for his body by his decree." 16 Yet Calvin is quick to disavow any suggestion that these sufferings are redemptive (referencing Augustine's comment in Io.eu.tr. 84.2 that "even if brothers die for brothers, none of the blood of the martyrs is shed for the remission of the brothers' sins" ${ }^{17}$ ), arguing that these sufferings are merely for the edification of the Church. ${ }^{18}$ While Calvin affirms a mystical union between Christ and the Church in deeply Augustinian terms, then, he is ill equipped to describe the sense in

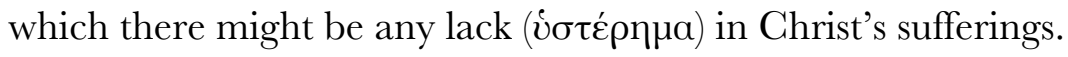

4. These sufferings of Paul are part of the messianic woes that must be fulfilled before the parousia. Yates identifies Ernest Best as a prominent expositor of this position; Sumney adds Eduard Lohse, Peter T. O’Brien, Andreas Lindemann, and James D.G. Dunn as recent expositors. ${ }^{19}$

Yates himself stakes out the position that "it would be unlikely that Paul meant that there was any deficiency in Christ's sufferings as far as His work of atonement is concerned; this would give away all Paul's case to the Colossian heretics." ${ }^{20}$ Instead, he offers a tantalizing but undertheorized proposal that

If we can think of Christians as being incorporated into Christ by their baptism into Him, as Paul undoubtedly did, then it is but a small step to the idea that the sufferings of the corporate body of Christians, the Church, and the sufferings of Christ are one; that Christ goes on suffering in the Church; and that Paul shares

\footnotetext{
14 Yates, "A Note," 90.

15 Yates, "A Note," 90.

${ }^{16}$ John Calvin, Commentaries on the Epistles of Paul the Apostle to the Philippians, Colossians, and Thessalonians, ed. J.B. Pringle (Edinburgh: The Calvin Translation Society, 1851), 164.

17 etsi fratres pro fratribus moriantur, tamen in fraternorum peccatorum remissionem nullius sanguis martyris funditur; translation mine.

18 Calvin, Commentaries, 167.

19 Sumney, "I Fill Up What Is Lacking," 665.

20 Yates, "A Note," 91.
} 
in those sufferings, which he endures not only for Colossians, but for the whole body. ${ }^{21}$

In what sense this is a "suffering for," or in what sense we can speak of anything "lacking" in Christ's sufferings, remains undefined.

Paul Trudinger responded to Yates by pressing exactly the point of the $\dot{\sigma} \tau \dot{\varepsilon} \rho \eta \mu \alpha$, suggesting that it goes too far even to say that Christ continues to suffer in the suffering of the Church, and that we should see Paul's suffering as merely imitative: "Paul speaks of his desire to be conformed to Jesus in His dying, to share in His sufferings. He is aware that he has not fully achieved this desire. The deficiencies are Paul's."22 Andrew Perriman provides textual support

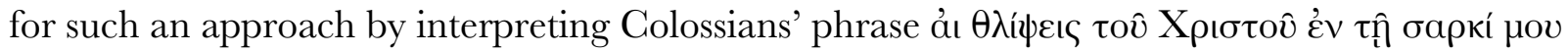
as the sufferings that Paul himself experiences in his flesh on behalf of Christ, rather than as the

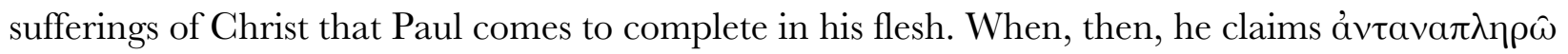

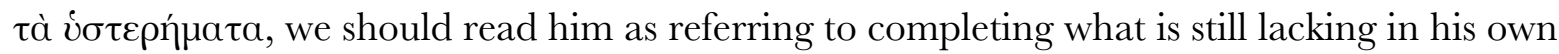
sufferings, rather than what is lacking in Christ's. ${ }^{23}$ The chief weakness of Perriman's approach is

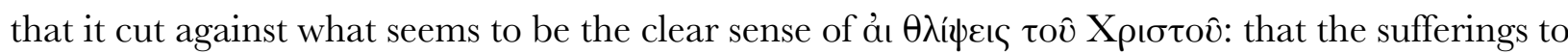
which Paul refers are Christ's own sufferings. ${ }^{24}$ Absent that, it becomes very difficult to see how

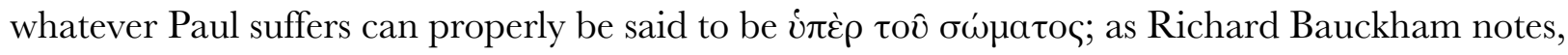
"If the deficiency is in the Church's conformity to the sufferings of Christ, then in what sense do Paul's personal sufferings supply the deficiency?"25

Bauckham's own approach, representative of what is likely the most popular interpretive option in the years since Yates' essay, extends the argument of Ernest Best as described in the fourth trajectory above. Bauckham suggests that Paul is reformulating in light of the Cross and Resurrection the Jewish theology of the "messianic woes," which held that the period leading up to the advent of the Messiah would be one of increasingly intense tribulation for the people of Israel.

By contrast the Christian reinterpretation, made in the light of the Cross and Resurrection and understanding these as proleptic and determinative apocalyptic events, focussed attention on the sufferings of the Messianic community, which must first share the sufferings of Christ if it would also share his glory (Rom. 8: 17; 1 Pet. 4: 13, etc.)...It is the worldwide preaching of the Gospel which involves the Church in worldwide persecution, and the movement is towards both a climax of

\footnotetext{
${ }^{21}$ Yates, "A Note," 91-2.

${ }^{22}$ Paul L. Trudinger, "A Further Brief Note on Colossians 1:24," The Evangelical Quarterly 45 (1973): 36-8; 38.

${ }^{23}$ Andrew Perriman, "The Pattern of Christ's Sufferings: Colossians 1:24 and Philippians 3:10-11," Tyndale Bulletin 42, no. 1 (1991): 62-79; 62-3.

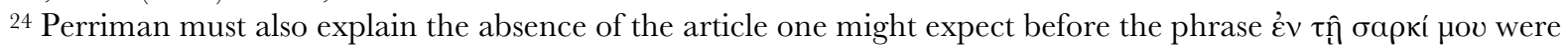

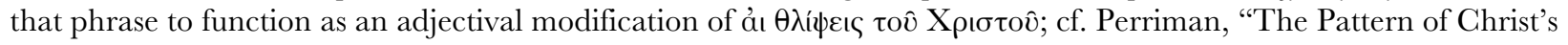
Sufferings," 63.

${ }^{25}$ Richard J. Bauckham, "Colossians 1:24 Again: The Apocalyptic Motif," The Evangelical Quarterly 47, no. 3 (1975): $168-70 ; 168$.
} 
persecution for the Church and a climax of judgment for those who reject the Gospel...the suffering required is that which the task of witness demands. ${ }^{26}$

But even here, problems abound. Evaluating Bauckham's proposal, Andrew Lincoln writes,

The Jewish concept of the woes in fact had no place for a suffering Messiah and did not hold that the Messiah would come before the suffering of God's people took place. In addition, the assumption that there was a clear-cut teaching about the "messianic woes" is dubious. There is considerable variation in the depiction of the nature, subject, and time of the woes in the writings from which the notion is said to come (e.g., 2 Bar. 20; 25; 1 Enoch 47; 4 Ezra 4:12, 33-37; 7; 13:16-19). And the thought of taking on a quota of suffering to hasten the inauguration of the new age does not fit particularly well in a letter that elsewhere contains no mention of the imminence of the eschaton. ${ }^{27}$

Bauckham would, no doubt, respond to Lincoln's first point by noting that he is already assuming considerable reevaluation of the preceding messianic theology by early Christians in light of the proclamation of Christ as Messiah; yet Lincoln's other two points do seem to present problems for Bauckham's otherwise plausible account.

In making this excursion into contemporary Biblical interpretation, I am certainly not proposing that the Augustinian outlook for which I have been arguing in these pages can provide a satisfying resolution to the argument over Colossians 1.24 among the guild of New Testament scholars. Though I suspect they are rather too quick to dismiss a mystical interpretation of corporate personhood in Christ as a later theological development, I will leave to them the question of what Paul or the writer in the Pauline tradition intended in writing these words; I am also attracted to an understanding of God's communication in Scripture that places relatively little importance on what Paul himself may have thought, and far more significance on the words of the Scriptural text as providentially ordained gifts for the Church's contemplation. What this discussion does accomplish, I hope, is to draw to light a set of theological desiderata in interpretations of Colossians 1.24. Among these are (1) clarity in the extension of the referent of

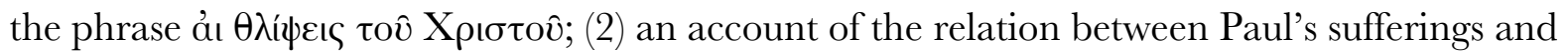

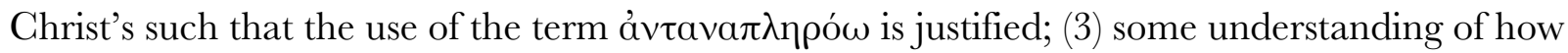
$\dot{v} \sigma \tau \dot{\varepsilon} \rho \eta \mu \alpha$ may be predicated of ảı $\theta \lambda \dot{\imath} \not \varepsilon ı \varsigma ~ \tau o \hat{~ X p ı \sigma \tau o v ̂ ~ w i t h o u t ~ i m p l y i n g ~ d e f i c i e n c y ~ o r ~}$ insufficiency in Christ's own performance of the work of redemption; (4) attention to the

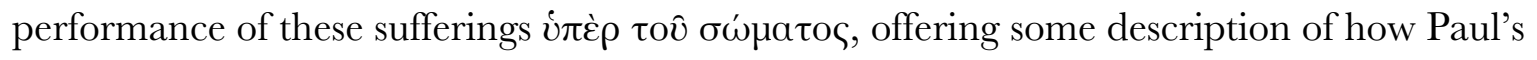
suffering contributes something to the body; and, finally, (5) some account of the role of such suffering plays in the internal constitution of the body of Christ, of these tribulations as the

\footnotetext{
${ }^{26}$ Bauckham, "Colossians 1:24 Again," 169.
}

${ }^{27}$ Lincoln, "Colossians," 614. 
inevitable result of a life lived in conformity to Christ in the midst of a sinful world, and as following necessarily from the proclamation of the Gospel.

It is my hope that the Augustinian christology I have proposed in this dissertation answers

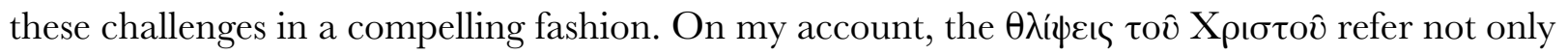
to the Passion of Christ, but also to the sufferings undergone by Christ in his body, the Churchand here it is important that the term $\theta \lambda \hat{\imath} \psi ı$ ç is nowhere else in the New Testament used to refer to the sufferings which are proper to Christ alone as head. In a far more realist sense than is commonly seen in contemporary christology, this Augustinian outlook tells us that we are Christ: our lives are conformed to his only as he dwells within us and is created within us by his Spirit; our lives, our bodies, souls, and agency, are drawn into his own life and will to save the world, and his redemptive work is accomplished through us as we become vital signs of him. His life is given its complete shape, he becomes our Redeemer, as he makes us into the very signs by which he redeems us. By his gracious will, he has chosen not to accomplish this work apart from us; though complete as vere Deus and vere homo by virtue of the Word's timeless act of assuming flesh, he wills to be the person that he $i$ s only with us, inclusive of our agency and the course of finite causality. Because of this intimacy between Christ's life and our own, we may even go so far as to say that he suffers in us, affirming the reality signified in the words Saul, Saul, why persecutest thou me? As he wills to take on human flesh interdependent with and vulnerable to our own flesh, he unites himself to all our suffering. As he undergoes suffering in his own body as head, he transfigures all suffering, teaching us that it will be overcome not only in his flesh but in ours as well.

When we thus speak of our own lives as filling up what is lacking in Christ's own sufferings, no deficiency or incompletion is suggested, for Christ receives our wounds as his own. Because Christ has two natures, our lives and agency are doubly related to his: we are noncompetitively related to Christ in his divine nature, and interdependent with him in his human nature. The fact that we can be both at once is due to Christ's humanity, for he too is noncompetitively related to the eternal act of God's life as the Word's own human life and will. By the work of the Holy Spirit, we are made into the extension of Christ's life: our lives become responsive to the dwelling of God's power within us in a manner closely related to the dwelling of the Word's power in Christ. Where we differ is that the human life of Christ is the very life of God - Christ's personhood is the personhood of the Word, who has united human nature to itself and hypostatizes that nature in the human life of Christ. Though we live always in dependence upon God's gift, we are granted the possibility of existing as individual human persons. However much our lives come to be noncompetitively enlivened by the presence of Christ's Spirit in us and determined by Christ's life as we come to desire with his desires and act with his will, there will always be a qualitative difference between his divine-human personhood and our human personhood in union with God. Yet the human nature the Word assumes exists interdependently with us, and the work of redemption that the Word wills in assuming flesh is only completed as our human lives enter into relation with Christ's human life. He has willed to include our own lives and action in his redemptive work, and so Christ's own work is not full and final until we are joined to it. His flesh draws our hearts back to the invisible God, and as our affections are pulled 
heavenward, we ourselves come to serve as signs of Christ's flesh that draw others back to God, and they us. Our sufferings, both those inflicted unjustly by the sin of others and those entered

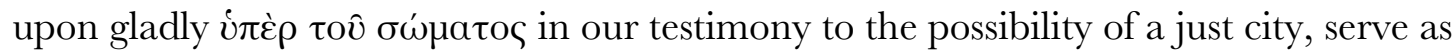
redemptive signs for others as we repeat the pattern of Christ's life in our own. Until this city comes, the Church is called to reflect in its own life and through faithfulness in the midst of tribulation the possibility of a life ordered by love of God and neighbor. Though it enacts this possibility only imperfectly, defined as much by its own failures in love as by the successes in loving it receives as the gift of the Spirit, the Church's collective life at its most faithful (and thus, inseparable from those who are dehumanized by the forces of human wickedness) teaches us that on the other side of violence, death, and sin is a life lived wholly in response to God's gift, a life of mutual recognition, a restored relation between a healed soul and incorruptible body, an everlasting communal life of embodied loving contemplation in the City of God.

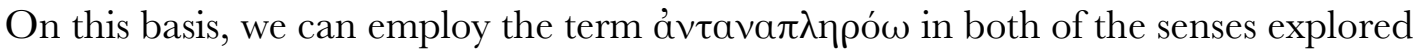
above in Demosthenes and Apollonius Dyscolus. As we undergo suffering in the body of Christ, we render the full extent of Christ's sufferings newly determinate, completing them just as a pronoun completes a verb. We need not say that Christ suffered imperfectly in the events of the Passion, just as the verb үpá $\phi \omega$ is perfectly well-formed in itself; but the verb's subject attains a new concreteness in the sentence structure when it is accompanied by the pronoun $\dot{\varepsilon} \gamma(\dot{\omega}$. Analogously, we may say that though Christ underwent his sufferings perfectly on Good Friday, we see the full extent of his afflictions as he suffers in our lives as well. It is in this sense that we can even speak with Demosthenes about our sufferings "filling up" Christ's sufferings in a quantitative sense - there is, even now, more for Christ to suffer, as the downtrodden of the world and those groaning under the weight of sin suffer on the cross of the world. There will continue to be a lack in Christ's sufferings until the necessarily painful work of reconciliation is accomplished, as the surgeon's hand cuts away our malignity and restores us to health.

Colossians 1.24 is certainly not among the verses Augustine cites most frequently in his christological reflections; reference to it is dwarfed by the number of times Augustine returns to Christ's cry of dereliction or his words to Saul on the way to Damascus. In his extensive corpus, he cites it only eight times: at Io.tr.eu. 98.5 and 108.5; en.Ps. 61.4, 86.5, 87.15, and 142.3; s. Dolbeau 22.20; and at trin. 4.3.6. Frequency is not the only measure of importance, of course, and we have already encountered a number of these texts as being among the most important sites of Augustine's christology. One of the passages I have not yet discussed offers perhaps Augustine's most striking discussion of the verse from Colossians. At en.Ps. 61.4, Augustine writes,

If you are numbered among the members of Christ, whoever you are, mortal sufferer who hear these words (and whoever you are who do not hear them, for that matter; though in fact you do hear them if you are a member of Christ), then whatever you may suffer at the hands of those who are not Christ's members was lacking to the sufferings of Christ. This statement that it 'was lacking' means that you are filling up the appointed measure: not that you are causing it to spill over, but that you are suffering just so much as was necessarily to be contributed from 
your passion to the universal passion of Christ. He suffered as our head, and he suffers in his members, which means in us. We each pay what we owe into this commonwealth of ours, according to our limited means; we contribute our quota of suffering from the resources allotted to us. There will be no final balancing of accounts in the matter of suffering until this world ends. ${ }^{28}$

In condensed form, we see in this passage what I take to be both the promise and the peril of Augustine's theology of the totus Christus. Without question, Augustine's words here threaten to naturalize our suffering: to sanctify it as the will of God, to commend us to pursue it as a spiritual exercise, to blunt any attempt to resist or escape from our suffering. Why, then, is suffering such a central aspect of the Christian life for St. Augustine, for St. Paul — for this dissertation?

This is a question with no simple answer. It is not, I hope, out of a misguided consecraction of suffering for suffering's sake; nor is it merely because I find suffering inescapable in this life. Even this way of putting it sounds wrong, for what have I suffered, really, in comparison others? It is the height of callousness to commend suffering as a means of participation in Christ while I sit in tranquility and relative plenty as others bleed. Indeed, it may be not only unfeeling but actively harmful, telling others to remain in their agony even as I work to insulate myself from it. I am very suspicious of myself on this score; I do not trust my intuitions here.

And yet. And yet I cannot escape feeling that the suffering we encounter throughout our lives is a sign of just how wrong our world is, and of just how good God has made it. To suffer the world is to experience its wrongness, to refuse the consolation of thinking that this is the way things should or must be. It is to dwell with our loss as loss, to grieve our own errors and to bear truthfully the pain inflicted on us by others. It is undoubtedly the case that this suffering can overwhelm us: there are some griefs that run so deep that we cannot recover from them, some pains so acute that they can signify only death to us. In these moments, the hope of new life may be entirely eclipsed. Some agonies are simply too much for us to bear.

Yet to the extent that our suffering does not eclipse our hope of new life, it testifies against the ultimacy of this world of sin and death. I do not mean here only the heroic suffering on behalf of others in combatting injustice, but also the pain felt by a mother who has lost her child too soon, the of the homeless man starving and cold, of the prisoner experiencing constant abuse, even of the field mouse snatched by the talons of the hawk. In experiencing our suffering as suffering, our loss as loss, we bear witness to the goodness of the world that is corrupted by evil and death, even as we see that world reduced to dust in our hands. Suffering is not only the perceived sensation of this corruption, but a revolt against it, the world acknowledging the tragedy of its own condition. None of this can suggest that we should remain in our suffering, or seek it out - suffering has no goodness in itself, but keeps vigil for the goods we have lost. In so doing, it keeps our hearts trained on those things from which death has separated us.

${ }_{28}$ WSA III/17, 204. 
As we are written into the life of Christ, we find our sufferings made his, and his made our own. This is depicted dramatically on the cross, but in the godforsakenness that finds expression there we must see the godforsakenness intrinsic to every defection from the goodness of creation. As each disease ravages each body, as every betrayal breaks the love between two people, as every injustice submits a bearer of the image of God to dehumanization, the creation forsakes the God who has made it. It is this fall away from God that Christ takes into his own life, by becoming united to our sinful lives. No moment of death is absent from Christ's life, because he has taken on relations to the whole created order in his human flesh. Every suffering is made his own, as he becomes the one who redeems it.

Inseparably from this fact, however, his sufferings become ours. As I have portrayed it, a central feature of the Christian life is our learning to see our sin (and the sin of others) as sin. This is the confessional crux of our incorporation into Christ, and with it comes our learning to grieve over the sins of the world. Sin's allure is the promise of a better world than the one we see before us, a glittering mirage in which the world is not really as damaged as we've been told; in which there's really very little that can be done, isn't there; in which we're really not so guilty, after all. The artifice of sin renders us insensible to the realities of suffering before us, and in our own lives; it tells us that these may be safely avoided. In Christ, we are taught to see the death of the world, to feel Christ's pain at injustice. It is like the saints who come to feel grief over their sin with greater intensity as they are sanctified. We will not have been perfected until we are able to experience with Christ the searing pain of the world's sin; this is the measure of suffering that must be completed in our own lives.

To the extent that our lives do not reflect the sanctifying work of the Spirit of Christ, this suffering is still lacking to Christ's body. It is filled up in us as we experience the pain of the world as it is, longing in our hearts for the resurrection of this world, and finding Christ's misericordia repeated in ourselves. By the Spirit's work, Christ's suffering is made our suffering, his life our life, his words our words, as we are freed to confess eternally all that we have been given and given again. 


\section{$\underline{\text { BIBLIOGRAPHY }}$}

\section{Works of Augustine in Translation}

In virtually all cases, I have cited from the Works of Saint Augustine published by New City Press, with citations given as (WSA Part/Volume, Page):

Augustine, Saint, Bishop of Hippo. The Works of Saint Augustine: a Translation for the $21^{\text {st }}$ Century. Edited by John E. Rotelle. 49 vol. Brooklyn, NY: New City Press.

The exceptions to this are:

Augustine. Against the Academicians and The Teacher. Translated by Peter King. Indianapolis, IN: Hackett Publishing Co., 1995.

Augustine. The City of God against the Pagans. Edited and Translated by R.W. Dyson. Cambridge: Cambridge University Press, 1998.

Augustine. On Free Choice of the Will. Translated by Thomas Williams. Indianapolis, IN: Hackett Publishing Co., 1993.

\section{Other Sources}

Adams, Marilyn McCord. Some Later Medieval Theories of the Eucharist: Thomas Aquinas, Giles of Rome, Duns Scotus, and William Ockham. Oxford: Oxford University Press, 2012.

Aland, Kurt, Matthew Black, Carlo M. Martini, Bruce M. Metzger, and Allen Wikgren. The Greek New Testament. 3rd Edition. Münster: United Bible Societies, 1975.

Anatolios, Khaled. "Oppositional Pairs and Christological Synthesis: Rereading Augustine's De Trinitate." Theological Studies 68 (2007): 231-253.

Anderson, James F. St. Augustine and Being: A Metaphysical Essay. The Hague: Martinus Nijhoff, 1965.

Anselm of Canterbury. The Major Works. Edited by Brian Davies and G.R. Evans. Oxford: Oxford University Press, 1998.

Apollonius Dyscolus. De Constructione Libri Quattuor (Peri Suntaxeos). Vol. II.2, in Grammatici Graeci, edited by Gustav Uhlig. Leipzig: B.G. Teubner, 1910.

Aquinas, Thomas. Summa Theologica. Translated by Fathers of the English Dominican Province. 3 vols. Westminster, MD: Christian Classics, 1948. 
Aristide, Jean-Bertrand. In the Parish of the Poor: Writings from Haiti. Maryknoll: Orbis Books, 1990.

Aristotle. Categories and De Interpretatione. Translated by J.L. Ackrill. Oxford: Oxford University Press, 1963.

Attridge, Harold W., Wayne A. Meeks, and Jouette M. Bassler. The HarperCollins Study Bible: New Revised Standard Version, Including the Apocryphal/Deuterocanonical Books. New York: HarperOne, 2006.

Auden, W.H. Selected Poems. Expanded 2nd Edition. Edited by Edward Mendelson. New York: Vintage International, 2007.

Ayres, Lewis. "'Where Does the Trinity Appear?" Augustine's Apologetics and "Philosophical" Readings of the De Trinitate." Augustinian Studies 43, no. 1/2 (2012): 109-126.

-. Augustine and the Trinity. Oxford: Oxford University Press, 2011.

—. "Augustine on God as Love and Love as God." Pro Ecclesia 5 (1996): 470-487.

—. "Augustine, Christology, and God as Love: An Introduction to the Homilies on 1 Fohn." In Nothing Greater, Nothing Better: Theological Essays on the Love of God, 67-93. Grand Rapids: Wm. B. Eerdmans Publishing Co., 2001.

—. "Between Athens and Jerusalem: Prolegomena to Anthropology in De Trinitate." Modern Theology 8, no. 1 (1992): 53-73.

—. "Christology as Contemplative Practice: Understanding the Union of Natures in Augustine's Letter 137." In In the Shadow of the Incarnation: Essays on Jesus Christ in the Early Church in Honor of Brian E. Daley, SF, edited by Peter W. Martens, 190-211. Notre Dame: University of Notre Dame Press, 2008.

—. "Into the Poem of the Universe: Exempla, Conversion, and Church in Augustine's Confessiones." Zeitschrift für antikes Christentum 13, no. 2 (2009): 263-81.

-. Nicaea and its Legacy: An Approach to Fourth-Century Trinitarian Theology. Oxford: Oxford University Press, 2004.

- " "Not Three People: The Fundamental Themes of Gregory of Nyssa's Trinitarian Theology as Seen in To Ablabius: On Not Three Gods." Modern Theology 18, no. 4 (2002): 445-74.

-. "Remember That You are Catholic (serm. 52.2): Augustine on the Unity of the Triune God." Fournal of Early Christian Studies 8, no. 1 (2000): 39-82.

—. "Representation, Theology, and Faith." Modern Theology 11, no. 1 (1995): 23-46.

- " "The Christological Context of Augustine's De trinitate XIII: Toward Relocating Books VIIIXV." Augustinian Studies 29, no. 1 (1998): 111-139. 
—. "The Fundamental Grammar of Augustine's Trinitarian Theology." In Augustine and His Critics: Essays in Honour of Gerald Bonner, edited by Robert Dodaro and George Lawless, 51-76. London: Routledge, 2002.

Babcock, William. "The Christ of the Exchange: A Study in the Christology of Augustine's Enarrationes in Psalmos." Unpublished diss., Yale University, 1972.

Baker, Lynne Rudder. "Why Christians should not be Libertarians: An Augustinian Challenge." Faith and Philosophy 20, no. 4 (2003): 460-78.

Bantum, Brian. Redeeming Mulatto: A Theology of Race and Christian Hybridity. Waco: Baylor University Press, 2010.

Barnes, Michel René. "Augustine in Contemporary Trinitarian Theology." Theological Studies 56 (1995): 237-250.

—. "De Régnon Reconsidered." Augustinian Studies 26, no. 2 (1995): 51-79.

—. "The Arians of Book V, and the Genre of De Trinitate." The Fournal of Theological Studies 44, no. 1 (1993): 185-95.

—. "The Visible Christ and the Invisible Trinity: Mt. 5:8 in Augustine's Trinitarian Theology of 400." Modern Theology 19, no. 3 (2003): 329-55.

Barth, Karl. Church Dogmatics I/1. Edited by G.W. Bromiley and T.F. Torrance. Translated by G.W. Bromiley. Edinburgh: T\&T Clark, 1975.

Bauckham, Richard J. "Colossians 1:24 Again: The Apocalyptic Motif." The Evangelical Quarterly 47, no. 3 (1975): 168-70.

Bavel, Tarsicius J. van. Recherches sur la christologie de saint Augustin, l'humain et le divin dans le Christ d'après Saint Augustin. Fribourg en Suisse: Editions universitaires, 1954.

—. "The Double Face of Love in Augustine." Augustinian Studies 17 (1986): 196-181.

BeDuhn, Jason. Augustine's Manichaean Dilemma, Volume 1: Conversion and Apostasy, 373-388 C.E. Philadelphia: University of Pennsylvania Press, 2010.

-. Augustine's Manichaean Dilemma, Volume 2: Making a "Catholic" Self, $388-401$ C.E. . Philadelphia: University of Pennsylvania Press, 2013.

Bevan, George A. "Augustine and the Western dimension of the Nestorian controversy." Studia Patristica, 2010: 347-52.

Bogost, Ian. Alien Phenomenology, or What it's Like to be a Thing. Minneapolis: University of Minnesota Press, 2012. 
Bonner, Gerald. "The Church and the Eucharist in the Theology of St. Augustine." Sobornost 7, no. 6 (1978): 448-61.

Bradley, F.H. Appearance and Reality. London: Swan Sonnenschein \& Co., 1893.

Bradshaw, David. "Augustine the Metaphysician." In Orthodox Readings of Augustine, edited by George E. Demacopoulos and Aristotle Papanikolaou, 227-252. Crestwood, NY: St. Vladimir's Seminary Press, 2008.

Broad, C.D. Scientific Thought. London: Routledge \& Kegan Paul, 1923.

Brown, Joanne Carlson, and Rebecca Parker. "For God So Loved the World?" In Christianity, Patriarchy, and Abuse: A Feminist Critique, edited by Joanne Carlson Brown and Carole R. Bohn, 1-30. New York: The Pilgrim Press, 1989.

Brown, Peter. Augustine of Hippo: A Biography. 2nd Edition. Berkeley: University of California Press, 2000.

Burns, J. Patout. "Christ and the Holy Spirit in Augustine's Theology of Baptism." In Augustine: From Rhetor to Theologian, edited by Joanne McWilliam, 161-71. Waterloo: Wilfrid Laurier University Press, 1992.

—. "How Christ Saves: Augustine's Multiple Explanations." In Tradition $E$ The Rule of Faith in the Early Church: Essays in Honor of Joseph T. Lienhard, S.J., edited by Ronnie J. Rombs and Alexander Y. Hwang, 193-210. Washington, D.C.: The Catholic University of America Press, 2010.

—. The Development of Augustine's Doctrine of Operative Grace. Paris: Études Augustiniennes, 1980.

Burnyeat, Myles F. "The Inaugural Address: Wittgenstein and Augustine De Magistro." Proceedings of the Aristotelian Society, Supplementary Volumes 61 (1987): 1-24.

Burrell C.S.C., David. Aquinas: God and Action. Scranton, PA: University of Scranton Press, 2008.

Butler, Judith. Giving an Account of Oneself. New York: Fordham University Press, 2005.

Bynum, Caroline Walker. Christian Materiality: An Essay on Religion in Late Medieval Europe. New York: Zone Books, 2011.

Calvin, John. Commentaries on the Epistles of Paul the Apostle to the Philippians, Colossians, and Thessalonians. Edited by J.B. Pringle. Edinburgh: The Calvin Translation Society, 1851.

- Institutes of the Christian Religion. Edited by John T. McNeill. Translated by Ford Lewis Battles. Louisville, KY: Westminster John Knox Press, 1960.

Cameron, Michael. "Augustine and Scripture." In A Companion to Augustine, edited by Mark Vessey, 200-14. Oxford: Wiley-Blackwell, 2012. 
- Christ Meets Me Everywhere: Augustine's Early Figurative Exegesis. Oxford: Oxford University Press, 2012.

Cameron, Ross P. The Moving Spotlight: An Essay on Time and Eternity. Oxford: Oxford University Press, 2015.

—. "Turtles All the Way Down: Regress, Priority, and Fundamentality." The Philosophical Quarterly 58, no. 230 (2008): 1-14.

Canning, Raymond. The Unity of Love for God and Neighbor in St. Augustine. Louvain: Australian Historical Institute, 1993.

Carter, Jason W. "St. Augustine on Time, Time Numbers, and Enduring Objects." Vivarium 49, no. 4 (2011): 301-23.

Cary, Phillip. Augustine's Invention of the Inner Self: The Legacy of a Christian Platonist. Oxford: Oxford University Press, 2000.

-. Outward Signs: The Powerlessness of External Things in Augustine's Thought. Oxford: Oxford University Press, 2008.

Cavadini, John C. "'The Tree of Silly Fruit": Images of the Cross in Augustine." In The Cross in Christian Tradition: From Paul to Bonaventure, edited by Elizabeth A. Dreyer, 147-68. New York: Paulist Press, 2000.

—. "Feeling Right: Augustine on the Passions and Sexual Desire." Augustinian Studies 36, no. 1 (2005): 195-217.

—. "Jesus' Death Is Real: An Augustinian Spirituality of the Cross." In The Cross in Christian Tradition: From Paul to Bonaventure, edited by Elizabeth A. Dreyer, 169-191. New York: Paulist Press, 2000.

—. "Simplifying Augustine." In Educating People of Faith: Exploring the History of Jewish and Christian Communities, 63-84. Grand Rapids: Wm. B. Eerdmans Publishing Co., 2004.

—. "The Darkest Enigma: Reconsidering the Self in Augustine's Thought." Augustinian Studies 38, no. 1 (2007): 119-132.

—. "Trinity and Apologetics in the Thought of St. Augustine." Modern Theology 29, no. 1 (2013): 48-82.

—. "The Structure and Intention of Augustine's De trinitate." Augustinian Studies 23 (1992): 103-23.

Chrétien, Jean-Louis. The Call and the Response. Translated by Anne A. Davenport. New York: Fordham University Press, 2004. 
Clair, Joseph. Discerning the Good in the Letters and Sermons of Augustine. Oxford: Oxford University Press, 2016.

Clancy S.J., Finbarr G. "The Cross in Augustine's Tractatus in Iohannem." Studia Patristica 33 (1997): $55-62$.

Coakley, Sarah. God, Sexuality, and the Self: An Essay 'On the Trinity'. Cambridge: Cambridge University Press, 2013.

-. Powers and Submissions: Spirituality, Philosophy, and Gender. Oxford: Blackwells Publishers Ltd, 2002.

Cone, James H. Black Theology \&̊ Black Power. Maryknoll, NY: Orbis Books, 2006.

—. God of the Oppressed. Revised Edition. Maryknoll, NY: Orbis Books, 1997.

Copeland, M. Shawn. Enfleshing Freedom: Body, Race, and Being. Minneapolis: Fortress Press, 2010.

Corbin, Alain. Village Bells: Sound and Meaning in the 19th Century French Countryside. New York: Columbia University Press, 1998.

Cornwall, Susannah. Sex and Uncertainty in the Body of Christ: Intersex Conditions and Christian Theology. Oxford: Routledge, 2014.

Corrigan, Gale Patterson. "The Milk of Salvation: Redemption by the Mother in Late Antiquity and Early Christianity." The Harvard Theological Review 82, no. 4 (1989): 393-420.

Cotsonis, John. "The Image of the Virgin Nursing (Galaktotrophousa) and a Unique Inscription on the Seals of Romanos, Metropolitan of Kyzikos ." Dumbarton Oaks Papers (Dumbarton Oaks, Trustees for Harvard University) 65/66 (2011-12): 193-207.

Couenhoven, Jesse. "Augustine's rejection of the free-will defence: an overview of the late Augustine's theodicy." Religious Studies 43 (2007): 279-298.

—. "'Not every wrong is done with pride': Augustine's proto-feminist anti-Pelagianism." Scottish Fournal of Theology 61, no. 1 (2008): 32-50.

-. Stricken by Sin, Cured by Christ: Agency, Necessity, and Culpability in Augustinian Theology. Oxford: Oxford University Press, 2013.

Cuskelly M.S.C., E.J. "Mary's Coredemption: A Different Approach to the Problem." Theological Studies 21, no. 2 (1960): 207-20.

Daley S.J., Brian E. "Word, Soul, and Flesh: Origen and Augustine on the Person of Christ." Augustinian Studies 36, no. 2 (2005): 299-326.

—. "A Humble Mediator: The Distinctive Elements in Saint Augustine's Christology." Word and Spirit 9 (1987): 100-117. 
—. "Making a Human Will Divine: Augustine and Maximus on Christ and Human Salvation." In Orthodox Readings of Augustine, edited by George E. Demacopoulos and Aristotle Papanikolaou, 101-26. Crestwood, NY: St. Vladimir's Seminary Press, 2008.

—. "The Giant's Twin Substances: Ambrose and the Christology of Augustine's Contra sermonem Arianorum." In Augustine: Presbyter Factus Sum, edited by Joseph T. Lienhard, Earl C. Müller and Roland J. Teske, 477-95. New York: Peter Lang, 1993.

Davis, Ellen F. Getting Involved with God: Rediscovering the Old Testament. Lanham, MD: Cowley Publications, 2001.

Deasy, Daniel. "The Moving Spotlight Theory." Philosophical Studies 172, no. 8 (2015): 2073-89.

DeHart, Paul. "Ter mundus accipit infinitum: The Dogmatic Coordinates of Schleiermacher's Trinitarian Treatise." Neue Zeitschrift für Systematische Theologie und Religionsphilosophie 52, no. 1 (2010): 17-39.

Deng, Natalja. "Our Experience of Passage on the B-Theory." Erkenn 78 (2013): 713-26.

Dewart, Joanne McWilliam. "Augustine's Developing Use of the Cross: 387-400." Augustinian Studies 15 (1984): 15-33.

—. "The Influence of Theodore of Mopsuestia on Augustine's Letter 187." Augustinian Studies 10 (1979): 113-132.

Diamond, Cora. "Wittgenstein on Religious Belief: The Gulfs Between Us." In Religion and Wittgenstein's Legacy, edited by D.Z. Phillips and M. von der Ruhr, 99-137. London: Ashgate, 2005.

Diepen, Herman. "L"Assumptus Homo' patristique." Revue Thomiste 71 (1963): 225-45.

Djuth, Marianne. "Will." In Augustine through the Ages: An Encyclopedia, edited by Allan D. Fitzgerald O.S.A., 881-5. Grand Rapids: Wm. B. Eerdmans Publishing Co, 1999.

Dodaro, Robert. "«Omnes haeretici negant Christum in carne uenisse» (Aug., serm. 183.9.13): Augustine on the Incarnation as Criterion for Orthodoxy." Augustinian Studies 38, no. 1 (2007): 163-74.

—. "Augustine's Revision of the Heroic Ideal." Augustinian Studies 36, no. 1 (2005): 141-157.

- Christ and the Fust Society in the Thought of Augustine. Cambridge: Cambridge University Press, 2004.

—. "Christus iustus and Fear of Death in Augustine's Dispute with Pelagius." In Signum pietatis. Festgabe für Cornelius P. Mayer OSA zum 60 Geburtstag, edited by A. Zumkeller, 341-61. Würzburg, 1989. 
-. "Light in the Thought of St. Augustine." In Light from light: scientists and theologians in dialogue, edited by Gerald O'Collins S.J. and Mary Ann Meyers, 195-207. Grand Rapids: Wm B. Eerdmans Publishing Co., 2012.

Drecoll, Volker. "Lewis Ayres, Augustine and the Trinity." Scottish Fournal of Theology 66, no. 1 (2013): 88-98.

Drever, Matthew. "Entertaining Violence: Augustine on the Cross of Christ and the Commercialization of Suffering." The Fournal of Religion 92, no. 3 (2012): 331-361.

-. Image, Identity, and the Forming of the Augustinian Soul. Oxford: Oxford University Press, 2013.

—. "The Self Before God? Rethinking Augustine's Trinitarian Thought." Harvard Theological Review 100, no. 2 (2007): 233-242.

Drobner, Hubertus. Person-Exegese und Christologie bei Augustinus: Zur Herkunft der Formel Una persona. Leiden: EJ Brill, 1986.

Dunfee, Susan Nelson. "The sin of hiding: A feminist critique of Reinhold Niebuhr's account of the sin of pride." Soundings 65, no. 3 (1982): 316-27.

Dupuy, Alex. The Prophet and Power: Fean-Bertrand Aristide, the International Community, and Haiti. Lanham, MD: Rowman \& Littlefield Publishers, Inc., 2007.

Ellacuría S.J., Ignacio. "The Crucified People." In Mysterium Liberationis, edited by Ignacio Ellacuría S.J. and Jon Sobrino S.J., translated by Phillip Berryman and Robert R. Barr, 580603. Maryknoll, NY: Orbis Books, 1993.

Evans, G.R. Augustine on Evil. Cambridge: Cambridge University Press, 1990.

Farmer, Paul. "Who Removed Aristide?" London Review of Books. April 15, 2004. https://www.lrb.co.uk/v26/n08/paul-farmer/who-removed-aristide (accessed February 22, 2017).

Farrow, Douglas. Ascension Theology. London: T\&T Clark International, 2011.

Feser, Edward. Scholastic Metaphysics: A Contemporary Introduction. Piscataway, NJ: editiones scholasticae, 2014.

Fiedrowicz, Michael. Psalmus Vox Totius Christi Studien Zu Augustins Enarrationes in Psalmos. Freiburg: Herder, 1997.

Fine, Kit. "Guide to Ground." In Metaphysical Grounding: Understanding the Structure of Reality, edited by Fabrice Correia and Benjamin Schneider, 37-80. Cambridge: Cambridge University Press, 2014. 
Fine, Kit. "Tense and Reality." In Modality and Tense: Philosophical Papers, 261-320. Oxford: Oxford University Press, 2005.

Fredriksen, Paula. Augustine and the Fews: A Christian Defense of Jews and Judaism. New Haven: Yale University Press, 2010.

Frei, Hans W. The Identity of Jesus Christ: the Hermeneutical Bases of Dogmatic Theology. Eugene, OR: Wipf and Stock Publishers, 1997.

Fulkerson, Mary McClintock. Places of Redemption: Theology for a Worldly Church. Oxford: Oxford University Press, 2007.

Gaine, Simon Francis. Did the Savior See the Father? Christ, Salvation and the Vision of God. London: Bloomsbury T\&T Clark, 2015.

Geerlings, Wilhelm. Christus Exemplum: Studien zur Christologie und Christusverkündigung Augustins. Mainz: Matthias Grünewald Verlag, 1978.

Gioia, Luigi. The Theological Epistemology of Augustine's De Trinitate. Oxford: Oxford University Press, 2008.

Grant, Jacquelyn. White Women's Christ and Black Women's Jesus: Feminist Christology and Womanist Response. The American Academy of Religion, 1989.

Green, Bradley G. Colin Gunton and the Failure of Augustine. Eugene, OR: Pickwick Publications, 2011.

Gregersen, Niels Henrik. "Cur Deus Caro: Jesus and the Cosmic Story." Theology and Science 11, no. 4 (2013): 370-393.

—. "Deep incarnation and kenosis: In, with, under, and as: A response to Ted Peters." Dialog 52, no. 3 (2013): 251-262.

-. "Deep Incarnation: Why Evolutionary Continuity Matters in Christology." Toronto Fournal of Theology 26, no. 2 (2010): 173-188.

—. "The Cross of Christ in an Evolutionary World." Dialog: A Journal of Theology 40, no. 3 (2001): 192-207.

Gregory, Eric. "Augustinians and the New Liberalism." Augustinian Studies 41, no. 1 (2010): 315332.

- Politics and the Order of Love: An Augustinian Ethic of Democratic Citizenship. Chicago: University of Chicago Press, 2008.

Griffiths, Paul J. Decreation: The Last Things of All Creatures. Waco, TX: Baylor University Press, 2014. 
-. Intellectual Appetite: A Theological Grammar. Washington, D.C.: The Catholic University of America Press, 2009.

Grillmeier, Aloys. Christ in Christian Tradition. Translated by J.S. Bowden. New York: Sheed and Ward, 1964.

Gunton, Colin E. The Promise of Trinitarian Theology. 2nd Edition. London: T\&T Clark, 1997.

Halberstam, Judith. The Queer Art of Failure. Durham, NG: Duke University Press Books, 2011.

Hampson, Daphne. "Reinhold Niebuhr on Sin: A Critique." In Reinhold Niebuhr and the Issues of our Time, edited by Richard Harries, 46-60. Oxford: Mowbray, 1986.

Hanby, Michael. Augustine and Modernity. New York: Routledge, 2003.

Harrison, Carol. Rethinking Augustine's Early Theology: An Argument for Continuity. Oxford: Oxford University Press, 2006.

-. The Art of Listening in the Early Church. Oxford: Oxford University Press, 2015.

Hart, David Bentley. "The Hidden and the Manifest: Metaphysics after Nicaea." In Orthodox Readings of Augustine, edited by George E. Demacopoulos and Aristotle Papanikolaou, 191226. Crestwood, NY: St. Vladimir's Seminary Press, 2008.

Hauerwas, Stanley. A Community of Character: Toward a Constructive Christian Social Ethic. Notre Dame: University of Notre Dame Press, 1991.

Hector, Kevin W. "Actualism and Incarnation: the high christology of Friedrich Schleiermacher." International Fournal of Systematic Theology 8, no. 3 (2006): 307-22.

Heil, John. "Relations." In The Routledge Companion to Metaphysics, edited by Robin Le Poidevin, Peter Simons, Andrew McGonigal and Ross P. Cameron, 310-321. London: Routledge, 2009.

Helm, Paul. Eternal God. 2nd Edition. Oxford: Oxford University Press, 2010.

Herdt, Jennifer. Putting on Virtue: The Legacy of the Splendid Vices. Chicago: University of Chicago Press, 2008.

Hilary of Poitiers. The Trinity. Translated by Stephen McKenna. Washington, D.C.: Catholic University of America Press, 1954.

Hudson, Hud. The Fall and Hypertime. Oxford: Oxford University Press, 2014.

Hume, David. A Treatise of Human Nature. Edited by David Fate Norton. Vol. I. II vols. Oxford: Clarendon Press, 2007. 
Husserl, Edmund. Analyses Concerning Passive and Active Synthesis: Lectures on Transcendental Logic. Translated by Anthony J. Steinbock. Dordrecht: Kluwer Academic Publishers, 2001.

Iafrate, Michael J. "Jesuits, The Totus Christus and the Crucified People: Re-Reading Augustine's Christology from Below with the Salvadorean." Fournal of Postcolonial Theory and Theology 2, no. 4 (2011): 1-49.

James, Mark Randall. Learning the Language of Scripture: Origen, Wisdom, and Exegetical Inquiry. Unpublished Ph.D. Dissertation, University of Virginia, 2016.

John of Damascus. Three Treatises on the Divine Images. Translated by Andrew Louth. Crestwood, NY: St. Vladimir's Seminary Press, 2003.

John Paul II. "General Audience, April 9, 1997." L'Osservatore Romano (English Edition), April 16, 1997: 7

Johnson, Elizabeth A. She Who Is: the Mystery of God in Feminist Theological Discourse. 10th Anniversary Edition. New York: The Crossroad Publishing Company, 2002.

Jones, Paul Dafydd. The Humanity of Christ: Christology in Karl Barth's Church Dogmatics. London: T\&T Clark, 2008.

Jones, Serene. Calvin and the Rhetoric of Piety. Louisville, KY: Westminster John Knox Press, 1995.

Jordan, Mark D. "Word and Words: Incarnation and Signification in Augustine's De doctrina christiana." Augustinian Studies 11 (1980): 177-96.

Kaufman, Peter Iver. "Christian Realism and Augustinian (?) Liberalism." Journal of Religious Ethics 38, no. 4 (2010): 699-724.

Keech, Dominic. The Anti-Pelagian Christology of Augustine of Hippo, 396-430. Oxford: Oxford University Press, 2012.

Keller, Catherine. Cloud of the Impossible: Negative Theology and Planetary Entanglement. New York: Columbia University Press, 2014.

—. The Face of the Deep: A Theology of Becoming. London: Routledge, 2003.

Kelly, Anthony J. Upward: Faith, Church, and the Ascension of Christ. Collegeville, MN: Liturgical Press, 2014.

Kierkegaard, Søren. Practice in Christianity. Edited by Howard V. Hong and Edna H. Hong. Princeton: Princeton University Press, 1991.

Kilby, Karen. "Is an Apophatic Trinitarianism Possible?" International fournal of Systematic Theology 12, no. 1 (2010): 65-77. 
King, Peter. "The Semantics of Augustine's Trinitarian Analysis in De Trinitate 5-7." In Le De Trinitate de Saint Augustin: Exégèse, logique et noétique, edited by Emmanuel Bermon and Gerard O'Daly, 123-135. Paris: Institut d'Études Augustiniennes, 2012.

Kolbet, Paul R. Augustine and the Cure of Souls: Revising a Classical Ideal. Notre Dame: University of Notre Dame Press, 2010.

Komisar, Lucy. "Follow Aristide's Money Offshore: How Haiti was looted with the help of tax haven shell companies \& secret bank accounts and U.S. citizens \& corporations." The Komisar Scoop. November 10, 2005. http://www.thekomisarscoop.com/2005/11/follow-aristidesmoney-offshore-how-haiti-was-looted-with-the-help-of-tax-haven-shell-companies-secretbank-accounts-and-us-citizens-corporations/ (accessed February 22, 2017).

Kripke, Saul. Naming and Necessity. Cambridge, MA: Harvard University Press, 1980.

Larsen, Sean. Naked and Unashamed: Rethinking Sex and Politics with Augustine. (forthcoming)

Lassalle-Klein, Robert. "Jesus of Galilee and the Crucified People: The Contextual Christology of Jon Sobrino and Ignacio Ellacuría." Theological Studies 70 (2009): 347-376.

Lawless, George. "Augustine's Decentering of Asceticism." In Augustine and His Critics: Essays in Honour of Gerald Bonner, edited by Robert Dodaro and George Lawless, 142-63. London: Routledge, 2000.

Le Poidevin, Robin. The Images of Time: An Essay on Temporal Representation. Oxford: Oxford University Press, 2007.

Leftow, Brian. Time and Eternity. Ithaca, NY: Cornell University Press, 1991.

Leininger, Lisa. "Presentism and the Myth of Passage." Australasian Fournal of Philosophy 93, no. 4 (2015): 724-739.

Levering, Matthew. "Christ, the Trinity, and Predestination: McCormack and Aquinas." In Trinity and Election in Contemporary Theology, 244-73. Grand Rapids: Wm. B. Eerdmans Publishing Co., 2011.

Lévinas, Emmanuel. Otherwise than Being: or, Beyond Essence. Translated by Alphonso Lingis. Dordrecht: Springer Science and Business Media, 1991.

Leyser, Conrad. Authority and Asceticism from Augustine to Gregory the Great. Oxford: Oxford University Press, 2000.

Liddell, Henry George, and Robert Scott, . A Greek-English Lexicon/with a supplement 1968. Oxford: Clarendon Press, 1985. 
Lincoln, Andrew T. "The Letter to the Colossians." In The New Interpreter's Bible, Volume XI, 551670. Nashville: Abingdon Press, 2000.

Lindbeck, George A. The Nature of Doctrine: Religion and Theology in a Postliberal Age. Louisville, KY: Westminster John Knox Press, 1984.

Lloyd, Vincent. Law and Transcendence: On the Unfinished Project of Gillian Rose. New York: PalgraveMcMillan, 2009.

—. "On the Use of Gillian Rose." The Heythrop Fournal 48, no. 5 (2007): 697-706.

—. The Problem with Grace: Reconfiguring Political Theology. Stanford: Stanford University Press, 2011.

—. "The Rhetoric of the Middle." Syndicate 1, no. 3 (September/October 2014): 58-63.

Ludlow, Morwenna. "Augustine on the Last Things." In The TET Clark Companion to Augustine and Modern Theology, 91-112. London: Bloomsbury T\&T Clark, 2013.

Lyon, Jodie L. "Pride and the Symptoms of Sin." Fournal of Feminist Studies in Religion 28, no. 1 (2012): 96-102.

MacIntyre, Alasdair. After Virtue. 3rd Edition. Notre Dame: Notre Dame University Press, 2007.

MacKendrick, Karmen. Divine Enticements: Theological Seductions. New York: Fordham University Press, 2013.

Madec, Goulven. La Patrie et la Voie: Le Christ dans la vie et la pensée de Saint Augustin. Paris: Desclée, 1989.

Marion, Jean-Luc. In the Self's Place: The Approach of St. Augustine. Translated by Jeffrey Kosky. Stanford: Stanford University Press, 2012.

- The Erotic Phenomenon. Translated by Stephen E. Lewis. Chicago: University of Chicago Press, 2007.

—. "The Invisibility of the Saint." In Saints: Faith without Borders, edited by Françoise Meltzer and Jas Elsner, translated by Christina M. Gschwandtner, 355-62. Chicago: University of Chicago Press, 2011.

Markus, R.A. Saeculum: History and Society in the Theology of St. Augustine. Cambridge: Cambridge University Press, 1988.

Marrevee, William H. The Ascension of Christ in the Works of St. Augustine. Ottawa: University of Ottawa Press, 1967.

Martin, M.G.F. "The Transparency of Experience." Mind \& Language 17, no. 4 (2002): 376-425. 
Mathewes, Charles T. A Theology of Public Life. Cambridge: Cambridge University Press, 2007.

—. Evil and the Augustinian Tradition. Cambridge: Cambridge University Press, 2001.

-. "The Liberation of Questioning in Augustine's Confessions." Journal of the American Academy of Religion 70, no. 3 (2002): 539-560.

Mazzaro, Jerome. "Dante and the Image of the "Madona Allattante"." Dante Studies, with the Annual Report of the Dante Society (The Johns Hopkins University Press) 114 (1996): 95-111.

McCarthy S.J., Michael. "An Ecclesiology of Groaning: Augustine, the Psalms, and the Making of Church." Theological Studies 66 (2005): 23-48.

McCormack, Bruce L. "Karl Barth's Christology as a Resource for a Reformed Version of Kenoticism." International Fournal of Systematic Theology 8, no. 3 (2006): 243-251.

McDaniel, Kris. "Degrees of Being." Philosopher's Imprint 13, no. 19 (2013): 1-18.

McDowell, John. Mind and World. Cambridge: Harvard University Press, 1996.

McGuckin, John. "Did Augustine's Christology Depend on Theodore of Mopsuestia?" The Heythrop Journal 31, no. 1 (1990): 39-52.

McNall, Joshua. A Free Corrector: Colin Gunton adn the Legacy of Augustine. Minneapolis: Fortress Press, 2015.

McTaggart, J.M.E. "The Unreality of Time." Mind, 1908: 457-74.

Meconi, S.J., David Vincent. The One Christ: St. Augustine's Theology of Deification. Washington, D.C.: The Catholic University of America Press, 2013.

—. "St. Augustine's Early Theory of Participation." Augustinian Studies 27, no. 2 (1996): 79-96.

-. "The Incarnation and the Role of Participation in St. Augustine's Confessions." Augustinian Studies 29, no. 2 (1998): 61-75.

Merdinger, Jane E. "Antoninus of Fussala." In Augustine through the Ages: An Encyclopedia, edited by Allan D. Fitzgerald O.S.A., John Cavadini, Marianne Djuth, James J. O'Donnell and Frederick Van Fleteren, 47-8. Grand Rapids: Wm. B. Eerdmans Publishing Co., 1999.

Merricks, Trenton. "Goodbye Growing Block." Oxford studies in metaphysics 2 (2006): 103-10.

Merricks, Trenton. "Persistence, parts, and presentism." Nous 33, no. 3 (1999): 421-38.

Milbank, John. "The Name of Jesus." In The Word Made Strange: Theology, Language, and Culture, 145-168. Oxford: Blackwell Publishers, Ltd., 1997. 
—. Theology and Social Theory: Beyond Secular Reason. Oxford: Basil Blackwell Ltd., 1990.

Miravelle, Mark. With Jesus: The Story of Mary Co-redemptrix. Goleta, CA: Queenship Publishing, 2003.

Moore, G.E. "External and internal relations." Proceedings of the Aristotelian Society 20 (1919): 40-62.

Morgan, Edward. The Incarnation of the Word: The Theology of Language of Augustine of Hippo. London: T\&T Clark, 2010.

Mulhall, Stephen. Inheritance and Originality: Wittgenstein, Heidegger, Kierkegaard. Oxford: Oxford University Press, 2001.

—. "Realism, Modernism, and the Realistic Spirit: Diamond's Inheritance of Wittgenstein, Early and Late." Nordic Wittgenstein Review 1 (2012): 7-34.

Mullins, R.T. The End of the Timeless God. Oxford: Oxford University Press, 2016.

Muñoz, José Esteban. Cruising Utopia: The Then and There of Queer Futurity. New York: NYU Press, 2009.

Næss, Arne. "The shallow and the deep, long-range ecology movement. A summary." Inquiry 16, no. 1-4 (1973): 95-100.

Newman, John Henry. Certain Difficulties Felt by Anglicans in Catholic Teaching, Vol. 1: In Twelve Lectures Addressed in 1850 to the Party of the Religious Movement of 1833. London: Longmans, Green, and Co., 1918.

Newman, John Henry. Remarks on Certain Passages in the Thirty-Nine Articles [No. 90 of Tracts for the Times]. Vol. 2, in The Via Media of the Anglican Church, 259-356. London: Longmans, Green, and Co., 1908.

Nichols O.P., Aidan. There Is No Rose: The Mariology of the Catholic Church. Minneapolis: Augsburg Fortress Press, 2015.

Niebuhr, H. Richard. The Meaning of Revelation. New York: MacMillan Publishing Company, 1941.

-. The Responsible Self: An Essay in Christian Moral Philosophy. New York: Harper and Row Publishers, 1963.

O'Collins, S.J., Gerald. Saint Augustine on the Resurrection of Christ: Teaching, Rhetoric, and Reception. Oxford: Oxford University Press, 2017.

O'Daly, Gerard. Augustine's Philosophy of Mind. London: Gerald Duckworth \& Co., Ltd., 1987. 
O'Donnell, James J. Augustine Confessions: Volume III: Commentary on Books 8-13. Oxford: Oxford University Press, 1992.

—. Augustine: A New Biography. New York: HarperCollins, 2005.

Palamas, Gregory. "The Uncreated Glory." In The Triads, edited by John Meyendorff, 71-92. Mahwah, NJ: Paulist Press, 1983.

Perriman, Andrew. "The Pattern of Christ's Sufferings: Colossians 1:24 and Philippians 3:10-11." Tyndale Bulletin 42, no. 1 (1991): 62-79.

Pius XII. "Vatican." Mystici Corporis Christi [Encyclical of Pope Pius XII on the Mysical Body of Christ]. June 29, 1943. http://w2.vatican.va/content/pius-xii/en/encyclicals/documents/hf_pxii_enc_29061943_mystici-corporis-christi.html (accessed May 30, 2016).

Plantinga, Alvin. Does God Have a Nature? Milwaukee: Marquette University Press, 1980.

—. The Nature of Necessity. Oxford: Oxford University Press, 1974.

Plaskow, Judith. Sex, Sin, and Grace: Women's Experience and the Theologies of Reinhold Niebuhr and Paul Tillich. Washington, DC: University Press of America, 1980.

Poe, Shelli. Essential Trinitarianism: Schleiermacher as Trinitarian Theologian. London: Bloomsbury T\&T Clark, 2017.

Pooley, Oliver. "Substantivalist and Relationalist Approaches to Spacetime." In The Oxford Handbook of Philosophy of Physics, edited by Robert Batterman, 522-86. Oxford: Oxford University Press, 2013.

- . "XVI - Relativity, the Open Future, and the Passage of Time." Proceedings of the Aristotelian Society 113, no. 3.3 (2013): 321-63.

Prevot, Andrew. Thinking Prayer: Theology and Spirituality among the Crises of Modernity. Notre Dame: University of Notre Dame Press, 2015.

Radde-Gallwitz, Andrew. Basil of Caesarea, Gregory of Nyssa, and the Transformation of Divine Simplicity. Oxford: Oxford University Press, 2009.

Rivera, Mayra. Poetics of the Flesh. Durham, NC: Duke University Press, 2015.

Robespierre, Maximilien. "'On the Death Penalty" (Speech at the Constituent Assembly, June 22, 1971 ), trans. Mitch Abidor." Marxists.org. 2004. https://www.marxists.org/history/france/revolution/robespierre/1791/death-penalty.htm (accessed February 22, 2017).

Roche, W.J. "Measure, Number, and Weight in St. Augustine." The New Scholasticism 15, no. 4 (1941): 350-76. 
Rogers, Eugene F. After the Spirit: A Constructive Pneumatology from Resources outside the Modern West. Grand Rapids: Wm. B. Eerdmans Publishing Co., 2005.

Rogers, Katherin A. "Anselm on Eternity as the Fifth Dimension." Saint Anselm Fournal 3 (2006): $1-8$.

—. "Augustine's Compatibilism." Religious Studies 40, no. 4 (2004): 415-35.

—. "Eternity has no Duration." Religious Studies 30, no. 1 (1994): 1-16.

—. Perfect Being Theology. Edinburgh: Edinburgh University Press, 2000.

—. "St. Augustine on Time and Eternity." American Catholic Philosophical Quarterly 70, no. 2 (1996): 207-23.

Rose, Gillian. Love's Work. New York: New York Review of Books, 2011.

- Mourning Becomes the Law: Philosophy and Representation. Cambridge: Cambridge University Press, 1996.

-. The Melancholy Science: An Introduction to the Thought of Theodor W. Adorno. London: Verso Books, 2014.

Rosheger, John P. "Augustine and Divine Simplicity." New Blackfriars 77, no. 901 (1996): 72-83.

Saiving Goldstein, Valerie. "The human situation: a feminine view." The Journal of Religion 40, no. 2 (1960): 100-12.

Schaffer, Jonathan. "Is there a fundamental level?" Nous 37, no. 3 (2003): 498-517.

Schleiermacher, Friedrich Daniel Ernst. The Christian Faith. Edited by H.R. Mackintosh and J.S. Stewart. Edinburgh: T\&T Clark, 1928.

Schumacher, Lydia. Divine Illumination: The History and Future of Augustine's Theory of Knowledge. Oxford: Wiley-Blackwell, 2011.

Shakespeare, William. The Oxford Shakespeare: Othello, The Moor of Venice. Oxford: Oxford University Press, 2008.

Shanks, Andrew. Against Innocence: An Introduction to Gillian Rose. London: SCM Press, 2008.

Shoemaker, Sydney. "Time without Change." The Journal of Philosophy 66, no. 12 (1969): 363-81.

Sider, Theodore. Four-dimensionalism: An Ontology of Persistence and Time. Oxford: Oxford University Press, 2001. 
Skow, Bradford. "Relativity and the Moving Spotlight." The Fournal of Philosophy 106, no. 12 (2009): 666-78.

Sokolowski, Robert. The God of Faith and Reason: Foundations of Christian Theology. 2nd Edition. Washington, D.C.: The Catholic University of America Press, 1995.

Sonderegger, Katherine. Systematic Theology: The Doctrine of God, Vol. 1. Minneapolis: Fortress Press, 2015.

Stalnaker, Aaron. "Spiritual Exercises and the Grace of God: Paradoxes of Personal Formation in Augustine." Journal of the Society of Christian Ethics 24, no. 2 (2004): 137-70.

Stewart-Kroeker, Sarah. Pilgrimage as Moral and Aesthetic Formation in Augustine's Thought. Oxford: Oxford University Press, 2017.

Studer, Basil. "Sacramentum et Exemplum chez saint Augustin." Recherches Augustiniennes 10 (1975): 87-141.

-. The Grace of Christ and the Grace of God in Augustine of Hippo: Christocentrism or Theocentrism. Translated by M.J. O'Connell. Collegeville, MD: Order of St. Benedict, 1997.

Stump, Eleonore, and Norman Kretzmann. "Eternity." The Fournal of Philosophy 78, no. 8 (1981): 429-58.

Sumney, Jerry L. "'I Fill Up What Is Lacking in the Afflictions of Christ": Paul's Vicarious Suffering in Colossians." The Catholic Biblical Quarterly 68, no. 4 (2006): 664-80.

Sutherland, Elizabeth. "Saints in Sight: Representations of Holiness in Late Medieval English Literature". Unpublished Ph.D. Dissertation, University of Virginia, 2017.

Swinburne, Richard. The Christian God. Oxford: Oxford University Press, 1994.

Tanner, Kathryn. Christ the Key. Cambridge: Cambridge University Press, 2009.

—. God and Creation in Christian Theology: Tyranny or Empowerment? Minneapolis: Fortress Press, 2005.

-.Jesus, Humanity, and the Trinity: A Brief Systematic Theology. Minneapolis: Fortress Press, 2001.

Taylor, Charles. Sources of the Self: The Making of the Modern Identity. Cambridge: Harvard University Press, 1989.

Teske, Roland J. "Augustine's Use of Substantia when Speaking about God." In To Know God and the Soul: Essays on the Thought of Saint Augustine, 112-130. Washington, D.C.: The Catholic University of America Press, 2008.

—. "Divine Immutability in Augustine." In To Know God and the Soul: Essays on the Thought of Saint Augustine, 131-52. Washington, D.C.: The Catholic University of America Press, 2008. 
Teubner, Jonathan D. "Prayer in the Latin Tradition: a study in the development of Augustinianism." Unpublished D.Phil. Thesis, University of Cambridge, 2013.

Tilus, Kerlens. "Quand le Roi des Rats Jean Bertrand Aristide Evoque le Déchouquage." Radio Television Caraibes. December 11, 2016. http://www.radiotelevisioncaraibes.com/opinion/quand_le_roi_des_rats_jean_bertrand_ari stide_evoque_le_d_chouqua.html (accessed February 22, 2017).

Tonstad, Linn Marie. God and Difference: The Trinity, Sexuality, and the Transformation of Finitude. New York: Routledge, 2016.

Trible, Phyllis. Texts of Terror: Literary-Feminist Readings of Biblical Narratives. Minneapolis: Fortress Press, 1984.

Trudinger, Paul L. "A Further Brief Note on Colossians 1:24." The Evangelical Quarterly 45 (1973): 36-8.

Turner, Denys. The Darkness of God: Negativity in Christian Mysticism. Cambridge: Cambridge University Press, 1998.

Wüthrich, Christian. "No presentism in quantum gravity." In Space, Time, and Spacetime, 257-78. Heidelberg: Springer Berlin, 2010.

—. "The fate of presentism in modern physics." In New Papers on the Present - Focus on Presentism, edited by Roberto Ciunti, Kristie Miller and Giuliano Torrengo, 1-23. Munich: Philosophia Verlag, 2012.

Ward, Graham. Christ and Culture. Oxford: Blackwell Publishing, 2008.

Wells, Gary L., and Elizabeth A. Olson. "Eyewitness Testimony." Annual Review of Psychology 54 (2003): 277-295.

Werner, Martin. "The Madonna and Child Miniature in the Book of Kells: Part I." The Art Bulletin 54, no. 1 (Mar 1972): 1-23.

Wetzel, James. Augustine and the Limits of Virtue. Cambridge: Cambridge University Press, 1992.

-. Augustine: A Guide for the Perplexed. London: T\&T Clark, 2010.

—. Parting Knowledge: Essays after Augustine. Eugene: Cascade Books, 2013.

—. "Splendid Vices and Secular Virtues: Variations on Milbank's Augustine." The Fournal of Religious Ethics 32, no. 3 (2004): 271-300. 
—. "The Force of Memory: Reflections on the Interrupted Self." Augustinian Studies 38, no. 1 (2007): 147-159.

—. "The Materiality of Augustine's Conversion." The Journal of Religion 91, no. 1 (201 1): 43-63.

—. "Time after Augustine." Religious Studies 31, no. 3 (1995): 341-357.

White, O.P., Thomas Joseph. The Incarnate Lord: A Thomistic Study in Christology. Washington, D.C.: The Catholic University of America Press, 2015.

Wilken, Robert Louis. "In Defense of Allegory." Modern Theology 14, no. 2 (1998): 197-212.

Williams, Bernard. Shame and Necessity. Berkeley: University of California Press, 2008.

Williams, Donald C. "The Myth of Passage." The Journal of Philosophy 48, no. 15 (1951): 457-472.

Williams, Rowan. Arius: Heresy and Tradition. Revised Edition. Grand Rapids: Wm. B. Eerdmans Publishing Co., 2001.

—. "Augustine and the Psalms." Interpretation 58, no. 1 (2004): 17-27.

-. "Augustine's Christology." In In the Shadow of the Incarnation: Essays on Jesus Christ in the Early Church in Honor of Brian E, Daley, SF, 176-89. Notre Dame: University of Notre Dame Press, 2008.

-. "Between politics and metaphysics: reflections in the wake of Gillian Rose." In Wrestling with Angels: Conversations in Modern Theology, edited by Mike Higton, 53-76. London: SCM Press, 2007.

-. On Augustine. London: Bloomsbury Continuum, 2016.

—. "Redeeming sorrows: Marilyn McCord Adams and the defeat of evil." In Wrestling with Angels: Conversations in Modern Theology, edited by Mike Higton, 255-74. London: SCM Press, 2007.

-. "Sapientia and the Trinity: Reflections on the De trinitate." In Collectanea augustiniana. Mélanges T. van Bavel, edited by B. Brunig et al., 316-32. Leuven: Peeters Publishers, 1990.

—. The Edge of Words: God and the Habits of Language. London: Bloomsbury, 2014.

—. "The Hulsean Lectures 2016: Christ and the Logic of Creation: Lecture 1. A Mediaeval Excursion: Aquinas' Christology and its Aftermath." University of Cambridge Faculty of Divinity. Jan 12, 2016. http://www.divinity.cam.ac.uk/events/the-hulsean-lectures-2016-christ-andthe-logic-of-creation (accessed Feb 8, 2016).

—. "The Paradoxes of Self-Knowledge in the De trinitate." In Augustine: Presbyter Factus Sum, edited by Joseph T. Lienhard, Earl C. Müller and Roland J. Teske, 121-134. New York: Peter Lang, 1993. 
Williamson, Beth. "The Virgin Lactans as Second Eve: Image of the "Salvatrix"." Studies in Iconography 19 (1998): 105-138.

Wisse, Maarten. Trinitarian Theology beyond Participation: Augustine's De Trinitate and Contemporary Theology. London: Bloomsbury T\&T Clark, 2011.

Wittgenstein, Ludwig. On Certainty. Edited by G.E.M. Anscombe and G.H. von Wright. Translated by Denis Paul and G.E.M. Anscombe. New York: Harper \& Row, 1969.

- Philosophical Investigations. 4th Edition. Edited by P.M.S. Hacker and Joachim Schulte. Translated by G.E.M. Anscombe, P.M.S. Hacker and Joachim Schulte. Oxford: WileyBlackwell Publishers, 2009.

Yates, Roy. "A Note on Colossians 1:24." The Evangelical Quarterly 42 (1970): 88-92.

Young, Frances M., and Andrew Teal. From Nicaea to Chalcedon: A Guide to the Literature and Its Background. 2nd Edition. London: SCM Press, 2010.

Zimmerman, Dean W. "Presentism and the Space-Time Manifold." In The Oxford Handbook of the Philosophy of Time, edited by Craig Callender, 163-244. Oxford: Oxford University Press, 2011.

Zimmerman, Dean W. "The A-Theory of Time, The B-Theory of Time, and 'Taking Tense Seriously'." dialectica 59, no. 4 (2005): 401-57.

Zizioulas, John. Being as Communion: Studies in Personhood and the Church. Crestwood, NY: St. Vladimir's Seminary Press, 1997. 